
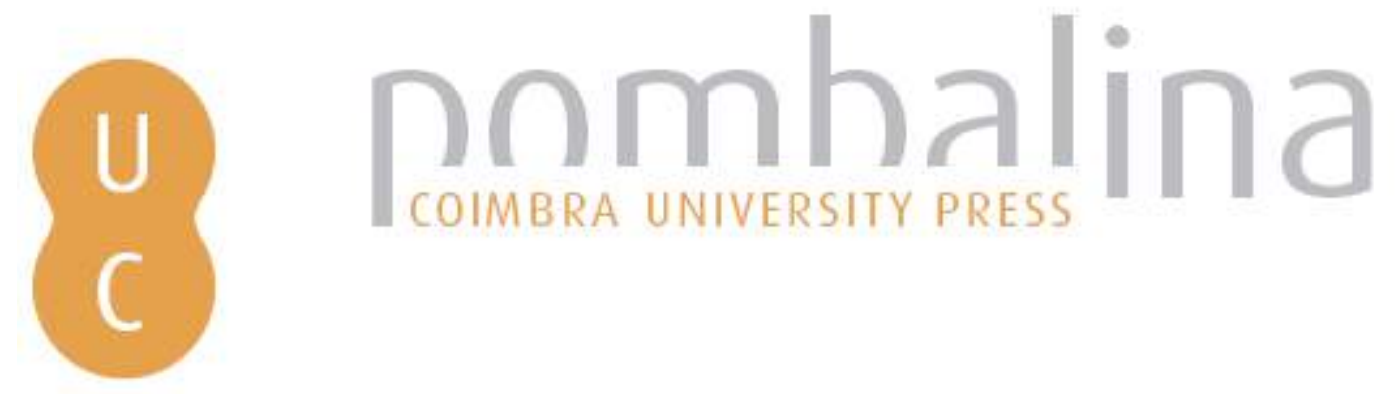

\title{
O governo da educação em Portugal: legitimação e contigência na escola secundária, 1974-1991
}

Autor(es): $\quad$ Gomes, Rui Machado

Publicado por: Imprensa da Universidade de Coimbra

URL

persistente: URI:http://hdl.handle.net/10316.2/2584

DOI: $\quad$ DOI:http://dx.doi.org/10.14195/978-989-26-0372-8

Accessed : $\quad$ 19-May-2017 17:42:39

A navegação consulta e descarregamento dos títulos inseridos nas Bibliotecas Digitais UC Digitalis, UC Pombalina e UC Impactum, pressupõem a aceitação plena e sem reservas dos Termos e Condições de Uso destas Bibliotecas Digitais, disponíveis em https://digitalis.uc.pt/pt-pt/termos.

Conforme exposto nos referidos Termos e Condições de Uso, o descarregamento de títulos de acesso restrito requer uma licença válida de autorização devendo o utilizador aceder ao(s) documento(s) a partir de um endereço de IP da instituição detentora da supramencionada licença.

Ao utilizador é apenas permitido o descarregamento para uso pessoal, pelo que o emprego do(s) título(s) descarregado(s) para outro fim, designadamente comercial, carece de autorização do respetivo autor ou editor da obra.

Na medida em que todas as obras da UC Digitalis se encontram protegidas pelo Código do Direito de Autor e Direitos Conexos e demais legislação aplicável, toda a cópia, parcial ou total, deste documento, nos casos em que é legalmente admitida, deverá conter ou fazer-se acompanhar por este aviso.

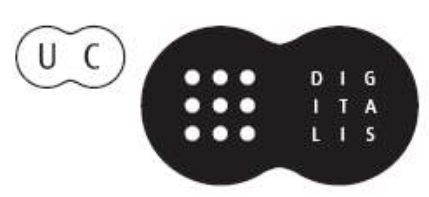


O Governo da

Educação em

Portug a I

RUI MACHADOGOMES

Coimbra I Imprensa da Universidade 
(Página deixada propositadamente em branco) 


\section{O Governo da \\ Educação em}

P ort u g a l

Le gitimação e contigência na escola secundária, 1974-1991

RU I M A C H A D G O M E S

Coimbra - Imprensa da Universidade 


\title{
COORDENAÇÃo EDITORIAL
}

Imprensa da Universidade de Coimbra

\section{CONCEPÇĀO GRÁFICA}

António Barros

\author{
PAGINAÇĀo
}

António Resende

[Universidade de Coimbra]

\author{
EXECUÇÃO GRÁFICA \\ G.C. - Gráfica de Coimbra, Lda. \\ Palheira - Assafarge - Apart. 3068 \\ 3001-453 Coimbra Codex
}

ISBN

972-8704-48-8

ISBN Digital

978-989-26-0372-8

DOI

http://dx.doi.org/10.14195/978-989-26-0372-8

DEPÓsITO LEgAL

$229954 / 05$

(c) JUNHO 2005, IMPRENSA DA UNIVERSIDADE DE COIMBRA 


\title{
ÍNDICE
}

INTRODUÇÃO 5

\author{
PRIMEIRA PARTE \\ MUDANÇA DE PROBLEMÁTICA: \\ DO ESTADO-EDUCADOR À GOVERNAMENTALIDADE DA ESCOLA
}

\section{CAPITULO I}

PROBLEMÁTICA 19

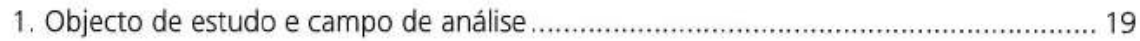

2. As teorias tradicionais do Estado ............................................................................ 23

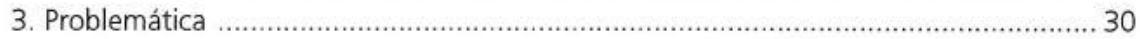

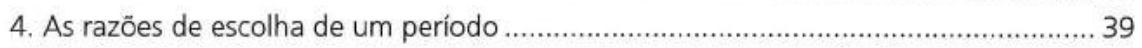

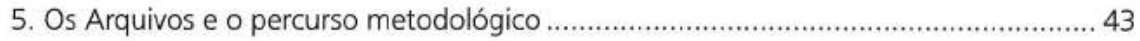

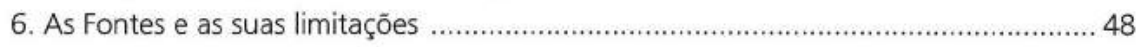

\section{CAPITULO II}

PARA UMA CONCEPTUALIZAÇÄO DA GOVERNAMENTALIDADE ESCOLAR: ESBOÇO GERAL E PARTICULARIDADES DOS PAÍSES SEMIPERIFÉRICOS ….......................59

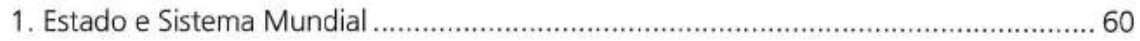

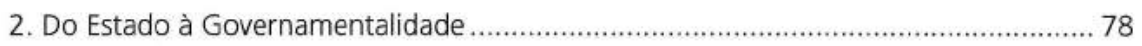

3. Racionalidades políticas, Estado e Governamentalidade .......................................... 84

4. As tecnologias de Governamentalidade da escola .................................................. 89

5. As particularidades da Governamentalidade na semiperiferia .................................. 94

6. Tipologia dos discursos educativos do Estado …................................................. 115

\section{CAPITULO III}

O MÉTODO: DAS ESTRUTURAS AOS DISCURSOS ..................................................... 141

1. A Arqueologia: as políticas educativas como texto ................................................ 142

2. As posições de sujeito e a selecção dos domínios dos discursos ............................ 147 
3. Dispersão, montagem e articulação dos discursos ................................................... 152

4. A constituição discursiva das estruturas: objectividade e hegemonia ..................... 156

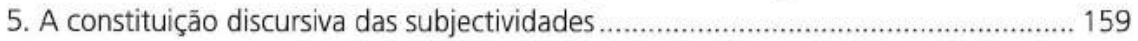

6. Formas e significados da linguagem política ...................................................... 161

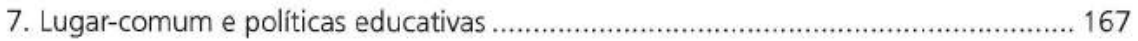

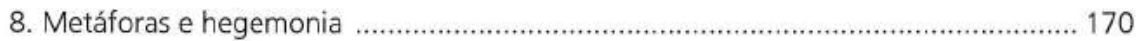

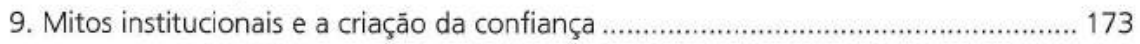

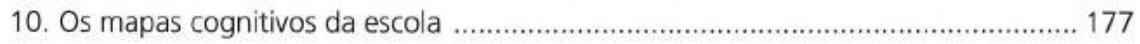

\section{SEGUNDA PARTE \\ O GOVERNO DA EDUCAÇĀO EM PORTUGAL}

CAPITULO IV

A ARQUEOLOGIA DO GOVERNO DA EDUCAÇĀO: A VONTADE DE CONHECER

PARA DOMINAR A SITUAÇÃO

1. O nó górdio da expansão do sistema: a construçăo escolar ...................................... 186

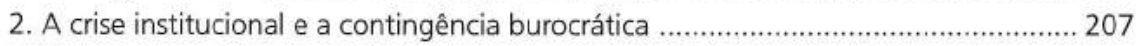

3. Governar um sistema calculável: as estatísticas e o planeamento ........................... 232

4. A despolitizaçăo das políticas educativas e o ciclo dos planificadores ...................... 240

\section{CAPITULO V}

AS TECNOLOGIAS DO ESPAÇO SOCIAL E DA SUBJECTIVIDADE

1. O Ensino Secundário Unificado: uma nova decomposição da população e do espaço escolar

2. Uma nova cartografia de inserção espacial da escola

3. O aperfeiçoamento das tecnologias de governo da população escolar: as tecnologias da autonomia e a nova subjectividade para a cidadania 


\section{INTRODUÇÃO}

O objectivo deste estudo é o de recolocar a questão da expansăo da escola secundária de massas, no Portugal contemporâneo, a partir do sistema de poder que se costuma identificar com o Estado. Ditas as coisas de forma mais directa pretende-se voltar aquilo que a historiografia e a sociografia têm designado por políticas do Estado-educador. Na última década, a análise do Estado tem sido alvo de um movimento de crítica e de profunda renovação teórica com repercussôes nas ciências da educação e nas suas relações com as outras ciências sociais. Passaremos em revista algumas destas críticas e inovaçōes, conquanto se saliente as suas potencialidades face às três questões centrais deste trabalho: a da heterogeneidade, a da multidimensionaliade e a da posiçăo intermédia dos sistemas educativos no conjunto das várias formas de poder social. Esta incursão permitir-nos-á identificar também limites destas abordagens e caminhos possíveis para a elaboraçăo de uma alternativa nos termos do que designamos como governamentalidade da escola de massas. Uma ideia central guia este livro: o poder exercido na escola não se limita ao poder político de dominação do Estado, o que implica ligar a problemática do Estado com as problemáticas das outras formas de poder e, em particular, as que atravessam os contextos da Produçăo, da Família e do Sistema Mundial.

Para além de razões de ordem académica e profissional que estiveram na origem do estudo agora apresentado, pode dizer-se, sem excesso de pretensăo, que este livro resultou de uma profunda revisão da relação institucional que mantive durante uma década com as Ciências da Educaçăo. O meu envolvimento nas problemáticas teóricas que presidem à produção deste livro remontam à origem do meu percurso científico e profissional na Universidade de Lisboa (Faculdade de Psicologia e de Ciências da Educação), instituiçăo na qual iniciei, no ano académico de 1990, as minhas actividades de ensino e pesquisa no interior das Ciências da Educação. A inserção institucional num grupo de docentes e de disciplinas que envolviam a História e a Sociologia da Educação, a Administração Escolar e a Educação de Adultos marcou 
necessariamente a minha forma de encarar a pesquisa, designadamente quanto aos princípios de interdisciplinariedade e de imaginação metodológica que a guiam.

Durante nove anos mantive uma participação activa em várias equipas de ensino e de investigação multidisciplinares centradas na análise sociocrítica das instituições e organizações escolares. Este percurso, pontuado sobretudo pela leccionação da disciplina de Análise Sociológica da Instituição Escolar, nas licenciaturas em Psicologia e em Ciências da Educação, e de Sociologia e Organização Escolar, na profissionalização em serviço, desenvolveu-se em dois períodos bem delimitados.

O primeiro período, entre 1990 e 1994, pode considerar-se o período centrado na análise das organizações escolares. É o período em que preparo, defendo e publico a tese de mestrado sobre as Culturas de Escola e Identidades dos Professores (1993), em que faço uma pós-graduação em Comportamento Organizacional e que participo numa equipa de investigaçăo em torno da problemática das relações entre a Escola e o Espaço Local (1992-1994) de que resultaria a publicação de um livro. Influenciado inicialmente pelos modelos de análise da Psicologia Social e Organizacional, rapidamente evoluo e os integro numa forte articulaçăo com a Sociologia da Educação e das Organizaçōes.

O segundo período, entre 1995 e 1999, é o período de transiçăo para um outro nível de análise e está marcado por uma profunda revisão da minha relação com as Ciências da Educação. Ancorado na observação das políticas educativas e da governamentalidade da educação preparo a minha tese de doutoramento sobre as Políticas Educativas em Portugal (Gomes, 2000). Faço duas visitas de estudo à Universidade de Wisconsin-Madison, em cujo ambiente intelectual, aberto aos debates científicos contemporâneos, inicio uma etapa de questionamento e ruptura com algumas certezas enraizadas na comunidade portuguesa das Ciências da Educação. Contacto com as discussöes semanais dos seminários de doutoramento dos professores Thomas Popkewitz e Michael Apple e retomo as reflexōes em torno de algumas teses de Foucault sobre a governamentalidade, o governo da subjectividade e as tecnologias de regulação e auto-regulaçăo dos sujeitos que já havia feito durante a licenciatura. É no interior desta linha de orientação crítica que apresento e publico mais tarde o artigo Teses para uma Agenda de Estudo da Escola (1996), que guiaria todo o dispositivo teorico-metodológico da dissertação de doutoramento, designadamente as que dizem respeito ao papel do Estado e dos especialistas no governo da educação, à importância de recuperar a experiência dos actores escolares como forma de elucidar a construção social que produz a sua própria vida, ao valor heurístico do conceito de discurso na apreensăo das formas de legitimação política e científica das realidades escolares. 
Em 1994, iniciava um duplo processo de questionamento sobre o conteúdo e o sentido das ciências da educação que me obrigou a colocar um parêntese no programa da pesquisa, uma hesitação deliberada sobre a natureza e o método da própria investigação. É sabido como a ideia de investigação se apurou num pano de fundo formado por enigmas e se traduz, invariavelmente, na restrição das possibilidades de interpretaçăo. Neste sentido, as descobertas fazem-se no interior de um cúmulo de soluções anteriormente alcançadas e, na maioria dos casos, à sua imagem. Thomas Kuhn $(1962,1983)^{(1)}$ designou esta lógica da pesquisa por ciência normal, năo para a desvalorizar, mas para sublinhar como a maior parte do tempo do cientista é consumido com actividades altamente convergentes, baseadas em firmes consensos estabelecidos.

Quando iniciei o percurso de investigação que me levou à redacção deste livro comecei por questionar muitos dos lugares comuns instalados em mim próprio e na comunidade das ciências da educação. As fontes que consultava, os documentos que percorria, os arquivos que compulsava não obtinham resposta interpretativa nos modelos dominantes e aqueles que já tinha utilizado não me pareciam agora satisfatórios. As perplexidades provocadas pelas fontes somavam-se às aberraçöes dos modelos que as pretendiam compreender. Algumas das minhas certezas iam sendo abaladas pela entrada em cena de interrogaçōes sem resposta. Valeria a pena tentar fazer algumas transgressōes disciplinares e metodológicas, de modo a confrontar a objectividade dos objectos de investigação com a perplexidade nua e branca que cria a irritação própria de não nos reconhecermos neles. Neste contexto, a objectividade significava para mim uma identidade reconhecivel do objecto de investigação, enquanto a perplexidade devia provocar a estranheza e a vontade de conhecer em espaços cada vez mais abertos, embora à custa de práticas contrabandeadas de outras áreas disciplinares e de um grande ecletismo metodológico.

Cometeria alguma injustiça, mas julgava perceber um excesso de crenças no campo de estudos das ciências da educação e, acima de tudo, uma agenda de pesquisa excessivamente marcada pela investigação aplicada e por objectivos legítimos de desenvolvimento e afirmaçăo institucional que, pessoalmente, nunca me interessaram. Tive que regressar ao exercício de reflexão proposto por Peirce (1958). Sugere este que a irritação da dúvida é o único motivo imediato do combate para se obter uma solução que, quando alcançada, se torna crença. Para Peirce a pesquisa visa essencialmente aquietar a opinião. Trata-se de uma tarefa que se impõe ao sujeito pelo

(1) Assinalam-se duas datas sempre que se utiliza uma ediçăo que năo a original de uma obra considerada de referência: a primeira data refere-se à edição original e a segunda à edição usada. 
oposto de um princípio de actividade. Após a soluçăo segue-se o repouso na crença. Pelo contrário, o mal-estar e a insatisfação inerentes à dúvida despertam um estímulo para a acção. Tal estado caracteriza-se por uma hesitação antecipada sobre o que faremos a seguir.

Dedico, por isso, parte da introdução à sistematização de algumas dúvidas e perplexidades que estiveram na origem deste livro. A não resolução sistemática de certos problemas observados pelo núcleo duro dos programas de investigação das ciências da educação levaram-me, nos anos 90, a uma investigação prévia sobre alguns dos seus operadores. $O$ resultado dessa interrogação permitiu-me enunciar um conjunto de contradiçōes e de dilemas.

O primeiro dilema consiste no seguinte: os últimos quinze anos marcaram decisivamente o regresso do indivíduo à cena da acção política e da educaçăo. E entrou de tal forma que o fez sob o crisma nobre de actor. No entanto, contrariando as visōes científicas regeneradoras do indivíduo, o individualismo metodológico e o discurso liberal o actor parece menos individual do que nunca. A crise do estruturalismo marcou a reinvenção das relações, dos processos e do sentido da acção. O pensamento científico volta-se para a observaçăo de situações empiricas em que as interacções produzem conhecimentos e formação de valores, afirmando a ética de responsabilidade weberiana que supõe o indivíduo. No limite, a instituição escolar passou a ser entendida menos enquanto instância produtora de comportamentos do que enquanto colecções de indivíduos livres. Foram os anos de análise das biografias e dos ciclos de vida dos professores, das trajectórias profissionais, do pensamento dos professores e da sua reflexividade, todas elas incorporadas no escopo da fenomenologia e do interaccionismo simbólico. Ao actor tudo parece reformável nos microssistemas de pertença e nada parece tranformável na sociedade como um todo. A pesquisa científica compraz-se em seguir ou estimular esta lógica, procurando nos espaços normativos de regulaçăo os lugares de autonomia e de emancipação individual ou de grupo. Neste encontro de formas, embora descoincidente nas finalidades, se encontra o movimento de fundo da episteme hegemónica formada em redor do binário indivíduo-sociedade.

Será que esta separação indivíduo-sociedade já faz parte da arqueologia do pensamento sociológico? Ou, pelo contrário, apressámo-nos quando jogámos fora o conceito de alienaçăo anterior a Crozier? Como articular a ambição ideológica do actor e os votos piedosos da participação com uma situação empírica em que a liberdade dos actores se tornou prisioneira de novos artefactos institucionais? Não estaremos em pleno reino do simulacro onde a repetição das mensagens individualistas e participativas fez desaparecer o referente original? 
O segundo dilema consiste no seguinte: nas décadas de 80-90 assistimos em Portugal à consolidação de um discurso centrado na necessidade de intensificar as práticas locais, à tendência de localização dos curricula e à criação de redes de partenariado nas organizaçōes escolares. Destas transformaçōes retira-se a ilação de que o Estado tem perdido influência e a sua capacidade de regulação social. No campo das ciências da educação (re)descobrem-se os conceitos de participação e de autonomia primeiro e de identidade depois, emergindo as investigações que sublinham os graus de liberdade dos indivíduos nas organizações e das organizações nas instituições. O modelo foucauldiano da instituição total, onde as disciplinas se fundam em conhecimento, que é ele próprio poder, deu lugar à reificação da instituição local que gere a imprevisibilidade das relaçōes desarticuladas entre poder e saber.

No entanto, no nosso quotidiano raramente somos confrontados com o espaço local e, pelo contrário, somos obsessivamente captados pela presença do Estado que regulamenta muito e desregulamenta outro tanto. Nas condições actuais de um Estado máximo que se apresenta como mínimo, a compulsăo normativa torna-se perversamente subtil, mole, leve e distante quando comparada com a situação anterior de um Estado mínimo, porque ineficaz, mas máximo, porque permanentemente presente nos seus procedimentos reguladores. $O$ pressuposto de que no mesmo espaço sistémico haja mais do que uma ordem administrativa - a central e a local —, o que no limite quer dizer mais do que um direito, carece de prova no estado actual das investigaçōes.

Será o Estado uma categoria analítica que deve deixar de interessar à análise das políticas educativas? Não abandonámos depressa demais as consequências dos estudos da microfisica do poder foucauldianos, segundo os quais é preciso fazer uma análise do poder de cima a baixo e de baixo a cima de modo a encontrar novos centros de poder na articulaçăo entre os mecanismos infinitesimais e os mecanismos molares?

O terceiro dilema pode ser captado a partir da seguinte formulação: as agendas políticas dos diferentes países europeus no domínio educativo revela-nos que os problemas mais instantes são, de novo, problemas de natureza estrutural. Alguns deles săo derivados da base económica da crise: défice orçamental, redução dos orçamentos para a educação, desemprego, polarização das qualificações com consequências na subqualificaçăo e na sobrequalificaçăo. Os sistemas educativos vivem também uma crise de adaptação às novas circunstâncias de funcionamento de uma economia global que preside à vaga de reformas dos últimos anos. O acréscimo de imigrantes de primeira ou de segunda geração nos sistemas educativos, resultante do post-colonialismo e da deslocação do conflito Norte-Sul para o interior das grandes metrópoles 
europeias, é dentre os novos fenómenos que põem problemas de legitimidade e governabilidade o que leva os velhos estados-nação europeus a ensaiar mais intensamente novas formas de controlo e regulação social. As teorias de regulaçăo pelo mercado entram decisivamente na agenda das administrações dos sistemas educativos, bem como políticas de multiculturalidade que andam a par do reforço nacionalista dos curricula.

Porém, ao arrepio destas tendências, a teoria e a análise das ciências da educação na última década têm vindo a desvalorizar o estrutural em favor do cultural e do simbólico; o macro em favor do meso e do micro; o político-sistémico em favor do năo-político-actor; os modos de produção de escolarização do Estado em favor dos modos de vida quotidiana das escolas. Pode mesmo dizer-se que a crítica que tem vindo a ser feita aos diversos estruturalismos e determinismos sociais anda a par do abandono do macrossocial, do económico e do político. Será que esta contradição macro-micro é real? Será que nos afastámos do núcleo analítico da escola? Ou, pelo contrário, as categorias analíticas em que assentavam as teorias estruturalistas são hoje desadequadas e exigem uma superação radical?

O quarto dilema reside na constatação de que os estudos educacionais se têm concentrado preferentemente nas formas escolares de organização da educação, quando se reconhece que a formaçăo exterior ao espaço escolar assume hoje um peso tăo ou mais importante que aquelas. O outro lado da escola que se surpreende na educação não formal, que umas vezes não é mais do que a escola em outro lado, mas que é também, na sua diversidade, outra forma de afirmar modelos não escolares de aprendizagem e de organização, encontra-se cada vez mais no centro das preocupações educativas. A crise do modelo escolar contribuiu de forma não desprezível para este renovado interesse pela educação năo formal. Contudo, as ciências da educação em Portugal têm centrado a sua observação em estudos de caso do modelo escolar e as alternativas educativas surgidas na educação não formal raramente săo comparadas com aqueles.

Será difícil não ver neste excesso de escola o resultado da adiposidade da formação de professores nas ciências da educação. A regulaçăo estatal nesta área é por demais evidente. Que relação tem o excesso de escola nas ciências da educação com o seu comprometimento na regulaçăo estatal do sistema? Os modelos utilizados na sociologia da educação continuam a ser derivados de modelos mais gerais de análise social e, desse ponto de vista, parecem cada vez menos adequados à educação tendendo a sugerir generalizações abusivas.

O quinto dilema resulta da oposiçăo tradicional no interior das ciências sociais e humanas entre a pretensão de objectividade e a impossibilidade de conhecer sem 
mediação da subjectividade. Há mundos que fogem às nossas referências habituais, quer porque fazem das lógicas que nos esforçamos por rejeitar a sua fonte de pensamento, quer porque escapam ao senso comum e aos paradigmas que formam a percepção de uma época e dos seus objectos. Achamos estranho o que não existe, o que é invenção dos nossos sonhos e desejos e até o que é combinação inaudita e heterodoxa do que já existe mas noutras combinações e configurações. A estranheza é uma forma de conhecimento limiar que nem sempre tem o seu equivalente nas formas de falar sobre a escola. É que ela interroga no seu âmago o sentido epistemológico do dualismo objectividade versus subjectividade que impregna o debate dentro das ciências sociais.

Estes e outros dilemas levaram-me ao limite da duplicaçăo, isto é, ao desprendimento institucional e ao trabalho crítico do pensamento sobre si próprio. Momentos há em que a questão não é a de procurar assimilar o conhecimento conhecido, mas a de procurar saber em que condições é possível pensar de modo diferente. E esse é um exercício solitário, em que o descaminho em relação aquilo que já se sabe é confundido, frequentemente, com diletantismo, intelectualismo e dadaismo que nem sempre as instituições estão capazes de aceitar. Este livro é, como quase todos os trabalhos de pesquisa em ciências sociais, uma ascese. Está aqui um percurso de rememoração, uma experiência modificadora feita em recolhimento, uma ruptura do ente próprio no jogo da verdade. Que agora se dá ao mundo em pensamento partilhável.

Durante o percurso da investigação tornou-se indispensável levar até às últimas consequências a transgressão de pensar de modo diferente, para ser possível ver coisas que ainda não se viam na observaçăo e reflexão sobre o objecto de estudo. Tal desconforto equacionou as próprias condiçōes da minha inserção no interior da "comunidade científica» das ciências da educação. Este exercício levou com frequência à necessidade do ensaio, que, nas suas exigências metodológicas, não se confunde com a mera opinião. $\mathrm{O}$ resultado é um livro com pressupostos mas sem seguranças. A sua força eventual provém da proposiçāo de um modelo de análise que pretende abrir outras vias de investigação, daí lhe advindo a necessária precariedade no cúmulo de provas empíricas. Embora o peso relativo do tratamento das fontes e da empiria se mantenha num nível aceitável, a necessidade de apresentar o modelo teórico antes da empiria e a frequência das sínteses conceptuais pareceu inevitável à medida que estas se afastavam da doxa científica dominante. Este método de trabalho impôs um estilo de redaç̧ão muito particular que se pode caracterizar pelo facto de o leitor poder adentrar-se por qualquer capítulo do livro sem com isso se sentir desorientado. $\mathrm{O}$ método de narrativa deve, pois, adaptar-se-lhe: optamos pela relevância, 
não pela exaustão descritiva; damos primazia à síntese e não à análise; utilizamos o escopro do conhecimento em espiral mais que a linha diacrónica do tempo. Entenda-se qual o seu porquê: relevância porque devemos centrar-nos no que é estruturante na construção do discurso educativo no período analisado; síntese porque as acções não falam por si, sendo necessário inseri-las no sistema de poder e de saber que lhes deu origem e significado; conhecimento em espiral porque uma tal óptica nos permite projectar o modelo teórico em sucessivas órbitas conceptuais, simultaneamente mais complexas e mais compreensivas.

O trabalho está dividido em duas partes. A primeira, intitulada «Mudança de Problemática: do Estado-Educador à Governamentalidade da Escola» procede à discussão dos obstáculos criados pelas concepções nominalistas do Estado e da sua relação com a educaçăo. Tratando teoricamente os problemas da heterogeneidade, da multidimensionaliade e da posição intermédia dos sistemas educativos no conjunto das várias formas de poder social, apresenta-se o quadro teórico e conceptual traduzido na utilização das virtualidades dos métodos arqueológico e genealógico propostos por Foucault. Esta incursão permitir-nos-á identificar também limites destas abordagens e caminhos possíveis para a elaboração de uma alternativa nos termos do que designamos por governamentalidade da escola de massas.

A segunda parte, intitulada "O Governo da Educação em Portugal», procede à análise da «realidade» do ensino secundário em Portugal no período 1974-1991. Nela se vai em busca das tecnologias e racionalidades de governo do ensino secundário. O nosso ponto de observação não é a sua organizaçăo formal. Não se pretende reconstruir o conjunto de princípios, de estruturas e de regras destinadas a assegurar a ordem e a coerência no seu funcionamento. Nos termos da nossa problemática, tal opção equivaleria a tomar os dispositivos de legitimaçăo como um mandato legítimo fundado em princípios e razōes aceitáveis, limitando o investigador na sua busca da matriz subjacente à própria concepção de escola como única forma organizada de pensar e realizar a educação. Como se exporá, os sistemas educativos explicam-se por princípios mas actuam pragmaticamente, adaptando-se às circunstâncias, adoptando diversas retóricas conforme as exigências do momento. É o reconhecimento desta característica, ou melhor, é a eleição deste ponto de observação movente para plataforma de construçăo do objecto de estudo, que torna exigente o percurso investigativo. Seguir tecnologias que se adaptam a circunstâncias é bastante diferente de reconstruir princípios que se aplicam a circunstâncias. Neste caso a localização do objecto é fixa, enquanto naquele é indeterminada. Também aqui o estilo de redacção se deve adaptar ao método. Em vez da forma tradicional que apresenta primeiro o objecto de estudo em traços largos e com poucos pormenores, para de- 
pois se adentrar na minúcia do detalhe, ou que, em alternativa, faz o percurso inverso, da grande escala muito sensível às pequenas diferenças, para a pequena escala indeferenciadora, o estilo de redacção utilizado compõe um objecto de estudo em mosaico. Cada peça do puzzle vale por si só e deve ser capaz de fazer uma viagem interescalar permanente. A composição final, mais do que agrupar os mosaicos num todo coerente deve ser capaz de produzir novos deslocamentos na leitura de cada um dos capítulos. O objectivo é mover, dilatar e fazer proliferar cada pequeno exemplo, cada ilustração empírica, para outros lugares, ficando embora no mesmo lugar; de tal modo que se tenha a sensação de ter andado muito não obstante mal se tenha acabado de começar. Este método de trabalho torna também mais exigente a tarefa do leitor: não se espera que seja ele a reconstruir a totalidade, por que se chega a propor uma chave de leitura, mas espera-se a inscrição de novas interpretações na matriz inicial. Também por isso esta é uma obra com pressupostos mas sem seguranças.

Cada uma das partes do trabalho encontra-se dividida em capítulos: três na primeira parte e dois na segunda. O primeiro capítulo faz um excurso pelas teorias do Estado, apresentando rupturas que abrem pistas novas, não deixando de assinalar os impasses que se mantêm. Não obstante, será possivel elaborar um primeiro guião para a alternativa conceptual proposta, orientada pela ideia base de articular a problemática da construção discursiva da escola com as estratégias quase-anónimas capazes de coordenar acçōes dissemelhantes na sua origem, mas calculadas, positivas e planeadas no seu ponto de aplicação. Retomam-se assim os modelos que reconhecem nas relações de poder uma intencionalidade sem subjectividade. A problemática assim constituída orienta as escolhas realizadas quanto ao período e às fontes analisadas, apresentadas segundo um percurso metodológico.

O segundo capítulo desta narrativa traça um esboço inicial da governamentalidade num país semiperiférico. Esta está estribada em três pilares: pressuposto da descontinuidade, recusa da existência de um mandato educativo moral baseado em princípios e carácter contingente das tecnologias políticas usadas pelos sistemas educativos. O conceito de tecnologia de governo tenta responder à necessidade de articular as formas de conhecimento com os campos práticos e pragmáticos nos quais as capacidades e os comportamentos humanos são problematizados. Em contraste à tradição da chamada história das ideias ou das mentalidades, a nossa hipótese de trabalho suspende a questão epistemológica de uma forma mais severa, permanecendo neutral relativamente à reivindicação de validade das diferentes formas de conhecimento que examina. Em vez de analisar as credenciais epistemológicas das ciências sociais e humanas, que orientam certas práticas, tentamos examinar como operam e tornam possível certos regimes institucionais. 
O terceiro capítulo identifica as principais referências metodológicas da pesquisa. Recorrendo aos conceitos de texto, discurso e intertextualidade tentamos responder às duas principais dificuldades criadas pelo conceito de governamentalidade: como interpretar conjuntamente práticas e discursos que se relacionam de forma não causal? Como identificar os princípios e as regras estruturantes dos discursos educativos sem regressar ao nominalismo puro?

O quarto capítulo, já na segunda parte do livro, adentra-se na arqueologia do governo da educaçăo e nos seus afloramentos, apreciando os principais factores de impulso à crise institucional e ao aumento dos níveis de contingência burocrática. Arrancando com a análise da construção escolar e dos seus pontos de inserção nas políticas de gestão e planeamento do sistema educativo, apresenta-se um mapa discursivo das sucessivas formas de gerir e reproduzir a crise. O quinto e último capítulo traça o papel da criação do Ensino Secundário Unificado em resultado da recolocação de Portugal no sistema mundial e das novas problematizações do governo da educação. Faz-se a crítica da sua génese enquanto cumprimento de princípios igualitários de governo, recentrando a compreensão do seu papel na criação de uma nova cartografia de inserção espacial da escola e no surgimento de uma matriz social mais extensa e desagregada. A construção de uma nova subjectividade do aluno é a charneira do capítulo. Neste pilar, o nosso principal interesse consiste em demonstrar como a educação funciona como uma disciplina ética, por intermédio da qual cada indivíduo da geração mais nova se converte ele próprio em sujeito reflexivo de acção moral. Chamamos a este trabalho de experiência de si as novas tecnologias do eu. Não se trata de fazer uma sociologia das prescrições morais, mas de captar as práticas de relação consigo mesmo. O que nos interessa na construção das subjectividades são as técnicas utilizadas pelos indivíduos na sua reflexão sobre si e sobre a sua acção, como se conhecem a si próprios e se auto-examinam. As técnicas de si são práticas de reflexão voluntárias através das quais os alunos se procuram transformar a si próprios, fixar-se regras de conduta e modificar-se na sua singular forma de ser. Trata-se do principal dispositivo de autogoverno dos indivíduos, que se exerce continuamente sem necessidade que haja quem governe directamente a conduta de cada um.

O livro fecha com as conlusões. Reporta-se em filigrana ao quadro compreensivo inicial, tanto pela consideração do que, através da realidade empírica o permite aprofundar, como pelo que, eventualmente, o infirma ou interroga. Assim se retoma o movimento constante de rupturas, impasses e contribuiçōes teóricas conducentes ao aperfeiçoamento do quadro teórico inicial e à sugestão de prolongamentos teóricos e metodológicos. 


\section{PRIMEIRA PARTE}

MUDANÇA DE PROBLEMÁTICA:

DO ESTADO-EDUCADOR

À GOVERNAMENTALIDADE DA ESCOLA 
(Página deixada propositadamente em branco) 
«O sentido é sempre infeliz. $A$ análise é por definiçăo infeliz visto que nasceu da desilusão critica. Mas a lingua é feliz, mesmo quando designa um mundo sem ilusāo e sem esperança. Essa seria mesmo a definiçâo de um pensamento radical: uma forma feliz e uma inteligência sem esperança» Jean Baudrillard, O Crime Perfeito, 1996

A proposta teórica que apresentamos nesta Primeira parte insere-se no movimento de renovação dos paradigmas dominantes nas ciências sociais. Traduzir-se-á na utilizaçăo das virtualidades dos métodos arqueológico e genealógico propostos por Foucault, no sentido de superar algumas das dificuldades criadas pelas concepçōes nominalistas do Estado e da sua relação com a educação. No caso do método arqueológico pretende-se fazer uma história dos conceitos sem sujeito individual. Quer dizer: faz-se um recorte das estruturas linguísticas que definem os campos em que os sujeitos individuais operam. No caso do método genealógico opera-se com a pequena história das práticas e das instituições naquilo que contêm de continuidade e de resistência. Com efeito, não se procura analisar como é que o processo de ajustamento das decisões estatais - os níveis político e administrativo do sistema educativo - é mediado e regulado automaticamente pelos outros sistemas, sejam eles o Indivíduo, a Família, a Produção ou o Sistema Mundial. Contrariamente, procurar-se-á analisar as problemáticas de regulação inscritas na Governamentalidade e como é que esse processo nāo se circunscreve ao domínio do Estado, constituindo antes uma certa mentalidade de regulação e de regra do bom governo da população e de cada indivíduo. Regra que inclui todos os que de uma forma ou de outra enunciam as razōes e as justificações dos acontecimentos, mobilizam os meios e os recursos e determinam os objectivos e as finalidades para atingir tal desiderato. $O$ resultado deste esforço não será uma outra teoria geral do Estado, nem tão-pouco uma teoria orgânico-institucional da separação de poderes, mas tão-só uma outra análise da dinâmica do poder. 
(Página deixada propositadamente em branco) 


\section{Capítulo I}

\section{PROBLEMÁTICA}

1. Objecto de estudo e campo de análise

2. As teorias tradicionais do Estado

3. Problemática

4. As razōes de escolha de um período

5. Percurso metodológico

6. As Fontes e as suas limitações

\section{Objecto de estudo e campo de análise}

O Governo da Educaçăo em Portugal, 1974-1991. Legitimaçăo e Contingência na Escola Secundária é o título escolhido para a obra que lhe apresentamos. Importa desde logo situar a noçăo de Ensino Secundário e o âmbito da análise a que o sujeitaremos. O termo năo é aqui utilizado com o sentido que a Lei de Bases do Sistema Educativo Ihe dá desde 1986. O alargamento da escolaridade obrigatória para nove anos retirou o actual $3 .^{\circ}$ ciclo do ensino básico da morfologia do Ensino secundário. No entanto, porque este livro atravessa o período que vai de 1974 a 1991, incluímos também os três anos de escolaridade que actualmente fazem parte do Ensino Básico na noção de Ensino Secundário. Sendo o Ensino Secundário Unificado (ESU) uma das medidas de política educativa que mais marcaram o período analisado não faria sentido utilizar anacronicamente a terminologia actual. Acresce a isto o facto de em muitos estudos de educação comparada, bem como nas estatísticas internacionais da Unesco, o ensino secundário, tal qual o usamos neste trabalho, servir de referencial do segundo grau. 
O livro tem como âmbito de análise o Ensino Secundário num dado período, mas năo tem a ambição de fazer a história exaustiva do Ensino Secundário para esse período. Tăo-pouco pretende eleger certos temas para, a partir deles, fazer um recorte vertical da sua evolução. Contrariamente, optamos por um percurso simultaneamente mais modesto e mais exigente. Mais modesto, porque utilizamos o ensino secundário como campo de observação para um objecto de estudo situado em outro lugar: as tecnologias e as racionalidades que presidem à legitimação e à contingência do seu governo. Neste sentido, utilizaremos selectivamente aquilo que no ensino secundário serve para este objectivo. Por conseguinte não se estranhará a falta de uma descrição genérica do ensino secundário - morfologia, orgânica, estrutura, finalidades, composição curricular, organização pedagógica, organização administrativa, evolução demográfica, etc. - aquilo que tradicionalmente é designado como o enquadramento geral do objecto de observação.

Este livro regressa ao tema das relaçōes entre Estado e educação. Tema sujeito a preconceitos de toda a ordem, provocados pelo monopólio legítimo de o Estado estabelecer a gramática para falar de si próprio e das suas acções, mais sobrecarregado fica de subentendidos quando se escolhe um período coetâneo do investigador como objecto de estudo. Estudar as relações entre o Estado e a escola secundária no período posterior à queda do Estado Novo, mais precisamente entre 1974 e 1991, não está isento de obstáculos, dificuldades e armadilhas.

Desde logo obstáculos epistemológicos: existe uma ortodoxia de pensamento inculcada nas dúvidas, polémicas e verdades do tempo do próprio investigador que atravessam toda a comunidade educativa, que foi espectadora contemplativa, interveniente activa ou mero receptáculo do poder e da sua organização. Armadilhas metodológicas, também, decorrentes do fenómeno de auto-referencialidade dos sistemas políticos: as matrizes mentais a partir das quais estes se descrevem, explicam e justificam, validando-se, fazem elas próprias parte do sistema. Deste modo, existem sempre, no mínimo, dois níveis de leitura das fontes socio-históricas que derivam da análise do momento descritivo-legitimador do sistema e do seu momento constitutivoreflexivo. Finalmente, dificuldades na obtençăo e consulta das fontes. Ao contrário do que habitualmente se pensa, as fontes contemporâneas são muitas vezes de mais difícil acesso por força quer da falta de organização, da incúria ou de limitações legais. Acresce a isto que as fontes estão polvilhadas de palavras e de procedimentos mágicos que parecem dispensar a prova ulterior, porque inscritas nos limites de consciência dos actores presentes e, neste sentido, são simultaneamente fonte e quase-produção sociográfica. Aspecto que tem sido bem analisado por Giddens (1992), do ponto de vista da reflexividade da modernidade, será entendido neste tra- 
balho como a sua característica marcante. Com efeito não tomaremos os discursos enquanto simples descritores da realidade por que são eles próprios que constituem as categorias da realidade de que falam. É fundamental encará-las menos como referentes empíricos do que enquanto superfícies discursivas. Uma sociologia dos factos educativos apenas pode ser pensada na medida em que seja capaz de pensar a própria linguagem que os evoca. $\mathrm{O}$ facto de sermos nativos da nossa racionalidade limita-nos na aproximação à razão dos outros, embora nos limite, antes do mais, na entrada pretensamente distanciada das nossa próprias razões.

Por tudo isto trata-se de um tema sujeito à familiaridade excessiva, aconselhando um redobrado esforço de construção do aparato crítico, conceptual e metodológico, das suas premissas. É por essa razão que seguimos um percurso que, ao tentar tornar estranho o familiar, toma o presente como um território não transparente. A estratégia seguida para obter esse fim é a de fazer proliferar os pontos de vista, na busca de uma perspectiva que não se compraz na auto-suficiência, porque está ciente dos seus próprios limites. Desde logo, o projecto de revisão do problema envolve o debate com duas visões tradicionais do Estado igualmente limitadas: a visão que centra a análise do Estado-educador preferentemente nas lutas de interesses de classes e grupos sociais que disputam a hegemonia do seu governo e a visão que prefere a análise da evolução da lógica interna da forma político-administrativa do Estado. No primeiro caso estamos em presença de uma análise do que sendo exterior ao Estado o determina; no segundo caso poder-se-ia falar de uma visão estadual centrista.

O Estado regressou às ciências sociais como categoria incontornável de análise. Os estudos de educação comparada da última década registam um interesse crescente por este objecto de investigação. Porém, a literatura portuguesa sobre a escola secundária de massas apresenta uma evidente ausência de teorização do Estado. Embora se reconheça que a educaçăo pública é em primeira instância uma funçăo do Estado e que este tem assumido uma parcela cada vez maior na sua expansão, as reflexōes socio-históricas sobre o Estado são apenas residuais. Na maioria dos casos - Estado aparece como entidade reificada no seu papel jurídico e normativo, analisado que é a partir dos respectivos produtos legais. A ausência do Estado na análise crítica anda a par da sua presença massiva na realidade escolar e social. O sector público da educação controla grande parte da oferta educativa total e a maior parte da educaçăo secundária. Empregava $41,8 \%$ dos efectivos civis da administração central em 1978, tendo crescido para 48,7\% em 1991.(2) É a área funcional do Estado de que

(2) Fonte: Inquérito aos Recursos Humanos da Função Pública de 1991. Direcção-Geral da Administraçāo Pública, 1995. 
dependem mais cidadãos e que influenciou directamente a quase totalidade da geração que entra agora no mercado de trabalho. Proporcionou directamente o fenómeno de mobilidade ascendente com maior visibilidade social: nas décadas de 70 e 80 cerca de $50 \%$ dos professores ascendiam à nova pequena burguesia por intermédio do diploma escolar e do crescimento do sistema educativo. Tal capacidade de o sistema se auto-reproduzir, limitando os efeitos de imobilidade provocados pela inflação de diplomas e pela crise económica, ter-se-á mantido pelo menos até ao final dos anos 80.(3) $O$ Estado produziu deste modo cidadãos que se habituaram a ver nele a expressão colectiva e consensual de aspiraçōes individualmente construídas. Esta tradiçăo intelectual articula-se bem com a definição que o Estado dá de si mesmo segundo a qual representa o interesse geral, donde neutral, de grupos concorrentes. A teoria implícita que subjaz a muitos dos estudos que 0 definem a partir das suas funções e da avaliação dos resultados das suas políticas segue o mesmo tipo de pressupostos. Uma tal visão do Estado tende a observá-lo como um conjunto de departamentos, por intermédio dos quais a colectividade de funcionários se mostra mais ou menos apta para formular e concretizar estratégias e políticas.

Para além desta visão funcionalista e instrumental que tem progressivamente evoluído para uma teorização do mercado de bens públicos, o Estado e a educação têm sido estudados com outros dois escopos teóricos a que chamaremos o paradigma classista e o paradigma estadualista. No primeiro, o Estado é o produto do conflito de classes e serve o processo de dominaçăo. A tradiçăo marxista e neo-marxista está hoje separada na avaliaçăo que faz do grau de autonomia do Estado, enquanto mediador da luta de classes inerente à acumulação de capital, mas mantém o consenso quanto ao reconhecimento da dominaçăo como principal mecanismo de poder. Tal ponto de vista remete-nos quase sempre para a relaçăo do Estado com o exterior, seja com o capital, com a lógica da arbitragem de interesses ou, ainda, com a lógica da autonomia burocrática do Estado (Offe, 1975) determinada pela ausência de posiçōes de classe coerentes e hegemónicas na sociedade.

O ponto de inserção da análise estadualista é tecido de dentro: são as configurações organizacionais do Estado e os seus padrões de acção que afectam a cultura política, encorajando a formação de certos grupos, tornando possível o desenvolvimento de certas acções e não de outras, na prossecução do interesse público.

(3) A análise dos dados publicados no Relatório sobre a situação do professor em Portugal (1988) revela que a maioria dos professores tinha no momento da aplicaçăo do questionário uma posiçăo social superior à que tinham os seus ascendentes: $21.5 \%$ dos professores eram filhos de operários, $14.8 \%$ eram filhos de trabalhadores por conta própria e 13.9\% de trabalhadores agricolas. (In Análise Social, 103-104: 1187-1293). 
Contraposta ao Estado que, neste âmbito, delimita a sociedade política, apresenta-se uma sociedade civil privada de poder de realização político, animada apenas pela defesa dos interesses particulares. Torna-se entăo imprescindível fazer um primeiro contraste entre as teorias tradicionais do Estado.

\section{As teorias tradicionais do Estado}

No início do século poucas crianças e jovens frequentavam a escola primária. No final do século a quase totalidade dos jovens portugueses até aos quinze anos terão passado pelo menos nove anos na escola. Porque é que se passa mais anos na escola? Porque é que a educação se expandiu e se transformou na religião mundial do proletariado moderno (lllich, 1973)? Porque é que passamos de sociedades năo-letradas, agrárias, a sociedades de base escolar, cultivadas? A resposta năo é simples e nas duas últimas décadas acumulou-se uma literatura extensa, embora fragmentada e não raro inconsistente, que apresenta respostas contrastantes a estas perguntas, travejadas em pressupostos teóricos e filosóficos muito distintos. Estudos provenientes de campos tão diferentes como a história, a sociologia, a ciência política e a educação comparada têm resultado numa dificuldade acrescida de obter fertilizações cruzadas a partir do diálogo multidisciplinar. Nesta proliferação de pontos de observaçăo o próprio objecto de estudo sofre frequentemente deslocamentos que lhe dão contornos pouco claros.

Na tentativa de responder à questăo relacionada com a génese e a expansão da escola de massas encontramos tipologias mais ou menos extensas que se distinguem pela maior ou menor desagregação que fazem das correntes respectivas (Craig, 1981; Rubinson, 1986; Fuller e Rubinson, 1992; Morrow e Torres, 1995). Nesta introdução limitamos a nossa revisão a quatro dessas correntes, devido ao peso relativo que cada uma delas assumiu desde os anos 70 na literatura teórica e, ainda, ao volume de estudos empíricos que originaram. Referimo-nos ao modelo funcionalista, ao modelo conflitualista da dominação de classe, ao modelo sistémico e aos modelos da formação do Estado e da institucionalizaçăo mundial da educação. Não faremos aqui uma revisão global e extensiva destas teorias, por que delas existe uma extensa bibliografia. Faremos nesta secção uma discussão das visões contrastantes de três destes modelos a partir dos aspectos nucleares deste trabalho. No ponto seguinte analisaremos com mais detalhe os modelos da formação do Estado e da institucionalizaçáo mundial da educação, já que estes fornecem um enquadramento conceptual pertinente para a construçăo do nosso próprio modelo de análise. Embora reconheçamos 
limites e impasses nestas teorias, será a partir da análise crítica de algumas das suas aporias que a construção de um modelo alternativo se tornará possível.

\section{O Modelo Funcionalista}

O modelo funcionalista tem na hipótese do capital humano a sua expressão mais elaborada. Segundo esta hipótese os sistemas de educação de massas emergem onde se desenvolvem modernos sistemas de produção. A educação formaria capital humano como resposta às exigências do sistema produtivo em força de trabalho especializada. Incluindo-se na racionalidade funcionalista do esquema parsoniano, ${ }^{(4)}$ o modelo prevê que a oferta de educação por parte de uma instituição integradora nacional propicia o aumento das qualificaçōes que, por sua vez, garantem a entrada num mercado de trabalho mais bem pago e mais produtivo. Consequentemente, a procura acrescida de educação que esta relação positiva provoca tem um efeito de agregaçăo do capital humano medido por intermédio dos aumentos de produtividade e do Produto Nacional Bruto (Schultz, 1961, 1971). O conceito de modernização sintetiza as duas forças que agem sobre a expansắo da escola: cooperação à escala nacional, com o Estado secular a assegurar o interesse geral, símbolos e regras sociais partilhados e uma língua unificada; socializaçăo dos indivíduos de modo a adaptá-los à mudança de processos de trabalho, de relaçōes sociais e de ideais morais. O Estado cumpre um papel nuclear de superação das diferenças culturais, da fragmentação religiosa e linguística e da diversidade dos interesses particulares integrando-os numa formação comum supra-ordenada. A escola socializa as crianças incorporando-as nesta autoridade central, adaptando-as às modernas exigências das instituições económicas.

Porém, alguns trabalhos puseram directamente em causa a correspondência entre formação e mercado de trabalho postulada pela hipótese funcionalista, nomea-

(4) O conhecido modelo AGIL de Parsons conceptualiza a sociedade a partir de quatro subsistemas, cada um dos quais consistindo em um conjunto de normas institucionalizadas, articuladas para dar resposta aos quatro problemas funcionais da sociedade: adaptaçăo, realização de objectivos, integraçāo e latência. Este modelo continua a ter uma especial influência no modo como a modernização é conceptualizada. Com efeito, Parsons (1971) desenvolveu uma teoria da modernização assente no pressuposto da diferenciação funcional. Segundo este processo, os componentes individuais da acção, incluindo os valores latentes, as normas integrativas, os recursos adaptativos e os motivos săo integrados nas realizaçōes de sistemas funcionais diferenciados. A modernização produz um acréscimo de diferenciação estrutural e funcional que resulta na correspondente evoluçāo dos mecanismos de integração. A diferenciação da modernização contém assim uma cada vez mais complexa divisão do trabalho e uma racionalidade produtiva de inovaçăo e crescimento, enquanto a integraçăo assegura a estabilidade social por intermédio do sistema normativo. 
damente nos países mais desenvolvidos. A cultura letrada e a escolarizaçăo formal não estão ainda firmemente estabelecidas em muitos países da periferia do sistema mundial. Nestas condições, quando o acesso ao segmento secundário do mercado de trabalho está associado às credenciais escolares, os padrões de procura dos postos influenciam mais fortemente a expansão escolar. Nos países em que a sociedade tem uma base escolar institucionalizada, a estrutura do mercado de trabalho, as mudanças tecnológicas e os níveis de desemprego exercem muito menos influência na expansão da escola de massas (Rubinson e Ralph, 1984). Um fenómeno de natureza semelhante acontece nas relaçōes entre rendimento familiar e o género. Em regiōes de economia rural de subsistência as famílias dão mais oportunidades de os rapazes virem a prosseguir estudos secundários e a entrar num mercado de trabalho assalariado. Em contraste, as raparigas de algumas regiões urbanas da América Latina prosseguem estudos mais prolongados do que os rapazes (Duncan, 1985).

Uma hipótese crítica dentro do modelo funcionalista considera que a escola produz diplomas e não qualificaçōes. A hipótese da sociedade credencializadora sugere que a escola selecciona e hierarquiza os indivíduos a partir de critérios ocupacionais considerados relevantes pelo sistema económico de acumulação capitalista. Na medida em que este sistema de expectativas é institucionalizado no modelo escolar, os níveis de procura e de frequência escolar tendem a expandir-se (Collins, 1979). A escola mantém um valor assinalável para os empregadores, independentemente de as destrezas requeridas para o trabalho aumentarem realmente. Do mesmo modo, os jovens mantêm-se na escola por um tempo mais prolongado independentemente dos custos de oportunidade dessa opção. Neste caso, a expansão escolar é orientada pelo aumento de credencialismo que resulta da competição entre grupos sociais para se manterem ou se moverem entre estatutos sociais (Collins, 1979).

\section{O Modelo Classista}

O modelo classista parte de uma avaliação realista das sociedades modernas reconhecendo a sua profunda diferenciação de classes. Ao procurar clarificar o papel destas profundas clivagens de interesses, as teorias do controlo social encontram na educação de massas um dos principais mecanismos de legitimaçăo da estrutura social. Os princípios de igualdade de oportunidades e de equidade inscritos na escola seriam uma mistificaçăo. O modelo classista tem no controlo social o seu escopo explicativo: a educação escolar desenvolve-se como processo economica ou simbolicamente determinado de modo a que os grupos sociais dominantes imponham aos que menos recursos possuem a sua visăo do mundo, incorporando-Ihes estruturas 
de pensamento que os vinculam à estrutura de classes existente. Para Bowles e Gintis (1976) a escola inculca disciplina, pontualidade, responsabilidade individual e respeito pela autoridade que, conjuntamente, desenvolvem uma classe trabalhadora dócil e eficaz. Segundo Bourdieu e Passeron os mecanismos de violência simbólica reforçam o estatuto e o poder simbólico das elites num ambiente institucional aparentemente igualitário. E daí retiram a sua força reprodutora: «ora a cultura da elite está tão próxima da cultura da escola que as crianças originárias dum meio pequeno-burguês (e a fortiori dum meio camponês ou operário) não podem adquirir, a não ser penosamente, aquilo que ao filho das classes superiores é oferecido - o estilo, o gosto, o espírito, em resumo, todos esses savoir-faire e savoir-vivre, próprios de uma determinada classe e que são precisamente a cultura dessa classe» (Bourdieu e Passeron, 1964, 1981: 92).(5)

Para os autores como Bowles e Gintis que enfatizam o primado dos interesses económicos, o Estado não tem autonomia institucional suficiente para orientar políticas que se afastem do projecto de expansão capitalista. Estado e escola são parceiros institucionais de uma superestrutura que se confina a um papel de correspondência necessária com os interesses económicos. Nesta lógica, é a estrutura económica que determina a expansão da escola e o estatuto futuro destinado aos grupos sociais. $\mathrm{O}$ Estado serve de intermediário na conservação das diferenças de classe social, não proporcionando movimentos de mobilidade social ascendente. As evidências empíricas que demonstram a incapacidade de a escola determinar o nível académico ou o estatuto profissional, independentemente do estatuto herdado da família, seriam argumentos adicionais para a demonstração de que as práticas escolares fazem uma interpretação coerciva e restritiva do bem comum. A desvalorização das diferenças culturais dos grupos sociais de baixo estatuto seria um aspecto particular da imposiçăo de classe por intermédio do Estado.

Mais recentemente, a partir do final dos anos 70, esta óptica estruturalista tem sido contrastada pela visão da institucionalização da escola pelo Estado que, depois de obter um largo consenso mítico da sociedade, teria a capacidade de se reproduzir como sistema autoreferenciado com as suas regras, os seus rituais e formas de conhecimento, os seus métodos e estatutos próprios. Tendo em J. Meyer o principal impulsionador, simultaneamente um institucionalista organizacional, percebe-se bem

(5) As citaçōes da bibliografia são feitas em português sempre que exista uma traduçăo disponível considerada de boa qualidade. Porém, a regra adoptada neste livro é a de fazer a citação na língua original, remetendo assim para a terminologia e o contexto linguístico do autor. 
como esta corrente apresenta a proposta de diferentes níveis de análise que incluem as expectativas individuais, os grupos e as organizações no mesmo mecanismo de construçăo da confiança simbólica na escola. Daí a semelhança das escolas dos sistemas educativos ditos centralizados e dos sistemas ditos descentralizados: o isomorfismo năo dependeria tanto da específica forma de controlo burocrático, mas dos mitos arquetípicos que os atravessam.

Claus Offe estabelece também, a partir dos anos 70, um desenvolvimento importante para as teorias classistas do Estado, ao reconhecer o carácter dual do Estado capitalista e das suas formas organizacionais. Nesta fórmula de síntese, Offe (1975) considera que o Estado, ao reclamar o papel de representante oficial da Naçăo como um todo, é, simultaneamente, objecto e produto do conflito de classes. Agindo como um factor de coesão, o planeamento a longo prazo do Estado sintetizaria as finalidades de reprodução económica e social do capitalismo, ultrapassando não obstante as disputas e as necessidades de curto prazo dos capitalistas individuais ou dos grupos corporativos. Este é o resultado do carácter dual do poder político do estado capitalista, na medida em que «the institutional form of this state is determined through the rules of democratic and representative government, while the material content of state power is conditioned by the continuous requirements of the accumulation process» (Offe e Ronge, 1984b: 121).

A dominação política estabeleceria desta forma um sistema de filtros sucessivos, interpostos pelos processos político-administrativos, que assim assegurariam uma racionalidade estratégica objectiva. Esta resultaria menos de uma instrumentalização de classe exterior do que da própria estrutura interna do sistema político institucionalizado. É neste quadro que o conceito de selectividade é uma figura nuclear na teorização da autonomia relativa do Estado que Claus Offe (1984b) apresenta. A selectividade consiste numa restrição sistemática do espaço de possibilidades que, segundo o autor, age preferentemente em quatro niveis: na estrutura, na ideologia, nos processos e na repressão. A selectividade estrutural diz respeito aos critérios de relevância da política estatal, fixados legalmente ou de jure. A conservação e universalização da forma-mercadoria constitui o exemplo típico de selectividade estrutural. O facto de certos grupos económicos e profissionais serem mais favorecidos pelas decisões năo seria um objectivo em si, mas o resultado de premissas inscritas automaticamente no sistema político-institucional. A selectividade ideológica é reponsável pela maior ou menor diferença entre o espaço de actuação disponivel e o grau de actuação possível no quadro restritivo das normas ideológicas e culturais. A selectividade processual, por seu turno, age sobremaneira nos mecanismos de planeamento e administraçăo, nas assessorias político-cientificas e no processo legislativo. 
Estas instâncias, ao conferirem privilégio de tratamento a certos temas e grupos de interesse deixam outros na penumbra da não-decisão. O conceito de não-decisão, que interessará particularmente à nossa pesquisa, diz respeito à eliminaçăo ou apoucamento de certos temas, propostas e discursos antes que possam participar na arena da decisão. Embora este conceito provenha de uma lógica analítica típica dos modelos de decisão política, enquanto arenas de incerteza, que não constitui o pano de fundo da nossa metodologia, será utilizado como operador analítico das tecnologias de governo. Com efeito, de todos os discursos jurídicos, o discurso administrativo, frequentemente procedimental, é aquele em que é mais imediato o desnivelamento e a tensão entre participantes profissionalizados e não profissionalizados e, como tal, a linguagem técnica utilizada constitui um «acelerador da implantação persuasiva da normatividade e da decisăo que dela decorre» (Santos, 1980: 34-35). Finalmente, a repressão consiste na selecção por aplicação ou acção coerciva do aparelho estatal. Embora a acçăo repressiva seja um mecanismo selectivo residual, não devemos excluir da eficácia deste dispositivo a ameaça de accionamento inscrita na simples presença do conjunto de meios disciplinares que podem ser legitimamente mobilizados.

A selectividade estabelecida nas políticas educativas seria um dos exemplos mais simples da articulação entre o nível estrutural e o nível processual. Como bem argumenta Offe, os funcionalismos liberal e marxista falham o alvo de análise quando tentam interpretar a política educacional do Estado nas articulações funcionais entre certas qualificações e certas fileiras económicas ou formas de trabalho. «Pois ninguém (e muito menos a burocracia estatal) pode saber que capitalista necessitará de que tipos de qualificações, e em que quantidades. Parece ser mais fecundo interpretar a politica educacional estatal sob o ponto de vista estratégico de estabelecer um máximo de opçōes de troca para o capital e para a força de trabalho, de modo a maximizar a probabilidade de que membros de ambas as classes possam ingressar nas relações de produção capitalistas» (Offe e Ronge, 1984a: 128).

\section{O Modelo Sistémico}

A perspectiva sistémica da morfogénese dos sistemas educativos tenta escapar ao efeito de espelho no processo de elaboração teórica. Para Archer (1982), o conceito de morfogénese é essencial à apreciação extensiva dos elementos que compõem a auto-elaboração dos sistemas educativos no tempo e à sua articulação com o resto da sociedade. Reconhecendo que existem três grandes fases de evolução dos sistemas educativos - génese, crescimento e inflação - considera que estes devem ser analisados a partir das relações de conflito, negociação e transacção entre Estado, 
grupos organizados e actores individuais. Desta análise conclui que a génese da escola está determinada pela oferta e pelo conflito competitivo entre corporações. A interacção da oferta e da procura que este conflito pressupõe, amplia as alternativas educativas. A transformação de actores individuais em grupos organizados corporativamente para efeitos educativos é um dos mecanismos que contribui para a abertura da escola a novos grupos sociais. Deste modo se teria iniciado uma segunda fase marcada pelo aparecimento dos sistemas educativos estatais e pelo crescimento da oferta, pressionada esta pela competição entre classes sociais, grupos étnicos, grupos religiosos e profissőes. Visto que os sistemas educativos e as elites que os administram obtiveram uma grande autonomia neste processo, podem eles próprios autoproduzir a expansăo por intermédio da iniciativa interna. Para além deste processo de negociação Archer distingue ainda as transacções externas - através das quais grupos de interesses externos negoceiam directamente com partes do sistema - e a manipulação política, de acordo com a qual os grupos de interesses influenciam as políticas educativas estatais. A partir da dinâmica destes três processos a autora faz um esforço de análise da expansão inflacionária de educação e do correspondente abaixamento do valor dos diplomas, concluindo que essa é a consequência de um paralelograma de forças irracional e não pretendido. Ao contrário de todas as outras correntes, Archer coloca a hipótese de a expansão inflacionária ser um efeito que ninguém pretendia e que não é em nenhum sentido necessário.

As ciências sociais desenvolvem-se utilizando o aguilhão dos modelos e imagens contrastantes que dirigem o seu olhar em diferentes direcçōes. Frequentemente, porém, parece que teríamos de nos pôr nos ombros de gigantes para sermos capazes de ver a síntese de todos esses pontos de vista. Em todo o género de história é necessário ter a precaução metodológica de considerar que a génese e a finalidade dos fenómenos sociais são pontos separados náo apenas pelo tempo, mas pelas interpretaçōes sucessivas a que são sujeitos. Uma vez criada a escola, esta viu-se submetida a forças que a usam para fins distintos. A nossa síntese limita-se, também por isso, a um exercício pragmático proposto por Peirce: traçar as consequências operativas destes conceitos a partir de um conjunto de estudos empíricos tematicamente seleccionados. No sentido de contornar o efeito năo cumulativo dos estudos das diferentes correntes, tanto Archer (1982), como Craig (1981) e Torres (1996), realizaram sínteses dos trabalhos empíricos que permitem responder a algumas questões que revertem para a nossa problemática. Em conclusăo desse exercício năo programático, que pretende responder a uma necessidade metodológica anti-essencialista, é possível definir um conjunto de preocupações e contribuições para a nossa análise futura: 
1) Os estudos empíricos revelam consequências não esperadas no processo de consolidação da escolaridade de massas (Archer, 1982);

2) As iniciativas dos actores centrais e periféricos têm graus muito diversos de institucionalizaçăo (Archer, 1982; Torres, 1996);

3) A estrutura estratificada da escola intervém significativamente no formato da oferta-procura (Craig, 1981);

4) Os sistemas educativos têm autonomia relativa de decisão, mas não revelam autonomia estrutural semelhante aos sistemas doméstico ou da produçăo (Archer, 1982);

5) A morfogénese da escola de massas revela-nos padrōes institucionais homólogos no tempo longo - organização curricular, horários, espaços disciplinares - e processos oscilatórios muito significativos no tempo curto. Esta concepção submete o modelo do isomorfismo estrutural à possibilidade de não contemporaneidade das estruturas sociais e, portanto, à desigualdade do seu curso (Archer, 1982).

Se analisarmos estes estudos empíricos aceitando a sugestão metodológica de Archer (1982) e de Craig (1981), no sentido de considerar simultaneamente o lado da oferta e da procura de educação, verificamos que a maior parte das hipóteses de que fizemos a revisăo se separam na leitura que fazem dos outputs dos sistemas escolares: mais estatuto salarial e social para uns, maior controlo e mais integração política para outros. A revisăo dos estudos não parece aconselhar uma visăo tão unilateral do processo. Os indivíduos, os grupos e o Estado podem investir ou desinvestir na educaçăo por múltiplos objectivos e embora se possa verificar regularidade nos seus efeitos, tal não demonstra a sua necessidade. Esta apenas existe enquanto esforço teórico para limitar a contingência radical de que padecem.

\section{Problemática}

A escola de massas não se limita a prolongar e a ampliar as características do modelo escolar. A génese e a consolidação da escola de massas constituem processos de longa duração que se articulam no mesmo tempo e espaço da edificaçăo do Estado-Nação. A ocupação do território nacional, por intermédio de uma rede escolar que visa enquadrar o conjunto da população em formas racionais de pensar com a língua nacional, é a metáfora por excelência do Estado moderno. A escola ajuda a construir a subjectividade do cidadăo enquanto sujeito universal com direitos e deveres iguais perante o Estado nacional. Por intermédio da escola pública, o sistema de 
representação do mundo sofre um abalo importante que evidencia a articulação dos fundamentos da escola de massas com outros fenómenos, tais sejam:

1. A formação do Estado-Nação como projecto soberano unificado. A escola de massas é um dos principais suportes à criaçăo de dispositivos de pertença nacional e de ligação simbólica entre os indivíduos e o Estado. Simultaneamente, o reconhecimento dos Estados-Nações no sistema inter-estatal mundial tem na expansão isomorfa da escola de massas uma fonte legitimadora imprescindivel (Meyer, Ramirez e Soysal, 1992). Segundo estes autores, os atrasos e os fracassos nacionais resultam frequentemente em movimentos reformistas, nos quais jogam um papel fulcral as reformas educativas. Qualquer Estado que pretendesse entrar e ser reconhecido no sistema interestatal competitivo Ocidental deveria adoptar os modelos sociais, económicos e culturais dominantes, ainda que na forma de políticas abstractas. Segundo este argumento, é a integração do Estado-Nação no sistema mundial e nos seus modelos de legitimação da organização política que explicam as extraordinárias similitudes na expansão da escolaridade de massas e não qualquer variabilidade nacional.

Cruzam-se nesta argumentação duas tradições teóricas. A primeira, filiada no modelo da formação do Estado moderno, sublinha a sincronia e o isomorfismo dos processos de formação do Estado e de construção da escola de massas; a segunda, filiada nos modelos do sistema mundial, enfatiza a imposição de modelos culturais transnacionais na própria formação dos Estados modernos. De qualquer modo, os dois modelos encontram-se de acordo quanto ao reconhecimento que fazem de uma ontologia da modernidade sustentada numa escola que garante a incorporação da populaçăo nos novos Estado-Nação. Andy Green (1990), no seu estudo comparativo dos sistemas estatais de ensino em França, Estados Unidos, Inglaterra e Alemanha conclui que os mesmos fenómenos que contribuem para a formação dos Estados modernos estão na origem do desenvolvimento dos sistemas escolares. Ameaças militares externas, necessidades de reconstrução nacional e programas de reforma contra o atraso económico teriam determinado a emergência de um Estado moderno, com o respectivo monopólio da violência e dos impostos. Pelo seu lado, a escola estabeleceu o padrão de cultura nacional legítima (Bourdieu, 1994), por intermédio do qual o Estado assimilou as culturas imigrantes, encorajou os valores patrióticos, generalizou as formas racionais de pensar e engendrou a identidade nacional. Em síntese, Green considera que é a natureza do Estado e dos seus processos de formação que determinam a cronologia e a forma de desenvolvimento dos sistemas educativos, em especial o seu carácter centralizado ou descentralizado. Em qualquer caso, o Estado pretendeu construir cada pessoa enquanto sujeito universal, mas fê-lo 
de forma diferenciada segundo a classe e o sexo: formou o cidadão responsável, o trabalhador diligente, o contribuinte complacente, o jurado fiável, o pai consciencioso, a esposa fiel, o soldado patriota e o votante escrupuloso ou submisso (Green, 1994: 10).

Para os teóricos do sistema mundial esta diferenciação năo explica a construção e expansão homogénea da educação de massas. É a exposição a uma integração crescente dos países no sistema mundial, em especial a partir do final do séc. XIX, por intermédio do comércio, dos tratados, da representação diplomática e das organizaçôes internacionais que está na origem do desenvolvimento isomorfo da escola de massas ao nível mundial. $O$ que não significa que năo existam formas particulares de génese. Boli, Ramirez e Meyer (1985) identificam em especial dois modelos escolares: aquilo que designam como o modelo de criação de membros societais e o modelo de criação de membros do Estado-Nação. No primeiro caso, enquadram-se os países que, tal como os Estados-Unidos, têm uma estrutura de autoridade central relativamente débil, em favor de estruturas sociais menos centrais. No segundo caso, enquadram-se a maioria dos países em que a escola se tornou o veículo por excelência da criaçăo de vínculos de lealdade ao Estado, produzindo cidadãos cuja identidade primeira é a de aceitar as obrigações de votar, guerrear e pagar impostos.

Poder-se-ia pensar que, também neste campo, os pontos de vista de Green e dos autores do sistema mundial se sobreporiam. Não parece, no entanto, ser esse o caso na medida em que o que resulta da apreciaçăo de Green é a constituiçăo de uma dicotomia entre sistemas educativos centralizados e sistemas educativos descentralizados, que o conduz à conclusão de que os sistemas centralizados estăo melhor colocados para montar um sistema educativo mais sistemático e capaz de se desenvolver. Enquanto no segundo caso resulta uma dicotomia matizada em torno da expansão do sistema escolar e da expansão da retórica legal e institucional, que os conduz à conclusão de que, em regra, a massificação da escola foi mais tardia onde a construção estatal dominou.

2. O estabelecimento de estruturas cognitivas que impõem um acordo tácito sobre as formas de visão e classificação do mundo que assim contribuem para a construçăo da identidade nacional (Bourdieu, 1994). A génese do campo burocrático estatal é o culminar de um processo de concentração de diferentes formas de capital, do monopólio da força física ao monopólio do capital simbólico que, desse modo, definem um campo de poder e uma gramática imanente a todos os sujeitos da nação. Tal enquadramento das práticas pelo Estado inculca uma doxa perceptiva e disposiçōes do corpo comuns que asseguram a integração nacional. Integração territorial, por intermédio da centralização geográfica — o aparecimento da capital — 
e da representação cartográfica da unidade territorial; integração económica, em virtude da criação de um espaço económico nacional suportado pelos impostos; integração linguística, através da definição de um padrão escolar comum e a consequente redução dos dialectos; integração jurídica, por força da submissão do direito particular ao primado da lei e desta ao código; integração social, em virtude da abolição ou atenuaçāo dos privilégios de nascimento. A escola de massas é parte integrante deste projecto de exclusividade e indivisibilidade do poder do Estado por intermédio de uma aculturação uniforme. A declaração dos princípios de obrigatoriedade e universalidade da escola primária, no primeiro quartel do séc. XIX, é, simultaneamente, acompanhada pela estabilizaçăo das suas principais garantias simbólicas. Na transição do século consolidam-se em definitivo as estruturas cognitivas que garantem o reconhecimento, legitimação e confiança na escola: alunos agrupados em classes de composição graduada e homogénea; espaços escolares exclusivos e separados que privilegiam a intervençăo pedagógica centrada na sala de aula; ritmos escolares diários, semanais e anuais que permitem a regulação social do tempo; divisão e organização disciplinar do conhecimento, enquanto controlo estatal do trabalho pedagógico; professores credenciados pelo Estado para, em nome do bem comum, serem mandatários do projecto social e político da modernidade.

3. A emergência de uma sociedade governamentalizada (Foucault, 1991) que provocou um movimento em duas direcções. Por um lado, baniu os princípios morais absolutos da esfera do governo, elaborando para tanto a doutrina da razão de Estado: a segurança e a prosperidade do Estado passavam a ser fins em si mesmos. Por outro lado, definiu a esfera da consciência individual como esfera de governo: cada sujeito devia escolher livremente as suas preferências, por intermédio de um exame racional de princípios morais concorrentes. Estes dois movimentos articularam-se na forma que hoje conhecemos como escola de massas.

O desenvolvimento de uma nova racionalidade de governo da escola está ancorada na aliança de duas tecnologias políticas e intelectuais com origem histórica diversa e aparentemente contraditórias: a tecnologia pastoral cristã de governo das almas e a tecnologia burocrática do Estado de governo da população (Hunter, 1994). A primeira, inspirada nas disciplinas espirituais de governo do eu, especialmente a confissão, tem expressão na relação pastoral do professor com o aluno, na sua particular mistura de vigilância e auto-exame, exemplaridade e autodesvelamento, obediência e auto-reflexão, controlo e autovigilância. Na tradição das disciplinas espirituais, a relação pedagógica contemporânea dá origem à problematização ética individual e à auto-responsabilizaçăo. O conceito de práticas éticas distingue-se aqui do domínio da moral que define sistemas universais de obrigação e interdição. A ética refere-se a 
tipos específicos de práticas que fazem de cada um o sujeito próprio de atençăo e solicitude. Entre outras tecnologias, o exercício escolar estabelece um novo contexto para o desenvolvimento das técnicas corporais, por intermédio de regimes moleculares que regem o movimento no tempo e no espaço. $O$ exercício escolar filia-se na tradição das disciplinas ascéticas monásticas e não se funda em princípios, mas em práticas de disciplina cujo objectivo é criar pessoas capazes de orientar-se por principios. Os exercícios da vida ascética constituíam tarefas de complexidade crescente que permitiriam a aquisição progressiva do saber e da boa conduta no caminho da perfeiçăo. À imagem da técnica espiritual, o exercício escolar permite uma regulaçăo permanente do indivíduo por si próprio e pelos outros. As tarefas repetitivas, mas de complexidade crescente, destinam-se a produzir atitudes individualmente caracterizadas, mas de utilidade colectiva. Embora Foucault (1975) enfatize no exercício escolar a orientação do mestre exemplar, que desse modo impõe um aperfeiçoamento autoritário do aluno, parece imprescindivel ver também o lado de auto-reflexão e de auto-regulação que este permite. Philippe Ariès $(1960,1973)$ situa-nos claramente nesse outro lado quando se refere ao papel da leitura silenciosa na consolidaçăo das práticas de reflexão solitária. Com a Segunda Reforma, iniciada pelo pietismo, a relação individual com a Bíblia é uma exigência nos países de tradição protestante, tornada universal quando os Estados passam a ter a exclusividade dos programas escolares. Ora, esta maneira de ler, que toca o leitor no seu íntimo teve, segundo Chartier (1990: 127), uma profunda influência na nova subjectividade da modernidade: «para aqueles que estão aptos a praticá-la, a leitura silenciosa abre horizontes inéditos. Antes de mais ela transformou radicalmente o trabalho intelectual, tornado, na sua essência, um acto da intimidade individual, um confronto pessoal com textos cada vez mais numerosos, uma memorização e um cruzamento de referências visualmente assinaladas nos livros. Permitiu em seguida uma piedade mais pessoal, uma devoção mais privada, uma outra relação com o sagrado, diferente da que era regulada pelas disciplinas e mediações eclesiásticas». O mesmo poderíamos dizer dos exercícios escritos que, ao oferecerem uma constante tentação à fuga à norma, são parte de um constante incentivo ao autogoverno do comportamento. Individualizaçăo e totalização caracterizam assim as técnicas pastorais escolares. Por outro lado, as tecnologias de cálculo e governo da população, respondem à necessidade de governar um sistema de educação de massas, por intermédio da problematizaçăo das capacidades das gerações mais novas da população. A noçăo de economia descentrou-se da família para revelar as regularidades da população: as estatísticas dos mortos, das doenças ou dos ciclos de escassez revelavam os efeitos agregados da população e a sua irredutibilidade à família. 
O exame constitui a tecnologia disciplinar que, no contexto escolar, estabelece a arte de governar a população e, simultaneamente, estabelece as estruturas cognitivas que tornam aceitável e necessário pessoas calculáveis (Hacking, 1986). Segundo Foucault (1975), o exame é introduzido na escola do século XVIII, com profundas repercussōes no modo como a mente ocidental organiza e trata o conhecimento. O exame estabelece um novo contexto para o desenvolvimento das técnicas intelectuais da leitura, escrita, memória e cálculo. Apesar de o exame já existir anteriormente em instituições universitárias medievais, na forma oral e não graduada (Hoskin, 1979), é no século XVIII que se desenvolve na sua forma moderna de exame escrito graduado. O exame moderno manifesta um novo poder da escrita. Em primeiro lugar, porque converte o aluno num campo onde o conhecimento deve ser vazado e difundido; em segundo lugar, porque torna possível a constituição de um arquivo escrito sobre a performance individual do examinado e a sua posição relativa numa população de examinados; em terceiro lugar, porque estabelece a norma da população escolar e respectivos desvios. A consolidação desta tecnologia permite que a aprendizagem se faça hoje sob um regime de escrita, exame e graduaçăo e a sociedade se organize segundo um regime de produtividade e performatividade. Um novo complexo de saber-poder se consituiu com a possibilidade de estabelecer, pela primeira vez na história, uma medida objectiva do valor humano. Se nos fixarmos neste plano podemos compreender a descriçăo histórica de Hoskin e Macve (1994: 70): «the mark functioned both as an account of past performance, and as a currency conveying a quantified expression of human value; when aggregated, marks became a measure of the underlying competence or 'ability' of the self, and by extension of the population of selves». (6) Durante muito tempo os comportamentos individuais estiveram ao abrigo da descriçăo. Conhecer o valor de cada um, por intermédio da sua história de vida, estava reservado a um restrito grupo social. Em todo o caso as narrativas de vida visavam constituir uma memória-monumento. Doravante não se tratava mais de constituir um «monumento para uma memória futura, mas um documento para uma utilização eventual» (Foucault, 1975: 193). O homem memorável dá lugar ao homem calculável. Graças ao aparelho administrativo que acompanha as técnicas de notação, registo e arquivo dos exames é possível estimar o valor de cada indivíduo e,

(6) Estes mesmos autores distinguem claramente a dimensăo de avaliação objectiva do valor individual, presente no exame moderno, da ordenaçăo simples, presente nos sistemas de graduaçăo utilizados pelos colégios jesuítas. Enquanto estes visavam a emulação dos melhores, por intermédio da comparaçáo, o exame confere um valor autónomo de cada desempenho individual, integrando-o em normas da população escolar. 
simultaneamente, apreciar e caracterizar os grupos. Por um lado, nasce uma nova modalidade de poder, em que cada um recebe como estatuto aquilo que parece ser o seu valor intrínseco; por outro lado, institui-se a repartição das diferenças individuais no conjunto da população. Num único lance, o Estado inicia a construção de uma estrutura de oportunidades universal, formas de mérito padronizadas e estratégias de obtençăo de estatuto em adulto.

A educação escolar sintetiza desta forma os ideais de modernidade de um sujeito autónomo e livre que se revê numa imagem de si nacional. Encarregada de transmitir, generalizar e tornar parte do senso comum as ideias de progresso linear e de racionalismo, a escola faz parte dos grandes mitos fundadores dos nacionalismos europeus, articulando individualizaçăo e totalização: o mito do indivíduo; o mito da nação enquanto agregado de indivíduos; o mito do progresso individual e nacional; o mito da socialização e da continuidade do ciclo de vida e o mito do Estado enquanto guardião da nação (Ramirez e Boli, 1987).

4. O advento de uma sociedade dos grandes números (Hacking, 1990) baseada na enumeração e nas estatísticas das pessoas e dos seus comportamentos. Segundo a célebre lei dos grandes números, a dispersão dos valores assumidos por um determinado elemento, no interior de um sistema, é da ordem da média, o que significa que as flutuaçōes podem ter um valor absoluto grande, embora o seu valor relativo tenda para zero para um $\mathrm{N}$ suficientemente grande. Dito de outra forma, desde que o sistema seja suficientemente grande, as suas flutuações, ainda que aparentes, são residuais e desprezíveis.

A lei dos grandes números figura nas obras clássicas do cálculo de probabilidades, como a lei da Gauss, desempenhando um papel central na descrição e administração dos comportamentos de uma população. O próprio conceito de população é inextricável desta lei. Seria impossível prever o comportamento demográfico, social e económico de uma população se as flutuações pudessem a qualquer momento pôr em causa o comportamento médio. Deste modo, garante-se a existência de pessoas calculáveis num contexto de indeterminação. A administração do Estado-Nação classifica e inscreve em tabelas e estatísticas, tanto mais, quanto maior é a indeterminação da situação. São os números das doenças, das contaminações, da pobreza, do crime, do suicídio e da loucura dos cidadãos que, em grande medida, inventam a normalidade e provocam a erosão do determinismo. A avalanche de números e das estatísticas corporiza novas classificaçōes de fenómenos sociais numa linguagem e num vocabulário que capacitam um novo tipo de intervenção das tecnologias administrativas do Estado: «the printing of numbers was a surface effect. Behind it lay new technologies for classifying and enumerating, and new bureaucracies 
with the authority and continuity to deploy the technology. There is a sense in which many of the facts presented by the bureaucracies did not even exist ahead of time. Categories had to be invented into which people could conveniently fall in order to be counted. The systematic collection of data about people has affected not only the ways in which we conceive of a society, but also the ways in which we describe our neighbours (Hacking, 1990: 2-3).

As técnicas de inscrição e acumulação de factos sobre a populaçăo, a economia nacional, a doença ou a pobreza não se limitam a descrever a realidade. Constituem espaços imaginados, delimitados por uma grelha de normas onde a administração pode intervir. Pasquale Pasquino (1978) no seu trabalho sobre a genealogia do Capital enumera as tarefas de polícia apresentadas por Obrecht e Von Justi nos tratados de governo alemães dos séc. XVII / XVIII: informação fixada em quadros estatísticos sobre o estado das populações e do território, nomeadamente no que diz respeito ao número de pessoas, de nascimentos e de mortes, crimes, actividades económicas e outros recursos; um conjunto de medidas que permitisse o aumento da riqueza da população e o aumento dos recursos financeiros do Estado; finalmente, a felicidade da população. Obrecht resumia estas funçōes na fórmula latina census e censura, que significava o dever de cada um pagar as suas taxas e de os poderes públicos cuidarem da vida de todos e de cada um.

Como bem se percebe, o termo polícia não é aqui utilizado com o significado que tem nos nossos dias, designadamente o significado administrativo de manutenção da ordem e prevenção dos perigos, que é mais tardio e se pode situar na transição para o séc. XIX. No séc. XVIII, a ciência de polícia constituía um corpo de saberes e de práticas que tinha vastos domínios de intervenção que iam da religião aos costumes, da higiene à saúde, do comércio aos estabelecimentos de alimentação, dos pobres aos criados, das estradas à construção civil. Tratava-se da ciência do governo, da riqueza, da virtude e da felicidade das populaçóes o que implicava, em primeiro lugar, no entender dos seus publicistas, a acumulação de informação precisa sobre o seu estado.

Para ser exercido o poder precisava de saber. Em contraste à antiga sociedade de ordens, a população demarcava um território com novas divisões sustentadas em racios de mortes, nascimentos e idades. Ao separar os indivíduos em unidades específicas, ainda que abstractas, que podem ser calculadas, organizadas e problematizadas, as práticas de governo, sustentadas pelo conhecimento das ciências sociais, articula o Estado com a consciência individual. Como sublinha Foucault (1994: 29): «uma das grandes novidades nas técnicas de poder, no século XVIII, foi o aparecimento, como problema económico e politico, da 'população': a população-riqueza, a popula- 
ção-mão-de-obra ou capacidade de trabalho, a população em equilibrio entre o seu crescimento próprio e os recursos de que dispõe. Os governos apercebem-se de que não estão apenas diante de súbditos, nem sequer de um povo, mas de uma 'população', com os seus fenómenos especificos e as suas variáveis próprias: natalidade, morbilidade, duração da vida, fecundidade, estado de saúde, frequência das doenças, forma de alimentação e de habitat».

Uma vez que o governo é concebido nos termos da gestão óptima de um território e da sua população, a sua intervenção é multiplicada por uma infinidade de domínios, da segurança à saúde e à disciplina moral, cada um dos quais é crescentemente controlado pelo seu próprio pessoal especializado. Um dos aspectos deste problema económico e político da população é a educação escolar. É preciso saber o número de inscritos e a sua idade, o número de escolas e a sua localização, o tipo de escolas e os métodos utilizados, o número de professores e a sua qualificaçăo. Através das estatísticas escolares forma-se um sistema normalizado e periódico de recolha de informaçōes sobre a situação da rede escolar. O processo de categorizaçăo da educação introduz uma função importante num meio onde se privilegiam as transacções sociais e interpessoais: a função de preservaçăo e estabilização do envolvimento social. A genealogia do sujeito escolar faz-se antes do mais a partir do lugar da anormalidade e do comportamento patológico. As categorias estatísticas dăo a quem as usa uma sensação de conhecimento e, consequentemente, uma forma de intervir, programar e controlar as anomalias. Todo um conjunto de assunçōes e expectativas são mobilizadas a partir do processo classificatório, ficando o indivíduo sujeito a comportamentos, maneiras de pensar e contextos que alteram as suas circunstâncias de vida. Tal controlo é feito a partir da multiplicaçăo dos olhares vigilantes de todas as instituiçŏes que, de perto ou de longe, contactam com a educaçăo e implica um registo contínuo, actualizado, das observaçōes e exames: professores, médicos, higienistas, juristas, penalistas, inspectores participam nesta corrente de informação. Constitui-se assim uma pirâmide contínua de olhares, no topo da qual se encontra a administração do Estado.

A multiplicação dos olhares é uma indicação repetida e actualizada em todos os textos sobre técnicas de diagnóstico e observação, especialmente a partir do momento em que são introduzidos, massivamente, os testes de inteligência e a higiene escolar. Esta técnica de poder só se torna eficaz se for perene, permanente e tiver uma organizaçăo piramidal. O registo contínuo faz-se a partir das fichas e da transferência da informação de baixo para cima, de modo a que nenhum acontecimento ou intervenção escape a esse saber. Este sistema de controlo tem por alvo a singularidade do indivíduo. Na individualização, o poder do exame - escolar, médico e psicológico - 
aparece como instrumento fundamental. A ficha constitui o procedimento mais poderoso para o exercício da vigilância permanente e classificatória que, ao permitir julgar, medir e localizar introduz os indivíduos num domínio que necessita do planeamento e da gestão governamental. Ainda hoje o historiador pode confirmar que este é o arquivo mais extenso e disponível para a sua observação.

A quem observa, diagnostica ou examina não cabe apenas esperar pelos momentos críticos que levam ao encontro das habilidades, da inteligência, das doenças ou das desigualdades. Estas devem ser suscitadas, provocadas por rituais, atraídas por exames, apanhada na complexa rede de produção da prova. O indivíduo é submetido a um ritual de produção da normalidade/anormalidade do seu comportamento, que se objectiva num método a todos acessível e que classifica um objecto permanente do conhecimento. A ficha e o verbete estatísticos não são mais do que um aspecto particular do desenvolvimento das estruturas do Estado e da sua infiltração nos comportamentos sociais e profissionais dos que, como os médicos e professores, cumprem funções de controlo social na escola. Partindo de um pressuposto de universalidade, impõe-se um objecto de conhecimento que deve ser reconhecível e aceite por todos como sendo natural, estável e manipulável. O princípio é válido para todos os acontecimentos do contexto escolar, sejam eles de natureza cognitiva, moral ou de higiene e saúde. À incerteza e à angústia da anormalidade escolar ou da doença que a acompanha, como fenómenos provocados pela ignorância das famílias, responde o poder médico-pedagógico-administrativo com métodos de intervenção normativos (Reese, 1986): determinando uma higiene pública e directivas para o uso de todos e propondo mecanismos de observação, taxonomização e controle da higiene. No cume deste projecto está o olhar da estatística que não se limita a ver: interroga, espera respostas, penetra as coisas e supõe a reflexividade normativa do olhar. Nestes termos, a administração estatal deve ser entendida como a tentativa de optimizar os vários domínios de governo, por intermédio de conhecimentos especializados, e não como o exercício de um mandato moral ou legal.

\section{As razões de escolha de um período}

Esta obra tem como limites temporais dois acontecimentos políticos e educativos: o golpe de estado que derrubou o Estado Novo em 1974 e a saída de Roberto Carneiro do Ministério da Educação em 1991. A montante, escolhe-se o ano de 1974, porque sendo o ano da transiçấo do regime corporativo e de ditadura para o regime de democracia parlamentar, ele define também um momento decisivo de constru- 
çăo da escola secundária de massas em Portugal. Se bem que a expansão do ensino secundário já mostrasse sinais estatísticos evidentes desde os anos 60, foi a partir de então que, tanto do lado da oferta como, sobretudo, do lado da procura se conjugaram efeitos e expectativas sinérgicas. A jusante, selecciona-se o ano de 1991, porque ele marca a saída de cena do Ministro da Educação que, depois do 25 de Abril, teve a presença mais prolongada no Ministério e, simultaneamente, apresentou propostas de reforma estruturantes num discurso educativo sistemático. O período de quatro anos em que Roberto Carneiro esteve à frente do Ministério corresponde ao máximo de consciência possivel dos reformadores da educação em Portugal. Neste sentido, é um período que prolonga as grandes tendências que se desenham desde 1974 e dá início às orientações que marcam toda a década de 90 .

A escolha deste período cronológico deve, porém, ser acompanhado de algumas exigências metodológicas. Marcado que está por acontecimentos político-institucionais, a selecção deste período não arrasta opções teóricas e conceptuais suportadas por uma visão estritamente estadualista ou institucional dos acontecimentos educativos. Os limites cronológicos não definem pontos fixos de um espaço estrutural que desse modo se teria desenvolvido do momento $A$ para o momento $B$; tão-pouco estabelecem o tempo em que a materialidade da sucessão de acontecimentos pode ser unificada e tipificada em sujeitos e grupos específicos. Os acontecimentos mais próximos não serão filiados em acontecimentos precedentes como se neles tivessem a sua necessária origem. Contrariamente, os limites cronológicos registam apenas uma orientação temporal para o mapa das relações que os sujeitos assumem nos espaços específicos em que circulam; săo estes espaços ou regiōes que delimitam os modos como certas tecnologias e racionalidades, com origens diversas, chegam a um encontro de formas e passam a articular-se em rede.

As práticas contemporâneas serão observadas na sua arqueologia, isto é na contingência histórica que as gerou. Com este conceito, adaptado de Foucault, queremos desvendar o conjunto de regras que constituem o campo onde discursos, tecnologias e racionalidades coexistem, vingam e perecem. Para Foucault (1991: 59-60) este conjunto de regras define, num certo período histórico e para uma dada sociedade, os limites do dizível, as formas da sua conservação, os modos e as formas de memorização e de reactivação de certas formações discursivas e os limites da sua apropriação. Foucault compara o método arqueológico com a descriçăo de um arquivo. Não um arquivo constituido por uma colecção de textos de um determinado período, mas enquanto regras da elaboração e condições de existência de certos discursos. $\mathrm{O}$ autor sugere cinco critérios metodológicos para definir as regras das formaçôes discursivas: (a) os limites e as formas do dizivel (De que se pode falar? De que não se 
fala?); (b) os limites e as formas de conservação do discurso (Que locuções estão destinadas a entrar na memória? Quais as que estão destinadas a desaparecer?); (c) os limites e as formas de memória (Que locuções são consideradas válidas, inválidas e discutiveis? Quais foram abandonadas como negligenciáveis ou aberrantes?); (d) os limites e as formas de reactivação dos discursos (Entre os discursos de períodos anteriores quais foram retidos e valorizados? Que processos de transformação sofreram?); (e) os limites e as formas de apropriação (Que indivíduos e grupos sociais têm acesso a certas formas discursivas? Que lutas se desenvolvem entre grupos sociais, nacionais, culturais e étnicos?).

A metáfora temporal, fundadora do pensamento moderno (Perelman, 1969, 1971), está ancorada numa visão progressista e melhorista da sociedade. O tempo é aparentemente linear, unidireccional e irreversível. Neste trabalho cederá o passo a uma visão que privilegia a metáfora espacial. A metáfora evolucionista favorece a ideia de mudança e desenvolvimento linear de formaçōes discursivas homogéneas. $\mathrm{Na}$ tentativa de analisar as práticas institucionais, sem depender das formas de auto-reflexividade produzidas pelos profissionais que as gerem e dirigem, a história e a sociologia refugiaram-se no estudo dos interesses e do impacto social das políticas. Com esta metodologia não obteríamos mais do que a datação das políticas e dos seus resultados: o passado estaria sempre grávido de presente e este tenderia a ser visto como o efeito de certas condiçōes históricas precedentes. Mas outra parece ser a história da difusão e do ponto de aplicação das tecnologias de governo da educaçăo. Como veremos, o seu carácter disperso e sedimentar, à imagem de estratos geológicos, torna muito duvidosa a ideia de ciclos temporais com um princípio e um fim. Não é verosímel, por exemplo, que tenha existido um ciclo de quantidade seguido por um ciclo de qualidade no sistema educativo português, na versão positiva de um certo funcionalismo. E tão-pouco parece verosímil que tenha existido uma época de restrição de acesso à educação para as classes populares, seguido por um período de dominação por intermédio de dispositivos curriculares inigualitários, implantado pelas classes dirigentes, na versão negativa de um certo marxismo. Ambas as versões laboram a partir de limites metodológicos: tentam explicar porquê e como acontecem os fenómenos, mas não o que acontece contemporaneamente. Melhor: o que acontece é tido como um prolongamento lógico dos efeitos verificados; ou como o resultado necessário de certos pressupostos históricos. Deste modo, deixam de fora as formas de auto-organização da instituiçăo escolar, os seus discursos legitimadores e crises bloqueadoras, as suas tecnologias próprias e os efeitos não esperados que produzem. Pelo contrário, a metáfora espacial reconhece com maior facilidade a dispersão de acontecimentos e a deslocação dos sujeitos dentro das regiōes definidas 
pelo mapa das suas posições iniciais. Preocupa-se mais com a existência contemporânea de uma linguagem e de um vocabulário próprios, que dotam certas tecnologias de governo da capacidade de se articularem sem que nada as obrigasse na sua origem histórica a fazê-lo. O espaço é aqui definido por fronteiras de inclusão/exclusão discursivas e năo por referências físicas; por conexões entre práticas e não por referências topográficas estáticas; por montagens de rotinas, hábitos e técnicas com origens diversas e não por arquitecturas rígidas. Opus incertum diziam os latinos para designar as obras arquitectónicas feitas de pedras irregulares cujo ajustamento se ia realizando. Esta ideia de montagem de um espaço que não é dado na ordenação anterior dos seus elementos é a metáfora ideal para estabelecer as possibilidades de articulação de elementos sem contiguidade temporal.

Pretende-se assim superar a hipótese desenvolvimentista segundo a qual o agora está sempre presente no então. A mudança é entendida como um fenómeno intrínseco ao movimento ou à actividade. Embora a hipótese desenvolvimentista tenha surgido de um princípio ex-nihilo, surge com todas as aparências de acreditar na evolução. De acordo com Blumenberg (1983), a elaboração do conceito de época pertence à historiografia moderna que designou a sua própria época como inaugural, permitindo assim construir uma consciência aguda de separaçăo em relação ao passado. $\mathrm{O}$ advento da modernidade marca uma ruptura com a autoridade da tradição religiosa e resulta no aparecimento de uma necessidade de autojustificação e de legitimidade. Dentre os fundamentos legitimadores, o poder do sujeito auto-reflexivo surge como a origem de todo o conhecimento. A escola seria o meio por intermédio da qual uma sociedade de indivíduos racionais escolheria livremente a forma da sua própria formação social. A filosofia liberal identifica este princípio com o desenvolvimento humano completo. A sociologia crítica de tradiçăo neo-marxista investe os processos colectivos desta mesma funçāo de orientação da humanidade no desenvolvimento integral das suas capacidades. É contra estas teses que se insurge lan Hunter em Rethinking the School (1994). A reflexăo aí desenvolvida vai contra a corrente das posições de princípio que tentam legitimar a escola de hoje a partir de uma certa imagem da personalidade, auto-reflexiva e autodeterminada, de acordo com a qual se pretende ver, em tudo o que os sistemas educativos produzem, o êxito ou fracasso de um certo mandato fundado em princípios morais. Hunter, ao interrogar a possibilidade de utilizaçăo de certos princípios educacionais na compreensão da escola, conclui pela negativa, por que aqueles são incompatíveis com a sua teoria da escola, segundo a qual a sua genealogia não radica em princípios morais, políticos ou outros. A escola é uma realidade improvisada resultante da montagem de certas tecnologias morais e governamentais disponiveis numa dada contingência histórica. 
Isso implica a criação de uma distância metodológica em relação aos princípios inscritos na escola, isto é, a possibilidade de analisar a adesão a tais princípios como uma prática com uma história própria, contemporânea e do mesmo nível da história da construção da própria escola.

Um estilo de redacção que integre os acontecimentos numa linha de tempo diacrónica ajuda a uma representação linear da história. Para um olhar treinado por esta representação, uma escrita assente na metáfora espacial parece cronologicamente lacunar e nilista na forma. Mas esse é um efeito intencionalmente procurado. $\mathrm{O}$ vaivém constante entre acontecimentos situados em momentos diferentes resulta da datação múltipla a que foram sujeitos: a invenção de certos conceitos nem sempre coincide com a cronologia da sua aplicação e muito menos com os efeitos que induzem. O esvaziamento do mandato moral que supostamente funda os sistemas educativos resulta da rasura a que sujeitamos o ideal de reflexividade que, desde o século XIX, orienta as ideias de legitimidade, liberdade e comunidade das correntes críticas e progressistas.

\section{Os Arquivos e o percurso metodológico}

Este trabalho desenvolve-se em três fases distintas no seu conteúdo, mas interdependentes nos seus produtos e consequências. As fases não representam aqui qualquer estatuto de precedência epistemológica, mas antes um procedimento metodológico que observa de diferentes ângulos, e activa de formas diversas, os campos de análise para, mais tarde, os reconstruir numa visão de conjunto. De tal modo que as fases de pesquisa não terão qualquer correspondência num plano sequencial de redacção e, muito menos, num plano diacrónico de apresentaçăo das fontes, dos acontecimentos e dos níveis de análise.

Do ponto de vista metodológico trata-se de uma investigação socio-histórica de tipo descritivo e interpretativo, incorporando contribuiçöes da micro-história, onde se estabelecem zonas de diálogo com a filosofia e a sociologia política. Opta-se pois por uma metodologia bicéfala que a par da análise horizontal dos contextos e dos discursos políticos e normativos se apresenta, em sucessivos cortes verticais, casos locais, que se reportam às relações entre regiōes discursivas.

Como modo de investigação adopta-se na primeira e segunda fases o estudo de séries homogéneas de materiais que permitam um estudo diacrónico da regulação de pequena escala. Na terceira fase utiliza-se como modo de investigação um caso de estudo de regulação de grande escala, centrado no Núcleo de Escolas do Oeste 
(NEO). A metodologia arqueológica e genealógica utilizada nas duas primeiras fases será discutida no ponto seguinte deste primeiro capítulo. No terceiro capítulo discute-se o método cartográfico das escalas bem como a discussão metodológica da terceira fase.

\section{1. ${ }^{\mathrm{a}}$ FASE}

\section{Constituição do corpus documental}

Uma apreciação global da política educativa no período analisado permite surpreender quatro tipos de origem do discurso legitimador produzido. Estas fontes discursivas deram origem à constituiçăo de quatro corpus documentais extensivos que consideram também o carácter multímodo da educação, associando-lhe para tanto outras séries documentais.

O corpus jurídico constituído por textos legais e quase-legais. Entendemos por textos legais as séries legislativas onde se integram os decretos-lei e as portarias governamentais. Entendemos por textos quase-legais as séries constituídas por ofícios e circulares que não fazendo parte do mesmo nível estabelecem muitas vezes um quadro normativo ainda mais poderoso.

O corpus técnico constituído pelo discurso produzido por especialistas da educação, psicólogos, pedagogos, estatísticos, planeadores e outros, especialmente dirigido aos técnicos da educaçăo e professores.

O corpus científico constituído pelo discurso produzido em contexto científico sobre as políticas educativas, dirigido à comunidade científica e profissional e aos decisores políticos.

O corpus político constituído pelo discurso de vários actores sociais - governo, partidos, sindicatos, confederaçōes de pais e outras associações — dirigido à opinião pública, quer pela via da comunicaçăo social quer dos instrumentos e meios institucionais.

Nesta primeira fase privilegiou-se $o$ trabalho em Arquivos, nomeadamente $o$ arquivo do Centro de Documentação 25 de Abril da Universidade de Coimbra, o arquivo histórico da Secretaria-Geral do Ministério da Educação, o arquivo da Direccçăo-Geral dos Ensinos Básico e Secundário, o arquivo da Direcção-Geral dos Recursos Educativos e o arquivo da Inspecção-Geral de Ensino. Em cada um destes arquivos foram privilegiados, a priori, certos corpus documentais, embora a inexistência de séries completas de muita da documentação procurada tivesse obrigado a desvios frequentes ao caminho inicialmente previsto. Refere-se seguidamente aquilo que em cada Arquivo foi motivo de consulta, bem como as principais fontes compulsadas. 
Arquivo do Centro de Documentação 25 de Abril da Universidade de Coimbra. A principal fonte de documentaçăo existente neste arquivo, para o período em apreço, provém do Espólio Victor Alves. Antigo Ministro da Educação do VI Governo provisório, entre Setembro de 1975 e Julho de 1976, o espólio pessoal de que fez doação contém, entre outras, as seguintes fontes referentes à educação:

- súmulas das reuniões de Conselho de Ministros entre Dezembro de 1974 e JuIho de 1976;

- resoluções do Conselho da Revolução entre 1975 e 1982;

- série dos despachos do Ministério da Educaçāo (Setembro de 1975 a Julho de 1976);

- recortes de imprensa sobre temática educativa;

- documentos e pareceres de grupos de trabalho, designadamente da comissão para a elaboração dos programas do $8 .^{\circ}$ ano de escolaridade; da comissăo encarregada de repensar a problemática do Serviço Cívico Estudantil; das comissões encarregadas da análise dos programas de História, Ciências Sociais, Vida Política, Introdução à Política e Filosofia do ensino secundário;

- comunicações efectuadas pelo ministro e por outros altos funcionários através da Televisão.

- actas e resumos das reuniões entre o MEIC e as interassociaçōes de pais e encarregados de educação (Junho de 1974 a Junho de 1976).

Arquivo Histórico da Secretaria-Geral do Ministério da Educação. Neste arquivo foram consultadas as seguintes fontes:

- processos da Direcção-Geral dos ensinos básico e secundário contendo documentação muito diversa e não organizada em colecções;

- série de despachos do gabinete do ministro (1974-1988); do secretário de estado adjunto do ministro (1983-1985; 1988-1989); secretaria de estado de orientaçăo pedagógica (1974-1978; 1982-1983); secretaria de estado dos ensinos básico e secundário(7) (1977-1980; 1983-1987); inspecçăo geral do ensino (1982-1986); secretaria de estado da administraçăo escolar ${ }^{(8)}$ (19741983; 1985-1987); secretaria de estado da educaçăo (1980-1981); secretaria

(7) Esta secretaria de estado teve várias designaçōes durante o período em análise: secretaria de estado da Orientação Pedagógica, secretaria de estado da Educaçăo, secretaria de estado da Educação e Juventude, secretaria de estado da reforma educativa.

(8) Esta secretaria de estado teve várias designaçōes durante o período em análise: secretaria de estado da Administração e do Equipamento Escolar, subsecretaria de estado para a Administração Escolar, secretaria de estado da Administração da Educação. 
de estado da educação e juventude (1981-1982); secretaria de estado da reforma educativa (1987-1989).

- relatórios das actividades da comissão consultiva de estatística do Ministério da Educação (1974-1980).

- inventários de carências (1976-1983).

- livros de entradas da divisão de Relaçōes exteriores: livro 25 a livro 32 (17/10/ 83 a 28/7/86).

Arquivo da Direccção-Geral dos Ensinos Básico e Secundário. Colecçōes de despachos e circulares da direcção-geral dos ensinos básico e secundário entre 1974 e 1991.

Arquivo da Direç̧ão-Geral dos Recursos Educativos. Neste arquivo foram consultadas as colecções de relatórios nacionais e as notas do Comité de Educação, do Comité Director do CERI (Centre Pour la Recherche et I'Innovation dans I'Enseignement) e do Comité de Direcção do Projecto PEB da OCDE entre 1974 e 1983.

\section{2. ${ }^{\mathrm{a}}$ FASE}

\section{Análise e periodização das politicas educativas}

Reconstrução analítica das políticas educativas, privilegiando os acontecimentos, conflitos e debates que neste período influenciaram a situação da educaçãa. Para tanto situamo-nos numa perspectiva temática centrada nos discursos e nas filosofias políticas, na reorganização da administração do sistema educativo, nas políticas de avaliaçăo e planeamento do sistema, na reestruturação do parque escolar e na reforma curricular.

\section{3. ${ }^{\mathrm{a} F A S E}$}

\section{Caso de estudo}

A nossa pesquisa propõe-se interrogar a penetração das problematizações de governo da escola realizadas nas regiōes continente e insulares do discurso educativo no conhecimento prático, de senso comum, dos actores escolares locais (vd. cap. III. 2). E propõe-se fazê-lo num duplo sentido de problematização que questiona, por um lado, como é que uma concepçăo elaborada no quadro de uma ciência particular ou de uma problematização técnica da administraçāo intervém nos processos de compreensão do real, das condutas sociais e da linguagem e, por outro lado, quais são as modalidades de conversão de uma teoria científica, de uma racionalidade de proble- 
matizaçăo ou de tecnologias práticas em sistemas de metáforas, opiniōes e atitudes de um grupo particular. Em reverso estudam-se os efeitos sobre a estrutura, o conteúdo e a linguagem dessa teoria, racionalidade ou tecnologia. Seleccionamos no lado da produção textos, obras, intervenções, relatórios que estão longe de pertencerem a um grupo de textos eminentes ou exemplares mas que, nem por isso deixam de propor expressões sistemáticas de bem comum que constituem hoje referência corrente. Do lado da recepçăo, selecciona-se um contexto administrativo particular constituído pela associação voluntária de um conjunto de escolas preparatórias e secundárias da região Oeste. Tendo iniciado a sua actividade com o agrupamento de seis escolas preparatórias em 1984, o Núcleo de Escolas Preparatórias do Oeste (NEPO) viria a reorganizar-se e ampliar-se, constituindo em Dezembro de 1987 o Núcleo de Escolas do Oeste (NEO), agrupando então vinte e cinco escolas, sendo três delas do ensino particular e cooperativo e treze do ensino secundário ou C+S. Para além das entrevistas realizadas a três antigos membros desta estrutura local de coordenaçăo informal, utilizamos ainda algum material empírico recolhido em 1992, em duas das escolas do NEO, no quadro do projecto de investigaçăo A Escola e o Espaço Local: Politicas e Actores. ${ }^{(9)}$

Selecciona-se também como caso de estudo das relações entre centro e periferia a institucionalizaçāo do diálogo técnico entre o GEP e as autarquias locais, no âmbito da elaboração do Inventário de carências. Dentro da estrutura de oportunidades criada pela construção escolar, os interesses sectoriais ou particulares intervêm na disputa de recursos escassos. É esta força centrífuga que melhor permite compreender os efeitos de fragmentação-coordenaçăo presentes nas diferentes fases de distribuição dos equipamentos educativos pelo espaço nacional, desde a detecção de necessidades à execução dos projectos. De um modo geral, os interesses sectoriais, organizados ou não, dirigem-se ao Estado por intermédio das suas estruturas políticas (parlamento, governo, ministérios) ou das estruturas administrativas (direcçōes-gerais, direcções regionais, gabinetes técnicos, etc). A ausência de tradição e a fragilidade da organizaçăo dos interesses sectoriais no campo educativo contribuiu especialmente para a utilização preferencial das estruturas administrativas como ponto de aplicação das formas de pressão. Esta relação privilegiada levou mesmo a administração central a eleger as autarquias como parte da sociedade civil, fazendo destas repre-

(9) Cf. Alves, Cabrito, Canário e Gomes, 1996, A escola e o espaço local. Politicas e actores. Lisboa: IIE. Ver também os relatórios parciais de progresso: Canário, Alves, Cabrito e Gomes, 1991, 1992. 1993, A escola e o espaço local. Politicas de gestão e formaçăo das instituições escolares e práticas dos actores sociais externos. Relatórios de progresso do $1 .^{\circ} \mathrm{e} 2 .^{\circ}$ ano e relatório final. Lisboa: FPCE - UL. 
sentantes de interesses locais, de interesses sectoriais ou, ainda, de interesses privados. A separaçăo administrativa entre as direcções-gerais que no MESA e no MEIC regulam os equipamentos educativos deve-se também à manutençăo das relações selectivas e repetitivas que, uma e outra, têm com diferentes sectores: no caso do MOP e do MESA com as forças políticas, com as empresas de construção e com os proprietários de terrenos; no caso do MEN e do MEIC com as autarquias, com as associaçōes de pais e com os sindicatos de professores. As formas privilegiadas de relaçăo que estas autonomias relativas concedem e promovem tornam muito heterogénea a actuaçăo do Estado. Não tendo sido possível aceder às séries completas da correspondência entre o GEP e as autarquias envolvidas no processo de diálogo subjacente ao Inventário de carências, limitamo-nos às informações quantitativas que é possivel obter nos quadros publicados pelo GEP no Inventário de Carências intitulada Processo de diálogo com as Autarquias envolvidas (1978-1979). No entanto, porque conseguimos obter nos arquivos da Secretaria de Estado do Ensino Básico e Secundário 78 processos referentes a pedidos de construçấo de escolas do ensino secundário ou de alargamento da tipologia $\mathrm{C}+\mathrm{S}$ ao ensino secundário, que nos dão uma amostra bastante razoável do tipo de problemas enunciados, optamos por interpretar este último período a partir da análise de conteúdo da correspondência. Os processos dizem respeito ao período entre 1980 e 1986 e compreendem o expediente enviado pelas Câmaras Municipais, Associações de Pais e Associações locais para várias entidades do Ministério da Educação.

\section{As Fontes e as suas limitações}

O objecto inicial desta investigação é constituído pelas políticas educativas que subjazem à regulaçăo da escola secundária pública, em Portugal, entre 1974 e 1991.

A análise destas políticas é realizada a três níveis:

- A Arqueologia do governo da educação

- A Genealogia de governo da educação

- A Simbólica de governo da educação

\section{A Arqueologia do governo da educação}

A análise arqueológica incide naquilo que podíamos chamar o subconsciente intelectual das políticas educativas. Não se trata de fazer um socio-história das ideias filosóficas, políticas ou pedagógicas que estiveram presentes na teorização de certos 
actores dominantes e da influência que estas exerceram nas práticas educativas. A análise recai antes num espaço cuja estrutura é definida por um sistema de regras discursivas que está para além das ideias dos actores individuais presentes nesse espaço. São as próprias estruturas da linguagem que definem os campos onde os sujeitos operam.

Elegemos como espaço arqueológico os campos definidos pelas tecnologias e racionalidades que têm na estatística e no planeamento os seus elementos predominantes. Pretende-se, deste modo, caracterizar discursivamente aquilo que numa visão tradicional das políticas educativas é considerado como estrutura ou como dados objectivos. Nesta visão, seriam estes elementos reais e positivos da situação do sistema educativo que permitiriam o exercício de intenções, programas, estratégias e vontades. Ao analista estaria destinado o papel de verificar o diferencial entre situação, políticas planeadas e respectivos resultados: tal diferencial dar-nos-ia acesso, entre outras coisas, à medida dos disfuncionamentos estruturais. Não é este, evidentemente, o nosso interesse. Não porque não reconheçamos o papel destas metalinguagens na actualizaçăo dos mitos da escola pública, mas porque esta forma de enunciar o problema é inapropriadamente funcionalista para estudos que pretendam interrogar tais mitos. E isto porque estudam a escola do lado das condiçōes formais de um determinado programa de acção - e.g.: aumento do número de efectivos + carência de instalaçōes = flexibilidade na construçāo escolar - e, ao fazê-lo, tomam os discursos assim cristalizados como um dado duradouro, uma variável independente que não está sujeita a conflitos e resistências que redefinem o próprio campo estrutural. Neste empreendimento não se analisam comportamentos ou ideologias, mas as problematizaçōes através das quais a escola se dá como podendo e devendo ser pensada. Por outras palavras, os factos contam, mas conta, sobretudo, o modo como os factos são contados, e o horizonte discursivo comum que resulta do seu entretecimento. Por conseguinte, na medida em que as várias fontes objectivas são utilizadas pelo investigador, as suas contribuições têm sempre um resíduo construtivo, que não se confundem aqui com erro ou distorção, que as torna indícios de novos códigos sociais, participantes num novo regime de verdade.

O nosso ponto de observação e de análise é justamente esse exercício positivo da vontade de conhecer como forma de dominar a situação e de a administração exercer o poder à distância. Pretendemos, deste modo, caracterizar a estatística, a tecnologia do planeamento da rede escolar e a evoluçăo das formas organizacionais da administração como regiões discursivas onde as políticas educativas são acamadas. O que nos interessa nas estatísticas não é tanto uma análise de segunda ordem sobre as realidades que reflectem; é antes uma análise de terceira ordem sobre as construçōes sociais que são capazes de gerar. As práticas estatísticas incluem voca- 
bulários e discursos que tornam visível um domínio com uma certa homogeneidade interna e fronteiras externas. Como argumenta o historiador da estatística lan Hacking (1981) a acumulação de estatísticas faz parte do processo de formação do Estado burocrático moderno. Ao transformar em informação quantificada um mundo que é qualitativo, tornando possivel a domesticação do acaso, estabelecem-se classificaçōes que tendem a expandir-se para além do campo originalmente destinado à sua intervençăo. Esta expansăo tem nas tecnologias do planeamento da administração o seu principal veículo: a multiplicidade de programas que pretendem administrar a acção dos indivíduos é posta em conformidade com normas políticas mais gerais.

Assim, numa primeira fase, temos como objectivo fazer um mapa topográfico das tecnologias envolvidas nos dois processos mais significativos com incidência nas políticas educativas e nas políticas organizacionais dos anos 70/80: a questão da construção escolar, desencadeada pela carência de instalações e pela explosão da procura de educaçăo; e a querela da desconcentração e descentralizaçăo do sistema educativo que a acompanhou. Estas tecnologias definem o espaço discursivo para a recomposiçăo da estrutura dominante na configuraçăo histórica da escola de massas - a ocupaçăo quadriculada do espaço nacional e a consequente procura de enquadramento da totalidade da população. Quais os instrumentos utilizados? Quais as metáforas sugeridas? Quais os indicadores estatísticos? Quais as racionalidades de planeamento da rede escolar? São algumas das questões que orientam a escolha das fontes.

Neste âmbito, as fontes primárias privilegiadas são constituídas essencialmente pelo chamado corpus técnico: séries estatísticas (análises conjunturais do Gabinete de Estudos e Planeamento (GEP) e da Divisăo de Estatística da Secretaria-Geral); documentos e actas da Rede escolar; Ficheiros de estabelecimentos de ensino; Inventário de carências; Carta Escolar; Relatórios e documentos do GEP; Relatórios da Direcção Geral de Equipamentos Educativos; Actas e relatórios do Projecto PEB-OCDE.

Numa segunda fase o objectivo é reconstituir a evoluçăo do planeamento e das estatísticas, no quadro das novas problematizações de governo da escola, centradas na igualdade de oportunidades educativas. O Ensino Secundário Unificado constitui a medida de política mais importante que marca grande parte dos debates educativos até meados da década de 80 . Tratando-se de uma área sobre a qual existe à partida muito proselitismo foi necessário proceder a um estudo mais intensivo das fontes, tendo como referência principal o Projecto de Avaliação do Ensino Secundário Unificado, integrado no acordo de cooperação luso-sueco de 1976. Os relatórios serão analisados não tanto pelos dados empiricos que sugerem mas antes pelas novas racionalidades e tecnologias que introduzem. $O$ objecto de estudo é definido, assim, 
pelos dispositivos e processos que permitiram o enlace entre a pesquisa e as políticas, por intermédio da avaliação de programas experimentais. Pela primeira vez pretendia-se avaliar em Portugal um processo educativo. Não por acaso, esta avaliação é orientada pelo Instituto de Educação de Estocolmo no quadro do acordo luso-sueco. A intenção de proporcionar informação que fundamentasse e legitimasse as decisões políticas recupera a tradição iniciada nos anos 60 e 70 na Suécia, quando o sistema de comprehensive school foi introduzido. Como recorda Hans Weiler (1983: 270), para o caso da avaliação da reforma sueca, «parece ser a legitimidade do processo, mais que os seus resultados, que tira proveito da conotação cientifica da avaliação da experiência». Também a avaliação portuguesa segue este modelo que Weiler designa como legitimação compensatória: numa situação de crise de confiança do Estado, este recorre aos especialistas para proceder a uma legitimação pelo conhecimento técnico-científico.

Pelas suas características de enlace administrativo-científico estes estudos de avaliação constituem um corpus documental imprescindivel ao estudo de um programa de larga escala que visava criar novas expectativas e novos objectivos sociais para o sistema educativo português. $O$ discurso legitimador que atravessa o extenso conjunto de volumes publicado ${ }^{(10)}$ permite verificar, na crueza dos números, das estatísticas e dos resultados escolares que, deste modo, se produziu um novo mapa social em que todos os grupos sociais ocupam o mesmo espaço moral de intervenção do governo da educaçăo. A análise comparativa dos corpus avaliativo, estatístico e do planeamento permite-nos assim o estabelecimento de um mapa dos novos critérios de decomposição dos públicos escolares e do espaço onde o discurso educativo tem lugar. Permite-nos ainda fugir à ilusão retrospectiva que pretende transformar a história-objecto em história-sujeito ou, dito de outro modo, encara a leitura de certos discursos como matrizes reais de práticas. Como expressamente nota Bourdieu (1989: 77) «reduzir os agentes ao papel de executantes, vitimas ou cúmplices, de uma politica inscrita na essência dos Aparelhos, é permitirmo-nos deduzir a existência da Essência».

(10) Durante o Projecto de Avaliação do Ensino Secundário Unificado, que decorreu entre Janeiro de 1977 e Dezembro de 1981, foram publicados dezasseis Relatórios parcelares e um Relatório final. Concretizado no quadro do Acordo de Cooperaçâo Luso-Sueco, o Projecto envolveu uma Equipa Central de técnicos do Gabinete de Estudos e Planeamento, alguns dos quais realizavam, simultaneamente, trabalho de investigaçăo com vista ao doutoramento no Instituto de Educaçăo de Estocolmo, uma equipa de consultores suecos, onde se integrava o Director Científico Ulf Lundgren e um dos coordenadores Stefan Haglund, e vários professores de equipas regionais. O financiamento do Projecto foi concretizado, na sua quase totalidade, pela Swedish Developement Agency (SIDA). 


\section{A Genealogia do governo da educação}

A análise genealógica incide num corte tranversal do presente na sua contingência radical. Renuncia-se assim à procura da origem do discurso, da determinação do momento ou da razăo fundadora do já-dito, que conduz, numa circularidade obsessiva, a um ponto infinitamente recuado no tempo. Não se trata de encontrar no passado as causas dos acontecimentos presentes, mas de aplicar sistematicamente $\circ$ conceito de descontinuidade, segundo o qual «aconteceu assim mas tudo poderia ter sido de outro modo". A genealogia é a história do presente feita a partir da identificaçăo das causas aparentemente insignificantes; questionam-se as problematizações a partir das práticas e das suas modificações.

Assim, numa primeira fase, temos como objectivo fazer uma análise da individualização dos discursos que circulam no interior do sistema educativo. $\mathrm{O}$ critério de individualização dos discursos consiste na identificação do espaço social e institucional onde têm origem: o discurso político com origem nas instâncias políticas (governo, partidos, sindicatos, associaçōes cívicas ou de interesses corporativos, etc.); o discurso normativo-legal com origem na administraçăo (despachos, circulares, ofícios); o discurso técnico com origem na tecno-estrutura do Ministério da Educação (GEP, DGEE, etc.) e nos especialistas que trabalham em projectos, grupos de trabalho e programas da administraçăo; o discurso científico com origem no contexto científico (teses, artigos publicados, livros) sobre as políticas educativas, dirigido à comunidade científica e profissional e aos decisores políticos.

Não é possivel tratar estas ordens de discursos como totalmente independentes dos agentes e das instituiçães que Ihe dão existência. Por isso adoptamos a teorização dos campos de Bourdieu (1989: 59-73, 1996: 246-322), para tentar elucidar os limites do campo de produçăo destes discursos, considerando por limite de um campo o limite dos seus efeitos ou, de outro modo, um individuo ou uma instituição fazem parte de um campo na medida em que nele sofre efeitos ou que nele os realiza.(11) Todavia, tomar por base do recorte e da construçăo do campo uma unidade institucional é correr o risco de regressar a uma definição da unidade enquanto comunidade

(11) Neste particular, a posiçăo de Bourdieu aproxima-se muito da concepçăo de Foucault sobre o campo das possibilidades estratégicas. Na verdade, enquanto Foucault analisa as interdependências entre as obras e os discursos no interior de um sistema regulado de diferenças e de dispersōes, Bourdieu (1996: 233) enuncia a hipótese de um espaço contemporâneo dos possiveis, quer dizer, «um sistema de tomadas de posições diferentes em relação ao qual cada um terá de se definirn. Resta como diferença entre a posição de Bourdieu e de Foucault a que resulta da ênfase diversa que um e outro dão à interdependência dos discursos dentro do campo ou à interdependência das posições objectivas 
de pensamento. Supor-se-ia assim que os membros de uma mesma comunidade (administrativa, cientifica ou outra) porque têm em comum problemas ligados a uma situaçăo comum teriam também uma problemática comum. Pecaríamos por formalismo se nos limitássemos a este nível de análise institucional da sua gestação. Desde logo porque a integração de um actor, por exemplo, no meio burocrático, não apouca as ligaçöes sociais primordiais nem as perspectivas e identidades que elas podem ditar. $\mathrm{O}$ que nos interessa nesta primeira aproximação săo as regras que individualizam uma certa formação discursiva: quais são os seus objectos comuns, ainda que pareçam dispersos; que operações comuns mobilizam, embora sem conexão temporal; que conceitos utilizam, mesmo que dicotómicos; que opçōes teóricas realizam, ainda que pareçam incompativeis.

Numa segunda fase, pretendeu-se fazer uma análise de conjuntos de discursos. O que está em causa são os critérios da sua transformação e correlação. Donde, a utilização de fontes que constituem, pela sua natureza híbrida, um contraponto à individualização. Quanto aos documentos utilizados são na sua maioria do tipo prescritivo, isto é, independentemente da sua forma, têm por objectivo principal a proposição de comportamentos e regras de conduta. Os textos doutrinais apenas serão utilizadas para esclarecimentos complementares. Interessaram-nos, neste caso, as fontes relacionadas com o desenvolvimento curricular, não apenas porque constitui o domínio por excelência da articulação de diferentes formaçōes discursivas - politica, normativa, técnica e científica - mas, também, porque é possivel detectar nelas a fragmentação curricular enquanto indicador da crise de hegemonia da escola. Relatórios de lançamento de novos anos de escolaridade; perfis terminais propostos para os diplomados do ensino secundário; relatórios da produção de programas escolares e a documentação de suporte à chamada Reforma Curricular săo fontes utilizadas para esse efeito.

Evidentemente que estes programas dependem de formas de racionalidade mais gerais do que as que directamente concretizam. Por exemplo, a racionalidade envolvida na construção do aluno autónomo năo é apenas o resultado de um cálculo imediatista que recupera soluçōes simples e pouco onerosas do self-control, mas

no interior do campo. Enquanto Foucault descreve os discursos como textos sobre textos, Bourdieu sublinha as relaçōes de força simbólicas entre os agentes e as instituiçōes que «tendo interesses plenamente vitais nas possibilidades propostas como instrumentos e paradas de luta, se esforçam, com todos os poderes que dispöem, por fazer passar ao acto as que the parecem mais em conformidade com as suas intençöes e os seus interesses especificos». (Idem, Ibidem, p.235). Esta questão será amplamente discutida no capítulo III. 
emerge de um conjunto de tecnologias de individualização, controlo terapêutico e participação na vida cívica que, não tendo origem exclusiva na instituição escolar, também nāo repercutem integralmente nela os seus efeitos. As referências aos campos da psicologia, da psiquiatria e da teoria política estăo evidentemente presentes na construção multimodal que é o aluno autónomo, mas de forma impura. O que se pretende mostrar não é a diferença entre a pureza do tipo ideal, elaborado em cada um desses campos singulares, e as perdas resultantes da sua aplicação parcial num campo de práticas, mas as diferentes estratégias que operam composiçōes, sobreposições e mesmo oposições entre tipos ideais, para assim estabelecerem um dispositivo escolar sólido e flexível. Assim sendo, utilizaremos também obras de divulgação ou problematização dos campos psicológico (desenvolvimento cognitivo, desenvolvimento sócio-moral), terapêutico (relato e apreciaçāo de experiências clínicas) e político (associativismo juvenil, participação) no encalce das grelhas de percepção que induzem formas de ver e avaliar os acontecimentos.

A utilização destas fontes não segue um princípio de exaustividade e totalização. Não se pretende constituir uma soma dos conhecimentos que circulavam neste período mas tão-só tentar reconstruir a sua episteme. O conceito não serve aqui de sinónimo de paradigma ou de grande teoria. Não se trata de um campo de unificação mas de dispersão; não se procura uma fatia de história comum a todos os corpus examinados, como se existisse um desenvolvimento geral e comum da razão, mas antes a relaçăo complexa dos seus sucessivos deslocamentos. Não se trata de encontrar o espírito da época ou as suas formas genéricas de pensamento, mas a pluralidade de discursos e as suas articulações não-necessárias.

O princípio da exaustividade estaria aliás limitado pela presença lacunar de algumas fontes. Em especial, as séries constituídas pelos discursos dos sucessivos Ministros da Educação do período analisado apresentam algumas lacunas importantes. Os diferentes arquivos do Ministério da Educação, e em especial o da sua Secretaria-Geral, não integram uma colecção de discursos dos ministros. Apesar dos esforços continuados para obter junto do Gabinete do Ministro as respectivas colecções não foi possivel ser bem sucedido porque, como nos explicaram, os discursos fazem parte do arquivo pessoal de cada Ministro e, sempre que um deles abandona o lugar, faz-se acompanhar do respectivo espólio. ${ }^{(12)}$ Poderíamos ser tentados a considerar que

(12) Isto mesmo tivémos oportunidade de confirmar quando, numa das muitas tentativas para tentar obter as séries de discursos junto do Gabinete do Ministro da Educação, um dos ministros que abandonava o lugar se fez acompanhar dos respectivos arquivos, no próprio dia da tomada de posse do seu substituto... Assim sendo, apenas foi possivel reconstituir as séries de discursos dos Ministros 
esta omissão dos arquivos históricos do Ministério da Educaçăo é apenas mais um caso em uma mais geral ausência de política de arquivos. Porém, como teremos ocasiăo de argumentar, esta confusăo genérica entre funções públicas e arquivo privado está para além desse aspecto. Do mesmo modo, não nos foi possivel obter os dados biográficos da maioria dos funcionários que exerceram funções de direcção na administração (Directores-Gerais e equiparados, Directores Regionais), a partir dos quais pretendíamos verificar as eventuais alteraçōes da origem social, académica e profissional dentro do campo administrativo.

\section{A Simbólica do governo da educação}

A análise simbólica incide nos sistemas de poder que legitimam a dominação por intermédio de instrumentos estruturantes da comunicação. Reconhece-se assim que as relações de força e de poder não se limitam a relações de comunicação e que as características dos campos que as produzem são, eles próprios, estruturados pelo poder material ou simbólico acumulado pelas instituiçōes.

A nossa proposta de análise centra-se naquilo que temos vindo a designar como configuraçōes simbólicas ou de sentidos (Gomes, 1993). O primeiro pressuposto desta proposta confirma a ideia de que todo o conhecimento é contextual e contingencial. Seguindo a proposta de Boltansky e Thévenot (1991) e aplicando-a ao domínio da educação, definimos cinco contextos simbólicos do conhecimento que apresentam pontos de contacto evidentes com três dos contextos estruturais definidos por Santos (1985): o contexto cívico, o contexto doméstico, o contexto industrial, o contexto comunitário e o contexto do renome (ou de opinião). Cada contexto é um espaço relacional, combinatório, dotado de uma especificidade que lhe é dada pelas características dos elementos que o constituem e pela intersubjectividade subjacente ao trabalho de construção dos indivíduos em situação.

Os elementos que constituem o nosso ponto de partida são: o referencial estrutural, o modo de racionalidade, o mecanismo de poder, a forma do saber, o lugar comum e a imagem institucional assumida pelos professores e pelos alunos. Estes elementos, apesar de estruturalmente autónomos e suficientes no plano teórico, estão articulados entre si e não esgotam o campo de elementos mobilizados pelos actores

da Educação por intermédio da colaboração gentil de alguns deles. Também foi possivel aceder a fragmentos de discursos através da pesquisa dos jornais da época ou da publicação ocasional em fontes impressas. 
sociais no seu trabalho de construção das situações em que interagem (Goffman, 1959; Joseph, 1982; Herpin, 1982). Por isso, durante a nossa pesquisa surgirăo inevitavelmente outros elementos constituintes que comporăo um quadro final em torno dos cinco contextos simbólicos.

$\mathrm{O}$ quadro seguinte sintetiza estes elementos iniciais.

Quadro 1 - Mapa das configurações simbólicas do sistema educativo

\begin{tabular}{|c|c|c|c|c|c|}
\hline \multirow{2}{*}{ ELEMENTOS } & \multicolumn{5}{|c|}{ CONTEXTO } \\
\hline & cívico & DOMÉSTICO & INDUSTRIAL. & RENOME & COMUNITÁRIO \\
\hline $\begin{array}{l}\text { Quadro de } \\
\text { Referência }\end{array}$ & Estado & Familia & Economia & $\begin{array}{l}\text { Opinião } \\
\text { pública }\end{array}$ & $\begin{array}{l}\text { Comunidades } \\
\text { locais e de } \\
\text { vizinhança }\end{array}$ \\
\hline Racionalidade & Interesse geral & $\begin{array}{l}\text { Laços } \\
\text { pessoais }\end{array}$ & $\begin{array}{l}\text { Eficácia } \\
\text { Competência }\end{array}$ & Notoriedade & $\begin{array}{l}\text { Lealdade } \\
\text { pessoal }\end{array}$ \\
\hline $\begin{array}{l}\text { Representação } \\
\text { do Professor }\end{array}$ & Funcionário & Pai/Mãe & Gestor & $\begin{array}{l}\text { Relações } \\
\text { públicas }\end{array}$ & $\begin{array}{l}\text { Mais velho } \\
\text { Amigo }\end{array}$ \\
\hline $\begin{array}{l}\text { Representação } \\
\text { do Aluno }\end{array}$ & Futuro cidadão & Filho & $\begin{array}{l}\text { Futuro } \\
\text { produtor }\end{array}$ & Cliente & $\begin{array}{l}\text { Mais novo } \\
\text { Amigo }\end{array}$ \\
\hline $\begin{array}{l}\text { Forma do } \\
\text { Saber }\end{array}$ & $\begin{array}{l}\text { Razão } \\
\text { Taxonomia }\end{array}$ & $\begin{array}{l}\text { Saber-ser } \\
\text { Afectivo }\end{array}$ & $\begin{array}{l}\text { Operatório } \\
\text { Instrumental }\end{array}$ & $\begin{array}{l}\text { Variável } \\
\text { Efémero }\end{array}$ & $\begin{array}{l}\text { Oral } \\
\text { Pragmático }\end{array}$ \\
\hline $\begin{array}{l}\text { Forma do } \\
\text { Poder }\end{array}$ & Contrato & $\begin{array}{l}\text { Favor } \\
\text { Protecção }\end{array}$ & Mérito & Influência & Diferenciação \\
\hline Lugar-comum & $\begin{array}{l}\text { Igualdade de } \\
\text { Oportunidades }\end{array}$ & $\begin{array}{l}\text { Situação } \\
\text { familiar } \\
\text { Personalidade }\end{array}$ & Resultados & Transparência & Reciprocidade \\
\hline
\end{tabular}

O contexto cívico estabelece as relações sociais entre os cidadăos com certas responsabilidades de controlo social e o Estado. Neste contexto, o quadro de referência

56 é o Estado, o modo de racionalidade define-se pela primazia do interesse geral e da vontade colectiva, a forma do saber é racional e taxonómica, a forma do poder é o contrato que desingulariza as relaçöes sociais, o professor é o funcionário representante da coisa pública e o aluno é um objecto de formação para a cidadania.

O contexto doméstico estende ao conjunto das relações sociais os modos de comunicaçāo, hierarquização e de relaçāo que têm lugar na família. Neste contexto, o modo de racionalidade é definido pelo reforço dos laços pessoais, onde domina o saber-ser dos afectos, a forma do poder é o favor e a protecçăo, o professor é a figura parental e o lugar comum a situação familiar e a personalidade. 
O contexto industrial figura nas relações que metem em primeiro plano as exigências de resultados e de eficácia das escolas. Neste contexto, o quadro de referência é a economia, o modo de racionalidade é definido pela primazia da eficácia e da competência, a forma do saber privilegia o que é da ordem instrumental, a forma do poder baseia-se no mérito individual, o professor apresenta-se como um gestor de aprendizagens que conduz os alunos ao mercado de trabalho e o lugar-comum são os resultados.

O contexto do renome compreende as relações da esfera pública entre os cidadãos, sem mediação do Estado. Neste contexto, o quadro de referência é a opinião própria e dos outros num universo público, a racionalidade é definida pelo reforço da notoriedade, a forma do saber assume a efemeridade e variabilidade deste, a forma do poder funda-se na influência recíproca, sendo que o professor é definido pelo papel de relações públicas e o aluno pelo de cliente. O lugar comum deste contexto é a transparência.

Finalmente, o contexto comunitário designa as relações sociais dependentes das identidades locais, regionais, de vizinhança e de etnia. A racionalidade dominante vincula os indivíduos a territórios simbólicos onde se procura maximizar as lealdades e as pertenças, o saber é oral e pragmático e o poder estabelece-se numa cadeia de dependências locais vinculada à supremacia dos mais velhos ou de outras hierarquias locais. A reciprocidade é o lugar comum que justifica relações convivenciais ou de desigualdade.

Cada um destes contextos funciona como um dispositivo que visa compatibilizar diferentes modos de coordenação das acções das escolas. Estes modos de coordenação remetem-nos para um saber comum que se exprime em valores e objectivos, mas se prolonga também ao mundo de objectos qualificados pelo senso comum como fazendo parte de uma certa ordem de grandeza. Neste entendimento, cada contexto pode construir uma ordem baseada na cooperação, no consenso e na comunicação ou, em alternativa, estabelecer uma hierarquia entre um dos contextos que é erigido em bem comum, e os outros que săo reduzidos, por uma operação crítica, à condição de bens particularistas (Boltansky e Thévenot, 1991).

O elemento principal do nosso argumento é o de considerar que o poder exercido na escola não se limita ao poder político de dominação do Estado, quer dizer, o contexto cívico não satura as possibilidades de produçăo e articulação das fontes de poder social. Como bem argumenta Santos (1985: 311), os sistemas educativos, como os sistemas de saúde, ocupam uma posição intermediária entre várias formas de poder, devido à sua textura interna heterogénea. Sugerindo uma análise das configurações simbólicas a nossa perspectiva assinala as comunidades de sentidos formadas pelos 
discursos, alargando assim estes espaços estruturais para um mapa simbólico que contém os respectivos mecanismos de racionalidade e de poder. Estas configurações são comunidades de significação produzidas no interior do próprio campo educativo e não espaços estruturalmente separados, autónomos, com materialidade própria, como se depreende do esquema proposto por Santos. As diferenças das suas formas discursivas derivam dos modos distintos como săo elaboradas. A natureza da sua intervenção na escola năo é uma consequência da colonização por parte de qualquer atributo relativamente a outros, mas um efeito da sua articulaçăo. 


\title{
CAPÍtULO II
}

\section{PARA UMA CONCEPTUALIZAÇÃO DA GOVERNAMENTALIDADE ESCOLAR: ESBOÇO GERAL E PARTICULARIDADES DOS PAÍSES SEMIPERIFÉRICOS}

\author{
1. Estado e Sistema Mundial \\ 2. Do Estado à Governamentalidade \\ 3. Racionalidades políticas, Estado e Governamentalidade \\ 4. As tecnologias de Governamentalidade da escola \\ 5. As particularidades da Governamentalidade na semiperiferia \\ 6. Tipologia dos discursos educativos do Estado
}

As pistas do capitulo anterior conduziram-nos para abordagens muito diferentes das que decorrem da estrita aplicação das concepções tradicionais do Estado-educador. Torna-se hoje evidente que não é possível reduzir os mecanismos de governo da educaçăo a meros mandatos do Estado, sejam estes interpretados por modelos conformistas ou por modelos críticos. Em qualquer dos modelos, a equação é semelhante: no primeiro caso, porque tratam os sistemas educativos enquanto realização total ou parcial de certos princípios que Ihe subjazem, especialmente o princípio da formação integral da pessoa humana; no segundo caso, porque criticam os sistemas educativos pelo facto de năo serem bem sucedidos no cumprimento desse mesmo princípio de emancipação e desenvolvimento da pessoa e dos grupos sociais, em especial dos grupos historicamente submetidos à exploraçăo e dominaçăo. Cada um dos termos desta equação será discutido.

As perspectivas genealógicas fornecem-nos várias hipóteses interessantes a este respeito. Argumenta Hunter $(1988,1994)$ que os modernos sistemas educativos não podem ser observados como se fossem expressões históricas de qualquer princípio 
político democrático ou de racionalidade humana. Com efeito, a educação de massas antecipou os modelos de organização política democrática, surgindo da adaptação pelos estados modernos das instituições de disciplina pastoral, para efeitos de formaçăo da população e construçăo do próprio Estado. Nesta pesquisa, associamo-nos aos autores que têm procurado uma alternativa a partir da noção de tecnologias politicas contingentes. Esta abordagem é proposta por Hunter (1994) e Rose e Miller (1992) como um contraponto aos modelos tradicionais da relação entre Estado e educaçăo, que ancoram na hipótese de o Estado ser a origem do modelo e do governo da escola de massas, porque permite pôr em realce que o Estado é apenas uma forma particular de governo, forma que não esgota o campo de cálculos e de intervenções que o constituem.

Por seu turno, esta conceptualizaçăo tem consequências evidentes no modo de analisar o fenómeno da globalização do modelo ocidental da escola de massas. Teorizado por Meyer e colegas, desde os anos 70, como a demonstração da expansão mundial isomórfica da cultura educacional, tem sido contrastada por alternativas que, embora diferentes em alguns dos seus pressupostos, se associam no argumento comum segundo o qual não há determinismos universais, porque as histórias são demasiado complexas e independentes umas das outras. Contra as suposições fundadas numa lógica integrada da história da educação mundial, sublinha-se assim o carácter contingente dos processos de globalização. Embora o livro năo se adentre na perspectiva comparada, esta discussão mostrar-se-á imprescindivel à análise de um país semiperiférico como Portugal. Dentre as teses que, no domínio da educação, têm levado mais longe esta hipótese de crise do universalismo que é, simultaneamente, uma falência das grandes teorias, havemos de introduzir a da simultaneidade dos processos de integração supranacional e dos processos de diversificação intranacional (Schriewer, 1998), da simultaneidade da difusão de modelos educacionais estandardizados e da diversidade dos processos da sua recepção (Schriewer, 1998), dos efeitos diferenciados nas políticas nacionais dos diferentes mecanismos de influência externa (Dale, 1998).

\section{Estado e Sistema Mundial}

Perdemos tudo, mas resta-nos a educação, proclama Fichte, recuperando um orgulho patriótico perdido, no rescaldo da derrota prussiana às mãos do exército napoleónico. A declaração encerra uma promessa destituída de qualquer desespero, já que esta se concretizaria poucos anos depois numa administração estatal da edu- 
cação na Prússia. A criação de um sistema educativo estatal era a oportunidade de concretizar um esforço mais unificado de construçăo da nação desafiada por circunstâncias adversas. O episódio revela bem como a educação é um meio simbolicamente eficaz de regeneração nacional quando se quer reconquistar ou consolidar influência e prestígio no sistema interestatal (Rowlinson, 1974; Green, 1990).

A crença na educaçăo enquanto meio de (re)construção de uma identidade imaginada acompanha a formação e consolidaçăo dos Estados europeus nos séculos XVIII e XIX. A escolarização de massas torna-se numa tecnologia central na criação de laços simbólicos entre os indivíduos e o Estado, garantindo assim um governo do território e da população. Estado que a si próprio se define como de todos e de cada um. Individuaçăo e totalizaçăo são termos inseparáveis da génese da escola: uma racionalidade que assegura o desenvolvimento individual através da orientação pessoal da conduta, a razăo do indivíduo; e o funcionamento da economia global da sociedade que garante a conduta da conduta, a razão de Estado. Esta estrutura social duplicada sobre si mesma, com uma ordem pública e uma ordem privada, serve para caracterizar sumariamente as primeiras formas da escola enquanto instrumento da governamentalidade (Foucault, 1991b). Firma-se uma aliança histórica entre o modelo de governo das almas, remanência da tradição pastoral da igreja, com o modelo burocrático de governo da nação, assente numa visăo secular do progresso e de glorificaçăo do homem-projecto. O indivíduo é a unidade social fundamental, a medida de todas as coisas, a partir da qual as comunidades são feitas; enquanto o Estado se torna a unidade institucional e referência para a construção da identidade social.

A descoberta da infância e o desenvolvimento das teorias da socialização, enquanto formas deliberadas dos representantes da sociedade orientarem as crianças, separando-as dos grupos naturais, articulam-se num movimento de institucionalização da escola. A tecnologia disciplinar (Foucault, 1975) inscrita na escola torna-a capaz de utilizar a plasticidade da criança na produção de cidadãos adultos bons, leais e produtivos. O século XIX é o século da criança (Somerville, 1982) numa época de nacionalismos (Gellner, 1983). Com efeito, o aparecimento das culturas de protecção e domesticação das crianças é contemporâneo do nacionalismo europeu (Bauman, 1987), decorrendo este da aliança entre Estado e cultura.

A par do monopólio da violência legítima que institui a unidade política soberana e maximiza a lealdade, o monopólio da certificação das qualificações estabelece o padrão de cultura codificada para a comunicação entre os homens da nação. A incorporação militar obrigatória e a educaçăo obrigatória fazem parte do mesmo projecto que visa conferir uma identidade nacional particular cuja base institucional é o Estado. Um governo de cada um e de todos com o propósito de garantir a segu- 
rança e a prosperidade da nação é a finalidade da educação que deste modo formaria cidadãos. No final do século XVIII português a naçăo era ainda um projecto inacabado devido às limitações da cultura letrada de base escolar. O monopólio da violência legítima estava ainda ameaçado pelas resistências ao recrutamento militar dos plebeus (cf. Costa, 1995). Tal resistência, que expunha o Estado à fragmentação das pertenças locais e de vizinhança, tinha na educação elementar a instituição capaz de precocemente transmitir a cultura nacional, glorificar os símbolos nacionais e assim criar uma uniformidade superadora dos grupos e ordens do Antigo Regime.

Esta apreciação da génese da escola de massas aceita alguns dos pressupostos da tese da escola-produtora-de-cidadãos (Ramirez e Boli, 1987) que pode ser resumida a partir de três eixos fundamentais.

\section{A construção do Estado-Nação}

Os Estados europeus adoptaram o modelo dos sistemas educativos estatais como estratégia de institucionalização de um conjunto de mitos que, no seu conjunto, definem o universo simbólico da sociedade nacional: a nação enquanto agregação de indivíduos; o progresso individual e nacional como visão linear do ciclo de vida dos indivíduos e de criação de riqueza das naçōes; o estado garante da segurança da nação. A batalha en torno de quem deveria controlar a socialização das crianças constitui um dos elementos mais importantes no processo de reforço da jurisdição do Estado. Durante dois séculos, o Estado moderno minimizou o papel da família, da igreja e das comunidades locais na socializaçăo das crianças, no intuito de reforçar a afiliação destas em relação a uma autoridade central.

\section{A mobilização nacional antecipa a industrialização}

A articulação da construção dos estados e das escolas foi coetânea de um processo global que integra transformações mais vastas, nomeadamente o impacto da Reforma e da Contra-Reforma, o estabelecimento de um sistema interestatal europeu e o triunfo da economia de mercado. Em conjunto, estas alteraçōes combinaram-se num movimento que legitimou formas organizacionais, modos de acção e discursos isomorfos em toda a Europa do século XIX, instituindo a escola estatal como meio preferentemente escolhido de mobilizaçăo nacional. Em consequência, a expansão da escola primária de massas antecede e não se correlaciona com os níveis de industrializaçăo e de urbanização (Craig, 1981; Furet e Ozouf, 1976; Kaestle e Vinovskis, 1980; Lesthaeghe, 1977; Mitch, 1978; Ramirez e Boli, 1987): na maioria 
dos países europeus e também nos Estados Unidos existe mesmo uma associação consistentemente negativa entre os niveis de industrialização e urbanização e as taxas de escolarização (Boli et al., 1985). Archer (1979) também milita a favor desta tese quando justifica o crescimento da oferta escolar na França dos estados a partir do processo competitivo entre eles e da ausência de hegemonia de qualquer das instituições que os representavam, incluindo um Estado débil ainda em construção. Embora exista uma quantidade apreciável de estudos que demonstram como a escolarizaçăo primária e a escrita se encontravam em expansão antes mesmo de a revolução industrial ter início, as mudanças tecnológicas e a acumulação de capital teriam tido efeitos significativos na expansăo da escola secundária nos Estados Unidos pré-industrial. Neste caso, a escola e o mercado de trabalho parecem articular-se de modo funcional. Porém, a expansăo mantém-se independentemente das mudanças tecnológicas e das suas repercussões na produtividade. Com efeito, a escolarização secundária cresce persistentemente, seja ela funcional ou não para o desenvolvimento capitalista, por força da lógica própria das credenciais e do valor simbólico estatutário que prenunciam (Rubinson e Ralph, 1984).

\section{Expansão mundial isomorfa}

A institucionalização da cidadania na Europa difundiu-se no sistema mundial através da expansão isomorfa de um modelo institucional único e de uma cultura partilhada, independentemente das características contraditórias dos sistemas políticos, do nível desigual de desenvolvimento económico ou das prioridades de política social nos respectivos países. Daí a expansão massiva da frequência dos sistemas escolares estatais desde o final da 2. ${ }^{a}$ Guerra e a generalização da sua obrigatoriedade no primeiro grau. $\mathrm{O}$ isomorfismo seria o resultado de uma cultura transnacional de base escolar com o seguinte padrăo (Meyer, 1977): metas de desenvolvimento económico nacional comuns; educaçăo para a cidadania entendida como mérito e responsabilidade; a crença no melhorismo dos indivíduos e dos países. A vitória da escola no sistema mundial impōe um modelo único de educação escolar caracterizado pela diferenciação em níveis, graus e exames; pela concentração espacial e temporal de classes segundo princípios de homogeneidade; pela diferenciação dos papéis de professores e alunos; pela conexão de carreiras escolares e profissionais através da certificação; pelo enquadramento administrativo das escolas financiadas pelo Estado e dos professores por este controlados; e por um desenho curricular semelhante. Nesta perspectiva, poder-se-ia falar de uma escola de massas única, universal, que é tanto mais mimetizada quanto menos centrais e menos poderosos são os respectivos paí- 
ses no sistema mundial. Como ilustração desta tese tem sido argumentado que a formação de novos estados africanos tem precedido a expansão da escola de massas nesses países. Sendo ainda frágeis e dependentes, os novos estados abrem escolas como sinal da construçăo das suas identidades imaginadas, procurando, simultaneamente, legitimar-se no sistema interestatal regional ou no sistema mundial. A escola representa assim o sistema mais visível e reconhecível da modernidade e do progresso (Fuller, 1991). Porém, este processo não é uniforme e apresenta combinações de acomodação e resistência ao modelo escolar ocidental, motivada esta por fenómenos religiosos, políticos e linguísticos, mormente os que são determinados pelo conflito entre a Igreja e as elites seculares. Surgem assim sistemas educativos duais, cindidos na própria arquitectura institucional, que ora privilegiam o formato organizacional de tipo ocidental, ora preferem o formato recitativo-tutorial islâmico (Morgan e Armer, 1992).

A nossa apreciação afasta-se desta perspectiva em três pontos essenciais.

\section{Para além do Estado}

O primeiro diz respeito ao foco de observação. Para compreender a emergência do modelo escolar não é apenas para o Estado que devemos dirigir a atenção analítica como o fazem os defensores da hipótese Estado nacional-Sistema Mundial. O estado deve também ser analisado, mas enquanto elemento integrante de uma montagem de tecnologias intelectuais e administrativas improvisadas para responder a desafios contingentes. A escola não é a concretização conseguida ou falhada de princípios morais ou de um projecto fatalmente determinado por certas circunstâncias históricas, mas antes um arranjo justaposto, permanentemente actualizado, de discursos, tecnologias e princípios disponíveis em cada momento, que assim definem um jogo de dependências entre o que se faz e o que se pode fazer e delimitam o que se diz e o que se pode dizer. Afastamo-nos pois do historicismo que encontra na prá-

64 tica política do Estado um papel taumatúrgico capaz de reduzir à insignificância o campo discursivo e de práticas em que opera. Apresentada como uma alternativa analítica à visão funcionalista de uma escola que tenta corresponder às necessidades de um específico regime de acumulação capitalista integrar as disrupçóes provocadas pela urbanização e pela industrialização, substitui-a por uma visão hiperfuncionalista que a compreende enquanto construção social que reflecte a lógica de o Estado-Nação produzir cidadãos e o sistema mundial criar subjectividades semelhantemente reconhecíveis. A regularidade de um processo năo implica necessariamente que ele seja lógico. Alguns trabalhos revelam como o Estado não se limita a incorporar cidadãos 
iguais na sociedade, podendo, em certas circunstâncias, favorecer determinados grupos sociais. Fuller, Hage e Garnier (1990), bem como Garnier, Hage e Fuller (1989) encontraram uma associação forte entre o grau de conflitualidade no interior do Estado e o alargamento ou restrição de acesso às escolas de elite nos casos da escola secundária não unificada em Inglaterra e em França. No primeiro caso, o voto trabaIhista local aparece associado ao alargamento da base social de recrutamento e, no caso francês, a centralização do sistema permitiu a limitação do acesso à fileira de ensino destinada a um estatuto social mais elevado.

\section{Génese, expansão e crise da escola de massas}

A argumentação sobre a génese dos sistemas estatais de massas no século XVIII e XIX é convincente. Porém, a utilizaçăo do mesmo esquema de análise para a fase de consolidaçăo e crise da escola parece empobrecedor e incapaz de captar as diferenças que abalam a sua legitimidade e hegemonia e as respostas institucionais nacionais variantes. Como sugere Hunter (1994, p. XVII): «the relative uniformity of the modern school was, however, more importantly determined by a different if related fact: namely, that the administrative and spiritual technologies with which European societies could develop the school as an instrument of government were quite 'rare' and therefore fairly invariant». Nesta perspectiva vale a pena notar que a manutenção do isomorfismo relativo da escola năo se deve à sua particular eficácia ou ao seu valor próprio mas antes ao facto de não poder ser substituído sem o recurso a outros elementos externos constitutivos que poriam em causa os consensos entretanto obtidos (Tyack e Tobin, 1994). A constituição de uma instituição é sempre baseada em convenções que excluem algo e assim estabelecem uma hierarquia entre os pólos resultantes. A objectividade social da escola, que a naturalizou e tornou racional e razoável, foi a expressão da sedimentação de um conjunto de práticas e de discursos cujo carácter conflitual foi anulado. Muitos dos padrōes comummente aceites e institucionalizados foram de facto criações que responderam a tensões sociais complexas e que são presentificadas como parte da realidade social de todos os dias, pressupostos não questionados da sua linguagem, que orientam a consciência prática.

Perspectiva diferente é a dos autores que se situam na visão estatista da escola. Ao descreverem os mitos que estão na sua origem incorporam-lhe um significado silencioso que se autopreserva e cristaliza numa origem perpétua. Assim, os discursos da virtude cívica republicana; dos direitos individuais da jurisprudência liberal; dos interesses e dos ajustamentos estratégicos da economia liberal ou, ainda, das técnicas diplomáticas e militares das relações internacionais poderiam ser sempre 
interpretados à luz de uma relação causal entre indicadores institucionais construídos pelo próprio Estado. A atenção selectiva que estes autores dedicam aos aspectos quantitativos da expansão da escola, ignorando assim a sua elaboração qualitativa, fornece-nos a teoria implicita subjacente: como o processo é universal, as diferenças sistémicas são apenas remanescentes. Por outras palavras, o determinismo global do modelo cultural do Estado-Nação concede pouco espaço para as contingências locais.

Ora, no espaço público da luta política, cada discurso pode coexistir, resistir ou desaparecer na sua relação com outros, desenvolvendo para tanto metadiscursos que não săo captáveis por intermédio de regimes de enunciação únicos e codificados. Referimo-nos aqui ao conceito de regime de enunciação de Foucault (1969). Este contém enunciados dispersos e heterogéneos, embora relacionados por semelhante prática discursiva. A distância de enunciação no interior de um conjunto de discursos năo autoriza formas codificadas de o fazer, seja através da correlação ou da relaçăo causal, por que estas tomam as categorias construídas como representando uma realidade discursiva e institucional petrificada, quando a flutuação é a sua principal característica. Este conceito parece particularmente adequado à crítica de uma visão excessivamente cognitivista e centrada nos mitos da cultura ocidental. Na verdade, a abordagem dos institucionalistas está ancorada no seguinte pressuposto culturalista: as políticas nacionais, incluindo as políticas educativas, longe de serem estabelecidas com autonomia no nível nacional, são na essência versôes de narrativas conformes e legitimadas pelos valores, culturas e ideologias-mundo. Dentre as narrativas culturais mais pregnantes na cultura-mundo encontram-se as da racionalidade, do progresso, da igualdade, do individualismo e da justiça. A extensão e o fôlego de tais narrativas tendem a subsumir no seu interior as clivagens que as atravessam, deixando pouco ou nenhum espaço para o conflito entre valores. Conflito que dá origem a regimes de enunciaçăo dispersos e heterogéneos. Isso mesmo parece ser implicitamente reconhecido pelos autores que, em diferentes ocasiōes, sublinham a débil relação entre 660 vínculo formal aos valores e as práticas e políticas reais: «there is only a loose relationship between organizational forms and practical needs and goals operating in local situations. In this sense, Western organizational structures are to be seen as ritual enactments of broad-based cultural prescriptions rather than the rational responses to concrete problems» (Meyer, Boli e Thomas, 1987: 32). Mas enquanto estes autores vêem na desarticulaçăo referida, uma promulgação ritual de prescriçōes culturais abstractas sem um centro, nós entendemos que ela é o resultado dos processos de recepção cultural, específicos a cada país, dependentes entre outros aspectos da posiçăo relativa de um dado Estado no espaço mundial. 
Como vários estudos comparativos de ciência política têm demonstrado não existe necessariamente uma relação positiva entre diferentes capacidades de intervenção do Estado (Skocpol et al., 1985). Significa isto que, a par do carácter conflitual dos processos de internacionalização, que envolvem trocas económicas desiguais e relações de força entre estados, a actividade de mediação levada a cabo pelos grupos sociais e pelos actores individuais nacionais joga um papel de primeira água nos processos de recepção dos modelos culturais. Do mesmo modo, a presunção de existência de vasos comunicantes entre a autonomia do Estado e o poder dos grupos sociais não tem demonstração empírica. Segundo esta presunção, cada elemento do par indivíduo-Estado seria inversamente enfraquecido ou fortalecido pela maior ou menor presença de grupos intermediários. Na verdade, indivíduos, grupos intermediários e Estado podem ampliar ou reduzir em conjunto e simultaneamente o seu poder de intervenção (Skocpol et al., 1985, pp. 347-366). Conclui-se assim que os sistemas educativos aparecem regulados por um conjunto de formas institucionais que através de normas, valores e formações culturais específicas asseguram a difusăo híbrida do modelo da escola de massas. Roger Dale (1999) é um dos autores que tem vindo a desenvolver esta perspectiva, apresentando seis formas institucionais básicas de as políticas nacionais filtrarem as influências externas: o mecanismo da aprendizagem, o mecanismo da harmonização, a disseminação, a estandardização, a imposição e a interdependência. Desenvolveremos em secção própria esta proposta analítica.

\section{Modelo transnacional único e estruturas nacionais variantes}

O terceiro tema de discordância diz respeito ao tipo de análise que é feito do sistema mundial. Partilhamos da ideia segundo a qual os Estados apenas em parte săo entidades autónomas que, no restante, operam num quadro de grande comunhão cultural. A economia capitalista mundial constituiu centros e periferias envolvidos na divisão internacional do trabalho e na competição económica e militar. Nesse processo institucionalizaram mitos universalistas que são o seu principal sustentáculo numa realidade de muitos particularismos que são o seu inevitável obstáculo. Estudos comparados dos sistemas políticos europeus realizadas nos últimos anos propõem uma visão bem mais matizada desta problemática. A Europa das identidades regionais (Scardigli et al., 1993) e das micro-ideologias (Todd, 1990) constituem frequentemente contrapontos da integraçăo supra-estatal, pondo a nu a descoincidência entre a integração promovida pelo enquadramento jurídico e institucional e a fragmentação infranacional dos territórios, das culturas e das línguas (Charpentier e Engel, 1992). Em qualquer caso, a ideia de causalidade complexa e de desvio em relação à depen- 
dência estrutural do sistema mundial sai reforçada. Como é possível articular teoricamente a óptica do sistema mundo feito de homologias, com o comparatismo que reconhece grande variedade social e organizacional entre diferentes Estados? Essas diferenças são verificáveis na distância relativa da escola à regulação estatal e às organizações económicas (Archer, 1979); no grau em que cada um dos termos do binómio ordem social-liberdade individual são salientados na formação da identidade nacional (Tyack, 1966); na existência de sistemas de educação unificados ou dualistas que oferecem fileiras de prestígios e certificados desiguais (Torres et al., 1993); na articulação entre o grau de centralizaçăo dos sistemas educativos, a estrutura de classes e os regimes políticos (Archer, 1979; Collins, 1979); no desenvolvimento desigual da expansăo das taxas de escolarização; no modo como as minorias étnicas săo separadas ou assimiladas pelos sistemas educativos estatais.

Diante de tantas diferenças parece excessivo continuar a argumentar com base nas homologias que, embora exteriores ao sistema nacional, năo deixam de exercer um papel funcional no esquema teórico proposto. Com efeito, se, por um lado, o argumento das necessidades de ordem social ou de reproduçăo das classes, gerados por processos endógenos é ultrapassado; por outro lado, o avanço para o nível de análise transnacional consagra uma óptica predominantemente ontológica que à partida se pretendia superar. A mão invisivel da economia dá lugar à măo invisível do sistema mundial capaz de fazer aderir os novos Estados à ideologia do progresso e à racionalidade científica por intermédio da escola de massas. 0 que nos conduz para um modelo global-integrador que anuncia o fim da história. Trata-se de uma forma de pensar a escola apenas a partir da oferta, dentro do discurso e dos mitos do Estado e do sistema interestatal, com os seus instrumentos e conceitos, tendo dificuldade em captar todos os níveis do jogo, em particular os do lado da procura de educaçăo.

No conjunto de estudos que vimos analisando os autores correlacionam as taxas de expansăo da escola primária, secundária e terciária de massas com a representação política formal; a participação política; a modernização política; a centralização estatal; o tamanho da burocracia estatal; a data de independência e a fragmentaçăo etnolinguística (Meyer et al., 1992). Nestes estudos o significado da expansão da escola é reificado na sua própria história social, por meio de um dispositivo que trata acontecimentos contingenciais como essências que podem ser retiradas do seu contexto e apresentadas como um padrão estatístico. Daí resulta um efeito de agregação estrutural que passa a restringir ou a ampliar os acontecimentos singulares dentro de uma lógica de circularidade teórica. Esta forma de enunciar o problema é inapropriadamente funcionalista para estudos que pretendam verificar variâncias e 
não confirmar invariantes. $E$ isto porque estudam tacitamente a escola do lado dos que têm o poder de, através da estrutura, definirem as condições formais de um determinado programa de acçâo - centralização estatal; autoridade educativa; legislação sobre educação obrigatória, etc - e, ao fazê-lo, tomarem a estrutura de dominação, para efeitos de investigaçăo, como um dado duradouro, uma variável independente que năo está sujeita a conflitos e lutas que redefinem o próprio campo estrutural. Um dos aspectos mais expressivo deste funcionalismo consiste na utilização da variável fragmentação linguística enquanto variável independente, quando se sabe que a globalização e aprofundamento de certas comunidades linguísticas, a par da correspondente restrição de outras, foi um dos aspectos em que a escola estatal mais se envolveu, contribuindo assim para a reprodução, expansão e contracção de populações e zonas linguísticas durante o processo de construção do Estado-Nação.

Apesar dos importantes contributos analíticos desta corrente para a compreensão da heterogeneidade de elementos que fundam a escola de massas, pressente-se a procura da causa global, dos fundamentos últimos que explicam a essência do fenómeno, contrária à nossa démarche analítica centrada na busca das condições de possibilidade de certas práticas e dos discursos que têm um efeito positivo na construção da escola. No final desta busca da essência encontram estes autores a universalização do modelo escolar e o monopólio do Estado como lugar de universalidade ao serviço do interesse geral. Segundo as suas próprias palavras «in all countries, educational curriculum and organization tend to emphasize the transmission of a national culture, the construction and glorification of the national history, and the teaching of the national symbols and the national language. Education, then, is an institutional agency for creating national uniformities among the heterogeneous status and class groupings in society. We are not here arguing that education is always successful in creating a national identity and national identification at the expense of ethnic, religious, or class identifications, though doubtless it sometimes is successful. Rather, we are arguing that the expansion of education and of its national political control reflects the pressures toward national identity and national culture» (Ramirez e Rubinson, 1979: 79).

A análise sociológica do Estado não pode ignorar a distância entre a norma de neutralidade tal qual é enunciada pelo discurso do direito administrativo e os efeitos năo igualitários, mormente na sua utilização particularista por uma parte da sociedade civil, que consistem em tirar proveitos privados da nāo aplicação do direito. Quando as ciências sociais subestimam as profundas polarizações e dualismos que coabitam nos sistemas educativos mundiais, especialmente na periferia e semiperiferia, correm 
o risco de contribuir para o esforço de construçăo da representaçăo universalizante do Estado. Os três exemplos seguintes ilustram a presença das representaçōes homogeneizantes do Estado e do sistema-mundo nos estudos destes autores.

A utilização das taxas de inscrição como medida da expansão dos sistemas educativos produz um enviesamento aditivo, por que se sabe que as taxas de frequência real dos presentes, as taxas de finalização do ciclo escolar e as taxas de abandono fornecem uma aproximaçăo mais válida dos desnivelamentos sociais de acesso à educaçăo. Vai no mesmo sentido a agregaçăo das taxas de inscrição no ensino secundário, apesar da evidência generalizada de que muitos países oferecem fileiras de prestígio e certificado desiguais para grupos sociais diferentemente colocados na hierarquia social. A não utilizaçăo das características sociais dos alunos que frequentam cada uma das fileiras invalida a conclusão dos autores segundo a qual a classe social não afecta a expansão da escola de massas.

$\mathrm{O}$ uso agregado dos dados referentes a grandes regiões ou continentes não parece adequado a uma análise matizada do sistema mundial, posto que no seu campo teórico se reconhecem as assimetrias entre países dentro da mesma região ou continente (Wallerstein, 1982, 1991) e as próprias agências internacionais têm desenvolvido uma pletora de novos conceitos e subcategorias estatísticas (Novos paises industrializados, Países subdesenvolvidos, Países em transiçăo, etc.) que consagram a sua hierarquia crescente. As séries temporais de efectivos escolares não são directamente utilizáveis no estudo da expansão da escola, se não na presença de invariância da correspondência entre formas de escolarização e categorias estatísticas. Um exame superficial destas mostra que tal só pode acontecer à custa de processos de agregação e manipulação completamente arbitrários (Briand, Chapoulie e Peretz, 1979).

A utilizaçăo das categorias curriculares nominais como base da comparação internacional também parece desadequado quando se pretende verificar o que realmente se ensina em cada sistema educativo. Num dos mais recentes trabalhos, Meyer e os seus colaboradores (1992) levaram a cabo um interessante projecto que visava comparar os modelos e as categorias curriculares ao nível mundial no século XX. Para tanto, procederam à recolha de dados referentes à composiçăo curricular e às cargas horárias respectivas, concluindo que existe um grau surpreendente de homogeneidade curricular em todos os países analisados. A explicação encontrada pelos institucionalistas para este fenómeno de estandardização centra-se, antes de mais, nos processos de legitimaçăo. Estes parecem ser autogerados, como sugerem em diversos textos: "schooling happened in Sweeden because it happened in Western civilization. The same can be said of any other Euro-American country in this period: schooling happened there because it happened elsewhere» (Boli, 1987: 73). O pro- 
cesso de legitimação seria do tipo recursivo: os Estados adoptariam políticas semeIhantes, tais como as categorias curriculares, na procura de legitimação externa e, por sua vez, aquelas obteriam a sua própria legitimidade da autoridade dos cientistas e dos especialistas que representam e incorporam os valores da modernidade Ocidental. Sendo certo que esta autoridade resulta menos da influência dos cientistas como grupo do que da Ciência enquanto verdade universal. As condições da difusão mundial de um modelo cultural único assentariam, portanto, em dois pilares: nas organizações internacionais, mormente nas que têm uma participação universal potencial (McNeely, 1995) e nas comunidades científicas. Numa interessante análise crítica desta teoria da circulação legitimatória, que nos leva sempre do mesmo ao mesmo, Roger Dale (1998) sugere que, nos seus pressupostos, a legitimação parece ser um processo espontâneo que prescinde de explicações e actua por osmose. Na verdade, tanto o pilar das relações internacionais quanto o pilar da racionalidade científica são tratados em termos estritamente cognitivos: a análise dos modelos contraditórios e das relações assimétricas nas diversas organizações internacionais é desprezado, bem como o papel das condiçōes políticas internas na conversão de uma certa racionalidade científica em tecnologias de governo. Daqui resulta um apagamento dos processos históricos que lhe subjazem, em especial os que dizem respeito às estratégias de pressão, de imposição e de ajuda pilotada que algumas agências internacionais, designadamente a Unesco e o Banco Mundial, usam como formas de difusão das suas políticas. São os próprios autores que introduzem, justamente, alguma prudência metodológica nas suas conclusões, quando sublinham no prefácio ao livro School Knowledge to the Masses: World Models and Curricular Categories in the Twentieth Century: «our data are perforce and limited or superficial. We know whether a given country's policies include a given curricular category or not, and how much emphasis is given on this category. We do not know what the category means in the country (for example, the syllabus, the materials, the instruction plan, or the test), we do not know how or whether the category has different meaning or implementation for children off differing class, ethnicity or gender» (Meyer et al., 1992: XI-XII). Todavia, esta prudência năo tem consequências evidentes nos pressupostos teóricos dos institucionalistas. Na verdade, os autores reforçam sempre as condições de difusão iniciais, desprezando o modo como os diferentes formatos organizacionais reconfiguram as mensagens que lhe chegam, o que é particularmente intrigante para quem, como os institucionalistas, sublinham nas suas hipóteses teóricas o importante papel mediador daqueles na filtragem e institucionalização das políticas (Dale, 1998).

Com o modelo explicativo da institucionalizaçāo da escola no sistema mundial tem-se a impressão de um processo harmonioso que conduz todas as sociedades para 
uma maior complexidade e capacidade adaptativa. A difusão é o processo dominante: valores circulam dos paises mais desenvolvidos para os menos desenvolvidos; as pressōes e incompatibilidades entre vários subsistemas no seio do sistema mundial submetem os novos estados a integrarem-se na lógica do sistema interestatal. As contratendências são consideradas menores e não impeditivas do desenvolvimento do fenómeno.

A apreciação que os autores fazem da expansão da escola ao nível mundial fundamenta-se na difusão do nacionalismo e do individualismo como pilares dos estados modernos. Ambos teriam propriedades essenciais e substantivas que fariam deles universalias da modernidade. Esta linha geral de interpretação propōe uma óptica que é fundamental contrastar: o nacionalismo vale menos pela orientação programática, substantiva, que estabelece do que pelo efeito pragmático que resulta da construção de comunidades imaginadas (Anderson, 1983). Conforme é evidenciado pelos próprios autores (Ramirez e Boli, 1987), sem que daí retirem as ilaçōes necessárias, a nação é uma construção plástica que objectiva a relação singular, pragmática, com a religião, os costumes, a tradiçăo e o ancestralismo. No caso francês a revoluçăo adoptou um ideal de uniformidade linguística que não de uniformidade religiosa (Weber, 1976). Em contraste, no Império Austro-Húngaro mesmo formas linguisticas muito próximas foram percebidas como linguagens nacionais e a nacionalidade operou uma nova forma de representar e configurar os interesses de classes pré-existentes (Verdery, 1983). O nacionalismo enquanto fenómeno historicamnte transversal é menos uma propriedade substantiva que, preferentemente, um princípio de organização social que usa várias feições da diferença humana para criar fronteiras entre comunidades. Pressupor que a maior ou menor ênfase nos grupos sociais intermédios ou o grau de fragmentaçăo etnolinguístico săo indicadores de nacionalismo é postular a existência de um quantum, definido pelo padrão ocidental, necessário ao seu estabelecimento.

Implicações na educação comparada

O conjunto de trabalhos de Meyer e dos seus colaboradores integram-se no que Skocpol e Somers (1980) caracterizam enquanto história comparativa analógica e história comparada macro-analítica. No primeiro tipo de estudos a justaposição de casos históricos destina-se a persuadir-nos de que as hipóteses derivadas de uma determinada teoria podem repetidamente mostrar a sua validade quando aplicadas a um conjunto de exemplos e situações históricas. As características típicas de cada caso são evitadas ou consideradas menores. Inversamente, a comparação contrastante 
utiliza as diferenças como teste rigoroso que pode afectar o suposto funcionamento de processos sociais globais. Quando se usam tipos ideais estes constituem apenas o pano de fundo para pontuar as singularidades de cada caso.

Nos estudos comparativos macro-analíticos as hipóteses explanatórias provenientes de uma teoria ou de teorias concorrentes são testadas para especificar configurações favoráveis ou desfavoráveis em relação a variáveis dependentes explicativas. É o caso dos estudos de Ramirez e Boli (1987) e de Meyer, Ramirez, Rubinson e Boli (1979), ao procederem ao teste das hipóteses concorrentes provenientes das teorias funcionalistas e conflitualistas com as suas próprias teses. Estes autores procedem segundo um desenho comparativo que Mill (1888, cit. in Etzioni e Dubow, 1970) designou por método do acordo: um conjunto de casos que têm em comum o fenómeno a ser explicado, também têm em comum os factores causais enunciados nas hipóteses (Boli, Ramirez e Meyer, 1985).

A nossa opção releva antes de uma estratégia comparativa contrastante por que mais adequada à captaçăo de níveis em profundidade da realidade social dificilmente mensuráveis. Não há nada de errado em seguir uma ou outra estratégia desde que fique explícito que cada uma delas analisa níveis diferentes dos sistemas educativos e de que alguns são deste modo negligenciados. A estratégia analógica dos estudos comparativos sofre de um viés centrocentrista que consiste em representar a essência dos sistemas educativos dos países ocidentais do centro, derivando entăo um conjunto de categorias em relaçăo às quais os outros sistemas săo comparados. Deste modo se tende a definir a priori que os princípios que explicam a dinâmica de um estado tardio de expansão da escola devem ser os mesmos do estado nascente. Semelhante viés se verifica quando se compara no mesmo sistema educativo o momento da sua génese com os períodos do seu desenvolvimento e maturaçăo. Provavelmente, como sugere Archer (1979), cada um destes tempos da morfogénese da escola necessita de teorias e indicadores mais matizados para a sua análise.

O estado actual da investigaçăo comparada não autoriza a conclusăo segundo a qual a convergência do sistema mundial se dirige para um modelo universal e muito menos que esse modelo significa a sua ocidentalizaçăo (Schriwer, 1998). Na sua revisão de literatura, Schriwer serve-se da mesma estratégia sugerida pelos trabalhos de Eisenstad (1992) na pesquisa comparativa sobre a modernização. Utilizando as conclusōes acumuladas pelos estudos de política comparada e de sociologia das organizações comparada, apresenta três campos em que se observa variabilidade internacional suficiente à dissoluçăo da suposta racionalidade universal, quer da educação quer do industrialismo: (a) articulação entre as políticas de emprego e as políticas educativas e sociais; (b) conexōes entre a educação vocacional, as estruturas de qua- 
lificação do emprego e os modos de organização do trabalho; (c) conexôes entre educaçăo, modernizaçăo e desenvolvimento.(13)

Quanto às relações entre as políticas educativas e as políticas de emprego, Schriwer apresenta um conjunto de estudos que contrariam os pressupostos das teorias macro-económicas. Segundo estes, a exposição a um envolvimento económico global resulta em princípios de racionalidade económica idênticos, enquanto alguns estudos comparativos demonstram que, embora a pressão para o incremento da produtividade seja global, as estratégias de inovação industrial e de regulação do mercado de trabalho são claramente divergentes (Sabel et al., 1987). No interior desta mesma orientação comparativa foram descritas variâncias significativas nos modos de organização económica, mesmo entre os países mais desenvolvidos (Goldthorpe, 1984; Kumon e Rosovsky, 1992). Variabilidade que tem repercussões evidentes sobre os diferentes caminhos seguidos pelos sistemas educativos e de formação (Turner e Auer, 1992).

Conclusões similares foram descritas quanto às articulaçōes entre educação, qualificaçōes dos empregos e modos de organizaçăo do trabalho. Contrariamente aos pressupostos da teoria do capital humano que, em larga medida, sustentam a equaçăo escolar da modernizaçăo - inovaçăo tecnológica + desenvolvimento económico = mudança das estruturas de formação - uma extensa bibliografia comparativa tem revelado como os sistemas educativos apresentam variantes devidas a factores societais e culturais (Iribarne, 1989), a padrões diferenciados de organização do trabalho (Sorge e Warner, 1987) ou, ainda, à cultura empresarial nacional (Hofstede, 1986).

Finalmente, as relaçŏes entre educação, modernização e desenvolvimento revelam uma maior disponibilidade para a variação nacional do que as análises iluminadas pelo modelo do sistema mundial fazem crer (Chabbott, 1997). Na verdade, em cada uma das dimensões relevantes para a legitimação das políticas nacionais no sistema interestatal das organizações internacionais ${ }^{(14)}$ - todas elas ancoradas numa cultura mundial que enfatiza o progresso e a justiça -, as conexões são débeis, problemáti-

(13) Estas referências assumem particular importância na análise das articulações discursivas entre educação, mercado de trabalho e desenvolvimento, em Portugal, durante toda a década de 80 . Como veremos no capítulo IV, esta articulaçăo, realizada em torno do lugar-comum da modernizaçăo, apresenta convergência formal com os padrōes dos países centrais, mas apresenta perfis nacionais muito diversos em face da dinâmica económica e dos modelos de especialização e organização económica nacionais.

(14) No que à educação diz respeito, podemos identificar as seguintes fontes de legitimação no sistema interestatal das organizações internacionais: desenvolvimento económico, produtividade individual, crescimento económico nacional, desenvolvimento cultural, democracia política, modernização das atitudes e dos valores, desenvolvimento do conhecimento e do currículo, democratização política e integração nacional. 
cas e disfuncionais, embora se reconheça que as anomalias tendem a ser justificadas nos termos dos princípios culturais mais globais. É isso que explica o paradoxo de, não obstante a incapacidade de a investigaçăo estabelecer um nexo de causalidade entre educação e desenvolvimento, os projectos de educaçăo para o desenvolvimento continuarem a marcar a agenda das organizações internacionais e das suas declarações de intenções. Todos os dispositivos de isomorfismo educativo, sejam eles a coerção, a imitação ou a normatividade se orientam no sentido de superar os particularismos nacionais e a variaçăo das condiçōes intranacionais que não permitem uma aplicação linear dos seus princípios (Fägerlind e Saha, 1985).

A utilização de grandes narrativas explicativas dos fenómenos mundiais tem resultado invariavelmente em um de dois efeitos: ora na redução das variantes nacionais a simples fenómenos de inércia residual, ora na impossibilidade destes se deslocarem do exotismo empírico para o campo da elaboração teórica. O domínio das ciências sociais comparativas por parte das grandes organizações internacionais e das comunidades académicas dos países do centro, que assim estabelecem um sistema internacional de comunicação, financiamento da investigação e publicação (Altbach, 1994) são um aspecto particular da legitimação universalista dos sistemas educativos que se reproduz também por meio da auto-representação cosmopolita que estas comunidades estabelecem para si próprias. De tal sorte que amplificam a validade dos sistemas conceptuais, o poder de descrição das classificações estatísticas e a difusão dos padrōes de qualidade usuais nas organizações internacionais. Deste modo, estabelece-se uma pressão de adaptação referenciada a um padrăo de investigaçăo e de reforma da educação a nível mundial, tanto mais eficaz quanto năo é percebida como tal (Hüfner, Meyer e Naumann, 1987). Neste contexto de aliança entre o sistema científico hierarquizado, a infra-estrutura internacional de publicações e a programática da educação a nível mundial (Schriwer, 1998) precisamos de mais estudos comparativos através do método do contraste, desenhando pesquisas em que o fenómeno a ser explicado e as hipóteses causais sejam testados em casos em que ambas estejam ausentes, embora sejam tão similares quanto possível nos restantes factores.

A tipologia que Roger Dale (1999) apresenta para estudar os mecanismos através dos quais os efeitos externos se fazem sentir nas políticas nacionais parece ser particularmente adequada a este objectivo. O autor compartilha da tese segundo a qual são factores globais que afectam as políticas nacionais. Contudo, recusando a mão invisível da globalização, considera que esta actua de formas muito variadas e enuncia a natureza e a extensão de tal influência. A principal tese que subjaz à tipologia é a de que é a forma tomada pelo mecanismo de influência que define a natureza do 
efeito, quer dizer, a forma como a mensagem é enviada tem autonomia própria no conteúdo da mensagem. Os mecanismos de influência apresentados são sete: imitação, aprendizagem, harmonização, disseminação, estandardização, interdependência e imposição. Os últimos cinco são considerados como específicos do efeito de globalização. Cada um destes mecanismos é descrito e comparado a partir de oito dimensōes que, segundo o autor, introduzem variabilidade nas políticas nacionais.

A primeira dimensão é designada por natureza da relação e diz respeito ao grau de imposição ou de adesão voluntária das políticas educativas no país destinatário. A graduação apresentada varia entre a adesão voluntária, a adesão formalmente voluntária e a compulsão e dá conta de diferentes modos de integrar nas políticas nacionais as políticas educativas globais. Contrariamente ao ponto de vista dos autores que se situam no world-system approach não se limita a identificar os efeitos de mimetismo voluntário, tentando descrever também os formatos de relação desigual no sistema mundial que estão na origem da imposição e do isomorfismo formal que assumem, por exemplo, as políticas curriculares. Contudo, não resvala também para a assimilação pura e simples dos efeitos da globalização ao imperialismo, reconhecendo que aqueles podem resultar de políticas construídas ao nível supranacional, enquanto as últimas correspondiam à imposição da lei do mais forte.

A segunda dimensão pode ser caracterizada pelo grau de explicitação dos processos de influência externos, que podem variar entre a influência explícita detectável nas actividades técnicas que envolvem o trabalho técnico especializado da OCDE/CERI e a influência implícita na adopção de certos discursos sobre as relações entre educação, mercado de trabalho e desenvolvimento nacional.

A terceira dimensão delimita o âmbito em que a reforma que circula na esfera da globalização tem impacto nas políticas nacionais. Dale chama a atenção para a necessidade de verificar se o âmbito se limita aos programas ou se estende a sua influência à organização e às finalidades dos sistemas educativos. Neste particular, importa sublinhar o papel das teorias do sistema mundial na compreensão da difusão transnacional dos mitos inscritos no modelo escolar tais como o mito do indivíduo, do progresso e da nação culturalmente homogénea e integrada. No seu conjunto, são em grande medida estes mitos, que no passado criaram algum ismorfismo mundial em torno da tríade nação-soberania-cidadão, que continuam ainda hoje a legitimar as finalidades globais mais do que a sustentar programas e modelos de organização escolar homólogos.

A quarta dimensão tenta identificar o locus de variabilidade dos diferentes mecanismos, quer dizer, qual a região que acolhe o ponto de origem da variação. Em geral, a tipologia prevê uma variação superior à tradicional dicotomia nacional-internacional, 
Quadro 2 - Tipologia dos mecanismos dos efeitos externos nas políticas educativas nacionais (adaptado de Dale, 1999)

\begin{tabular}{|c|c|c|c|c|c|c|c|c|}
\hline \multirow{2}{*}{$\begin{array}{l}\text { CARACTERISTICAS } \\
\text { DOS MECANISMOS }\end{array}$} & \multirow{2}{*}{ IMITAÇÃO } & \multicolumn{2}{|c|}{ APRENDIZAGEM } & \multirow{2}{*}{ HARIMONIZAÇĀO } & \multirow{2}{*}{ DISSEMINAÇĀOO } & \multirow{2}{*}{ ESTANDARDIZAÇĀO } & \multirow{2}{*}{ INTERDEPENDENCIA } & \multirow{2}{*}{ IMPOSIÇĂO } \\
\hline & & Normal & Paradigmática & & & & & \\
\hline $\begin{array}{l}\text { NATUREZZA DA } \\
\text { RELAÇĀO }\end{array}$ & Voluntária & Voluntária & $\begin{array}{l}\text { Formalmente } \\
\text { voluntária }\end{array}$ & $\begin{array}{l}\text { Formalmente } \\
\text { voluntária }\end{array}$ & $\begin{array}{l}\text { Formalmente } \\
\text { voluntária }\end{array}$ & $\begin{array}{l}\text { Formalmente } \\
\text { voluntária }\end{array}$ & Voluntária & Compulsiva \\
\hline $\begin{array}{l}\text { GRAU DE } \\
\text { EXPLICITAÇÃO }\end{array}$ & Explícita & Varia & Varia & Explicita & Explicita & Muito explicita & Explicita & Explicita \\
\hline ÄMBITO & $\begin{array}{l}\text { Processos } \\
\text { politicos } \\
\text { particulares }\end{array}$ & $\begin{array}{l}\text { Parâmetros } \\
\text { reconhecidos }\end{array}$ & $\begin{array}{l}\text { Metas } \\
\text { politicas }\end{array}$ & $\begin{array}{l}\text { Políticas } \\
\text { diversas }\end{array}$ & Políticas diversas & Politicas diversas & Metas politicas & $\begin{array}{l}\text { Metas politicas } \\
\text { particulares }\end{array}$ \\
\hline $\begin{array}{l}\text { LOCUS DE } \\
\text { VARIABILIDADE }\end{array}$ & Nacional & Nacional & Externo & $\begin{array}{l}\text { Organizaçōes } \\
\text { regionais }\end{array}$ & $\begin{array}{l}\text { Externo } \\
\text { ou nacional }\end{array}$ & $\begin{array}{l}\text { Fora } \\
\text { internacionais }\end{array}$ & $\begin{array}{l}\text { Herança comum } \\
\text { da humanidade }\end{array}$ & $\begin{array}{l}\text { Organizaçôes } \\
\text { internacionais }\end{array}$ \\
\hline PROCESSO & Imitação & «Aprendizagem» & «Ensino» & $\begin{array}{l}\text { Acordo } \\
\text { colectivo }\end{array}$ & Persuasão & $\begin{array}{l}\text { Condição } \\
\text { de adesão }\end{array}$ & Persuasão & Influência \\
\hline $\begin{array}{l}\text { RELAÇOES ENTRE } \\
\text { PARCEIROS }\end{array}$ & Bilaterais & $\begin{array}{l}\text { Bilaterais e } \\
\text { internacionais }\end{array}$ & Internacionais & Multinacionais & Internacionais & Multinacionais & Global & Multinacionais \\
\hline $\begin{array}{l}\text { FONTE DA } \\
\text { INICIACAAO }\end{array}$ & Destinatário & $\begin{array}{l}\text { Comunidade } \\
\text { politica } \\
\text { nacional }\end{array}$ & $\begin{array}{l}\text { Modelo } \\
\text { internacional }\end{array}$ & Colectiva & $\begin{array}{l}\text { Órgãos } \\
\text { supranacionais }\end{array}$ & $\begin{array}{l}\text { Comunidade } \\
\text { internacional }\end{array}$ & $\begin{array}{l}\text { Organizaçöes } \\
\text { não-governamentais }\end{array}$ & $\begin{array}{l}\text { Orgãos } \\
\text { supranacionais }\end{array}$ \\
\hline $\begin{array}{l}\text { DIMENSÃO } \\
\text { DO PODER }\end{array}$ & $\begin{array}{l}\text { Decisăo } \\
\text { consciente }\end{array}$ & $\begin{array}{l}\text { Decisão } \\
\text { consciente }\end{array}$ & $\begin{array}{l}\text { Marcação } \\
\text { da agenda }\end{array}$ & $\begin{array}{l}\text { Decisăo } \\
\text { consciente }\end{array}$ & $\begin{array}{l}\text { Marcaçẫo } \\
\text { da agenda }\end{array}$ & Regras do Jogo & $\begin{array}{l}\text { Marcação } \\
\text { da agenda }\end{array}$ & $\begin{array}{l}\text { [as três } \\
\text { dimensōes } \\
\text { referidas] }\end{array}$ \\
\hline $\begin{array}{l}\text { EFEITOS NA } \\
\text { EDUCAÇÃO }\end{array}$ & $\begin{array}{l}\text { Directa: no } \\
\text { sector ou na } \\
\text { organização }\end{array}$ & Varia & Varia & Sector implicado & Directa - sector & Directa-regime & $\begin{array}{l}\text { Indirecta - regime } \\
\text { Directa - org. }\end{array}$ & $\begin{array}{l}\text { Indirecta } \\
\text { - Regime }\end{array}$ \\
\hline $\begin{array}{l}\text { ILUSTRAÇÃO } \\
\text { NA SITUAÇÃO } \\
\text { EM PORTUGAL. }\end{array}$ & $\begin{array}{l}\text { Unificaçăo } \\
\text { do ensino, } \\
1976 .\end{array}$ & $\begin{array}{l}\text { Teorias do } \\
\text { capital humano } \\
\text { (década de } 80 \text { ) }\end{array}$ & $\begin{array}{l}\text { Aumento dos } \\
\text { encargos } \\
\text { directos com } \\
\text { a educaçâo }\end{array}$ & $\begin{array}{l}\text { Programas } \\
\text { comunitários europeus } \\
\text { em matéria de } \\
\text { educaçăo e formação }\end{array}$ & $\begin{array}{l}\text { Projecto } \\
\text { PEB-OCDE }\end{array}$ & $\begin{array}{l}\text { Declaraçăo } \\
\text { da Unesco: } \\
\text { Educaçāo } \\
\text { Para Todos }\end{array}$ & $\begin{array}{l}\text { Projecto de } \\
\text { avaliaçāo do } \\
\text { ESU pelo SIDA }\end{array}$ & $\begin{array}{l}\text { Empréstimos } \\
\text { do Banco } \\
\text { Mundial }\end{array}$ \\
\hline
\end{tabular}


alargando-a aos diferentes locais onde as políticas são elaboradas: organizações regionais, fora internacionais e organizaçōes internacionais.

A quinta dimensăo propõe-se apreender a variabilidade pelo lado dos processos envolvidos na influência externa. Para além de processos já descritos pelos institucionalistas, no âmbito das mudanças isomórficas (DiMaggio e Powell, 1991), tais como a coerçăo, o mimetismo e a normatividade, que Dale utiliza para descrever a diferença da influência externa, sugerimos ainda que a variabilidade dos efeitos externos pode resultar de diferentes problemas de legitimidade interna e da mobilização desigual das respostas standard desencadeadas pela incerteza.

A sexta dimensão comporta a génese das politicas educativas e diz respeito à iniciaçăo das reformas. Dale considera que a origem da reforma se encontrava nos próprios destinatários e nas comunidades políticas nacionais, antes da globalização, enquanto agora se deslocou cada vez mais para as organizaçōes internacionais, interestatais e năo-governamentais e para as novas comunidades internacionais imaginadas.

A sétima dimensão designa as formas de poder e introduz a tiplogia de poder desenvolvida por Luke (1974): exercício da superioridade de alguns estados nos fora internacionais, por intermédio de processos de decisão claramente definidos; capacidade de impor os temas e o ritmo da agenda política, bem como de retirar outros do processo de decisão; capacidade de controlar as regras do jogo em que o poder é exercido.

Finalmente, a oitava dimensão diz respeito ao modo como a mudança externamente introduzida é mediada ao nível educativo. A principal cautela analítica introduzida pela tipologia dirige-nos para um olhar simultaneamente atento tanto às mediaçōes explícitas no sector educativo e nas suas organizaçōes, quanto às mediações indirectas ou decorrentes, tais como as que silenciosamente vão harmonizando as políticas curriculares europeias. $\mathrm{O}$ quadro 2 sintetiza e adapta a tipologia de Dale, apresentando ainda alguns exemplos ilustrativos dos diferentes mecanismos para o caso do sistema educativo português.

\section{Do Estado à Governamentalidade}

Em oposição a uma visăo teleológica da história e da escola preferimos a alternativa que não conjectura uma episteme escolar sustentada no desenvolvimento geral da razão. A escola năo emerge de interesses económicos, capacidades intelectuais, princípios morais ou estratégias estatais pré-definidas. Parece-se mais com uma 
tecnologia improvisada, um habitus que acolhe os escassos recursos que a cultura tem ao dispor para imaginar e orientar a educação. Deste modo sofre sucessivas deslocações devidas à complexa relaçăo de factores que geram a oferta e a procura de educaçăo. Reconhece-se a singularidade dos fenómenos e a possibilidade de que tendo acontecido assim, poderia ter acontecido de outro modo. Não existe uma imanência, uma razăo-clara ou auto-evidente nos acontecimentos históricos. Como comentava Furet (1981: 19): «o postulado segundo o qual o que 'realmente aconteceu' o fez por necessidade é uma ilusão retrospectiva clássica da consciência histórica, que vê o passado como um campo de possibilidades no qual o que realmente aconteceu se apresenta ex post facto como o único futuro para aquele passado».

Os fundamentos desta teorizaçăo provêm da interpretaçăo moral e espiritual do Estado-educador. Habitualmente apresentada enquanto mandato tem uma versão funcionalista e outra crítica. A primeira entende que a escola estatal é o resultado do desenvolvimento histórico orientado para a perfeição moral da pessoa. Os funcionalistas liberais consideram que este é o mal menor para uma sociedade civil que nem sempre possui a vontade moral de educar as jovens gerações. Em alternativa propōem-se «libertar o ensino» da tutela estatal entregando-a à sociedade civil por que aquela seria sempre sinónimo de insensibilidade perante os clientes.

Por seu lado, os defensores da tese da difusăo mundial do modelo escolar ocidental reconhecem-lhe, embora sem proselitismo, um conjunto de valores e de mitos que Ihe fornecem o suplemento necessário à sua pregnância global. Finalmente, os adeptos da tese conflitualista vêem no Estado o instrumento burocrático que actua em nome da exploraçăo, remetendo para o seu simétrico contrário: a defesa de uma escola igualitária, democrática e justa de acordo com princípios morais de resistência (Giroux, 1989), mormente por intermédio da pedagogia da experiência e da autonomia emancipatória.

Deste modo, a gramática da escola passa a estruturar-se pelas oposições entre estado e sociedade civil, público e privado, coerçăo e autonomia, conhecimento canónico e conhecimento experiencial, inovação e tradição, autodesenvolvimento e desenvolvimento burocrático, democracia e meritocracia. Simultaneamente, tais dicotomias dispersam o olhar analítico da característica dominante do poder político da modernidade: o poder não se exerce apenas através do constrangimento e coacção; antes se realiza por intermédio da montagem e de alianças entre diferentes instâncias que governam os domínios da actividade económica e da vida social colectiva e da conduta individual. Esta composição de elementos heterogéneos resulta da íntima relação entre um modo de reflexăo política e instrumentos, práticas e objectivos de governo. Nesta perspectiva, a autonomia não é a antítese do poder político 
mas um pressuposto essencial do seu exercício. Os indivíduos jogam um papel directo nas operações de poder, por intermédio das disciplinas e das tecnologias que os fazem autores da sua própria conduta. Foucault caracterizou esta combinação aparentemente contraditória entre a pública administração dos cidadãos e a subjectivação dos indivíduos como sendo o resultado da fusão da metáfora grega do sacrifício dos cidadăos à cidade com a metáfora pastoral cristã (Foucault, 1981: 239). O principal tópico de interesse de Foucault consiste em captar a racionalidade presente na realizaçăo do que ele designa por montagem moderna do jogo-cívico e do jogo-do-rebanho: a invenção de uma forma de orientaçăo pastoral secular que associa individualizaçăo e totalização.

Este jogo implica a incorporação de princípios morais na construção do Estado? Pelo contrário, a nova racionalidade emerge em consequência de guerras religiosas que derivavam o governo de princípios morais absolutos, contra os quais o Estado opôs uma base pragmática separada de princípios espirituais, formulada na doutrina da razão de Estado (Koselleck, 1988). Esta forma de encarar o Estado amplia o campo teórico e analítico da escola para o campo da governamentalidade (Foucault, 1991). O traço distintivo desta nova forma de governo é a rejeição de qualquer doutrina que o legitime na disposição natural para o bem ou para a verdade. A crença numa consciência natural tende a ser substituída pela teoria lockiana da tabula rasa. É nesta tradição filosófica que se funda o governo da subjectividade. A governamentalidade năo se compraz em governar as coisas, acrescentando à soberania do príncipe sobre o território três complexos de poder e conhecimento: o jurídico, o disciplinar e o governamental. O primeiro tem origem na extensão da lei secular canónica; o segundo na proliferação das técnicas de normalização do século XVII e o último na genealogia da subjectividade dos séculos XVIII e XIX.

O conceito de governamentalidade é aqui utilizado em contraste com o de soberania que, em nossa opinião, serve de apoio às teses nominalistas do Estado: uma visão redistributiva do poder a partir de um centro que o distribuiria de forma desigual. É neste quadro que se pode compreender o debate sobre a inclusão e exclusão de certos grupos nas políticas sociais do Estado. Um maior grau de representaçăo dos grupos organizados nas decisŏes tende a ser visto como um mecanismo de participação e inclusāo social. Pelo contrário, um baixo grau de representação seria a expressão de um sistema de dominação centralista que assim excluiria alguns do sistema político. O Estado é apreciado enquanto actor uno e abstracto capaz de organizar, por intermédio das suas políticas, mecanismos de inclusão e exclusăo; a sociedade civil é reificada na hipótese liberal do exercício igual da autonomia individual, tendo artes de conquistar, no seu exercício, poder à «sociedade política». Deste 
modo, as relações do poder do Estado são postas em posição de exterioridade relativamente a outros tipos de relaçōes - relaçōes pedagógicas, relaçōes de trabalho, relações pessoais, relações organizacionais - não permitindo verificar como estas são atravessadas por relaçōes de força que compōem o diagrama final do poder.

Propõe-se como alternativa a esta forma tradicional de ver o poder e o Estado um modo relacional e imanente de o fazer. O poder está em toda a parte; năo que seja global e total, mas porque provém de todo o tipo de relações, sejam elas locais ou globais. As relaçóes de poder săo o efeito das assimetrias e desnivelamentos que se produzem no seu interior e que desse modo as constituem. Não existe, portanto, centro e território nas relações de poder, embora existam formas de integraçăo institucional das relações de poder como as que o Estado utiliza.

A escola tem sido investida por liberais e críticos de uma grandeza de princípios que a menorizou frequentemente, quando comparada com as suas obras, e por uma abundância de expectativas sociais que, por não realizadas, a remeteram para o lugar de instituição em crise permanente. Esta constatação dirige-nos para o núcleo central do nosso ponto de vista: a escola não será observada enquanto concretização falhada de principios, mas antes como uma montagem improvisada, constantemente actualizada, de tecnologias governamentais e morais disponiveis em cada momento, aptas a moldarem-se a diferentes contingências históricas. Neste sentido, a crise da escola de massas corresponde a uma história de diferenças permanentes provocadas pela sua intrinseca falta de autonomia. A aplicaçăo sistemática do conceito de descontinuidade encontra porém um certo número de obstáculos travejados na metáfora biológica e evolucionista e nas noçōes de progresso, desenvolvimento, adaptação e evoluçăo que permitem descrever acontecimentos discretos como sendo a manifestação de um único princípio organizador ou da evolução para um certo estado normativo. Estas sínteses previamente estabelecidas tendem a cristalizar em dicotomias tais sejam inovação/inércia, adaptação/regressão e movimento/imobilidade que fornecem uma visão iluminista da sociedade. Quer a óptica melhorista da versão liberal quer a óptica radical da versão marxista năo permitem reconstruir a simultaneidade das diferenças no seu efeito de conhecimento disperso, de pequenas diferenças e de insignificantes flutuações que constituem o arquivo de possibilidades de acção inscritos nas práticas e nos discursos actuais dos autores e destinatários da escola.

Tendo em atenção o que foi dito parece pouco interessante continuar a perguntar se a escolarizaçăo tem sido ou não uma tendência civilizadora global na Europa ocidental e no mundo. Também parece limitado questionar apenas as razôes da expansão da escola de massas sem Ihe associar as racionalidades políticas que alteram 
os campos discursivos nos quais o exercício do poder sobre a escola é conceptualizado. Em seu lugar colocamos a questão das condições de interdependência locais que estão relacionadas com o tipo de escola que vimos analisando e em que condições isso não se passa. Para responder-lhe são necessários dois requisitos: o primeiro renuncia às pretensōes universalizantes e prefere olhar mais de perto para os contextos de espaço-tempo; o segundo estabelece como método de trabalho a necessidade de criar laços mais compreensivos entre as condições de interdependência locais e a escola de massas, o que implica um refinamento destas duas categorias.

As interdependências locais: para além do Estado. A escola nasce no mesmo espaço-tempo da invençăo do sujeito como objecto de conhecimento fáctico e da sua incorporação no Estado. Produçăo de cidadãos e produção de sujeitos é o projecto do Estado-Nação que origina um conjunto de sistemas de poder que regulam a experiência humana e as formas e saberes nos quais os indivíduos se passam a reconhecer enquanto subjectividades. Neste sentido, o Estado moderno institui menos uma razão de Estado que uma administração responsável por uma certa organização da vida que promove um estado de razão individual. A este processo de distribuiçăo para baixo, para os comportamentos individuais, do mesmo tipo de princípios e de saberes do bom governo do Estado chamou Foucault a governamentalidade. Processo complexo que resulta também na distribuiçăo para cima de novos procedimentos, técnicas e instituições que têm na população o seu alvo de conhecimento e de intervenção. Neste quadro, analisar qualquer ponto de entrada deste sistema tríplice formado por poderes, saberes e subjectividades implica sempre a eleiçăo de referenciais multímodos que estejam aquém e para além do Estado, incluindo neste percurso transversal o próprio Estado.

O Estado não se reduz a um certo número de funçōes relacionadas com a acumulaçăo capitalista e a legitimação política. O Estado elaborou e concentrou um capital simbólico por intermédio dos seus próprios mecanismos de formação. Bourdieu (1994) enuncia alguns: o monopólio legítimo da violência; a cunhagem de moeda e a imposição de um sistema de impostos; a fusão do território através da lingua nacional e da criação de um sistema único espaço-temporal; a unificaçăo jurídica e administrativa concebida como forma universal de falar com a sociedade. Do interior destes mecanismos emerge o capital simbólico de autoridade reconhecida que concentra a forma particular de eficácia da sua acção. Para Bourdieu, a ordem simbólica apoia-se na imposição ao conjunto da população de estruturas cognitivas, pré-reflexivas, que devem o acordo tacitamente obtido à aparência de coerência com as estruturas objectivas do mundo social. Em consequência, o Estado năo tem, necessariamente, de exercer a coacçăo física ou de optar pela injunçăo para obter comportamentos orde- 
nados. Isto só é possível porque se estabeleceu um acordo entre as estruturas cognitivas que a história colectiva e individual inscreveu nos corpos e as estruturas objectivas do mundo ao qual se aplicam (Bourdieu, 1994: 127). Mais do que formas de consciência, as estruturas cognitivas são disposiçōes do corpo.

Estas consideraçôes sobre o Estado levaram alguns analistas a aceitar uma epistemologia realista na sua conceptualização. Para o realismo, a essência do conceito subjaz na sua relação com o conteúdo verdadeiro, material e tangível do próprio objecto que analisa. Os estados seriam actores unificados, reificados na sua autonomia de poder sobre a nação. Para os nominalistas, como Bourdieu, a essência do conceito deve ser dissolvida na sua relação com o universo de significado arbitrário, relacional, de onde deriva a sua cristalização. A institucionalização do quadro jurídico e a formação de um corpo de funcionários e de instâncias administrativas e a separação deste do universo particularista da economia confinaram ao espaço público a lógica dos direitos cívicos, enquanto em espaços adjacentes, sobretudo na família e na produção, outras formas de organização tinham lugar. É desta separação do espaço público e do espaço privado que resulta a capacidade de o Estado moderno fazer a «naturalização da economia capitalista de exploração e a neutralização do potencial revolucionário da política liberal». (Santos, 1994: 109).(15) É nesta separaçăo que se funda também a fragmentaçăo da governamentalidade. Nesta óptica, a questão deixa de ser o que é o poder do Estado e passa a ser a de compreender como e em que medida é que este se articula com outros poderes; que outras forças e conhecimentos mobiliza; por que meios e técnicas se tornam operatórios; que discursos Ihe actualizam, e por que formas, o seu poder simbólico. A questão passa a ser o que deve ser compreendido hoje por poder de Estado?

É justamente neste ponto que prolongamos a reflexăo de Bourdieu. Remeter o acordo tácito e a submissão à ordem estabelecida para uma espécie de experiência

(15) Ver também este artigo para uma análise crítica da dicotomia Estado-Sociedade civil. Neste artigo, bem como em outros que o antecedem (Santos, 1985, 1989), o autor desenvolve e aprofunda a análise das funçōes latentes desta distinção conceptual. São particularmente importantes para a nossa proposta os seguintes argumentos de Santos: a exterioridade do Estado relativamente às relaçōes de produçăo deriva da representaçăo destas como tendo lugar no espaço privado das transacçőes entre indivíduos, obscurecendo assim que é o Estado que garante o cumprimento do direito de propriedade; as relaçōes de produção são a imagem em negativo da universalizaçăo da cidadania, por que a fábrica se rege por princípios despóticos imunes ao ideal democrático de participaçăo igualitária; a concentração da sede do direito e da política no espaço público do Estado encobre o facto de a forma democrática do Estado coexistir com outras formas antidemocráticas de direito e de política como as que se icluem no contexto doméstico, no contexto da produção e no contexto das profissőes corporativamente reguladas. 
primeira do mundo, pré-reflexiva, condena-nos a ignorar a dimensão activa, reflexiva, da produção simbólica do Estado. Esta apenas foi possível em resultado de confrontos, submissōes e acordos entre visões concorrentes que se mantêm hoje sobre outras formas. As estruturas cognitivas permanecem porque sofrem uma actualização permanente; não porque se reproduzam como universalias pré-reflexivos. A procura de um conceito unificado de Estado contraria neste caso o nivel de análise da sua putativa utilização. Pelo que a universalidade realista deve dar lugar à análise relacional ditada por critérios de utilidade, fecundidade e plausibilidade de um determinado campo cientifico de observaçăo do objecto em causa. Consequentemente é preciso encontrar um dispositivo analítico que integre as definiçōes reais, fenomenológicas, do Estado sem se deixar captar por elas; bem como questionar o objecto real a partir de definiçōes do campo científico, metodologicamente controladas, sem esquecer as constantes alteraçōes substantivas, particularmente as discursivas, que definem o objecto no mundo real.

O problema não é o de saber se o conceito unificado de Estado pode ou não ser obtido, tarefa a que não nos dedicaremos, mas o de saber se um determinado objectivo pode ser melhor servido por um tal conceito ou por uma série de noções operatórias. $\mathrm{O}$ alargamento que fazemos do conceito de Estado ao processo mais amplo da governamentalidade pressupōe a possibilidade de usar conceitos do campo de análise estatista do Estado sempre que tal se justificar. Sendo certo que a noção de governo utilizada não designa um aparelho político particular, situado no Estado e na sua administração, nem um determinado leque de regras administrativas, mas um conjunto heterogéneo de práticas orientadas para a supervisăo calculada de uma dada população e de cada um dos seus membros.

\section{Racionalidades políticas, Estado e Governamentalidade}

Na conferência realizada em 1978 no Colégio de França, Foucault ao dissertar sobre a governamentalidade traçava-Ihe a sua principal característica: conjunto formado pelas instituições, métodos, análises e reflexões, cálculos e tácticas que permitem o exercício desta especifica embora complexa forma de poder, que tem como alvo a população, como principal forma de conhecimento a economia politica e como meios técnicos essenciais os aparelhos de segurança (Foucault, 1991: 102). Dito de outro modo, a governamentalidade não tem um centro; vem de toda a parte e possui um conjunto de racionalidades e de tecnologias que o produzem a cada instante. Assim se formam relaçōes múltiplas de força que actuam nos indivíduos, nos grupos, nas 
famílias e nas instituiçōes; estas formam um diagrama de forças que atravessa as disposições e as escolhas individuais e, simultaneamente, produz efeitos hegemónicos estabilizados em instituições. Podemos assim definir o poder como aç̧ões sobre as acções (Deleuze, 1988, 1998) que impōem uma tarefa, produzem um efeito útil ou induzem um discurso. Em síntese, a governamentalidade é a consequência não necessária da articulaçăo entre racionalidades políticas, tecnologias e subjectividades.

Por racionalidades entendemos os campos discursivos através dos quais é dado um significado colectivo aos ideais que põem em sintonia os objectos e objectivos de governo. A governamentalidade tem um carácter discursivo: a análise das conceptualizaçōes, cálculos e programas que circulam no campo governamental requer uma atenção particular à linguagem do exercício do poder, às justificaçōes morais usadas para formas particulares de agir e à concepção das formas apropriadas de intervenção. As racionalidades políticas săo formas de conhecimento que requerem a invenção de procedimentos de notação, formas de recolha e apresentação de estatísticas, transposição destes dados para centros onde os cálculos e os julgamentos sejam possíveis. As práticas estatísticas são mais do que a agregação numérica de inscriçôes, custos e outras categorias pretensamente descritivas. Incluem vocabulários e discursos que se concatenam em vários níveis colectivos, articulando-se em diversos espaços para responder diferentemente às necessidades de acção. É por intermédio deste trabalho de composição discursiva, deliberado ou não consciente, que práticas particulares como são as envolvidas nas estatísticas se expandem para além do campo originalmente destinado à sua intervençăo. O planeamento consiste numa multiplicidade de programas que pretendem administrar as acçōes dos indivíduos em conformidade com as normas políticas mais gerais.

Por tecnologias entendemos todos os cálculos, aparelhos, documentos, técnicas, organizaçōes e instituiçōes e outros instrumentos que agem sobre os indivíduos em conformidade com um conjunto particular de ideias. As tecnologias de governo fazem parte das condiçōes de exercício da governamentalidade, imbricando-se nas racionalidades políticas. Esta noção de tecnologia pretende descrever o modo como um dado conhecimento, científico ou outro, se insere no interior do exercício prático do poder. Torna-se, deste modo, um operador central no nexo postulado entre formas de conhecimento e regimes de práticas. Porém, este nexo foi também proposto por duas outras tradições de análise que devemos constrastar antes de prosseguir: a chamada história das ideias ou das mentalidades e a corrente da sociologia do conhecimento. A primeira corrente distingue-se quer pelo estudo dos efeitos desejados pelo autor de um determinado conhecimento, quer pelos efeitos do lado dos recep- 
tores das ideias. Tomando como exemplo o papel das ciências sociais no exercício da autoridade, săo estudados os modos de disseminação, apropriação diferencial e influência das suas ideias. É criada uma distância epistemológica relativamente ao discurso científico enquanto conhecimento verdadeiro, incluindo-o na categoria mais genérica das ideias, embora se mantenham e respeitem as actuais normas de constituição do campo científico como base da trajectória traçada. A sociologia do conhecimento, na tradição de Mannheim e Merton (1968) e de Berger e Luckmann (1966), cria também um recuo epistemológico com base no contraste entre os contextos macrossocial e microssocial do conhecimento. A esta divisão preside uma separação nítida entre factores internos e externos da ciência e entre condiçōes teóricas e năo teóricas de validaçăo da ciência enquanto sistema de conhecimento. Ao fazê-lo distinguem o que é da ordem do condicionamento social da ciência, questionando nesse nível as próprias condiçōes teóricas e metodológicas inerentes ao processo científico, e o que é da ordem do condicionamento institucional e biográfico da ciência, questionando nesse nível os rituais, as rivalidades, os conflitos e os percursos biográficos que subjazem à produção científica. Estabelece-se assim uma fronteira entre epistemologia e sociologia da ciência que dificilmente pode ser superada.

Em contraste a estas duas tradições, a nossa proposta suspende a questão epistemológica de uma forma mais severa, permanecendo neutral relativamente à reivindicação de validade das diferentes formas de conhecimento que examina. Daí, a rejeição das oposições entre macro e micro, entre condições cognitivas e não cognitivas, entre ideias e contexto ou entre ideologias e ciência que subjazem à incomunicabilidade e incomensurabilidade da sociologia do conhecimento tradicional. Em vez de analisar as credenciais epistemológicas das ciências sociais e humanas, que orientam certas práticas, tentamos examinar como operam e tornam possivel certos regimes institucionais. O conceito de tecnologia de governo tenta responder à necessidade de articular as formas de conhecimento com os campos práticos e pragmáticos nos quais as capacidades e os comportamentos humanos são problematizados.

Dentre as articulações existentes, a que situa o conhecimento científico no contexto institucional estatal é uma das que mais atravessa este trabalho. Percebe-se porquê: foi no campo discursivo que o Estado estabeleceu o monopólio legítimo de conceber os instrumentos conceptuais, o vocabulário e o idioma para falar de si. Tal ortodoxia de pensamento tornou-se um obstáculo epistemológico à sua crítica. Como sugere Bourdieu (1994), a análise do Estado faz-se muitas vezes nos seus próprios termos e conceitos. Esta circunstância aconselha um processo de invenção conceptual que permita uma alternativa teórica à circularidade do regresso do mesmo ao mes- 
mo e a superaçăo da subjectividade monumental do Estado que tende a colonizar outras subjectividades com existência no campo educativo A nossa proposta de análise centra-se naquilo que temos vindo a designar como configurações simbólicas ou de sentidos (Gomes, 1993, ver cap. I.6).

De acordo com Meyer e com os restantes institucionalistas o aspecto mais importante da construção da escola é que esta assume uma funçăo social nova sem ter de inventar qualquer norma. A regulação da escolarizaçăo deriva da autoridade pública, é um mimetismo, por que a institucionalização da relação entre cidadão e pessoa resulta automaticamente numa organização semelhante à do Estado. Numa outra óptica, as teses da apropriação classista do Estado assumem que a escola tem o seu próprio código, mas com uma organização similar à da empresa.

Estes dois pontos de vista devem ser criticados em relação a duas questōes essenciais para o desenvolvimento do nosso argumento. Em primeiro lugar, porque levam demasiado longe a identificação do formato organizacional e de poder no Estado e na empresa com o formato organizacional e de poder da escola. Os seus argumentos não consideram suficientemente as diferentes racionalidades em que estes três contextos operam. É justamente nessas diferenças e na sua articulação que os processos de governamentalidade da modernidade capitalista se distinguem das soluções que a precederam. Em segundo lugar, estas correntes concebem o poder na escola como uma escolha dentro do par consentimento-coerção, derivando-a, no primeiro caso, do princípio da confiança em instituiçōes percebidas como legítimas e, no segundo caso, na imposição de um código particularista e desigual. Se bem que estes dois mecanismos existam isso não significa que tal escolha esgote os meios de regulação produzidos no interior da própria escola. Tão pouco quer dizer que a legitimidade seja sempre subjectivamente vivida como consentimento ou, contrariamente, que a coerçăo seja exclusivamente percebida como mistificação ou constrangimento. Estes argumentos sofrem de uma mesma dificuldade em inter-relacionar estruturas sociais e subjectividade. É que se a experiência subjectiva é cultural e institucionalmente mediada a recíproca também é verdadeira. Nem a autonomia da subjectividade e da consciência clara que domina o discurso liberal, nem a falsa consciência que provém da tradiçăo marxista enunciam a hipótese de as práticas reproduzirem e mudarem simultaneamente os sistemas simbólicos de poder e de estes elaborarem a subjectividade dos actores que os actualizam e transformam. Deste ponto de vista a institucionalização é sempre uma dupla institucionalização e a des-institucionalização uma re-institucionalização. É por isso que temos vindo a propor um mapa de cinco configurações simbólicas que articulam as diferentes racionalidades e tecnologias de poder que se cruzam no espaço estruturalmente heterogéneo da escola. 
Uma das características principais das cinco racionalidades é que se apresentam sob a forma de retóricas morais. Justificam a sua grandeza por comparação com as outras num balanço linguistico que integra princípios de liberdade, equidade, eficiência e justiça. Tais princípios limitam o espaço epistémico em que circulam, se relacionam e se diferenciam. A segunda característica alarga o modo de articulação das racionalidades políticas da retórica aos idiomas. Estes definem as formas e os limites do que é dizível, formando o quadro de referência que torna a realidade pensável. A terceira característica diz respeito à transmutabilidade dos princípios e idiomas entre racionalidades discursivas. Quando se compara, por exemplo, as transformações que tiveram lugar nas duas últimas décadas nas relaçōes da escola e da família năo se pode deixar de encontrar simetrias entre a normalização escolar da familia realizada através do desenvolvimento de formas burocráticas e cívicas de regulaçăo e da familiarização da escola por via do desenvolvimento da chamada "comunidade escolar». No primeiro caso criou-se um conjunto de tecnologias de aconselhamento, de orientação e de testagem que formou o complexo de polícia das famílias (Donzelot, 1979); no segundo caso, a administraçăo burocrática do Estado ao encontrar na família uma esfera social autónoma, feita de imperativos afectivos destinados à protecçăo e promoçăo dos seus próprios membros, desenvolveu um conjunto de técnicas de relação - serviços de orientação; dispositivos associativos de representação; representaçăo na gestăo - agregadas num discurso de bem comum. Estes desenvolvimentos definem um conjunto de dependências intradiscursivas e interdiscursivas que săo o espaço de posições e funções diferenciadas dos sujeitos (Foucault, 1991: 58).

Finalmente, a quarta característica das racionalidades discursivas coloca-nos no cerne da governamentalidade: a acção à distância (Latour, 1989, 1995). Esta capacidade depende dos mecanismos pelos quais são delegados para os domínios não públicos e, portanto, tidos como não políticos a regulação de certas esferas de actividade. Isto é tornado possível por intermédio dos especialistas, dos gestores e das famílias que respondem a certo tipo de interpelações sob formas discursivas descontextualizadas. Como ilustração da descontextualizaçăo, imprescindivel a qualquer forma de acção à distância, podemos referir que a partir do final da década de 70 a participação na escola entrou em declínio (Lima, 1992; D'Espiney, 1988) enquanto as ideias de comunidade escolar e de representação mais alargada nas decisões escolares passaram a estar obsessivamente presente nos discursos da reforma dos anos 80. Esta descoincidência entre significante e significado tem vindo a ser resolvida por meio de signos convencionais. Um corpo de especialistas, gestores, em diferentes níveis do sistema, instrumentalizam e mobilizam técnicas de planeamento participativo 
para uma participação que já não existe; definem um espaço de autonomia com novos mecanismos de burocratização e de controlo das actividades; refazem o perfil de profissionalização dos professores a partir do aprofundamento das especializações. A prevenção de disputas provocadas pela discrepância entre discursos argumentativos e práticas sociais nāo exclui a articulação daqueles com tecnologias de regulação e de controlo, e mesmo o uso da força e da coacção.

O resultado destas operaçōes são persuasões, negociaçōes, acordos e desacordos. Estabelece-se uma forma mais ou menos partilhada de ver o mundo, consistente ou resistente, que em outro trabalho analisamos pela óptica da cultura de escola (Gomes, 1993). Uma visão da realidade epitomizada numa gramática de metáforas, imagens e vocabulários. Produzem-se conexões estruturalmente débeis mas discursivamente fortes entre actores, acontecimentos e sistemas de acção que muitas vezes são formalmente distintos e autónomos. Quando se elabora um consenso local, fora da estrutura formal do Estado, em que cada um interpreta os valores de outros na sua própria linguagem, definindo assim um padrão subjectivo regulador da sua conduta própria, forma-se um sistema de acção à distância.

Nos resíduos destas actividades justificadas discursivamente mantém-se o movimento incessante das tecnologias improvisadas para cumprir o programa de governo das escolas. O Estado não é o beneficiário último deste programa nem o inspirador de uma qualquer maquinaçăo. Sem as tecnologias da governamentalidade, que implicam técnicas e actores policentricamente colocados, o Estado não estaria apto a produzir as condições subjectivas sob as quais funciona a noção contratual cidadãosociedade.

\section{As tecnologias de Governamentalidade da escola}

As tecnologias de governo são técnicas propriamente ditas e estratégias, tácticas, dispositivos e procedimentos. Nenhuma tipologia estaria em condiçōes de lhe organizar uma taxonomia. E isto porque a par do corpo de procedimentos e de modos de intervenção padronizados numa linguagem universal, como é a que o Estado em regra utiliza, outros existem que resultam da miríade de conexões que envolvem os diferentes níveis da textura social. Nesta definição inicial as tecnologias não possuem qualquer programa ideal de intervençăo; distinguem-se pelo seu pragmatismo de intervenção e de adaptação. Em tese, as tecnologias podem ser tantas quantas as circunstâncias em que devem ser montadas, pelo que não é uma tipologia das modalidades que importa obter. A descrição das suas modalidades seria infindável por 
que em princípio utiliza meios finitos para fins infinitos. A possibilidade de estarem à disposição, prontas a serem usadas, sem que necessariamente o sejam, são condição da sua eficácia.

\section{Governar pessoas calculáveis}

Tomemos como exemplo o conjunto de procedimentos, de técnicas e de tácticas que envolvem as estatísticas e o planeamento da educação. A quantificação não é um mero exercício estratégico de descrição do mundo natural e social, mas o meio em virtude do qual aqueles são produzidos, processados e reconfigurados. Articulados com sistemas de controlo administrativo criam uma contabilidade que fornece estabilidade a acontecimentos contingenciais e irregulares.

O conceito de escola de massas é parcialmente um conceito estatístico. Quando as primeiras estatísticas sobre a frequência escolar se tornaram disponíveis em 1844 os números criaram um novo fenómeno. Não era tanto a sua magnitude que impressionava; a regularidade e a generalidade tornava possível, aceitável e desejável a produção de cidadãos dentro de um segmento específico da população que assim se tornava visível. A fragmentação, incipiência e pequenez da instituição é transformada num fenómeno de larga escala, genérico, social e com visibilidade nacional a partir da concentraçăo, estandardizaçăo e agregação que os números permitem. A experiência de ir à escola em contextos sociais dispersos e marcados ainda por algum comunitarismo, próprio da relação de face-a-face, torna-se numa realidade sem espaço nem tempo, intrinsecamente transportável e manipulável pela administração, que assim passa a conhecer um corpo social inevitavelmente impessoal.

A contabilidade estatística requer a intervenção administrativa e a criação de centros de cálculo envolvidos numa rede de recolha de informação. O que nos interessa nas estatísticas educativas do período que analisamos não é tanto uma análise de segunda ordem sobre a realidade que reflectem; é antes uma análise de terceira ordem sobre as construções sociais tornadas realidades que são capazes de gerar. As estatísticas públicas são tanto mais válidas e capazes de descrever a realidade quanto mais tenham participado na sua própria construção. O reconhecimento de que as estatísticas administrativas são medidas de aspectos da própria actividade da administração, segundo as suas categorias, e não a representação exacta das características dos indivíduos e das situaçōes que observa, conduz-nos para a necessidade de interpretação sociológica do campo político e administrativo que define as condições da sua produção. Embora o produto final das estatísticas seja importante, os discursos que acompanham os processos de elaboração revelam o seu verdadeiro papel 
generativo. Saber qual o seu curso; quais os conflitos originados pela sua realização; quais as descontinuidades das categorias utilizadas; quais as categorias de percepção dos que nos estabelecimentos de ensino fazem a colecta de dados são elementos imprescindiveis para a compreensão das estatísticas enquanto tecnologia de governo da população.

O estudo dos inquéritos estatísticos demonstra que estes são um recurso escasso usado, por exemplo, na negociaçăo da rede escolar que tem lugar nas áreas pedagógicas. A diversidade de estudos oferecidos por um certo estabelecimento não é o resultado da correspondência da oferta à procura ou o efeito de uma qualquer inércia histórica; depende das suas condições de funcionamento específicas. A necessidade de declarar efectivos suficientes de alunos para conservar postos de professores ou de os inflacionar para efeitos de redistribuição do excedente pelas restantes escolas da área, são características constantes das estratégias concorrenciais com impacto evidente no momento da recolha de dados. Do mesmo modo, o uso da invisibilidade estatística dos abandonos, considerando como inscritos até ao final do ano escolar os alunos que, entretanto, deixaram a escola, ou que nunca a frequentaram, é um exemplo típico de jogo de soma positiva das estatísticas administrativas. Com efeito, ambos os jogadores ganham: a escola porque deste modo pode apresentar contagens que impliquem o alargamento ou a redução de turmas e de cursos de acordo com as suas necessidades locais de massificaçăo, desmassificação ou selecção social; a administração porque regista uma sobrestimação sistemática dos efectivos por via da duplicação das contagens do mesmo aluno em dois ou mais estabelecimentos.

A reificação de uma certa categoria estatística não implica ausência de escaramuças nas suas fronteiras ou entorses à convenção estabelecida. Uma das dificuldades dos estudos comparativos reside justamente na impossibilidade de saber para cada caso qual é a instabilidade relativa das fronteiras entre categorias. Esta questão é habitualmente resolvida pela presunçăo do erro residual ou da equivalência do erro que não deixam de ser em si próprias coisificações de uma regularidade estatistica completamente improvável.

Tratar as formas estatísticas desta óptica não releva de qualquer forma de denúncia da falsidade ou de maquinação do Estado. Pretende-se tão-somente devolver aos esquemas cognitivos e às técnicas estatísticas da educaçăo a conexão com as categorias do discurso político. O elo é muito mais directo do que a incorporaçăo das estatísticas na reflexividade social deixa perceber: a tecnologia política das estatísticas não transforma o significado ou a forma do acto educativo, mas concatena-se com as condições da sua inserção e funcionamento, moldando os modos de existên- 
cia do discurso educativo. A ligaçăo entre a prática política do Estado e os discursos educativos não se deve à sua capacidade de impor a razão do Estado, à superioridade moral de modelar consciências ou de sistematizar conceitos que se impōem aos restantes actores. A montagem é muito mais pragmática e age por intermédio de um conjunto de operações das quais apenas trataremos das referentes à tecnologia do planeamento e das estatísticas. No capítulo IV são analisados os critérios de decomposiçăo do objecto educativo (abandonos, insucesso, nível socioeconómico, imigrantes, análise custo-benefício) em articulação com a elaboraçāo de técnicas de decomposição do espaço e de planeamento (e.g. carta escolar, análise das disparidades regionais) e de novos discursos educativos.

A quantificação referente à frequência, ao abandono ou ao sucesso escolares têm efeitos diferenciados na reelaboração, mudança ou estabilizaçăo do sistema, dependendo da fase do seu processamento. Elaborar e operacionalizar a categoria estatística, recolher, enviar, tratar, agregar e publicar dados são operações que fornecem uma forma particular de visibilidade aos acontecimentos e produtos escolares correspondente ao modo como se pensa ou se actua no fenómeno: os professores incorporam novos vocabulários; os administradores e planeadores revelam outras técnicas; os decisores políticos constroem diferentes racionalidades.

No momento da recolha de dados a norma estatística instalada na reflexividade social por cálculos anteriores permanece e fornece um ponto de referência mais ou menos prolongado. Mesmo quando os individuos pretendem evitar, enviesar ou subverter as estatísticas. Os actores que se relacionam directamente com a recolha de dados, sejam eles administrantes ou administrados do censo ou inquérito, não possuem competências reflexivas semelhantes. Ao carácter instável de todo o conhecimento baseado empiricamente devemos acrescentar as diferentes capacidades singulares de perceber a categoria estatística. Pese embora a dificuldade de o leigo dar definiçôes técnicas formais de taxas de transição ou despesa por aluno, qualquer professor demonstra nas suas operações diárias um domínio tácito e prático dessas noções. Trata-se do efeito de agregação institucional provocado pela racionalização dos procedimentos do sistema. Para lá de toda a eficácia real que possam ter na sua gestão, os mitos da estatística fazem parte dos meios institucionais tidos como necessários para a obtenção das finalidades. Deste modo, incluem-se num processo estrutural mais geral das sociedades modernas actualizarem a confiança nas instituições em virtude da credibilidade dos sistemas periciais (Giddens, 1992).

O princípio da confiança não exclui o cepticismo e a reserva. As estatísticas oficiais ocupam um espaço sujeito à contestação. A validade dos números que contêm é confrontada pela má interpretação prévia das categorias ou por interesses próprios 
de grupos específicos. Desrosiéres e Thévenot (1988), discutindo os problemas de codificaçăo das categorias sócioprofissionais no INSEE, calculam que em mais de $20 \%$ dos casos de replicação da entrevista um indivíduo é colocado em categorias ocupacionais diversas. Este enviesamento é devido à diferente interpretaçăo dos que administram o inquérito e à relaçăo específica que mantêm com as regulamentaçōes. O grau de variabilidade desta relação tende a ser tanto maior quanto mais distante está o agente do centro que produz e valida as categorias utilizadas. A validade, como a raiz latina da palavra traduz, implica o exercício do poder por intermédio de um conjunto de procedimentos administrativos que sedimentam uma tradução particular, uma convenção restritiva, de um conceito sujeito a interpretações contrastantes e a resultados contingentes.

A partir do momento em que a categoria cristaliza numa taxonomia passa a ser coisa com vida própria. A história social das taxonomias estatísticas permite-nos perceber as operações de codificaçăo que subjazem às equivalências entre objectos diferentes mas agrupados na mesma classe. ${ }^{(16)} \mathrm{A}$ visibilidade de um grupo, classe ou categoria é o resultado de circunstâncias históricas que lhe permitem uma determinada mobilização social representada por uma comum forma de se apresentar ao mundo.

$\mathrm{O}$ contexto educativo deve ser refeito antes de ser objecto de quantificação. As categorias das pessoas devem ser definidas; as medidas devem ser intermutáveis; em alguns casos os inputs, os recursos e os resultados devem poder ser representados por um equivalente em dinheiro. Trata-se de um processo de racionalizaçăo que implica um certo grau de centralizaçăo. Quantificar é moldar a realidade que se conta.

Como demonstra a comparação internacional, a consolidaçăo destas categorias está ligada à intervenção do Estado. A pressão externa sobre os sistemas educativos conduziu a um aumento da importância do cálculo na administração e na definição das políticas. A sofisticação cada vez maior dos sistemas periciais actualiza o prestígio da objectividade científica. Uma maior atenção da opinião pública sobre o sistema educativo promove a objectividade, que é reconhecida enquanto tal devido às exigências de uma certa situação política e não à sua capacidade de resolver problemas.

(16) Sobre a construçẵo social das categorias sociais e, especialmente, dos quadros e das profissōes ver Kocka (1981), Boltansky (1982) e Freidson (1988). 


\section{As particularidades da Governamentalidade na semiperiferia}

A década de 70 da sociedade portuguesa está marcada por um brusco aceleramento do tempo histórico provocado pelo movimento social mais extenso e

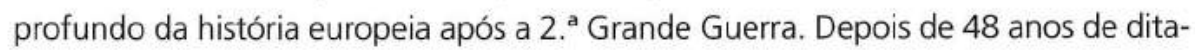
dura e de 13 anos de guerra colonial o regime autoritário cai num golpe militar dirigido por um grupo de jovens oficiais democratas que querem pôr fim à guerra colonial e regressar à democracia parlamentar. A queda da estrutura institucional do regime polícia política, tribunais políticos, sistema de partido único, organização corporativa sem liberdade sindical — é acompanhada, em 1975, por uma crise revolucionária curta, mas de grandes proporções. Iniciada com a nacionalização maciça dos bancos, das seguradoras e da indústria é seguida por um movimento social de ocupação e expropriação de terras, pela criação de cooperativas, a ocupação de casas e a constituição de comissões de moradores. O tempo histórico adiantado em relaçăo a si próprio faz confluir no mesmo momento as duas vagas de direitos, políticos e económico-sociais, que haviam sido vividas em separado no centro capitalista.

Em 25 de Abril de 1974 o Estado Novo colapsa a partir de dentro pelo seu elo mais fraco. O regime encontra-se, na sua fase derradeira, numa posição de impasse insustentável face à política colonial: incapazes de ganhar a guerra contra os movimentos de libertação, as forças armadas deslegitimam-na primeiro, transferem o ónus da solução política para o governo depois e, finalmente, recusam-se a continuá-la. Acossado pelas crises de hegemonia e de administração provocadas pela recomposiçăo da burguesia industrial-financeira, o regime apoia-se na guerra como sede da tutela político-burocrática. Porém, ao transferir as contradições para o interior do aparelho militar, o regime acelera o seu colapso: a politização inevitável das forças armadas é o sinal da incapacidade para dispersar as contradições provocadas por um novo modelo de crescimento económico emergente no final dos anos 60 . A internacionalização progressiva da economia portuguesa, bem como a constituição de grupos financeiros dotados de grande capacidade de controlo da vida económica constituem a base material da transferência da opção africana para o debate sobre a opção europeia. A entrada de Portugal na EFTA define uma solução institucional para uma realidade económica em mutação: as colónias absorviam menos de um quarto do comércio externo, enquanto a Europa absorvia já metade e com tendência para aumentar.

O bloqueio ideológico do regime cristaliza na oposição entre uma ideologia capitalista tradicional e uma ideologia capitalista tecnocrática. A primeira sustenta-se na burguesia fundiária e terratenente, beneficiária da exploração de matérias-primas 
coloniais, dos proteccionismos económicos e da legislação corporativa; a segunda apoia-se na modernização, racionalizaçăo e concentração das estruturas produtivas internas e numa visăo europeia e neocolonial das relaçōes exteriores.

As reformas educativas da fase terminal do Estado Novo (1970-74) são um reflexo muito aproximado deste bloqueio ideológico. As propostas reformistas de Veiga Simão interpretam o objectivo de expansão da escolarização, do pré-escolar ao superior, das correntes desenvolvimentistas e, concomitantemente, a continuidade do modelo de regulação social sem as garantias mínimas da democracia formal. Percebe-se a ênfase na democratização do acesso: embora os acréscimos relativos da procura de educação, por força da expansão da pequena burguesia e do alargamento do campo das expectativas sociais, se traduzam em taxas de crescimento do ensino secundário muito superiores às décadas anteriores, Portugal chega à década de 70 com os mais baixos índices de escolarizaçăo europeus. Também por virtude da intervenção crescente da OCDE a valorização do capital humano passa a ser a lógica dominante das reformas. $\mathrm{O}$ discurso liberal meritocrático começa a fazer o seu caminho na educaçăo, procurando embora legitimar-se numa retórica humanística e de justiça social. Entretanto, a escola socialmente segregada mantém-se: o liceu destina-se à burguesia e à nova pequena-burguesia em expansão; a escola técnica e comercial aos filhos da classe operária. E o autoritarismo repressivo do Estado não cede: a «liberdade responsável» e o apelo à "participação activa na vida nacional», incluídas na retórica da reforma, têm como contraponto a impossibilidade de os estudantes participarem no governo escolar, a vigilância e invasão das universidades por forças policiais, o encerramento das associaçōes de estudantes, a expulsâo de estudantes e a sua incorporação compulsiva no exército.

\section{A posição semiperiférica da sociedade portuguesa: a centralidade do Estado numa sociedade em transição}

Esta centralidade do Estado mantém-se no processo de transição do regime de regulação do Estado corporativo para o regime democrático e parlamentar. Tal transição é feita de contradiçōes e de não-correspondências de grande intensidade. Desde logo porque Portugal se propōe passar da escola socialmente segregada, com várias fileiras de ensino, para a escola de massas, no tempo de uma geração. No campo educativo as duas năo-correspondências mais evidentes são: (a) entre uma law in books e uma law in action, abundantemente demonstrada pela forte incorporação legislativa dos padrōes de escolarização dos países do centro e, simultaneamente, a manutençăo de indicadores educativos mais próximos da periferia; (b) entre o quadro 
institucional que regula as relações educativas e as práticas sociais muito heterogéneas que lhe está subjacente. Em conjunto, estas não-correspondências actualizam o processo de construção retórica da educação, caracterizado pela precocidade das medidas legislativas e pela sua tardia ou arrastada concretização (Soysal e Strang, 1989: 277-288). Este é o resultado de um Estado externamente fraco e internamente forte. No plano das relaçōes internacionais, o Estado compromete-se formalmente com o padrão de escolarizaçăo dominante; porém, porque o conflito e a concorrência educativa entre grupos sociais dotados de autonomia é fraca, e o Estado enfrenta pouca oposição interna, este pode descomprometer-se com facilidade da sua concretização sem grandes quebras de legitimação.

A posição semiperiférica da sociedade portuguesa dá ao Estado um estatuto de centralidade com o monopólio de força correspondente sem que, no entanto, tal força se repercuta automaticamente em legitimação. É uma centralidade que se reproduz enquanto ineficácia. Como consequência, o espaço das políticas sociais assume um papel decisivo na reprodução da contradição permanente entre acumulação e legitimação que se traduz no facto de o Estado, para obter consentimento social, precisar de fazer despesas acima dos seus recursos. Quando tal não é de todo possível, o Estado toma iniciativas de compensação simbólica que pressupõem uma participação activa das organizações e das forças sociais. Tais iniciativas criam ou induzem a criação de novos actores sociais capazes de aceitar a regulação estatal. Sucessivamente são mobilizadas as associações de pais, as associações profissionais e sindicais, os especialistas e as comunidades educativas. Porém, os contratos sociais daí resultantes são implícitos e são menos a expressăo de uma intermediação política institucionalizada entre parceiros sociais, ou a manifestação da pressão de certos grupos de interesses sobre o Estado, do que a consequência de uma ligação directa de grupos económicos e das autarquias com a burocracia estatal. Esta forma de regulação, informal e labiríntica, tem dado origem a sucessivas tentativas de constituição de uma opinião pública educativa que, falando em nome do cidadăo comum, lhe deixa muito pouco espaço de intervenção e decisão.

A articulação não-necessária do Estado, dos grupos sociais institucionalizados e das relações internacionais marca decisivamente as políticas educativas dos cinco períodos que analisamos. $\mathrm{O}$ quadro seguinte resume as características fundamentais de tal relação. ${ }^{(17)}$ (1999)

(17) Seguem-se de perto as tipologias propostas por Margaret Archer (1979) e por Roger Dale 
Quadro 3 - Tipologia dos mecanismos com efeitos nas políticas educativas nacionais: internos (grupos sociais) e externos (relaçōes internacionais)

\begin{tabular}{|c|c|c|c|c|}
\hline Período & $\begin{array}{c}\text { Crise } \\
\text { dominante }\end{array}$ & $\begin{array}{l}\text { Lógica } \\
\text { reformadora } \\
\text { dominante }\end{array}$ & $\begin{array}{l}\text { Relações entre } \\
\text { grupos sociais }\end{array}$ & $\begin{array}{c}\text { Relaçốes } \\
\text { Internacionais }\end{array}$ \\
\hline $1974-75$ & $\begin{array}{l}\text { Crise de } \\
\text { legitimidade }\end{array}$ & $\begin{array}{l}\text { - Expansāo } \\
\text { escolarizadora. } \\
\text { - Igualdade de } \\
\text { oportunidades } \\
\text { de acesso. }\end{array}$ & $\begin{array}{l}\text { Professor/Aluno } \\
\text { INICIAÇĀO } \\
\text { INTERNA }\end{array}$ & $\begin{array}{l}\text { - Unesco. } \\
\text { - Relaçōes bilaterais } \\
\text { com paises socialistas. } \\
\text { APRENDIZAGEM }\end{array}$ \\
\hline $1976-80$ & $\begin{array}{l}\text { Crise de } \\
\text { hegemonia }\end{array}$ & $\begin{array}{l}\text { Normalizaçăo } \\
\text { da participaçăo } \\
\text { dos actores }\end{array}$ & $\begin{array}{l}\text { - Associaçōes } \\
\text { de Pais } \\
\text { - Sindicatos } \\
\text { - Associaçōes } \\
\text { empresariais } \\
\text { TRANSACÇĀO } \\
\text { EXTERNA }\end{array}$ & $\begin{array}{l}\text { - 1. Acordo com o } \\
\text { Banco Mundial (1978) } \\
\text { FMI } \\
\text { IMPOSIÇĀO }\end{array}$ \\
\hline $1981-85$ & $\begin{array}{l}\text { Crise } \\
\text { institucional }\end{array}$ & $\begin{array}{l}\text { Consenso } \\
\text { entre actores }\end{array}$ & $\begin{array}{l}\text { - Especialistas de } \\
\text { planeamento } \\
\text { - Autarquias } \\
\text { - Comunidades } \\
\text { educativas } \\
\text { TRANSACC̄ÃO } \\
\text { EXTERNA }\end{array}$ & $\begin{array}{l}\text { - Programa PEB/OCDE } \\
\text { de construçáo escolar. } \\
\text { - Exame da Política } \\
\text { Nacional de Educação } \\
\text { (OCDE, 1984). } \\
\text { - OCDE/CERI: } \\
\text { programas escolares, } \\
\text { indicadores de ensino } \\
\text { e indicadores de } \\
\text { qualidade escolar. } \\
\text { ESTANDARDIZAÇĀO } \\
\text { DISSEMINAÇĀO }\end{array}$ \\
\hline $1986-91$ & $\begin{array}{l}\text { Crise de } \\
\text { hegemonia }\end{array}$ & $\begin{array}{l}\text { Reforma } \\
\text { curricular }\end{array}$ & $\begin{array}{l}\text { Especialistas } \\
\text { curriculares } \\
\text { MANIPULAÇĀO } \\
\text { POLITICA }\end{array}$ & \multirow{2}{*}{$\begin{array}{l}\text { - Prodep (CEE) } \\
\text { - Erasmus } \\
\text { - Petra } \\
\text { - Prodep II } \\
\text { - Unesco: módulos } \\
\text { de formaçắo } \\
\text { em administração } \\
\text { escolar. } \\
\text { - Eurydice } \\
\text { HARMONIZAÇĀO }\end{array}$} \\
\hline 1992 & $\begin{array}{l}\text { Crise } \\
\text { institucional }\end{array}$ & $\begin{array}{l}\text { Reforma da } \\
\text { gestão e da } \\
\text { administração }\end{array}$ & $\begin{array}{l}\text { Especialistas em } \\
\text { administração } \\
\text { MANIPULAÇÃO } \\
\text { POLITICA }\end{array}$ & \\
\hline
\end{tabular}

(1) Apresenta-se em letras maiúsculas a designação do mecanismo de regulação segundo a tipologia de Margaret Archer (1979) em Social origins of Education Systems.

(2) Apresenta-se em letras maiúsculas a designaçăo do mecanismo de influência segundo a tipologia proposta por Roger Dale (1999) em Specifying globalization effects on national policy: a focus on the mechanisms. 
1. O ciclo de expansão escolarizadora da crise revolucionária (1974-75) está associado aos maiores níveis de participação directa e divergente dos actores educativos e à procura de legitimação ideológica internacional.

2. O ciclo de reconhecimento da crise educativa (1976-80) está associado ao enquadramento institucional e normalização da participaçăo dos actores e aos acordos com o Banco Mundial e a participaçăo crescente em projectos da OCDE.

3. O ciclo da consensualização (1981-86) anda a par da construção de novos actores sociais sob a denominação genérica de "comunidades educativas» e da integração progressiva no espaço educativo europeu.

4. O ciclo da reforma educativa (1986-91) articula um veio discursivo de regulação neoliberal, desregulamentador, com o aumento constante da intervençăo estatal nos planos jurídico-legal, curricular e gestionário. A aprovação do primeiro Programa de Desenvolvimento da Educação para Portugal (Prodep), por parte da Comissão Económica Europeia, coloca definitivamente a direcção das políticas educativas no conjunto do espaço europeu.

5. O ciclo da eficácia (1992 em diante) consolida a participaçāo dos especialistas nacionais e internacionais na elaboração das políticas educativas, como forma de legitimação técnica de opçōes políticas realizadas no quadro da construçăo de um curriculum europeu isomorfo.

\section{A crise de um Estado-Providência tardio e a crise da Escola Secundária}

A crise revolucionária terá reflexos inevitáveis nas escolas. Pela primeira vez o Estado confronta-se com movimentos sociais que visam uma nova relaçăo do sistema educativo com a sociedade. A segunda metade da década de 70 está marcada pela promulgação de legislaçăo semelhante à que vigora nos países centrais da Europa, como é o caso da unificação do ensino secundário, e até pela instauração de modelos mais avançados no plano da gestão escolar. Porém, o Estado continuou a tolerar e mesmo a promover a violação dos direitos à educação das classes populares. Este é um fenómeno mais geral que Santos (1990) caracterizou como Estado paralelo e que assumiu diferentes formas no campo educativo: tolerando a violação da lei do trabalho infantil; planeando selectivamente a distribuição da rede escolar; não dotando as escolas suburbanas e do interior dos recursos humanos e financeiros necessários ao cumprimento da escolaridade obrigatória; tolerando a selectividade social do abandono e insucesso escolares. A moldura formal estatal não corresponde sempre às suas práticas formais e informais. $\mathrm{O}$ quadro seguinte revela algumas dessas contradições. 
Quadro 4 - Elementos comparativos das políticas económicas, sociais, administrativas e educativas (1970-1990)

\begin{tabular}{|c|c|c|c|}
\hline Campos & 70 & 80 & 90 \\
\hline $\begin{array}{l}\text { POLITICAS } \\
\text { EDUCATIVAS }\end{array}$ & $\begin{array}{l}1970 \text { - } 74 \\
\text { - Prolongamento } \\
\text { da escolaridade } \\
\text { obrigatória. } \\
\text { - Reconversão do } \\
\text { Ensino Secundário. } \\
1974 \rightarrow \\
\text { - Fases no } 1 .^{\circ} \text { ciclo. } \\
\text { - Unificaçăo do } \\
\text { ensino secundário. } \\
\text { - Novo modelo de } \\
\text { gestảo escolar. } \\
\text { - Serviço Cívico } \\
\text { Estudantil. }\end{array}$ & $\begin{array}{l}\text { - Criaçăo do } 12 .^{\circ} \text { ano, } 1980 . \\
\text { - Criação dos cursos } \\
\text { técnico-profissionais, } 1983 \\
\text { - Criação do Conselho } \\
\text { Nacional de } \\
\text { Educação, } 1986 . \\
\text { - Lei das Bases do } \\
\text { Sistema Educativo, } 1986 . \\
\text { - Escolaridade obrigatória } \\
\text { de nove anos. } \\
\text { - Reorganização do } \\
\text { parque escolar } \\
\text { - Alteração dos } \\
\text { conteúdos curriculares } \\
\text { (1. a ao } 12 .^{\circ} \text { anos). } \\
\text { - Desconcentraçăo do } \\
\text { sistema de ensino, } 1986 . \\
\text { - Estatuto da carreira } \\
\text { docente, } 1989 .\end{array}$ & $\begin{array}{l}\text { - Constituiçăo das Escolas } \\
\text { profissionais (Prodep). } \\
\text { - Alargamento da rede do } \\
\text { ensino pré-escolar. } \\
\text { - Departamentalizaçăo da } \\
\text { administraçăo educativa. }\end{array}$ \\
\hline UNIVERSIDADE & $\begin{array}{l}\text { - Criação de novas } \\
\text { universidades. } \\
\text { - Introdução do ano } \\
\text { propedêutico e do } \\
\text { numerus clausus. } \\
\text { - Criação do Ensino } \\
\text { Superior Curto. }\end{array}$ & $\begin{array}{l}\text { - Exames de acesso à } \\
\text { universidade, } 1988 \text {. } \\
\text { - Incentivos à criaçăo de } \\
\text { universidades privadas. }\end{array}$ & $\begin{array}{l}\text { - Alteração do sistema de } \\
\text { financiamento de ensino } \\
\text { superior, } 1992 . \\
\text { - Prova de aferiçāo e } \\
\text { provas especificas para a } \\
\text { seriaçāo de candidatos, } \\
1992 \text {. }\end{array}$ \\
\hline $\begin{array}{l}\text { POLITICA } \\
\text { SOCIAL. }\end{array}$ & $\begin{array}{l}\text { - Alargamento da } \\
\text { Segurança Social. } \\
\text { - Criação do Serviço } \\
\text { Nacional de Saúde. } \\
\text { - Subsidio de } \\
\text { desemprego. } \\
\text { - Regulamentaçăo das } \\
\text { férias e subsidios } \\
\text { de maternidade. }\end{array}$ & $\begin{array}{l}\text { - Políticas restritivas para } \\
\text { a segurança social. } \\
\text { - Regulamentação do estatuto } \\
\text { do trabalhador-estudante. } \\
\text { - Fundo de garantia salarial. }\end{array}$ & $\begin{array}{l}\text { - Reforma do serviço } \\
\text { nacional de saúde: } \\
\text { financiamento de outras } \\
\text { entidades para além do } \\
\text { Estado; gestão privada } \\
\text { de instituiçōes e serviços. } \\
\text { - Melhoria das pensōes } \\
\text { da segurança social. }\end{array}$ \\
\hline POLITICA & $\begin{array}{l}\text { - Derrube da ditadura. } \\
\text { - Descolonizaçắo. } \\
\text { - Liberdade sindical } \\
\text { e legislação laboral: } \\
\text { direito à greve; } \\
\text { salários indirectos; } \\
\text { salário mínimo; } \\
\text { contratação colectiva; } \\
\text { restriçóes aos } \\
\text { despedimentos. }\end{array}$ & $\begin{array}{l}\text { - Integração na } \\
\text { Comunidade } \\
\text { Europeia (1985). } \\
\text { - 1." revisão constitucional } \\
\text { quanto à formulaçăo das } \\
\text { instituiçōes de poder } \\
\text { político (regime } \\
\text { semipresidencial, 1982). } \\
\text { - } \text { 2. }^{a} \text { revisão constitucional } \\
\text { em torno da organização } \\
\text { económica (1989). } \\
\text { - Eleiçăo do primeiro } \\
\text { presidente da } \\
\text { república civil (1986). }\end{array}$ & $\begin{array}{l}\text { - Entrada em vigor do } \\
\text { Tratado da União } \\
\text { Europeia, } 1993 . \\
\text { - Depreciação do papel } \\
\text { do Parlamento. } \\
\text { - Reforço do papel da } \\
\text { tecno-estrutura } \\
\text { administrativa. }\end{array}$ \\
\hline
\end{tabular}


Quadro 4 - (Continuação) - Elementos comparativos das políticas económicas, sociais, administrativas e educativas (1970-1990) -

\begin{tabular}{|c|c|c|c|}
\hline Campos & 70 & 80 & 90 \\
\hline ECONOMIA & $\begin{array}{l}\text { - Nacionalizaçăo da } \\
\text { banca, dos seguros e } \\
\text { das empresas } \\
\text { monopolistas (1975). } \\
\text { - Reforma Agrária: } \\
\text { ocupaçáo, expropriação } \\
\text { e criaçăo de } \\
\text { cooperativas. } \\
\text { - } 1^{\circ} \text { acordo com o FMI } \\
\text { (1978). }\end{array}$ & $\begin{array}{l}\text { - Aumento da dívida externa } \\
\text { (90 \% do PIB em 1984). } \\
\text { - 2. acordo com o FMI (1983). } \\
\text { - Aumento da inflação. } \\
\text { - Baixa dos salários reais } \\
\text { e salários em atraso. } \\
\text { - Contra-reforma agrária. } \\
\text { - Adopção das convençōes } \\
\text { da OIT sobre política de } \\
\text { emprego e formação } \\
\text { profissional. } \\
\text { - Flexibilização e precarização } \\
\text { do mercado de trabalho. }\end{array}$ & $\begin{array}{l}\text { - PEDIP (Programa } \\
\text { Especifico de } \\
\text { Desenvolvimento da } \\
\text { Indústria Portuguesa) } \\
\text { (1989-1992). } \\
\text { - Concretizaçăo de } \\
\text { investimentos em } \\
\text { infra-estruturas, } \\
\text { em grande parte } \\
\text { financiadas por } \\
\text { fundos comunitários. } \\
\text { - Processo de } \\
\text { desregulamentação } \\
\text { e redução do } \\
\text { papel interventor do } \\
\text { Estado na economia. }\end{array}$ \\
\hline ADMINISTRAÇĀO & $\begin{array}{l}\text { - Racionalizaçăo das } \\
\text { estruturas e funçőes. } \\
\text { - Novas técnicas de } \\
\text { gestāo (planificação, } \\
\text { controlo, orçamento), } \\
\text { - Informatização. } \\
\text { - Saneamentos } \\
\text { individuais }\end{array}$ & $\begin{array}{l}\text { - Criação da } \\
\text { administração consultiva. } \\
\text { - Desconcentraçāo. } \\
\text { - Enfase na qualidade. } \\
\text { - Preocupaçōes com as relações } \\
\text { administraçăo-cidadão. }\end{array}$ & $\begin{array}{l}\text { - Gestão financeira. } \\
\text { - Gestăo pelos resultados. } \\
\text { - Mecanismos de controlo } \\
\text { pelo mercado. }\end{array}$ \\
\hline
\end{tabular}

O quadro fornece alguns elementos comparativos das políticas económicas, sociais, administrativas e educativas que revelam, no seu conjunto, a impossibilidade de proceder a uma periodização conjunta destas políticas. ${ }^{(18)}$

A consolidação da escola de massas em Portugal foi tardia e contraditória na sua concretizaçăo. Exigia um quadro económico de expansăo, mas teve lugar num momento de crise financeira do Estado e depressão dos investimentos redistributivos.

(18) A leitura deste quadro deve ser precedida por duas precauçōes metodológicas: em primeiro lugar, o alinhamento de reformas e acontecimentos nas diferentes esferas sociais năo resulta de uma co-determinação entre eles, mas em uma mera probabilidade de articulação não-necessária. Assim, há reformas de política educativa que, embora racionalmente desarticuladas das reformas politicas e económicas, acabam por se articular com elas; enquanto outras, que são pensadas e planeadas em conjunto, resultam em disjunção não esperada. A segunda precaução metodológica diz respeito à linha do tempo: a organizaçăo das colunas em décadas deve ser entendida mais como estratos geológicos do que enquanto transcurso linear do tempo. Pressupōe-se assim a possibilidade de sobreposiçăo de orientaçōes estratégicas e năo a substituiçăo de uma por outra. 
As novas expectativas sociais criadas pelo ciclo da igualdade de oportunidades de acesso obrigou o Estado a expandir a rede escolar sob pena de custos políticos insuportáveis. Porém, pressionado pela crise de acumulaçăo, o Estado não mostrava condições financeiras para realizar investimentos sociais acima dos seus recursos. Desta contradição resultam políticas também elas contraditórias e ao sabor das conjunturas: preponderância das retóricas racionais quando o sistema se expande demograficamente e em recursos distribuídos pelo Estado e o predomínio das retóricas normativas quando a economia se contrai sem que, simetricamente, se possam contrair os fluxos de alunos e de expectativas optimistas crescentes no sistema educativo. Nesta ambiguidade permanente, a "flexibilização» das tecnologias de intervenção tenta compatibilizar normatividade e racionalidade. A flexibilizaçăo teve consequências, por exemplo, no planeamento da rede escolar quando se restringiu o acesso à escolaridade obrigatória de grupos sociais com pouca capacidade de mobilização de recursos políticos, construindo escolas secundárias em vez de escolas básicas, ou quando se deteriorou a qualidade das construçōes, em nome das flutuaçōes demográficas e da sua reutilização futura para outros serviços sociais.

Ao contrário de outros países europeus, Portugal só muito recentemente tem promovido a consolidaçăo da escola de massas através do alargamento da escolaridade obrigatória para nove anos e do aumento das taxas de escolarização. Apenas em 1990 se atingiram os $99 \%$ no $1 .^{\circ}$ ciclo, $70 \%$ no $2 .^{\circ}$ ciclo e $55 \%$ no $3 .{ }^{\circ}$ ciclo. Se nos reportarmos a 1987, Portugal apresenta a mais baixa taxa de escolarização entre os países da Comunidade Europeia.

Por outro lado, no que diz respeito à reorganizaçăo do parque escolar só no final da década de 80 se assistiu a uma política de investimentos em construções e recursos educativos que garantissem o mínimo indispensável ao funcionamento regular da escola e à sua desmassificação. Ainda assim, estes investimentos deveram-se à participaçăo decisiva dos fundos europeus, o que denuncia a manutenção actual da descapitalização das instituições de ensino público e a acentuação das assimetrias regionais no acesso e distribuição dos fundos.

A crise de crescimento implicava um contexto de expansão dos investimentos na educação. Pelo contrário, se olharmos para dois dos indicadores de investimento percentagem do Produto Interno Bruto e a percentagem do Orçamento Geral do Estado dedicado à educação - verificamos que os investimentos săo, mais uma vez, os mais baixos da Europa (4,1\% do PIB em 1985 e 4,8\% em 1990; 10,9\% do OGE dedicado à educaçăo em 1985 e 11,3\% em 1990). Ou seja: necessitando o sistema educativo português de um contexto económico de expansão distributiva, realiza-se num momento de crise de acumulação do Estado e de depressão dos investimentos. 
Por isso, a crise de crescimento continua a adiar o cumprimento da igualdade de oportunidades de acesso. Daí a crise de legitimidade que impede a escola de ser consensualmente aceite.

Em síntese, podemos considerar três tipos de contradições na base da crise da escola de massas em Portugal. Apresentaremos sucessivamente algumas das incidências destas contradições na crise de legitimidade, na crise de hegemonia e na crise institucional. Para tanto, havemos que introduzir inicialmente a discussão conceptual sobre as crises do capitalismo.

\section{Crise de legitimidade e crises do capitalismo}

Considera-se que há uma crise de legitimidade quando uma dada estrutura social deixa de obter consentimento no campo social em que actua. Para Max Weber, o problema da legitimidade residia na aceitabilidade e no reconhecimento, validado no agir social, dos costumes adquiridos, da autoridade ou da exemplaridade. Max Weber fazia depender da racionalidade valorativa a validação de uma ordem social, fosse ela uma obrigação ou um modelo. A ordem legítima pode depender de diferentes fundamentos: crenças afectivas, crenças na tradiçăo e crenças provenientes da racionalidade valorativa ou da legalidade. Embora cada um destes fundamentos corresponda aos três tipos de dominação legítima, Weber considera que nenhuma dominaçăo pode prescindir da legalidade legítima. Quando distingue os três tipos-ideais de autoridade fá-los corresponder a outros tantos tipos de legitimação: a autoridade racional-legal, a autoridade carismática e a autoridade tradicional. A primeira corresponde ao tipo de dominação legítima preponderante nas sociedades democráticas modernas, suportado pela razão do direito e pela legalidade de a administração o regular. É neste contexto que Weber (1947: 152) procede à distinção probabilistica entre poder e autoridade: o primeiro, estaria condicionado pela probabilidade de um indivíduo estar em posição de realizar a sua própria vontade, no interior de uma relação social, não obstante a resistência de outros; o segundo, consistiria na probabilidade de uma ordem ser obedecida de forma pronta e automática por um grupo de pessoas. Mas foi a vulgarização da definição de autoridade enquanto poder legítimo que associou o conceito de legitimidade ao de autoridade e este ao de legalidade, embora Weber (1956, 1971: 30) estabeleça uma hierarquização do seu grau de estabilidade que nem sempre é favorável a esta. Assim, para Weber, uma ordem que se apoia unicamente no costume é mais estável que uma outra que se apoia exclusivamente na razăo; e esta é, incomparavelmente, menos estável que aquela que se afirma graças à exemplaridade e à obrigação. 
Nestes tipos-ideais de legitimidade de Weber o conceito de autoridade legítima corresponde, nas sociedades modernas, a uma crença na legalidade. É certo que a problemática da legitimidade da autoridade política ganhou novos contornos nos últimos vinte cinco anos. Esta preocupação mais recente deriva da verificação de que - Estado moderno enfrenta sérios problemas de credibilidade e de aceitação social. Retomado o tema com a obra de referência de Habermas, Legitimation Crisis (1973, 1978), a legitimidade passou a ser encarada no efeito de espiral provocado pelo incremento de actividades estaduais: estas repercutem-se no aumento desmesurado das necessidades de legitimação que, por sua vez, redundam em mais Estado. Simultaneamente, outros autores, faziam uma análise na tradição marxista da estrutura-superestrutura: Claus Offe (1975) e Alan Wolfe (1977) procuram na descoincidência entre o processo de acumulação e os dispositivos de legitimação a tensão intrínseca entre liberalismo económico e democracia sob as condições do capitalismo.

As análises de Habermas coincidem num ponto com as de Weber: na necessidade de produzir justificações racionais. Mas, enquanto em Weber não existem critérios de justificação universais da legitimidade, por que faz uma distinção tácita entre validade social e validade ideal das normas, em Habermas (1979) o consenso obtido na argumentação possui um carácter racional e universalizante. O mesmo é dizer que é possível estabelecer pretensões normativas à validade quando a estrutura de argumentação é separada da experiência e liberta dos constrangimentos da acção social. Esta pista é interessante, desde que a estrutura de argumentaçăo sofra um alargamento que inclua aquilo que neste trabalho temos designado como tecnologias da governamentalidade, isto é, há-de considerar-se os efeitos dessas tecnologias, de origem muito diversa, na construção de novas categorizações e normas. Falar do carácter instrumental da governamentalidade não se refere à sua subordinaçăo a propostas técnicas exteriores; em vez disso, significa que o governo das sociedades modernas está dependente de instrumentos de cálculo e intervenção que transformaram o exercício do poder em uma actividade racional. A dificuldade da abordagem de Habermas reside no facto de assumir a capacidade das elites políticas formarem $e$ mudarem as atitudes e opiniōes das massas em esferas condicionadas por causas não políticas. Ora, como bem chama a atenção Taylor-Gooby (1983: 168) «the problem is that the social mechanisms that produce allegiance are not under the control of policy, because they originate in a different level of society (...) The political system cannot itself guarantee to produce the values required to assure loialty to its policies. Values derive from culture which is independent of the state». 
Num artigo de 1983, Hans Weiler estabelece, nos seguintes termos, a razão principal por que a educação está particularmente exposta a elevados níveis de conflitos normativos, com inevitáveis consequências nos níveis elevados de justificação legitimatória: «education has a key role in allocating statuses and in socializing different groups in society into accepting and sustaining existing structures of wealth, status and power» (p. 261). Tal formulação resulta do dilema que as reformas educativas provocam nas sociedades capitalistas, no termo do qual as expectativas geradas tendem a criar necessidades para as quais o Estado não tem nem os meios nem a vontade de satisfazer (Offe, 1975). Nesta situação, o Estado tem todo o interesse em compensar o défice, transformando o dilema num dos principais veículos de decisăo política, ou, nos termos utilizados por Habermas, as estratégias de compensação dirigem-se para a manipulaçăo deliberada. Nesta linha de argumentação, Weiler (1983: 262) identifica três estratégias de manipulação deliberada ou de compensação: (a) a legalização das políticas educativas por intermédio da crescente invocação das normas legais e institucionais; (b) utilização do conhecimento e dos especialistas científicos no processo de decisão política, especialmente na experimentação de programas e no planeamento; (c) estímulo à participação dos clientes no processo de decisão.

Estas três estratégias de compensação não são mais do que um efeito de interiorizaçăo das contradiçōes sociais que impendem da legitimação. Como esta depende da capacidade de aceitação das políticas sociais pelos diferentes grupos e estes têm interesses contraditórios e recursos políticos assimétricos, o Estado, ao tentar compatibilizá-los, entra em contradiçăo. Se esta se puder continuar a reproduzir enquanto contradição a crise não sobrevirá. A capacidade de se auto-reproduzir enquanto contradição é condiçăo da sua permanência enquanto solução. Mas, enquanto nas sociedades centrais, de capitalismo desenvolvido, as contradiçōes foram vividas numa aparente sequência diacrónica, sublinhada ainda pelas tendências ideais apresentadas na elaboração teórica, nas sociedades semiperiféricas como Portugal, desenvolveram-se tardiamente e, nesse efeito retardado, sobrepuseram-se no curto período de dezassete anos que analisamos. A análise que fazemos da crise de legitimidade da escola secundária em Portugal permitiu-nos verificar que estas năo se apresentam compartimentadas em fases sequenciais. A articulação em órbitas que se encontram é a regra. Tal efeito de sobreposiçăo e de atracção orbital deve colocar-nos de sobreaviso relativamente à adaptação mecânica das tipologias de raiz habermasiana (e. g. Hargreaves, 1989) que continuam a reflectir no seu interior a visão marxista dos três níveis de profundidade — base, estrutura e superestrutura —, desta feita transmutados em sistema económico, sistema político e sistema sóciocultural. Para Habermas, a crise de legitimação anda a par de outras crises: a crise de 
racionalidade que emerge do sistema político, a crise económica com origem no sistema económico e a crise de motivaçăo resultante das mudanças no sistema sóciocultural. No esquema teórico que propomos a crise de racionalidade interessa sobretudo na sua componente institucional, porque é nela que se aplicam as tecnologias que visam reproduzir a contradiçăo; a crise económica interessa preferentemente à hegemonia, porque é nela que se reflectem as racionalidades que visam reproduzir a contradição; a crise de motivação interessa antes do mais à legitimidade porque é nela que se inserem as soluções que visam reproduzir as suas contradições.

Neste esquema existe uma crítica implícita ao modelo analítico proposto por Hargreaves em 1989. Sugere o autor que existe homologia entre o tipo de crise analisado por Habermas e a tipologia das crises educativas em Inglaterra. Neste pressuposto, apresenta uma periodizaçăo das crises educativas e dos pontos de aplicação das reformas educativas, como segue:

- uma crise de administração educacional, nos anos 50-70, a que corresponde uma crise de racionalidade com a consequente reorganização da morfologia do sistema educativo. A criaçăo da comprehensive school, acompanhada pela retórica política da igualdade de oportunidades, atende em primeiro lugar ao crescimento da economia e às crescentes aspiraçōes sociais decorrentes das políticas de welfare do após-guerra.

- uma crise curricular, nos anos 70, a que corresponde uma crise de legitimidade com o consequente debate em torno da remodelaçăo do currículo. A alternativa de um currículo comum em oposição a um currículo que permitia a diferenciaçăo social resulta, antes do mais, da necessidade de reparar as bases do consentimento e da coesão sociais, postos em causa pela recessão económica dos anos 70 .

- uma crise de avaliação, nos anos 80, a que corresponde uma crise de motivação com o aparecimento dos registos de avaliação e a definição dos perfis de aluno a obter. A promoçăo das aprendizagens, por intermédio da racionalização acrescida dos modos de avaliação, resulta de uma intenção deliberada de socializar as jovens gerações para novas exigências do trabalho.

Este tipo de interpretação teórica sofre de duas limitações. Por um lado, força excessivamente o vínculo entre as crises educacionais e a base económica da crise; por outro lado, define com muita rigidez as fronteiras das crises como se os três tipos de crises não convivessem e não se articulassem na sincronia. O que nos leva a esta- 
belecer duas regras prévias. Estas não são imperativos metodológicos; são simples prescriçōes de prudência.

A primeira regra diz respeito à continuidade e polivalência das contradiçöes e das soluçōes. Enquanto nas sociedades centrais a tensão das contradições é temporalmente longitudinal, no nosso esquema não existe qualquer plano prévio para o seu desencadeamento. Tal efeito tardio foi frequentemente antecipado pela hipótese cumulativa segundo a qual «várias crises simultâneas potenciam uma crise generalizada». Ao contrário, este efeito tardio resulta umas vezes na agudização de uma crise e outras vezes na sua dispersāo ou superação, na medida em que uma crise fornece as tecnologias e as racionalidades de solução para uma crise paralela. A regra de prudência é simples: năo procurar nenhum esquema de transformaçăo nuclear que explique a crise, năo determinar previamente um sistema onde as estratégias que pretendem superá-la têm origem e pontos de fixação.

A segunda regra reflecte a descontinuidade dos discursos presentes nas reformas educativas. $\mathrm{O}$ que se disse sobre os mecanismos de compensação não deve ser analisado como simples forma de recuperação da lealdade política das massas. A separação analítica entre racionalidade e legitimação provoca uma disjunção analítica entre funçōes de reposição do controlo administrativo e produtivo do sistema (estrutura) e reforço da homogeneidade cultural (legitimidade) que acabam por obscurecer a intrínseca articulação saber-poder que as atravessam.

Este efeito aparece mais evidentemente numa interessante aplicação da tipologia de Habermas ao desenvolvimento da política educativa em Espanha, nos anos oitenta, realizada por Félix Angulo (1993). Utiliza para tanto um modelo de análise em que inclui as três formas de legitimação compensatória de Weiler (1983). Segundo este autor, a principal medida de política educativa do Estado espanhol consistiu no desencadeamento de uma estratégia de legalizaçăo, por intermédio da Ley de Ordenacion del Sistema Educativo, com repercussões nas crises de racionalidade, legitimação e motivação. No mesmo lance conseguia a colaboração de especialistas e a consagração do princípio de participação dos clientes na nova política. Estratégia que teria assegurado a aceitação das propostas realizadas. Adentrando-se na crise de motivação o autor classifica as funçōes da avaliação em primárias, secundárias e terciárias segundo a sua importância relativa na relegitimação do Estado e na debelação da crise do capitalismo. As funçōes classificadas em primárias destinar-seiam ao ressurgimento da ideologia meritocrática: selecção dos alunos, controlo administrativo e gestão eficiente do sistema. As funçōes designadas por secundárias são as que apresentam maior grau de conflitualidade porque se destinam a cumprir objectivos contraditórios, dirigidos, por um lado, para o reforço da homogeneidade 
cultural e, por outro lado, para a valorização de conteúdos interculturais. Finalmente, as funções apresentadas como terciárias serviriam sobretudo objectivos de retórica política: fortalecendo o mito da mobilidade social e melhorando assim a motivação individual.

Neste tipo de análise, o discurso é concebido como uma série de segmentos contínuos em que as funções primárias se destinam essencialmente à estrutura económica e de poder do sistema e as funções secundárias e terciárias ao saber, i.e., ao sistema sóciocultural. A partir deste pressuposto imagina-se uma repartição de funções em uma distribuição do poder relativamente fixa. É esta distribuição que determina a continuidade discursiva por que coloniza e determina todas as outras. Repare-se que o conceito de legitimidade weberiano continua a estar omnipresente: é o privilégio atribuído à lei que desencadeia a reposição da autoridade em crise. A regra de prudência a introduzir procura conhecer o esquema de relaçōes de força naquilo que o seu próprio funcionamento implica. Não se procura quem tem o poder de repor a racionalidade - a legislação, os especialistas, etc. — e quem está privado dele — os alunos, os professores, etc. — nem quem tem a ạutoridade de legitimar pelo saber currículo, regras de participação, etc. - e quem é mantido afastado desse processo. Procuram-se antes as matrizes de transformação, com o que isso pressupõe de variantes e de efeitos diferenciados, de acordo com a posiçăo de poder de quem fala, o contexto institucional onde se situa e a tecnologia utilizada. As relações institucionais são de não-determinação entre o sistema económico e o sistema sóciocultural. Por esta razão, o discurso é concebido na sua descontinuidade original cuja funçăo não é estável nem uniforme, com o que isso significa também na ordem das utilizações de fórmulas idênticas para objectivos contraditórios. Pense-se, por exemplo, no que aconteceu à fórmula igualdade de oportunidades que marcou o período analisado. A extrema prolixidade e vulgarização do princípio e a simultânea dificuldade em o concretizar, permitiu, durante muito tempo, um funcionamento ambivalente: por um lado, uma atenção continuada à concretizaçăo do princípio (verificável no conjunto de estatísticas produzidas directamente pela administração ou por sua encomenda que pretendem verificar as taxas de desperdício do sistema) e, por outro lado, uma tolerância muito vasta quanto ao seu não cumprimento (que se deduz das próprias estatísticas de cobertura da escolaridade obrigatória, da extensăo do trabalho infantil ou da desigualdade social dos resultados escolares). Ora, o aparecimento, desde 1974, de uma tecno-estrutura que produz um discurso técnico e administrativo sobre as causas do abandono, da repetência, do insucesso, da exclusăo, do risco permitiu a elaboraçăo de medidas de compensação que são simultaneamente novos controlos sociais. Mas permitiu também a constituição de um discurso do outro lado: a socio- 
logia da educação crítica construiu alguns modelos de análise das desigualdades sociais (Benavente e Correia, 1980; Benavente, Costa, Machado e Neves, 1987; Costa e Machado, 1992) e regionais (Alves Pinto, 1987), enquanto a economia da educação determinava custos de oportunidade e necessidades da economia. Uma denuncia, outra assinala desajustamentos, mas ambas se apoiam no princípio da igualdade de oportunidades. O que, num certo sentido, revela a eficácia da episteme discursiva: ela contém no seu interior blocos tácticos contraditórios dentro da mesma estratégia.

A crise de legitimidade da escola secundária portuguesa funda-se na contradição social entre a funçăo de instruçăo de massas, que promove a igualdade de oportunidades, e a função de hierarquização que garante a apropriação desigual do sistema de ensino pelos grupos sociais melhor colocados na lógica da dominaçăo para o fazer. Deste modo é provocada uma descoincidência entre as expectativas de escolarização induzidas em segmentos crescentes da população, através do aumento da rede escolar, e a capacidade de o Estado e das escolas responderem a tais expectativas. Esta descoincidência tem provocado uma crise de legitimidade da escola que a leva a prometer mais do que aquilo que pode dar e a elevar as aspiraçôes na mesma medida que as arrefece através dos mecanismos de selecção escolares (Grácio, 1986). São exemplos desta contradição algumas medidas de política educativa e de reforma que analisaremos em detalhe em próximos capítulos e outras que apenas referiremos: o lançamento do Ensino Secundário Unificado, o Serviço Cívico Estudantil, o Ano Propedêutico e o lançamento do $12 .^{\circ}$ ano (capítulo V); o relançamento do Ensino Técnico-Profissional e as escolas Profissionais.

Tais medidas resultaram em uma controvérsia política e científica mais geral que colocou em confronto as opções de formação geral (liceal) versus formação técnica e profissional.

\section{Crise institucional}

A crise institucional define-se pela incapacidade de uma dada condição social poder continuar a assegurar as condições da sua reprodução estável. A contradição institucional da escola funda-se na incompatibilidade entre a racionalidade burocrática do Estado, distributiva, centrada nas leis, nos normativos e nas regras formais e uma racionalidade industrial e de mercado, produtiva, centrada nos resultados, que, distribuindo a responsabilidade destes pelos novos actores sociais pretende garantir a extensão e a partilha do processo legitimador. Esta contradição resulta num confronto do Estado dentro de si mesmo, apresentando-se simultaneamente modelos racionais e normativos de gestão do sistema educativo: os primeiros destinados à 
racionalização e optimização de recursos; os segundos respondendo a problemas de consentimento, mobilizaçăo e envolvimento dos actores educativos.

São exemplos desta contradição algumas medidas de política educativa e de reforma que analisaremos em detalhe em próximos capitulos: desconcentração e descentralização do sistema educativo (capítulo IV); o lançamento de medidas que visam a autonomia relativa das escolas e os sucessivos modelos de gestăo escolar assente numa lógica gerencial neotailorista (capítulo IV).

A controvérsia política centralização vs. descentralizaçăo e a controvérsia científica autonomia vs. novos modelos de controlo social da educação atravessaram também esta contradição.

\section{Crise de hegemonia}

A crise de hegemonia caracteriza o momento em que uma dada condição social deixa de ser considerada necessária ou exclusiva no seu campo de intervençăo. A contradiçăo funda-se na incompatibilidade entre as necessidades de aculturação homogeneizante que legitima as funçōes credencializadoras do sistema educativo e, por outro lado, as exigências de diferenciação que acolha pertenças sociais e culturais diversificadas do público escolar. Esta contradição manifesta-se na incompatibilidade progressiva entre conhecimentos canónicos e conhecimentos instrumentais, entre formação cultural e formação profissional, entre formação para a vida activa e formaçăo para o prosseguimento de estudos. Deste modo se evidencia a desarticulação entre a valorização de uma via de modernização, economicamente liberal, que instrumentaliza a escola na obtenção de capital humano e de estatuto social e a desvalorização correspondente das justificaçōes propriamente escolares da escola. 0 aumento das heterogeneidades sociais e escolares arrastou novas necessidades de diferenciação curricular, pedagógica, organizacional e profissional para as quais nem o Estado nem os professores estavam preparados. O abaixamento do nível profissional dos professores, provocado por um acesso facilitado à profissão e pela reduçăo das exigências de formaçăo, manifestaram-se numa crise de confiança pública na escola.

A escola vê-se confrontada com uma sociedade pedagógica que valoriza a formação como um factor de produção e, paradoxalmente, desvaloriza o contexto de socialização pouco eficaz e legítimo da escola. Apresentam-se assim outros dispositivos ou meios de socialização como alternativas viáveis à inadequação do sistema educativo, à sua incapacidade para se relacionar produtivamente com o mundo do trabalho, sublinhando as dificuldades da escola cumprir integralmente o preceito de cada indivíduo, segundo o seu mérito, obter um estatuto superior ao herdado. 
São exemplos desta contradição algumas medidas de política educativa e de reforma que analisaremos em detalhe em próximos capítulos: a progressiva fragmentação curricular e a diversidade de opções de estudo (capitulo V); a pedagogia centrada na autonomia e na individualização (capítulo V). Tais reformas vieram colocar em questão os fundamentos da tradicional sequência educação-trabalho.

A crise de hegemonia é caracterizada pela obsolescência dos modos de acesso aos saberes, conhecimentos e competências. Esta crise tem sido equacionada a partir de dois pontos de vista diametralmente opostos. De um lado, interroga-se os currículos escolares e os modos de organização do trabalho pedagógico enquanto subtis mecanismos de produção de desigualdades na escola. Assinala-se, em particular, os que dizem respeito à violência simbólica oculta nos conteúdos escolares que, ao imporem códigos e atitudes, desvalorizariam a cultura dos novos sectores sociais que agora têm acesso à escola.

Do lado do novo discurso modernizador esta crise tem vindo a ser equacionada pelo ângulo do abaixamento do nível do ensino, da diminuiçăo da conformação de atitudes e da desadaptaçăo dos conteúdos aos desafios do fim da modernidade. Propõe-se, por isso, a modernização e a diversificação das fileiras do ensino como forma de adequar os seus conteúdos e métodos às diversas competências exigidas pelas economias modernas (OCDE, 1985, 1989). Neste contexto, a criaçăo de uma fileira técnico-profissional e a abertura das escolas profissionais revelam a impossibilidade estrutural de o Estado responder à contradição entre conhecimentos canónicos e conhecimentos funcionais no quadro do ensino unificado. Conceitos como eficácia, optimizaçăo e escola de qualidade acompanham a ideia de empresarizaçăo da escola enquanto one best way para a concretização de opções políticas e sociais que são apresentadas como determinismos à escala europeia e mundial. Desta forma, o lado político das decisōes é esbatido, já que estas ficam sem alternativa possível, determinadas que estão pela escolha científico-racional dos especialistas das agências internacionais.

Para esta lógica industrial são os constrangimentos de performance e eficácia que săo chamados a primeiro plano nas propostas de reforma. Parte destas propostas apoia-se na procura do mercado de trabalho cujos postos de trabalho são concebidos como flexíveis, post-fordistas e modernos mas exigindo altos niveis de adequaçăo disciplinar. Apoiados numa relação de homologia e correlaçăo entre o sistema escolar e as estruturas do emprego e da economia, marcam uma exigência de elevação global do nivel de competência e de desenvolvimento local e nacional. Dá-se a passagem de uma regulaçăo suportada pela centralizaçăo geográfica à inter-relaçăo de diversas instituições e padrões discursivos que, deste passo, são integradas no inte- 
resse geral. Articulando-se com esta, a lógica de mercado põe em evidência a nova atitude liberal de concorrência por recursos escassos. Baseada na teoria da livre escoIha e de um mercado educativo não sectorizado propõe-se que cada escola mostre eficácia de modo a tomar uma boa posiçăo na competição entre organizações, postas em rivalidade pela reduçăo aparente da intervenção do Estado nas escolas. Redução aparente porque o que mudou foi a racionalidade das políticas distributivas, substituída por uma racionalidade produtiva que propõe a descentralização dos investimentos, partilhada agora com as comunidades locais. Colocando o centro de gravidade da acçăo escolar na reputaçăo, uma nova cultura escolar emerge: cultura dos pais clientes e dos alunos-produto. A recente generalização dos testes nacionais na educaçăo obrigatória e não-obrigatória fazem parte desta estratégia de coordenação pelos resultados, providenciando aos pais e à opinião pública referenciais de comparação de resultados entre escolas.

$\mathrm{O}$ quadro seguinte sintetiza os mecanismos de resposta à tripla crise do sistema educativo português, bem como as racionalidades e tecnologias dominantes em cada uma delas. Referem-se também quais os pontos de observação utilizados neste livro.

Quadro 5 - Tipologia dos Mecanismos, Racionalidades e Tecnologias utilizados para dispersar as contradiçőes criadas pelas crises de legitimidade, de hegemonia e institucional

\begin{tabular}{|c|c|c|c|}
\hline $\begin{array}{l}\text { TIPO DE CRISE } \\
\text { MECANISMO }\end{array}$ & RACIONALIDADE & TECNOLOGIAS & CASOS ESTUDADOS \\
\hline $\begin{array}{l}\text { CRISE DE } \\
\text { LEGITIMIDADE } \\
\text { LEGALIZAÇ,ĀO }\end{array}$ & $\begin{array}{l}\text { Juridica e Normativa } \\
\text { [Actualização do } \\
\text { potencial de } \\
\text { imposiçāo da norma] }\end{array}$ & $\begin{array}{l}\text { - Decretos } \\
\text { - Despachos } \\
\text { - Circulares } \\
\text { - Oficios } \\
\text { - Processos do STA } \\
\text { - Processos } \\
\text { disciplinares } \\
\text { da IGE } \\
\text { - Pareceres } \\
\text { da Comissāo } \\
\text { Constitucional } \\
\text { - Acórdāos do } \\
\text { Tribunal } \\
\text { Constitucional } \\
\text { - Queixas à } \\
\text { Provedoria } \\
\text { de Justiça }\end{array}$ & $\begin{array}{l}\text { - Unificação do } \\
\text { ensino secundário } \\
\text { com o objectivo de } \\
\text { modernizar o estado } \\
\text { segundo os padrōes } \\
\text { dos paises centrais. } \\
\text { - Normalizaçăo [ref. } \\
\text { ao ministro Cardia]. }\end{array}$ \\
\hline
\end{tabular}


Quadro 5 - (Continuação) - Tipologia dos Mecanismos, Racionalidades e Tecnologias utilizados para dispersar as contradiçōes criadas pelas crises de legitimidade, de hegemonia e institucional

\begin{tabular}{|c|c|c|c|}
\hline $\begin{array}{l}\text { TIPO DE CRISE } \\
\text { MECANISMO }\end{array}$ & RACIONALIDADE & TECNOLOGIAS & CASOS ESTUDADOS \\
\hline $\begin{array}{c}\text { CRISE DE } \\
\text { LEGITIMIDADE } \\
\text { ESPECIALIZACC̄OO }\end{array}$ & $\begin{array}{l}\text { Técnica e Cientifica } \\
\text { [Maximização } \\
\text { da eficácia] }\end{array}$ & $\begin{array}{l}\text { - Relação entre } \\
\text { pesquisa e políticas: } \\
\text { experimentaçāo. } \\
\text { - Avaliação das } \\
\text { politicas educativas. } \\
\text { - Planeamento } \\
\text { educativo. } \\
\text { - Administraçăo } \\
\text { consultiva } \\
\text { intermitente } \\
\text { e informal: } \\
\text { comissōes e grupos } \\
\text { de trabalho mistos } \\
\text { (administraçăo e } \\
\text { especialistas). }\end{array}$ & $\begin{array}{l}\text { - Avaliação do ESU. } \\
\text { - Planeamento da } \\
\text { rede escolar. }\end{array}$ \\
\hline $\begin{array}{l}\text { CRISE DE } \\
\text { LEGITIMIDADE } \\
\text { PARTICIPACCAO }\end{array}$ & $\begin{array}{l}\text { Política } \\
\text { [Ampliação da } \\
\text { lealdade civica] }\end{array}$ & $\begin{array}{l}\text { - Participação no } \\
\text { planeamento } \\
\text { da Rede. } \\
\text { - Participação das } \\
\text { familias: construção } \\
\text { do associativismo } \\
\text { familiar. } \\
\text { - Participação } \\
\text { dos alunos. } \\
\text { - Autonomia } \\
\text { das escolas. } \\
\text { - Administração } \\
\text { consultiva: Conselho } \\
\text { Nacional de } \\
\text { Educaçăo. }\end{array}$ & $\begin{array}{l}\text { - Do inventário de } \\
\text { carências à carta } \\
\text { escolar. } \\
\text { - Cooptaçăo dos } \\
\text { especialistas. } \\
\text { - Comunidade escolar } \\
\text { e autonomia das } \\
\text { escolas: estudo de } \\
\text { caso (NEO). } \\
\text { - Educação cívica. }\end{array}$ \\
\hline $\begin{array}{c}\text { CRISE DE } \\
\text { LEGITMMIDADE } \\
\text { INTERNACIONALIZAÇAO }\end{array}$ & $\begin{array}{l}\text { Recolocação no } \\
\text { sistema mundial } \\
\text { [Mimetismo dos } \\
\text { modelos culturais } \\
\text { dominantes] }\end{array}$ & $\begin{array}{l}\text { - Harmonização } \\
\text { da agenda } \\
\text { política nacional } \\
\text { pelos temas } \\
\text { das agências } \\
\text { internacionais. } \\
\text { - Acordos bilaterais } \\
\text { e multilaterais. } \\
\text { - Traduçăo das } \\
\text { declaraçōes } \\
\text { internacionais } \\
\text { em politicas } \\
\text { nacionais. }\end{array}$ & $\begin{array}{l}\text { - Programa } \\
\text { PEB-OCDE. } \\
\text { - Projecto de } \\
\text { Avaliaçăo do ESU. }\end{array}$ \\
\hline
\end{tabular}


Quadro 5 - (Continuaçăo) - Tipologia dos Mecanismos, Racionalidades e Tecnologias utilizados para dispersar as contradiçōes criadas pelas crises de legitimidade, de hegemonia e institucional

\begin{tabular}{|c|c|c|c|}
\hline $\begin{array}{l}\text { TIPO DE CRISE } \\
\text { MECANISMO }\end{array}$ & RACIONALIDADE & TECNOLOGIAS & CASOS ESTUDADOS \\
\hline $\begin{array}{l}\text { CRISE DE } \\
\text { HEGEMONIA } \\
\text { FRAGMENTACCAO } \\
\text { CURRICULAR }\end{array}$ & $\begin{array}{l}\text { Técnica e cientifica } \\
\text { [Coesão e } \\
\text { consentimento social } \\
\text { sem perda de } \\
\text { eficácia] }\end{array}$ & $\begin{array}{l}\text { - Lançamento das } \\
\text { opções vocacionais } \\
\text { nos } 90^{\circ} \text { e } 10{ }^{\circ} \text { anos } \\
\text { de escolaridade. } \\
\text { - Racionalização do } \\
\text { acto pedagógico: } \\
\text { Pedagogia por } \\
\text { Objectivos. } \\
\text { - Currículo nacional } \\
\text { versus currículo local. } \\
\text { - Curriculo comum } \\
\text { versus curriculo } \\
\text { diversificado. }\end{array}$ & $\begin{array}{l}\text { - Pedagogia por } \\
\text { objectivos. } \\
\text { - Perfil cultural } \\
\text { desejável do } \\
\text { diplomado do } \\
\text { ensino secundário, } \\
1988 \text {. }\end{array}$ \\
\hline $\begin{array}{l}\text { CRISE DE } \\
\text { HEGEMONIA } \\
\text { DIVERSIDADE } \\
\text { DA OFERTA }\end{array}$ & $\begin{array}{l}\text { Técnica e cientifica } \\
\text { [Coesão e consentimento } \\
\text { social sem perda } \\
\text { de eficácia] }\end{array}$ & $\begin{array}{l}\text { - Cursos } \\
\text { técnico-profissionais } \\
\text { do ensino secundário } \\
\text { e Escolas Profissionais. }\end{array}$ & \\
\hline $\begin{array}{c}\text { CRISE DE } \\
\text { HEGEMONIA } \\
\text { CONSENSUALIZAÇĀO } \\
\text { E PRIVATISMO SEM } \\
\text { MERCADORIZAÇÃO }\end{array}$ & $\begin{array}{l}\text { Politica } \\
\text { [Ampliação da } \\
\text { lealdade cívica] }\end{array}$ & $\begin{array}{l}\text { - Lei de Bases } \\
\text { do Sistema } \\
\text { Educativo, } 1986 . \\
\text { - Projecto Global de } \\
\text { Reforma, } 1988 . \\
\text { - Desenvolvimento } \\
\text { Pessoal e Social. }\end{array}$ & $\begin{array}{l}\text { - A pedagogia da } \\
\text { autonomia como } \\
\text { auto-governo do } \\
\text { sujeito. }\end{array}$ \\
\hline $\begin{array}{c}\text { CRISE } \\
\text { INSTITUCIONAL } \\
\text { BUROCRATIZAÇĀO }\end{array}$ & $\begin{array}{l}\text { Juridica e Normativa } \\
\text { [Estandardização } \\
\text { dos procedimentos } \\
\text { de trabalho e de } \\
\text { funcionamento] }\end{array}$ & $\begin{array}{l}\text { - Desconcentração } \\
\text { e descentralização. } \\
\text { - Aumento dos níveis } \\
\text { de contingência } \\
\text { burocrática e } \\
\text { coordenaçāo } \\
\text { subsequente. }\end{array}$ & $\begin{array}{l}\text { - Desconcentração, } \\
\text { descentralização } \\
\text { e regionalização } \\
\text { no planeamento } \\
\text { da rede escolar. }\end{array}$ \\
\hline $\begin{array}{c}\text { CRISE } \\
\text { INSTITUCIONAL } \\
\text { PROJECTO/AVALIAÇĀO }\end{array}$ & $\begin{array}{l}\text { Sistémica } \\
\text { [Estandardizaçăo } \\
\text { dos resultados] }\end{array}$ & $\begin{array}{l}\text { - Projecto educativo } \\
\text { de escola. } \\
\text { - Auto-avaliaçáo } \\
\text { e auditoria das escolas: } \\
\text { indicadores de } \\
\text { desempenho. } \\
\text { - Novas estruturas de } \\
\text { coordenação escolar: } \\
\text { departamentalização } \\
\text { informat. }\end{array}$ & \\
\hline
\end{tabular}




\section{A legitimidade compensatória: profissionalização, participação e internacionalização como retóricas da política educativa}

O Estado tenta compensar a redução de bens, serviços e recursos com a expansão de bens simbólicos. Desde meados dos anos 70 que a reforma do sistema educativo português assenta em três tópicos retóricos fundamentais: o primeiro regula a "reforma modernizadora» por intermédio da assimilação ou diferenciação comparativa com os países centrais europeus. Trata-se de um processo complexo de internacionalização que ora apresenta o país como «atrasado» ora o imagina como parte integrante do centro. Num primeiro momento, a intervençāo do Banco Mundial dirigiu-se para a reabilitação, interna e externa, do Estado: tratava-se de superar atrasos estruturais. Num segundo momento, a inclusão progressiva de Portugal no espaço europeu das políticas educativas aumentou o consenso sobre as transformações a operar no sistema educativo: tratou-se de reduzir a conflitualidade política das opções em nome da aproximação do «espaço europeu moderno".

O segundo tópico consiste na retórica que concede aos professores o papel de agentes privilegiados da reforma. Trata-se de um dispositivo de profissionalização estatal porque, ao contrário de outras formas de profissionalismo, é o próprio apareIho de Estado a promover uma ligaçāo directa entre os especialistas da reforma e os seus executores, propondo uma lealdade baseada no colegialismo da profissão, mas à margem das organizações autónomas da profissão. Os professores são chamados a participar na fase de execução quando já há muito pouco para decidir.

O terceiro tópico incita as comunidades locais - pais, autarquias e empresas - a participarem na gestão, financiamento e decisão dos projectos educativos de escola. Trata-se neste caso da tentativa de uma negociação centrífuga do acordo social que sustenta os consensos educacionais. Confrontado com a crise financeira que impõe ao Estado uma alteraçăo da composiçăo interna das despesas com as políticas educativas e, simultaneamente, com a impossibilidade de fazer cortes radicais nessas despesas, por força das expectativas criadas pelos direitos da escola de massas, o Estado procura que a educaçăo seja gerida com os mesmos modelos e princípios das organizações que operam no mercado. Trata-se da concretização daquilo a que o ministro da educação Roberto Carneiro chamou a empresarização da escola. Incapaz de garantir o cumprimento da igualdade de oportunidades de acesso, em plena crise de legitimidade, o Estado procura um movimento centrípeto de aproximação orgânica entre os seus mandatários, os professores, e os clientes, por cima ou à margem dos mecanismos políticos de participação. No entanto, a participação directa tem-se revelado residual. Não obstante, desenvolveram-se a partir de meados da 
década de 80 mecanismos de administração educativa consultiva (Conselho Nacional de Educaçăo, Conselho de Acompanhamento da Reforma Curricular) e uma administração informal intermitente, predominantemente constituída por grupos de trabalho, que assim permitem o enlace entre membros da administração e certos grupos e instituições tais como os especialistas em educação, as associaçōes de pais e as autarquias.

Neste sentido pode dizer-se que a necessidade de políticas de desconcentração e de autonomia é tanto maior quanto menores são as possibilidades realmente concedidas para a participação dos diferentes grupos de interesses na escola. O princípio organizador da participação é o de que para que alguém ganhe recursos e poder alguém tem de os perder.

0 excesso de força do Estado enfraqueceu os mecanismos de integração. A legitimidade viu-se enfraquecida pelo fortalecimento da centralidade. A desconcentração do sistema educativo e a autonomia relativa das escolas constitui uma resposta pragmática a este problema. Visto que se torna improvável a reconstruçăo do acordo sobre princípios gerais a nível nacional, delega-se esta função no nível local, esperando-se que os enlaces e acordos aí realizados tornem viáveis os compromissos. Procura-se assim fortalecer o pólo da legitimidade à custa do pólo da centralidade.

Até aos meados da década de 80 o Estado considerava que a democratização passava pela reabsorção das diferenças entre os estabelecimentos de ensino. Só o Estado centralizado estava em condições de fazer este trabalho, assegurando assim a igualdade de oportunidades. A lógica cívica era claramente dominante. Hoje, ganha terreno a ideia segundo a qual a democratizaçăo se joga na integraçăo da escola num mercado educativo local de direcção partilhada, que tome em consideração as diferenças contextuais. Justificada por imperativos de flexibilização do sistema educativo português, o Estado argumenta a necessidade de se pôr em sintonia a igualdade de oportunidades no acesso e as exigências do processo de modernização da economia. Apresenta-se assim um novo pacto educativo que temos designado por acordo cívico-industrial.

\section{Tipologia dos discursos educativos do Estado}

Os sistemas educativos escolares são aqui tratados como dispositivos que visam compatibilizar diferentes modos de coordenação das acçōes. Esses modos de coordenação remetem para imperativos simbólicos expressos em valores, para imperativos de realização definidos por finalidades e objectivos e para mecanismos de coordena- 
ção propriamente ditos, classificados como objectos de uso comum, como são as estatísticas, as reuniões, os relatórios, os grupos de trabalho, as memórias e os documentos. A análise sistemática destas formas de coordenação e das suas relaçōes permite ligar a complexidade do sistema escolar à singularidade das situações quotidianamente vividas e assim compreender as tensōes que daí impendem, os esforços realizados para as atenuar e os compromissos resultantes.

Um programa de pesquisa centrado nos diferentes modos de coordenação das situaçōes não está longe da tradição weberiana, interessada pela pluralidade das orientaçôes da aç̧ão e dos modos de autoridade legítima. Mas pode ligar-se também aos trabalhos dos interaccionistas sobre a noção de situação e a pluralidade de modos de interacção e da sociologia cognitiva (Cicourel, 1973) sobre a ordem subjacente à acção ou a ordem negociada (Strauss, 1978). Em síntese, o que a nossa pesquisa põe em destaque săo as formas, as metafísicas e as justificaçōes, de senso comum ou eruditas, que produzem o novo acordo necessário ao funcionamento dos estabelecimentos escolares, num período de transiçăo da escola cívica de massas, baseada no interesse geral, para a escola industrial baseada no mercado. Qual o impacto que esta transição tem nas comunidades de saber partilhadas na opinião pública educativa? Quais os modos de coordenação e de comunicação utilizados para constituir o novo acordo?

A nossa principal fonte de inspiração resulta da aplicação do quadro teórico desenvolvido por Boltansky e Thévenot (1991) à instituição escolar. Em particular, o imperativo de justificação que caracteriza a procura de uma definição da situação aparece como uma fórmula que supera os problemas tradicionais levantados pela articulaçăo dos niveis micro e macro. As lógicas de justificação constituem princípios de justiça que ultrapassam as pessoas e os objectos em presença, remetendo para uma reserva de evidências ou convicçōes partilhadas pelos participantes na situação e referida, simultaneamente, a um princípio de legitimidade exterior. Espécie de princípio kantiano de universalização do senso comum, a procura de uma ordem legítima deve resolver a tensão criada pela situação. Segundo estes autores, a resolução da tensão faz-se através de duas cláusulas que devem verificar as ordens de grandeza dos argumentos e dos objectos mobilizados. A primeira marca as diferenças entre as ordens de grandeza e as escalas de avaliação ilegítimas, associando aquelas à definição do bem comum que exige que os maiores beneficiem os mais pequenos. A segunda cláusula reclama a separaçấo do estado de grandeza das pessoas concretas para que esse estado possa ser reapreciado em qualquer momento numa situação de prova. Trata-se de fazer uma operação de integração da filosofia política e da pragmática do julgamento, na busca do compromisso entre a incerteza das circunstâncias 
e os princípios de justiça gerais. Nesta busca de um compromisso para a acção é a delegação nos objectos que o faz perdurar, sem o ónus de uma permanente abertura das discussōes sobre princípios gerais. ${ }^{(19)}$ É também por isso que renunciamos à análise tradicional das filosofias políticas ou das ideologias que subjazem às políticas educativas. As filosofias e as ideologias situam-se no nível dos princípios e dizem-nos muito pouco sobre as condiçōes de realização de um acordo efectivo.

Em resumo, as diferentes situações analisadas podem ser reportadas a várias ordens de grandeza, cada uma das quais comportando três elementos:

a) uma comunidade de pessoas e um conjunto de objectos da mesma natureza que estabelecem um princípio de justiça comum e a paridade entre os seus membros;

b) um modo de avaliação generalizável da importância dos seres convocados que estabelece um princípio de ordem, hierarquizando as ordens de grandeza, i.e., avaliando a sua importância relativa, constituindo assim uma das lógicas em bem comum e as outras em bens particularistas através de uma operação de crítica;

c) uma forma de fazer prova desta avaliação geral, ou seja, a abertura a situações em que um ou vários actores escolares devem pôr à prova ou fazer prova de que a sua definiçăo é a melhor, ligando assim a exigência de justiça à exigência de racionalidade.

A problemática da ordem negociada e da construção da ordem escolar baseada em situaçōes de prova permite fenómenos como a transferência de lógicas, o relativismo que foge à crítica, a recuperação de argumentos de uma lógica por outra, a transmutaçăo da ordem do discurso, a conversão e a submissão que, em conjunto, nos remetem para os processos de influência social. As cinco lógicas de

(19) O dispositivo de delegaçăo nos objectos foi inicialmente exposto por Latour (1984), sendo posteriormente desenvolvido por Boltanski e Thévenot (1991: 30), nos seguintes termos: «/'analyse de la remise en cause des grandeurs dans une situation, à partir des actions qui s'y déroulent, fait apparaitre, en effet, la place des objets qui doivent être engagés pour que l'épreuve ait un caractère de réalité. L'attention aux liens entre les raisons et les objets engagés à l'appui, entre les modèles de justice et la pragmatique, permet de ne pas faire porter le poids de la coordination des conduites ni exclusivement sur des croyances ou des représentations unifiées, ni sur des systèmes ou des lois qui mettraient toutes les potentialités d'ordre du côté de la regularité des choses, selon une opposition récurrente dans les sciences sociales entre culture et société, représentation et morphologie, ou communication et système, dans la synthèse habermassienne». 
orientação da escola de massas que temos vindo a analisar em Portugal devem ser entendidas neste quadro de conflitualidade: a lógica cívica, a lógica doméstica, a lógica comunitária, a lógica industrial e a lógica de mercado podem ser verificadas a partir da análise do discurso político e educativo dos últimos vinte anos em Portugal. Sendo a expressăo do projecto de modernidade anunciado para a sociedade portuguesa, estas cinco lógicas sobrepõem-se no tempo e nas práticas reguladoras do sistema educativo, convocando para tanto três princípios fundadores e justificadores da transformação operada nas sociedades modernas: o princípio do Estado, o princípio da comunidade e o princípio do mercado.

1. ${ }^{\text {a }}$ Fase (1974-1976): O Estado-educador numa escola aberta: educação para a cidadania, para todos

Na lógica cívica, a justiça é definida pela conformidade ao interesse geral. Apoiando-se no princípio do Estado, a escola é um serviço público e a recusa de laços pessoais e locais é considerado como a condição de igualdade. O direito territorial define um espaço a partir de uma hierarquia administrativa vertical em que o estabelecimento educativo aparece como extraterritorial.

A metáfora que estrutura esta primeira fase é a metáfora orgânica que fala da escola como um corpo, um organismo ou um sistema vivo. E ao fazê-lo reconhece que a escola existe num meio, do qual depende para a satisfação de várias necessidades. Daqui se conclui que a realização de um certo tipo de relaçōes com o envolvimento pode levar a escola a melhorar a sua eficácia e a ultrapassar a crise provocada pelo seu crescimento demográfico. A ideia de uma escola-fortaleza dá lugar à escola aberta por pressão do aumento de expectativas positivas em relação à escola.

Muitos dos argumentos que pretendem justificar o bem-estar ou o mal-estar que se vive na escola radicam na ideia de que os professores e os alunos são seres humanos com necessidades complexas, expectativas e aspirações e que, consequentemente, a escola não se resume a um problema de maior ou menor eficácia técnica. É preciso conhecer as necessidades das pessoas e estas não passam sobretudo pela organização formal. No entanto, a metáfora orgânica não leva até aos seus limites o reconhecimento da existência de uma organização informal paralela à organização do sistema educativo. Pelo contrário, em boa ortodoxia sistémica, ambiciona conseguir a harmonia funcional, a unidade funcional do sistema educativo. Os sucessivos ministros da educação dos anos 74-76 utilizam a retórica da ausência de um verdadeiro sistema educativo para assim justificar a sua reconstrução. Fazendo crer que a unidade e a homeostase dos organismos sociais é possivel e desejável mantêm uma crítica permanente à desorganização, aos desacordos, aos grupos, aos conflitos de 
interesses que marcam a vida escolar. A escola deve ser um verdadeiro sistema. Sottomayor Cardia expressa bem esta ideia nos seguintes termos: «em rigor não se pode falar de um sistema educativo desde o 25 de Abril (...) Estamos, portanto, numa situação que se caracteriza por uma conservação de incongruências e que, quanto a mim, resultam do facto de diversos sistemas de ensino estarem residualmente em vigor, embora nenhum esteja plenamente em vigor».(20)

É este permanente desejo de ultrapassar as incongruências que tem expressão nas medidas de política educativa tendentes a superar o individualismo do professor, o isolamento da sala de aula, a disjunção das disciplinas. Estas justificam a produção de um conjunto de normas, de regras e de princípios que ponham coerência na "anarquia» que passou a ser o estabelecimento educativo. Para que este possa escapar ao caos, à divisão e à fragmentação os membros da escola devem exercer os seus direitos e cumprir com as suas obrigaçōes colectivas. Assim, as escolas devem ter objectivos comuns que the conferem uma personalidade colectiva ao abrigo das iniciativas particulares: "especialmente nos centros urbanos, um novo terror, de sinal contrário, abateu-se sobre grande parte das escolas secundárias e a quase totalidade das superiores (...) O governo fará o que estiver ao seu alcance para modificar esse estado de coisas. Foi já publicado um diploma criando e regulamentando os órgãos que, nos estabelecimentos de ensino preparatório e secundário, ficam responsáveis pelo seu funcionamento. Pôs-se assim termo a um vazio legal».(21)

Para resistir à tendência sempre renascida que envolve os indivíduos no particularismo, os representantes da vontade colectiva devem actualizar em permanência as referências míticas deste universo cívico colectivo. As disposiçōes e os órgãos constituídos neste processo de actualização, para que tenham existência reconheci-

(20) Citação de uma intervenção do ministro da educação Sottomayor Cardia na mesa-redonda organizada pelo O Jornal de Educação e que teve também a participaçăo de Fraústo da Silva e de António Teodoro: in «1974-84: como é a educaçăo dez anos depois do 25 de Abril?», O Jornal de Educação, 76, 1984, p. 22. Esta mesma ideia seria mais tarde repetida pelo ministro do VI Governo Constitucional, Vítor Crespo: «de facto aquilo que encontrámos ao tomar posse do Vı Governo nāo se pode chamar com rigor um sistema educativo, mas pelo contrário um conjunto de situaçōes educativas, que tem de ser harmonizadas num processo relativamente lento para não inflingir danos irreparáveis nos alunos e demais componentes do sistema (...) Isso leva-nos a afirmar que a melhoria do sistema educativo se deve processar por sucessivos ajustamentos enquadrados por objectivos bem definidos e prosseguidos com determinaçăo segundo as adequadas linhas de força» (In discurso proferido no Instituto de Defesa Nacional, 15/5/81, p. 4 (documento policopiado).

(21) Discurso proferido pelo ministro da educaçăo e investigaçăo científica do I Governo Constitucional, Mário de Sottomayor Cardia, em 28 de Outubro de 1976, na RTP, editado pela Secretaria de Estado da Comunicação Social, com o título Educaçăo e Democracia, p. 4. 
da, terão uma forma de fazer chegar a sua voz a toda a escola. Para que a sua voz apareça de modo saliente, as pessoas colectivas devem ser circunscritas no espaço por fronteiras que marquem a sua existência e por rituais de presença: «dispôs-se, por isso, que professores profissionalizados participem nos vários órgãos: conselho directivo, pedagógico e administrativo. Estabeleceu-se que a participaçăo de alunos se verifique em conselhos pedagógicos e directivos, embora quanto a estes apenas nos estabelecimentos que ministrem cursos complementares. Determinou-se ainda que só sejam válidas eleiçöes em que participem 60 por cento do total de eleitores e requer-se que a lista eleita o seja por 51 por cento dos votos. Isso foi ditado pela necessidade de se caminhar para a estabilizaçăo da vida escolar».(22)

A definição prévia da situaçăo educativa enquanto caos e crise foi fundamental para a legitimação da intervenção normalizadora de Sottomayor Cardia. Esta definição pode ser real ou fictícia. Porém, não é essa avaliação que importa aqui, mas antes a capacidade de a autovalidar criando um communis consensus acerca da sua existência real. A metáfora apresenta em geral três vantagens no plano das tecnologias de governo: procura a legitimaçăo no nível supralegal em ideias abstractas como o sistema social livre e democrático, a liberdade de ensino, etc; simplifica as situações de decisão, elegendo critérios claros para a acçăo, centrando-se em regra numa intervenção de sinal contrário ao que vinha sendo feito; torna excêntricas as reivindicaçōes que năo podem ser formuladas no quadro que referencia a crise.

No entanto, a simplificação das situações de decisão só é possivel se prevalecer uma interpretaçăo funcional da crise: a crise é problematizada em termos de situaçōes em que certas acçōes devem ser realizadas. Ora, desde o primeiro momento, Sottomayor Cardia escolheu uma interpretação causal para a crise: nomeou interesses, culpou partidos, enfrentou deliberadamente organizaçōes estudantis, fechou universidades, afastou quadros superiores, suspendeu professores e assim polarizou a crise em vez de a consensualizar. ${ }^{(23)}$ Deste modo, o ciclo legal da política administrativa colocou-se na dependência de legitimaçōes extralegais. Os processos empíricos contraditórios que têm lugar na relação entre a periferia e os diversos organismos da administraçăo deixam de poder orientar-se pelas normas de direito disponíveis, tornando-as moldáveis. Sottomayor Cardia dá-se conta do logro de uma política de

\footnotetext{
(22) Idem, Ibidem, p. 5.

(23) Neste mesmo sentido vai a argumentaçăo de Stephen Stoer na análise que faz deste período em Educação e Mudança social em Portugal: 1970-1980, uma década de transição, Porto: Afrontamento, 1986, pp.145-154.
} 
intervenção negativa quando faz o balanço dos seus dois anos de ministério: «entre os vários erros cometidos, reconheço como um deles a pouca atenção prestada à necessidade de divulgar as acçōes empreendidas e os projectos em estudo». (24) Em qualquer dos casos, o que sobressai da argumentação dominante neste período é a definição de um serviço público que se encontre ao abrigo das pressões das famílias, dos professores, das corporações e dos interesses locais. O modelo cívico do interesse geral regressa como condição de imparcialidade, (25) embora se conheçam bem os limites práticos de tal ambição. Este mesmo princípio transbordará facilmente da retórica política para a organização disciplinar do saber. Para além dos objectivos de luta política claramente incritos nas intervenções do ministro Sottomayor Cardia, dirigidos contra a "visão unilateral e sectária das matérias», (26) regista-se uma oposição determinada aos saberes transversais ou aos saberes proliferantes provenientes das relações quotidianas. A suspensão da disciplina de Educação Cívica Politécnica, bem

(24) In Dois anos de politicas de ensino (documento dactilografado, sem data, arquivo pessoal de Mário Sottomayor Cardia).

(25) No documento Dois anos de politica de ensino, o ministro Sottomayor Cardia expressa nos seguintes termos este princípio: «Da normalizaçăo da actividade escolar, entendo dever dizer pouco. Os factos săo em geral suficientemente conhecidos e as iniciativas oficiais foram estreitamente ligadas à intervenção pessoal do Ministro e dos colaboradores mais directos. Enunciarei apenas os tópicos das principais dessas iniciativas evitando formular quaisquer juízos de valor: substituiçăo de uns quantos quadros superiores cuja acção se não harmonizava com a política de pluralismo ideológico que o Governo se impôs seguir no sector pedagógico; abertura de concursos para professores do ensino preparatório e secundário segundo critérios objectivos e condução do processo sem intervenção de 'comissōes de luta' ou outras entidades privadas; extensão às escolas do magistério primário do regime de concursos em substituiçăo do regulamento por convite; revisão de certos programas de conteúdo mais marcadamente sectário; publicaçăo de normas sobre recrutamento de pessoal auxiliar de estabelecimentos de ensino, pondo termo à nomeaçăo desse pessoal por 'graça' do Ministro sob pressăo dos 'influentes'; levantamento dos cursos universitários criados e em funcionamento; nova legislação sobre a gestão das escolas preparatórias e secundárias e das escolas superiores; reintegração de estudantes e professores ilegitimamente afastados por motivos políticos, o que obrigou ao encerramento temporário da Universidade de Coimbra; reestruturaçăo de algumas escolas superiores; revisāo das situaçōes de professores universitários equiparados mediante pareceres de especialistas; resistência à destruiçăo do ensino médio universitário, contrariando pressōes de certos sectores de médicos hospitalares; determinação da realizaçăo de exames nacionais no termo do ciclo complementar do ensino secundário e da admissăo à Universidade; fixaçăo de numerus clausus na admissão à matrícula em todas as escolas superiores e médias; decisăo de năo ceder a pressōes ilegítimas e ameaças aparentemente fortes dos sindicatos de professores no sentido de introduzir precedentes ou agravar distorçōes no regime do funcionalismo público que subverteriam regras fundamentais de gestão dos funcionários e agentes do Estado; recusa do princípio de negociaçăo entre o estado e os sindicatos de funcionários públicos na elaboração de diplomas legais» (pp. 2-3).

(26) Cf. Educaçăo e Democracia, discurso proferido pelo ministro da educaçăo e investigação científica, Mário Sottomayor Cardia, a 28 de Outubro de 1976, Secretaria de Estado da Comunicaçăo Social, 1977, designadamente no seu ponto 2 , intitulado Trabalhar pela objectividade do conteúdo do ensino (pp. 9-11). 
como a substituição das Ciências Sociais pela História no $7 .^{\circ}$ ano de escolaridade,(27) corresponde, em larga medida, a um regresso ao conhecimento disciplinar suportado por uma epistemologia favorável aos saberes construídos tradicionais. Se a este elemento acrescentarmos as preocupaçōes na definição das habilitações necessárias ao exercício da profissão docente, geridas directamente pelo ministro Sottomayor Cardia, (28) ficamos em condiçōes de perceber a importância da recuperação da legitimidade disciplinar no projecto de reconstrução das fundaçōes abaladas do princípio da confiança. Princípio da confiança que é ao mesmo tempo um princípio de controlo à distância, como sublinha Derouet (1992: 91): «la discipline constitue um mode d'organisation où um ensemble de connaissances très diverses peut être mis en ordre à partir d'un très petit nombre de principes (...) Les professeurs tirent leur légitimité de l'appartenance à cette communauté universelle qui se constitue autour de la discipline et sont contrôlés para une instance lointaine qui exprime cette communauté, I'Inspection générale. Cette hiérarchie les affranchit de tout contrôle local, qui constituerait por la dignité et l'impartialité de la magistrature publique une pression injustifiable».

2. ${ }^{a}$ Fase (1977-79): O Estado regulador numa escola comunitária — a educação na sociedade pedagógica

Na lógica comunitária há um regresso nostálgico ao passado cultural e à identidade local e nacional míticas. Ao contrário da lógica cívica, mete em primeiro plano as ligações pessoais de face-a-face e remete para os modos de gestão e de fazer da família e dos grupos primários. Enfatizando o princípio da comunidade assente na descentralização e na democracia participativa, a igualdade formal do cidadão vê-se confrontada com a necessária igualdade substantiva. $\mathrm{O}$ direito doméstico, constituído a partir da maximização dos afectos, define um espaço muito ambíguo que se

(27) Despacho n. $^{\circ} 243 / 76$ de 4 de Agosto. Este é um dos exemplos típicos em que as contingências de desenvolvimento interno dos sistemas educativos nacionais introduzem variantes à expansão mundial isomorfa dos currículos. Na verdade, enquanto Wong (1991) e Meyer e Ramirez (1998), ao analisarem os currículos do ensino primário e secundário, detectaram uma forte tendência mundial dos sistemas educativos de massas adoptarem o modelo curricular americano dos Estudos Sociais, em detrimento das disciplinas tradicionais de Geografia e História, em Portugal, pelo contrário, depois de uma primeira iniciativa nesse sentido, deu-se um recuo ao modelo universitário das disciplinas, bem como à delimitação rigorosa do campo de intervençăo de cada ciência, dos seus objectos, métodos e programas.

(28) Pudemos confirmar no arquivo pessoal de Mario Sottomayor Cardia que o despacho conjunto n. ${ }^{\circ} 113 / 77$ de 28 de Abril, que define as habilitaçōes próprias para a docência no ensino preparatório e secundário, foi redigido directamente pelo ministro. 
confunde ora com a tradição religiosa da escola comunitária, ora com a tradição do hic et nunc pedagógico, mas que, em qualquer caso, significa convergência de pontos de vista e obscurecimento das contradições sociais e estatutárias.

A metáfora comunitária manifesta-se como a que tem maior presença no discurso político dos anos 77-79. E percebe-se que assim seja se recordarmos que a escola portuguesa tinha uma imagem pública e uma imagem própria de um certo fechamento ao meio e de algum conservadorismo. É o programa do $\mathrm{V}$ governo constitucional que pela primeira vez inscreve as relações escola-comunidade como um dos objectivos explícitos de política educativa. Fá-lo nos seguintes termos: "a conveniência em que sejam dinamizadas, numa base de vida concreta, as relações entre a Escola e a Comunidade, de forma a articular a acção educativa com um sentido de utilidade social e com uma prática de participaçăo democrática».(29) O ponto de apoio deste modelo comunitário é a pessoa do aluno e não o saber. Ao invés do modelo cívico simples que dominou os primeiros anos após a queda da ditadura, a lógica comunitária que agora se Ihe associa năo visa separar o aluno do seu meio, mas antes a integrá-lo e adaptá-lo a uma sociedade em transformação. Não pretende construir o aluno genérico e universal pela generalidade e universalidade dos saberes disciplinares, mas antes porque "atende ao aluno na sua plenitude». E daí a crítica à erudiçăo. Uma vez obtidas e dominadas as capacidades intrínsecas dos alunos, a quantidade de conhecimentos assimilados pouco importa: "enfim, se se pretender enunciar a finalidade última da acção educativa, dir-se-á, como alguém já escreveu, que o 'saber fazer, mesmo quando humanizado pelo saber ser, não basta já para uma sociedade em transformaçăo. É o saber evoluir que importa desenvolver'. Assim se caracteriza toda uma nova finalidade da acçăo educativa, aberta para a vida, criando a atitude e a capacidade de julgar e modificar as formas de relação e intervenção no mundo em que se vive. $\mathrm{E}$ isto leva à intençăo de substituir uma prática orientada para propósitos de erudição por outra que privilegia o poder de iniciativa, o espírito crítico, a solidariedade social, a consciência da temporalidade das situaçôes. No fundo, procurar-se-á preparar um homem permanentemente adaptável e actuante perante o fluir da História». (30) Sem embargo de nunca chegar ao menosprezo total dos conteúdos, o que se valoriza aqui é a experiência em si da aprendizagem, o valor humano das relações pessoais estabelecidas, a busca de si próprio e a

(29) In Programa de Actividades do Ministério da Educação no âmbito do Programa do V Governo Constitucional, Lisboa: Ministério da Educaçăo, 1979, p. 13.

(30) Idem, Ibidem, p. 11. 
autoconstrução dos indivíduos. Doravante, educar não é tanto promover o que há de comum aos jovens, mas responder a necessidades em sua natureza diversas. A lógica da procura faz o seu longo caminho: primeiro, por intermédio dos imperativos individuais; depois, por força da diversidade de contextos; finalmente, através das necessidades da produção. O Estado e a sua escola nāo são mais os portadores de um projecto político de sociedade, mas antes os fornecedores de um espaço comum em que se expressam os indivíduos, as comunidades e os interesses particulares.

O princípio da comunidade infiltra-se no discurso político educativo por intermédio das organizaçōes internacionais. Dentre os documentos que maior influência terăo tido na agenda política portuguesa sobressaem os resultantes dos três seminários sobre inovação no ensino do CERI/OCDE. ${ }^{(31)}$ Com efeito, a participação portuguesa no seminário organizado pelo CERI, em Catânia (Janeiro de 1979), dedicado ao tema Comunidade escolar e Problemas práticos de Planificação Regional, contribuiu de forma explícita para a definição da agenda política portuguesa. Este seminário constitui uma fonte de iniciação/reactivação do discurso comunitário, por força da influência do corpo de especialistas internacionais da OCDE. Sendo o derradeiro seminário de um conjunto de três, organizados entre 1977 e 1979, pelo CERI/OCDE, integra-se num projecto mais global sobre Inovação no ensino. ${ }^{(32)}$ Este é um caso típico do papel transnacional assegurado por um grupo de pedagogos que tem ao seu dispor possibilidades extraordinárias de financiamento e de divulgação junto da administração. Do relatório da técnica do GEP, dirigido ao ministro e secretário de estado, destaca-se uma das ideias-força essenciais que influenciará senăo a prática imediata, ao menos os discursos de política educativa: «a ideia do distrito escolar nasceu da necessidade de um novo tipo de intervençăo, face à crise dos estabelecimentos de ensino e à das relações entre a escola e a sociedade, e consistia em reconhecer uma larga responsabilidade ao escalāo local a fim de reconstruir a funçăo

(31) Referimo-nos aqui à importância do mecanismo de disseminaçăo (Dale, 1999) no processo de globalizaçăo das políticas educativas comunitárias.

(32) O primeiro seminário realizou-se em Bruxelas (Problema geral que a inovação pōe aos responsáveis administrativos de educaçăo, 1977) e teve representação portuguesa; o segundo realizouse em Bordéus, sem a presença de representantes da administração portuguesa. O terceiro seminário tem a presença da técnica do GEP e membro do Secretariado Técnico da Regionalização, Maria de Fátima Ascenso, que fará um relatório circunstanciado ao ministro da educaçăo do IV governo constitucional, Valente de Oliveira. Neste relatório, a técnica tenta associar as linhas de orientaçăo do CERI, bem como a experiência italiana, com que contactara, à experiência portuguesa, referindo na respectiva nota de apresentação as experiências portuguesas em Alcochete e nos Açores, assim como a necessidade de regulamentar a intervençăo do Secretariado das Associaçōes de Pais criado ao abrigo da lei $n .^{\circ} 7 / 77$, de 1 de Fevereiro. 
da educação partindo da base, aproximando os utentes dos serviços educativos, de molde a que o mundo da escola e a colectividade local, integrados, não se furtem às graves responsabilidades e opções necessárias à harmonia entre a escola e a sociedade (indo mesmo, segundo certa perspectiva, assumir a responsabilidade da função entre a educaçăo e o emprego). (...) Todavia, para além dos resultados de carácter geral obtidos com as recentes intervençōes regionais, ainda que limitadas, na politica educativa, o que de mais positivo ressalta é o despertar do interesse natural da colectividade local para uma participação global, e não mais apenas sectorial, na política educativa, com vista à soluçăo da crise e das dificuldades de funcionamento da escola pública».(33). A comunidade surge aqui como uma estratégia de recuperação da legitimidade perdida da escola pública. As acções da escola passam a ser vistas a uma nova luz: velar pelo seu bem-estar, pela qualidade dos produtos escolares e pelo seu próprio futuro é uma responsabilidade dos indivíduos, das famílias, das empresas e das parcerias comunitárias que supostamente os articulam. A vantagem evidente desta estratégia é a de permitir ao Estado dispersar as fontes de conflito, intercalando filtros adicionais de separação entre estes e o resto do sistema. A comunidade constitui uma nova forma de espacialização do exercício do governo, garantindo a intersecçăo entre o mercado, o consumo e o contrato cívico. Tendo na base o indivíduo activo e responsável pelo seu próprio governo, o dispositivo de lealdade não é mais travejado na relação de obrigação entre o cidadão e o Estado, mas numa relaçăo de lealdade de espacialidade variável. Cada indivíduo é situado numa rede heterogénea de preocupaçōes e investimentos pessoais que são a nova fonte das relaçōes de mútua obrigaçăo. As comunidades escolares pretendem justamente constituir essa rede imaginária, capaz de segregar crenças e valores para uma nova integraçăo dos grupos sociais na escola. Muitas vezes estas comunidades não são

(33) In Breve Relatório do Encontro Internacional de funcionários com alta responsabilidade administrativa no dominio da educação sobre 'Comunidade escolar e problemas práticos de planificaçăo regional', de Maria de Fátima Lencastre Ascenso, sem data [entrada no gabinete do ministro a 5/3/79 com a menção 'tomei conhecimento do relatório e documentação, que considero do maior interesse]. Dentre a documentação, de difusão restrita, anexada a este relatório de missão, encontram-se duas importantes notas do secretariado do CERI/OCDE, uma das quais intitulada $L a$ Communauté scolaire (CERI/TA77.05, Paris, 19 de Abril de 1978, p. 7) que expressa bem o sentido pragmático e gestionário desta noçāo: «14. centralisation et notion de communauté scolaires ne s'excluent pas. Il est concevable qu'une autorité centrale puisse définir avec une certaine précision le cadre de liberté dans lequel la communauté pourra exister. 15. Mais, les véritables problémes sont: de réaliser l'équilibre nécessaire entre la cohésion générale d'un système d'enseignement et I'autonomie des communautés scolaires; de déterminer les procédures qui rendent possibles la recherche d'un consensus et la participation réelle de la communauté scolaire aux decisions à prendre». 
mais que realidades virtuais sem espaço ou tempos reais. Noutros casos facilitam o trânsito das lealdades discretas para as colectividades globais mais abstractas, sejam elas a comunidade nacional, a comunidade europeia ou a comunidade global. Em qualquer caso, esta ambiguidade é devida à situação limítrofe em que a escola se encontra. Objecto de fronteira, sujeito à influência de espaços discursivos com maior homegeneidade, não consegue a sua aceitação senão à custa de concessões de boa vizinhança. De um lado, os actores económicos com interesses num mercado concorrencial disseminam princípios de justiça mercantis; de outro lado, os actores sociais, submetidos a normas, fazem valer a universalidade do seu sistema explicativo das condutas humanas; finalmente, os actores domésticos, submetidos à maximização dos afectos, afirmam a família como um princípio natural primordial.

3. ${ }^{a}$ Fase (1980-1986): O estado (des)regulador numa escola moderna e eficaz: a educação face à economia

Na lógica industrial são os constrangimentos de performance e eficácia que são chamados a primeiro plano. Apoiados numa relaçăo de homologia e correlação entre o sistema escolar e as estruturas do emprego e da economia, os discursos industriais marcam uma exigência de elevação global do nível de competência e de desenvolvimento local e nacional. Dá-se a passagem de uma regulação suportada pela centralização geográfica à inter-relação de diversas instituiçōes e padrões discursivos que, deste passo, são integrados no interesse geral: "o sistema de educaçăo actual como sistema de massas terá de ser alterado no sentido de uma maior diversificação, individualizaçăo e descentralizaçăo, devendo aproximar-se da realidade socioeconómica; dever-se-á procurar uma maior participaçăo da comunidade local ao nível de escola nomeadamente no que se refere a uma maior responsabilização por parte dos pais e das famílias» (Carneiro, 1988: 83). Porém, o apelo ao reforço da ligação funcional do sistema educativo com o sistema produtivo não está desprovido de um novo quadro de referência comum. O discurso da modernização e da eficácia anda a par da reconfiguração do humanismo liberal, caracterizado por Rose (1996a: 327) a partir da nova espacializaçăo do governo: «the rise of the language of globalization indicates that economic relations are no longer easily understood as organized across a single bounded national economy. Community has become a new spatialization of government: heterogenous, plural, linking individuals, families and others into contesting cultural assemblies of identities and allegiances». A passagem progressiva do social, como alvo de governo, para uma comunidade imaginária que pressupōe um mundo de indivíduos sem contradições é essencial neste dispositivo de incorporação dos interesses económicos particulares no contexto político da decisão. 
A metáfora empresarial — o Ministro Roberto Carneiro fala da empresarização da escola e da escolarização da empresa ${ }^{(34)}$ - conota a escola com uma empresa para, por oposição ou semelhança, evidenciar as obrigações de controlo e responsabilização pelos resultados que pesam sobre os estabelecimentos de ensino. Na tradiçăo liceal os alunos são os futuros cidadãos que necessitam de uma formação geral e global não especializada. Mas a este ethos apōe-se agora uma nova tarefa: a escola deve formar também para responder ao mercado de trabalho e às expectativas dos alunos que não querem prosseguir estudos prolongados. Porém, o discurso modernizador faz questão de incorporar as referências post-fordistas que rejeita os saberes profissionais especializados: «trata-se, assim, de acolher a necessidade de formar generalistas, que terão um maior poder de adaptação, e não especialistas uma vez que o mundo do trabalho sofre alterações a um ritmo tão acelerado que cada indivíduo ao longo da sua vida activa terá necessidade de passar por várias profissões, implicando sucessivas reconversōes» (Carneiro, 1988: 84).(35)

O saber privilegiado pela metáfora empresarial é o saber operatório e instrumental da racionalidade técnica. Este saber denuncia implicitamente a tradiçăo liceal das escolas. Tal denúncia anda a par do discurso da modernização da sociedade: a modernidade da escola consistiria na capacidade de integrar na oferta curricular mais cursos técnico-profissionais: "o sistema de ensino regular tem dedicado à preparação para o trabalho e o exercício qualificado das profissões uma atenção generalizadamente reconhecida como muito insuficiente. Por um lado, ao nível da educação geral, não têm sido significativamente promovidas a aprendizagem de competências transferí-

(34) Roberto Carneiro desenvolve esta ideia em diversos artigos e discursos de que o citado é apenas um exemplo: «as linhas de desenvolvimento concebidas deverăo, por um lado, ser acompanhadas por uma alteração profunda do conceito da 'escola' e da empresa uma vez que a primeira deverá funcionar cada vez mais no estilo empresarial, enquanto que a segunda irá gradualmente perfazer funcōes no domínio da formação e da pesquisa» (Carneiro, 1988: 18).

(35) Sobre este tema é particularmente elucidativa a análise de Correia, Stoleroff e Stoer (1993: 25-51), ao revelarem a contradiçăo entre o discurso modernizador, que banaliza as formaçōes especializadas, e as práticas educativas das escolas profissionais, mais vocacionadas para a produção de qualificaçōes fordistas: «embora alguns documentos oficiais reconheçam que a 'formaçāo para uma determinada profissão não cria o emprego em questăo, mas permite adquirir competências que serâo utilizadas para a realização do trabalho' (Documentos Preparatórios I, 1987: 49) e que seja necessário pôr em causa 'a ideia corrente em alguns circulos de que a formação profissional escolar deve ser estimulada para permitir o desenvolvimento económico' (lbidem), a verdade é que os niveis de qualificação profissional definidos no documento da Comissäo de Reforma do Sistema Educativo (a que temos vindo a fazer referência) se baseiam numa classificação de niveis ocupacionais produzidos pelo Minsitério das Cooperaçōes e Segurança Social/Fundo do Desenvolvimento de Mão-de-Obra publicado em 1973, e que a tipologia das áreas profissionais e áreas de formação ai definidas subentendem uma organização do trabalho mais próxima do taylorismo do que uma nova divisão do trabalho apregoada pelo discurso da modernização» (Correia, Stoleroff e Stoer (1993:40). 
veis para o desempenho de papéis profissionais, a aquisição de saberes relevantes sobre a organizaçăo e o funcionamento do mundo do trabalho ou a adopção de expectativas positivas relativamente à preparação para o trabalho. Por outro lado, ao nível do ensino secundário, e apesar da via técnico-profissional, năo têm sido oferecidas oportunidades credíveis, em termos quantitativos e qualitativos, de formação para o exercício qualificado das profissões de nível intermédio». (36) Embora o modelo curricular proposto para as escolas profissionais contemple competências gerais, é nos papéis profissionais existentes na formação social que se encontra a justificação da primazia dada à componente técnica. Não por acaso, a referência simbólica das profissões de nível intermédio surge como o sinalizador principal de uma relação salarial polarizada. ${ }^{(37)}$ Deste modo se transfere para um sistema educativo renovadamente dual a tarefa de reproduzir, funcionalmente, as hierarquias e as desigualdades que existem no mundo do trabalho. Mas, segundo os decisores políticos, esta é também a via para obter mais recursos para a escola. Na concepção industrial, a escola deve tomar a iniciativa, desenvolver projectos, correr riscos: «a nova relaçăo com a sociedade caracteriza-se por uma grande confiança nas energias, iniciativa e criatividade das pessoas e instituições. Assim, as empresas são chamadas a apadrinhar escolas, os agentes culturais a colaborar com elas, dão-se apoios à criaçăo por iniciativa privada de centros de educaçăo pré-escolar, estimula-se a criaçăo particular e empresarial de escolas profissionais, desenvolve-se o ensino particular. No fundo confia-se na autonomia da sociedade civil».(38) No interior deste argumento também se torna verosímil a hipótese de Offe (1984a: 124), segundo a qual «não săo fundamentalmente os agentes do processo de acumulação que estão interessados em instrumentalizar o poder estatal, mas, ao contrário, são os agentes do poder estatal que a fim de assegurarem a sua própria capacidade de funcionamento obedecem como seu mandato mais alto ao imperativo de constituição e consolidação de um desenvolvimento económico favorável». Este argumento é especialmente pertinente

(36) In Proposta Global de Reforma, CRSE, Lisboa: GEP, 1988, p. 261.

(37) No citado artigo de Correia, Stoleroff e Stoer (1993: 39) reconhece-se também que, mais do que responder a qualquer pressão proveniente da esfera empresarial, o subsistema de formaçăo técnico-profissional, de iniciativa estatal, se destina a reforçar a posição autónoma deste no processo de acumulaçăo. Daí que «a criação do ensino técnico-profissional são, pois, respostas (porventura parciais e condicionadas) a solicitaçōes sociais de reconhecimento das competências escolares no mercado do trabalho, que servem de pretexto para uma redefinição da ligação Escola/Mundo da Produção onde este se confunde com o mundo empresarial e para uma reinstitucionalização de alguns dos procedimentos de inculcação moral imprescindiveis à aprendizagem da relaçăo salarial»».

(38) In conferência do secretário de estado da Reforma Educativa, As linhas mestras da Reforma Educativa, 27 de Novembro de 1989 (documento policopiado), p. 49. 
numa conjuntura de crise de acumulação e de desinvestimento educativo, já que o Estado se propõe alterar a composição interna das despesas em educação, transferindo parte delas para o mercado. Entre outras fontes, o argumento é expandido pela própria Comissão de reforma do sistema educativo (CRSE, 1988b: 245), que sugere, em troca, a participação dos diferentes actores na definição dos próprios planos curriculares: «consagra-se a participação activa dos diferentes parceiros sociais na definiçăo dos perfis profissionais e na elaboraçăo, aplicação e avaliação das políticas de formação técnica e profissional, não só como forma de lhes garantir adequação às necessidades sócio-económicas do País, mas também como um modo de motivar os empresários e os trabalhadores para as novas qualificaçōes profissionais, tanto nos seus conteúdos como nos seus custos». Todavia, embora a proposta de parceria parecesse aliciante, a participação das empresas nos custos das escolas profissionais nunca foi mais que residual. Não se pense, contudo, que a ineficácia do projecto, nos seus primeiros anos, restringe este discurso a uma mera retórica. Mais que efeitos práticos imediatos, pretende-se consagrar neste veio discursivo um novo regime de verdade sobre o sistema educativo português. Doravante, é a produtividade das escolas, quer dizer, a sua capacidade de gerar perfis de trabalho, que se tornará central na avaliação do seu funcionamento. $\mathrm{O}$ incitamento à procura de recursos externos, não estatais, é o elemento principal da futura política gerencial.

O aluno é entendido também como o futuro produtor cujo referencial é a economia: «a economia portuguesa, carenciada em mão-de-obra qualificada e concentrando grande parte do emprego em sectores tradicionais em reconversão, dificilmente manterá níveis que assegurem a sua competitividade internacional, sem conceber e implementar novas estratégias de gestão de recursos humanos (...) É desejável estimular uma formação a mais longo prazo, criando maior poder de escolha das alternativas técnico-profissionais, tanto públicas como privadas, e criando sinergias, que poderiam incluir cooperações em todos os sentidos e nos vários níveis de ensino, procurando centrar-se na necessidade dos destinatários do mercado, da economia e da cultura». (39) A diversidade do mundo da produçăo aparece como a raiz da diversidade da esfera educativa. Na boa ortodoxia sistémica torna-se funcional o que é contingente. A correlação ilusória daí resultante fornece os elementos necessários à episteme segundo a qual os sistemas de formação assegurariam a inserção num mercado de trabalho moderno e, portanto, bastante heterogéneo.

(39) Palavras do ministro da educação, Roberto Carneiro, no seminário A Educação e a Cultura: imperativos da Europa no mercado interno, Évora, 1 de fevereiro de 1991 (documento policopiado), pp. 7-8. 
Finalmente, a metáfora empresarial serve para distinguir a qualidade do que é funcional, eficaz e profissional daquilo que é ineficaz, improdutivo ou inadaptado. Os utilizadores da metáfora exprimem a organização de um sistema em que cada um tem a sua funçăo, a sua posição, num universo tecnicamente previsível. 0 disfuncionamento causado pelos inadaptados é assumido abertamente como uma situação a combater pela introdução de um sistema funcional de formações que assegure o seu potencial de actividade. As qualidades prescritas para o «professor da reforma» devem exprimir a sua capacidade para se integrar na engrenagem do sistema ao mesmo tempo que aumenta a sua previsibilidade. (40) Numa das intervenções que faz sobre este assunto, o secretário de estado identifica inicialmente três competências tradicionais do docente - competência científica, competência pedagógica e competência profissional e pedagógica - , inventariando seguidamente as competências especificas decorrentes da reforma. Enuncia năo menos que doze novos papéis a desempenhar pelos professores: papel intercultural, educação para a saúde, educação familiar, educaçăo para o lazer, necessidades especiais de aprendizagem, assistentes sociais educativos, bibliotecários, orientadores, especialistas em gestão, especialistas em planeamento educativo, especialistas em cooperação, investigador aplicado. ${ }^{(41)}$ A perspectiva do professor multifuncional, que Hameline descreve com a imagem da criada para todo o serviço, é a que se apresenta mais forte na perspectiva da reforma, colocando o professor numa busca permanente de saberes e técnicas

(40) Entre muitas outras passagens em que esta ideia aparece, respigamos a seguinte: "tal perfil do professor năo pode ser definido arbitrariamente ou de acordo com uma qualquer ideologia de moda ou preconceito partidário. Tem que ser, em primeiro lugar, o resultado de um longo trabalho de inferência dos grandes quadros legislativos que regem a reforma educativa e aonde os consensos da sociedade portuguesa se cristalizam - a Lei de Bases do Sistema Educativo, o Estatuto da Carreira Docente, o Ordenamento Jurídico da Formação de Professores e os vários diplomas sobre a autonomia das escolas. O perfil do professor da reforma terá que ser, em segundo lugar, o resultado de um trabalho de prospectiva sobre as necessidades futuras da sociedade. Para sabermos que tipo de professor queremos, precisamos de nos referir ao tipo de aluno que esperamos. Finalmente, a definição do perfil do professor terá que ser o produto de um trabalho de consciencializaçāo da minha experiência subjectiva como professor e educador e de intuiçăo da visão da equipa governativa, a começar pela do Ministro da Educaçāo". (In O perfil do professor de acordo com a Reforma Educativa, intervençăo na Conferência organizada pelo Movimento dos Educadores Católicos, Centro Paulo VI, Fátima, 5 de Maio de 1990, documento policopiado).

(41) Referimo-nos à intervenção do secretário de estado da reforma educativa, Pedro D'Orey Cunha: O perfil do professor de acordo com a Reforma Educativa, intervençăo na Conferência organizada pelo Movimento dos Educadores Católicos, Centro Paulo VI, Fátima, 5 de Maio de 1990 (documento policopiado). Ver ainda, sobre este tema: Para uma deontologia da Carreira Docente, palestra proferida num encontro do Movimento da Escola Católica, Leiria, 17 de Fevereiro de 1990 (documento policopiado). Esta imagem do professor multifuncional fora já identificada por alguns especialistas da educação a partir dos anos 70: ver, designadamente, Maurice Debesse e Gaston Mialaret (coord.), Traité des Sciences Pédagogiques, vol. 7, 1978, pp. 26. 
exteriores ao campo pedagógico. No mesmo lance de argumentos apresenta-se um pensamento moderno centrado na variabilidade, indeterminação e efemeridade dos contextos escolares. Numa palavra, sugere-se um investimento dos professores em novos papéis sociais, decorrentes da reforma e de uma sociedade que experienciara a perda de ideais, dos símbolos e modos de vida que constituem a sua herança comum, mas que parece voltar agora a um equilíbrio. ${ }^{(42)}$

Todavia, este optimismo sobre o mundo resulta de outras reflexōes paralelas que o colocam à mercê da anomia e da perda do seu passado profundo. Como se pode confirmar na comunicação do secretário de estado à reuniăo do Comité da Educaçăo a nível ministerial da OCDE, realizada em 13 de Novembro de 1990, intitulada Educação para a busca do sentido e a educação para os valores, factores essenciais da qualidade do ensino. Nesta comunicaçăo evidencia-se o carácter dúplice da equaçăo da qualidade proposta pela equipa ministerial: por um lado, reconhece-se a multiplicidade de opções decorrente da globalização, da sociedade de informação e da sociedade de consumo; por outro lado, pretende submeter-se a interpretação da sociedade a critérios de autenticidade morais. O secretário de estado propõe a introduçăo das seguintes duas alteraçōes ao comunicado final da reunião do comité ministerial, que são bem reveladoras desta duplicidade: « 5 . a busca de um sentido para a vida e a percepção e escolha de valores são problemas que cada vez mais preocupam as pessoas e as instituições nesta década de 90 . A comunicação rápida entre países e regiões, a mobilidade das pessoas, a liberalização das ideologias e dos sistemas de pensamento não podem deixar de pôr em causa os modelos tradicionais de transmissão de valores. Assim, os sistemas educativos verăo necessariamente aumentadas as suas responsabilidades nesta área. V. Prevenir a anomia: a procura de um sentido para a vida e o desenvolvimento moral dos jovens deve ser assegurado pelos sistemas de educação de base. O analfabetismo moral é tanto ou mais pernicioso que o analfabetismo literal. Quer esta área da educaçăo seja garantida prioritariamente pelas religiões, quer por instituições para tal vocacionadas, quer pelos sistemas educativos em regime de supletividade, terá sempre que ser objecto de cuidadoso planeamento, e deverá sempre integrar-se no desenvolvimento cognitivo e científico

(42) Em introduçăo à sua intervençâo O perfil do professor de acordo com a Reforma Educativa, p.3, o secretário de estado sublinha que "felizmente vivemos numa época de síntese e equilíbrio. Tanto ao nivel nacional como ao nivel internacional resolveram-se muitas crises, esbateram-se muitas tendências exageradas, reencontraram-se grandes plataformas de consenso e integração. Depois de um século em que as várias geraçōes se habituaram a viver em crise, chegamos ao fim do milénio, com graves problemas, sim, mas com a sensaçăo de casa arrumada, de equilíbrio conceitual, de paz ideológica entre os sexos, as geraçōes, os blocos políticos». 
dos jovens». (43) Em suma, apresenta-se em filigrana um retrato de uma sociedade assente em opções que ameaçam sempre a raiz da consciência colectiva. Em intervençăo anterior, o secretário de estado propusera já a outra componente da regulação da profissão capaz de responder a esta ameaça às raízes: o código ético-deontológico. Assente na autoridade ética, que busca o exercício do poder numa verdade interna e não numa verdade externa normativa, remete a obtenção do bem colectivo comum, designadamente, aquele que diz respeito à efectiva democratizaçăo da educação, para a obrigação moral do professor. Quer dizer, as desigualdades sociais e as desigualdades escolares, cujas verdadeiras causas estão sujeitas à conflitualidade social e à controvérsia científica, passam a ser vistas à luz do imperativo moral. As reformas concebidas num plano de decisão em que os professores não participam deixam de ser uma opção política para passarem a ser uma obrigação: "as implicações deste aspecto do compromisso pedagógico são inúmeras. Ao nível sistémico e global significa que o docente, pelo simples facto de o ser, terá a obrigaçăo moral de promover pelos meios ao seu alcance as reformas estruturais que conduzam a uma generalizaçăo efectiva da educação. De onde a luta pela igualdade de oportunidades educativas para todas as minorias étnicas e sociais e para ambos os sexos; a promoção do ensino recorrente e de segunda oportunidade para todos os adultos; a extensăo a toda a comunidade do direito de participar na direcção das escolas e da política educativa; o estabelecimento dos estímulos sociais necessários e as práticas pedagógicas suficientes para eliminar o insucesso escolar e o abandono precoce da escola e para evitar a reprodução sistemática das desigualdades provenientes de expectativas educativas diferenciadas».(44).

4. ${ }^{a}$ Fase (1987-1991): O Estado (des)regulador numa escola concorrencial: o mercado educativo

As propostas de autonomia e descentralizaçăo dos investimentos em educaçăo e as novas necessidades de mobilização de recursos próprios colocou na ordem do dia a produção de uma imagem de marca das escolas. Mas este apelo do Estado ao local parece trazer novas interrogações: por um lado, porque a desregulação local põe em evidência as hierarquias entre estabelecimentos de ensino, entre escolas ricas e pobres, entre escolas para a continuação de estudos e escolas para o mercado de

(43) Educação para a busca do sentido e a educação para os valores, factores essenciais da qualidade do ensino, comunicação na reunião do Comité da Educação a nível ministerial, 13 de Novembro de 1990, documento policopiado, pp. 14-15..

(44) O perfil do professor de acordo com a Reforma Educativa, pp.10-11. 
trabalho; por outro lado, porque os fenómenos de desigualdade face à educaçăo são produzidos pela própria escola e não apenas por efeito de uma delegação social do Estado.

Na base destas propostas está uma nova engenharia social assente em três mecanismos: a subordinação ao utente, a internalização de controles e a fiscalização a posteriori. ${ }^{(45)}$ A subordinação ao utente conduz a uma primeira homologia entre a escola e os bens de consumo, trânsito facilitado pelo direito à escolha e à qualidade: «urge agora operar uma segunda reforma estrutural, já em marcha em muitos países do mundo, qualquer que seja a sua ideologia política, e que eu chamaria 'subordinação ao utente'. (...) Não se trata aqui de pôr em conflito uma classe de pessoas contra outra classe de pessoas. Todos nós somos utentes, todos nós somos compradores, mesmo quando noutras situaçōes somos também produtores e vendedores. $\mathrm{O}$ que se trata portanto é de atender à nossa condiçăo de utente, passando para esta condição o papel de controle de qualidade».(46) Na linha de outras reflexões realizadas em França, propōe-se a reduçăo da sectorização das escolas e a emulaçăo entre estabelecimentos de ensino. Num livro significativamente intitulado Les consommateurs d'ecole, Robert Ballion (1982) dá conta dos fenómenos de hierarquização dos estabelecimentos educativos provocada pela publicaçăo, no Figaro Magazine, de uma classificação dos liceus, em função das percentagens de admissões no baccalauréat. Comenta o autor que este movimento, iniciado nos anos 80 , convida os pais a comportar-se enquanto consumidores activos da escola e os directores das escolas como comerciantes de graus escolares: «tout cela est conforme à l'esprit d'une société mercantile où tout est coté, mis à prix, hiérarchisé. Dans cette perspective, les proviseurs deviennent des marchands de baccaulauréat. C'est à qui vendra le meilleur produit (la plus forte chance de succès)». Alguns anos mais tarde, procedendo à avaliação da experiência de discriminaçăo positiva das ZEP (Zones d'éducation prioritaires) e da redução da sectorizaçăo, conclui que a liberdade de escolha reforça as desigualdades (Ballion, 1991), adiantando três riscos principais da estratégia mercantil: hierarquizaçăo acentuada e auto-reproduçăo dos estabelecimentos; a procura tende a moldar a oferta das escolas; as escolas tendem a querer captar a melhor parte do mercado escolar. A introduçăo de uma possibilidade de escolha

(45) In discurso do secretário de estado da Reforma Educativa, Pedro da Cunha, no Congresso Nacional da Qualidade das indústrias de serviços e dos serviços das indústrias, sessăo de encerramento, 12 de Maio de 1989 (documento policopiado), p. 5. Na discussăo que se segue utilizamos predominantemente esta referência.

(46) Idem, Ibidem, pp. 6-7. 
institui o princípio da diferença entre estabelecimentos. Ora, como argumenta Derouet (1992: 113): «les parents raisonnent en acteurs rationnels: puisqu'il y a une possibilité de choix, c'est qu'il y a des différences entre les établissements. Ils cherchent ces différences et, en les cherchant, les créent». Embora este tipo de avaliação da experiência francesa tivesse já apreciaçōes críticas anteriores, nem por isso colocou em risco a imagem positiva do princípio de emulação entre estabelecimentos de ensino. Vindo mesmo a influenciar a comissão de professores do Collège de France, insuspeita de neoliberalismo, que elaborou em 1985 o relatório Propositions pour l'enseignement de l'avenir. Não obstante a chamada de atençăo para os excessos que pudessem pôr em risco os estabelecimentos mais desfavorecidos, reconhece-se o benefício da concorrência moderada: «l'enseignement devrait dépasser l'opposition entre le libéralisme et l'étatisme en créant les conditions d'une émulation réelle entre des institutions autonomes et diversifiées, tout en protégeant les individus et les institutions les plus défavorisés contre la ségrégation scolaire pouvant résulter d'une concurrence sauvage».

Em Portugal a opção de dar voz aos consumidores de escola passa em primeiro lugar pela participação na gestão escolar: «os serviços escolares, em Portugal como noutros países, săo prestados com grande competência nalgumas regiōes e com grande desleixo noutras. Ora, são os pais que mais directa e imediatamente captam a sofrem a diferença. Não deveriam ser eles então os utentes dos serviços, os que estariam naturalmente vocacionados para denunciarem o desleixo e estimular a excelência? Contudo, até agora, os pais não têm tido qualquer participação de poder na gestão e direcção das escolas, limitando-se a sua intervenção ou a um papel meramente consultivo, ou, no auge da frustração, a escrever cartas impotentes aos órgãos centrais e locais da administração escolar. A intenção deste Governo é que os pais obtenham um papel maior na gestão escolar, alargando assim aos utentes a capacidade de controlar o serviço. No novo projecto de Gestão Escolar, os pais têm assento próprio no órgão colegial de direcção da escola, completando assim os requisitos mínimos da tăo desejada 'gestăo democrática'».(47) Trata-se de uma nova tecnologia de gestão do sistema que opta por coordenar a partir dos resultados, reduzindo os controlos normativos do Estado. Os objectivos de controlo não são sequer escondidos: «a hipótese consiste, assim, em que quanto mais presentes estiverem os pais (controle do utente) mais ausentes poderão estar os controles externos do Ministério». (48)

(47) Idem, Ibidem, pp. 7-8.

(48) Idem, Ibidem, p. 8. 
Entretanto, os impulsos necessários ao desenvolvimento de comportamentos mercantis multiplicam-se em diversas regiões do discurso: o GEP elabora indicadores de desempenho das escolas; as escolas assumem a livre iniciativa como o princípio organizador da autonomia; disputam-se localmente os mesmos recursos escassos. Tudo isto na antecipação do fim da sectorizaçăo anunciada pelo ministro e pelo secretário de estado: «não basta que os pais estejam presentes para poderem controlar a qualidade dos serviços educativos. Devem também poder escolher, ir-se embora, recusar o produto e encontrar alternativas. É neste contexto que se situa o desenvolvimento e apoio ao ensino particular, por um lado, e o plano ainda em elaboração de possibilitar aos pais a matrícula dos filhos em escolas fora da zona da sua habitação. Quando as escolas tiverem de competir para atrair alunos, talvez que então o sentido de serviço se desenvolva e a preocupação pela qualidade se afirme ainda mais». (49)

A internalização dos controles dá prioridade à explicação endógena dos sistemas educativos. Por este meio, pretende-se que sejam os próprios actores a encontrar por si as estruturas e as regras do jogo características do contexto de acção da sua mútua dependência: «o que se pede entāo ao Estado não é tanto que julgue e penalize, mas que organize consequências de mútua dependência de tal modo que os elementos da sociedade se controlem mutuamente sem interferência externa. Assim, uma sociedade opressiva não é uma sociedade que tem controles, é uma sociedade em que os controles são externos. Inversamente, a sociedade democrática não é a sociedade sem controles, mas a sociedade de controles internos». (50) A forma de racionalidade política proposta conduz-nos a uma coordenação das acções que pressupõe a responsabilidade social mútua e as solidariedades colectivas. $E$ assim se transformam os cidadãos possuidores de direitos e deveres constitucionais em seres sociais capazes de julgamento ético. A internalização dos controles não se confina à elaboração de formas de avaliação informal mútuas e pressupõe a criação de laços de dependência e lealdade comunitários. O que nos remete para sistemas de regulação e de mobilização mistos que repousam, à vez ou concomitantemente, nos três tiposideais de coordenação da actividade humana: o mercado (a liberdade de escolha dos pais, os processos de avaliaçăo a partir dos resultados e a concorrência entre estabelecimentos); a organização (a hierarquização interna dos estabelecimentos) e a solidariedade (a comunidade escolar, o sentimento de pertença e lealdade). É este dispositivo misto que justifica a conceptualizaçăo de Boltansky e Thévenot (1991),

\footnotetext{
(49) Idem, Ibidem, p. 8.
}

(50) Idem, Ibidem, p. 9. 
no termo da qual se reconhece que na sucessāo de situaçōes de interacçăo, os indivíduos podem passar rapidamente de um regime de justificação para outro na busca de arranjos locais. ${ }^{(51)}$

A fiscalização a posteriori culmina o processo de transferência da racionalidade cívica para a racionalidade que toma como referência mais notável a actividade económica, a organização produtiva e o mercado: «ora, grande parte destes controles poderia desaparecer se, por um lado se estabelecessem códigos de qualidade para as diversas actividades e, por outro lado, se se instituíssem vistorias aleatórias de controle à posteriori. A iniciativa não seria abafada e os desvios seriam penalizados, prevenindo assim a sua ocorrência». É preciso, portanto, gerir a escola enquanto indústria de mão-de-obra ${ }^{(52)}$ que recentra os sistemas educativos «sobre as necessidades do mercado, da economia e da cultura e não sobre os interesses da burocracia». (53) É neste contexto que surgem novas medidas do desempenho educativo como as que são propostas no Observatório da Qualidade da Escola, no âmbito do Programa de Educaçăo para Todos/2000. Passa-se a utilizar insistentemente a linguagem da qualidade, da eficácia e da produtividade escolar que aparece traduzida em indicadores racionais e objectivos para todo o sistema educativo (Gomes,1999b). Esta mudança, reconhecem alguns dos especialistas envolvidos na produção das medidas avaliativas, inclui-se no movimento de privatização das escolas: "a devolução dos poderes concentrados no Estado às comunidades locais, trouxe um movimento que se tem chamado de 'privatizaçāo' das escolas, na medida em que significa a sua coresponsabilização pelo desenvolvimento educativo local, pelo seu co-financiamento, pela definição de prioridades e metas, pelo desenvolvimento de projectos especificos. A implementação de certas regras da economia de mercado e a abertura à competitividade são outras duas componentes da privatização que se tem tentado introduzir na gestão das escolas, enquanto estratégia para promover a sua eficácia».

(51) Boltansky e Thévenot (1991) distinguem a noção de arranjo local da de compromisso, considerando a última como a que é mais favorável à procura de um interesse geral. Neste sentido, a nobreza de princípios do compromisso diferencia-se do acordo entre pessoas, no qual os indivíduos transigem e fazem concessões momentâneas acerca da definiçăo do bem comum respeitante a uma situação determinada: «l'arrangement est un accord contingent aux deux parties («tu fais ça, ça m'arrange; je fais ça, ça t'arrange) rapporté à leur convenence réciproque et non en vue d'un bien général. Le lien qui rassemble alors les personnes n'est pas généralisable à tous» (p. 408). 0 compromiso, pelo contrário: «suggère l'éventualité d'um principe capable de rendre compatible des jugements s'appuyant sur des objets relevant de mondes différents. II vise un bien commun qui dépasserait les deux formes de grandeur confrontés en les comprenant toutes deux» (p. 338).

(52) Cf. OCDE, La qualité de L'enseignement, 1984, Paris: OCDE (documento policopiado).

(53) Intervenção do secretário de estado da Reforma Educativa no seminário Nova Europa e Reformas educativas, Hotel Altis, Lisboa, 17 de Janeiro de 1991 (documento policopiado). 
(Clímaco, 1990: 111). No domínio dos critérios de avaliação, a dificuldade mais notória está em medir a qualidade de produtos incomensuráveis tais como o carácter, o impacto das qualificaçōes no mercado de trabalho, as repercussões da formação no nivel cultural da sociedade e outros produtos qualitativos. Como nas empresas de configuraçăo divisionalista (Mintzberg, 1982), o principal mecanismo de coordenação proposto é a estandardização dos resultados. Obtida através da determinação quantitativa do produto a alcançar, tem dois formatos privilegiados de avaliação: um que remete para cada organizaçăo ou departamento a elaboraçăo dos critérios de produtividade e de qualidade; outro que os subordina a critérios universais e uniformes. Este último foi o caminho escolhido pelas tecnologias de avaliação, tanto no ensino secundário como na universidade. ${ }^{(54)}$ Como argumenta Lima (1992a: 74), face às dificuldades criadas pela medida quantitativa de finalidades intrinsecamente qualitativas «ou se centraliza, uniformiza e controla em termos tais que o cálculo da eficácia e o controlo da qualidade passam a ser possiveis, porque subordinados a critérios uniformes e, como tal, passiveis de comparação, ou entăo os discursos da eficácia e da qualidade assumem o carácter de retórica com propósitos de reposição da confiança no sistema e de legitimaçăo institucional. Bastará, então, falar em eficácia e em qualidade, mesmo sem a sua obtenção empírica, para alcançar aqueles propósitos». (55) Mas os limites do quantitativismo dos indicadores seleccionados não se ficam por aqui, já que o recurso à operacionalizaçăo quantitativa beneficia a avaliação dos produtos e objectivos mais facilmente quantificáveis, em detrimento daqueles que resistem a tal procedimento. Como os indicadores năo se limitam a descrever a rea-

(54) Cf. o capítulo de B. Sousa Santos (1994: 163-201) intitulado "Da ideia de Universidade à Universidade de ideias», em especial a tese segundo a qual a avaliaçăo do desempenho é concomitante da crise de hegemonia da universidade. A crise de hegemonia caracteriza-se entre outras coisas pela multiplicidade de fins a que a universidade se tem obrigado, na vã tentativa de manter a sua tradicional centralidade: "a produçāo e transmissăo de conhecimento cientifico, a produçăo de trabalhadores qualificados, a elevação do nivel cultural da sociedade, a formaçăo do carácter, a identificação de talentos, a participação na resoluçăo de problemas sociais são produtos, não só muito variados, como dificeis de definir» (pp. 187-188). Nestas condiçōes, o recurso a medidas quantitativas tende a «favorecer utilidades de curto prazo, sejam elas cursos curtos em detrimento de cursos longos, formaçōes unidireccionadas em detrimento de formações complexas, investigação competitiva em detrimento de investigaçăo pré-competitiva, reciclagem profissional em detrimento de elevação do nivel culturals (p. 189).

(55) Embora concordemos com as premissas do argumento não nos revemos na dicotomia práticas de qualidade-retórica de qualidade que lhe subjaz. Com efeito, não se trata de obter, por um qualquer meio científico autónomo, uma medida real de tal qualidade, coisa que nos parece de todo impossivel, na medida em que o próprio campo científico está sujeito às mesmas tensões do restante campo educativo (qualidade para quê e para quem?), mas de verificar em que medida as tecnologias de medida da qualidade e as racionalidades que as suportam e as criticam se articulam, de tal modo que a sua simples nomeaçăo basta para formar um novo regime de verdade sobre o sistema educativo. 
lidade e, contrariamente, introduzem os objectivos e resultados desejados do próprio sistema nas lógicas de acção dos actores situados fora do alcance da influência imediata do centro que os operacionaliza e contabiliza, apenas a relação mediata daqueles está capaz de fazer valer o seu poder. Em face do regime de verdade que a tecnologia estatística instaura, qualquer retórica destinada à sua justificação e legitimaçăo, ou a resistir-lhe, está condenada a seguir critérios de validaçăo cada vez mais auto-referenciados e, portanto, incapazes de dar conta da conflitualidade que Ihes subjaz.

O quadro seguinte faz a sintese destas fases a partir dos principais elementos do discurso educativo nos períodos referentes aos três ministros da educaçăo com mandatos mais longos. 
Quadro 6 - Principais elementos do discurso educativo nos periodos referentes aos três ministros da educaçăo com mandatos mais longos

\begin{tabular}{|c|c|c|c|}
\hline & $\begin{array}{c}\text { Sottomayor Cardia } \\
(76-78)\end{array}$ & $\begin{array}{l}\text { Vitor Crespo } \\
\qquad(80-82)\end{array}$ & $\begin{array}{l}\text { Roberto Carneiro } \\
\qquad(87-91)\end{array}$ \\
\hline FORMA & $\begin{array}{l}\text { - Entrevistas e comunicaçōes ao país } \\
\text { - Estilo exortatório e legal } \\
\text { - «Há uma luta entre os que vivem } \\
\text { para reunir e os que vivem para } \\
\text { trabalhar» }\end{array}$ & $\begin{array}{l}\text { - Intervençōes junto da administraçăo } \\
\text { - Estilo legal e administrativo } \\
\text { - «o MEU tem a caracteristica do } \\
\text { departamento de serviços. } \\
\text { Funcionar bem é considerado normal. } \\
\text { Falar pouco dele é a melhor prova } \\
\text { de que as coisas funcionam bem» }\end{array}$ & $\begin{array}{l}\text { - Intervenção centrada na opinião pública e profissional } \\
\text { - Estilo exortatório e legal } \\
\text { - «a aproximação e visibilidade administrativa junto } \\
\text { das populações no terreno é o principal problema } \\
\text { de governabilidade» }\end{array}$ \\
\hline RACIONALIDADES & $\begin{array}{l}\text { - Juridico-legal } \\
\text { Ciclo legal }\end{array}$ & $\begin{array}{l}\text { - Técnico-funcional } \\
\text { Cíclo dos Planificadores }\end{array}$ & $\begin{array}{l}\text { - Sistémica } \\
\text { Ciclo dos especialistas }\end{array}$ \\
\hline TECNOLOGIAS & $\begin{array}{l}\text { - Centenas de portarias e decretos-lei } \\
\text { - Democracia representativa versus } \\
\text { democracia participativa } \\
\text { - Selecçāo-exclusão } \\
\text { (numerus - clausus) }\end{array}$ & $\begin{array}{l}\text { - Inventário de carências } \\
\text { - Proposta de Lei de Bases } \\
\text { - Exame das politicas educativas (OCDE) }\end{array}$ & $\begin{array}{l}\text { - Comissōes e grupos de trabalho } \\
\text { - Reforma curricular } \\
\text { - Escolas profissionais } \\
\text { - Desconcentraçáo do Ministério } \\
\text { - Novo modelo de gestão das escolas } \\
\text { - Mecanismos de diálogo com a opiniāo pública }\end{array}$ \\
\hline $\begin{array}{l}\text { LUGAR. } \\
\text {-COMUM }\end{array}$ & $\begin{array}{l}\text { - Estabilização } \\
\text { - Normalização } \\
\text { - Reconstrução da vontade geral } \\
\text { do povo expressa no governo } \\
\text { - Igualdade de oportunidades }\end{array}$ & $\begin{array}{l}\text { - Coordenar } \\
\text { - Planificar } \\
\text { - Executar }\end{array}$ & $\begin{array}{l}\text { - Projecto } \\
\text { - Concentração } \\
\text { - Participação } \\
\text { - Qualidade } \\
\text { - Eficácia }\end{array}$ \\
\hline METÁFORAS & $\begin{array}{l}\text { CAOS } \\
\text { CRISE }\end{array}$ & $\begin{array}{l}\text { DESARTICULAÇÃO } \\
\text { FRAGMENTAÇÃOO }\end{array}$ & $\begin{array}{l}\text { COMUNIDADE }(87-89) \\
\text { EMPRESA }(89-91)\end{array}$ \\
\hline
\end{tabular}


(Página deixada propositadamente em branco) 


\section{CAPITULO III}

\section{O MÉTODO: DAS ESTRUTURAS AOS DISCURSOS}

1. A Arqueologia: as políticas educativas como texto

2. As posiçōes de sujeito e a selecçăo dos domínios dos discursos

3. Dispersāo, montagem e articulaçăo dos discursos

4. A constituição discursiva das estruturas: objectividade e hegemonia

5. A constituição discursiva das subjectividades

6. Formas e significados da linguagem política

7. Lugar-comum e políticas educativas

8. Metáforas e hegemonia

9. Mitos institucionais e a criação da confiança

10. Os mapas cognitivos da escola

Neste capítulo procedemos à identificação das principais referências metodológicas da pesquisa. Recorrendo aos conceitos articuladores de texto e discurso e, simultaneamente, a conceitos de médio alcance tais como o de dispersão e articulação dos discursos, tentamos responder às duas principais dificuldades criadas pelo conceito de governamentalidade: como interpretar conjuntamente práticas e discursos que se relacionam de modo não causal? Como identificar os princípios e as regras estruturantes dos discursos educativos sem regressar ao nominalismo puro? Inserindo-se num campo de teorização das formas discursivas no interior da sua materialidade própria, oposta à visão idealista de uma subjectividade pura, pretende-se enunciar algumas condições que presidem às políticas educativas a partir da noção de jogos de linguagem. Este modo de conceber a articulação e a montagem dos discursos encaminhar-nos-á para uma tese que tentaremos demonstrar: nem as estruturas sociais nem as subjectividades são absolutamente fixas ou absolutamente não fixas. 


\section{A Arqueologia: as políticas educativas como texto}

Os procedimentos convencionais de análise da escola pressupõem a condução das operações do seu estabelecimento por intermédio do silêncio esfíngico das estruturas. Ao analista está destinado o papel de desvendar a intencionalidade de um pensamento ou a causa última de uma acçăo, na medida em que estes são conduzidos fora e antes dos discursos. O contexto é habitado por relaçōes de causa, analogia ou representação, mas, em qualquer dos casos, nunca assumindo mais do que a imagem de um debrum debotado da realidade. Não é essa óptica que nos orienta. A experiência não será entendida como acção social, mais as formas de falar sobre ela, mas antes como construçăo do próprio discurso: «os discursos deverăo então ser vistos como relaçôes verificáveis com o conjunto de outras práticas» (Foucault, 1991a, p. 64). Não se trata de analisar a experiência por um lado e os discursos por outro, mas de os acoplar numa epítome feita da sua interioridade e exterioridade. Interioridade que fornece os elementos necessários ao diagnóstico da modificaçăo das regras de funcionamento do discurso e dos sistemas da sua formação e acolhimento; exterioridade que dá acesso às suas condições de existência, à sua inserção e funcionamento.

Esta formulaçăo contraria a separação entre práticas discursivas e não discursivas que alguns pressentem na teorização de Foucault (Laclau e Mouffe, 1985). Tal distinção residiria na necessidade de observar as técnicas e as instituições como objectos onde circulam discursos e de separar analiticamente o linguístico do não-linguístico. Em relação ao primeiro argumento é o próprio Foucault que assinala a falta de pertinência da dicotomia ao observar que as instituiçōes hospitalares, militares ou escolares não săo formadas a priori, independentemente das condições discursivas da sua emergência. Os complexos de saber-poder referem-se precisamente à ausência de precedência substantiva de qualquer dos termos. Esta posição năo se confunde com o idealismo filosófico que nega a existência de um mundo exterior aos sentidos.

142 Os acontecimentos existem, a realidade material também e as instituições têm uma materialidade tangível nas técnicas e tecnologias. Porém, fora das condições discursivas que lhe dão sentido estes objectos não têm visibilidade.

$O$ segundo argumento apresenta possibilidades mais interessantes para a nossa análise. A distinçăo entre acontecimentos linguísticos e não linguísticos é evidentemente verdadeira. $\mathrm{O}$ silêncio expressa o acontecimento mais visível de expressão não verbal a que se devem acrescentar os artefactos, os gestos, os afectos e alguns símbolos. $\mathrm{O}$ que se contesta é que estes eventos e objectos tenham uma existência não-discursiva. O silêncio é um dos exemplos mais típicos de regulação do próprio 
discurso por parte dos grupos dominantes. Desde logo porque faz parte integrante do processo de comunicaçăo e de gestão do significado (Bourdieu, 1982). As palavras e os conceitos mudam o seu significado e os seus efeitos à medida que são desencadeados e integrados em diferentes sequências de linguagem-silêncio. A gestão política da retórica da invisibilidade, que implica o balanço entre presença e ausência, é um caso típico de utilizaçăo discursiva do silêncio. ${ }^{(56)}$ Aproveitamos neste particular da penetrante análise de Gil (1996) sobre os efeitos da invisibilidade do discurso nas estratégias de poder. Embora a análise deste autor discorra sobre um regime autoritário e o seu chefe, algumas consideraçōes sobre a invisibilidade do discurso político apresentam um interesse mais geral na análise do poder político, especialmente nas suas articulaçōes com outras espécies de poder. Destacamos neste particular duas hipóteses de trabalho: (a) a hipótese de o discurso, qualquer discurso, seja ele o discurso político, científico, pedagógico ou terapêutico, poder conter elementos que apelam à invisibilidade do poder de quem o faz, criando uma 'imagem-nua' do movimento retórico, que o autor define do seguinte modo: «convém agora precisar a definição acima proposta da 'imagem-nua' do movimento retórico recortado no silêncio. De que se trata? De produzir inconsciente a partir da disjunção linguagem/imagem năo verbal. Se retirarmos a expressão verbal às imagens, criamos imagens-nuas. Ora, Salazar constrói imagens-nuas do sentido: amputa-se sentido verbal ao sentido (verbal), de tal modo que este se encontra afectado pela falta de algo. Isto define uma operação retórica específica que denominamos por torção da linguagem: digo o contrário daquilo que faço ao dizê-lo, o meu dizer é precisamente aquilo que não se deve fazer. Desta disjunção entre o discurso verbal e uma parte do seu sentido resulta uma imagem-nua do próprio sentido» (Gil, 1996: 39); (b) a hipótese de a invisibilidade do discurso político se tornar essencial à sua conversão em outro tipo de discurso, incluindo o moral, o científico e o pedagógico: «a invisibilidade garante a disseminação, a infiltração epidémica do princípio espiritual em todos os domínios da vida. É ela que assegura a passagem do político ao moral, do moral ao espiritual: a conversão do político (e do social, do económico, ou de qualquer outra actividade pedagógica, cientifica, artistica, etc) em moral consigna um indice de 'espiritualidade' no político que passa a acompanhá-lo como a sua sombra invisivel» (Idem, Ibidem, pp. 47-48). Quanto à primeira hipótese, a sua pertinência será verificada no modo como se articulam em cada espaço estrutural os

(56) Ver sobre esta temática o ensaio de José Gil (1996), Salazar: a retórica da invisibilidade. Lisboa: Relógio D'Água, designadamente a penetrante análise sobre os efeitos da invisibilidade nas estratégias de poder. 
discursos provenientes de princípios com origem em espaços estruturais diversos: por exemplo, como se articula o discurso comunitário proveniente do espaço estatal com os princípios de justiça cívicos típicos desse espaço. Quanto à segunda hipótese, as suas formas de articulação são menos evidentes e mais arriscadas nos seus resultados: por exemplo, como é que o poder político pode retirar todos os imperativos categóricos do seu direito positivo, abandonando todas as conotaçōes morais, sem sacrificar as condiçōes racionais de legitimidade de origem legal que incluem cada vez mais o direito moral, derivado a priori da razăo prática, e a racionalidade cognitivo-instrumental, derivado da ciência.

A distribuição do silêncio na construção da retórica política do sistema educativo português, nas duas últimas décadas, é muito sugestiva a este respeito, por que articula momentos de presença linguística fortes com silêncios também fortes e prolongados do Estado. Como veremos, os ministros da educação distribuiram silêncio ou palavras de acordo com a importância política de dar voz ou de silenciar os restantes intervenientes no processo. Contrariamente a certas análises segundo as quais, por que o silêncio é um recurso escasso, estaríamos inevitavelmente em presença de jogos de linguagem de soma nula, a análise mais detalhada revela-nos também jogos de soma positiva e jogos de soma negativa. Os ministros invisibilizaram-se quando pretenderam reduzir a presença do campo educativo na sua totalidade, deixando funcionar a regulaçăo silenciosa do sistema. A inércia discursiva deste era considerada suficiente por que permitia consensos práticos por via da redução dos momentos de conflitualidade argumentativa (e.g. Vítor Crespo e José A. Seabra). Pelo contrário, os ministros desdobraram-se na sua apariçăo pública discursiva quando pretenderam captar, mobilizar e persuadir as energias discursivas do sistema (e.g. Roberto (arneiro). A dinâmica discursiva era considerada imprescindível às alteraçōes no posicionamento relativo dos actores ou à construçăo de novos actores sociais. Noutras circunstâncias, a produçăo discursiva dos ministros (e.g. Sottomayor Cardia) correspondia à necessidade de limitar a capacidade de expansăo dos discursos periféricos pela duplicaçăo da sua presença própria. Sendo certo que a medida da visibilidade/invisibilidade do discurso educativo do Estado não se refere apenas à presença/ausência física, ou à intensidade verbal dos seus actores, mas, preferentemente, aos mecanismos de criação e apagamento de sentido por intermédio do próprio discurso. Se um discurso precisa de outro discurso para a sua compreensão, também o próprio silêncio se diz na palavra.

Năo se pode concluir, entretanto, que os elementos linguísticos e não-linguísticos se justapõem nos seus efeitos automáticos. As posiçōes diferenciais dos sujeitos no campo discursivo, incluindo a dispersão relativa dos elementos năo-linguísticos, ma- 
teriais, rituais e práticos não responde a uma necessidade funcional, mas antes à articulaçăo de elementos, ou à aparência de que o fazem, por que obtêm um certo resultado. A sua racionalidade é um efeito que pode ser reconstruido ex post facto sem qualquer equivalência num plano de constituição apriorístico.

Renuncia-se assim à procura da origem do discurso, da determinação do momento ou da razão fundadora do já-dito que reconduz, numa circularidade obsessiva, a um ponto infinitamente recuado no tempo, mas usualmente presente nos seus efeitos institucionais actuais. As três teorias básicas sobre a origem da escola de massas, que têm proporcionado modelos técnico-funcionais, de conflito de classes e de institucionalização mundial da educação orientam a análise para a visão prévia de uma continuidade apenas justificável pelo jogo da sua permanente ausência-presença. Ausência por que as três teorias postulam a impossibilidade de, na ordem do discurso sincrónico, captar a irrupçāo de acontecimentos verdadeiros: há sempre uma origem secreta que é preciso desvelar. Presença por que as estruturas discursivas assim reveladas se tendem a reproduzir isomorficamente, e institucionalmente, no decorrer do tempo: há sempre uma causa ou causas primeiras, sejam elas a evolução tecnológica, as classes, o Estado ou o sistema mundial que são a origem de todas as coisas.

Uma vez feita a economia das continuidades é preciso reconstituir cada momento do discurso na sua irrupção prática, na dispersão dos efeitos, que permite a sua apropriação, reactivação, conservação, esquecimento ou transformação na relaçăo com outros discursos. A descrição exaustiva e o isolamento dos eventos discursivos não determina a soberania de um qualquer enunciado, mas, contrariamente, permite a sua inserção em acontecimentos que são do universo político, técnico, económico ou cultural. A arqueologia da escola não implica o recorte vertical da sua história em direcção à génese da sua arché, aceitando, consequentemente, recortes provisórios, sincrónicos, onde o investigador pressente que os acontecimentos discursivos parecem estar mais relacionados. O corte horizontal assim consumado irradia em direcção a diferentes constelações de práticas e discursos colocados em domínios aparentemente dissemelhantes.

Como argumenta Deleuze (1998), o método arqueológico contraria as duas principais técnicas usadas pelos arquivistas: a formalização e a interpretação. Para Foucault o método arqueológico pressupõe a positividade do enunciado. A Arqueologia não pretende descobrir a verdade por baixo da aparência, o escuro por trás da luz, o quadro-inscrição por trás do quadro-expressão: «para que a linguagem possa ser tomada como objecto, decomposta em níveis distintos, descrita e analisada, é preciso que exista um dado enunciativo, o qual será sempre determinado e não-infinito; a aná- 
lise de uma lingua efectua-se sempre a partir de um corpus de palavras e de textos; a interpretação e a apresentação de significações implicitas assentam sempre num grupo delimitado de frases; a análise lógica de um sistema implica na reescrita, numa linguagem formal, um conjunto dado de proposiçōes» (Foucault, 1969, in Deleuze, 1998: 36-37). Os enunciados que Foucault toma em consideraçăo na Archéologie du savoir são formações que se destacam do seu corpus quando os sujeitos da frase, os autores, se anulam e se dissolvem numa família impessoal, com um sentido do fala-se que Deleuze Ihe confere. No modo como cada enunciado se distribui e se dispersa numa regra, confirmando-a ou resistindo-lhe, é que reside uma espécie de rumor anónimo do discurso, e não nas palavras, frases ou proposiçōes recortadas a partir de critérios de autoria. Não por acaso, o corpus de enunciados que seleccionamos não são textos canónicos, nem textos de grandes autores de referência, que aliás năo existiriam em Portugal para este período, mas enunciados produzidos nas microtecnologias do poder: categorias estatísticas, documentos de inventário, matrizes de planeamento, relatórios de avaliaçăo. Mas também nas sedes difusas de resistência que rumorejam em torno de certas problemáticas. Por exemplo, o rumor das ciências da educaçăo em torno do conceito de autonomia relativa dos sistemas periféricos implicou um certo grau de formalização das suas reflexōes em propostas. A sistematizaçăo e formalizaçăo científica integrou-se assim numa formaçăo múltipla de saber. Porém, as ciências da educaçãa não absorveram a formação discursiva na qual o enunciado da autonomia se constituiu: o estatuto científico năo suprime as decisões políticas, os textos jurídicos e normativos, nem o senso comum sobre a autonomia. A multiplicidade dos discursos coloca no mesmo plano de análise uma proposta científica e um enunciado quotidiano, embora tais regiões não se equivalham. Como admite Foucault (1969, in Deleuze, 1998: 40): «a prática discursiva não coincide com a elaboração científica à qual pode dar lugar; e o saber que ela forma não é nem o esboço grosseiro nem o sub-produto quotidiano de uma ciência constituída».

Parece claro que Foucault não estabelece qualquer equivalência entre prática discursiva e textos eminentes, ao contrário de Vattimo (1983) que, na interpretação que faz da obra de Gadamer, considera que a língua, identificada com o ser, está marcada por obras características que cristalizam em formas de significaçăo exemplar. E esta é uma das fontes da técnica de interpretação: porque a subjectividade monumental das obras eminentes é irrepetível, a interpretação introduz uma dupla inscrição que preenche lacunas e clarifica significados. $O$ método arqueológico é muito mais contido e condensado, compreendendo na sua unidade de análise as funções de sujeito, as funções de objecto e as funções de conceito. Cada uma destas funçōes determina uma fatia de espaço discursivo: o espaço colateral derivado dos enuncia- 
dos provenientes da mesma família; o espaço correlativo derivado das posiçōes do sujeito; o espaço complementar derivado do meio institucional em que se formam. Começamos pelo espaço correlativo derivado das posiçōes de sujeito.

\section{As posições de sujeito e a selecção dos domínios dos discursos}

A capacidade de produzir discursos não é nivelada. Está na dependência de múltiplos factores tais sejam a posição nas hierarquias sociais, sejam elas disciplinares, profissionais ou administrativas, o acesso assimétrico a recursos e a informação e, em geral, à acumulação de créditos que, associados à autoridade de um determinado discurso, o transforma em poder social. Sendo desigualmente distribuída a capacidade de discurso é também o discurso da capacidade e do poder.

No espaço social de construçăo de um novo discurso legitimador sobre a educação disputaram-se, no período que analisamos, regiōes discursivas que marcaram relaçōes de poder. Caracterizaremos e analisaremos quatro regiōes discursivas:

Uma região continente definida pelos discursos do aparelho político e da tecno-estrutura do Ministério da Educação, onde se incluem os decisores políticos e os especialistas que constituem e divulgam um saber de tipo político, jurídico e técnico.

Duas regiões insulares: uma, definida pelos discursos dos actores sociais com representação orgânica e estatuto de parceiros sociais - partidos, sindicatos, confederação de pais e outras associaçōes - que se exprimem de forma programática, normativa e avaliativa sobre o sistema educativo; outra, definida pelo campo científico, que tende a coincidir com o sistema de formação e investigação universitário onde se incluem os produtores e divulgadores do saber na área das ciências da educação e da psicologia.

Uma regiāo local constituída pelos discursos dos professores e actores locais da educação - autarquias, associaçōes familiares e culturais locais, etc. - que materializam e executam as consequências provenientes dos discursos de outras regiōes, confrontando-as e reinterpretando-as à luz dos diferentes códigos de prática.

A utilizaçăo da metáfora geográfica continente-insular-local pretende valorizar a noção de território social que as diferentes regiōes discursivas ambicionam ocupar e os auditórios a que se destinam. ${ }^{(57)}$ A regiăo continente apresenta-se numa forma

(57) Discutiremos mais tarde, neste mesmo capítulo, a problemática das audiências e da cartografia dos discursos. 
totalizante que ocupa todo o espaço nacional e se dirige a um auditório universal; as regiōes insulares apresentam-se em formas diversificadas que vão das totalizantes às corporativas e se dirigem a auditórios particulares ou especializados; a região local apresenta-se numa forma localizada, ocupa um espaço territorial específico e dirige-se a auditórios particulares. A multiplicidade de discursos que estas regiōes supōem especificam lugares topológicos e não tipos de discursos.

As profissões que exercem a sua actividade na educação podem ser distinguidas por meio da estrutura do campo discursivo. Considera-se assim que a organização interna das profissões pode ser diagnosticada pela relação que diferentes tipos de especialistas estabelecem com a produçăo do discurso. Na região insular científica observa-se a lógica de acumulação de capita/ simbólico: o que está em causa é a produçăo de um conhecimento verdadeiro sobre um segmento de realidade social a que a profissão se dedica. É o discurso científico propriamente dito que autoriza a falar. Para a administração, e aqui restringimos a administração aos especialistas que têm um papel central ou local de administração das profissões relacionadas com a educação, os limites da verdade do discurso săo estabelecidos pelo código de gestăo de pessoas e de recursos. Acumulam capital de distribuição por intermédio da alocação de recursos, de pessoas ou de conhecimentos. A relaçăo que mantêm com este não depende da notoriedade, originalidade ou validade, mas de critérios de produtividade, eficiência e exequibilidade. Estes especialistas entram numa espécie de dupla aliança que os deve ligar às autoridades políticas por via do vocabulário gerencial e aos especialistas práticos que previamente depositaram o seu próprio código de verdade baseado na relação directa com o público escolar.

Para os especialistas colocados na região local do discurso regista-se a lógica da consciência prática de quem está confrontado com a pluralidade de discursos produzidos noutras regiões e na região nativa e, portanto, compelido à negociação entre diferentes doxa. A actividade reflexiva própria que mantêm elabora um capital prático: o que está em causa é a resolução pragmática de problemas a que a profissão se dedica. São a exequibilidade, a economia de meios e o teste da eficácia prática, intersubjectivamente construído, que autoriza a falar. Este capital pode evoluir para capital de distribuição por intermédio de uma especialização em domínios de acção prática como a gestão, a formação e outros.

As regiōes do discurso não definem pontos fixos num espaço estrutural; tão-pouco estabelecem o espaço em que a materialidade do discurso pode ser unificada na consciência de um sujeito ou grupo específico; contrariamente, registam um mapa inicial das possibilidades das posições dos sujeitos concretos surgirem dispersas numa formação discursiva. A dispersão é, simultaneamente, deslocaçăo entre regiôes porquanto 
estas năo definem identidades sociais rigidamente protegidas da discursividade exterior. É precisamente nos interstícios destas regiöes que se situa a articulaçăo entre discursos. No limite, podemos encontrar os discursos profissionais no vocabulário do ministro e surpreender o discurso do ministro no idioma dos especialistas práticos. A armadilha, metodológica que tais deslocamentos coloca provém da hipótese de os tomarmos como puros fenómenos linguísticos ou retóricos. Para superar esta armadilha, a análise do discurso deve sofrer uma expansăo semelhante à proposta por Ricoeur (1975) para o caso da metáfora: a frase e não a palavra deve ser a primeira unidade de significaçăo. Neste entendimento, a metáfora resulta do reflexo na palavra de uma produção de sentido que ocorre num enunciado mais vasto. Dito de outro modo: os textos das políticas educativas são multidiscursivos porque provêm de diferentes campos de conhecimento e dão origem a interpretaçōes múltiplas. Envolvem escritores e leitores, legisladores e intérpretes, falantes e ouvintes, ditos e não ditos e, por conseguinte, indivíduos com intençōes diversas que só podem ser cobertas pelo recurso a outros textos. O recurso a textos para traduzir outros textos dá conta da intertextualidade. O tratamento puramente retórico do discurso levar-nos-ia a percebê-lo como um tropo e, consequentemente, à tentação de medir a distância do significado actual ao significado original da palavra. Ora não é o código que aqui está em causa; são os acontecimentos e as condições singulares da sua existência. O discurso é o resultado da tensăo entre espaço de produçăo e produção do discurso.

Enquanto objecto de análise sócio-histórico o discurso político pode ser diferenciado em três dimensões que se relacionam no seu escopo comum: as linguagens; os actos de fala e a experiência (Pocock, 1985). Dimensōes que têm na orientaçăo semiológica da linguística um aparato metodológico imprescindível, tomam do conceito de performance linguística de Foucault uma referência teórica incontornável. Para este autor, a performance linguística são arquivos arqueológicos que recuperam permanentemente o significado de acontecimentos discretos.

A dimensão que mais captou a atenção de Foucault pode ser caracterizada a partir da estrutura conceptual e metafórica da linguagem. Formada esta por um conjunto relativamente estável de retóricas e de usos convencionais, agrega as regras que definem os limites em que é possível pensar a realidade. A linguagem define assim um universo comunicacional que delimita aquilo que conta no espaço público da discussão política. Neste espaço circulam muitos discursos que coexistem e se articulam em textos que revelam e modelam diferentes contextos. Para que uma análise geral do discurso político seja possível torna-se imprescindivel reconstruir o significado das palavras, demonstrar a força paradigmática das convençōes retóricas e o seu poder 
estruturante e, então, transformar as suas configuraçōes implícitas em modelos hipotéticos explícitos que permitam a identificação de um discurso particular em outros textos e contextos. Este conjunto de operações não são da ordem da construção linguística ou da dedução formal, mas antes delimitam as correlações com outros enunciados, estabelecem os limites de exclusăo de enunciados concorrentes, fixam a singularidade social da sua existência. É nesta dimensão que os conceitos de montagem e articulação se mostram operatórios. A montagem designa linhas de variação contínua que não podem ser homogeneizados num processo linear de transformação. O princípio geral da montagem é-nos fornecido pela relação entre forma e forças proposto por Deleuze (1988): a forma obtida passa a ser uma componente das relações entre forças, o que nos permite fugir à substancializaçăo das entidades. As entidades, tais sejam os objectos de conhecimento, as organizaçōes, as tecnologias ou as subjectividades passam a ser vistas na sua multiplicidade.

A segunda dimensão do discurso inclui os actos linguisticos específicos que modificam ou transformam o quadro previamente definido da linguagem. $O$ discurso pressupōe um contexto comunicacional formado por uma comunidade argumentativa de indivíduos livres onde o poder se realiza na acção sobre a acção dos outros, na remanência de discursos em outros discursos, ampliando assim o conjunto de possibilidades práticas e éticas inscritas nas capacidades dos indivíduos. O discurso é elaborado neste processo de constante interacção entre linguagem e fala, regras e desvios, implicações e exclusões. Foucault designa por desvio enunciativo a medida da impossibilidade dos enunciados se integrarem em cadeias sintácticas únicas, de tal sorte que, no caso do discurso político, embora central na nossa análise, essa posição não é transponível para qualquer papel constituinte ou normativo dos discursos sobre a escola quando comparado com outros. É nesta dimensão que o conceito de dispersão discursiva tem operacionalidade.

A terceira dimensão apoia-se na relaçăo entre linguagem e experiência na dupla irredutibilidade de uma na outra. Por um lado, se o conhecimento da experiência é transformado em experiência com significado por intermédio do discurso, aquela nunca é apenas experiência-em-si, sendo acessivel por intermédio da mediação deste. Semelhantemente, se a prática do discurso não é um mero inventário de significados fixos, autorizando as transformações individuais e sociais com origem nos actos de fala performativos, vinculados à experiência, aquele nunca é simplesmente discurso-já-feito, sendo captável nesta. O que permite individualizar os discursos na imbricação discursos-experiências é o campo de possibilidades estratégicas que abrem: o mesmo discurso pode dar lugar a várias opçōes teóricas ou práticas, bem como a mesma experiência, o mesmo acontecimento, ou o mesmo objecto podem aparecer 
em conjuntos discursivos distintos. Se, por exemplo, a retórica política sobre a democratização do ensino faz parte dos discursos de meritocráticos, modernizadores e críticos não é porque representem os mesmos interesses ou porque estes correspondam a uma mesma economia do discurso ou, ainda, porque se verifique uma recuperação retórica de oportunidade argumentativa. Estas duas opções têm origem no mesmo campo estratégico correspondente à regra, à episteme, de constituição e distribuição de todas as opçôes possíveis. A esta tentativa de dominar o campo do discurso e de assim tentar fixar um sentido, anulando, submetendo ou apoucando outros chamamos a regionalização do discurso. Estas regiôes tentam estabelecer centros que detenham parcialmente o transbordamento de sentidos. Alguns tendem a ver nisto o efeito civilizacional, moral ou de paradigma que se impõe a uma determinada época histórica como forma inteligivel e legítima de codificar a linguagem e as práticas sociais. Contrariamente, preferimos um questionamento mais modesto e directo, mas, simultaneamente, mais descritivo: quais as condições de existência de certos discursos? Qual a sua relação com outros acontecimentos simultâneos ou prévios? Qual é o domínio constituído desse discurso? Quais são os limites e as formas dos regimes de verdade? Que saberes são elaborados e para o uso de que indivíduos, grupos ou instituiçōes? Que relações institucionais são estabelecidas para conectar os discursos aos seus destinatários?

Não há domínios da experiência que se dêem espontaneamente à actividade de formalização e idealização da linguagem política. Não havendo mundo fora da linguagem, esta não se resume a um poder de nomeação, que permitiria a supressão das coisas por força do nominalismo. Contrariamente, a abundância de perspectivas impede qualquer tentativa de conceber o mundo nos termos de um único horizonte. Pressente-se frequentemente a ilusăo de que os discursos educativos - o científico incluido - ancoram nos próprios processos de escolarização; de que a elaboraçăo científica é uma forma sofisticada de segmentar a experiência e depois agregar o que nos é dado observar na experiência social da escola. Deste modo, o referente aprisionaria as regras de formação do próprio objecto científico ou político. Para que o discurso se liberte da experiência imagina-se então uma ruptura epistemológica com a opinião de senso comum. Sujeita-se assim o discurso científico a uma razăo que funda e reproduz as suas hipóteses, asserções e métodos e passa a controlar a sua própria identidade. A nossa hipótese de trabalho é mais modesta e considera que entre o conhecimento, que ordena o empírico numa reversibilidade infinita e a experiência, há o saber: o espaço onde se podem separar e situar a ciência, o conhecimento político e a experiência. Neste sentido, o saber é simultaneamente objecto e instrumento de pesquisa. 


\section{Dispersão, montagem e articulação dos discursos}

Na introdução aos Grundrisse de 1857 Marx argumenta que nem a produção em geral nem a produçăo geral existiam. Apenas se conhecia a produção específica e a totalidade da produção. Do mesmo modo podemos argumentar que năo existe discurso em geral nem discurso geral; o que se dá ao conhecimento são discursos particulares ou a totalidade do discurso. Faz sentido tentar elaborar um conceito abstracto de discurso, mas no universo da análise apenas existem elementos finitos de discurso. Chamamos articulação às práticas que estabelecem a relação entre estes elementos. À totalidade resultante chamamos montagem do discurso. A metáfora da montagem é-nos sugerida pela actividade de bricolage. Năo se trata, porém, neste caso, da montagem de um conjunto de apetrechos com um plano previamente definido, mas de uma actividade que, embora se realize num contexto restritivo conhecem-se à partida o elenco de peças e de instrumentos que se podem utilizar não se pode antecipar o resultado final. Cada bricoleur pode fazer montagens diferentes com os mesmos recursos iniciais.

O processo de articulação que organiza as relaçōes sociais determina formações discursivas que não são entidades unificadas. Estabelecem uma relaçăo năo necessária entre discursos heterogéneos. A nossa proposta de trabalho consiste em explorar os padrões de governo da educação enquanto amálgama de relaçōes não causais. Foucault (1969) definia a totalidade que as correlaciona como a regularidade da descontinuidade. A contradição dos termos significa que o conjunto resultante não é a expressão de qualquer princípio estruturante exterior à própria formação discursiva; designa apenas o conjunto de posiçōes e de funçōes diferenciais dos sujeitos. Assim sendo, o discurso tem um espaço social e um lugar de onde é feito; não é pura expressão mental do pensamento. $\mathrm{O}$ que estabelece a posição e a função dos sujeitos e as possibilidades do seu deslocamento de uma posiçāo para outra posiçāo sāo, entre outros elementos, aqueles que definem os limites e as formas de apropriaçăo dos discursos típicos de cada região discursiva. Estas regiões limitam o acesso a tipos específicos de discurso; pontuam a luta entre comunidades, grupos ou corporações pelo seu controlo; marcam a relaçāo deste com as audiências electivas e epitomizam as suas condiçōes de existência.

A teorização dos actos de fala no interior da sua materialidade própria, oposta à visão idealista de espaço onde irrompe a subjectividade, teve vários momentos de desenvolvimento de que apenas referimos alguns temas e autores mais marcantes. Com Wittgenstein $(1958,1987)$ as palavras constituem um todo formado pela linguagem e as actividades com as quais ela está entrelaçada, o que faz do conhecimento 
um jogo de linguagem com as suas regras a serem adquiridas por intermédio do uso. Nada que seja exterior ao jogo o pode legitimar, o que impossibilita a procura dos fundamentos últimos do que ocorre. O que a concepção dos jogos de linguagem torna necessário é a superação da tradicional hierarquia entre representação e experiência, discurso e prática, através da construção de conceitos que nos permitam compreender as conexões inesperadas das práticas actuais do discurso num contexto quotidiano. Wittgenstein vai mais longe ao considerar que tais conceitos não devem ser concebidos como actividade fundadora, recusando toda a pretensão científica de a filosofia determinar os usos da linguagem. Como método de compreensão propõe o autor que desenvolvamos conceitos fictícios, que procuremos a expansão das metáforas e conexões inesperadas para observarmos os problemas a uma luz nova. O que assim é recusado é a apresentação de razões que pretendam o estatuto da objectividade e causalidade. Os jogos de linguagem não têm essência; apenas existência. Não se articulam por causa de nem com a finalidade de mas porque são os recursos escassos que naquele momento estão à disposição dos jogadores.

Este modo de conceber a articulação e a montagem dos discursos encaminha-nos para uma conclusão clara: nem as estruturas sociais nem as subjectividades são absolutamente fixas ou absolutamente não fixas. Analisemos a primeira parte da afirmação. A impossibilidade de captar o significado último das coisas não inviabiliza, no entanto, os esforços de fixação parcial por via da hegemonização de um certo campo discursivo. Tal hegemonia implica a construção de um significado objectivo que se cristaliza em estruturas com toda a aparência de serem o que são. Este horizonte totalizante é possível quando os limites definidos pela dispersão dos discursos se torna fronteira, numa lógica de equivalência e hierarquia que divide e separa o que Ihe está a montante do que está a jusante; o que está dentro de si do que está fora de si; o que é maior do que é mais pequeno; o que é incluído do que é excluído.

Se, entretanto, todas as características diferenciais de um objecto se tornam equivalentes, torna-se improvável expressar positivamente alguma coisa sobre ele; apenas o exercício de equivalência parcial está em condições de expressar aquilo que o objecto não é. Ilustremos com um exemplo. Numa escola, a existência de diferenças étnicas e culturais é diariamente sublinhada por uma grande variedade de sinais. Diferentes modos de falar, diversidade no vestir, diferenciação nos resultados escolares, habitus culturais assimétricos, estereótipos étnicos, cor da pele. Desde que cada uma destas características seja equivalente às outras no que respeita à sua comum diferenciação dos imigrantes, perderá a sua condição de diferenciação global, adquirindo a condição de simples elemento diferenciador. Deste modo, o jogo da equivalência 
subverte o carácter diferenciado dos termos, anulando-se mutuamente por que expressa algo de idêntico que a todos une. A denegação da discriminação racial nas escolas assenta em grande medida nesta equivalência total. O resultado é uma identidade negativa da cultura dominante, discursivamente caracterizada como não-étnica ou não-imigrante.

Saussure $(1916,1983)$ analisa a linguagem nos termos de um sistema de diferenças sem positividade. O significado é segundo ele puramente relacional, sendo determinado por um valor que o coloca em oposição a todos os outros. Ainda que não nos identifiquemos com o estruturalismo de Sausurre, no que há nele de sistema fechado capaz de fixar o significado de qualquer elemento pelo seu valor, retemos a crítica à ideia de nomenclatura enquanto unidades de linguagem que se referem a um objecto. A representação de um espaço relacional do discurso é basilar na compreensão do conceito de articulação. Esta distingue-se da simples contiguidade espacial ou temporal pelo facto de dispor de um princípio que determina as relações de equivalência. A questão que subjaz a toda a problemática do discurso enquanto relaçăo é a da presença relativa do único e do reiterável nos seus enunciados. Deve-se a Bakhtin (58) a teorização do princípio da reiterabilidade, segundo o qual é impossível estabelecer equivalências absolutas entre textos. Com efeito, Bakhtin parte de uma concepção da língua como um todo, composto de unidades que embora reiteráveis originam enunciados sempre únicos. Deste modo, nega a possibilidade de estabelecer equivalências absolutas entre textos, moderando, no entanto, este argumento, com a hipótese de nenhum discurso constituir a expressăo original do querer dizer de um sujeito, por que este é precedido pelos discursos vindos do exterior. O que resulta, como argumenta Kristeva (1970: 5-21), na cisão entre o sujeito abstracto, senhor do seu discurso, e o outro, resultante da antecipação da resposta integrada nos diversos ambientes e práticas institucionais.

O reverso da fixação parcial do discurso em formas hegemónicas são as derivas sofridas por uma formaçăo discursiva. Tais derivas têm sido associadas, com alguma frequência, às estruturas dissipativas de Prigogine (1986). Seguindo a proposta deste autor, nos sistemas ainda afastados do equilibrio não se aplica necessariamente o segundo princípio da termodinâmica segundo o qual a entropia é uma orientação geral de todo o sistema. Nos termos deste princípio os sistemas tendem a conservar energia, transformando-a num estado de equilíbrio que os orienta para uma evolu-

(58) Ver sobre este tema o livro de Robert Young (1997), Torn halves. Political conflict in literary and cultural theory. Manchester e New York: Manchester University Press. 
ção finalizada. O paradoxo apresentado por Prigogine consiste em reconhecer que os sistemas sujeitos a instabilidade formam novas estruturas e uma nova ordem enquanto se dá a dissipação de energia. Longe do equilíbrio, podem originar-se novos estados dinâmicos do sistema na dependência da interacção com os sistemas envolventes. Esta nova imagem do mundo físico teve profundas consequências no modo de encarar o mundo social, em especial na forma como é analisada a comunicação entre vários pontos do sistema social no intuito de obter a sua complexidade máxima. Aceitando a sugestão do próprio Prigogine que em $A$ Nova Aliança postula ser a velocidade de comunicaçăo que determina a capacidade de os sistemas sociais escaparem ao caos permanente, absorvendo-o em novas estruturas, vários autores desenvolveram as condiçôes de instabilidade que proporcionam a inovação ou a recriação. Segundo Calabrese (1988: 164), uma das principais condições de instabilidade introduzida pela comunicaçăo na cultura de massa, consiste na elevada produção de paródia dos géneros e discursos culturais. Entende o autor que a paródia é um estádio final da degeneração dos géneros ou então consiste na introdução deliberada de turbulências que provocam genuínas flutuações discursivas. $O$ desenvolvimento destas flutuaçōes pode conduzir ao aparecimento de géneros novos. Um exemplo do campo educativo que poderíamos integrar neste tipo de flutuação é o que consiste nas sucessivas transformaçōes (paródias) que a chamada componente curricular local sofreu durante a reforma curricular: do projecto inicial que previa a participação das escolas na elaboração de $30 \%$ do desenho curricular, passou-se à área-escola com uma carga horária própria e, finalmente, à área-escola sem um crédito horário especificamente destinado, distribuído que foi pelas restantes disciplinas do plano de estudos. Assim, de uma perspectiva inicial de desenvolvimento curricular partilhado, que pressupunha a articulação dos curricula nacionais e locais, passou-se ao máximo controlo interno do currículo, mantendo embora a mesma superfície retórica de tipo participativo.

A flutuação pode ser também provocada por leituras anómalas. Dentre as interpretações mais interessantes para a compreensão da instabilidade das formações discursivas, em virtude das leituras não autorizadas, está a de Umberto Eco (1979) sobre as leituras aberrantes. Eco conduz-nos à compreensão do consumo produtivo dos textos que ocorre sempre que se instala um conflito entre o texto lido e as atitudes do leitor. Quer isto dizer que, quando nos confrontamos com um qualquer discurso, não nos limitamos a um consumo passivo, introduzindo-lhe leituras divergentes e mesmo leituras anómalas que aquele não autoriza ou não sugere. Propõe então Calabrese (1988: 166) que é a conflitualidade introduzida pelo leitor que torna instável o discurso, concluindo que «se, em seguida, alguma leitura anómala dá 
lugar a perceptos estáveis e comummente aceites, estaremos em presença de uma nova ordem cultural. E, paradoxalmente, acontecerá que as novas obras individuais que se teriam podido atribuir à ordem precedente serăo antes produzidas sob o signo da nova».

Estamos assim colocados diante das descontinuidades no interior de uma dada formação cultural ou discursiva. Descontinuidades que implicam uma análise das transformaçōes nas suas respectivas especificidades. Para a análise das descontinuidades no campo educativo, aceitamos como método de trabalho a sugestão de Foucault (1991: 56) quanto às hipóteses de transformação dos discursos (limitamo-nos por agora a ilustrar cada uma das transformaçōes com um exemplo que será aprofundado em outros capitulos):

Mudanças por dedução ou implicação: as noçōes de flexibilidade e de adaptação inicialmente reintroduzidas no âmbito das construçōes escolares implicam a sua utilização no planeamento educativo e a reutilizaçăo pela pedagogia.

Mudanças por generalização: extensão do conceito de ensino unificado ao conjunto do ensino secundário.

Mudanças por limitação: o conceito de currículo local é especificado pela noção de área-escola.

Mudanças por passagem para o outro termo de um par de alternativas: o ciclo da quantidade, caracterizado pela expansăo demográfica do ensino secundário, dá lugar ao ciclo da qualidade, caracterizado pela procura da eficácia.

Mudanças por inclusão ou exclusão: a noção de comunidade escolar ora é usada para ampliar o campo de influência da escola, estendendo-o aos contextos doméstico, da produção e das organizações locais, ora é utilizada para limitar e excluir todos os que não trabalham directamente nela.

\section{A constituição discursiva das estruturas: objectividade e hegemonia}

Formulemos de outro modo o argumento da última secção. Certos discursos e práticas institucionais asseguram as condiçōes de existência objectiva de entidades abstractas pertencentes a outras ordens do discurso. É o caso da entidade abstracta comunidade utilizada no contexto institucional escolar. Se esta formulação é usada para designar as relaçōes existentes no conjunto das escolas é evidente que tal noção é usada como um substantivo, um nome que tenta captar todos os referentes que são objectos constituídos diferentemente por outras práticas e discursos. O con- 
junto das escolas não são simplesmente comunidades ou não-comunidades escolares mas o espaço de multiplicação de outras metáforas e práticas sobre a percepção global da escola. Consequentemente, qualquer exterioridade, seja a das relaçōes comunitárias, das relações laborais ou das relaçōes burocráticas se pode substituir às condições de existência reais. Noutros termos, o significado não esgota a possibilidade de variação potencial e real do significante, embora em certos momentos uma determinada formação discursiva possa colonizar outras.

O conceito gramsciano de hegemonia permite-nos compreender os processos de deslocamento dos actores que desse modo acrescentam ou subtraem significado às formas discursivas originais. Trata-se de uma relação tipicamente metonímica que podemos verificar no exemplo do discurso comunitário com origem na administração. Este vai para além das práticas tradicionais que lhe estão atribuídas. Ao fazê-lo, a administração tenta encontrar um esquema de intervenção com base em diagnósticos e problematizações de proveniência múltipla, não-políticas na sua maioria, embora secantes na identificaçăo que fazem do isolamento do meio como principal patologia da escola. Discursos científicos reconhecem a reduzida autonomia da escola como um problema; o associativismo das famílias protesta uma maior intervençāo no interior da escola; empresários assinalam o afastamento dos conteúdos escolares das necessidades do mercado de trabalho; economistas acentuam o desfasamento entre procura e oferta de qualificações; psicólogos e psiquiatras reconhecem no fechamento da escola a origem de algumas patologias individuais e familiares. Este conjunto disperso de problematizações foi construído a partir de diferentes regiōes, com vários idiomas, associado a práticas díspares e por intermédio de especialistas năo articulados, ou debilmente articulados, no plano orgânico.

A complexidade empírica deste processo é analisada em outro lugar; o que destacamos neste ponto são as derivas de significado e a hegemonização do discurso num contexto original em que se defrontavam diferentes ópticas. Um dos discursos presentes propunha soluções próximas do princípio da comunidade através da informalização e horizontalidade das relações dentro da escola. Deste modo se devia concretizar o princípio da correspondência de poder: o poder outorgado a alguém deve ser correspondido por uma distribuição de nível semelhante aos restantes parceiros da relação. Não obstante, a articulação de discursos fez outro caminho tornando pensável e factível a mercadorização limitada da escola por intermédio da metáfora da comunidade escolar. Esta desdobrou-se em três planos de intervenção: introdução da linguagem da escolha dos clientes e da autonomia das escolas; prescrição das noções de autoridade, responsabilidade e racionalidade na gestão escolar; diminuição das prerrogativas dos professores. Cada um destes planos de intervenção 
conseguiu, como veremos, operacionalizações de escala muito diferente. Produz-se assim uma deriva de significaçăo por excesso e por defeito. Por excesso, porque a metáfora passou a integrar idiomas do discurso cívico e de mercado: mecanismos de democracia representativa; formas de gestão empresarial e processos de escolha dos clientes. Por defeito, porque a primeira operação criou um princípio de equivalência entre as diversas formas possíveis do princípio da comunidade se materializar, excluindo ou menorizando aquelas que expressavam a sua energia emancipadora.

A relação entre os discursos cívico, comunitário e de mercado é complexa. A igualdade inscrita na lógica do discurso cívico toma as escolas como colecçōes de indivíduos com direitos e deveres abstractos iguais, onde a vontade geral se concretiza no interior de uma administração burocrática supra-ordenada. A igualdade formal colide assim com a reivindicação do discurso comunitário assente em práticas de democracia participativa, auto-reflexividade, argumentação divergente e correspondência horizontal de poder. Esta tensão entre uma subjectividade individual, regulada pelos pares e uma subjectividade controlada e objectivada pelo Estado, é dissipada pela introdução do discurso mercantil da livre escolha que assim absorve as ideias de descentralização e autonomia no ideário privatista e consumista da escola. A nova configuração discursiva resultante marca uma renovada hierarquia entre Estado, mercado e comunidade sem que se tenha decidido, ao menos provisoriamente, para o lado da regulação mercantil. A desregulação regulada pela intervenção estatal não permitiu a libertação de energias suficientes nem do pólo da comunidade nem do mercado. De tal modo que mesmo o discurso mercantil se viu colonizado e reduzido às formas gerenciais de administraçăo escolar. A relação de equivalência permite deste modo subtrair a especificidade das posições iniciais. Consequentemente, a relação de equivalência tende a absorver a positividade das relações entre posições diferentes elidindo ou deslocando o significado de uma ou várias delas. A hegemonia define o momento em que na articulação realizada num campo discursivo, discursos contraditórios ou contrastantes são hierarquizados e rearticulados para produzirem uma 158 narrativa única representativa do todo.

Se neste processo de rearticulação e de colonização nunca se chegar a uma equivalência total, isto é, à redução do campo a dois campos antagónicos, então é bem possivel que a hegemonia de um momento se torne na institucionalização da hegemonia e no reconhecimento pelo campo discursivo da existência objectiva e autónoma do objecto arbitrariamente construído. Conclui-se, consequentemente, que a hegemonia não anula os discursos que têm uma existência exterior ao campo discursivo. É essa existência que garante a articulação, por que de outro modo haveria apenas mediação. 


\section{A constituição discursiva das subjectividades}

Regressemos à segunda parte do argumento: as identidades não são absolutamente fixas ou absolutamente não fixas. A subjectividade do sujeito, na esteia de Foucault, não é um pressuposto; é um efeito de práticas de objectivação e subjectivação que se reforçam reciprocamente (Dreyfus e Rabinow, 1983). Corpo e consciência ocupam assim o espaço da subjectividade construído em função dos saberes que os localizam, descrevem e objectivam em conhecimento. Num registo diferente, em que se tenta separar desta visão, Santos (1991) considera que o processo histórico da cidadania e o processo histórico da subjectividade săo autónomos pelo que é possível antecipar diferentes soluções para esta, incluindo uma maior emancipaçăo, no quadro da posiçăo central que o Estado tem vindo a conquistar com o desenvolvimento do capitalismo. Noutro passo considera que a subjectividade «para além das ideias de autonomia e de liberdade envolve as ideias de auto-reflexividade e de auto-responsabilidade, a materialidade de um corpo (real ou fictício), e as particularidades potencialmente infinitas que conferem cunho próprio e único à personalidade» (p. 141). Pressente-se nesta definição a fonte principal da divergência com Foucault: ao contrário deste, Santos admite que o sujeito tem uma subjectividade transparente para si próprio e concebe-a enquanto origem e unidade base das relaçōes sociais, irredutivel a qualquer subjectividade colectiva. É desse lugar que critica a subjectividade monumental do Estado e a subjectividade monumental da classe operária.

Acompanhamos Santos quando argumenta que o processo histórico da cidadania e o processo histórico da subjectividade têm genealogias autónomas. O sujeito autoconstitutivo é o resultado de práticas de refinamento da subjectividade, inicialmente religiosas, que antecedem as tecnologias de governo estatal do sujeito. A genealogia da subjectividade de Foucault não põe em causa este percurso autónomo. A problemática que escolheu faz uma aproximação diferente que consiste em procurar saber qual o lugar das práticas éticas e espirituais quando foram incorporadas nos estados burocráticos e nas modernas tecnologias de governo. Quando os estados se propuseram governar o comportamento ético que identificamos com o sujeito, fizeram-no tomando de empréstimo os instrumentos das disciplinas de orientação pastoral religiosa. Porém, como Weber argumenta, estes não têm uma ductilidade infinita que lhes permita incluir-se completamente no Estado. Se os comportamentos dos sujeitos são o resultado das disciplinas, estas não esgotam as formas de programação da totalidade da conduta dos cidadãos. É aliás nesta cesura que se fundamenta o debate sempre renovado das ciências sociais entre estrutura e 
subjectividade, sistema e acção, contexto e actores enquanto pólos de uma inelutável oposição. Foucault tenta superar a dicotomia por intermédio da constituição discursiva da subjectividade.

A crítica que é feita a Foucault fundamenta-se em grande medida na presunçăo de que a genealogia do sujeito esvaziou-o da sua subjectividade, retirando-lhe assim quaisquer escapatórias emancipatórias. Esta crítica deixa quase sempre de lado o último Foucault das lições do Colégio de França e das suas reflexões históricas sobre a governamentalidade. Nestas fica mais claro que o sujeito não é construído como um mero artefacto de poder e que ele próprio exerce poder. Torna-se mais difícil sustentar a tese das disciplinas enquanto iron cage quando grande parte da argumentação de Foucault é dedicada à demonstração de que aquelas pressupõem a actividade e a liberdade dos que são alvo da sua acção. Enquanto em Vigiar e Punir (1975) Foucault sublinha a subjectivação dos indivíduos por intermédio das técnicas de sujeição; nos seus últimos escritos sobre o governo estabelece uma relaçăo entre estas e as técnicas da existência na construção da subjectividade.

Dentro da perspectiva da governamentalidade, a introdução de uma ética da existência, inscrita nas técnicas do Eu, parece conduzir ao afrouxamento da conexão entre subjectivação e sujeiçăo. Menos que um liame trata-se de uma articulação que pressupōe a năo determinação das disciplinas sobre as técnicas da existência. A governamentalidade é precisamente o nódulo em que as técnicas de coerção e de autonomia se encontram. $\mathrm{O}$ conjunto de tácticas e de procedimentos que o governo das sociedades modernas envolve não se teria estabelecido se as relações da subjectivaçăo com a sujeição agissem sempre sob um princípio de correspondência necessário e de mútuo reforço. O seu espaço de acçăo e de invenção tem expressão na ausência de sobreposiçăo das tecnologias dos sistemas disciplinares e das tecnologias da subjectividade. $\mathrm{O}$ estado de correspondência e de harmonia total satura as possibilidades de intervenção da governamentalidade; esta não provoca a homogeneidade das formas de poder, mas a sua heterogeneidade. A governa-

160 mentalidade liberal não pode ultrapassar este limite senão à custa da redução dos efeitos que pretende induzir: a racionalizaçăo da conduta livre e o autogoverno dos indivíduos. Ultrapassado este limite regressa-se à soberania.

É evidentemente verdadeira a presunção segundo a qual Foucault não enuncia as condiçōes de emancipação da subjectividade. Limita-se a constatar que qualquer solução não se pode restringir à evocação de uma sociedade civil independente ou oposta ao Estado, exigindo, entre outras coisas, a redefiniçăo dos modelos políticos e sociais de auto-identidade. A questão deixa de ser o modo como somos governados por outros e passa a ser também a interrogaçāo das formas e práticas em que 
governamos os outros. Esta interrogação é definitivamenhte um problema de constituiçăo da subjectividade e năo do seu fenecimento.

\section{Formas e significados da linguagem política}

O significado do discurso é muitas vezes a forma, não o conteúdo. McLuhan sintetizou esta ideia na fórmula bem conhecida segundo a qual o meio é a mensagem. A identificação dos estilos de linguagem política é um momento imprescindivel da tipificaçăo dos meios utilizados na transmissão da linguagem política. Este foi um aspecto menosprezado por Foucault que se preocupou mais com a análise da relaçăo entre discurso e meio institucional. $\mathrm{O}$ discurso é mais vasto do que a retórica ou a linguagem. Não se limitando à arte da persuasăo, por virtude da linguagem argumentativa, inclui práticas não linguísticas. Por isso o conteúdo da forma é tão importante quanto a forma do conteúdo. A actividade discursiva da governamentalidade, enquanto tecnologia de conhecimento, requer uma atenção especial aos dispositivos de escrita, cálculo, listagem e notação que fazem de objectos dispersos universos conhecíveis. Conhecer um objecto para o governar não é uma actividade meramente especulativa: procede de dispositivos e de estilos que respondem a várias regiōes do discurso e se dirigem a audiências específicas.

O esforço de classificação prévio deve ser entendido como uma referência analítica que não esgota o campo de possibilidades empíricas. Adapta-se aqui uma antiga tipologia da linguagem política sugerida por Edelman (1964). $O$ autor identifica quatro estilos de linguagem: exortatório, legal, administrativo e de negociaçăo. A utlização destes estilos de linguagem parece ser uma forma de organização mais sensível às funçōes do discurso do que a tradicional divisăo entre linguagens legislativa, executiva e judicial que corresponde às funções dos estados modernos.

A linguagem exortatória é identificável nas campanhas eleitorais; nos apelos que acompanham os pedidos de apoio político; nos debates legislativos, apresentação de programas de governo e interpelaçōes no Parlamento; e, em geral, nas discussōes que antecedem o processo de decisão política. Este estilo consiste em declarações de intenção, premissas formais e conclusōes. A exortação condensa a evidência maior do estilo: aqueles a quem o discurso se dirige devem estar abertos à influência, porque o governo da conduta se realiza no apoio que as políticas públicas obtêm. A exortação procede por meio da autoridade carismática ou racional-legal. Os seus argumentos estăo dotados sobretudo do poder de convicção, embora năo excluam as verdades absolutas. $\mathrm{O}$ escopo básico deriva do senso comum e de pontos de vista 
reconheciveis cujas referências substituem a necessidade de demonstraçăo. $\mathrm{O}$ universo em que a influência se concretiza não é o da correcção ou incorrecção, mas o da força ou fraqueza com que transforma o communis consensus numa conclusão aceitável. Bernstein designa por circularidade compreensiva este entendimento entre emissores e audiência que pressupõe normas comuns que a linguagem reflecte $\mathrm{e}$ reforça.

As formas rituais de apresentação do discurso são especialmente importantes neste estilo de linguagem: cerimónias, encontros com a imprensa, audiências, discursos públicos e anúncios oficiais são algumas das formas utilizadas para justificar as politicas à audiência universal ou a audiências particulares. A definiçăo desta enquanto nação, pais, professores ou opinião pública define menos a audiência específica a que se dirige a mensagem que a forma como esta é elaborada e construída.

O segundo estilo que atravessa grande parte dos processos governamentais é a linguagem lega/ que subjaz às leis, aos despachos, aos estatutos, aos tratados internacionais, aos orçamentos e às regras legais. Todos os anos são emitidos centenas de decretos e de despachos cuja aplicação é mediada por inspectores, juízes e administradores. Na sua forma sintáctica, a linguagem legal consiste em definiçōes e injunçōes que se pretendem de grande rigor e precisão. Para o leigo, porém, não é a imprecisāo, mas antes a incompreensão, que lhe permite a introduçāo de ambiguidades na sua interpretação. É justamente esta ambiguidade que dá à inspecção e aos administradores a autoridade de reporem o seu sentido verdadeiro. A frequente referência ao quadro jurídico-legal tem por funçăo criar uma atmosfera de normatividade que sublinha a impessoalidade e isenção do intérprete: a voz que fala não é a sua, mas a do bem público que representa. A característica mais saliente da linguagem legal reside no facto de a sua legitimidade se realizar pela diminuição e despojamento de quem a actualiza, em detrimento de entidades colectivas que garantem o interesse geral. A medida da grandeza do discurso assenta na sua descontextualização. $O$ caso concreto só existe porque ilustra a possibilidade de aplicação unívoca de normas 162 gerais.

A análise da linguagem legal per si revela-nos apenas as premissas de onde se deduz a eficiência funcional do sistema e não as inconsistências, irracionalidades e infidelidades que regulam a sua actualização. A linguagem legal não absorve completamente a complexidade conflitual da sua aplicação. Os correlatos da linguagem legal são as valorações éticas extralegais que acompanham a sua aplicação e que, frequentemente, contrariam as premissas inscritas na retórica dedutiva. Consequentemente, năo se pode restringir a análise ao carácter mecânico do processo de aplicaçăo que apenas capta a superfície desta linguagem. 
O estilo administrativo tende a ser confundido frequentemente com a linguagem legal. O seu estatuto é diferente por que os meios da sua difusăo são outros — ofícios, regras, regulamentos, relatórios e estatísticas - e também por que a audiência e o emissor se relacionam diferentemente. A linguagem administrativa é dirigida a um auditório constituído por funcionários que, segundo a regra, devem corresponder automaticamente ao imperativo que aquela estabelece. $O$ significado da linguagem administrativa é isomorfo aos seus elementos formais. O jargão que a atravessa caracteriza a autoridade de um grupo fechado na posse de separadores linguísticos automáticos.

A lógica técnico-operacional que preside a este estilo é tanto mais eficaz quanto maior for a profissionalizaçāo dos seus agentes e a burocratização do sistema. A formalização e a quantificação da linguagem são invariantes da sua apresentação. As estatísticas são um caso específico de abstracção suficiente a uma análise separada das coisas em que eventualmente serão aplicadas. Estruturas cognitivas são construídas por intermédio de noçōes incorporadas nas estatísticas. Bernstein sugere a este propósito que a linguagem formal tem uma maior percentagem de substantivos do que de verbos em virtude do primado das coisas sobre os processos.

A linguagem de negociação tem um carácter menos público que as restantes. Em alguns casos tem mesmo carácter quase privado, embora seja a forma com maior transversalidade: está presente nas negociações do ministério com os sindicatos ou as associações de pais; nas negociações dentro da administração, entre os seus diferentes níveis de decisăo; nas negociaçōes entre as escolas e a administração. Genericamente, integra todas as situações em que uma acção, um problema ou um resultado necessitam de ser justificados.

Esta tipologia deve ser entendida como um instrumento analítico e não como a descrição empírica das formas de linguagem realmente verificáveis. Estas apresentamse quase sempre numa forma híbrida, combinatória, reforçando ou enfraquecendo a sua eficácia. A nossa preocupaçăo ao analisar o discurso político não é determinar quais as posições realistas e as que são irrealistas; quais as linguagens verdadeiras e quais as falsas; quais as medidas correctas e as que săo incorrectas; quais os discursos substantivos e quais os que são aparências. Como constatava Hannah Arendt (1963, p. 94) em política, mais do que em qualquer outro caso, não há a possibilidade de distinguir entre ser e parecer; no universo dos assuntos humanos, ser e parecer são realmente uma e a mesma coisa». Os jogos de linguagem têm um papel generativo, pelo que, mesmo quando somos levados a usar as formas de dedução lógica na desconstrução dos discursos, o objectivo não é descobrir a realidade verdadeira por detrás das aparências, mas o de compreender melhor a sua relação com 
outras práticas, as condiçōes sociais da sua produçăo e a sua capacidade de troca nos mercados linguísticos em que sucessivamente circulam e são recebidos. Dar conta da dimensăo retórica de certos conceitos não equivale a sugerir que o pensamento pode ser expresso sem o recurso à retórica, nem que seria necessário expurgar e purificar o discurso de toda a retórica para que então tivéssemos acesso à sua natureza verdadeira. Apenas se sugere que os efeitos retóricos dependem das formas e das circunstâncias particulares em que certas proposiçōes são inscritas em domínios e campos intelectuais diversos. As condiçōes deste processo săo também uma consequência da capacidade de troca nos mercados linguísticos que depende, em larga medida, do modo como os emissores elaboram e constroem o auditório. Quando caracterizámos as quatro regiôes discursivas designámos também as audiências a que se destinavam: a audiência universal, as audiências particulares e as audiências locais.

Um dos aspectos mais interessantes da perspectiva de Boaventura S. Santos sobre o Estado heterogéneo em Portugal é a criaçăo nos últimos vinte anos de novos actores sociais «capazes de aceitar e de reproduzir um modo de regulação semi-periférico» (Santos, 1993: 33). Nos termos deste acordo, os actores sociais organizados aceitam dialogar estabelecendo um pacto social. B. S. Santos designa tal estratégia por normalizaçăo contratual, referindo-se preferentemente à contratualizaçăo das relaçōes entre trabalho e capital. Porém, a heterogeneidade dos sistemas educativos está duplicada sobre si mesma, visto que contém a heterogeneidade proveniente da crise de acumulação do capital e a heterogeneidade decorrente da crise de legitimidade. No primeiro caso, o sistema institucional adapta-se à diversidade da composição interna do capital, reestruturando as relaçōes com o sistema económico e o mercado de trabalho. A criaçăo do Conselho Permanante da Concertação Social, com a presença simultânea de representantes dos sindicatos, do governo e das associaçōes industriais, comerciais e agrícolas constituiu um momento simbólico e orgânico essencial no processo de normalização. No segundo caso, a esta heterogeneidade somam-se as heterogeneidades do espaço doméstico, do espaço comunitário e do espaço profissional. A criação do Conselho Nacional de Educação na Lei de Bases do Sistema Educativo de 1986, com amplas funções consultivas, constitui o elemento mais visível deste processo.

Numa primeira fase, o Estado reproduz a heterogeneidade do sistema educativo aceitando ou promovendo a fragmentação dos actores sociais organizados: sindicatos de professores, associações profissionais, associaçōes de estudantes, associações de pais e encarregados de educação. Em 1974, Portugal tem uma evidente falta de tradição de associativismo de interesses particulares. De outro modo, a sociedade 
civil é fraca e, em reverso, a centralidade do Estado não se converte facilmente em aceitação das suas decisões. Como argumenta Offe, uma subestrutura associativa é decisiva para o sucesso, legitimação e durabilidade da intervenção do Estado: «this is because formally organized and centralized collective actors are more sensitive and 'responsive' to the specific means of intervention employed by public policy - money, law, ingormation - than is to be expected when weak, pluralistic, or fragmented political actors dominate the state's field of action, or when the development of formal associations has not taken place or cannot take place for structural reasons» (Offe, 1996: 113).

De acordo com esta hipótese, os parceiros associativos funcionam como estações de relais que percebem e medeiam a linguagem financeira e legal e os sinais informacionais de que as políticas públicas são feitas. A constituição de actores colectivos pretende atingir uma audiência universal, embora a fragilidade e incipiência da organização destes resulte, frequentemente, em fronteiras corporativas que originam audiências particulares. Um exemplo típico de construção destas audiências verifica-se no período da normalização do ministro Cardia em que as associações de pais e encarregados de educação se tornaram no mediador privilegiado em detrimento das associações profissionais e de estudantes.

A criaçăo de actores sociais é um processo muito ambiguo. Por exemplo, as associações de estudantes e as associações de pais, ao mesmo tempo que são reconhecidas, vêem a sua acçăo regulamentada e limitada. Tal ambiguidade não diz apenas respeito à regulação estrita dos momentos e dos órgãos escolares em que podem intervir (Silva, 1999; Gomes, 1995), mas, sobremaneira, ao facto de existir uma duplicidade discursiva que, por um lado, se dirige directamente à prática quotidiana do indivíduo e, por outro lado, promove, regulando, a participação cívica dos actores.

No cerne desta ambiguidade encontra-se o desígnio de o Estado construir um auditório universal. Em ordem a que um bem se transforme num bem público deve existir uma colectividade em que os seus membros se refiram a si próprios como nós. $\mathrm{Na}$ ausência ou fragilidade de tais colectivos civicamente organizados e regulados, ou numa situação de Estado paralelo como a que se viveu em Portugal entre 1976 e 1986, o Estado constroi retoricamente um auditório universal, mas permeabiliza-se a auditórios particulares; define juridicamente um modelo de serviço público ancorado no interesse geral, mas submete-se, frequentemente, aos interesses particularistas da economia e da família. Particularmente interessante é o caso da família. Utilizando o mapa das configurações simbólicas proposto no capítulo I, o contexto doméstico orienta-se por uma racionalidade de maximização das relações pessoais e afectivas. No interior da escola tal racionalidade caracteriza-se por uma relação de favor e de 
protecção particularista: atender à personalidade dos alunos e ao seu meio familiar, proporcionar a proximidade e o calor entre as pessoas. No entanto, os pais e encarregados de educação deslocam-se progressivamente para o auditório universal do interesse geral e do contrato, organizando-se e fazendo-se representar por associaçōes regulamentadas pelo Estado, embora reivindicando a autonomia do seu espaço de intervençăo. Por sua vez, estas associaçōes representam mais os interesses dos seus membros do que os interesses gerais dos que universalmente representam. Estão assim construídos dois quadros interpretativos das políticas educativas: um quadro particularista que promove a domesticidade da escola e um outro universal que garante a tutela cívica da família. O que se altera não são as medidas de política, mas a interpretação estabelecida pelo auditório.

Esta primeira fase decorre até ao ano de 1986. Neste ano, a discussão pública da Lei de Bases do Sistema Educativo culmina, com a aprovaçăo por unanimidade na Assembleia da República, um processo de consensualização e legitimaçăo das políticas educativas. A partir de então regista-se um novo binário na construção dos auditórios das políticas educativas. É um binário que se polariza em torno do indivíduo e da comunidade. Trata-se de uma oposição que coincide com os mitos legitimadores promovidos nos sistemas educativos europeus pela OCDE e outras agências internacionais como a Unesco (Popkewitz e Brennan, 1998; Meyer e Ramirez, 1998). Nas últimas duas décadas deu-se um deslizamento das concepções sobre o direito de cada pessoa ao completo desenvolvimento do seu potencial: das considerações sobre o capital humano, passou-se à autonomia das decisões dos pais; das distorçōes competitivas existentes no mercado de trabalho para as indevidas oportunidades oferecidas aos professores para promoverem os seus interesses estatutários. Os parâmetros de equivalência ou de equidade sofreram um processo de erosão: da noçăo universalista dos direitos humanos de todos passou-se para a noção de interesse da nação; desta, passou-se para a noçăo de necessidades do mercado de trabalho; do mercado passou-se para a defesa dos interesses de certas categorias de contribuintes, de certos grupos profissionais ou comunidades culturais e, finalmente, desta, passou-se para os interesses do indivíduo. Em todos os casos, a mudança decisiva não se deu na forma dos objectivos e dos factos, mas no nível das interpretações.

Daí a importância decisiva do auditório universal como meio de totalizaçăo de discursos que nem sempre o têm por destinatário. Como recorda Perelman (1993: 33) o auditório năo é uma realidade social concreta, mas uma construção de quem fala, baseada na sua própria experiência: «se se quer definir o auditório de forma útil para o desenvolvimento de uma teoria da argumentação deve-se concebê-lo como o conjunto daqueles que o orador quer influenciar pela sua argumentação». 


\section{Lugar-comum e políticas educativas}

O lugar-comum é com frequência associado ao conhecimento vulgar ou à vulgata do conhecimento. Não é esse o sentido que tem neste trabalho. Recuperando o significado da palavra na tradição retórica dos Gregos, os lugares-comuns (topoi) são opiniōes e argumentos geralmente aceites. Cícero definiu-os como depósito de argumentos. $\mathrm{O}$ extremo grau de generalidade faz do lugar-comum um meio válido de orientação e penetração persuasiva das políticas educativas.

A definição de políticas educativas está ela própria associada ao lugar-comum da resoluçăo de problemas. A interpretação das políticas tende assim a ser vista do ponto de vista da linguagem exortatória, legal ou administrativa. São os outputs que servem de referencial para a sua análise. Propomos um deslocamento da análise da resolução de problemas para a sua construção. É nesse espaço que o lugar-comum aparece com todo o vigor por que mais distante dos sistemas normativos que envolvem a resoluçăo de problemas. A construção dos problemas educativos realiza-se em todas as regiōes do discurso onde a discussão, a argumentação e a justificação prévia à acção tem lugar. Em outro trabalho analisamos a construção de problemas no nível local (Gomes, 1993). Os topoi então analisados revelaram apreciável ductilidade. Eles estăo abertos a matizes que dependem dos problemas que devem criar. A sua discussão prévia não pode pois iniciar-se por um exercício de classificação impossível.

Os topoi podem integrar também a linguagem legal ou administrativa mas não procedem da mesma lógica estandardizada e normativa daquelas. Estas formas de linguagem ambicionam a universalidade de uma dada ordem racional-legal; os topoi são tentativos, razoáveis e plausíveis. A sua força não reside na demonstraçăo; a persuasão é a origem do convencimento que alcançam. É nas formas de linguagem exortatória e de negociaçăo que os topoi ganham maior visibilidade e eficácia. Ambas repousam em situações de prova que, tendo em conta as circunstâncias, sejam simultaneamente justificáveis a partir de princípios gerais. No primeiro caso, certos princípios de filosofia ou de pragmática política devem penetrar os objectos de acção com os quais se possa medir o seu valor relativo e assim pôr-se de acordo quanto ao apoio a dar à posição exortada. A conclusão parte de uma justificaçăo genérica para situaçōes de prova analíticas que permitem deduções lógicas. No caso das situações de prova directas, como as que envolvem a linguagem de negociação, parte-se de aproximaçōes sucessivas e ajustamentos necessários entre factos e valores. A deliberaçăo procede de um processo de razão prática onde se procuram compromissos capazes de tornar compatíveis julgamentos que se apoiam em topoi diferentes. 
A conclusăo deriva da plausabilidade e exequibilidade e funda-se na probabilidade do acordo.

As comissōes e os grupos de trabalho formados pela administração são um contexto típico onde as situações de prova têm lugar. Cada comissão ou grupo de trabalho tem a sua história própria e características invariantes. Estas são particularmente visiveis nas comissões consultivas que incluem membros do campo burocrático e representantes de organizações profissionais, personalidades isoladas e membros da comunidade científica. A interpenetração de altos quadros da função pública com membros da comunidade científica define desde logo o princípio fundamental de funcionamento do campo burocrático. A sua função legislativa, parcialmente dependente do trabalho da comissão, só é realizável na condição de confrontar e rejeitar os interesses particulares e privatistas. Estes deverão manter-se numa posição subordinada relativamente aos detentores estatutários ou simbólicos do que é definido como interesse geral. Estando em condições de sugerir ou de impor as regras de discussão e de registo das conclusões, nomeadamente por intermédio da designação dos relatores, os funcionários do Estado podem conservar o monopólio das decisões sociais. Para tanto devem estruturar situações de prova em que o topos do interesse geral se confronte abertamente com o topos do interesse particular.

Deste ponto se pode tentar compreender o paradoxo de um Ministro neoliberal como Roberto Carneiro, defensor da liberdade de ensino e da sua maior privatização, ter provocado durante o período do seu ministério uma maior intervenção do Estado. Com efeito, as situações de prova construídas reforçaram a posiçăo estratégica do campo burocrático. As vibrações dos discursos particularistas, ancorados nos topoi da quantidade e da qualidade, submeteram-se a um compromisso orientado pela lógica do interesse geral. Deste modo se puderam compatibilizar topoi primitivamente contraditórios: a modernização do sistema deveria ter em consideração as aspirações dos alunos e o seu desenvolvimento integral; a relação com o mercado de trabalho passaria a articular-se com a satisfação das necessidades individuais; a eficácia da gestāo racional da escola repousaria na dignidade do colectivo de professores; a especialização de competências năo sacrificaria a obtençăo de consensos verificáveis nos mecanismos de representação; mais qualidade do processo não deveria sacrificar a quantidade do acesso.

Procurar fazer uma análise do discurso e encontrar as suas regras sem ter em consideração que estas residem em grande parte nas leis de construção do espaço social de produção do discurso, interdita qualquer possibilidade de lhe captar o sentido. 0 lugar-comum não tem um uso indiscriminado mas a sua activação pode obter efei- 
tos diferentes segundo a economia dos casos. Por conseguinte, o seu verdadeiro significado está condicionado pelo espaço de produçăo do discurso. Este, sem deixar de ser uma condição é também o discurso produzido. No limite, a sua existência é posta em causa quando o discurso produzido (espaço social) dissolve a possibilidade de produzir discurso (produto final). ${ }^{(59)}$ É neste movimento de vaivém entre espaço de produção e produção do discurso que se encontra a possibilidade de escapar ao círculo hermenêutico proposto por análises mais formais do sentido discursivo.

Os lugares-comuns articulam-se num duplo sentido. Porque um lugar-comum pode ser utilizado para definir os limites em que outro pode emergir: é o caso do lugar-comum do interesse geral que frequentemente é precedido pelo da quantidade. Ou porque lugares-comuns que são contraditórios na sua essência chegam, com frequência, a compromissos: é o caso do lugar-comum da equidade de acesso ao ensino, simultaneamente justificado em termos de rentabilidade económica e de igualdade política.

Os lugares-comuns asseguram um princípio superior de coordenaçăo e de equivalência entre os objectos e os sujeitos. Ao estabilizarem uma grelha comum de classificação e de qualificação de um universo constituído por objectos e por sujeitos, permitem determinar a sua importância relativa independentemente das contingências da comparação. No entanto, os topoi năo são princípios gerais: enquanto estes pretendem expressar conteúdos verdadeiros de uma dada ordem legal, os primeiros săo reconhecíveis pelo poder de persuasão e manipulaçăo que contêm (Santos, 1974). Os princípios gerais referem-se a padrões normativos inscritos numa dada ordem legal, enquanto os lugares-comuns são communis principiu que năo têm essa referência jurídica, mas permitem fazer raciocínios do tipo «A equivale a $B$ em relaçăo ao principio X».

Os lugares-comuns pontuam os limites e as formas como a memória integra as formaçōes discursivas. Permite reconhecer quais as proposições válidas e as que săo negligenciáveis ou que foram excluídas. Como a sua variabilidade é uma co-variância que acompanha as suas condiçōes de existência, regista também as relaçōes entre as proposições actuais e o corpo de proposições passadas. Nesta perspectiva, a análise dos topoi faz um recorte diacrónico da formação discursiva.

(59) É o caso de algumas comissöes de elaboração de programas da reforma curricular - e.g. Filosofia e Inglês - que deixaram de ser reconhecidas no seu trabalho de universalização e assim perderam a legitimidade necessária à aceitaçăo do produto final. 


\section{Metáforas e Hegemonia}

Richards (1936) na sua obra seminal The Philosophy of Rhetoric rejeitou com vigor argumentativo a visão restritiva da metáfora enquanto tropo. Este seria a mera alteraçăo do significado original de uma palavra ou frase por outro significado. Para ele a metáfora é muito menos uma questão de substituição e de embelezamento da frase que uma forma de interacção e de experimentação. $\mathrm{O}$ alargamento de campo introduzido por esta perspectiva permite-nos conceber a metáfora na sua função generativa: ela passa a mediar a transferência de quadros de referência de um domínio da experiência para outro domínio. Sabe-se que nem todas as metáforas săo generativas. Algumas limitam-se a condensar maneiras de ver as coisas. Neste caso a analogia é apresentada como um dado e não como uma sugestão; a metáfora amplia a posiçāo da analogia. A metáfora generativa, contudo, é indutora de novas percepções e explicações da natureza das coisas. O raciocínio metafórico permite o alargamento das opções de codificação da informação disponível num determinado espaço político ou social. Os mesmos tópicos metafóricos dependem das inferências contextuais da sua inserção. As metáforas de que falamos circulam em contextos institucionais restritivos que contêm eles próprios outras metáforas, símbolos e lugares-comuns cristalizados e que assim orientam o potencial de inferência da metáfora.

A metáfora tem um papel decisivo no diagnóstico e construção dos problemas de política educativa. Os problemas não existem enquanto dados directamente tangíveis e apreensíveis da realidade social. São construções que pretendem responder a situaçōes de incerteza que perturbam o sentido da realidade social anteriormente alcançado. O enquadramento dos problemas depende em grande medida de metáforas que geram o diagnóstico e a orientação da solução de problemas, seja por intermédio de narrativas qualitativas ou de instrumentos de quantificaçăo da situação. Por sua vez, as metáforas geradas no processo de diagnóstico e de planeamento são as mesmas que tendem a dominar o processo de intervenção. Donde a importância relativa desse momento na definição das políticas educativas. Afastamo-nos assim da corrente de análise das políticas educativas que compara a relação entre o que é planeado e o que é concretizado. Enquanto esta valoriza a medida diferencial de inputs e outputs, na nossa perspectiva são as regras de construção do discurso que são decisivas para a compreensão da abundância de imagens e horizontes a que dá origem. O facto de considerarmos as políticas educativas acima de tudo como fenómeno de problematizaçăo leva-nos a explorar o dialogismo proposto por Bakhtin (1963), em virtude do qual nenhuma palavra, metáfora ou frase é unívoca, encerrando já no seu interior uma multiplicidade de vozes e de pontos de vista. Neste sentido, a noção de dialogismo articula-se bem com a de dispersão discursiva de Foucault. 
Retomemos o exemplo que tem servido para ilustrar este capítulo. Uma das narrativas socialmente mais fortes que marcou o diagnóstico da escola secundária portuguesa nos anos 70 e 80 foi a da fragmentação e isolamento das escolas. A força destas metáforas multiplicou-se em diversas formas e regiões do discurso: ministros afirmaram que não havia propriamente um sistema educativo; as associaçōes de pais confirmavam que a escola e a família estavam de «costas voltadas»; as análises da rede escolar registavam a dispersão e ausência de racionalidade da oferta. Uma das metáforas mais interessantes deste período é a da cartografia ${ }^{(60)}$ que dá origem ao mapeamento topográfico da oferta escolar no território nacional por intermédio da sua localização precisa. O rigor posto no diagnóstico antecipa a racionalidade do planeamento e intervenção futuros. A medida pontilhista do fenómeno da distribuição da oferta, a descrição da relação que mantém com grupos específicos e com a totalidade da população, o cálculo da distância entre oferta proporcionada e procura antecipada detecta anomalias que reforçam o poder de intervenção do Estado na distribuição da terapêutica. A associação metafórica fragmentação-isolamento conduz invariavelmente à prescrição de medidas de coordenação e de abertura pelo valor positivo que estas contêm. Aquelas só são um problema se forem entendidas como cesura de uma integração e abertura prévias que devem ser repostas. O sentido valorativo da metáfora depende em grande medida da bipolarização tácita que subsume. A sua força advém-Ihe do facto de nāo ser confrontada com outras inferências possíveis da metáfora como seria a da positividade dos sistemas fragmentados. O próprio conceito de autonomia foi captado pela energia da metáfora, orientando-o para a perspectiva de uma integração mais directa, rápida e racional e, portanto, menos onerosa do sistema. O discurso da autonomia da escola constituiu-se a partir da metáfora desintegradora. Os que a năo desejavam viam nela a fonte da fragmentação; os que a defendiam concebiam-na como possibilidade de maior envolvimento dos actores e de uma mais completa adequação dos objectivos às realidades espacial e socialmente próximas. Adaptabilidade, integração e adequação definem uma trilogia que marca as tecnologias de intervenção da década 74-84. Neste quadro, a metáfora da eficiência que hegemoniza o campo educativo no período seguinte é menos uma necessidade criada pelo discurso mais geral da modernizaçăo do após-integração europeia, do que um efeito de remanência das tecnologias en-

(60) Esta metáfora tem no Ficheiro de estabelecimentos de ensino de 1975 um dos principais pontos de origem, continuada depois no Inventário de carências e na Carta escolar. Ver cap. IV para uma análise detalhada. 
tão utilizadas. A pretensão de obter melhores resultados com menos custos contém tacitamente o conceito de eficiência. As políticas neoliberais de gestão da actividade educativa ganham pertinência relativamente ao campo de problemas pré-definidos e dependem do alcance obtido pela inter-relação de departamentos, interesses, cálculos e representações da fase anterior.

A metáfora serve o processo de hegemonia funcionando como um buraco negro que absorve a energia dos termos que circulam em diferentes esferas, fundindo-os num significado dominante. Mas este é também o risco maior a que se submete, por que deste modo a metáfora sofre uma erosão que Ihe fixa o significado e, finalmente, a transforma num vocábulo que designa um referente. Perelman $(1969,1996)$ designou por metáfora dormente este efeito de perda do poder sugestivo da metáfora. Neste caso, quando a metáfora perde a relaçăo com a ideia inicial que denotava e se torna dormente está sempre em condiçōes de ser reactivada por qualquer parcela de material analógico integrado na linguagem institucionalmente reconhecível. A metáfora pode ser acordada do seu turpor por novas analogias que the dêem um carácter não familiar em face das circunstâncias em que são utilizadas.

As racionalidades educativas săo processos metafóricos que se arrimam nas concepçōes pré-teóricas e politicamente constitutivas do mundo social. Contudo, o jogo de linguagem que os actores jogam com a analogia é limitado pelas fronteiras e pela constituição interna dos campos discursivos. A metáfora é um dos processos de criar novos significados no interior de contextos de representaçấo restritivos e de assim fazer parte do campo constitutivo do social. Não é apenas uma forma de pensamento analógico que adiciona um segundo sentido a um sentido primeiro que determinaria a verdadeira literalidade das relações sociais. Tem um papel central na reactivação dos discursos: define o regime e as formas de discursos exteriores à formação discursiva serem actualizados ou reconstituídos. Como é que discursos que circulam no espaço mundial das organizações internacionais são interpretados e integrados nas formações nacionais? Como é que discursos educativos dormentes são reelaborados e activados? Por vezes a torção moderada de uma expressão metafórica pode mostrar-se suficiente para a sua reactivação, pelo que esta deve ser considerada nas suas fases de evocação, argumentação e persuasão. Em particular, a evocação só pode ser reconhecida pela audiência se cobrir convenientemente as suas expectativas contextuais. Como tem sido extensamente comprovado por estudos no campo linguístico, a descoberta do sentido metafórico e a correspondente rejeição do sentido literal é realizada por processos simultâneos de criaçăo e selecção de sentido, mas orientada por significados prévios que circulam no contexto da audiência (Gerrig e Healy, 1983; Inhoff, Duffy e Carroll, 1984). 


\section{Mitos Institucionais e a criação da confiança}

As instituições são narrativas e regras de visão e divisão do seu universo de influência. Para os neo-institucionalistas as instituições são prescrições impessoais racionalizadas (Meyer e Rowan, 1977, 1991) inscritas nos sujeitos que as integram. Podemos considerar também tais narrativas como padrões que impõem à vida social certas regularidades, fronteiras e recursos que facilitam a compreensão dos acontecimentos e das práticas sociais. Da frequente ausência de fundamento, ou do recuo infinito deste, retira Giddens (1984) a distinção entre consciência prática e consciência discursiva e entre reflexividade consciente e tácita. Decorre desta perspectiva a importância que Giddens confere à rotina, que considera específica da modernidade, na manutenção da estrutura social. Este conceito de estruturação reconhece que muitos dos padrōes comummente aceites e institucionalizados foram de facto criações sociais, que responderam a tensões sociais complexas, mas são vistas hoje como parte da interacção social de todos os dias, da sua linguagem e das suas práticas. É esta ausência da história na vida de todos os dias que determina a descontextualização dos discursos. As categorias e distinções institucionais utilizadas no quotidiano escolar nem sempre têm uma relação directa com pessoas e acontecimentos. O significado da acção năo emerge da linguagem, mas das práticas institucionais, das relações de poder e da posiçăo social. A experiência de todos os dias é permanentemente sujeita à descontextualizaçăo e reformulada segundo regras, valores e injunçōes institucionais.

Dentre as narrativas institucionais mais pregnantes está a da racionalidade que preside à acção dos indivíduos e das organizações. No artigo de Meyer e Rowan (1977), Formal structure as myth and ceremony, os autores argumentam que muitas organizaçōes são incapazes de se orientarem de uma forma adequada e eficaz. No entanto, o público-alvo manter-se-á confiante na sua acção se estiverem conformes aos padrões e comportamentos racionais socialmente sancionados. A avaliação e, em geral, o exame interferiu, já o dissemos, na formação de ideias e valores sociais. O seu contributo para a fixação de ideias de objectividade e de vida calculável, bem como a substituição do qualitativo pelo quantitativo, alia-se a uma generalização do probabilismo, o qual corresponde à transposição para o domínio dos valores da possibilidade de estabelecer um número ilimitado de equivalências. A objectividade é condição de imparcialidade da avaliação e a impessoalidade condição da justa avaliação do mérito de cada um. A homologia com o funcionamento meritocrático do mercado de trabalho é evidente e assim se cumpre uma das principais funções latentes da escola que consiste em inculcar valores positivos perante a organização da produção. A doxa constitui uma das principais fontes de institucionalização da estru- 
tura formal das organizaçōes. A autolegitimidade de certas regras racionais de funcionamento isentam-nas de validação e funcionam como autênticos mitos. Esta forma de construção social da realidade escolar parece particularmente adaptada a um período de crise de legitimidade das escolas e dos professores, caracterizado pela exaustão da confiança nos sistemas abstractos (Giddens, 1992) e pela necessidade de produzir novos mecanismos de confiança.

Trataremos de discutir em primeiro lugar a lógica de confiança para depois nos adentrarmos na noção de sistema abstracto. Num artigo posterior, Meyer e Rowan (1978, 1992: 72) concretizam quais os mitos que garantem a legitimidade da instituiçăo escolar, designando tal legitimidade por lógica de confiança: «higher levels of the system organize on the assumption that what is going on at lower levels makes sense and conforms to rules, but they avoid inspecting it to discover or assume responsibility for inconsistencies and ineffectiveness». Com efeito, o crescimento dos sistemas educativos não se fez acompanhar de um crescimento correspondente dos mecanismos de controlo burocrático do ensino. Consequentemente, o ensino tende a manter-se separado da estrutura organizacional. Esta propriedade das organizações escolares foi designada por alguns autores pelo termo loosely coupled systems (sistemas debilmente conectados) para assim sublinharem a desconexão entre estrutura e actividade técnica e entre esta e os seus efeitos. Tal desconexão é ainda ampliada pela separação entre estrutura organizacional e estrutura institucional ou, dito de outro modo, entre padrōes de regulação do trabalho das escolas e padrōes de regulaçăo do conjunto do sistema educativo.

Os padrões de regulaçăo mais globais são travejados nas regras de validação social da educação, designadas por gramática da escola por Tyack e Tobin (1994): tipologia das escolas, qualificaçōes dos professores, tipos de alunos, organizaçăo das disciplinas e programas escolares, cargas horárias, alocaçăo de espaços e de fundos. Trata-se de categorias rituais duras que pressupõem uma conjugação adequada que nem sempre é conseguida. Com efeito, a dureza das classificações nada tem a ver com o seu grau de eficácia. $\mathrm{O}$ apelo que fazem a uma coordenação de tipo burocrático confronta-se frequentemente com a resistência e as infidelidades (Lima, 1992).

Mas as escolas têm também rituais debilmente conectados: a relação da sala de aula; o planeamento das aulas; o currículo real e oculto; a avaliação das disciplinas e por diante. Trata-se de categorias rituais moles que pressupõem apenas uma relação de cada professor com os seus alunos, embora atinjam um grau de isomorfismo muito elevado. Também neste caso a moleza das categorias reguladoras nada tem a ver com o seu grau de eficácia. A socializaçăo e a formaçăo profissional comum dos professores compensam a ausência de conexão com a estrutura. 
Nesta desconexão reside um dos principais mecanismos de dispersão das tensōes do sistema. O Estado, não podendo superar as causas que provocam as contradições básicas da escolarizaçăo - a contradiçăo entre igualdade formal e desigualdade social, entre dinâmica das qualificações e dinâmica ocupacional, etc - procura manter num nível aceitável as consequências sociais destas tensões. Chamamos a isto o efeito de biombo: um resultado serve para ocultar uma actividade paralela, uma actividade serve para reforçar uma estrutura organizacional com a qual não tem relação directa, a ignorância relativa serve para manter a confiança, o envolvimento directo do público no funcionamento escolar serve para retomar a confiança global no sistema. O efeito de biombo é um efeito de claro-escuro que joga com os três principais elementos da definição de confiança: descontextualização das relações sociais, contingência e ignorância. Para Giddens (1992: 22-28) não haveria qualquer necessidade de confiar num sistema que fosse inteiramente transparente no seu funcionamento e cujos processos técnicos fossem completamente percebidos. A falta de informaçăo completa é uma condição básica da confiança nos sistemas abstractos, na medida em que esta assume a forma de compromissos năo-presenciais, assentes na deferência para com o funcionamento de saberes técnicos que o indivíduo comum não domina. Embora o currículo oficial da escola vise a difusão do conhecimento, o seu currículo oculto inculca uma atitude de respeito pelo saber técnico e uma imagem de conhecimento científico fiável que reforça a confiança nas situações de contingência.

Simultaneamente, contudo, os leigos mantêm uma atitude ambivalente para com o conhecimento científico e técnico tipicamente escolares, i. e., pedagógico. Este conhecimento tem características próprias que o coloca frequentemente à prova de uma dupla contingência. Uma é interna: o mesmo conhecimento técnico aplicado em circunstâncias diferentes pode ter resultados diametralmente opostos. Outra é externa: não é provável que os pais e a sociedade continuem a confiar tacitamente na escola se, e quando, têm conhecimento dos erros cometidos nas salas de aula, quando sabem que os horários e os programas não são cumpridos, quando os professores são considerados incompetentes ou quando o diploma escolar tem pouco valor no mercado de trabalho.

A contingência permite que o cepticismo nos sistemas periciais surja e a crise de motivaçăo se instale. Mas os pontos de iluminação do sistema deixam no escuro outros e reforçam-Ihe mesmo a aura de imprescindibilidade. Quando se desconfia da competência do professor, tem-se por referência a necessidade de formar bons professores; quando não se tem a certeza de cumprimento dos programas, reforça-se a confiança nas suas virtudes; quando não se vê resultados práticos no diploma, incorpora-se 
o conceito de (de)mérito. É por esta razão que não acompanhamos os institucionalistas nas duas principais consequências metodológicas que retiram da desconexão, segundo as quais o que se passa diariamente nas escolas tem pouco a ver com as regras institucionais formais e que para a legitimaçăo da escola se realizar lhe basta incorporar os mitos já existentes no seu envolvimento externo. Resguardados do ónus da contingência prática, os mitos institucionais ficariam assim ao abrigo da dispersão. Pretendem os institucionalistas que as operaçōes sấo conduzidas fora ou ao lado do discurso institucional, no idealismo dos mitos ou no silêncio grave das práticas; que, consequentemente, o discurso não é mais que um aditivo, um suplemento que encobre sem precisar de se declarar, uma aparência que mistifica a realidade. A regra metodológica seria então a de procurar o significado da diferença entre aparência e realidade ou procurar desvelar o năo-dito da consciência prática. Em suma, procura-se a unidade da formação discursiva no seu a priori transcendental. Em alternativa propomos uma inversão do pressuposto metodológico: o discurso está na diferença entre o que se pode dizer correctamente num período e o que realmente é dito. $\mathrm{O}$ que faz da dispersão o verdadeiro princípio de unidade. Dispersão dos pontos de referência - e.g.: estatuto de quem fala, local técnico e institucional de onde fala - e dispersão das posições - e.g.: rituais e práticas que estruturam o discurso. Duas importantes conclusōes metodológicas resultam desta proposta. A primeira considera que tanto a legitimidade quanto a normatividade, que a lógica de confiança pressupõe, sofrem um processo de actualização sem plano previamente estabelecido. A segunda consequência chama-nos a atenção para a fixação relativa dos discursos. A fixação do discurso por intermédio do exercício do discurso como fixação é o resultado da impossibilidade prática de o descrever de outro modo que não o da aparente captaçăo de um momento fixo. A escrita do discurso introduz sempre elementos de cristalizaçăo semelhantes ao da apropriaçăo do evento pela fotografia. Mas isso não significa que o texto não esteja sujeito à precaridade e a um destino errante. Depois de escrito separa-se do seu autor para adquirir ele próprio singularidade absoluta, jamais apropriável. Popkewitz (1996: 2-10) exemplifica bem este fenómeno quando analisa o papel da psicologia construtivista de Vigotsky na reinserção do binário cartesiano mente/mundo objectivo. Embora Vigotsky argumente contra os binários cartesianos, a sua reactivação é realizada no conjunto de articulaçōes que as práticas discursivas da pedagogia construtiva incorporam: «this occurs as constructivist research accept the premise that knowledge is socially constructed, but assert simultaneously a knowledge base. This presumes disciplinary knowledge as stable and fixed, with constructivist pedagogies providing multiple strategies for students to understand that knowledge». 
Wittgenstein insistiu na impossibilidade de fixar o significado verdadeiro ou último do discurso. A ausência de um significado transcendental inscrito nos discursos retira-Ihe qualquer possibilidade de constituir um centro normativo. Se a este acentrismo somarmos a intertextualidade decorrente das diferentes interpretaçōes, teremos razōes de sobra para crer na não-fixação definitiva do discurso porque, como argumenta Deleuze (1998), as formações discursivas são verdadeiras práticas, e as suas linguagens, em vez de serem um logos universal, são linguagens mortais, aptas a promover e por vezes a exprimir mutaçōes.

\section{Os mapas cognitivos da escola}

Jameson introduziu o termo cognitive mapping na literatura pós-moderna, em 1984, no ensaio Postmodernism or the Cultural Logic of Late Capitalism. A sua definiçăo de mapeamento cognitivo, retirada ela própria de Kevin Lynch, serve-nos aqui de ancoradouro: «involves the practical reconquest of a sense of place and the construction or reconstruction of an articulated ensemble which can be retained in memory and which the individual can map and remap along moments of mobile, alternative trajectoires» (p. 51). A questão essencial sobre a qual Jameson reflecte neste ensaio é também a aporia principal deste trabalho, qual seja a de perceber como e por que meios o sujeito individual, psiquicamente isolado, se relaciona com a realidade objectiva, total, socialmente dispersa. Jameson admite que os mapas cognitivos são uma espécie de soluções imaginárias para contradições reais, que vão a par da necessidade de totalização cognitiva de uma realidade quotidiana sempre mais fragmentada. Todos os conceitos utilizados pela ciência, pela administração ou pelo senso comum para representar a realidade têm uma espessura espacial, física e simbólica, no interior dos quais identificamos o real. Mas os mapas cognitivos assim construídos não fazem uma representação mimética, exacta, da realidade física e săo antes alegorias que pretendem contar uma história sobre outra história. Os mapas cognitivos são alegorias dos mapas que, para desempenharem as suas funções de representaçăo e orientaçăo, devem inevitavelmente reduzir e distorcer a realidade. Como nos recorda Boaventura S. Santos no seu ensaio sobre a Cartografia Simbólica das Representações Sociais (1988: 143) «para ser prático, o mapa não pode coincidir ponto por ponto com a realidade. No entanto, a distorção da realidade que isso implica não significa automaticamente distorçăo da verdade, se os mecanismos de distorção da realidade forem conhecidos e puderem ser controlados. E, de facto, assim é. Os mapas distorcem a realidade através de três mecanismos principais: a escala, a projeç̧ão e a simbolização». 
A escala pode determinar a mudança de representação de um fenómeno. Os mapas de grande escala apresentam um grau mais elevado de pormenor porque cobrem uma área inferior à que é coberta pelos mapas de pequena escala. Como sugere Keates (1982) a criação de fenómenos espaciais e sociais segue o princípio da suficiência de poder, reduzindo e ampliando a sua representação na medida suficiente ao seu exercício. Nestes termos, o que distingue os mapas cognitivos do sistema escolar português săo as redes de factos e de problemas que vão criando. Retomemos o exemplo do ficheiro de estabelecimentos de ensino, elaborado em 1978, pelas Comissōes de Planeamento Regional. Usando a pequena escala e a informaçăo geocodificada que the permite a introdução do sistema de quadriculagem, o ficheiro localiza e associa a cada quadrícula todos os recursos e equipamentos sociais que nela estão contidos. No contexto mais amplo da intervenção estatal, o estabelecimento escolar é apenas uma das dimensões de outras localizações mais amplas em que facilmente identificamos a economia, a saúde, etc. Trata-se de uma lógica de identificação central de recursos que visa uma redistribuiçăo racional dos equipamentos sociais.

As forma educativas distinguem-se também segundo o tipo de projecção da realidade escolar que promovem. A projecção trata da forma como săo representados os objectos e os espaços escolares. Distinguimos a este propósito dois tipos de projecção: a projecção lisa e a projecção estriada. Aceitamos assim a metáfora que Deleuze e Guattari $(1980,1997)$ usam em Mille Plateaux para falar da projecção mental do espaço. Na projecção estriada, as linhas e os trajectos têm tendência a subordinar-se aos pontos; no espaço liso dá-se o inverso, os pontos subordinam-se ao percurso. No primeiro caso vai-se de um ponto a outro, no segundo caso é o percurso que determina as paragens. Na projecção estriada do espaço, e esse é o caso dos ficheiros de estabelecimentos de ensino e dos inventários de carências, privilegia-se a objectividade, a extensăo do espaço e as dimensōes; na projecçăo lisa, como no caso da ocupação do espaço escolar, privilegia-se a direcção, os acontecimentos e a intensi-

178 dade das relações. Contudo, a dicotomia liso/estriado não é sobreponível à dicotomia local/global. Enquanto a espacialização inscrita na primeira está dependente dos itinerários dos indivíduos e dos colectivos, a espacialização prevista na segunda está dependente da tendência de globalização do capital e da economia. Deste ponto de vista, esta última espacializaçăo inscreve-se numa tradição figuracionista que visa apreender o real em toda a sua complexidade, embora se reconheça que o real constitui uma causa ausente para a qual toda a representação é necessariamente desadequada (Bartolovich, 1996: 375). Nos termos da teoria de Jameson, os mapas cognitivos devem ser usados enquanto forma de construçăo de uma totalidade inicial- 
mente inexistente, permitindo assim uma acção de resistência inteiramente consciente. Jameson (1991: 418) insiste de tal modo na monumentalidade deste projecto que chega a comparar o mapa cognitivo com o tradicional conceito marxista de consciência de classe.

Expliquemo-nos. Jameson classifica o mapeamento cognitivo de Lynch como pré-cartográfico porque os diagramas dele resultantes se referem mais aos itinerários do que aos mapas. Para Jameson, a produção cartográfica do espaço é tributária dos diferentes períodos do capitalismo, registando-se em cada um deles um desenvolvimento muito específico. O período do capitalismo liberal caracteriza-se pelo desenvolvimento sem precedentes do princípio do mercado. O espaço-grelha é típico do mercado e caracteriza-se pela ambiçāo realista de fragmentar o todo sem deixar de o representar. A expansăo das cidades comerciais e industriais, bem como a intervenção cada vez mais profunda do Estado seriam as âncoras da representação em grelha, que teriam os seus equivalentes na racionalidade estética do grande romance realista e no projecto iluminista de secularização do mundo. O segundo período é marcado pela emergência do capital monopolista, caracterizado pela produção de um novo espaço nacional expandido, internacionalizado que está pelo imperialismo. O espaço da metrópole colonial deixa de coincidir com o seu espaço real, deslocado que foi para os territórios colonizados. Jameson liga esta sobreposiçăo dos territórios ao modernismo. O cume da tendência para a especialização e diferenciação funcional dos diferentes campos de racionalidade tem expressão nos espaços das grandes cidades onde a recusa do contexto social anda a par da ansiedade da contaminação (Huyssen, 1986). A intensidade desta ansiedade resulta de uma racionalidade assente no processo de integração/exclusão que provoca separaçōes e autonomias fortes entre alta cultura e cultura de massas, entre conhecimento científico e conhecimento do senso comum, ou ainda pela demarcaçăo de fronteiras disciplinares dentro da racionalidade científica. Boaventura S. Santos identifica a ansiedade de contaminação como um processo assente num défice de totalidade que resulta em dispositivos convergentes e em hegemonia. Que caracteriza do seguinte modo: «no caso da racionalidade moral-prática está presente, por um lado, na forma política do Estado que ao mesmo tempo que penetra mais profundamente na sociedade fá-lo através de soluçōes legislativas, institucionais e burocráticas que o afastam progressivamente dos cidadãos, aos quais, de resto, é pedida cada vez mais a obediência passiva em substituição da mobilização activa. E está, por outro lado, presente na emergência e consolidação de uma ciência jurídica, dogmática e formalista, pseudamente isenta de preferências axiológicas e políticas» (Santos, 1994: 78). O terceiro período, do capitalismo desorganizado, que começa nos anos sessenta, vem marcado pelo de- 
saparecimento dos grandes impérios coloniais e pelo crescimento exponencial do mercado mundial. Por força da presença massiva das empresas multinacionais, enfraquece a capacidade reguladora das economias nacionais. Os Estados nacionais perdem a capacidade para continuar a regular a esfera da produção, alterando-se profundamente a configuração espacial da produção e a própria configuração das regiões. A expansão extensiva do mercado corre em paralelo à expansão intensiva de novas tecnologias que permitem a superação instantânea de fronteiras. Consequentemente, o espaço post-moderno de Jameson envolve uma incomparável supressão da distância e saturação do espaço que resulta numa inevitável crise da sua representação. Segundo este autor, a dispersão e fragmentação das condições de existência dos sujeitos torna cada vez mais difícil a sua compreensão global. A expansão do capital teve como efeito a disjunção no sujeito da experiência fenomenológica e a representaçăo do mundo, ou melhor, entre o excesso e rapidez das experiências locais e o défice de compreensăo do mundo: "the phenomenological experience of the individual subject becomes limited to a tiny corner of the world, a fixed camera view of a certain section of London or the countryside or whatever. But the truth of that experience no longer coincides with the place in which it takes place. The truth of that limited daily experience of London lies, rather, in India or Jamaica or Hong Kong» (Jameson, 1991: 349).

As sociedades modernas tornaram-se progressivamente espacializadas. Do Panopticon de Bentham ao nascimento do asilo, passando pela elaboração do espaço escolar ou pelo planeamento urbano, o que se evidencia é o grande confinamento, uma forma de classificar e localizar os indivíduos em lugares reconhecíveis. A importância que o regard tem neste projecto de espacializaçăo é central na compreensăo dos dispositivos de poder que nele se inscrevem. Na verdade não parece possível fazê-lo apenas a partir dos movimentos de capital e das distribuições na geografia, introduzindo também o papel das tecnologias demográficas, médicas e pedagógicas. No encalce de tal tecnologia de construção do espaço moderno, Foucault passa do grande confinamento, apoiado na centralizaçăo do poder de classificar, para a noção de distribuição que torna coextensivo a todo o espaço social a localização dos indivíduos submetidos a um registo e à sua monitorização. Tal capacidade de construir matrizes de distribuição é designada em Deleuze por cartografia da organização do espaço social e em Foucault por diagrama: «já vimos que os relacionamentos de forças ou de poder eram microfisicos, estratégicos, multipontuais, difusos, que eles determinavam singularidades e constituiam funçōes puras. O diagrama, ou a máquina abstracta, é o mapa dos relacionamentos de forças, mapa da densidade, da 
intensidade, que procede por ligações primárias não localizáveis e que passa a cada instante por todo e qualquer ponto, 'ou antes por por toda e qualquer relação entre um ponto e outro's (Deleuze, 1998: 61).

Esta relação entre um ponto e outro do diagrama levará Deleuze à conhecida nomadologia que contrapōe nómadas e Estado. Os primeiros, ocupam um espaço liso sem contagem ou mediçăo prévia; os segundos, contam e medem o espaço para depois o ocuparem. Todavia, o espaço liso năo contém em si próprio princípios emancipadores, apenas as condiçōes para novos itinerários, novos ritmos, novos obstáculos para os nómadas. O nomadismo pode ser de inclusão ou de exclusăo: há os que circulam pelos pontos determinados pelos mapas do espaço estriado e os que são empurrados ou escolhem as margens desse espaço, em busca do espaço liso. No nomadismo de inclusão as referências dos mapas cognitivos são descontínuas e convencionais: categorização profissional e disciplinar dos professores; organização do saber em disciplinas; graduação e homegeneização da transição dentro do espaço escolar. No nomadismo de exclusão as referências dos mapas cognitivos são contínuas, em construção e, frequentemente, anómicas: rejeição emotiva da escola; abandono escolar; absentismo escolar por efeito das convivialidades grupais; insucesso escolar repetido, sem abandono e associada a uma atitude de satisfação com a escola (Pais, 1998); prolongamento das trajectórias escolares como fuga ao desemprego.

A virtualidade deste tipo de abordagem consiste na possibilidade de articular a análise estrutural do discurso e a análise fenomenológica. A separação destes dois tipos de análise conduziu no passado a formulaçōes do discurso enquanto imanaçôes da subjectividade pura e a interpretações da fenomenologia como realidade exterior aos indivíduos. $\mathrm{O}$ sentido que os indivíduos davam ao mundo era tido como o completamento necessário ao desconhecimento correlativo que tinham dele; enquanto a realidade Ihes aparecia demasiadamente fragmentada para que pudesse constituir-se na sua consciência plena. Na descoincidência trabalharam as oposiçōes clássicas da sociologia: estrutura-actores e sistema-accção. Nos mapas cognitivos e na sua incompletude, promovida pela interpretação nómada, surge uma oportunidade de iniciar uma «conversa sempre inacabada entre a representação do que somos e a orientação que buscamos» (Santos, 1988: 168). E deste modo tentar escapar ao círculo hermenêutico baseado na autocompreensão dos actores. A genealogia da escola secundária portuguesa que procede sacrifica o sujeito do conhecimento em favor do regime de verdade que os transforma em sujeitos cognoscentes. A perspectiva de uma autoconsciência sistémica da globalidade, com um centro no sujeito, é substituída pelo carácter acêntrico da multiplicidade de espaços processuais. 
(Página deixada propositadamente em branco) 


\section{SEGUNDA PARTE}

\section{$\bullet$}

O Governo da EducAÇÃo

EM PORTUgAL 
(Página deixada propositadamente em branco) 


\section{CAPÍtulo IV}

\section{A ARQUEOLOGIA DO GOVERNO DA EDUCAÇÃO: A VONTADE DE CONHECER PARA DOMINAR A SITUAÇÃO}

1. O nó górdio da expansão do sistema: a construçāo escolar

2. A crise institucional e a contingência burocrática

3. Governar um sistema calculável: as estatísticas e o planeamento

4. A despolitização das políticas educativas e o ciclo dos planificadores

O sistema educativo português viveu no período em apreço uma contradiçăo básica entre autonomia institucional, própria de um sistema baseado em direitos, e heteronomia, própria de um sistema onde se cruzam diferentes espaços estruturais. De entre estes, o espaço produtivo foi o que mais contribuiu para que a gestão desta tensão se manifestasse enquanto crise institucional. B. Sousa Santos (1994: 166) sintetizou de forma exemplar o significado da crise institucional no caso da universidade: «há uma crise institucional sempre que uma dada condição social estável e auto-sustentada deixa de poder garantir os pressupostos que asseguram a sua reprodução». A escola secundária portuguesa de post-1974 sofreu uma crise institucional porque o modelo organizativo vigente foi posto em causa por dentro e por fora do Estado. Por dentro, surgiram propostas para uma maior flexibilidade estrutural, articuladas a partir das noções de autonomia, descentralização e regionalização. Por fora, emergiram sugestões de um novo isomorfismo: em substituição da tradicional comparação com os modos de organização da administração pública propunha-se o mimetismo com outras instituiçōes, especialmente as que agiam no mercado, apresentadas como mais eficazes e eficientes. A crise do Estado-Providência tem diversas facetas tendo sido estudada de vários pontos de vista. Interessa-nos sublinhar neste capítulo, entre outros, um dos seus aspectos que designamos por aumento dos níveis de contingência burocrática. 


\section{O nó górdio da expansão do sistema: a construção escolar}

A complexidade da crise institucional só é completamente discernivel quando apreendida em simultâneo com as restantes crises de legitimidade e hegemonia da escola secundária que serăo tratadas em capítulos seguintes. Basta-nos aqui recordar que a crise institucional da escola anda a par da crise do Estado-Providência e da crise de produtividade, particularmente nos países do centro capitalista. A contingência burocrática resulta da enorme proliferação da administração pública. A expansão dos direitos sociais provoca o aumento da burocracia estatal. Com efeito, a maioria das políticas sociais não se limita a dispêndios de dinheiro em bens sociais e pressupõem a criação de estruturas administrativas destinadas à sua execução. Em consequência, cada sector administrativo do Estado tende a criar uma certa autonomia que torna muito difícil a coordenação central da actividade administrativa do Estado. Esta autonomia relativa atinge por vezes um tal grau que alguns autores falam mesmo na existência de micro-estados dentro do Estado (Santos, 1990). Para se ter uma ideia deste fenómeno basta recordar que o processo de desconcentração do Ministério da Educação com a criação das Direcções Regionais e das Coordenações de Área Educativa fez crescer a administração em cerca de mais 2500 funcionários. Os conflitos de competência de decisão que têm origem nestes três níveis hierárquicos e as decisōes contraditórias que com frequência chegam às escolas ilustram bem a ideia que pretendemos demonstrar.

Para o desenvolvimento do nosso argumento interessa-nos destacar a influência confluente de alguns destes factores na redefinição das racionalidades e tecnologias de decisão de política educativa em Portugal num período de expansão da escola secundária de massas. Tomaremos como estudo de caso o planeamento da rede escolar, um dos aspectos mais críticos dos anos de expansão do ensino secundário. $E$ isto porque na política de rede escolar ganha maior visibilidade a sobreposição das duas variáveis críticas do sistema educativo português: pressionado pelo crescimento das expectativas optimistas relativamente aos diplomas escolares post-obrigatórios, o Estado viu-se obrigado a expandir a rede, sob pena de custos políticos insuportáveis; pressionado pela crise de acumulação, o Estado não mostrava condições financeiras para realizar investimentos sociais que considerava acima dos seus recursos.

Nestas circunstâncias, o período em análise comporta no seu interior os três ciclos tradicionais apresentados pelos especialistas de planeamento para dividirem os sistemas educativos (Carneiro, 1978):

(1) a fase de expansão, correspondente à explosão de aspirações sociais e educativas: prevalece então o primado da escolarização básica universal e o aumen- 
to da procura dos ensinos post-obrigatórios. Os modelos tradicionais utilizados no planeamento educativo são a determinação da procura social de educação, a previsão das necessidades de mão-de-obra e os cálculos de rendibilidade do investimento educativo. São utilizados preferentemente os modelos quantitativos de inspiração econométrica, de optimização ou de simulaçăo.

(2) a fase da qualidade do ensino, correspondente a políticas ambíguas de procura de equidade social nos resultados e de maior exigência avaliativa: prevalece então o primado das diferenças individuais e dos factores institucionais de eficácia. O planeamento educativo socorre-se de modelos de simulação sistémica, das teorias da decisão e dos modelos probabilísticos. No planeamento da rede escolar emerge com importância crescente o microplaneamento.

(3) a fase da relevância, correspondente à fase dominante na maioria dos sistemas educativos que estão pressionados pela crise económica e por orçamentos públicos insuficientes. Prevalece a procura de articulações com o sistema produtivo e tecnológico. O instrumento privilegiado é o planeamento estratégico. No planeamento da rede escolar, a carta escolar pretende responder simultaneamente a problemas de microplaneamento e de intervenção estratégica.

Devido às características específicas do sistema educativo português estas fases não se apresentam sequencialmente mas antes sobrepostas. Para comprovar esta tese apresentaremos as principais características dos instrumentos de planeamento da rede escolar entre 1974 e 1991 (ver quadros nas páginas seguintes).

\section{Ficheiro de estabelecimentos de ensino}

A utilização dos ficheiros de estabelecimentos e do Inventário de Carências entre 1975 e o final da década de 80 revela uma das características dominante e recorrente da administração educativa em Portugal: a construção de um saber que reduza a padrōes únicos e comparáveis a multiplicidade dos territórios sujeitos à administração. Por isso, cada edifício é considerado como unidade autónoma e independente. Supõe-se que os equipamentos são intermutáveis e que oferta e procura são variáveis independentes. Conhecida a situação exacta do parque, cabe ao Estado regular a oferta de acordo com uma racional ocupação do espaço nacional. Concretiza-se deste modo a sua racionalidade primeira: numa administraçăo burocrática-legal a eficiência depende da subordinação constante das acções a premissas. A relação de confiança assim instituída define idealmente os ouputs como uma consequência racionalmente calculável, utilizável por toda a administraçăo, das normas jurídicas, dos programas e dos procedimentos. É neste pressuposto que o IV Governo Provisório, 
Quadro 7 - Instrumentos de Planeamento dos Equipamentos Educativos no período 1974-1991

\begin{tabular}{|c|c|c|c|c|}
\hline & $\begin{array}{c}\text { FICHEIRO DE } \\
\text { ESTABELECIMENTOS } \\
\text { DE ENSINO } \\
1975-1978\end{array}$ & $\begin{array}{c}\text { INVENTÁRIO DE CARÊNCIAS } \\
\text { EM INSTALAÇŌES } \\
1977-1990 \\
\text { (DESP. } 80 / 78 \text { DE } 14 \text { DE ABRIL) }\end{array}$ & $\begin{array}{c}\text { DESENVOLVIMENTO REGIONAL } \\
\text { DE EQUIPAMENTOS EDUCATIVOS } \\
1981-1984 \\
\text { (PROJECTO OCDE-PEB) }\end{array}$ & $\begin{array}{c}\text { CARTA ESCOLAR } \\
1989 \\
\text { (DESP.28/SERE/SEAM/88) }\end{array}$ \\
\hline METÁFORA & $\begin{array}{l}\text { Cartografia [Pequena escala] } \\
1: 25000 \text { (SCE) } \\
1: 5000 \text { (IGC) } \\
\text { Quadriculagem } \\
\text { Define posiçôes }\end{array}$ & $\begin{array}{l}\text { Cartografia [Escala média] } \\
1 / 500000 \\
\text { Rede } \\
\text { Micro-ordenamento }\end{array}$ & $\begin{array}{l}\text { Cartografia [Escala média] } \\
\text { Define movimentos } \\
\text { Malha } \\
\text { Zonas de influência }\end{array}$ & $\begin{array}{l}\text { Cartografia [Escala média] } \\
\text { Território } \\
\text { Satelização } \\
\text { Movimentos } \\
\text { Flexibilidade }\end{array}$ \\
\hline $\begin{array}{l}\text { RACIONALIDADES } \\
\text { DE PLANEAMENTO }\end{array}$ & $\begin{array}{l}\text { - Quantas escolas } \\
\text { - Localizaçắo } \\
\text { - Tipologia das escolas } \\
\text { - Quantos alunos e professores }\end{array}$ & $\begin{array}{l}\text { - Análise sistémica } \\
\text { - Mecanismos de interacçáo } \\
\text { - Controlo } \\
\text { - Centrípeto } \\
\text { - Estática: não integra os } \\
\text { fenómenos migratórios } \\
\text { - Probabilistico }\end{array}$ & $\begin{array}{l}\text { - Análise sistémica } \\
\text { - Centrífugo } \\
\text { - Recusa inicial da lógica } \\
\text { custo-beneficios } \\
\text { - Probabilistica/ hipóteses }\end{array}$ & $\begin{array}{l}\text { - Planeamento estratégico } \\
\text { - Cenários } \\
\text { - Custo-benefícios } \\
\text { - Diversidade } \\
\text { - Flexibilidade } \\
\text { - Complementaridade }\end{array}$ \\
\hline $\begin{array}{c}\text { UNIDADE } \\
\text { ADMINISTRATIVA }\end{array}$ & $\begin{array}{l}\text { - Áreas Metropolitanas de } \\
\text { Lisboa e Porto } \\
\text { Minho } \\
\text { Douro e Trás-os-Montes } \\
\text { Beiras } \\
\text { Estremadura e Vale do Tejo } \\
\text { Alentejo } \\
\text { Algarve }\end{array}$ & $\begin{array}{l}\text { - Agrupamentos de Municípios } \\
\text { - Distrito } \\
\text { - Concelho }\end{array}$ & $\begin{array}{l}\text { - Regional } \\
\text { - Distrito }\end{array}$ & $\begin{array}{l}\text { - Regional } \\
\text { - Concelho }\end{array}$ \\
\hline $\begin{array}{l}\text { ESTABELECIMENTO } \\
\text { DE ENSINO }\end{array}$ & $\begin{array}{l}\text { - «nidade constituida por um ou mais } \\
\text { edificios agrupando alunos onde Ihes }\end{array}$ & $\begin{array}{l}\text { - Infra-estrutura material e técnica } \\
\text { destinada ao ensino, que serve uma }\end{array}$ & $\begin{array}{l}\text { - O termo equipamento engloba } \\
\text { igualmente diversos serviços }\end{array}$ & $\begin{array}{l}\text { - ¿Centro ou elo de uma rede } \\
\text { dispersa de locais de ensino }\end{array}$ \\
\hline
\end{tabular}




\begin{tabular}{|c|c|c|c|c|}
\hline $\begin{array}{l}\text { ESTABELECIMENTO } \\
\text { DE ENSINO }\end{array}$ & $\begin{array}{l}\text { é ministrado o ensino por um ou mais } \\
\text { professores» }\end{array}$ & $\begin{array}{l}\text { mesma unidade geográfica segundo } \\
\text { a sua localizaçăo e a proximidade } \\
\text { da populaçăo escolarizável. }\end{array}$ & $\begin{array}{l}\text { através dos quais a comunidade } \\
\text { (compreendendo, ela própria, as } \\
\text { crianças em idade escolar) } \\
\text { procura, a satisfação das } \\
\text { necessidades sociais - serviços } \\
\text { de ensino, bibliotecas, momentos } \\
\text { livres, serviços médicos, } \\
\text { serviços sociais, compreendendo } \\
\text { os serviços de alojamento» } \\
\text { (In Relatorio do Colóquio } \\
\text { A escola e a comunidade: } \\
\text { os equipamentos na } \\
\text { dinámica urbana) }\end{array}$ & $\begin{array}{l}\text { e formaçăo, e num espaço } \\
\text { de mútiplas e diversas } \\
\text { actividades de cariz } \\
\text { comunitário» (In Carta Escolar) }\end{array}$ \\
\hline $\begin{array}{l}\text { CRITÉRIOS } \\
\text { DE PRIMAZIA }\end{array}$ & (näo aplicável) & $\begin{array}{l}\text { - Sobrelotação. Fundamenta a } \\
\text { escolha das localidades e das } \\
\text { opçōes que deverăo existir no } \\
\text { ămbito do } 2{ }^{\circ} \text { projecto de } \\
\text { acordo com o Banco Mundial } \\
\text { que se ocupa da construçăo } \\
\text { dos espaços oficinais para os } \\
\text { cursos complementares do } \\
\text { Ensino Secundário: «adoptou-se } \\
\text { como critério fundamental para } \\
\text { distribuiçāo das áreas de estudo } \\
\text { o peso dos sectores de actividade } \\
\text { na regiåo, o que poderá implicar } \\
\text { importantes modificaçōes em } \\
\text { relaçăo à actual estrutura. } \\
\text { Segundo este critério diminuirá } \\
\text { bastante o papel dos estudos } \\
\text { humanísticos e aumentarāo os } \\
\text { cursos do sector primário e do } \\
\text { sector secundário. Numa futura }\end{array}$ & $\begin{array}{l}\text { - Relaçāo Professor/Aluno } \\
\text { - Reduçăo do tempo de } \\
\text { deslocaçăo escola-habitação } \\
\text { - Adequaçăo dos edificios às } \\
\text { exigências mínimas } \\
\text { estabelecidas nos Programas } \\
\text { - Integração de outros } \\
\text { equipamentos (levantamento } \\
\text { de infra-estruturas sociais) }\end{array}$ & $\begin{array}{l}\text { - Irradiação-Acessibilidade } \\
\text { - Integração nas lógicas } \\
\text { urbanas e regionais } \\
\text { - Inadaptaçáo entre oferta e } \\
\text { procura (ausência de escolas, } \\
\text { desarticulação da rede, } \\
\text { inapropriada dimensão das } \\
\text { unidades). }\end{array}$ \\
\hline
\end{tabular}




\begin{tabular}{|c|c|c|c|c|}
\hline $\begin{array}{l}\text { CRITÉRIOS } \\
\text { DE PRIMAZIA }\end{array}$ & & $\begin{array}{l}\text { fase do trabalho será necessário } \\
\text { encontrar medidas compensatórias } \\
\text { que pudessem permitir uma } \\
\text { evoluçăo suave para estas } \\
\text { transformaçōes" (In Estudo da Rede } \\
\text { dos Cursos Complementares em } \\
\text { funçăo da situaçăo socioeconómica } \\
\text { e do inventário de carências em } \\
\text { instalaçōes escolares - Zona Norte, } \\
\text { João Alpiarça, GEP, 1978, p. I). }\end{array}$ & & \\
\hline INDICADORES & $\begin{array}{l}137 \text { variáveis } \\
\text { - Considera entre outras: salas e sua } \\
\text { área média, tempo médio de ocupação, } \\
\text { equipamento didáctico, número de } \\
\text { alunos e de turmas segundo o ano e } \\
\text { número de turmas, número de } \\
\text { professores colocados, categorias } \\
\text { de habilitaçס̋es segundo a lei. }\end{array}$ & $\begin{array}{l}\text { - Distância } \\
\text { - Congestionamento } \\
\text { - Dimensão prevista } \\
\text { - Valor relativo da localidade } \\
\text { - Capacidade descentralizadora } \\
\text { - Hierarquia na descentralização }\end{array}$ & $\begin{array}{l}\text { - Descriçăo física das instalaçōes } \\
\text { - Ingressos por nível } \\
\text { - Repetências } \\
\text { - Abandonos em cada nível } \\
\text { - Percurso dos alunos } \\
\text { - Procura preferencial de escola }\end{array}$ & $\begin{array}{l}\text { - Taxas de ocupaçăo } \\
\text { - Cobertura escolar } \\
\text { - Indice de carência } \\
\text { de infra-estruturas (obtido por } \\
\text { agregação de indicadores de } \\
\text { sobreocupaçāo, subocupação, } \\
\text { estado do parque e evoluçăo } \\
\text { da populaçăo). }\end{array}$ \\
\hline DIVISẢO DO PAISS & $\begin{array}{l}\text { - Divisão Provincial do projecto de } \\
\text { administração Regional do MAl } \\
\text { (Janeiro de 1976) } \\
\text { - Agrupamento de Municípios } \\
\text { - Municipios }\end{array}$ & - Distrito & $\begin{array}{l}\text { - Distrito } \\
\text { - Concelho }\end{array}$ & $\begin{array}{l}\text { - Distrito } \\
\text { - Concelho } \\
\text { - Freguesia }\end{array}$ \\
\hline $\begin{array}{c}\text { TRATAMENTO } \\
\text { ADMINISTRATIVO }\end{array}$ & $\begin{array}{l}\text { - Comissōes de Planeamento Regional } \\
\text { - Comissão de Planeamento Regional } \\
\text { de Lisboa com apoio da divisão de } \\
\text { informática e matemática aplicada } \\
\text { do Gabinete da Área de Sines }\end{array}$ & $\begin{array}{l}\text { - GEP } \\
\text { - MOP/DGCE } \\
\text { - DGAE } \\
\text { - DGEE } \\
\text { - DINE (Departamento } \\
\text { de Inovaçāo, Normas e Estudos) }\end{array}$ & & $\begin{array}{l}\text { - GEP } \\
\text { - DRE } \\
\text { - CCR } \\
\text { - Autarquias } \\
\text { - Associaçס̄es de pais } \\
\text { e encarregados de educaçăo }\end{array}$ \\
\hline
\end{tabular}


por intermédio do Secretário de Estado da Administração Escolar, decide criar um ficheiro de estabelecimentos de ensino, que justifica do seguinte modo: "É em função do ano escolar que se estimam o número de alunos, o número de professores a atribuir a cada escola, se procede à previsão das necessidades de edifícios e equipamento diverso, enfim se define a política de curto prazo para o sector. É fundamental, por isso, que se conheçam pelo menos com uma relativa antecedência do início de cada ano escolar, os valores que irăo determinar as decisōes a tomar» (MAl, Comissōes de Planeamento Regional, 1978: 12). E prossegue mais adiante com a apresentação da matriz de base do ficheiro de estabelecimentos a criar: "o sistema desenvolvido no Gabinete da Área de Sines permite implementar em computador informaçăo geocodificada pela introdução de sistemas de quadrículas, e consiste fundamentalmente em associar a cada quadrícula duma cobertura da região em estudo todas as entidades que nela estejam contidas, utilizando para isso apontadores» (Idem, Ibidem, p. 13). Nesta perspectiva, o planeamento imagina o futuro em semelhança do passado, extrapolando os elementos quantitativos da sua história para o presente.

\section{Inventário de carências em instalações}

O inventário de carências continua a privilegiar a metáfora do Estado-Nação centralizado por intermédio da cartografia de divisăo administrativa do território. Desta feita, a quadriculagem tradicional que privilegia um centro é substituída pela metáfora da Rede. Esta estabelece vários centros administrativos que, embora centrífugos na sua irradiação, têm por finalidade ligar os elementos dispersos no território. A noção de rede não se restringe a uma utilização meramente técnica e logística tal qual se apresenta na definição operacional de Rede escolar: «entende-se como a distribuição no território dos estabelecimentos de ensino e suas respectivas ligações» (in Critérios de Planeamento da Rede Escolar, GEP, 1990, p. 13). Este é um ponto de partida essencial para perceber a ambiguidade da noção, estado que the assegura uma utilizaçăo metafórica em diversos conjuntos discursivos, frequentemente com significados contraditórios. Se conjugarmos as duas dimensões que presentificam a definiçăo de rede escolar verificamos que a dimensăo geográfica remete para um conjunto de lugares dispersos e a dimensão simbólica estabelece ligações imaginárias incertas em torno de um equipamento social. Contudo, a dispersão da distribuição e a incerteza das ligações tem uma ordem: as necessidades a que pretende responder e as finalidades que persegue são ambas formuladas por decisores institucionais. Como bem sublinha Kohn (1994: 112), a criaçăo do dispositivo em rede precede a chegada dos seus utilizadores: «ce sont eux qui instaurent, officiellement, par voie 
hiérarchique, les cadres pour la mise en place des actions réticulaires correspondant aux objectifs qu'ils annoncent; les membres du réseau fournissent aux destinataires les services préconisés». Em última instância, a rede não é um espaço horizontal, de relações niveladas e com reciprocidade de poder, mas antes uma estrutura hierárquica, enquadrada por procedimentos administrativos que determinam os níveis e o estatuto de cada um segundo os níveis e os territórios que ocupam. É na rede que deve residir a ordem, como ordem do sistema. Todos os mecanismos de legitimação do sistema educativo têm como pressuposto a pretensão de encontrar essa ordem. É isto que explica que a construção escolar surja ao mesmo tempo que o aperfeiçoamento das estatísticas como eixo central do planeamento educativo, constituindo este duplo surgimento um campo, o do planeamento, em que a aliança entre o normativo e o teórico, o jurídico e o científico revelam a sua máxima necessidade e complexidade. Situamos este duplo surgimento na Conferência da OCDE, realizada em Outubro de 1961, em Washington, debaixo da influência das políticas de crescimento económico e da exportação do modelo da modernização para os países em vias de desenvolvimento. ${ }^{(61)}$

A rede identifica posições e determina distribuições; a partir da expressão numérica da população escolarizável - identificada pelo método da evolução demográfica ou pelo método dos fluxos de um ciclo ao outro, tendo por referência os inscritos no primeiro ano de escolaridade, determina a irradiação, a área de drenagem e a área de influência.

O conceito de irradiação imagina os trajectos territoriais do beneficiário do equipamento em função da distância máxima entre a escola e a habitaçăo. O planeamento em rede, ou melhor, a imaginaçăo em rede do planificador constrói um mapa cognitivo que supostamente individualiza os problemas sociais segundo a particularidade de cada caso. Contudo, neste tipo de rede, determinada pelos equipamentos, todas as decisões estão dissociadas dos seus utilizadores, não Ihe restando outra alternativa que não seja a de o utilizar, não o utilizar ou de o abandonar. Alternativas que são

(61) Conferir, a este propósito, Politiques de croissance économique et d'investissement dans I'enseignement, Paris: OCDE, 1965 e Papadopoulos, L'OCDE face a l'Éducation - 1960-1990, Paris: OCDE, 1994). Embora os primeiros afloramentos deste campo, em Portugal, remontem ao Projecto Regional do Mediterrâneo (ver, entre outros, Le projet régional méditerranéen. Rapports par pays: Grèce, Italie, Portugal, Espagne, Turquie, Yougoslavie, Paris: OCDE, 1965) e à criaçăo do Gabinete de Estudos e Planeamento da Acçẩo Educativa, em 1965, as estatísticas portuguesas continuaram a ter grandes dificuldades em acompanhar a introduçâo das novas categorias propostas pela OCDE. Apenas na segunda metade da década de 70 se pode dizer que o campo do planeamento tecnocrático se constituiu em Portugal. 
também reconhecida pelos planificadores, na medida em que os indicadores que 0 planeamento em rede utiliza para compensar os défices da irradiação são, precisamente, a medida das taxas de desperdício (abandonos) e a diferença entre a população escolarizável e a populaçăo escolarizada. Neste caso, estamos perante um planeamento centrípeto, embora o conceito de irradiação sugira muitas vezes o contrário.

A área de drenagem circunscreve o «território cuja área e configuraçăo resultam exclusivamente da aplicação à área em estudo dos valores de irradiação correspodentes a um determinado estabelecimento de ensino" (GEP, 1990: 14). Enquanto a irradiaçăo convoca um registo centrado nos recursos, de contornos circulares, em que se torna central o aproveitamento e o fechamento homeostático, a área de drenagem, pelo contrário, coloca o problema na perspectiva da dissipação, da abertura, da transição ou retenção da população escolar para outros equipamentos. Na origem das perdas e do desinvestimento estaria a falta de articulação e de planeamento. Neste caso estamos diante de um planeamento centrífugo.

Finalmente, a área de influência considera "o território físico e populacional servido em boas condiçōes por um determinado estabelecimento de ensino" (Idem, Ibidem). Segundo este critério deveria verificar-se a compatibilizaçāo entre a extensão da população a escolarizar, os valores de irradiação da escola e a sua capacidade de acolhimento. É a área de influência que melhor condensa a vontade de conjugar as exigências de equidade e as condicionantes financeiras e materiais que a permitem obter. Deste modo, segue-se o princípio segundo o qual cada aluno deveria ter as mesmas possibilidades de escolha dos diferentes níveis de ensino, em especial os níveis obrigatórios, qualquer que seja o seu lugar de residência. $\mathrm{O}$ que pressupõe a possibilidade de o planeamento definir, em definitivo, a melhor localizaçăo para os equipamentos educativos, favorecendo assim o livre jogo da repartição dos alunos pelas diversas fileiras de ensino. Porém, as condicionantes financeiras bem como a desigual possibilidade das diferentes forças de pressão - pais, autarquias, empresários, notáveis locais - influenciarem as decisōes a seu favor, distorce frequentemente o princípio da equidade. Verifica-se, por exemplo, uma similitude muito evidente na evolução das disparidades inter-distritais na realização de estudos pós-obrigatórios quando comparadas com as condiçōes físicas de escolarização. Com efeito, o estudo sobre as Disparidades Regionais dos Niveis de Instrução dos Jovens (CRSE, 1987) apresenta os Distritos de Braga, Viseu, Viana do Castelo, Vila Real e Beja como aqueles em que a diferença é maior para o Distrito de Lisboa, que apresenta a melhor posição quanto à prossecução de estudos pós-obrigatórios, enquanto a Classificação dos Distritos do Continente em Matéria de Condiçōes de Desenvolvimento da Escolarização (GEP, 1982) conclui que são os Distritos de Viana do Castelo, Braga, Porto, Setúbal, 
Coimbra e Bragança como aqueles que apresentam piores condiçōes físicas de escolarizaçăo.

Não obstante, ainda que a distribuição dos recursos humanos, materiais e financeiros fossem equivalentes, subsistiriam desequilibrios inter-regionais. Evidência empírica deste tipo provém dos estudos que se interrogam sobre as desigualdades resultantes do alargamento uniforme dos níveis de escolarizaçăo post-obrigatórios a todo o espaço nacional (Jegouzo e Brangeon, 1976, Paci, 1982, Blaug, 1987). Também segundo o estudo sobre as Disparidades Regionais que vimos utilizando, o desemprego e as migraçōes maciças das populaçōes jovens mais instruídas, das zonas rurais para as zonas urbanas, são dois efeitos visíveis de uma igualdade a montante que se transforma em desigualdade a jusante: «se o efeito da drenagem dos jovens com níveis superiores de instruçăo para os centros urbanos e industriais não for contrariado, podemos prever que as disparidades intradistritais não deixarão de se agravar. Só uma política descentralizada de criação de empregos, exigindo competências especializadas, poderá fixar os jovens com maiores níveis de instrução aos concelhos mais desfavorecidos. De outro modo, o esforço que as diferentes regiōes fizerem (e especialmente as mais desfavorecidas) para assegurar um aumento de escolarizaçăo da sua população residente, reverterá sobretudo em vantagem para as regiões que, no ponto de partida, já eram as mais favorecidas». (CRSE, 1987: 478).

Terão sido estes novos indicadores estatísticos, nunca antes utilizados no sistema educativo português, que consolidaram a passagem de uma problemática centrada nos equipamentos para uma problemática centrada no território. Dito de outro modo, a administração acrescenta às localizações do espaço liso, os deslocamentos sociais do espaço estriado. $\mathrm{O}$ que a obriga a um planeamento menos normativo de onde decorrem os princípios da diversidade, da flexibilidade, da complementaridade e da integraçăo de equipamentos introduzidos pela Carta Escolar a partir de 1989. Na verdade, o princípio da diversidade visa permitir uma ampla gama de soluções tão-só adequadas à natureza local e às especificidades de cada região; o princípio da flexibilidade pretende abrir a planificação a soluções suficientemente versáteis de modo a permitirem sucessivas adaptações aos métodos pedagógicos e à evolução da procura; o princípio da integração resulta directamente da lógica da flexibilidade e visa facilitar a coordenação dos equipamentos educativos no conjunto de outros equipamentos sociais locais; o princípio da complementaridade pressupōe a racionalização dos recursos físicos existentes num determinado território por meio da sua boa articulaçẫo. No seu conjunto, tais princípios questionam a existência mesma de tipologias sem nunca renunciar à sua utilização. No entanto, os dispositivos postos em marcha, ao integrarem o microplaneamento de certos «territórios educativos» no macroplanea- 
mento tradicional, não deixam de deslocar progressivamente o olhar da tecno-estrutura do Ministério para os casos.

O caso é uma espécie de interstício sobrante desta transiçăo no planeamento dos equipamentos educativos. Com efeito, a administração já năo consegue planificar como antes, mas ainda não consegue planificar como quer. Em 1982, é a própria Comissão de Rede Escolar que reconhece no relatório anual os limites do seu planeamento e verifica a opção cada vez mais frequente pela casuística: «em síntese e tendo presente o anexo II verificaram-se no movimento de rede previsto para o triénio de 80/81 a 82/83, três fenómenos fundamentais: 1 . A escassa participação, no total das criações previstas, daquelas que se encontram incluidas no Inventário de carências; 2. O carácter diferenciado da programação decorrente do Inventário, com privilégio para a criação de ensino aos níveis pós-obrigatórios; 3 . O carácter diferenciado da programação sequencial das pressöes locais, com privilégio para o lançamento de um nivel de ensino em estabelecimentos anteriormente providos de um ou mesmo dois níveis antecedentes».

É nesta contradiçăo que, em grande medida, se fundam as sucessivas iniciativas de desconcentração. Esta é uma das formas mais tradicionais de a administração burocrática se adaptar à maior complexidade do meio: à multiplicaçăo e diversificação dos aparelhos destinados a responder a novas solicitaçōes e problemas, corresponde a administração com a diferenciação, mantendo, no entanto, a unidade do Estado e as divisões do território intocadas. Nesta concepção, a descentralização é essencialmente uma tecnologia de repartição de funções que, neste particular, se propõe repartir geograficamente. Sendo esta um fenómeno interno do Estado, não implicando, portanto, o reconhecimento de outras entidades colectivas públicas, reserva-se-lhe o termo desconcentração, introduzido ainda no século XIX por Aucoc ${ }^{(62)}$ em França.

Em Portugal, desde cedo que esta distinção foi acolhida, sendo Marcello Caetano um dos seus principais divulgadores, nas sucessivas ediçōes do Manual de Direito Administrativo. Logo na primeira edição de 1937 escrevia Caetano: "o alargamento da competência de uma autoridade dependente do governo, e que permanece nessa

(62) Segundo Caupers (1993: 256-265), existem razōes suficientes para crer que foi Aucoc que inventou o termo desconcentração para designar as medidas tomadas pela reforma da administração francesa de 1852, distinguindo-as assim de descentralização. Nas conferências sobre administraçăo e direito administrativo, realizadas entre 1862 e 1869, Aucoc reserva o termo desconcentraçăo para os casos em que a direcção e controlo do poder central não é tocado na nova repartiçăo geográfica de funçöes. 
dependência quanto às novas atribuições conferidas, é mera desconcentração ou descongestionamento burocrático dos serviços centrais» (p. 113). Esta distinção entre desconcentração e descentralizaçăo viria a estabilizar e a fixar como principal critério distintivo a personalidade jurídica da instância onde os princípios organizativos são aplicados: sendo o primeiro reservado ao âmbito delimitado pelo quadro global da administração pública e, o segundo, ao quadro interno de cada ente público. Mais recentemente, Caupers (1993: 264) propos uma clarificaçăo da distinçăo, introduzindo o debate em torno da administração autónoma e administração indirecta, que tem alguma relevância para a nossa argumentação posterior: «supomos que se ganharia em clareza se se reservasse o termo descentralização para a administração autónoma (com o âmbito que Ihe fixámos, isto é, abrangendo as autarquias locais e as associações públicas), falando em desconcentração dentro do quadro organizativo do Estado, ou seja, abrangendo tanto a nossa administraçăo directa desconcentrada, como a nossa administração indirecta - que mais não são, como dissemos, do que diferentes técnicas organizativas e jurídicas de prossecução dos interesses públicos da comunidade estadual»). Quanto a esta distinção importa referir ainda que, segundo Freitas do Amaral $(1986,1988)$, as associações públicas, como as ordens, integram a administração indirecta, ao lado dos institutos públicos, por que aquelas não têm por finalidade a defesa dos interesses dos associados e, assim sendo, o Estado pode tomar, se o desejar, a direcção dos interesses públicos confiados à associação. No interior desta lógica não se percebe, aliás, porque razão o autor não estende a tipologia da administração indirecta a outras associaçōes públicas, como as associações de pais ou as associações profissionais e científicas que, não dispondo também de direitos sindicais, se dedicam sobretudo à prossecução de interesses sociais específicos, prolongando ou substituindo o Estado. A esta objecção, responde Caupers com as duas características que afastariam as associaçōes públicas do âmbito da administração indirecta: por um lado, os titulares dos órgãos dirigentes são eleitos pelos membros e năo designados pelos órgãos tutelares, como nos institutos públicos; por outro lado, a definiçăo dos seus objectivos e a orientação da sua acção não são supervisionados pelo governo. Neste debate, os argumentos de Freitas do Amaral parecem aproximar-se mais da nossa própria apreciação sociológica, porque se é verdade que, de um ponto de vista estrito do Direito administrativo, as associaçōes públicas disfrutam de um grau de autonomia maior face ao Estado, também se reconhece que o Estado entrega o prosseguimento de interesses públicos às associaçōes, a troco da protecção dos interesses particulares e sectoriais dos seus membros. E assim se formam zonas mais vastas da governamentalidade, onde as fronteiras entre estado e năo-estado deixam de ser pertinentes, por que o estado abdica de parte do monopólio da defini- 
ção do interesse público e a sociedade civil abdica de parte das suas reivindicações. É no espaço criado por esta dupla abdicaçăo que surge a noçăo de autonomia e novas formas de poder. Novas formas de poder que haviam sofrido já uma extensão importante com o poder disciplinar do século XVIII, assente na normalização proporcionada pela institucionalização das diferentes ciências sociais e humanas (Foucault, 1975) e com o poder governamental, assente na positividade e produtividade do autogoverno dos indivíduos e dos grupos no quadro do bom governo da populaçăo. É nesta ampliação do conceito de poder que reside a nossa principal crítica aos fundamentos da distinção entre Estado e sociedade civil, nos termos da qual o Estado é poder e a sociedade civil liberdade e autonomia. De qualquer modo, tanto a extensão que Freitas do Amaral faz do conceito de administração indirecta, quanto a limitação proposta por Caupers são a expressão, no Direito, de uma constataçăo sociológica mais geral, com particular visibilidade em Portugal, segundo a qual é cada vez mais difícil determinar onde o Estado acaba e a sociedade civil começa. Neste particular, o défice de hegemonia do Estado português e a heterogeneidade dos espaços estruturais da sociedade civil — em especial o da produção e o doméstico (Santos, 1994: 113-117) — tendem a criar interdependências muito grandes no seu processo de reprodução. São também estas interdependências que desaconselham uma visăo tão nominalista como a que nos é proposta pelo modelo estadualista do Direito. Donde se conclui que este pequeno excurso serve nāo tanto para situar a nossa posiçăo em relaçăo ao debate interno do direito administrativo, mas para revelar como a dicotomia Estado-sociedade civil é contraditória nos seus termos e arbitrária nas suas fronteiras. Contraditória porque, como reconhece Caupers, o Estado já não é o titular do monopólio do interesse público, seja porque é considerado como um inimigo da liberdade individual, seja porque os interesses particulares se foram impondo ao Estado na definição do interesse público; arbitrária, porque o grau de delegação, autonomia ou cooptação na definição do interesse público não é intrínseco aos objectivos do associativismo da sociedade civil, mas depende do monopólio da lei para a sua definição. É este carácter arbitrário da definição político-jurídica da noção de autonomia que faz dela uma espécie de boite d'outils, utilizada pelos actores sociais na recomposição das regiōes de poder, com pouca utilidade analítica, a não ser a que nos pode ser proporcionada pelo seu deslocamento para o próprio campo em estudo.

\section{Desenvolvimento regional de equipamentos educativos}

O Projecto de desenvolvimento regional de equipamentos educativos (PDREE), lançado em 1981 e integrado no PEB-OCDE, situa a questão da desconcentração no 
plano do território. Sendo o território o espaço significante (Lefebvre, 1974) em que se projecta o poder do Estado, podemos considerar que esta é uma das primeiras iniciativas, no âmbito do Ministério da Educaçāo, a enunciar directamente a ideia de gestão do espaço. Até então, todas as iniciativas que visavam a desconcentração do Ministério faziam uma divisão do espaço nacional a partir de meros exercícios abstractos, derivando as unidades orgânicas desconcentradas das funçōes e da estrutura existente, entretanto multiplicada e tornada mais complexa, numa lógica de diferenciação da administração pública.

O que o PDREE acentua, pelo contrário, é a repartição territorial do poder, fazendo depender a concretizaçăo efectiva do projecto da detenção da titularidade de poderes públicos por parte de instâncias sociais legitimadas pelo voto. Se estas fossem concretizadas na forma de Autarquias regionais eleitas, pressupunha-se assim uma operação jurídico-política que fizesse coexistir no mesmo território diversas divisões espaciais, ambas com fontes de legitimidade próprias. É nesta desmultiplicação funcional do território (Caupers, 1993) que às divisōes tradicionais do território Distrito, Concelho, Município, Freguesia - se vem acrescentar a Região política. Porque a sua criação implica a atribuição de funções políticas e não meramente administrativas, o projecto tenta criar uma visão do território de baixo para cima. $E$ por isso mesmo que à noçăo de espaço reticular se acrescenta a metáfora da malha de equipamentos que nos sugere, na linha de Deleuze (1980, 1997), a noção de espaço estriado. Enquanto Popper lembra que a malha nunca é tão apertada que não deixe lugar ao indeterminismo, Deleuze propõe que a malha represente os movimentos e a rede a estrutura sólida. Embora Popper considere que as tentativas para «examinar exaustivamente o mundo através das nossas redes» se confrontam sempre com a «malha que há-de sempre deixar fugir algum peixe miúdo: haverá sempre folga suficiente para o indeterminismo» (Popper, 1988: 62), pode sempre admitir-se uma malha nos limites do fechamento. Neste caso, a malha não apresentaria vantagens quando comparada à rede. Como vimos em capítulo anterior, a representaçăo do

198 espaço estriado é mais sensível aos movimentos do que a representação reticular; é mais adaptada à relação orgânica com a procura do que o espaço reticular; suscita maior atenção aos equipamentos já existentes e às possibilidades de relação entre eles, do que à inserção de novos. Em síntese, a metáfora da malha aceita a existência prévia de equipamentos e de relações sociais que formam a trama onde será possível entretecer novas relações e novos equipamentos; enquanto a metáfora da rede estabelece o primado da carência e do seu preenchimento como condição prévia ao funcionamento das relações entre os seus utilizadores. Também por esta particular forma de introduzir o tema do espaço no planeamento da rede, a noção de malha, 
derivada depois em bacia de formação e outras, terá efeitos estruturantes importantes na futura articulação das noções de autonomia e de comunidade escolar.

Não se deve, em todo o caso, pensar que este projecto obteve impacto instrumental significativo nos modos operacionais de planear os equipamentos educativos. Seria igualmente inexacto supor que a sua influência imprimiu alteraçōes de fundo nas concepções de planeamento ainda dominantes no sistema educativo português. Mas ele é, concerteza, a iniciativa mais consequente para concretizar algumas das reflexões e medidas que se vinham tomando no interior do PEB-OCDE, embora progressivamente mitigados pela ausência de reformas políticas que permitissem a regionalização administrativa ou politica. Dentre as medidas mais insistentemente preconizadas pelo Programa descentralizado de construção escolar da OCDE destacamos três delas (OCDE, 1982, Ader, 1983) :

- é desejável que as decisōes administrativas sobre os equipamentos educativos sejam tomadas no mesmo espaço em que se desenvolvem as actividades educativas, económicas e sociais dos seus destinatários, fazendo apelo à participação de cada comunidade: propōe-se assim a participação directa dos utilizadores nas decisōes referentes à rede, às adaptações de edifícios ou de construção de novos, bem como a sua implicação na gestão e conservação;

- só assim as comunidades poderão apropriar-se dos espaços escolares, integrando-os no conjunto de outros equipamentos sociais, numa perspectiva de utilização polivalente (formação profissional, actividades de lazer, centros de terceira idade, etc): propõe-se neste âmbito a coordenação de todos os equipamentos numa perspectiva de redistribuiçăo, reciclagem e transformaçăo do stock existente, de modo a obter reduçáo de custos recorrentes;

- é preciso promover a negociação politica entre autoridades locais, regionais e nacionais de modo a reduzir as disparidades regionais de oferta de educação: propōe-se a criação de dispositivos de gestão territorial que permitam a resolução de conflitos entre comunidades vizinhas e a salvaguarda dos interesses nacionais.

Consegue-se perceber nestas propostas as transformações de natureza do poder estatal, por força da crise financeira do Estado. Em boa verdade, o colóquio de Lochem (MHOP/DGCE, 1982: 5-17) tem como pano de fundo a solução do conflito entre crescimento das necessidades e diminuição dos recursos, solução tanto mais urgente nos países, como Portugal, em que o crescimento das necessidades é multiplicado por uma situação particularmente deficitária e distorcida de oferta educativa e a diminui- 
ção dos recursos é ampliada pelo seu estatuto periférico. Pode entăo argumentar-se que as reformas propostas pela OCDE se destinam a cumprir um duplo objectivo: contribuem para reduzir a crise financeira do Estado e amortecem o impacto da sua perda de legitimidade, resultante do desinvestimento nas políticas públicas.

$\mathrm{O}$ argumento da crise financeira tem sido desenvolvido por vários autores (Offe, 1975, Santos, 1990) a partir dos ciclos de acumulação-legitimação. Terminado o ciclo virtuoso da economia e as condições de valorização do capital que haviam permitido até ao início da década de 70 o reforço dos direitos sociais e, portanto, da componente de legitimaçăo, seguiu-se um ciclo de crise económica que levou o Estado a desinvestir selectivamente nas políticas sociais, pondo assim em risco a consensualização da sua acção. Segundo o argumento da crise financeira, as propostas de participação, comunitarização e negociação da OCDE destinar-se-iam a distribuir os encargos financeiros por diversas instâncias sociais, incluindo a administração autónoma representada pelas autarquias, tornando assim possivel os cortes nas despesas públicas sem grandes custos políticos.

No entanto, o argumento da descentralização, enquanto amortecedor da crise financeira do estado, tem uma fragilidade que consiste em saber se a construçăo integrada de equipamentos é realmente menos onerosa, facto que não está comprovado, ou se se destina sobretudo a criar novas zonas de incerteza e de mobilização política que compensem a escassez de distribuição de recursos materiais com o aumento da distribuição de recursos políticos e simbólicos. Esta objecção tem uma dupla pertinência na situação portuguesa, a avaliar pela baixa intensidade de utilização da estratégia de gestão integrada dos recursos materiais e pela amplitude elevada com que o apelo da autonomia, participaçāo e comunidade escolar sobreveio. ${ }^{(63)}$

(63) Com efeito, como descreveremos mais tarde neste capítulo, a gestão integrada é a excepçăo, enquanto as reformas que prevêem a participaçăo dos pais e das comunidades na vida escolar é a regra. Esta mesma tendência se detecta em outros domínios sociais como o direito, a saúde e a cultura. Para o caso do direito, B. Sousa Santos (1982: 25) analisa de forma concorrente as reformas da informalização e da comunitarizaçăo da justiça, nos seguintes termos: «dado que a expansão estatal tomou em geral a forma de criação de novos direitos sociais, qualquer corte nos gastos produzirá mudanças nas relações de repressão/legitimação entre o Estado capitalista e as classes trabalhadoras. Confrontado com uma crise de legitimação, o Estado recorre às reformas da informalizaçāo e da comunitarização da justiça (e aos cortes de gastos públicos que elas eventualmente permitem) porque elas apelam para a participação popular, a auto-gestão da vida colectiva, o renascimento das comunidades reais, a vida social consensual, e a luta contra a burocracia e, por essa via, podem compensar a nivel ideológico ou simbólico a perda da legitimidade resultante de cortes nas despesas públicas». 
Numa visăo tradicional da análise das políticas educativas este projecto seria considerado relativamente marginal nas práticas repetitivas da administração, desde logo porque, em Portugal, o modelo funcional proposto năo tem correspondência nas estruturas políticas que o acolhem. Como se sabe, apenas as construções escolares do primeiro ciclo foram delegadas para as autarquias locais, mantendo-se os outros níveis concentrados na administração central. Tal descoincidência é, contudo, uma vantagem, na medida em que integra como problematizações técnicas, opçōes de planeamento que dependem sobretudo de tecnologias políticas. E aqui reside um dos principais mecanismos de protecção da administração pública portuguesa contra os excessos imprevisiveis da politização. Ao introduzir as novas racionalidades sob o formato organizacional de projectos ou de programas, ainda que contraditórias com a vontade politica do momento, pode prevenir ou domesticar potenciais conflitos futuros numa estrutura excêntrica aos fluxos normativos principais da administração.

Neste caso específico, o projecto leva mais longe a prevenção do conflito centro-periferia, que já vinha sendo enunciado desde 1975, inserindo-o e circunscrevendo-o à administraçăo. Quando o meio social a governar é de reduzida dimensăo e complexidade - como é o caso dos sistema educativo português até ao final da década de 60 - a diferenciaçăo centro-periferia tem pouco relevo. A projecçăo das medidas políticas pode ser imaginada a partir de um centro que se reproduz em cascata num território homólogo. Quando o meio se torna mais extenso e arborescente, a diferenciaçăo centro-periferia serve para pôr em relevo a diversidade de condições em que as decisões tomadas no centro devem ser aplicadas, dramatizando ou atenuando a turbulência do meio, na medida das necessidades próprias de controlo. Torna-se então difícil escolher a dimensão e o estatuto do espaço aonde as decisões administrativas unitárias devem atingir os cidadãos, localizados que estăo em espaços de acçăo heterogéneos. Não porque a heterogeneidade seja uma ameaça de dissensão, como veremos nos casos analisados, mas porque constitui um desafio à racionalidade interna do Estado. E daí, o centro, que é a ordem, a regra, a conformidade e o interesse geral, imaginar uma periferia que é a excepção, o desvio e o interesse particular. A contraposiçăo centro-periferia não é assim uma construção da periferia social, uma resistência desta a um estado-maior constrangedor, até porque o Estado năo teve que adaptar-se a agendas políticas postas de fora das suas próprias racionalidades, mas é antes uma nova forma de o centro representar e regular as condições de domínio do espaço significante.

As condições de construção da periferia săo muito particulares e nunca assumiram, no caso dos equipamentos educativos, senão residualmente, as características de informalização típicas da acção comunitária. Contudo, existem alguns exemplos, 
e o Núcleo de Escolas do Oeste (NEO) é um deles, da tentativa de cooptar o poder normativo produzido nas relações institucionais periféricas, articulando-o e reintroduzindo-o nas relações com o centro. Na medida em que o Estado consegue, por este meio, controlar acçōes dificilmente reguláveis pelos meios burocráticos tradicionais ao seu dispor e integrar mais recursos informacionais decorrentes da iniciativa local, está de facto a expandir-se. Mesmo que para isso tenha que se abrir à fragmentação e à adocracia limitada, que surge tantas vezes como um processo de retracção ou, ao menos, de invisibilidade da administração. É muito significativo, quanto a este propósito, a análise que o GEP faz, no lançamento do ano lectivo de 1976/77. Justifica nos seguintes termos a criação de delegados distritais do GEP: «afigura-se que a situaçăo actual é caracterizada por um divórcio - que, frequentemente, vai até à hostilidade - entre os estabelecimentos de ensino e aquilo que estes chamam ao MEIC — os serviços centrais - esquecendo-se os primeiros de que também são MEIC (...) Por outro lado, esta situação contribui para alimentar o círculo vicioso em que o MEIC cada vez se envolve mais: o divórcio com os estabelecimentos de ensino e a atitude destes aumenta os problemas e as dificuldades com que se debatem os serviços centrais e estes, em consequência, cada vez têm menor capacidade para promover e aguentar o diálogo, talvez, em certos casos, evitando-o mesmo, numa atitude de defesa (...) Como já se deu a entender, afigura-se difícil — para năo dizer impossível — que a actual estrutura central do MEIC — ainda que tal não seja igualmente válido para todos os serviços - tenha capacidade para promover e aguentar uma forte e imediata dinamizaçăo de uma participação dos estabelecimentos de ensino (...) Assim, preconiza-se como solução transitória e conjuntural, a imediata criaçăo de delegados distritais do GEP, a quem competiria, fundamentalmente, garantir: a) a permanente informaçăo dos estabelecimentos relativamente à evolução dos trabalhos para o lançamento do ano lectivo de 1976/77, b) a coordenaçăo e o encaminhamento, para os serviços centrais, das contribuições dos estabelecimentos de ensino". (64)

202 É por isso que assume tanta importância a análise do formato organizacional utilizado no estudo das inovaçōes administrativas. Não por acaso, as estruturas que, entre 1975 e 1986, estudaram e fizeram propostas para a organizaçăo dos serviços regionais do Ministério da Educação, assumiram a forma de grupos de trabalho, comissões ou secretariados. Para além da tradicional justificação administrativa da

(64) In GEP, Lançamento do ano Lectivo de 1976/77 (ensinos básico e secundário). Participação dos estabelecimentos de ensino, 29 de Abril de 1976. 
transversalidade, que argumenta a presença imprescindivel de vários níveis e sectores da administração, numa decisão orgânica que afecta o conjunto do Ministério e da administração pública, não podemos esquecer que uma tal decisão implica novos poderes de divisão e a desmultiplicaçăo funcional do território, resultando daí inevitáveis perdas de poder de certos sectores administrativos. Por outro lado, a desmultiplicação funcional do território serve de instrumento para a afirmação da autonomia periférica, podendo esta ser confundida com interesses locais ou corporativos, incluindo os interesses de certos grupos administrativos. Ora, a administração, que se obriga a classificar o seu espaço de intervenção enquanto centro e periferia, só tem alguma probabilidade de pôr correctamente o problema das reclassificações espaciais e administrativas e de conhecer tudo o que, no seu novo objecto, é produto de actos de classificação, se puder demonstrar equidade, distância e imparcialidade em relação ao centro e à periferia.

O formato organizacional do grupo de trabalho ou das comissōes duplica a imparcialidade que permite falar em nome do interesse geral. Pode assim imaginar a contraposição centro-periferia como um confronto no interior da própria administração, diante do qual têm o dever de distância e de imparcialidade. Ao fazê-lo, constitui um dispositivo auto-referenciado de reduçăo da entropia. $\mathrm{E}$ isto porque foge à tendência dos sistemas fechados se degradarem à medida que resistem à influência do meio. A periferia é o seu meio, embora dependente em larga medida dos seus próprios outputs, por que, simultaneamente, não se deixa arrastar pela casuística do caso concreto e pela visão de curto prazo de quem executa. A matriz comum destas oposições é a antítese entre dois pontos de vista que, antes de mais, são duas posições hierárquicas dentro da administração: o ponto de vista dos funcionários colocados no vértice da hierarquia, aptos a fornecer uma visăo de conjunto, que confere compreensão global e a busca permanente do interesse geral, que se opõe à visão mais limitada dos sectores que executam, apoucados que estão ao caso concreto, às pressōes locais e às especificidades individualizadoras. Concluem então as comissōes, nas suas propostas de desconcentração que, centro e periferia, estão condenadas a entender-se, procurando na sua complementaridade novos equilíbrios. A dicotomia centro-periferia estabelece, deste modo, um cordão discursivo protector diante da multiplicidade caótica de acontecimentos potenciais. Não porque os ignore; mas porque os integra. Não porque os rejeite; mas porque é a mesma administração que os cria, na forma domesticada de problemas inventariados por estatísticas cada vez mais desagregadas ou de programas de intervenção probabilísticos.

Não deixa de ser curioso que a questão da desconcentração seja deslocada para a problemática do território por meio da influência de um projecto da OCDE. Entre 
1981 e 1983 Portugal está em pleno processo de renegociação do seu estatuto no sistema mundial. Findo o ciclo colonial, os governos constitucionais ultimam as negociações para a entrada numa das grandes regiōes do sistema mundial. A integração de Portugal na CEE passa a constituir um novo espaço mítico que lhe permite imaginar-se como centro, embora todos os indicadores económicos e educativos situem o país em posiçăo periférica quando comparado com os países centrais europeus. Isso mesmo se vê confirmado pela colocação de Portugal nos chamados "países minoritários» do PEB-OCDE que, a par da Espanha, Irlanda e Turquia se caracterizam por baixos níveis comparativos de escolarizaçăo obrigatória e post-obrigatória, que implicam uma dinâmica de crescimento rápido da oferta educativa num contexto de recessăo económica. Dinâmica de crescimento a qual está em contraciclo aos países centrais que começam então a viver uma situação de estagnação e de recessão dos investimentos em equipamentos educativos, quer por razōes de quebras demográficas quer de cobertura elevada obtida nos anos do ciclo virtuoso da economia. É por este motivo que a partir de 1981 o PEB introduz um programa específico para os países, como Portugal, em que o sistema educativo está em desenvolvimento. Tal programa inscreve nos seus objectivos claras preocupações de eficiência e de redução de custos, mobilizando para a gestão dos baixos níveis de investimento previstos as autoridades locais: "explorer les façons possibles d'utiliser une large gamme de bâtiments pour satisfaire les nouveaux besoins éducatifs; élaborer des directives générales mettant à même les autorités locales de répondre aux besoins avec le minimum possible de nouvelles constructions; étendre la capacité des autorités locales à assumer leurs responsabilités dans la mise en oeuvre des politiques d'equipements éducatifs» (OCDE/PEB(81)3, p. 12). Impossibilitada a expansăo da rede pela crise financeira, os organismos internacionais propõem reformas que permitam uma inflexão da estratégia de legitimação. Sob condições de crise estrutural da economia, os projectos de planificação regional, bem como os movimentos regionalistas, podem ajudar a aliviar a crise financeira do Estado, tornando-se funcionais à gestão da escassez de recursos.

A redescoberta do território nacional por via da planificação regional ocorre no mesmo processo em que Portugal se começa a transformar numa localidade da Europa, isto é, o pensamento infranacional anda a par do pensamento supranacional. Nisto se confirma também como é contraditória a dicotomia centro-periferia, já que ela pode ser sujeita a sucessivas deslocações que, por exemplo, situem o centro nas organizaçōes internacionais (e.g.: OCDE) e a periferia na administração dos sistemas educativos nacionais, ou o centro numa região do sistema mundial (e.g.: CEE) e a periferia numa região política ou estatística do espaço nacional. De qualquer modo, 
as assimetrias estruturais entre o núcleo dos países hegemónicos das organizações internacionais e os países periféricos não permitem a equivalência simples que a dicotomia centro-periferia parece induzir. O mesmo é dizer que não se pode esperar que as reformas propostas no centro se difundam com o mesmo grau de concretização nas diferentes periferias. Em tais condições, tanto a produção de símbolos que compensem a recessão de equipamentos e serviços, quanto o grau de concretização da participação popular e dos poderes políticos locais sofre distorções importantes. $\mathrm{O}$ grau de descoincidência entre a adesão da administração nacional a princípios legitimados pelas organizaçōes internacionais e as suas práticas internas é tanto maior quanto menor é o peso do país na arena internacional. É por isso que, em Portugal, as reformas participativas da comunitarização e regionalização dos equipamentos tiveram durante mais de uma década apenas afloramentos retóricos, enquanto o funcionamento do planeamento se manteve nos moldes tradicionais.

\section{Carta escolar}

A característica mais marcante dos trabalhos conducentes à carta escolar, iniciados pelo GEP em 1989, com a publicaçăo do Primeiro contributo para a Carta Escolar, consiste na descentração da gestão da rede escolar da escola-edifício para a escola-organização. Isso mesmo aparece sublinhado em diversos documentos quando se critica a perspectiva do planeamento tradicional que considera cada edifício como uma unidade autónoma e independente. Contrariando esta prática de planeamento, massivamente presente no inventário de carências, a Carta Escolar reconhece que a «escola tende a transformar-se cada vez mais num centro ou elo de uma rede dispersa de locais de ensino e de formação, e num espaço de múltiplas e diversas actividades de cariz comunitário» (GEP, 1992: 75). Deste modo, o planeamento da rede desloca-se de uma perspectiva de mera alocaçăo de recursos, baseado na equação mais recursos = mais educação = mais igualdade de oportunidades, para uma visăo integrada em que a escola-organizaçăo se articula com outras unidades de formação e centros de recursos diversificados. A escola-organização passa a ser a unidade de base do planeamento, com repercussões também na definição das zonas ou áreas pedagógicas que concretizam a rede. É, aliás, nesse quadro que a metáfora da satelitizaçăo ganha sentido, já que esta envolve a integração, numa determinada área geográfica, de um conjunto de escolas que asseguram o cumprimento da escolaridade obrigatória. Organiza-se assim o espaço concelhio, pela primeira vez, para efeitos de planeamento, numa lógica de território educativo, quer dizer, possibilitando a 
acessibilidade da população escolar, no interior desse território, a equipamentos e apoios pedagógicos superiores. Equacionam-se as articulaçōes horizontais entre as escolas satélites e as relações orbitais destas com as escolas-núcleo. Esta solução terá, mais tarde, o acolhimento favorável do Conselho Nacional de Educaçăo que a recomenda também como proposta de gestão das escolas isoladas: «parece necessário estabelecer zonas pedagógicas e integrar em cada zona pedagógica todos os recursos disponíveis, geridos localmente, de modo a garantir a mobilização e responsabilizaçăo da comunidade local pelos problemas de todos e de cada parcela da comunidade» (Parecer n. ${ }^{\circ} 1 / 91$ ).

A par desta articulação integrada, a programação de equipamentos passa a subordinar-se a uma planificação estratégica que prevê três princípios: a diversidade de tipologias, a flexibilidade de soluçōes e a complementaridade na gestão e utilizaçăo dos recursos. Planeamento flexível passa a ser o oxímoro capaz de tornar a Carta escolar um «instrumento e prática de planeamento estratégico» em contraste com a "carta escolar documento». Contudo obscurece também o dilema fundamental de toda a estratégia, qual seja o de tentar reconciliar a simultaneidade das necessidades de mudança e de estabilidade dos sistemas educativos. Dilema que é reconhecido na bem documentada obra de síntese de Mintzberg sobre a Ascensão e queda do planeamento estratégico (1994: 184): «what the writers on planning failed to address was the strategists' fundamental dilemma of having to reconcile the concurrent but conflicting needs for change and stability. On one hand, the world is always changing - more or less - and so organizations must adapt. On the other hand, most organizations need a basic stability in order to function efficiently»s.

Pergunta-se entăo: planeamento flexível para quê? Para assegurar aos indivíduos, aos grupos, aos estabelecimentos educativos e, em geral, aos públicos externos o encontro de cada um com critérios nacionais de interesse geral, tendo como condição sobredeterminadora os critérios de planeamento da rede escolar e a tipologia dos estabelecimentos de ensino (ver entre outros GEP, 1990: 255-271; GEP, 1992b: 71-82). Nesta acepção, o planeamento flexível consistiria essencialmente na procura de uma estabilidade básica, sacrificando a adaptabilidade futura pela eficiência corrente. Assegurar a coerência nacional e favorecer a equidade das condiçōes de oferta escolar são os pressupostos principais de um planeamento que está em continuidade com os inventários de carências.

Planeamento flexível para quê? Também para incitar os indivíduos, os grupos e as organizaçōes a libertarem-se de códigos caducos, a transgredir as normas de grupo em que crêem, a desafiar os preconceitos e as resistências dos grupos corporativos de pertença e a inovar nas organizaçōes escolares. Nesta acepção, o planeamento 
flexível consistiria essencialmente num critério de adaptabilidade ou originalidade, capaz de responder perenemente a tudo em principio e a nada na prática como sublinha Weick (1979: 247).

A pergunta implícita que o planeamento flexível contém é a de saber se teremos ou não que aprender a viver com esta contradição entre estabilidade e mudança. A sua resposta é relativamente simples: os planos que se elaboram devem ser, simultaneamente, programas de enquadramento e realizaçăo e projectos de mudança, sendo uns a condiçăo de existência dos outros. O planeamento estratégico tenta resolver este dilema básico dos sistemas complexos, propondo a sua regulação num único instrumento de planeamento e gestão. A sua adopçăo permitiria a conjugação da engenharia e da visão do futuro. A engenharia organizacional, observando as situações, estruturando os ambientes, planificando a sua acção, avaliando os progressos e controlando os resultados. Num dos primeiros documentos públicos em que se apresenta a estratégia de desenvolvimento da Carta escolar fica claro o eixo da engenharia (Fazendeiro, in GEP, 1992: 76), quando se faz depender a sua concretização do reforço prévio do enquadramento institucional e do desenvolvimento da capacidade técnica: "disponibilizar o conjunto de elementos conducentes à estruturação dos novos ambientes institucionais e orgânicos, à valorizaçăo dos quadros, à modernização dos instrumentos normativos e metodologias e à melhoria dos suportes de informaçăo; e promover a divulgaçăo e internalizaçăo destes elementos estruturantes na actividade normal dos serviços envolvidos». Entretanto, a visão do futuro integra também o planeamento estratégico através do recurso ao método dos cenários. Este consubstancia uma atitude mental de adesão à mudança, fazendo apelo à especulação sobre uma grande variedade de futuros. Quer dizer, quando se torna impossível prever o futuro, multiplica-se este em várias alternativas possíveis, de modo a poder escolher o que parece mais favorável.

2. A crise institucional e a contingência burocrática: estudo de caso das relações entre administração central e administração periférica

Em Abril de 1974, as reponsabilidades no domínio da construção escolar estão repartidas entre os Ministérios da Educação e o Ministério das Obras Públicas. Por sua vez, no Ministério da Educação vários sectores administrativos intervêm em alguma das fases da função equipamentos educativos. Cabia ao Ministério da Educação definir a política global e ao Ministério das Obras Públicas a concepção dos edifícios e a responsabilidade pela sua execução. Enquanto a criação da Direccção-Geral das 
Construções Escolares (DGCE), em 1969, ${ }^{(65)}$ no seio do Ministério das Obras Públicas (MOP), colocava o centro de gravidade da construção escolar no seu processo construtivo, desde logo porque o (MOP) tinha um orçamento próprio para esse efeito; a criaçāo da Direcção-Geral da Administraçăo Escolar (DGAE), em 1971, (66) marca a primeira fase do lento, mas progressivo, deslocamento da construção escolar para o Minsitério da Educação e para uma lógica centrada nas suas tipologias pedagógicas. Em qualquer caso, a existência destas duas direcções gerais corresponde a imperativos tendencialmente contraditórios. Por um lado, a criaçăo da DGAE decorre das novas necessidades de racionalidade interna dos sistemas de prestação de serviços educativos previstos na Reforma de Veiga Simão. O sistema educativo português sofrera uma expansão demográfica evidente nos últimos anos. Por força do alargamento da rede escolar na década de 60 e da pressão da procura, já no final dessa década, o MOP mostrava dificuldades em expandir a rede ao ritmo da procura. $O$ previsível alargamento da rede decorrente da Reforma Veiga Simão, bem como a sua lógica top-down, justificam nos círculos da administração a necessidade de um verdadeiro estado-maior para a "batalha da educação», como reconhece Marcelo Caetano no seu Depoimento de 1974 (Caetano, 1974: 149): «a Reforma do Ensino exigia que o Ministério da Educação fosse reorganizado de modo a poder responder ao esforço que tinha de realizar. E a reorganização fez-se por Decreto-Lei n. ${ }^{\circ}$ 408/71, de 27 de Setembro, em termos de profunda renovação e sem olhar a encargos: o que era preciso era dotar a campanha educativa de um estado maior suficiente, competente e eficaz, apetrechado com todos os serviços que Ihe permitissem planear com visão e executar a tempo. Por isso a nova Direcçăo-Geral da Administração Escolar recebia inclusivamente poderes para fazer obras, montar e conservar instalaçôes, ficando para o Ministério das Obras Públicas, através da sua Direcção-Geral de Construçōes Escolares, a edificação de grandes escolas definitivas e a sua grande reparação».

A criação da DGAE estava justificada pelas novas necessidades de expansão da escolarizaçăo reconhecidas, sancionadas e promovidas pela Reforma Veiga Simăo, isto é, dirigia-se para a regulação das condiçōes de legitimidade e aceitação do siste-

(65) O Decreto Lei 49169 de 24 de Julho de 1969 publica a Lei Orgânica da Direcção-Geral das Construçôes Escolares.

(66) O Decreto-Lei 408/71 de 27 de Setembro cria a Direcção-Geral da Administração Escolar e o Decreto-Lei 46/73 publica a sua Lei Orgânica. Pela primeira vez, uma Direcção-Geral do Ministério da Educaçăo propōe-se fazer uma gestão integrada das instalaçöes, do pessoal e das finanças. Embora as competências para a execução de obras de construçăo estivessem limitadas ao valor máximo de 2000 contos, esta direç̧ão-geral retira funções até então situadas no MOP ou em outros sectores administrativos do Ministério da Educação. A lei orgânica previa ainda a criação de serviços regionais que nunca viriam a ser criados. 
ma. Por outro lado, a manutenção do papel estruturante da DGCE, até final de 1985 , responde às necessidades de regulação de exigências tradicionais do processo de acumulaçăo: escolha de terrenos; processos de expropriação e posse administrativa; ordenamento do território e apreciação dos planos urbanísticos, elaboração de normas construtivas, orçamento e financiamento das construçöes. Com efeito, a DGCE, dotada de autonomia financeira, relacionando-se directamente com os proprietários dos terrenos, com as autarquias e com as empresas construtoras, está em melhores condiçōes administrativas para compatibilizar as necessidades previsíveis do processo de acumulação e as possibilidades orçamentais, resguardando assim, umas e outras, das exigências excessivas da procura de educação. Não por acaso, é nesta direcçãogeral que se produzem com maior frequência reflexões sobre a capacidade das empresas de construçăo, sobre o papel da construçăo escolar no combate ao desemprego ou, ainda, sobre a legislação que regulamenta as expropriações e a aquisição de terrenos para a construção escolar. Esta contradição entre acumulaçắo e legitimação, já inscrita nos processos de racionalização da administração no final do Estado Novo, transita para a crise revolucionária e para o período constitucional que se segue, até à entrada de Portugal na CEE. Cumpre compreender agora as condições que garantem a reprodução da contradição em forma de constantes inovações e reformas administrativas.

Estas reformas assumem preferentemente um carácter provisório e intermitente quanto ao tempo da sua aplicação e a ambição de horizontalidade e de descentralização quanto à morfologia orgânica. Dizem respeito, em primeiro lugar, às necessidades de coordenaçăo provocadas pelo processo de transiçăo para um Estado-Providência. Os incrementos sucessivos das políticas públicas, fortemente impulsionados pela legalização ad-hoc, levada a efeito pelos movimentos sociais, durante a crise revolucionária, integra novos tipos de necessidades na agenda política. A propósito da legalizaçāo ad-hoc, B. Sousa Santos (1990: 32-33) considera que esta foi uma das formas, embora frágil e ambígua, de os movimentos sociais pressionarem a função legalizante do Estado. A sua fragilidade advém da desvalorização jurídica a que está sujeita no confronto com a legalidade de continuidade baseada na ordem jurídica do Estado Novo. Continuando o seu argumento, o autor distingue ainda uma outra forma de recorrer ao estado legalizante, que designa por inovação legislativa. Esta procura pôr as formas jurídicas tradicionais ao serviço dos novos conteúdos. Frequentemente suportada por forças políticas com influência na administração, pretende assim regular os excessos dos movimentos sociais. O trabaIho de Licínio Lima (1994: 230-236), sobre as várias edições da gestão democrática, revela bem a coexistência destes dois formatos de legalização que situamos, no caso 
da legalização ad-hoc, nos primeiros ensaios de autogestão das comissões de gestão e, no caso da inovação legislativa, na cobertura legal fornecida pelo Decreto-Lei n. ${ }^{\circ} 735$-A/74 de 21 de Dezembro. O mesmo tipo de interpretaçăo pode ser utilizado em outros casos, como o dos movimentos estudantis de 1974 contra os exames de aptidăo de acesso à universidade. Numa primeira fase é a legalizaçăo ad-hoc que, sob pressão dos movimentos estudantis, inscreve sucessivos abaixamentos nas médias de acesso à universidade. Mais tarde, a inovaçăo legislativa acaba por abolir os exames de acesso. No entanto, uma e outra forma revelam bem as suas fragilidades, por que terminada a curta fase de paralisia administrativa do Estado, que admite a sobreposição de inovações numa ordem jurídica tradicional, a selecção regressa, de forma autoritária, por intermédio de medidas administrativas que impedem a entrada na universidade.

Para os administradores de políticas públicas educativas, a integração repentina do acesso alargado à educaçăo, em todos os níveis, particularmente no ensino secundário, mostra as múltiplas tensões que nelas se movem, frequentemente limitada por razōes orçamentais intransponiveis. Tais limites têm na construçăo escolar um verdadeiro nó górdio. As tensões derivam de pontos muitos diferentes: dos interesses sociais que não vêem reconhecidos na agenda política as oportunidades que julgavam possíveis (e. g. construção de escolas do $1 .^{\circ} \mathrm{e} 2{ }^{\circ}$ ciclo versus escolas secundárias); do consequente alargamento das funções do Estado e da parcela de orçamento dedicada à manutenção das estruturas administrativas e dos recursos por elas criados; da fricçăo latente ou expressa entre os diferentes departamentos, resultante da diferenciação de funçōes, na medida em que assim se criam novas zonas de incerteza e de disputa na gestão de meios financeiros, na relação com grupos de interesses e, mesmo, no recrutamento e organização de serviços.

O alargamento do campo de acção do Estado aumenta evidentemente a espessura da sua mediação com a cidadania. A apropriação de novas funçōes pelo Estado estabelece relaçōes mais intensas de dependência social sob a força gravitacional (Aguiar, 1989) do Estado. Esta força gravitacional tem um centro instrumental que problematiza e oferece soluçōes técnicas para as necessidades sociais. De tal sorte que o centro instrumental, ao elaborar e propor consensos técnicos, racionais, recria controlos administrativos, entretanto exauridos pela ineficácia demonstrada. Tudo se passa como se o par necessidade-regra assegurasse a renovação da representabilidade da administração. A noçăo de necessidade, umas vezes operacionalizada em termos de desenvolvimento, outras na forma de carência (Inventário de carências em instalaçôes), mostra como o conflito de interesses năo deve ser dado à consciência de quem os experimenta na forma de desejos incontrolados, podendo tomar forma na 
sua representação técnica, separada de toda a paixão. O papel dos conceitos, inverso ao de regra, é o de mostrar como a insistência primária na necessidade espontânea, o infinito sem lei da reivindicação são de facto organizáveis por um impensado individual que tem no pensamento supraordenado da administração o seu substituto colectivo. Categorias como "área de influência da escola», «normalização dos equipamentos escolares» ou "congestionamento da escola» são utilizados como conceitos universais, que podem ser utilizados como forma válida e imparcial de responder, equitativamente, às necessidades de acesso igual ao ensino. A função distribuiçăo de equipamentos pelo território nacional tem por papel mostrar como as estruturas da vida escolar podem dar lugar à sua representaçăo em quadros e mapas que estabelecem prioridades.

Assim se compreende por que é que estas e outras categorias, que analisaremos mais tarde, podem organizar as inovações propostas para o campo administrativo, especialmente as que dizem respeito à coordenação interdepartamental e à desconcentração periférica da administraçăo. É que elas atravessam o sistema educativo de uma ponta à outra, mantêm à distância e ao mesmo tempo conjugam as positividades empíricas da vida escolar. Com efeito, sendo a política de construção escolar aquela onde confluem grande parte das invariantes escolares é também a que mantém maior nível de monopólio e de opacidade. Nenhuma outra entidade ou grupo social tem acesso ao mesmo tipo e quantidade de recursos nem é possível, ou sequer reivindicado, que alguma instância se substitua ao Estado nas funções de equipamento escolar.

A expansão do Estado origina várias hipóteses de inovação e reforma administrativa, hipóteses que estão registadas na literatura:

- a possibilidade de implosâo do Estado em consequência do seu peso excessivo (Huntington et al., 1975);

- a hipótese de delegar tarefas públicas em sistemas financeiros parafiscais e a formas de organização e decisão particulares ou semipúblicas (Offe, 1984a, 1984b), afastando os encargos financeiros dos níveis centrais do Estado para a proximidade dos directamente atingidos pelas medidas;

- a hipótese da sua fragmentação progressiva com a constituição de núcleos duros, quase-estatais, de tipo neocorporativo (Schmitter, 1986);

- a interdepartamentalidade, isto é, o agrupamento administrativo, intermitente ou contínuo, destinado à formulação e gestão de um conjunto de políticas públicas originalmente situadas em instâncias separadas (Rose e Peters, 1978); 
- a hipótese da desconcentração da administraçăo e da introduçăo de critérios de decisăo casuísticos, flexibilizando simultaneamente as formas legais que suportam as decisōes (Offe, 1984a).

No caso em apreço, as hipóteses da fragmentaçăo e da interdepartamentalidade obtiveram alguma visibilidade empírica, embora outras hipóteses revelassem alguns afloramentos, em especial a hipótese da desconcentração. O planeamento dos equipamentos educativos assenta em políticas distributivas que se realizam com base em recursos financeiros obtidos pelo Estado através dos impostos. A profunda crise financeira do Estado na primeira década que analisamos (1974-1985), por força de taxas de acumulaçăo baixas e de acordos de financiamento externo onerosos, torna muito difícil o cumprimento do direito à educaçăo para todos entretanto institucionalizado. Compatibilizar as reivindicações institucionalizadas com os meios financeiros e administrativos para a sua satisfação passa a ser o principal problema interno do Estado. Dado que esta compatibilização não se limita à regulaçăo do fluxo de recursos a dispender e pressupõe a criação de estruturas administrativas destinadas à sua problematização técnica, resulta daí a diferenciação de novos sectores administrativos.

Esta diferenciação é particularmente visível nas direç̧ōes gerais e gabinetes que intervêm nas diferentes fases do planeamento da rede escolar. O Gabinete de Estudos e Planeamento é um dos sectores onde tal diferenciação é mais visível. Quando foi criado em Dezembro de 1972, designado entăo por GEPAE (Gabinete de Estudos e Planeamento da Acçăo Educativa), tinha sete unidades: três orientavam-se para a planificaçăo (carta escolar, planificaçăo macro-educativa e programação dos planos de desenvolvimento), três destinavam-se à pesquisa (estudos pedagógicos, ensino técnico e profissional e políticas educativas) e uma dedicava-se à informaçăo e documentação especializada. Em 1975, foram acrescentadas mais duas unidades: um núcleo de estatística no serviço de planeamento e um núcleo de avaliação no serviço de estudos. Entretanto, em 1976, passam também a funcionar no GEP o grupo de trabalho para a organização dos serviços regionais do MEIC, ${ }^{(67)}$ o grupo de trabalho para a gestão financeira ${ }^{(68)} \mathrm{e}$ as relaçōes internacionais. ${ }^{(69)}$ As sucessivas reorganizações internas registam uma cada vez maior diferenciação de funções: em 1981, o GEP apresentava no seu plano de actividades para além da direcção-geral, duas direcções de serviços (estudos e planeamento), constituída cada uma delas por cinco

\footnotetext{
(67) despacho n. ${ }^{\circ} 31 / 76$ de $9 / 2$.

(68) despacho n. ${ }^{\circ} 32 / 76$ de $9 / 2$.

(69) despacho n. ${ }^{\circ} 10 / 76$ de $23 / 1$.
} 
unidades. A primeira: estudos prospectivos, educaçăo e vida activa, administração da educaçăo, apoio à investigação pedagógica e projectos no âmbito do acordo de cooperação luso-sueco; a segunda: planeamento global, rede escolar, programação e controle, financiamento da educação e cálculo automático. Para além destas unidades, mantém ainda o núcleo de análise, documentaçăo e informação e colabora em dez grupos de trabalho, alguns deles coordenados pelo GEP. Na lógica de uma das leis de Parkinson (1986), segundo a qual cada sector administrativo do Estado tende a criar uma certa autonomia, traduzida na capacidade de fazer depender outros sectores administrativos de si e de desvincular a sua existência dos serviços externos que presta, a fragmentação seria, antes de tudo, uma força auto-referenciada, destinada a justificar o próprio Estado. É também nesta linha de auto-referencialidade que Luhmann sustenta o meio principal de os sistemas administrativos reduzirem a complexidade do envolvimento através dos processos recursivos. Explica Luhmann (1990: 72) que quanto maior é a complexidade do envolvimento, mais o sistema se diferencia dele, usando a dependência crescente como incremento da autonomia. Isto é alcançado por processos recursivos, designados assim porque «it uses the results of its own operations as the basis for further operations - that is what is undertaken is determined in part by what has occurred in earlier operations».

Se é verdade que os ganhos ou perdas de relevância dos funcionários envolvidos nas políticas públicas têm um papel na fragmentação, já que estes tendem a apreciá-la como uma ameaça ao seu peso relativo no conjunto da administração, a autonomia é, não obstante, multiplicada pela conflitualidade social. A recursividade e a oposição surda à coordenação intersectorial não esgotam os processos envolvidos na fragmentaçăo. ${ }^{(70)}$ Neste caso, a conflitualidade latente é provocada pelo acesso desi-

(70) Năo se desconhece a análise crítica de alguns autores, designadamente de Habermas (1987, 1990), quanto aos excessos de auto-referencialidade da teoria dos sistemas de Luhman. De acordo com os pressupostos deste, todo o sistema auto-referencial selecciona o meio circundante que ele próprio se proporciona, năo existindo, consequentemente, meio circundante-em-si. Por isso, todos os sistemas elaboram meios circundantes, multiplicando assim a sua complexidade. Como não se podem agregar na forma de uma unidade de consciência transcendental, no lugar de um centro produtor de sentido - seja ele o Estado, a Sociedade, a Consciência de Classe ou outra entidade monumental -, surgem vários meios circundantes sistemicamente relacionados. Habermas procede à crítica desta teoria, que se pretende um esboço de uma teoria universal da sociedade, argumentando contra a construçăo de uma consciência socioglobal a partir da filosofia do sujeito. Como alternativa, apresenta uma estratégia conceptual assente na intersubjectividade de nivel superior construída no confronto das esferas públicas: «se os individuos são inseridos e submetidos como partes no sujeito de nivel superior da sociedade enquanto todo, surge um jogo de resultado nulo no qual os fenómenos modernos, como os crescentes espaços de manobra e de movimento e os crescentes niveis de liberdade dos individuos, não podem ser acolhidos correctamente. Dificuldades são provocadas também por uma consciência socioglobal que é representada como auto-reflexăo de um macro-sujeito. Em 
gual aos bens e serviços educativos distribuídos pelo Estado. Dentro da estrutura de oportunidades criada pela construçăo escolar, os interesses sectoriais ou particulares intervêm na disputa de recursos escassos. É esta força centrífuga que melhor permite compreender os efeitos de fragmentação-coordenação presentes nas diferentes fases de distribuição dos equipamentos educativos pelo espaço nacional, desde a detecção de necessidades à execuçăo dos projectos.

De um modo geral, os interesses sectoriais, organizados ou não, dirigem-se ao Estado por intermédio das suas estruturas políticas (parlamento, governo, ministérios) ou das estruturas administrativas (direccções-gerais, direccções regionais, gabinetes técnicos, etc). A ausência de tradiçăo e a fragilidade da organização dos interesses sectoriais no campo educativo contribuiu especialmente para a utilizaçăo preferencial das estruturas administrativas como ponto de aplicação das formas de pressão. A institucionalização do diálogo técnico entre o GEP e as autarquias locais, no âmbito da elaboração do Inventário de carências, reforçou esta tendência, estabelecendo assim formas de relação e de conivência entre interesses sectoriais e certas estruturas administrativas. Esta relação privilegiada levou mesmo a administração central a eleger as autarquias como parte da sociedade civil, fazendo destas representantes vicariantes ora de interesses locais, ora de interesses sectoriais, ora de interesses privados. A separaçăo administrativa entre as direcçōes-gerais que no MESA e no MEIC regulam os equipamentos educativos deve-se também à manutenção das relaçōes selectivas e repetitivas que, uma e outra, têm com diferentes sectores: no

sociedades diferenciadas ocorre um conhecimento exigente, orientado para a totalidade da sociedade, se necessário em sistemas de saber especializados, mas não no centro da sociedade na qualidade de um saber da sociedade inteira sobre si mesma. Em todo o caso, encontrámos uma estratégia conceptual alternativa que nos salvaguarda de ter de abandonar a concepçăo de uma autorepresentação da sociedade em geral. Esferas públicas podem ser entendidas como intersubjectividades de nivel superior. Nelas podem articular-se autodefiniçōes colectivas que forjem a identidade. $E$ na esfera pública superiormente agregada também se pode forjar uma consciência socioglobal. Esta não precisa então de satisfazer a exigência de precisão que a filosofia do sujeito tem de colocar à autoconsciência» (Habermas, 1990: 342). Na construçăo da argumentaçăo que se segue, consideramos que a recursividade dos sistemas auto-referenciais de Luhman e a esfera pública superiormente agregada pela comunicação intersubjectiva de Habermas, mais do que dois modelos conceptuais antagónicos destinados à discussão das formas de compreensão transcendente da sociedade, constituem dois processos empíricos que ora se apresentam concorrentes, ora se apresentam complementares. Daí que aceitemos os pressupostos de Luhman quanto à ausência de uma consciência auto-evidente e unificada numa forma de os sistemas se conduzirem. O que nos orienta para a análise da contingência e processualidade dos sistemas educativos: a sua racionalidade sistémica săo o conjunto de condiçōes propiciadoras da sua própria conservaçăo. Porém, a processualidade tende a ser unificada nos sistemas de conflitualidade que introduzem metafísicas morais a posteriori, ganhando todas as aparências dos verdadeiros motivos que presidiram às acçōes meramente operativas. 
caso do MOP e do MESA com as forças políticas, com as empresas de construção e com os proprietários de terrenos; no caso do MEN e do MEIC com as autarquias, com as associações de pais e com os sindicatos de professores. As formas privilegiadas de relaçăo que estas autonomias relativas concedem e promovem tornam muito heterogénea a actuação do Estado. Como veremos, a heterogeneidade da administração segue muitas vezes princípios selectivos na interacção, caracterizados por Santos (1994: 116-117) como estando mais próximo da racionalidade do espaço doméstico (maximização da afectividade) do que do espaço da cidadania (maximização da lealdade). Com efeito, a burocracia do Estado oscila, neste caso, entre a extrema rigidez com que rejeita propostas de construção de escolas provenientes da sociedade civil estranha, com o argumento de que não estão referenciadas no Inventário de carências, e a extrema prontidão e informalidade com que trata, para os mesmos efeitos, a sociedade civil íntima (e. g.: empresas de construçăo em crise ou forças de pressão mediadas por autarquias com peso político e capacidade de influência pessoal).

Esta distinção nem sempre é fácil de realizar. Apesar dos esforços e tentativas efectuadas, durante três anos, năo foi possível ter acesso às séries completas da correspondência entre o GEP e as autarquias envolvidas no processo de diálogo subjacente ao Inventário de Carências. Por isso havemos de limitar-nos às informaçōes quantitativas que é possível obter nos quadros publicados pelo GEP no Inventário de Carências intitulada Processo de diálogo com as Autarquias envolvidas (1978-1979). No entanto, porque conseguimos obter nos arquivos da Secretaria de Estado do Ensino Básico e Secundário 78 processos referentes a pedidos de construção de escolas do ensino secundário ou de alargamento da tipologia $C+S$ ao ensino secundário, que nos dão uma amostra bastante razoável do tipo de problemas enunciados, optamos por interpretar este último período a partir da análise de conteúdo da correspondência. Os processos dizem respeito ao período entre 1980 e 1986 e compreendem o expediente enviado pelas Câmaras Municipais, Associaçōes de Pais e Associaçōes locais para várias entidades do Ministério da Educação. O primeiro quadro apresenta resumidamente as características principais das propostas, designadamente: proveniência dos pedidos (localização e instituição), tipo de intervenção proposto, lógica de justificação da acção, lógica de recusa ou de apoio. O segundo quadro utiliza as mesmas categorias para analisar o processo de diálogo entre o GEP e as autarquias no ano lectivo 197879. Neste caso sugere-se alguma prudência quanto à interpretaçăo do peso relativo das instituições envolvidas no processo. Na verdade, o facto de o próprio processo de negociação da rede incluir a relação directa entre o GEP e as autarquias conduz-nos a um viés devido à predominância muito notória das Câmaras Municipais no segundo quadro. 
Quadro 8 - Propostas referentes a pedidos de construção de escolas do ensino secundário ou de alargamento da tipologia $C+S$ ao ensino secundário de iniciativa local (78 processos do período 1980-1986)

\begin{tabular}{|c|c|}
\hline $\begin{array}{c}\text { LOCALIZAÇÃO } \\
\text { (Distritos) }\end{array}$ & $\begin{array}{l}\text { - Aveiro }-2 \\
\text { - Braga - } 5 \\
\text { - Castelo Branco }-3 \\
\text { - Coimbra }-7 \\
\text { - Evora }-1 \\
\text { - Faro }-2 \\
\text { - Guarda }-1 \\
\text { - Leiria }-4 \\
\text { - Lisboa }-27 \\
\text { - Porto }-15 \\
\text { - Santarém-3 } \\
\text { - Setúbal }-8 \\
\text { TOTAL }-78\end{array}$ \\
\hline INSTITUIÇĀO & $\begin{array}{l}\text { - Câmara Municipal - } 52 \\
\text { - Junta de Freguesia - } 12 \\
\text { - Comissão/Associaçăo de Pais } \\
\text { e Encarregados de Educação - } 10 \\
\text { - Movimentos locais - } 2 \\
\text { - Jornal local - } 2\end{array}$ \\
\hline $\begin{array}{c}\text { TIPO DE } \\
\text { INTERVENÇÃO }\end{array}$ & $\begin{array}{l}\text { - Construçăo de escola C+S - } 5 \\
\text { - Construçăo de escola do ensino secundário - } 51 \\
\text { - Criaçáo de ensino secundário em escola C+S-3 } \\
\text { - Ampliaçăo da capacidade - } 19\end{array}$ \\
\hline $\begin{array}{l}\text { LOGICA DE } \\
\text { JUSTIFICAÇĀO } \\
\text { DOMINANTE }\end{array}$ & $\begin{array}{l}\text { - Más condiçoes de funcionamento da escola } \\
\text { (sobrelotação, etc.) - } 25 \\
\text { - Area de influência - } 5 \\
\text { - Igualdade de oportunidades - } 16 \\
\text { - Necessidades do mercado de trabalho local - } 12 \\
\text { - Integração social dos jovens - } 10 \\
\text { - Expectativas das familias - } 10\end{array}$ \\
\hline $\begin{array}{l}\text { LOGICA DE } \\
\text { RECUSA OU APOIO }\end{array}$ & $\begin{array}{l}\text { - Critérios de gestão locais năo devem sobrepor-se } \\
\text { aos do planeamento da rede - } 5 \\
\text { - Subutilização de escola existente - } 11 \\
\text { - Sobreposição de áreas de influência - } 25 \\
\text { - Escola existente é reconvertivel - } 8 \\
\text { - Ampliaçáo injustificável com base no } \\
\text { cálculo de frequências - } 29\end{array}$ \\
\hline
\end{tabular}


Quadro 9 - Análise do processo de diálogo entre o GEP e as autarquias a partir do Inventário de Carências em instalações no ano lectivo 1978-79

\begin{tabular}{|c|c|}
\hline $\begin{array}{c}\text { LOCALIZAÇÄO } \\
\text { (Distritos) }\end{array}$ & $\begin{array}{l}\text { - Aveiro-6 } \\
\text { - Beja - } 8 \\
\text { - Braga - } 8 \\
\text { - Bragança - } 5 \\
\text { - Castelo Branco-1 } \\
\text { - Coimbra - } 15 \\
\text { - Evora - } 3 \\
\text { - Faro- } 6 \\
\text { - Guarda - } 6 \\
\text { - Leiria - } 19 \\
\text { - Lisboa - } 19 \\
\text { - Portalegre - } 8 \\
\text { - Porto- } 55 \\
\text { - Santarém-16 } \\
\text { - Setúbal - } 4 \\
\text { - Viana do Castelo-7 } \\
\text { - Vila Real - } 13 \\
\text { - Viseu - } 22 \\
\text { TOTAL- } 221\end{array}$ \\
\hline INSTITUIÇÃO & $\begin{array}{l}\text { - Carmara Municipal - } 159 \\
\text { - Assembleia Municipal-1 } \\
\text { - Junta de Freguesia - } 22 \\
\text { - Governo Civil-26 } \\
\text { - Professores - } 1 \\
\text { - Comissão/Associaçăo de Pais e } \\
\text { Encarregados de Educaçăo - } 3 \\
\text { - Movimentos locais - } 4 \\
\text { - Escolas - } 2 \\
\text { - Associaçăo de escolas-1 } \\
\text { - Casa do Povo-1 } \\
\text { - Inspecção-1 }\end{array}$ \\
\hline $\begin{array}{l}\text { TIPO DE } \\
\text { INTERVENÇĀO }\end{array}$ & $\begin{array}{l}\text { - Concordancia com inventário de carencias - } 101 \\
\text { - Uma escola em cada localidade - } 10 \\
\text { - Construçăo de escola C+S năo prevista - } 25 \\
\text { - Construçăo de escola do ensino secundário - } 31 \\
\text { - Escola secundária em vez de C+S-12 } \\
\text { - Criaçăo de ensino secundário em escola C+S-17 } \\
\text { - Ampliação da capacidade - } 25\end{array}$ \\
\hline $\begin{array}{l}\text { LOGICA DE } \\
\text { JUSTIFICAÇĀO } \\
\text { DOMINANTE }\end{array}$ & $\begin{array}{l}\text { - Discordância do sistema de prioridades nacional - } 11 \\
\text { - Critérios de gestáo escolar - } 1 \\
\text { - Area de influência local - } 18 \\
\text { - Mudança de prioridade - } 91\end{array}$ \\
\hline
\end{tabular}


Quadro 9 - (Continuação) - Análise do processo de diálogo entre o GEP e as autarquias a partir do Inventário de Carências em instalaçōes no ano lectivo 1978-79

\begin{tabular}{|c|c|}
\hline $\begin{array}{l}\text { LOGGICA DE } \\
\text { RECUSA OU APOIO }\end{array}$ & $\begin{array}{l}\text { - Critérios de gestão locais não devem } \\
\text { - sobrepor-se ao planeamento da rede - } 10 \\
\text { - Subutilizaçäo de escola existente - } 13 \\
\text { - Sobreposiçăo de áreas de influência - } 31 \\
\text { - Escola existente é reconvertivel - } 2 \\
\text { - Ampliação injustificável com base } \\
\text { no cálculo de frequências - } 10 \\
\text { - Dispensável face à distância da outra escola - } 14 \\
\text { - Desconcentraçăo năo se justifica - } 12 \\
\text { - Não tem dimensão mínima - } 8 \\
\text { - Sem justificação - } 20\end{array}$ \\
\hline
\end{tabular}

A forma preferida de as colectividades locais canalizarem a procura social de educação parece ser a autarquia. Deste modo, a procura das famílias, representadas pelas associações de pais e de encarregados de educação, faz-se sentir junto da administração por intermédio dos representantes locais eleitos. Deve sublinhar-se, no entanto, que a forma não deve obscurecer o conteúdo: năo se pode dar como certo, a priori, que quando os eleitos locais prometem a abertura de uma escola, ou veiculam tal reivindicação, estejam a exprimir exclusivamente uma procura prévia das famílias; pode supor-se também, e existem alguns sinais nesse sentido, que visam satisfazer uma fracção específica do seu eleitorado, como por exemplo os professores, que ganham neste período um peso cada vez mais importante nas autarquias locais (ver Cruz et alii, 1988 e Teodoro, 1993). Por exemplo, a abertura de certas opções no $9 .^{\circ}$ ano de escolaridade ou de certos cursos do ensino secundário permite a algumas escolas superar os limites impostos pela área de recrutamento inicialmente prescrita, garantindo assim a diversificaçăo das fileiras de ensino e, portanto, a clientela futura. A predominância de propostas de afectação do ensino secundário a escolas $\mathrm{C}+\mathrm{S}$ provém, maioritariamente, de uma lógica interna do interesse da gestão dos estabelecimentos de ensino, e ocasionalmente de grupos de professores cujos postos parecem ameaçados. Acredita-se que deste modo é possível contrariar a baixa de efectivos na transição do ensino obrigatório para o ensino secundário. Nestas circunstâncias, pode dizer-se que a construção social da procura corresponde, de facto, a uma adaptação da procura à oferta. Adaptação que no caso descrito amplia a procura, embora noutros casos a contenha. Como exemplo de tal contençăo podemos referir a recusa de certas escolas com ensino técnico-profissional em abrir cursos di- 
ferentes das especialidades do seu quadro docente das áreas tecnológicas (ver Alves, Cabrito, Canário, Gomes, 1996: 131-137).

\section{Os mecanismos de coordenação}

A fragmentação organizacional e a assimetria relacional abrem vias novas de dispersăo das contradições criadas pela intervençăo do Estado. Estas vias assumem o formato de mecanismos de coordenação e estão desigualmente distribuídas pelas várias regiões da dominação política e da intervençăo administrativa. A nossa hipótese de trabalho é que se formam três regiões que designamos, à imagem das regiōes discursivas, por região continente, região insular e região local. O Estado concentra os seus recursos principais em mecanismos de dispersão na região continente. Aí, o que é Estado e o que não é Estado tem fronteiras claramente definidas; o envolvimento decisional é racional e programável e os vários departamentos administrativos apresentam autonomia relativa. Pelo contrário, a região local é uma região onde não se distinguem perfeitamente as fronteiras entre o que é Estado e o que não é Estado; o envolvimento decisional é flexível e não prescritivo e, embora o tipo de estruturação interna aproveite o formato institucional, assume funções administrativas supletivas e compensatórias. Finalmente, as regiōes insulares são regiōes muito difusas e móveis de regulação; tratam-se de zonas de disputa e de incerteza destinadas à resoluçăo de conflitos e à criação de uma ordem negociada; ocupadas preferentemente por sectores administrativos do Estado, os principais mecanismos de dispersão utilizados são os processos recursivos, os resultados mutuamente acordados, a coordenação intermitente e a desconcentração de funçōes. Porque esta primeira formulaçăo tem ainda um grau de generalidade muito grande importa, desde já, ilustrar, exemplificando, as três regiōes do ponto de vista organizacional: a regiāo continente contém inicialmente a DGCE e a DGEE; na regiâo local seleccionou-se o Núcleo de Escolas do Oeste, embora se situem nela, também, as autarquias, as associações de

pais e os interesses empresariais não organizados, e, nas regiões insulares, consideram-se os diferentes formatos de coordenaçăo interdepartamental assumidos pelas relações entre o GEP, a DGCE e a DGEE e entre estes e as autarquias.

Com base neste modelo teórico, adaptado do Interacting Spheres Model de Bacharach (1981), tentaremos analisar as sucessivas inovaçōes administrativas que se enquadram nas designações gerais de desconcentração, descentralização e regionalização. Estas problematizações e reformas, embora muito diversificadas, tiveram a sua origem e principal ponto de aplicação no campo dos equipamentos educativos. 
Quadro 10 - Modelo de interacção entre as regiôes formadas pela fragmentaçăo organizacional e as assimetrias relacionais

\begin{tabular}{|c|c|c|}
\hline REGIÃO CONTINENTE & REGIÕES INSULARES & REGIÃOLOCAL \\
\hline \multicolumn{3}{|c|}{ CARACTERISTICAS GERAIS E LOCALIZAÇĀO ORGANIZACIONAL DE CADA REGIĀO } \\
\hline $\begin{array}{l}\text { - Envolvimento racional } \\
\text { - Autonomia relativa } \\
\text { - DGCE } \\
\text { - DGEE }\end{array}$ & $\begin{array}{l}\text { - Ordem negociada } \\
\text { - Resolução de conflitos } \\
\text { - Coordenação parcial } \\
\text { entre administração central, } \\
\text { GEP, autarquias e escolas }\end{array}$ & $\begin{array}{l}\text { - Envolvimento flexível } \\
\text { - Funções administrativas } \\
\text { compensatórias e supletivas } \\
\text { - Núcleo de Escolas do Deste }\end{array}$ \\
\hline \multicolumn{3}{|c|}{ ZONAS DE DISPUTA ENTRE AS REGIŌES } \\
\hline - Orçamento geral & $\begin{array}{l}\text { - Projectos específicos } \\
\text { do estabelecimento } \\
\text { educativo que necessitam de } \\
\text { recursos suplementares }\end{array}$ & - Orçamento da escola \\
\hline $\begin{array}{l}\text { - Definiçắo dos } \\
\text { curricula nacionais }\end{array}$ & $\begin{array}{l}\text { - Projectos sócio-educativos } \\
\text { de intervenção comunitária }\end{array}$ & $\begin{array}{l}\text { - Decisōes de articulação local } \\
\text { dos curricula nacionais } \\
\text { - Projectos interdisciplinares }\end{array}$ \\
\hline $\begin{array}{l}\text { - Formação de } \\
\text { recursos humanos }\end{array}$ & $\begin{array}{l}\text { - Formação contínua } \\
\text { centrada na escola } \\
\text { - Qualificação associada ao } \\
\text { desenvovimento da escola }\end{array}$ & - Selecçāo de áreas de formaçăo \\
\hline
\end{tabular}

Este modelo sugere a presença de uma grande diversidade de formas de dispersão das contradições que partilham de algumas características comuns:

- os problemas emergem e as decisōes são tomadas como se o envolvimento do sistema escolar caminhasse de condiçōes estáveis para condições de grande turbulência;

- os problemas são construídos num sistema constituído por múltiplas regiões de influência;

- cada regiáo de influência é configurada pelas problematizações, necessidades e interesses específicos identificados em cada envolvimento;

- o envolvimento é construído por processos recursivos; 
- as regiōes de influência dominante são aquelas que gravitam em torno da distribuição de recursos e da determinação de áreas de construção prioritárias:

- cada região de influência tem uma medida relativa da sua autonomia no processo de tomada de decisão, bem como a identificação dos constrangimentos a essa autonomia;

- decisões específicas que são tomadas em mais do que uma região de influência caem dentro de uma região insular onde se criam bolsas de incerteza e disputa;

- as decisões tomadas sobre um problema que cai numa região insular são negociadas formal e informalmente, convertendo-se numa ordem negociada;

- esta ordem negociada caracteriza-se pela ênfase em resultados mutuamente acordados, em lugar da injunção; pela decisăo casuística, em lugar das decisões por estrita obediência normativa;

- algumas necessidades e problemas que caem nas regiões insulares são sujeitos a processos de apoucamento, redefinição de prioridades e desvalorização técnica que os desloca para zonas de não-decisão ou de desperdício institucional;

- as regiões coligadas pela ordem negociada formam a base de um sistema com débil articulação;

- a região continente desenvolve tácticas para influenciar normativamente ou por conciliação as regiões locais e nas regiões insulares cada região autóctone envolvida desenvolve estratégias defensivas para proteger a sua autonomia contra intervençōes externas;

- as regiōes locais desenvolvem tácticas para influenciarem informalmente a esfera de influência da administração e a administração desenvolve estratégias defensivas para utilizar umas em seu proveito e rejeitar selectivamente outras.

De acordo com este modelo, os principais mecanismos de coordenação elaborados pela administração estăo dependentes do reconhecimento dos limites impostos pela fragmentação. $\mathrm{O}$ quadro seguinte faz uma primeira aproximação comparativa das principais medidas organizacionais dirigidas para a coordenação dos vários sectores que na administração se dedicam aos equipamentos educativos. Na primeira parte do quadro identificam-se os principais mecanismos de fragmentação e de coordenação, a par das tensōes principais que esta dicotomia cria no discurso dos especialistas em equipamentos educativos. Na segunda parte, prolonga-se esta lógica ao conjunto de medidas dirigidas para a coordenação da administração escolar no seu conjunto. 
Quadro 11 • Parte I-Mecanismos de fragmentaçăo e de coordenação com origem nos equipamentos educativos

\begin{tabular}{|c|c|c|c|c|}
\hline $\begin{array}{l}\text { MECANISMO DE } \\
\text { FRAGMENTAÇĀO }\end{array}$ & $\begin{array}{l}\text { MECANISMO DE } \\
\text { COORDENAÇĀO }\end{array}$ & $\begin{array}{c}\text { DESIGNAÇÃO } \\
\text { ADMINISTRATIVA }\end{array}$ & $\begin{array}{l}\text { CONTEÚDO } \\
\text { DA MEDIDA }\end{array}$ & TENSOOES PRINCIPAIS \\
\hline $\begin{array}{l}\text { - Recrutamento local } \\
\text { de técnicos por } \\
\text { vários serviços } \\
\text { do ministério. } \\
\text { - Ausência de } \\
\text { critérios uniformes } \\
\text { no mesmo } \\
\text { empreendimento. }\end{array}$ & $\begin{array}{l}\text { - Coordenaçăo } \\
\text { técnica ad-hoc. }\end{array}$ & $\begin{array}{l}\text { - Secçôes Regionais } \\
\text { Técnicas } \\
\text { (Out. 1974) }\end{array}$ & $\begin{array}{l}\text { - Criação de } \\
\text { departamentos } \\
\text { regionais com a } \\
\text { representação de todos } \\
\text { os departamentos do } \\
\text { ME envolvidos na } \\
\text { construçāo de } \\
\text { instalaçōes. }\end{array}$ & $\begin{array}{l}\text { - Tensăo entre objectivos e } \\
\text { recursos controlados por } \\
\text { diferentes departamentos } \\
\text { - Tensăo entre } \\
\text { funçōes normativa, } \\
\text { de controlo } \\
\text { e de execuşão. }\end{array}$ \\
\hline $\begin{array}{l}\text { - Duplicação e } \\
\text { dispersão dos } \\
\text { esforços de } \\
\text { construçăo por } \\
\text { dois ministérios } \\
\text { MESA e MEIC). }\end{array}$ & $\begin{array}{l}\text { - Inventário de } \\
\text { necessidades. } \\
\text { - Elaboraçăo de } \\
\text { programas de } \\
\text { aç̧áo imediata. } \\
\text { - Tentativa de } \\
\text { unificação da } \\
\text { DGCE e DGEE }\end{array}$ & 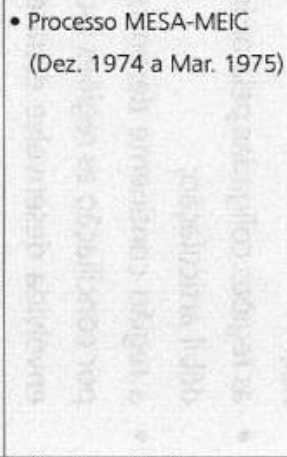 & $\begin{array}{l}\text { - Criação de cinco } \\
\text { grupos de trabalho } \\
\text { interministeriais nos } \\
\text { seguintes domínios: } \\
\text { detecção de } \\
\text { necessidades; programaçāo } \\
\text { preliminar, análise de } \\
\text { sistemas construtivos, } \\
\text { terrenos e planeamento } \\
\text { físico, planificação } \\
\text { e programaçăo. }\end{array}$ & $\begin{array}{l}\text { - Tensão entre função de } \\
\text { coordenaçăo e funçẫo } \\
\text { sectorial de execução } \\
\text { de politicas públicas. } \\
\text { A funçăo de coordenaçắo } \\
\text { mostra-se vulnerável à } \\
\text { atitude de resisténcia das } \\
\text { estruturas burocráticas } \\
\text { permanentes. }\end{array}$ \\
\hline
\end{tabular}




\begin{tabular}{|c|c|c|c|c|}
\hline $\begin{array}{l}\text { - Duplicação e } \\
\text { dispersão dos } \\
\text { esforços de } \\
\text { construção por } \\
\text { dois ministérios } \\
\text { MESA e MEIC). }\end{array}$ & $\begin{array}{l}\text { - Integraçáo faseada dos } \\
\text { sectores que nos dois } \\
\text { ministérios se ocupam } \\
\text { das construções } \\
\text { escolares. }\end{array}$ & $\begin{array}{l}\text { - Comissăo para } \\
\text { a execuçăo de } \\
\text { construçōes } \\
\text { escolares (Maio } \\
\text { de 1976) }\end{array}$ & $\begin{array}{l}\text { - Criação de estruturas } \\
\text { administrativas } \\
\text { horizontais articuladas } \\
\text { com os órgăos } \\
\text { politicos. }\end{array}$ & $\begin{array}{l}\text { - Tensăo entre } \\
\text { delimitação/integração } \\
\text { entre o Ministério da } \\
\text { Educação e o Ministério } \\
\text { das Obras Públicas. }\end{array}$ \\
\hline $\begin{array}{l}\text { - Incompatibilidade } \\
\text { entre as } \\
\text { necessidades locais } \\
\text { e os meios } \\
\text { de execuçăo. }\end{array}$ & $\begin{array}{l}\text { - Estabelecimento } \\
\text { de programas } \\
\text { diferenciados para } \\
\text { o nível de } \\
\text { planeamento } \\
\text { central e regional. }\end{array}$ & $\begin{array}{l}\text { - Programa de } \\
\text { assistência técnica } \\
\text { da OCDE (Maio de } \\
\text { 1977) }\end{array}$ & $\begin{array}{l}\text { - Criaçăo de uma equipa } \\
\text { piloto com o objectivo } \\
\text { de estudar uma } \\
\text { metodologia para } \\
\text { detecçăo de } \\
\text { necessidades de } \\
\text { equipamentos. }\end{array}$ & $\begin{array}{l}\text { - Tensāo entre indicadores } \\
\text { de planeamento central } \\
\text { e indicadores } \\
\text { de planeamento } \\
\text { regional. Tensão } \\
\text { entre planos anuais e } \\
\text { planos plurianuais } \\
\text { (transformaçăo do } \\
\text { inventário de carências } \\
\text { em planos de execução) }\end{array}$ \\
\hline $\begin{array}{l}\text { - Acumulaçăo das } \\
\text { funçōes normativas } \\
\text { e de execução nos } \\
\text { mesmos órgãos da } \\
\text { administração. }\end{array}$ & $\begin{array}{l}\text { - Desconcentraçăo } \\
\text { das fases de } \\
\text { planeamento e } \\
\text { execução de } \\
\text { equipamentos para } \\
\text { o nivel regional. }\end{array}$ & $\begin{array}{l}\text { - Projecto de } \\
\text { Desenvolvimento } \\
\text { Regional de } \\
\text { Equipamentos } \\
\text { Educativos (1981). }\end{array}$ & $\begin{array}{l}\text { - Criação de um modelo } \\
\text { de avaliação contínua } \\
\text { das necessidades } \\
\text { em educação, } \\
\text { compatibilizando-as } \\
\text { com a oferta } \\
\text { já existente. }\end{array}$ & $\begin{array}{l}\text { - Tensão entre } \\
\text { desconcentração } \\
\text { administrativa, } \\
\text { descentralizaçáo } \\
\text { política e } \\
\text { regionalização do } \\
\text { poder político. }\end{array}$ \\
\hline
\end{tabular}


Quadro 11 • Parte II - Principais medidas organizacionais dirigidas para a coordenaçăo da administraçăo

\begin{tabular}{|c|c|c|c|c|}
\hline & $\begin{array}{c}\text { DESCONCENTRAÇÃOO } \\
1975-1980\end{array}$ & $\begin{array}{c}\text { REGIONALIZAÇÃO } \\
1981-1983\end{array}$ & $\begin{array}{c}\text { DESCENTRALIZAÇÃO } \\
1984-1987\end{array}$ & $\begin{array}{c}\text { AUTONOMIA } \\
1988-1991\end{array}$ \\
\hline $\begin{array}{l}\text { ENQUADRAMENTO } \\
\text { INSTITUCIONAL }\end{array}$ & $\begin{array}{l}\text { - Grupo de Trabalho, } 1975 \\
\text { - Secretariado Técnico para } \\
\text { a Regionalização, } 1976 \\
\text { - Grupo de Trabalho, } 1978 \\
\text { - Grupo de Trabalho, } 1979 \\
\text { - Secretariado, } 1979 \\
\text { - Gabinete para a } \\
\text { Desconcentraçăo, } 1979\end{array}$ & $\begin{array}{l}\text { - Projecto de } \\
\text { Desenvolvimento } \\
\text { Regional de } \\
\text { Equipamentos } \\
\text { Educativos, } 1981 .\end{array}$ & $\begin{array}{l}\text { - Grupo de Trabalho, } 1984 . \\
\text { - CRSE, } 1986 . \\
\text { - Lei de Bases do } \\
\text { Sistema Educativo, } 1986 .\end{array}$ & $\begin{array}{l}\text { - CRSE } \\
\text { - Decretos-Leis }\end{array}$ \\
\hline $\begin{array}{l}\text { LOGICA } \\
\text { DOMINANTE }\end{array}$ & $\begin{array}{l}\text { - Racionalizaçāo } \\
\text { das estruturas. } \\
\text { - Racionalização dos } \\
\text { métodos. } \\
\text { - Eficiência. } \\
\text { - Interdepartamentalização }\end{array}$ & $\begin{array}{l}\text { - Ordenamento } \\
\text { do território. } \\
\text { - Racionalização do } \\
\text { parque escolar. } \\
\text { - Reduçáo das assimetrias } \\
\text { regionais. }\end{array}$ & $\begin{array}{l}\text { - Desburocratização. } \\
\text { - Simplificação dos } \\
\text { procedimentos. } \\
\text { - Modernizaçăo. } \\
\text { - Limitação da intervenção } \\
\text { do Estado. }\end{array}$ & $\begin{array}{l}\text { - Qualidade } \\
\text { - Responsabilizaçăo }\end{array}$ \\
\hline INICIATIVAS & $\begin{array}{l}\text { - Grupos coordenadores } \\
\text { nas sedes de Distrito } \\
\text { (Porto, Coimbra, } \\
\text { Santarém, Evora e Faro) } \\
\text { integrados por } \\
\text { representantes dos } \\
\text { sectores administrativo } \\
\text { e pedagógico. }\end{array}$ & $\begin{array}{l}\text { - Elaboração de } \\
\text { programas } \\
\text { plurianuais de } \\
\text { execução de } \\
\text { equipamentos } \\
\text { educativos. }\end{array}$ & $\begin{array}{l}\text { - Anteprojecto de } \\
\text { lei-quadro das Direcções } \\
\text { Regionais de Educação. } \\
\text { - Lei Orgânica do Ministério } \\
\text { da Educação e criação } \\
\text { das direç̧ōes-regionais. }\end{array}$ & $\begin{array}{l}\text { - Regulmentaçăo } \\
\text { da autonomia } \\
\text { administrativa } \\
\text { das Direcçōes Regionais. } \\
\text { - Regime Juridico } \\
\text { de autonomia } \\
\text { das escolas. }\end{array}$ \\
\hline
\end{tabular}




\begin{tabular}{|c|c|c|c|c|}
\hline 9 & $\begin{array}{l}\text { - Lançamento dos Centros } \\
\text { Regionais de informação } \\
\text { e dos Centros Regionais } \\
\text { de Apoio Pedagógico (1975/76 } \\
\text { - Serviços Regionais } \\
\text { do Ministério } \\
\text { da Educaçăo (1977)*. }\end{array}$ & & & \\
\hline CONTROVERSIAS & $\begin{array}{l}\text { - Projectos diversos } \\
\text { de divisão territorial. } \\
\text { - Resistência das } \\
\text { direcçōes gerais. } \\
\text { - Desconexăo com } \\
\text { outros ministérios. }\end{array}$ & $\begin{array}{l}\text { - Inexistência de } \\
\text { uma Lei de Bases. } \\
\text { - Năo concretização } \\
\text { da regionalizaçăo } \\
\text { politica. }\end{array}$ & $\begin{array}{l}\text { - Desconcentraçãol } \\
\text { descentralizaçáo } \\
\text { - Diferenciaçãol } \\
\text { Homogeneidade }\end{array}$ & $\begin{array}{l}\text { - Administraçăo autónoma/ } \\
\text { - Administração indirecta. } \\
\text { autonomia decretada/ } \\
\text { autonomia praticada. }\end{array}$ \\
\hline DOCUMENTOS DA & $\begin{array}{l}\text { - Despacho n. } 26 / 75(14 / 2) \\
\text { - Despacho n. } 280 / 75(12 / 7) \\
\text { - Despacho n. } 31 / 76(9 / 2) \\
\text { - Decreto-tei n. } 137 / 77(6 / 4) \\
\text { - Despacho n. } 374 / 78 \\
\text { - Despacho conjunto } \\
\text { n. } 68 / 79(28 / 2) \\
\text { - Despacho n. } 93 / 79(22 / 3) \\
\text { - Resoluçăo n. } 341 / 79(31 / 10) \\
\text { - Despacho } n .^{\circ} 312 / 79(6 / 12)\end{array}$ & $\begin{array}{l}\text { - Programa de } \\
\text { desenvolvimento } \\
\text { regional de } \\
\text { equipamentos } \\
\text { educativos no } \\
\text { Distrito de Portalegre. } \\
\text { Lisboa: DGEE,1981. } \\
\text { - PDREE - Relatorio } \\
\text { e Anexos por } \\
\text { Concelho. } \\
\text { Lisboa: DGEE, } 1983 . \\
\text { - Estruturas centrais } \\
\text { que interferem nos } \\
\text { equipamentos educativos: } \\
\text { análise funcional, } \\
\text { Rita Veiga da Cunha, } \\
\text { Lisboa: DGEE,1984. }\end{array}$ & $\begin{array}{l}\text { - Despacho n. }{ }^{\circ} 79 / 84 \text { (12/4) } \\
\text { - Decreto-Lei n. } 3 / 87 \text { (3/1) } \\
\text { - Centralização e } \\
\text { Descentralizaçăo, Cáncio } \\
\text { Martins, in M. Silva e M. } \\
\text { Isabel Tamen, Sistema de } \\
\text { Ensino em Portugal. Lisboa: } \\
\text { FCG, 1981, pp. } 95 \text {-116. } \\
\text { - Gestāo do Sistema de } \\
\text { Ensino, M. Prostes da } \\
\text { Fonseca, in M. Silva e M. } \\
\text { Isabel Tamen, Sistema de } \\
\text { Ensino em Portugal. Lisboa: } \\
\text { FCG, 1981, pp. } 117 \text { - 142. }\end{array}$ & $\begin{array}{l}\text { - Proposta Global de } \\
\text { Reforma, } 1988 . \\
\text { - Decreto-Lei n. }{ }^{\circ 4} 439 \text {. } \\
\text { - Decreto-Lei n. }{ }^{\circ} 361 / 89 \\
\text { (18/10). }\end{array}$ \\
\hline
\end{tabular}

(*) Apenas os grupos coordenadores tiveram uma actividade que se prolongou por mais de um ano. Todas as outras iniciativas, ou não chegaram a concretizar-se ou tiveram uma existência muito precária. 
O período crítico da construção escolar tem uma duração longa com mais de uma década. Só após a entrada de Portugal na CEE, em 1985, e com a mobilização de fundos permitida pelo Programa de Desenvolvimento Educativo para Portugal (Prodep), começou a ser visível a reorganização do parque escolar e a correspondente desmassificação das escolas. Dentre os aspectos estruturais mais persistentes neste período crítico encontra-se a política de solos. Não é nossa intenção proceder a uma análise das políticas públicas fundiárias. Porém, há-de registar-se as referências recorrentes dos documentos internos da Direcçăo-Geral das Construçōes Escolares às dificuldades em obter terrenos com as condições indispensáveis para equipamentos escolares. A gestão destas dificuldades é um dos principais argumentos que justifica a existência independente desta direcção-geral. A título de exemplo refere-se a informaçăo-proposta ${ }^{(71)}$ que o Secretário de Estado das Obras Públicas, Eng. ${ }^{\circ}$ Garcia dos Santos, envia ao Ministro, em 17 de Maio de 1976. Esta proposta viria a estar na origem da inviabilização da resolução do Conselho de Ministros, de 14 de Abril de 1976, que aprovara a criação de uma Comissão para a Execução de Construçōes Escolares da iniciativa da Secretaria de Estado da Administração Escolar. Opondo-se a esta centralização das construções no Ministério da Educação, argumenta o secretário de Estado: «para além das preocupações já assinaladas anteriormente posso, em síntese, referir algumas outras que resultam basicamente da proposta do MEIC ao Conselho de Ministros, e já aprovada: o MEIC obtem cobertura para formas de actuação da DGEE que ultrapassam as que são permitidas, por lei, à DGCE; a situaçăo criada, relativamente às intençôes de ligação com os empreiteiros de construção civil por sistemas de pré-fabricaçăo, tem implicaçōes de vária ordem, a saber: a) retira-lhes (aos empreiteiros) o interesse (e obrigatoriedade legal) de homologarem os seus sistemas através do LNEC; b) sobrecarrega-os de trabalho, retirando-Ihes a capacidade de responderem a solicitaçōes da DGCE quer para obras que já tenham em curso, quer para obras novas; c) pode retirar-Ihes o interesse de caminhar no sentido da criação do Consórcio preconizado pelo MEIC (assunto muito delicado e na concretização do qual o MOP deveria participar) uma vez que dispōem da possibilidade de lhes serem adjudicados individualmente obras completas por Serviços distintos dos do MEIC. O MEIC năo deve dispor, neste momento, de terrenos para a concretização do plano que propōe, nem de estrutura capaz de lhe permitir a sua obtenção conveniente quer em tempo quer em qualidade».

A extensa citação justifica-se pelo facto de, nesta passagem, se encontrarem as três referências centrais que marcaram a contingência burocrática do Estado no que

(71) In Arquivo da Secretaria-Geral do Ministério da Educaçăo. 
concerne às políticas educativas: a) descaso entre necessidades de legitimação (mais construção escolar neste caso) e impossibilidade de as concretizar do lado da acumulaçăo; b) ampliação do peso relativo de cada sector no conjunto da administraçăo, através da substituição, modificação ou neutralização dos objectivos políticos que lhe são impostos pelo governo; c) protecção das tradicionais zonas de interacção e conivência com a sociedade civil (empreiteiros, autarquias e proprietários de terrenos neste caso específico).

Durante a crise revolucionária, a exigência de nacionalização do solo e de criação de grandes reservas fundiárias nunca chegou a ocupar um lugar central na agenda política. Para além de algumas medidas avulsas, tomadas na corrente das ocupações da grande propriedade fundiária, as intervençōes no estatuto da terra foram em geral tímidas e nunca deixaram de assentar na defesa da propriedade privada. Com o encerramento da crise revolucionária, no final de 1975, a conjuntura político-ideológica ainda mais acentuou o respeito pela propriedade da terra. O fracasso relativo da política fundiária é particularmente agudo nos grandes centros. Por um lado, nos centros urbanos, a inexistência de uma política coerente de municipalização dos solos impossibilita a fuga à alta de preços; por outro lado, «na proximidade dos centros que estruturam a Região (de Lisboa) existem ainda com frequência áreas livres. Não correspondem contudo a solo disponível, por diversas razões: encontram-se já vinculadas a ocupaçōes definitivas em que os equipamentos sociais não foram admitidos; no local existem bairros clandestinos cuja reconversão é difícil e onerosa; correspondem a encostas muito inclinadas ou vales ensombrados que a expansăo urbana rejeitou; o seu valor venal atinge níveis especulativos e incomportáveis, principalmente em locais onde previamente foram aprovados planos altamente valorizadores do solon (MHOP/ DGCE, 1979: 17).

Daqui derivam tempos de espera enormes na execução dos equipamentos. Para uma mesma escola programada acontece, frequentemente, que vários terrenos tenham que ser aprovados, sucedendo-se negociações morosas e alterações que impedem a construção nos locais previamente designados. Os instrumentos básicos de intervenção estatal na política do solo são usados de forma muito diversa, não enfrentando, com o mesmo grau de eficácia, as várias formas de propriedade fundiária. Assim, a aplicação de políticas de aquisição pública, de políticas de criação de reservas fundiárias e de políticas de posse administrativa variam segundo o tipo de propriedade. Enquanto o Estado enfrenta com alguma eficácia a propriedade parcelar de utilizadores directos, já o mesmo não sucede com as formas cada vez mais dominantes de propriedade industrial-financeira, incluindo a propriedade sujeita à especulação imobiliária. Nas zonas rurais, as medidas mais frequentemente usadas 
pelos técnicos especializados do MHOP, que negoceiam directamente, são a posse administrativa, a expropriação ou a negociação amigável: «os técnicos especializados que procedem à aquisição, devem receber assim, completamente informados, os processos necessários ao início das negociações com os proprietários, facto que, não salvaguarda contudo o aparecimento de contenciosos difíceis de resolver e que estăo na origem de novos e por vezes indeterminados atrasos. Apesar de se procurar sempre proceder a aquisiçōes por meio de negociaçōes amigáveis, nem sempre é possivel dispor de alternativas onde uma tal situação se verifique. As situaçōes mais difíceis surgem sempre, nos casos em que os proprietários dos terrenos os destinam a fins especulativos» (Idem, Ibidem, pp-28-29). Pelo contrário, nas grandes concentrações urbanas, as resistências levantadas por certas formas de propriedade tornam-se intransponíveis: «é contudo de salientar que essas acçōes (reservas de terrenos segundo Normas de designação urbanística de terrenos escolares, 1971) desenvolvidas num contexto geral pouco favorável, se revelaram insuficientes, especialmente nas áreas onde as concentraçōes urbanas assumiam maiores proporçōes. Năo só a dimensão das áreas já construídas impedia a existência de terrenos livres, como também a abundância de operações especulativas sem regras dificultava a aceitação de normas que, para cada loteamento, exigiam a cedência às Câmaras, ou ao Estado, de uma percentagem considerável de solo para equipamentos colectivos» (Idem, Ibidem, p. 22). A subida constante dos preços do solo urbano, a falta de meios financeiros do Estado e a impotência para enfrentar a propriedade industrial-financeira, a que se somam factores de natureza ambiental ou de defesa do património, fazem com que a diferença entre o número de escolas preparatórias e secundárias, programadas pelo MEIC, e os respectivos terrenos para construção aumente no período entre 1977 e 1980.(72)

Entretanto, a DGCE participa com frequência em reuniões da OCDE, especialmente no âmbito do Projecto PEB/OCDE (Program on Educational Building), em que se vinham produzindo duas ordens de problematizaçōes. Por um lado, discutia-se o papel da construção escolar na inovação do ensino e, por outro lado, procedia-se à elaboração das condiçōes técnicas necessárias à eficácia da escolarização e à rentabilidade dos investimentos em equipamentos educativos.

É a perspectiva da eficácia e da rentabilidade dos investimentos que terá um maior impacto na interpretação e adaptação que a DGCE faz dos documentos da OCDE à

(72) Note-se que, enquanto em Janeiro de 1977 o MEIC programara 40 novas escolas preparatórias e secundárias, existindo 13 terrenos aprovados pela DGCE; em Abril de 1978, para 180 novas escolas programadas, havia apenas 75 terrenos aprovados (Fonte: MHOP/DGCE, Explosão escolar e carências de instalaçőes, Lisboa: DGCE, p. 34). 
situação portuguesa. Em particular, porque, em 1975, a OCDE produz um dossiê intitulado A escola e a construção industrializada (OCDE, 1975) que é considerado especialmente adaptado às condições de urgência criadas por uma situação de explosão demográfica dos sistemas educativos. Uma das características principais desta proposta consiste em utilizar sistemas de construção lineares, uniformes, que possibilitem a modelizaçăo e a generalizaçăo rápidas, bem como economias de escala. Centrados na sala de aula tradicional, dificilmente se adaptam a condiçōes flexíveis de utilização do espaço escolar, como as que são exigidas pela presença de centros de documentação e informação, espaços individuais de trabalho ou grandes espaços de anfiteatro. Como explicitamente se reconhece, a diversidade de modos pedagógicos praticados pelas modernas pedagogias, que acolhem grupos de dimensăo variável e acções pouco estandardizadas e de duraçăo indeterminada, põe problemas de difícil resolução aos técnicos de construção escolar. A questăo da concertação entre projecto pedagógico e projecto construtivo torna-se um imperativo que tem como resultado um Relatório, no ano seguinte, sobre a adaptabilidade e a flexibilidade da construção escolar (OCDE, 1976). Os dois conceitos passam não só a fazer parte do vocabulário sobre as construções escolares como a articular-se com conceitos pedagógicos homólogos. A adaptabilidade diz respeito a modificaçōes de grande amplitude e baixa frequência: «l'ádaptation peut rendre nécessaire de déplacer, remplacer, retirer ou ajouter soit des éléments de la construction soit des services» (p. 10). A flexibilidade comporta as mudanças de baixa amplitude e de grande frequência: "varier les activités, les horaires, les effectifs des classes, etc., dans une école sans qu'il soit besoin d'adaptation telle qu'elle vient d'être définie» (Idem, Ibidem). 0 elenco de mudanças pedagógicas que podem dar origem às alteraçōes previstas registam em espelho a flexibilidade e adaptabilidade das construções: alteração do número total de alunos; modificaçăo do número de alunos envolvidos nas actividades; mudança da natureza das actividades curriculares; introdução de actividades novas e de novas relações entre elas; reexame das relações entre teoria e prática; passagem do ensino à aprendizgem activa; inovação tecnológica. No entanto, a flexibilidade e a adaptabilidade continuam a ser consideradas propriedades intrínsecas dos equipamentos, denunciando assim a perspectiva técnica da diligência.

Em 1980, é criado um regime de excepção denominado Programa especial de execução de escolas preparatórias e secundárias. ${ }^{(73)}$ Este regime permite que os empreendimentos nele incluídos sofram a simplificação de alguns procedimentos

(73) Decreto-lei n. ${ }^{\circ} 76 / 80$ de $15 / 4$. 
administrativos, imprimindo-lhes assim um ritmo de execução superior ao normal. Até 1987 foram incluídos 218 empreendimentos correspodentes a um volume de obra de 45 milhōes de contos. Entre 1980 e 1987, do conjunto de 374 intervençōes no parque escolar, incluindo escolas novas e ampliações, contabilizadas pela Comissão de avaliação do Programa especial nomeada pelo Despacho 53/ME/87, 70\% foram realizadas ao abrigo do Programa Especial. ${ }^{(74)}$ Este programa especial teve, segundo a Comissão de Avaliação, resultados pouco favoráveis, desde logo, devido à uniformização das tipologias utilizadas e pelo inacabamento de muitos dos edifícios: «utilizaram-se projectos tipo, solução que permitiu fazer um grande número de escolas em prazos muito curtos, mas em contrapartida esta orientação conduziu a que se construisse escolas com o mesmo projecto em locais e regiōes muito diferenciados, o que se considera inconveniente». Os acessos, a iluminação, os arranjos exteriores e os pavilhões ficam quase sempre inacabados ou para segunda fase. No período inicial de 1980-83 muitos edifícios săo construídos com base em sistemas pré-fabricados leves. Apesar disso, o custo total dos edifícios e infra-estruturas é sempre mais elevado nos planos especiais do que nos planos normais. ${ }^{(75)}$

Debaixo da pressão da urgência e dos custos o modelo-tipo impõe-se. As fontes que tratam numa perspectiva globalizante o problema das construçŏes escolares não deixam de se centrar na rapidez dos procedimentos de programação, no volume de construção e nos seus custos. As exigências de qualidade dos espaços escolares só mais tarde serão introduzidas, embora as recomendações e regulamentos sobre construção escolar retomem com frequência as prescrições gerais e os dados técnicos comuns ao edifício e a cada local específico da escola, incluindo os espaços administrativos e de gestão escolar. ${ }^{(76)}$ Săo estas prescrições gerais que normalizam o espaço

(74) Cálculo efectuado a partir das informaçōes da DGEE constantes do Relatório de Avaliaçăo (pp. 7-11).

(75) Para se ter uma ideia da escala de elevaçăo dos custos por m2 de construção em Plano Especial pode citar-se o relatório de avaliação que situa em $41 \%$ e $25.8 \%$ o aumento registado respectivamente em 1980 e 1982. Tal aumento deve-se sobretudo a rubricas como «imprevistos» e "trabalhos a mais».

(76) Cf. Magos, Maria Júlia Tomás (1985), Recomendaçōes sobre construção escolar no âmbito do ensino preparatório e secundário unificado. Lisboa: DGEE (trabalho apresentado no concurso interno de acesso na categoria de arquitecto assessor). Esta monografia retoma em várias fichas alguns imperativos funcionais e físicos de construção escolar dispersos em documentos e legislação avulsa. Inclui os espaços interiores e os espaços exteriores. Nos primeiros, distingue espaços de ensino, espaços de apoio ao ensino, espaços complementares de apoio e espaços de circulação; nos segundos, distingue espaços verdes, espaços de recreio, espaços desportivos e espaços de circulaçăo. No capítulo dedicado aos espaços de ensino, a listagem revela bem o modelo tradicional que lhe está subjacente, coincidente com os espaços entretanto construídos: sala de aula normal ("caracterizado por um ensino direccional», p. 38); sala de aula para grandes grupos; sala de aula para pequenos grupos; sala de 
escolar a construir e determinam os modelos-tipo, descrevendo em detalhe as proporçōes dos equipamentos interiores e exteriores. Simultaneamente, neutralizam os dispositivos de socializaçăo dos alunos inscritos no próprio espaço escolar, por intermédio de uma espessa superfície de normas sobre higiene, segurança, luminosidade, comportamento térmico e comodidade. Em qualquer caso, os textos regulamentares sobre o espaço escolar não estão subordinados a um conhecimento explícito do seu funcionamento pedagógico, o que revela bem como a sua utilização é tida por evidente. Para além disso, a modelização da construçăo escolar dos anos 80 nem sequer os imperativos inscritos nos regulamentos cumpre, produzindo muitas anomalias que ainda hoje se fazem sentir na degradação constante do parque escolar. As anomalias a que nos referimos são discriminadas de forma impressionista no Relatório de Avaliação do programa especial de execução de escolas preparatórias e secundárias, Lisboa: ME (p. 37): «inadequada articulação dos espaços, falta de recreios cobertos e de galerias de ligaçăo entre blocos, a falta de certos tipos de espaços especializados, as deficientes condições de salubridade no Inverno, as más condições de iluminação natural e de protecção solar, alguma inadequação dos revestimentos, a má qualidade de certos componentes da construção, a carência de instalações gimnodesportivas, a perda de estanquidade da envolvente, a rotura de canalizações, algum mobiliário insatisfatório, a deficiente concepção do bufete e, sobretudo, a inadequação dos espaços exteriores». Esta descriçăo, para além de nos pôr ao corrente das condiçōes grandemente deficitárias como se processou a construção escolar nos anos 74-86, serve para confirmar o carácter normativo da construçāo e a sua lógica economicista, já que a avaliação se limita a seguir uma lista de verificaçăo do que está previsto nos regulamentos e a sugerir que as economias realizadas num primeiro tempo se transformaram em deseconomias de escala, em virtude dos

aula para educação visual e ciências da natureza; sala de desenho; sala de trabalhos oficinais; sala de ginástica; ginásio; biblioteca. Trata-se, portanto, de um espaço tipicamente disciplinar, centrado na sala de aula e na turma, organizado em séries de conteúdos curriculares e numa grelha de tempo repetitiva. No aparente desprendimento técnico do documento inscreve-se, de facto, um método para a determinação do número e diversidade dos espaços escolares. Trata-se de um método centrado na turma, que faz corresponder a cada turma uma sala de aula. Os espaços especificos são programados de acordo com as particularidades do ensino a ministrar. Porém, este método determina o aumento do número de salas e, consequentemente, custos acrescidos. A escola pluricurricular e com dois turnos determinou constrangimentos importantes no plano da composiçăo dos espaços e do tempo escolar que obrigou à procura de optimizaçāo das respectivas taxas de utilização. 0 agrupamento por afinidades disciplinares tornou-se assim, frequentemente, no método privilegiado, soluçăo ainda reforçada pelo aparecimento de extensōes curriculares e não curriculares (informática, clubes, etc.). Cf. também Recintos escolares. Critérios para designação urbanistica, Lisboa: DGCE, 1985. 
investimentos avultados que a reparação das anomalias encontradas no parque impunha. O grau de adequaçăo das construções ao projecto pedagógico nunca é enunciado, confirmando assim o modelo. Como se explica num documento do Programa descentralizado sobre construção escolar, traduzido pela DGCE (MHOP/DGCE, 1982: 17-18), da autoria de John Mayfield, as tecnologias organizacionais, económicas e administrativas têm um papel mais importante que os critérios de natureza pedagógica. E nesse, como em outros casos, é a dinâmica da contingência e não os princípios morais ou de justiça que marcam a racionalidade do sistema: «é possível que novos tipos de instituições possam aparecer por efeito da reorganização de parte do sistema escolar, independentemente de qualquer política ligada à diminuição ou aumento do número de alunos. A própria diversidade de sistemas de organização indica que há poucos critérios de natureza pedagógica, se é que os há, que conduzam a uma forma específica de organização. De facto, é a exploraçăo de formas diversas de organização que pode conduzir a transformações que, no cômputo geral, sejam pedagógica ou economicamente preferiveis. Um melhor aproveitamento dos recursos existentes depende dum certo grau de reorganização do sistema escolar e, apesar de muitas vezes serem apresentados argumentos de ordem pedagógica contra tais transformações, os verdadeiros impedimentos encontram-se, antes, noutros aspectos como as estruturas de pessoal, as expectativas tradicionais e as regulamentaçōes administrativas».

No quadro 12 apresenta-se uma síntese dos processos envolvidos nas diferentes fases da distribuição de equipamentos educativos no espaço nacional, desde a detecção de necessidades até à lógica de distribuição dos alunos pelas respectivas áreas pedagógicas. Nesta descrição, adquirem saliência os mecanismos de dispersăo utilizados pela administraçăo, bem como a funcionalidade de certos níveis de contingência burocrática.

\section{Governar um sistema calculável: as estatísticas e o planeamento}

Na metodologia do inventário de carências e da carta escolar existem duas noções comuns: área de recrutamento e normalização dos equipamentos. Segundo Hallak (1976), a área de recrutamento consiste na zona geográfica servida pelo estabelecimento de ensino: "pour préciser l'aire de recrutement d'une école, il suffit d'identifier les lieux de résidence des élèves et de tracer la plus petite surface comprenant l'origine géographique de tous les élèves» (p. 197). O papel das áreas de recrutamento no planeamento da rede escolar pressupõe, consequentemente, a 
Quadro 12 - Mecanismos de dispersão utilizados na coordenaçăo dos vários sectores que na administração se dedicam aos equipamentos educativos

\begin{tabular}{|c|c|c|}
\hline REGIÃO CONTINENTE & REGIOES INSULARES & REGIẢO LOCAL \\
\hline $\begin{array}{l}\text { - Detecçăo de necessidades } \\
\text { de equipamentos } \\
\text { educativos } \\
\text { - Critérios de oferta nacionais }\end{array}$ & $\begin{array}{l}\text { - Recursos suplementares } \\
\text { para mais escolas ou não } \\
\text { decisão em funçăo da } \\
\text { disputa entre Cămaras ou } \\
\text { outros actores } \\
\text { Reajustamento/não-decisão }\end{array}$ & $\begin{array}{l}\text { - Zonas de influência } \\
\text { pedagógica } \\
\text { - Critérios de gestão (procura } \\
\text { preferencial de escola em } \\
\text { função das opçōes). } \\
\text { Lógica da procura }\end{array}$ \\
\hline $\begin{array}{l}\text { - Localização em funçăo do } \\
\text { inventário de carências }\end{array}$ & $\begin{array}{l}\text { - Processo de diálogo com as } \\
\text { autarquias envolvidas. } \\
\text { Reacção contingencial/ rejeição }\end{array}$ & $\begin{array}{l}\text { - Localização em função das } \\
\text { necessidades reconhecidas } \\
\text { pelos actores locais } \\
\text { (escolas, associaçôes de } \\
\text { pais, juntas de freguesia, } \\
\text { comissōes de moradores, } \\
\text { Câmara Municipal). }\end{array}$ \\
\hline $\begin{array}{l}\text { Distribuição de alunos } \\
\text { em função das áreas } \\
\text { pedagógicas }\end{array}$ & $\begin{array}{l}\text { - Negociaçăo entre escolas e } \\
\text { Direcçóes Regionais nas } \\
\text { áreas pedagógicas } \\
\text { Aplicação parcial }\end{array}$ & $\begin{array}{l}\text { - Previsăo do número de } \\
\text { alunos, número de turmas } \\
\text { e opçŏes em funçăo das } \\
\text { inscriçōes contabilizadas } \\
\text { no próprio estabelecimento } \\
\text { de ensino. }\end{array}$ \\
\hline $\begin{array}{l}\text { - Determinação de número } \\
\text { de professores em funçắo } \\
\text { da oferta das áreas } \\
\text { pedagógicas }\end{array}$ & $\begin{array}{l}\text { - Negociaçăo entre escolas } \\
\text { e Direcçőes Regionais nas } \\
\text { áreas pedagógicas } \\
\text { Aplicação parcial }\end{array}$ & $\begin{array}{l}\text { - Previsăo do número de } \\
\text { professores em função das } \\
\text { disciplinas e opçóes } \\
\text { previstas no plano de } \\
\text { estudos da escola. }\end{array}$ \\
\hline
\end{tabular}

existência de regras de inscrição e frequência em função do local de residência dos alunos. A representaçăo gráfica das áreas de recrutamento sob a forma de círculos, como as que foram utilizadas nos inventários de carências, fixam-se ainda noutro conjunto de invariantes iniciais que permitem formalizar o modelo, como sejam: uma repartição homogénea da população; iguais possibilidades de acesso de todos os lugares da área de recrutamento e similitude de características das escolas. Este é um planeamento típico dirigido para o governo da população, segundo o qual o Estado-administrador pressupõe a homogeneidade do espaço nacional; a atomicidade da oferta e procura de educação, centrada que está na resposta à procura individual; a transparência, que imagina um estado perfeito da informação sobre a procura por parte da administração; a autonomia da oferta e da procura, porque a primeira depende das condições técnicas e orçamentais do Estado e a segunda das preferências 
individuais quanto à decisão de prosseguir ou interromper os estudos; a fixidez dos dados demográficos, já que não tem em consideraçăo fenómenos migratórios e outros que alteram significativamente a pressão sobre o sistema educativo. Como bem resume Hallak, a realidade é bem diferente e mais heterogénea do que a representação produzida pelo planeamento central do Estado faz crer: «l'habitat est souvent réparti le long des axes routiers et ne se disperse pas uniformément sur l'aire géographique concernée; il est trés rare de disposer d'une topographie sans accident de relief; les possibilités d'accès à l'école varient; et malgré les efforts des services centraux de l'éducation, les écoles continuent à différer entre elles quand on les examine selon certains critères» (p. 201).

Todavia, é a própria representação estatística da população escolar que mais afecta o cálculo da área de recrutamento, em virtude dos fenómenos da mobilidade e do envelhecimento (Hallak, 1976: 151-160). A mobilidade da população escolar é um fenómeno com contornos muito complexos no espaço urbano, por que assume uma estrutura pendular, que ora favorece o movimento das populaçōes do centro das cidades para as zonas suburbanas, dando lugar ao terciário, ora favorece o movimento de alguns grupos da classe média para zonas históricas entretanto reabilitadas. O envelhecimento constitui um fenómeno típico da inércia das estatísticas. Qualquer que seja a fórmula utilizada, quando se decide construir uma escola admite-se a correspondência entre as suas características (tamanho, tipologia, etc.) e a pirâmide demográfica da sua zona de irradiação. Porém, ao fim de algum tempo, a pirâmide é afectada na sua forma, podendo sofrer desvios de amplitude diversa, que tornam as escolas excedentárias ou deficitárias em número de lugares. Se a este tipo de mobilidade estatística, que não tem em conta a pertença social, somarmos a mobilidade assimétrica dos grupos sociais, e a evidente diferenciaçăo regional, teremos então um quadro cada vez mais complexo.

O projecto O desenvolvimento da escolarização a nivel Regional (GEP, 1982a) constata um certo número de assimetrias regionais, das quais destacamos as seguintes:

- preponderância de taxas de enquadramento elevadas e de baixos níveis de qualificação do pessoal docente nos distritos do norte do País como Viana do Castelo e Vila Real;

- baixos níveis de cobertura da população escolar nos distritos com maior densidade populacional;

- baixos índices de democraticidade, devidos às baixas taxas de acesso e elevadas taxas de repetência, em distritos como o Porto, Bragança, Viana do Castelo e Vila Real; 
- predominância dos distritos do interior nos grupos com mais baixos índices de eficácia, medidos pela percentagem de alunos com idade superior ao grupo etário legalmente estabelecido.

Tais discrepâncias não parecem aconselhar critérios de planeamento que tenham em conta sobretudo as projecções demográficas segundo a pirâmide dos grupos etários. Esta constatação vem introduzir mais um factor de incerteza que os especialistas em planeamento educativo tentam resolver por intermédio da sofisticação dos meios de cálculo.

A normalização dos locais e dos equipamentos implica a definição do tamanho máximo, mínimo e óptimo dos estabelecimentos de ensino (GEP, 1990), bem como as suas tipologias. No caso em apreço, compreendendo o ensino secundário seis anos de escolaridade, no intervalo que vai do $7 .^{\circ}$ ao $12 .^{\circ}$ ano, são propostas três tipologias básicas: a) EB $1,2,3$; b) EB 2,3 ; c) ES $10{ }^{\circ}, 11 .^{\circ}, 12 .^{\circ}$. Segundo se trate de uma ou outra tipologia, os tamanhos mínimo e máximo alteram-se significativamente. Assim, enquanto para a tipologia a) a variação min-max é de 168-480 alunos e na tipologia b) de 264-576 alunos, já na tipologia c) se admite uma maior concentração com o intervalo a variar entre 384 e 720 alunos. A variabilidade das tipologias permite compreender que o critério económico de utilização dos estabelecimentos se sobrepõe ao critério das condições pedagógicas. Por um lado, porque quanto mais diferenciada é a tipologia do estabelecimento, por exemplo no que diz respeito aos seus equipamentos laboratoriais, maior é o tamanho proposto, procurando deste modo reduzir os custos unitários de utilização de certos equipamentos. Por outro lado, porque o tamanho proposto coincide com a pressão relativa sobre as tipologias existentes: os indicadores de $87 / 88$ revelam que na tipologia $C+S$ havia cerca de $45 \%$ dos estabelecimentos com taxas de ocupação superiores a 1.00, enquanto na tipologia SU+ES esse valor subia até aos 69\% (GEP, 1990: 29).

Por seu turno, os estudos da Rede dos cursos complementares em função da situação socioeconómica e do inventário de carências em instalaçôes escolares, realizados pelo GEP e publicados em 1979, inscrevem-se abertamente na lógica do capital humano. Submetidos às orientações previstas no $2 .^{\circ}$ Acordo com o Banco Mundial, pretendem estabelecer qual a oferta de cursos complementares em função do padrão de especialização de cada concelho. A análise da estrutura socioeconómica denuncia o carácter da análise: em primeiro lugar, considera a distribuição da população activa por sectores de actividade (primário, secundário e terciário); depois considera a estrutura produtiva em cada sector (indústrias alimentares, indústria transformadora, construçăo civil e sector administrativo); e, finalmente, projecta as 
perspectivas de desenvolvimento em função das Grandes Opções do Plano. O 2. ${ }^{\circ}$ acordo com o Banco Mundial, que prevê a construção e o equipamento oficinal de escolas do ensino secundário, insere-se num discurso dúplice sobre o Desenvolvimento que inclui referências ao manpower planning dos anos 50 e à modernização dos anos 70. Por um lado, reflecte as tendências de planeamento promovidas pelas agências internacionais, nos anos 50, que sustentavam uma gestão prudente dos recursos autóctones como força motriz do desenvolvimento e, por outro lado, submete as políticas educativas a um ajustamento estrutural que sirva directamente o crescimento económico e a modernização tecnológica. A maior parte dos estudos conduzidos pelo GEP e pelo Grupo Coordenador dos Projectos de Cooperação com o BIRD incluemse nos termos do acordo: «carrying out a manpower planning study, pursuant to terms of reference established in consultation with the Bank, to determine Portugal's major manpower needs through 1990 by forecasts of demand and supply in the major occupational categories in order to develop manpower policies and training requirements» (Part G3, Loan Agreement 1559 PO, June 1978). ${ }^{(77)}$

Por seu lado, a análise da situação do ensino - frequência e quebras entre os vários níveis de ensino - integra-se nos indicadores de qualidade de vida, que assinalam também a qualidade da habitação e o nível de consumo de energia. Incluem ainda qual a situação de cada concelho no inventário de carências. A conjunção destes três tipos de indicadores resulta, em regra, em sugestões quanto à oferta futura de áreas de estudo e de opções nos cursos complementares, sendo que o critério de primazia é, em alguns casos, a correspondência entre opçōes e sectores de actividade e, noutros, particularmente na zona de Lisboa, a complementaridade das ofertas de cada escola. A título de exemplo, tomamos o Distrito de Coimbra para ilustrar o primeiro caso: «tendo em atenção o ponto 9.3. onde se tentou esboçar a actividade económica do distrito e analisando a distribuição da populaçăo activa pelos sectores de actividade, parece-nos conveniente apontar para uma situação em que as opçōes dos cursos complementares se deverão distribuir segundo os seguintes valores: $35 \%$ 236 no sector primário, 30\% no sector secundário e 35\% no sector terciário (a distribuição da população activa apresentava, para dados de 1970, a seguinte distribuição: $42 \%$ no sector primário, $26 \%$ no sector secundário e $32 \%$ no sector terciário, prevendo

(77) Ver, designadamente, o estudo, intitulado Estratégia de desenvolvimento dos Recursos Humanos, publicado em Setembro de 1981, no Boletim Informativo n. ${ }^{\circ} 14$ do Ministério da Educação e das Universidades. Neste trabalho descrevem-se as aplicaçōes do Modelo integrado de previsão das necessidades de mấo-de-obra proposto pelo Banco Mundial, nos termos do qual se procura o ajustamento entre a oferta e a procura. Para uma crítica a este modelo tradicional ver Maria João Rodrigues, 1988, O sistema de emprego em Portugal - Crise e mutaçōes. Lisboa: Dom Quixote. 
as Grandes opçōes do plano a redução da população activa no sector primário) » (Idem, Ibidem, Zona Centro, 1979, p. 75). O segundo caso pode ser ilustrado pelas zonas da linha do Estoril, da linha de Sintra e da linha de Vila Franca: «com diferentes graus de industrialização estas três regiões situam-se na cintura industrial de Lisboa e bastante perto da grande metrópole pelo que a rede dos cursos complementares deve ser estudada não em função da estrutura económica local mas sim em função da complementaridade que todas estas escolas poderăo oferecer» (Idem, Ibidem, Zona Lisboa, p. 1).

Segundo o primeiro critério propōe-se a diminuição considerável dos estudos humanísticos e o aumento dos cursos do sector primário e do sector secundário. Considera-se, no entanto, que no futuro seria necessário «encontrar medidas compensatórias que pudessem permitir uma evolução suave para estas transformações, uma vez que a tradição e o número importante de raparigas no sistema irão contrariar a curto prazo, todas as medidas que se tomarem no sentido de se adaptar o sistema educativo ao sistema produtivo e ao desenvolvimento científico e tecnológico" (Idem, Ibidem, Zona Norte, p. I). O acordo com o Banco Mundial é aqui apresentado no seu vector principal: descentrar o ensino post-obrigatório dos estudos generalistas para a educação para o trabalho, incluindo nele os conhecimentos utilitários e a formação de aptidões técnicas especializadas, capazes de responder aos desafios do desenvolvimento tecnológico no espaço da produção. Conquanto se reconheça que tal opção não deixará de ter impactos negativos na democratização do acesso, em especial das raparigas. Não deixa de ser significativo que a referência à democratização do acesso seja justamente associada à pressâo dos alunos do sexo feminino, ainda que tal pressão se apresente como uma «resistência ao desenvolvimento» e como uma predisposição das raparigas contrária à educação científica. Com efeito, neste mesmo período começa a generalizar-se a utilizaçăo da percentagem de alunos matriculados do sexo feminino como um dos indicadores mais importantes da democraticidade do sistema de ensino. (78)

(78) Em 1982 são publicados pelo GEP dois estudos, iniciados ainda no final dos anos 70, sobre o desenvolvimento da escolaridade a nivel regional, cujos indicadores estatísticos revelam uma preocupação preferencial pela equalização. Cf. in O desenvolvimento da escolarização a nivel regional: o caso da escolaridade obrigatória, Lisboa, GEP (Luís Tibúrcio et al.) e Classificação dos Distritos do Continente em matéria de condiçöes de desenvolvimento da escolarizaçăo, Lisboa, GEP (Ana Maria Calado et al.). Pela importância que os indicadores estatisticos utilizados nestes estudos assumem na argumentação que se seguirá, apresentamos nesta nota uma listagem exaustiva, de modo a tornar menos pesada as referências no corpo do livro. Assim, no primeiro estudo, sugere-se a utilizaçăo dos indicadores apresentados por Gabriel Carron e Ta Ngoc Chan, numa clara referência ao campo científico das ciências da educaçăo: a) indicadores de meios: equalizaçăo da acessibilidade: custo de oportunidade das famílias; equalizaçăo da qualidade formal: composiçẫo do pessoal docente por nivel 
Esta representação da oferta de cursos em função dos sectores revela uma primeira aproximação, embora grosseira, do paradigma tradicional do capital humano, segundo o qual é possivel e desejável um ajustamento entre as qualificações requeridas pelo mercado de trabalho e as qualificações produzidas pelo sistema de educação. Nestas teorias, o mercado de trabalho aparece representado como uma articulação de cadeias de mobilidade nas quais as formaçōes escolares se integram, e não como um mecanismo aleatório de distribuição de pessoas pelos sectores de actividade. Acresce ainda que a apreciação dos sectores de actividade não permite dar conta dos perfis profissionais requeridos por estes, na medida em que se encontram na dependência de outros vectores tais como os processos de produção, os modelos organizacionais e os modos de gestão da mão-de-obra (ver Rodrigues, 1988: 60). Contudo, a principal consequência desta abordagem não está na impossibilidade de prever adequadamente os perfis profissionais requeridos pelo mercado de trabalho. Ainda que esta seja uma limitação genericamente reconhecida neste tipo de problematização, a positividade com que o faz permite equacionar a relaçăo entre sistema de ensino e sistema produtivo de um ângulo técnico e não apenas retórico ou político. Com efeito, a chamada relação entre a escola e a vida passa a ter uma equação técnica que é possivel quantificar e, sucessivamente, melhorar. $A$ construção de escolas e a oferta de cursos da escolaridade post-obrigatória deixa de ser uma função atribiliária de resposta à procura espontânea de educação e passa a ser uma função calculável do desenvolvimento económico. Pouco importa aqui a reduzida sofisticação da análise ou a improbabilidade de fazer coincidir necessidades económicas com

de ensino e região; oportunidades de formaçăo e reciclagem do pessoal docente; qualidade e tipo de instalaçōes e equipamentos escolares; organizaçăo da actividade pedagógica; composiçăo social dos alunos; equalizaçăo da qualidade real: intensidade de utilizaçăo das infraestruturas e equipamentos escolares; atitudes e métodos dos professores; clima social da escola. b) indicadores de resultados: equalizaçăo do acesso; probabilidade de entrada em cada ciclo; equalização do processo escolar; $n .^{\circ}$ de anos gastos em excesso por cada aluno; taxa de passagem; taxa de retençăo por nível de ensino segundo o sexo; idade; grupo social; equalizaçăo do resultado escolar: taxa de conclusão segundo a idade, sexo e origem social.

No segundo estudo são utilizados indicadores que pōem em primeiro palno a lógica input-output e introduzem os conceitos de qualidade e eficácia com origem nas agências internacionais, especialmente na OCDE e Unesco. a) qualidade do serviço educativo: taxa de qualificação dos professores; taxa de enquadramento; taxa de conclusăo; taxa de desperdício (abandono e repetência). b) condiçōes físicas de escolarização: \% de estabelecimentos de ensino em relação ao número de alunos amatriculados; taxa de enquadramento. c) democraticidade do sistema de ensino: taxa de escolarização real; taxa de acesso; taxa de transiçăo; \% de alunos matriculados do sexo feminino; \% de estabelecimentos de ensino em relação ao total de matriculados no ensino oficial; taxa de transiçăo; taxa de abandono; taxa de repetência; taxa de conclusão. d) eficácia do sistema escolar: \% de alunos com idade superior ao grupo etário legal por cada ciclo de ensino. 
necessidades educativas. O que determina a eficácia da problemática é a capacidade de actualizar o mito da correspondência entre desenvolvimento educativo e desenvolvimento económico, associada a normas mais gerais sobre o progresso e o bem estar: a educação é confirmada como um investimento em capital humano que promove a produtividade do trabalho e contribui para o crescimento económico e $\circ$ desenvolvimento.

Este é o tema charneira da passagem do Estado educador ao Estado promotor do desenvolvimento (Charlot, 1994b). Não porque o quase-estado-providência português não mantenha resquícios das dissociaçōes típicas do estado educador, como sejam as que opõem as opções femininas às opções masculinas, ou as que opõem as fileiras que se ocupam dos estudos humanísticos às fileiras que se ocupam dos estudos destinados ao trabalho, mas porque as políticas de selecção directa se viram substituídas por políticas de regulação dos fluxos escolares, em função das necessidades económicas do país. Inserir profissionalmente os jovens num posto que, simultaneamente, seja o mais eficaz para a sociedade e o mais correspondente às capacidades individuais, passa a estar tacitamente inscrito nas problematizaçōes de governo, antes mesmo de surgirem no discurso político. E isto porque o estado-promotor-de-desenvolvimento inverte a lógica de pilotagem das políticas educativas. Em lugar do controlo pelo projecto político, a orientaçăo pelos resultados; em vez da selecçăo a montante, a regulação dos fluxos escolares a jusante.

Desenvolvimento é o conceito central: desenvolvimento do país e desenvolvimento individual. Dentro da economia deste trabalho năo nos são permitidas grandes incursões no universo teórico que inspira estas problematizaçōes sobre o desenvolvimento. Importa, no entanto, dar conta das reflexões que, simultaneamente, se realizam em outras agências internacionais, como o IIEP (International Institute for Educational Planning) e a OCDE, que começam a integrar nos seus debates a conflitualidade típica da economia e da sociologia do desenvolvimento.

Não sendo imprescindível fazer uma síntese desse debate no âmbito deste trabaIho, limitar-nos-emos a respigar os argumentos que servem para ilustrar o reducionismo presente na agenda inicial dos especialistas portugueses em planeamento educativo. Contudo, como veremos, alguns dos contributos das novas problematizações sobre o desenvolvimento vão sendo também incorporadas no planeamento educativo, fornecendo-lhe a ductilidade e a ambiguidade próprias de um sistema com quadros de referência muito heterogéneos. Pode dizer-se, sem dificuldade, que a ambiguidade central do planeamento educativo português, na primeira década após a queda da ditadura, contribuiu para pôr em marcha certas problematizaçöes técnicas sobre $o$ desenvolvimento, sem nunca explicitar claramente um modelo ou uma teoria sobre 
o desenvolvimento. Em consequência, limitou-se a incorporar os modelos que iam sendo difundidos pelas agências internacionais de planeamento, geralmente de forma pontual, desarticulada quanto aos conteúdos e diferida quanto ao tempo da sua aplicação.

Desarticulação e desfasamento que se tornaram funcionais porque introduziram diversos patamares para o que Callon (1986) designa por operaçăo de tradução. Nesta operação, pessoas e grupos com interesses e programas contraditórios encontram em certos dispositivos, vocabulários ou problematizações pontos de passagem comuns e obrigatórios que lhes fornecem recursos suficientes para a defesa dos seus interesses próprios. A tradução é uma forma de articulaçăo discursiva que năo anula a autonomia de cada discurso, mas antes define um campo de dispersão em relação a regras comuns. Reconstruir alguns dos pressupostos comuns a tais problematizaçōes é o objectivo do quadro 13. Nele comparamos os discursos gerais e os discursos educativos sobre o desenvolvimento, segundo a sua inserçăo mundial e a tradução nos discursos educativos e nas problematizações de política educativa em Portugal. Ao colocarmos lado a lado os núcleos discursivos sobre o desenvolvimento ao nível mundial e as traduçōes realizadas no espaço nacional, pomos em evidência que o mecanismo da imitação presente na sua institucionalizaçăo, anda a par do mecanismo da sua desarticulação real crescente. A situação específica portuguesa raramente foi utilizada como fonte inspiradora para a reflexăo teórica e os modelos de recolha de dados empíricos misturam, a maior parte das vezes, indicadores propostos por quadros teóricos dos anos 60 com outros inspirados em modelos teóricos dos anos 70 e 80 . A realidade portuguesa surge como ilustração empírica, exótica, de esquemas teórico-metodológicos produzidos pelas agências internacionais.

\section{A despolitização das políticas educativas e o ciclo dos planificadores}

Procedemos neste ponto a uma síntese do capítulo e ao lançamento das questões em aberto que abordaremos em secçōes e capítulos seguintes. Fazêmo-lo a partir da sua característica central, que consiste no processo de despolitização das decisões políticas, por força da crescente intervenção do planeamento e dos especialistas em planeamento. Controlar o aparecimento dos acontecimentos pela caracterização prévia dos produtos a obter passou a ser tarefa árdua para uma administração centrada na simples previsão de tendências. Esta racionalidade faz o futuro assemelhar-se ao passado, mas numa escala diferente. Antecipar o futuro resultava de um exercício de extrapolaçăo da memória histórica do sistema. Uma burocracia clássica adapta-se bem 
Quadro 13 - Temas dos discursos educativos sobre o desenvolvimento

\begin{tabular}{|c|c|c|c|c|}
\hline DECADA & $\begin{array}{l}\text { DISCURSO SOBRE O } \\
\text { DESENVOVIMENTO } \\
\text { (GLOBAL) }\end{array}$ & $\begin{array}{l}\text { DISCURSO } \\
\text { EDUCATIVO SOBRE } \\
\text { O DESENVOLVIMENTO } \\
\text { (OCDE-UNESCO) }\end{array}$ & $\begin{array}{c}\text { DISCURSO } \\
\text { EDUCATIVO SOBRE } \\
\text { O DESENVOLVIMENTO } \\
\text { (PORTUGAL) }\end{array}$ & $\begin{array}{c}\text { PROBLEMATIZACCOES DE } \\
\text { POLITICA EDUCATIVA } \\
\text { (PORTUGAL) }\end{array}$ \\
\hline 70 & $\begin{array}{l}\text { - Necessidades } \\
\text { humanas } \\
\text { básicas } \\
\text { - Crescimento } \\
\text { com } \\
\text { equidade } \\
\text { - Redução da } \\
\text { pobreza } \\
\text { - Nova ordem } \\
\text { económica } \\
\text { internacional }\end{array}$ & $\begin{array}{l}\text { - Educaçăo básica } \\
\text { - Desenvolvimento } \\
\text { dos Recursos } \\
\text { Humanos } \\
\text { - Ensino dos grupos } \\
\text { desfavorecidos }\end{array}$ & $\begin{array}{l}\text { - Igualdade de } \\
\text { oportunidades } \\
\text { - Educação básica } \\
\text { para todos } \\
\text { - Planeamento das } \\
\text { qualificaçoes } \\
\text { profissionais } \\
\text { - Teoria do capital } \\
\text { humano } \\
\text { - Necessidades de } \\
\text { mão-de-obra }\end{array}$ & $\begin{array}{l}\text { - Formação Profissional e } \\
\text { o Sistema educativo } \\
\text { Português, GEP, } 1976 . \\
\text { - Estudo prévio sobre } \\
\text { necessidades de mão-de- } \\
\text {-obra qualificada para os } \\
\text { sectores da indústria e os } \\
\text { serviços, } 1977 \text { (José } \\
\text { Cardim e M. }{ }^{2} \text { do Carmo } \\
\text { Ferreira). } \\
\text { - Estudo da rede dos } \\
\text { cursos complementares } \\
\text { em função da situação } \\
\text { socioeconómica e do } \\
\text { inventário de carências } \\
\text { em instalaçōes escolares, } \\
1979 \text { (João C. Alpiarça). }\end{array}$ \\
\hline $80 / 90$ & $\begin{array}{l}\text { - Ajustamento } \\
\text { estrutural das } \\
\text { economias } \\
\text { nacionais ao } \\
\text { sistema } \\
\text { internacional } \\
\text { - Interdependência } \\
\text { e globalização }\end{array}$ & $\begin{array}{l}\text { - Eficiência e } \\
\text { eficácia } \\
\text { educativas } \\
\text { - Qualidade do } \\
\text { ensino e da } \\
\text { aprendizagem } \\
\text { - Integraçăo dos } \\
\text { grupos de risco e } \\
\text { minoritários }\end{array}$ & $\begin{array}{l}\text { Desenvolvimento } \\
\text { dos recursos } \\
\text { humanos } \\
\text { - Qualidade da } \\
\text { escola } \\
\text { - Eficiência e eficácia } \\
\text { do ensino e da } \\
\text { aprendizagem }\end{array}$ & 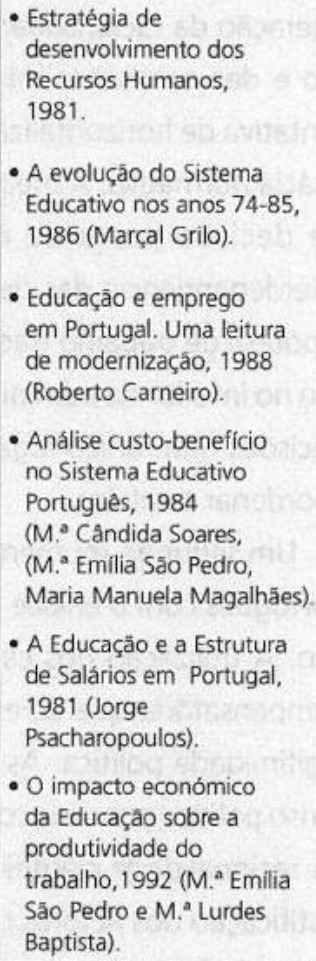 \\
\hline
\end{tabular}


a este modelo de decisão. Porém, produzir acontecimentos impōe uma atitude voluntarista bem diferente em que a burocracia clássica se mostra ineficiente. A administração deixa de confiar na capacidade de os seus membros obterem as informaçōes e de mobilizarem os conhecimentos específicos necessários à resolução dos problemas que the cabem. Consequentemente, recorrem com maior frequência a especialistas externos, peritos ou consultores, de forma ad-hoc ou integrando-os na própria administraçăo.

As novas tecnologias da governamentalidade postas em acção pressupõem a organização das premissas segundo a sua funcionalidade. Este é também o resultado de uma outra forma de a opinião pública se relacionar com a coisa educativa. A partir do momento em que a educação secundária se situa num espaço a todos acessível, surge à consciência pública uma forma de experiência não mais assente em evidências, fundamentos ou mandatos, mas antes em problemas e justificações, consolidando assim uma era crítica da educaçăo. É também por isso que a administração passa a reelaborar e reconceptualizar as directivas como problemas. O desenvolvimento de métodos de planeamento racional na educação visa controlar mais directamente os acontecimentos, produzindo-os de forma planeada. Um primeiro momento desta alteraçăo da racionalidade dominante é visivel na proliferaçăo dos grupos de trabaIho e das comissões intra e interministeriais entre 1974 e 1984. Trata-se de uma tentativa de horizontalizar a administraçăo e definir outputs que se substituam à ineficácia normativa. À medida que a diferenciação funcional e hierárquica do processo de decisão progride em diversos pontos do sistema, aumenta também a interdependência das decisōes parciais. Deste modo se vai tornando desajustada a hipótese de trabalho tradicional da burocracia, segundo a qual uma qualquer discussăo no interior da administração pressupõe a condensação dos resultados globais das decisões num único lugar. Os centros de decisão proliferam e as dificuldades de os coordenar também.

Um segundo momento é captável no processo de Reforma do Sistema Educativo Português com o enlace entre os reformadores políticos e os especialistas em educaçăo. A utilizaçăo dos especialistas consiste num típico mecanismo de legitimação compensatória que acrescenta prestígio e credibilidade científica onde se rarefaz a legitimidade política. Assim se faz substituir os mecanismos da participação e consenso político por uma consensualização técnica supostamente fundada em princípios de racionalidade científica intocáveis. Esta fase consolida o modelo dominante de justificação dos actores políticos. Estes não se justificam por quererem o que fazem, mas pelo facto de năo poderem fazer outra coisa. 
Governar a conduta da conduta implica intermediários. O Estado não está apto a governar à distância uma tẫo grande diversidade de indivíduos. É neste espaço que se formam alianças entre os objectivos dos que pretendem exercer uma regra universal sobre a população e os que possuem o conhecimento positivo das esferas de expressão das condutas humanas - economia, higiene, medicina, psicologia, educaçăo. Este poder é partilhado mas mantendo separações entre a esfera do político e do não-político. Embora a capacidade de governo esteja incontestavelmente dependente do conhecimento dos especialistas - e esse não é um simples problema de legitimação compensatória - o regime de verdade do discurso especializado é mantido separado do domínio político. Esta separação é um problema complexo da governamentalidade que se inscreve na tradição disjuntiva Estado-sociedade civil. A crítica desta tradição liberal tem sido feita por Santos $(1985,1995)$. Pela sua importância tratamos em ponto autónomo os argumentos necessários à compreensão da capilaridade entre Estado, especialistas e sociedade civil.

Finalmente, um terceiro momento caracteriza-se por um apelo generalizado a uma participação alargada e ao empenhamento dos diferentes actores. São criados mecanismos da administração periférica consultiva e mecanismos de administração informal intermitentes. No primeiro caso encontram-se o Conselho Nacional de Educação, a Comissão de Reforma, o Conselho de Acompanhamento da Reforma Curricular e o Instituto de Inovação Educacional; no segundo caso, assiste-se à proliferaçăo de centenas de grupos de trabalho eventuais, descontínuos, por vezes com maioria de membros exteriores à administração. Também nesta categoria se devem incluir os mecanismos de planeamento participado como os que integram a produção da carta escolar desde 1989.

Entre 1974 e 1986, os processos de decisão da administraçăo do sistema educativo estão marcados pela constante renovação de duas dicotomias: concentraçãodesconcentração e centralização-descentralização. Neste processo assiste-se à despolitização dos processos de decisão da administração. A procura de estratégias novas, adequadas à solução de problemas no interior da administração, passa pela construção de um discurso dicotómico que hegemoniza e reduz as possibilidades de solução, acentuando um ou outro lado da dicotomia, mas nunca a resolvendo. É este estado de imperfeição da solução que faz da sua procura um processo potencialmente infinito. Ao contrário do que um certo senso comum faz crer, os pressupostos práticos do liberalismo assentam mais na noção de falha do que na de infalibilidade. $O$ liberalismo enquanto falha resulta justamente da capacidade de tornar as necessidades do discurso de senso comum, depois de despolitizadas pela tecno-estrutura, em candidatas à sua provisão pelo Estado burocrático. A este fenómeno de tradução e 
despolitização pela administração está associado a construção daquilo que é tido como social.

A repolitização da administração dos anos 86-91 não depende tanto da invenção deliberada de novos critérios de relevância, quanto do processo de erosão crescente dos programas de acção do Estado burocrático-legal. Tal erosão tem como consequência que a administração passa a ter necessidade de se empenhar na coordenação e persuasão directa dos interessados e alvos dos programas. Numa situação de ausência ou redução significativa do valor das anteriores premissas de acção, não resta outra saída ao Estado senăo a busca de formas de legitimação extralegais. Estas deslocam a intervenção do Estado do interior da administração para o espaço público da discussão política. Dentre estas C. Offe define as formas supralegais e as infralegais como as mais características de um Estado-Providênca em crise. Dentre as formas supralegais havemos de sublinhar as que se relacionam com a legalização e juridificação do sistema educativo: o lustro que vai de 1987 a 1991 é o período onde se concentra a maior produção de decretos, despachos e circulares do Ministério; é também aquela onde se intensifica a legislação parlamentar e os pareceres do ConseIho Nacional de Educação; finalmente, é o período de maior produçăo disciplinar com origem em queixas das associações de pais e encarregados de educação. ${ }^{79)}$ Todo este trabalho de legitimação compensatória faz-nos crer que os processos empíricos contraditórios que têm lugar na relaçăo entre a periferia e os diversos organismos da administração deixam de poder orientar-se pelas normas de direito disponíveis, tornando-as, portanto, moldáveis e adaptáveis. E esta é uma nova porta de entrada para a politização das decisões.

A protecção da acção administrativa contra os riscos imprevisíveis de uma politização excessiva foi realizada por dois mecanismos principais de dispersăo que aqui identificamos como a externalização das políticas educativas e o planeamento educativo participativo. A externalidade apresenta-se numa forma dúplice: a externalidade que toma o sistema industrial e de emprego como referência principal do sistema educativo e a externalidade internacional que toma por referência as agências internacionais ou os países mais desenvolvidos para a construçăo das retóricas de política educativa. No primeiro caso, o mecanismo principal é o da harmonizaçăo. Esta consiste para as correntes derivadas da teoria do capital humano na maximização da rentabilidade do investimento educativo, adequando os investimentos às necessidades do desenvolvimento; enquanto para as correntes críticas a harmonização deve

(79) Procedemos à análise destes indicadores em Gomes (2002). 
dar-se do lado da economia, por intermédio da absorção útil das formações escolares. Em qualquer caso, o princípio de legitimidade é comum. $\mathrm{O}$ desenvolvimento é o principal mandato do sistema educativo em que todos se revêem. Na externalidade internacional os mecanismo centrais são a imposição, a disseminaçăo e a estandardização. É como imposição que devem ser entendidas as intervenções do Banco Mundial. ${ }^{(80)}$ É como disseminação que pode ser compreendida a participação de Portugal nos Projectos da OCDE/CERI. É como estandardização que devemos perceber a recepção das políticas de desenvolvimento promovidas nos fora da Unesco.

Quanto ao planeamento participativo ele é, em primeiro lugar, o reconhecimento da contradição entre as prioridades definidas na política educativa e a capacidade diferencial de os actores locais, por intermédio da influência política e social, a pressionar em outro sentido. É por exemplo muito significativo analisar as actas da Comissão de Rede Escolar no final dos anos 70 e verificar que aí se reconhece abertamente que, embora as prioridades de construção escolar se centrassem entăo no ensino obrigatório, os poderes locais autárquicos, associativos e da chamada sociedade civil próxima conseguirem deslocar em muitos zonas os investimentos para o ensino secundário: "estes fenómenos são claramente reveladores de duas linhas mestras fundamentais da implementação do movimento de rede no triénio analisado: a prevalência das soluções casuísticas com base em pressões locais sobre uma efectiva planificação com base num quadro global de carências aferidas em ordem aos objectivos consagrados em diplomas legais; o maior impacto das pressões locais exercidas na solicitaçăo do ensino secundário, particularmente o ensino secundário complementar que justificou a agregação dos grupos etários correspondentes ao

(80) Sobre o mecanismo da imposiçăo, Stoer (1986: 205-248) analisa também, de forma penetrante, embora numa perspectiva de análise com um pendor mais estatista e ideológico, o duplo papel de imposição e legitimaçăo da intervenção do FMI e do Banco Mundial. É especialmente interessante que Stoer conclua que alguns sectores habitualmente hostis à intervençăo de organizaçōes internacionais estivessem tacitamente de acordo com o projecto: «no respeitante ao campo da educaçăo, o envolvimento do Banco Mundial pode ter desempenhado igualmente um papel, ao dar apoio externo a um Ministério da Educação desesperadamente necessitado duma nova imagem, depois da perda de autoridade sofrida durante o periodo revolucionário. Na verdade, as frouxas estruturas de autoridade do Ministério podem muito bem ter criado as condiçōes para que uma agência exterior impusesse modos de proceder em pelo menos um sector do sistema de ensino (isto, na verdade, terá sido bem recebido mesmo por aqueles sectores por norma ideologicamente hostis à intervenção de organizaçōes internacionais) » (Stoer, 1986: 232). Também nós verificámos esse consenso a partir da análise das problemáticas do desenvolvimento e das relações entre a educação e o mercado de trabalho. Todavia, enquanto Stoer sugere uma concessão ideológica, o que nós sugerimos é uma dispersão discursiva a partir de um processo comum de problematização técnica, que escapa à mera esfera do ideológico. Terá sido no campo das tecnologias de problematizaçăo que o enlace se terá dado. 
preparatório, ao secundário unificado e ao complementar, pela primeira vez desde a definição da actual escolaridade obrigatória de 6 anos». (Relatório da Comissão de Rede Escolar, 1981/82, pp. 40-41)

Como se verifica, os efeitos năo esperados da contingência burocrática aparecem aqui como a base racional de um reforço da tecnologia do planeamento. Abrem-se entăo dois caminhos que, fazendo parte da mesma formação discursiva, criam a dicotomia planeamento central versus planeamento com abertura às pressŏes locais. Na acta da reuniăo da Comissăo de Rede Escolar de 19/11/80 o representante da Direcçăo-Geral de Pessoal e o Presidente da Comissão de Rede definem os futuros deslocamentos da racionalidade que estará na origem do Projecto de Desenvolvimento Regional de Equipamentos Educativos: «o representante da Direcção-Geral de Pessoal chamou a atenção para a necessidade de uma reflexão sobre a discordância entre os movimentos anuais de rede escolar que resultam de acções ajustadas às pressões locais e a inventariação de carências levada a cabo pelo GEP o que, em seu entender, deverá conduzir à revisăo do Inventário de referência para ajustá-lo eventualmente às sensibilidades locais. A este propósito o Presidente da CRE interveio referindo a necessária interligação entre o planeamento da rede e a legislaçăo, incluindo a Lei de Bases do Sistema Educativo bem como a necessidade de detecção dos pedidos locais de alteração à rede escolar que possam ter sido atendidos à margem do processo normal de planeamento, por forma a verificar-se da necessidade de revisão do Inventário de Carências, o que implicaria novos contactos com as autarquias locais»

Deste modo, a contingência burocrática, enquanto fenómeno não intencional, inesperado e indeterminado cumpre funções compensatórias de uma descentralização ainda inexistente. Permitindo a canalização dos grupos de interesse por intermédio de diferentes sectores da administração, garante-se a dispersão das zonas de conflito e das contradiçōes. $\mathrm{O}$ aumento gradual dos mecanismos de interface entre a administração e a sociedade civil, parcialmente constituída pela própria administraçăo, estabelece novos meios da governamentalidade. A desconcentração de 1986 e - aumento dos níveis de contingência burocrática que a acompanha resulta também na redução da intervenção casuística. O caso, a excepção e a aberração tendem a inscrever-se no próprio sistema de planeamento, obrigando este a adoptar modelos probabilísticos de coordenaçăo a partir dos resultados. O Inventário de Carências em instalações nos Ensinos preparatório e secundário de 1983 orienta-se já para esta hipótese de trabalho: "finalmente, convém referir que, em 1982, o Núcleo da Rede Escolar iniciou o processamento de todos os 'pedidos' entrados no GEP em referência a uma hipótese de estratégia alternativa à norteadora do Inventário. $\mathrm{O}$ dossier 
corespondente, subordinado ao subtítulo de Estudos de Caso (1982), é introduzido de forma a alertar a decisão para as implicações globais do abandono da estratégia perfilhada por uma mais permissiva à dispersão do equipamento, de acordo com desejos locais" (Inventário de Carências em Instalações nos Ensinos Preparatório e Secundário, 1983a, p. 6).

A administração fica sujeita a um teste de consenso politico de que estăo também dependentes os dirigentes políticos. Harmonizar interesses, reduzir resistências, negociar consensos passam a ser tarefas da administração, superando a tradicional divisão de trabalho do sistema político-administrativo que deixava tais funçōes ao subsistema político. Nesta função assume papel de relevo o trabalho de consensualização técnica das assessorias científicas especializadas. Cabe a estas substituir 0 consenso político, anulando ou reduzindo os momentos de conflito, por intermédio da desqualificação tácita ou expressa das opiniōes contrárias dos leigos. A ascensão dos especialistas reconfigura o que é percebido como político. No âmago desta reconfiguração da política encontra-se a capacidade de os especialistas encararem a conduta, os critérios de juízo próprios e as técnicas em uso do ponto de vista do conhecimento positivo e não da tradição ou da autoridade moral. A intervenção dos especialistas, ao situar-se entre a decisão político-legal e a decisão operacional, serve também como forma de selecção processual. A selecção processual é um instrumento que elimina, apouca ou torna latente na arena de decisão propostas que reivindicam outra forma de redistribuição dos recursos. Os especialistas, ao conferirem a certos temas políticos maior probabilidade de realização, outorgando-lhes a qualidade de one best way, condenam as posições concorrentes ao silêncio, instituindo verdadeiros circuitos de não-decisăo. Porém, os dispositivos de participaçăo no planeamento da rede escolar constituem, simultaneamente, pontos de entrada dos leigos no sistema, somando-lhe uma profunda ambiguidade: desenhados para protegerem a acção administrativa de uma politização excessiva, podem sujeitar cada vez mais o próprio conhecimento científico e técnico ao escrutínio público.

Esta nova racionalidade define para o Estado a função de gestor dos vários domínios de governo, não mais fundada nos direitos morais ou legais dos cidadãos, mas no especial conhecimento das tecnologias governamentais próprias. É este conhecimento fundamental que delimita, nas suas consequências, o campo de acção e reflexão da governamentalidade. Neste sentido, a análise deste campo não pode prescindir de uma visão de dentro dos seus mecanismos de funcionamento.

Quando, em 1986, é aprovada a Lei de Bases do Sistema Educativo que distingue explicitamente as estruturas de âmbito nacional, regional autónomo, regional e local do Ministério da Educação, estăo criadas duas condiçôes imprescindiveis da 
governamentalidade. Por um lado, o nível de contingência burocrática tinha sido mantido num grau suficientemente funcional de modo a acolher no seu interior as invaginaçōes ${ }^{(81)}$ da sociedade civil próxima. Por outro lado, a actualização repetitiva das dicotomias concentração-desconcentração e centralização-descentralização havia criado uma espécie de cordão de segurança que protegia as decisōes políticas do Ministério da Educaçăo dos excessos de conflitualidade social.

Como tivémos oportunidade de demonstrar, a contingência burocrática foi um dos principais dispositivos de dispersão das contradições de um sistema educativo duplamente heterogéneo. Assim sendo, a diferenciação e a fragmentação do sistema, entendida pelas teorias sistémicas como uma variável da complexidade técnico-administrativa que, para ser racionalmente regulada, deve conduzir à formação de novos centros de decisão delegada (desconcentrados ou descentralizados), sem os quais o colapso administrativo é inevitável, não vieram a ocorrer. Com efeito, durante mais de uma década, a contingência burocrática foi contida pelos sucessivos vaivéns regulamentares que ora dependiam de uma vontade centralizadora, ora dependiam de regulamentaçōes descentralizadoras, mas, em qualquer caso, colocando sempre a administraçăo à beira de uma fragmentação sem remissão. A nossa tese principal consiste, justamente, no reconhecimento da funcionalidade deste diagnóstico. Com efeito, o recurso à dramatização da fragmentação e desconexão, como principal problema da administação, contribuiu decisivamente para a institucionalização dos dispositivos de dispersão, tais como a inclusão, a exclusão, a não-decisão e a aplicação selectiva.

Para melhor compreender o funcionamento destes dispositivos importa considerar a subdivisão funcional que a administraçăo introduz nos seus próprios processos de decisão. Em todos os grupos de trabalho sobre a desconcentração e a descentralização se consideram três funçōes tradicionais das burocracias: a função normativa, a funçăo executiva e a funçăo de controlo. Esta subdivisão segue genericamente a tipologia que desde os anos 70 foi introduzida no planeamento das organizações internacionais, segundo a qual existem quatro subsistemas de decisão distinguindo-se quanto à sua natureza normativa, estratégica, operacional ou administrativa. As decisōes normativas diriam respeito à prescrição do que deve ser feito, as decisões estratégicas problematizam aquilo que pode ser feito, as decisōes

(81) Utilizamos, metaforicamente, o termo médico invaginaçăo no seu sentido patológico. A invaginação dá conta de um acidente que consiste em uma porção de tecido se revirar para dentro. Também neste caso o Estado sofre um acidente espontâneo que consiste em expandir-se para dentro, na forma de sociedade civil. 
operacionais determinam o que será feito e as decisōes administrativas controlam e avaliam o que se está a fazer. Na ortodoxia burocrática, tal subdivisão nem sempre tem uma localizaçăo funcional exacta da decisão, embora corresponda sempre a uma intenção latente de diferenciar as estruturas, de acordo com a classe de decisões que deve tomar. É no interior deste pensamento burocrático que a questão da autonomia relativa de cada nivel se coloca, sendo certo que, nesta lógica administrativa, o estabelecimento escolar é, evidentemente, o nível terminal, aquele que se situa mais perifericamente. Para este fim, entende-se por autonomia a latitude de que dispōe cada nível para bloquear ou modificar as decisōes de cada um dos outros níveis. Quanto maior for a classe de decisōes que um certo nível administrativo pode tomar ou modificar mais autónomo será o sistema. Assim sendo, a autonomia pode resultar quer da configuração da morfologia do sistema, delegando decisōes em outros níveis, quer da conquista que estes obtêm, dependente da construção de zonas mais alargadas de acçăo, quer da ineficácia revelada por qualquer nível — tolerando assim a ocupação compensatória de um espaço deixado livre. Neste quadro, a administração do sistema educativo português parece ter desenvolvido uma percepção muito positiva sobre o grau de autonomia relativa dos estabelecimentos educativos, não porque acredite na bondade da nova morfologia desconcentrada do sistema, mas porque está consciente da sua própria ineficácia centralista (OCDE, 1995). 
(Página deixada propositadamente em branco) 


\section{CAPITULO V}

\section{AS TECNOLOGIAS DO ESPAÇO SOCIAL E DA SUBJECTIVIDADE}

1. O Ensino Secundário Unificado: uma nova decomposição da população e do espaço escolar

2. Uma nova cartografia de inserção espacial da escola

3. O aperfeiçoamento das tecnologias de governo da população escolar: as tecnologias da autonomia e a nova subjectividade para a cidadania

A nossa tese principal sobre a criação do Ensino Secundário Unificado é a seguinte: o Ensino Secundário Unificado foi criado em resultado da recolocação de Portugal no sistema mundial e das novas problematizações do governo da educação. A sua concretização não se pode compreender enquanto cumprimento de princípios igualitários de governo ou como ruptura provocada por movimentos sociais igualitários. Não porque estas retóricas ideológicas não tenham o seu papel na integração institucional do modelo, mas porque a criação do ESU utiliza tais retóricas apenas como forma de validação externa, embora a sua necessidade enquanto tecnologia de governo das expectativas sociais há muito estivesse enunciada. Năo lhe faltavam condições políticas para se impor, embora as contradições e as resistências existissem, nem condiçōes sociais e culturais que o justificassem, bem realçada pela crescente procura de educação escolar, mas, sobretudo, escasseavam condições de racionalidade e as tecnologias que lhe permitissem a sua constituição. Foram essas condiçōes que se criaram progressivamente no período analisado. Centramo-nos designadamente na criação de uma nova cartografia de inserção espacial da escola, no surgimento de uma matriz social mais extensa e desagregada, no vocabulário renovado comum e na construção de uma subjectividade diferente do aluno. 


\section{O Ensino Secundário Unificado: uma nova decomposição da população e do espaço escolar}

Tudo leva a crer que o Estado Novo teria concretizado o Ensino Secundário Unificado (ESU), com essa ou com outra nomenclatura, sem que isso tivesse como consequência a aproximação do princípio moral da equidade. Mais do que uma ruptura programática, o ESU expressa a medida de política educativa de maior continuidade com o caminho que a Reforma Veiga Simăo vinha seguindo. Como é aliás reconhecido por Rui Grácio, um dos principais impulsionadores da reforma, num dos textos mais documentado e interessante que escreveu sobre o ESU: «não obstante contextos político-ideológicos constrastados tendo Abril de 74 por marco de separação, se verificaram durante a ditadura medidas e projectos governamentais que podem inscrever-se na mesma linha tendencial: assaz tímidas e retardadas sem dúvida, pelos anos 60, mais ousadas e procurando explicitamente acelerar o processo pelo início dos anos 70» (Grácio, 1985: 88). As medidas tendenciais a que se refere Rui Grácio traduziam-se em decisōes de política e projectos tais como a extensão da escolaridade obrigatória a oito anos, quatro dos quais de um tronco comum de ensino preparatório, a abertura de cerca de sessenta escolas secundárias polivalentes e a criação do ensino liceal nocturno. Na verdade, todas estas medidas se destinavam a atenuar a distância entre o ensino liceal e o ensino técnico. Em especial, a criação das escolas secundárias polivalentes, fazendo coexistir no mesmo estabelecimento cursos diferenciados, dava um passo simbólico muito importante no sentido da unificação, facilitando a mudança de orientaçăo, sem necessidade de sair do mesmo estabelecimento. Antecedendo estas medidas, o Gabinete de Estudos e Planeamento da Acção Educativa havia publicado entre 1970 e 1972 uma dezena de estudos descritivos sobre as estruturas de ensino unificado em nove países europeus, Brasil e Estados Unidos da América que confirmavam as duas orientaçôes principais da Unesco, da OCDE e do Conselho da Europa: substituir os modelos paralelos diferenciados por modelos globais integrados; adiar a selecção escolar para um ponto mais tardio do percurso escolar, fazendo prevalecer a orientaçăo escolar apoiada.

Com a criação, em 1975, do ensino secundário unificado, toda a morfologia do sistema educativo se vê alterada. ${ }^{\left({ }^{2} 2\right)}$ Portugal entra, com atraso considerável, na

(82) O Ensino Secundário Unificado foi criado por despacho ministerial publicado em 1 de Agosto de 1975. Criado ao abrigo do decreto-lei n. ${ }^{\circ} 47587$ de 10 de Março de 1967, conhecido como o 
tendência geral da maior parte dos países europeus, ocidentais e de leste, implantarem um tronco comum de ensino no primeiro segmento do ensino secundário. À escolaridade básica obrigatória de seis anos, seguir-se-ia agora um ciclo unificado de três anos que viria a culminar, em 1986, com o alargamento da escolaridade obrigatória para nove anos. As finalidades do ESU são desde logo anunciadas: romper com a distinção entre ensino liceal e ensino técnico; romper com a dualidade entre escola e comunidade e adiar as opções de trajectória escolar para os quinze anos. A criação de um via única procura, segundo o n. ${ }^{\circ} 1$ do despacho de criação do ESU, «uma adequação do ensino às exigências políticas, económicas e culturais da sociedade portuguesa». É a ruptura com a dualidade escola-comunidade que toma a dianteira nesta finalidade, por que, como diria Rui Grácio (1985: 107), o binário empobrece uma e outra: «empobrece a escola e a educação formal por se privarem do estímulo directo dos problemas concretos do meio natural e social, dos recursos humanos comunitários (pais, oficiais de todos os ofícios, grupos organizados, instituiçōes diversas), das actividades produtivas e sociais (...) 2. Empobrece a comunidade e a educaçăo não formal, por se privarem dos recursos humanos, materiais e logísticos disponíveis nas escolas». Não por acaso, a temática das relações entre a escola e a comunidade vinham adquirindo foros de primeiro plano nas agências internacionais. Em 1973, a

\footnotetext{
decreto das experiências pedagógicas, o despacho dá continuidade à circular $n \cdot{ }^{\circ} 3 / 75$ do Ministério da Educação e Cultura que, em 27 de Junho de 1975, estabelece os objectivos do $7 .^{\circ}$ ano de escolaridade. A circular e o despacho culminam os trabalhos e as propostas do Secretariado da Reestruturação do Ensino Secundário criado pelo Secretário de Estado da Orientação Pedagógica [Rui Grácio] por despacho de 15 de Maio de 1975. Segundo a interpretaçăo do própio Rui Grácio, num extenso artigo de balanço publicado mais tarde (Grácio, 1985: 53-154), o Secretariado situou os seus trabalhos na continuidade da avaliação dos $3 .^{\circ} \mathrm{e} 4 .^{\circ}$ anos experimentais do curso preparatório lançado pela Reforma Veiga Simão: «Foi a estes últimos, como também ao $5 .^{\circ}$ ano sequencial chamado de transição, que se foram buscar, sem exclusão dos demais cursos referidos, elementos importantes para a fixaçăo do currículo e dos programas de ensino e actividade do secundário. Cabe aqui dizer: a avaliação científica daqueles $3 .^{\circ} \mathrm{e} 4 .^{\circ}$ anos foi entregue a um grupo que, no âmbito do Gabinete de Estudos e Planeamento, desenvolveu o seu trabalho sob a orientação técnica da especialista norte-americana Frances Link, destacada pela OCDE, e que para o efeito se deslocou várias vezes a Portugal durante o ano lectivo de 1974-75. Embora os trabalhos nâo estivessem concluidos quando se preparou a decisão de unificar o secundário, a opinião do grupo, então ouvido, foi a de que os resultados apurados se mostravam favoráveis à 'experiência'. O que foi tomado na devida conta» (Grácio, 1985 108). Na tradiçáo de outras reformas análogas, e colhendo também da experiência do Secretariado da Reforma Educativa, que havia ficado na dependência directa do Ministro Veiga Simão, o Secretariado da Reestruturação do Ensino Secundário pretende contornar a lógica administrativa das direç̧õesgerais, adoptando para tanto uma racionalidade e um aval de tipo científico. O Secretariado será extinto durante o I Governo Constitucional pelo despacho n..$^{\circ}$ 247/76 de 9 de Agosto.
} 
OCDE/CERI ${ }^{(83)}$ realiza pela primeira vez uma Conferência sobre o tema das relações entre a escola e a colectividade, que dá origem a um relatório (OCDE/CERI, 1975) que influenciará grande parte dos debates posteriores. Sob a pressão dos movimentos de desescolarização, o debate cristaliza em torno das alternativas da educação formal e não formal, mas em todo o caso pondo em questão o monopólio da escola. Ficam a partir de entāo enunciados os quatro tipos de interacçōes entre a escola e a comunidade que marcarão os discursos educativos durante as décadas de 70 e 80 : a) interdependência entre escola e comunidade na partilha dos recursos materiais e humanos, em nome do interesse geral e do desenvolvimento colectivo; b) adaptação da escola às necessidades da economia local e nacional; c) participaçăo nos processos de decisão dos agentes políticos e dos grupos de interesses locais; d) escolarização dos grupos minoritários por intermédio de estratégias de integração nas escolas normais ou da criação de escolas alternativas. Embora o debate não tenha sido conclusivo foi indubitavelmente no âmbito das construções escolares que mais se avançaria. Como vimos no capítulo anterior, também em Portugal esse constitui o sector que mais influencia a disseminação técnica do discurso comunitário.

(83) O CERI (Centre pour la Recherche et l'Innovation dans l'Enseignement) é inicialmente constituido em Janeiro de 1968, por um período limitado de dois anos. Impulsionado por Michael Harris, que aproveita as suas relaçōes privilegiadas com a Fundaçăo Ford, o Centro não tem nos seus primórdios um estatuto de plena integração na OCDE. Na verdade, até 1971, data em que o financiamento passa a a ser feito inteiramente pelos países membros da OCDE, o CERI é financiado pela Fundação Ford e pela Royal Dutch Shell. Segundo os termos do relatório da OCDE que está na origem da sua constituição, os temas da mudança e da inovação, especialmente dos conteúdos e dos métodos pedagógicos, passam a ser centrais na reacção dos sistemas educativos às pressões legítimas do mundo moderno (In OCDE, La modernisation de l'enseignement: la réforme des programmes et le développement de l'education, 1966). Paradoxalmente, a atençăo renovada sobre os programas é o resultado das medidas drásticas tomadas pela $O C D E$, na sequência de uma avaliação dirigida pelo seu secretário-geral adjunto Michael Harris, em 1964 (ver George Papadopoulos (1994) L'OCDE face à l'Éducation, 1960-1990, Paris: OCDE), que concluira pela ineficácia dos programas de ajuda directa aos projectos experimentais em cada país. Desta avaliação resultariam medidas tais como a cessaçăo do financiamento do Projecto Regional do Mediterrâneo e a supressão de muitas actividades ligadas à formação de pessoal técnico e científico. Em substituição destes programas, cujos mecanismos principais eram a imposição e a estandardização de objectivos de política educativa muito específicos e de alcance limitado, o CERI inaugura a fase em que a disseminação é o mecanismo central de influência sobre as políticas educativas de cada país. Sendo a persuasão o principal processo de estabelecimento das agendas de politica educativa, o seu alcance multiplica-se por diferentes áreas. Com efeito, os programas da OCDE que envolviam directamente os seus técnicos em dezenas de projectos experimentais eram onerosos e de extensăo reduzida, enquanto o CERI pretendia antes mobilizar os escassos recursos consagrados por cada país à Investigaçăo e Desenvolvimento, nomeadamente daqueles que menos gastavam, para apoiar e aproveitar da experiência dos países mais dotados. Criaram-se deste modo grupos de interesse nacionais, mormente no seio da tecno-estrutura ligada à pesquisa e ao planeamento, favoráveis aos temas e às metodologias utilizadas pelo Centro. 
Adaptando uma formulação que costuma ser usada para outros fins, diríamos que a criaçăo do ESU foi determinada por elementos de integração supranacionais, mas sobredeterminada por elementos de desenvolvimento interno do próprio sistema educativo. Destes factores, o mais decisivo é, sem dúvida, a crescente procura de educação secundária, com expressão muito significativa na expansão da rede de liceus entre 70-74 e na triplicação dos matriculados nesse mesmo período (Grácio, 1986: 131). Os elementos sociais exteriores, em especial os do contexto doméstico e da produção, tiveram neste caso um papel secundário, embora se deva recordar a heterogeneidade intrínseca do sistema educativo e, portanto, a presença destes contextos no seu interior em proporções variáveis. O crescimento da pequena-burguesia e as expectativas de mobilidade social ascendente das famílias tiveram o seu papel, bem como a maior influência política das correntes económicas desenvolvimentistas. No entanto, estes factores externos não haviam tido nem o tempo nem os recursos para se transformarem em novas problematizações de governo.

Com o curto-circuito provocado pela crise revolucionária de 74-75 tais problematizaçōes entram pela porta do fundo da administração. Todas as experiências conhecidas de unificaçăo tinham sido antecedidas de grandes estudos estatísticos que mostravam as correlações entre origem social, resultados escolares e destinos sociais da populaçăo escolarizada. Durante o Estado Novo, a produção de tais estatísticas restringia-se a algumas iniciativas limitadas realizadas no âmbito do GIS (Gabinete de Investigaçōes Sociológicas) ou de trabalhos académicos (ver Ângelo, 1975). Realizados em larga escala, em outros países europeus, permitiram determinar, por exemplo, a magnitude da "perda de talentos» provocada pelos sistemas educativos selectivos (Husén, 1960). Entre as problematizações mais importantes que as novas tecnologias estatísticas permitem encontra-se a da desigualdade social face à educação. A partir dos anos 60 as estatísticas europeias sofisticam-se ao ponto de medirem as consequências educacionais das atitudes parentais, do tipo de envolvimento habitacional, dos recursos culturais, do estatuto socioprofissional ou dos estilos de ensino (Husén, 1972; Husén, 1975). Os resultados revelam, invariavelmente, que os filhos da classe operária, em comparação com os grupos sociais mais elevados na hierarquia social, estavam em desvantagem, tanto no plano do acesso como no dos níveis educacionais obtidos. Esta nova representaçăo dos sistemas educativos problematiza directamente a questão da optimização dos recursos educativos, em benefício da elevação do padrão educativo dos grupos em desvantagem. Chegar ao padrão já atingido por uma elite, reduzindo os desperdícios, era o objectivo principal do governo da educação. A generalização de programas de educação a grupos até então afastados da educação secundária foi, certamente, orientado pelas exigências 
de reconstrução nacional do pós-guerra. O círculo virtuoso da economia, ancorado no modelo fordista da produção em massa, tailorizada, com acesso ao consumo de massas e à providência estatal, também teve o seu papel. Porém, a unificação do ensino em vários paises europeus, é muito menos a consequência de um mandato democrático, decorrente de um direito moral eterno ao desenvolvimento integral das capacidades de cada um, do que um efeito das novas tecnologias de representação e de planeamento de governo da população, decorrentes da procura de mais riqueza, de maior harmonia e de maior eficácia na mobilização da população. Com efeito, as problematizaçōes introduzidas pelas novas categorias estatísticas dos anos 50 e 60 antecedem a unificação e garantem a integração de todos os grupos sociais no mesmo espaço das preocupaçōes de governo. Ao contrário da maioria dos países europeus, este tipo de problematização faz-se a par da decisão de lançamento do ESU. Não que os responsáveis pela decisão política năo tivessem consciência da necessidade de o fazer, mas porque se poderia perder a oportunidade política. Com efeito, desde o seu lançamento que o ESU foi atacado por diferentes sectores políticos e corporativos, dentro e fora do Ministério(84). Rui Grácio, já depois de ter abandonado a Secretaria de Estado da Orientação Pedagógica haveria de justificar a urgência da medida nos seguintes termos: "com a urgência, improvisa-se, e pode comprometer-se o melhor. Mas apetece inventar um adágio que não há: 'mais vale cedo que nunca...'. Eu pergunto seriamente: com 'o novo curso da vida política', com forças ascendentes de pressão direitista a proporem o referendo da futura Constitui-

(84) A Interassociaçăo de pais e encarregados de educação foi uma das mais activas organizações na tomada de posição contra o ESU. Entre os dias 26 de Junho de 1974 e o dia 20 de Dezembro de 1975, esta organização realizou várias reuniões com o Ministério da Educaçăo, aproveitando para criticar recorrentemente a indefiniçâo da política de ensino, considerando que tal indefinição era uma forma deliberada de "por forma subreptícia, em áreas pontuais e bem escolhidas, estabelecer uma orientação de raízes exclusivamente marxistas e materialistas naturalmente avessas ao sentir da maioria dos portugueses e, como tal, registadas, de maneira a, pela táctica do facto consumado, conseguir posiçōes que, em diálogo aberto e democrático, não seriam atingiveis» (In Resumo de reuniōes das Interassociações e MEIC e MEIC e interassociações, entre 26 de Junho de 1974 e 20 de Dezembro de 1975 , p. 3, Espólio Vítor Alves). Mais tarde, em notas e comentários sobre o lançamento do $7 .^{\circ}$ ano de escolaridade, emitidas em Fevereiro de 1976, a Interassociação tomaria uma posiçăo mais frontal, năo se limitando a críticas procedimentais: «somente através do DG n. ${ }^{\circ} 197,1^{\text {a }}$ série, pp. 1239-40, de 27 de Agosto de 1975 é conhecido um despacho ministerial do dia 1 daquele mês que, ao abrigo do DL 47587 de 10 de Março de 1967, fixa os objectivos gerais do $7 .^{\circ}$ ano de escolaridade (...) Um grupo específico, dentro do MEC preparou todo o $7 .^{\circ}$ ano de escolaridade e conseguiu impô-lo ao povo português numa manobra golpista e traiçoeira. Tal manobra foi avalisada pelo então ministro, major José Emilio da Silva. Assinala o aludido despacho de 1 de Agosto de 1975, na sua parte introdutória que 'com esta medida se procurará uma adequação do ensino às exigências políticas, económicas e culturais da sociedade portuguesa. Ora, a constituiçăo não está aprovada, vivemos num período transitório, quem, pois, legitimamente, pode definir as exigências da sociedade portuguesa» (p.2). 
ção que está a ser preparada por uma Assembleia com legitimidade representativa, a proporem que a Reforma Agrária, com toda a legitimidade revolucionária, e a da lei, seja suspensa do voto da futura Assembleia Legislativa - eu pergunto, ressalvadas naturalmente todas as proporções, se o ensino secundário unificado não tivesse nascido para o ano lectivo de 1975/76, chegaria a ver a luz do dia em 76/77». (85) Desde o início que os decisores políticos têm a consciência de que a medida sofrerá problemas de legimitação se não se tomarem medidas adequadas de legitimação a posteriori. Previstas medidas de avaliação desde o lançamento do $7 .^{\circ}$ ano unificado, estas viriam a ser concretizadas em dois planos, um de natureza política, com a discussão pública do documento sobre o lançamento do $8 .^{\circ}$ ano de escolaridade, ${ }^{(86)}$ outra de natureza técnico-científica, com o GEP a ser encarregado a partir de Maio de 1976 da avaliação do $7 .^{\circ}$ ano de escolaridade. ${ }^{(87)}$ Este processo de avaliação viria depois a

(85) Entrevista publicada in O Jornal, 6 de Fevereiro de 1976.

(86) Despacho 523/75 de 22 de Dezembro de 1975.

(87) O primeiro passo desta avaliaçăo teve como referência o ano lectivo de $1975 / 76$ e foi apresentado num seminário realizado em 1976 no âmbito do Acordo de Cooperação Luso-Sueco. Discutida neste seminário a possibilidade de cooperaçăo entre Portugal e a Suécia para a avaliaçăo do ESU, viria esta a concretizar-se em 1977 num Projecto de colaboração entre o GEP e o Instituto Internacional de Educação de Estocolmo e, a partir de 1978, numa colaboração entre o GEP e o Instituto de Educação de Estocolmo. O Projecto decorreria até ao final de 1981, sendo publicados dezassete relatórios. Porque estes relatórios constituem uma das principais fontes deste capitulo menciona-se desde já a referência discriminada e numerada, sem embargo de o voltarmos a fazer na rubrica das fontes: 1- Breve introdução à avaliaçăo em educaçăo. 1977. 2- Ensino Secundário Unificado. Avaliaçāo da aprendizagem da Matemática, $7 .^{\circ}$ e $8 .^{\circ}$ anos. I. Testagem. Maio de 1978. 3- Ensino Secundário Unificado. Frequência do $7 .^{\circ}$ ano de escolaridade $75 / 76$. Breve análise estatística retrospectiva. 1978. 4- Ensino Secundário Unificado. A aprendizagem da Matemática em 1977/78, $7 .^{\circ}$ e $8 .^{\circ}$ anos. Novembro de 1980. 5- Ensino Secundário Unificado. Relatório de Avaliaçăo do $7 .^{\circ}$ ano de escolaridade, 1975/1976. Junho de 1979. 6-Ensino Secundário Unificado. Avaliação do $8 .{ }^{\circ}$ ano de escolaridade, 1977/78. Estudos de caso. Abril de 1980. 7- Ensino Secundário Unificado. Relatório de Avaliação do $7 .^{\circ}$ ano de escolaridade, 1976/77. Fevereiro de 1980. 8-Ensino Secundário Unificado. Inquérito a professores do 9. ${ }^{\circ}$ ano de escolaridade, 1978/79. Fevereiro de 1980. 9- Ensino Secundário Unificado. Relatório de avaliação do $79^{\circ} .8 .^{\circ}$ e $9 .^{\circ}$ ano de escolaridade de $1977 / 78$. Julho de 1980. 10- Ensino Secundário Unificado.A aprendizagem da Matemática em perspectiva: $09 .{ }^{\circ}$ ano de $1978 / 79$ e sua relação com os $7 .^{\circ}$ e $8{ }^{\circ}$ anos de $1977 / 78$. Julho de 1980. 11- Ensino Secundário Unificado. A aprendizagem da Matemática: influência da escola e da familia - $7 . .^{\circ}, 8^{\circ}$ e $9 .^{\circ}$ anos de escolaridade de 1977 a 1979. Maio de 1981. 12- Ensino Secundário Unificado. Relatório de avaliação do $9 .^{\circ}$ ano de escolaridade de 1978/79. Inquérito a Conselhos Directivos. Maio de 1981. 13- Ensino Secundário Unificado. Relatório de avaliaçăo do 9. ${ }^{\circ}$ ano de escolaridade de 1978/79. Os alunos. Maio de 1981. 14. Ensino Secundário Unificado. Relatório de avaliaçăo do $9 .^{\circ}$ ano de escolaridade de 1978/ 79. Entrevistas a Encarregados de Educaçăo do 6. ${ }^{\circ}, 9^{\circ}$ e $10^{\circ}$ anos. Julho de $1981.15-$ Ensino Secundário Unificado. A aprendizagem da Matemática: a capacidade em cálculo básico matemático. Setembro de 1981. 16- Ensino Secundário Unificado. Relatório de avaliação: impacto social da reforma do Ensino Secundário Unificado. Entrevistas a empresas, 1979/80. Novembro de 1981. 17- Ensino Secundário Unificado. A caminho duma Reforma do Ensino Secundário Unificado. Relatório Final. Dezembro de 1981. 
alargar o seu âmbito, estendendo-se aos três anos de escolaridade do ESU, bem como a prolongar o tempo de duração, decorrendo até 1981. No seu conjunto, constitui o exemplo mais conseguido, no sistema educativo português, de aliança entre discurso científico, político e administrativo. Mais do que a retórica política de legitimação do ESU, seria a lógica de legitimaçăo técnico-científica que a partir de agora tomaria o primeiro plano, facto de que os próprios avaliadores têm plena consciência: «a Educaçăo tornou-se, cada vez mais, um instrumento através do qual a Sociedade podia ser mudada e profundos objectivos políticos (tais como a igualdade) serem atingidos. Ao darem à Educação um papel central no sentido da mudança, as estratégias de planeamento tinham de ser conduzidas com base em modelos mais racionais e pragmáticos, nos quais as decisōes fossem tomadas com base em estudos científicos, na experimentação e na avaliaçãon. (88)

Em Portugal, este novo espaço de objectivos e expectativas sociais apenas será introduzido por força da crise revolucionária, antecipando assim a problematizaçăo da administração, incipiente no final do Estado Novo e paralisada durante a crise. E daí, também, a ilusão ideológica de que teria sido a inscrição do princípio da educação para todos na Constituiçăo e nos sucessivos programas de governo provisório a comandar a racionalidade da unificaçăo. A nossa tese é diferente e oferece um ponto de vista complementar para a análise: foram as problematizações realizadas a par do lançamento do ESU e, consequentemente, as racionalidades e as tecnologias mobilizadas que sustentaram, legitimaram e ampliaram os efeitos da sua criação. Deste modo, a chamada licealização do ensino unificado não pode ser considerada como a demonstraçăo do fracasso da aplicação do princípio do desenvolvimento igualitário das capacidades de cada um e de todos, por que tal principio não existia.

A crise revolucionária produziu, segundo Santos (1990: 35), um Estado dual caracterizado pela existência de um núcleo central da burocracia estatal resistente às novas solicitações e pela criação de instituições paralelas, mais abertas às contradiçōes, entretanto desencadeadas e, em alguns casos, com funcionários activamente identificados com os movimentos sociais revolucionários. No campo educativo, a tentativa de articular o Estado com os movimentos estudantis e dos professores foi uma constante evidenciada na relação de legalidade de continuidade instituída. O recurso à legalizaçăo estatal assumia um formato adocrático, devido, em regra, à iniciativa dos movimentos sociais que se apoiavam nos técnicos da máquina paralela. Alguns

(88) In Ensino Secundário Unificado. A caminho duma Reforma do Ensino Secundário Unificado. Relatório Final. Dezembro de 1981, p. 4. 
saneamentos, bem como a substituição dos reitores por comissōes de gestão são um exemplo evidente das novas formas de legalização (ver Lima, 1992). Para além das formas de legalização que incluiam também a inovação legislativa, o principal mecanismo de influência consistiu na introdução, nos estudos da administraçăo do sistema educativo, dos indicadores de contexto social que provocavam a selecção escolar.

A teoria dos sistemas autopoiéticos de Niklas Luhmann (1982; 1990a) tem aqui um papel na compreensão dos fenómenos de auto-referencialidade dos sistemas educativos: os sistemas alteram-se a si próprios, de um modo imprevisto, por intermédio da descoberta de novas estruturas e tecnologias. A criação de uma administração aberta à influência dos movimentos sociais, seja por força da influência política partidária ou pela adesão não organizada, ajudou a criar redes de problemáticas que deixaram uma memória no sistema. Tal memória permaneceu mesmo após o fim da crise revolucionária e do Estado dual.

A estandardização é a condição prática que os sistemas educativos construiram para garantir a sua forma particular de justiça, segundo a qual cada individuo deve ser julgado de acordo com o seu próprio mérito. O Estado Novo havia introduzido grandes distorçōes ao funcionamento deste princípio, embora as estruturas que tradicionalmente o sustentam estivessem intactas e tivessem transitado para o período pós-revolucionário: programas de ensino definidos por um poder regulamentar central, uma carta escolar para a implantaçăo dos estabelecimentos escolares, sectorizaçăo pedagógica para a distribuição dos alunos e graus nacionais para a colocação de professores. Entretanto, estas garantias simbólicas que estruturam em grande medida o principio de confiança na escola viram-se abaladas. Novas racionalidades e novas tecnologias foram mobilizadas para as actualizar ou reactivar.

\section{Novas racionalidades e novas tecnologias de governo da educação}

Em capítulo anterior (ver cap. II) fizémos uma primeira aproximação ao conceito de racionalidades de governo. Daremos agora um passo mais na argumentação para estabelecer os limites conceptuais em que é utilizado neste capítulo. Para Gordon (1991), a racionalidade de governo consiste num sistema de pensamento sobre a natureza das práticas de governo: quem pode governar, o que é governar, quem ou o que é governado? Tal sistema não se esgota nos circuitos fechados de controlo do Estado, alargando-se a todas as zonas de interacção sujeitas às problematizaçōes do governo. Foucault contrapōe ao monolítico objecto postulado pelas teorias do Estado o regime múltiplo da governamentalidade, concluindo pela necessidade de tornar menos rígidas as tradicionais fronteiras entre Estado e sociedade civil. Deste modo 
chama a atenção para a multiplicidade de formas de poder em circulação na sociedade. Também Boaventura S. Santos (1994: 105-117) desenvolveu esta tese da distinção Estado/sociedade civil referindo que tal distinção impõe uma concepção homogénea de poder político-jurídico com origem no Estado, diluindo todas as outras formas de poder na família, nas empresas e nas instituições não estatais. Tentando superar a falta de especificidade das formas de poder exteriores ao Estado, encontrada em Foucault, apresenta quatro modos básicos de produçăo de poder que se articulam de maneiras específicas: o patriarcado no espaço doméstico, a exploração no espaço da produçăo, a dominação no espaço da cidadania e a.troca desigual no espaço mundial. Formulada esta proposta, Santos (1994: 113-117) aplica-a à sociedade portuguesa nas suas três características semiperiféricas: grande heterogeneidade interna dos vários espaços estruturais, centralidade e défice de hegemonia do Estado, excesso de autoritarismo do Estado.

Para Santos, a centralidade do Estado português, por força do seu autoritarismo e fraqueza hegemónica, tornaria mais difícil determinar onde o Estado acaba e a sociedade civil começa. É neste contexto teórico que Santos (1993: 31) identifica o fenómeno do Estado paralelo: «um Estado formal que existe paralelamente a um Estado informal; um Estado centralizado que endossa as atitudes contraditórias dos múltiplos micro-Estados existentes no seu seio; um Estado oficial maximalista que coexiste, lado a lado, com um Estado não oficial minimalista». Por seu lado, a heterogeneidade dos espaços estruturais, em especial do espaço doméstico e do espaço de produção, criariam autonomias relativas em cada um destes espaços estruturais da sociedade portuguesa, cujo efeito seria o bloqueio relativo da actuaçăo do Estado. É neste contexto teórico que Santos (1993: 33) identifica uma das estratégias estatais de regulaçăo social semiperiférica: a construção de novos actores sociais.

Embora o mapa estrutural dos modos de produçăo do poder apresente potencialidades interessantes no nosso próprio trabalho, o seu grau de generalidade e abstracção é excessivo, não permitindo captar a totalidade dos processos em causa no sistema educativo. Dentre os processos que é possivel analisar com este mapa conceptual sobressaem os que dizem respeito à construçăo de novos actores sociais nas articulações possíveis entre os espaços da cidadania, da produção e da família no interior do processo educativo. A primazia do espaço da cidadania na educação, sob a forma do Estado, coexiste com a sua dependência em relação aos outros espaços e por essa via a forma do poder de Estado exerce-se, muitas vezes, em combinaçăo com as formas típicas de outros espaços estruturais. Por exemplo, quando o processo educativo estatal reconhece a necessidade de produzir competências para o 
mercado de trabalho local está a conferir grande particularismo à sua actuação. Esta derivação do interesse geral para o interesse particular é tornada logicamente necessária pela necessidade de ligar a escola à vida activa e o trabalho intelectual ao trabalho manual, fazendo coincidir retoricamente os interesses do «tecido empresarial» com o interesse geral. Deste modo se incorporam os particularismos. Tal particularismo pode resultar também da interpenetração do espaço doméstico e do espaço da cidadania, por exemplo, no caso em que a actuação do Estado e o exercício da cidadania săo delegados formalmente em Associaçōes de Pais ou, informalmente, nas famílias. Contrariamente ao espaço estatal da cidadania, o espaço doméstico apresenta-se atomizado na diversidade e dispersăo das famílias existentes numa dada sociedade. O poder patriarcal, embora se possa exercer noutras relaçōes sociais, tem no espaço doméstico a unidade de prática social preeminente. Năo se apresentando ligadas por uma rede funcional e por uma estrutura hierárquica semelhantes aos departamentos que compōem o Estado, as famílias dificilmente conseguem superar a dispersão que Ihes limita a participaçăo política. Precisam para tanto de mudar de forma quando mudam de unidade de prática social. É o que se passa com a regulação associativa que lhes permite uma certa intervenção nos assuntos e nas decisões das escolas. Deste modo, o espaço doméstico sofre uma alteraçăo, por força da politizaçăo da sua representaçăo. Esta politização é multidimensional. Envolve, em primeiro lugar, as relaçōes na escola: o que distingue a intervenção atomizada das famílias, da intervenção por intermédio dos seus representantes são as características da sua racionalidade. Enquanto a primeira tende a ser parcial, pontual, particularista, centrada nos laços pessoais e afectivos e destinada a proteger o filho; a segunda, tende a ser global, geral, impessoal nas apreciaçōes e destinada à defesa do interesse geral das famílias. Em segundo lugar, a politização do espaço doméstico envolve as relações na família. Algumas vezes, a presença maioritária das mulheres na organizaçăo e direcção das associações, tende a reduzir as relações de dominação patriarcais da família, assentes na discriminaçăo sexual. Porém, outras vezes, o associativismo das famílias é também uma forma de confirmar a matriz a partir da qual outras formas de poder săo legitimadas para produzir discriminaçăo social. É que a conquista de um espaço de intervençăo das famílias pode ser obtido à custa da total separaçăo entre o espaço da cidadania e o espaço escolar. Não é evidente que a uma maior representação corporativa das famílias na vida escolar corresponda uma maior participação na vida política. Pode mesmo postular-se a hipótese contrária: a intervenção associativa das famílias e a representaçăo política, no âmbito de cada escola, podem ser decisivas para trivializar as relações de poder escolares, ancoradas em mecanismos imunes à democracia representativa. Neste sentido, os eventuais ganhos conseguidos pelos 
pais-cidadăos podem ser obtidos em detrimento dos cidadãos-pais, na medida em que a participação no espaço escolar esgota e isola, e por isso camufla no seu paroquialismo, todas as energias de participação cívica.

Mas outros processos de governo da educação não se podem incluir neste modelo conceptual. Dentre os processos que não é possível analisar destacamos dois que assumem um papel central no nosso trabalho: a fertilização cruzada entre diferentes agências e especialistas, públicos e privados e a mobilização simbólica do mítico espaço comunitário. O primeiro processo resulta da articulação entre os espaços da cidadania e o espaço das ciências que mais directamente intervêm na educação, designadamente as Ciências da Educação e a Psicologia. Também nestas articulaçōes são construídos novos actores sociais. O nosso argumento considera que, embora este espaço não tenha constituído ainda uma homogeneidade estrutural do mesmo nível do espaço da cidadania, a crescente mobilizaçăo dos especialistas para programas de governo, bem como a autonomia da sua região discursiva, aconselham a uma análise mais matizada dos dispositivos de poder que deles decorrem. ${ }^{\left({ }^{(89)}\right.} \mathrm{O}$ segundo processo resulta do conjunto de relaçōes sociais, reais ou imaginadas, que tendem a

(89) Esta problemática está desde o início presente na ambiguidade orgânica do projecto de avaliaçăo do ESU, dirigido pela tecno-estrutura do ministério que, a par da função avaliativa, junta também a função de planeamento da política educativa avaliada. Na verdade, reconhece-se desde logo, no primeiro relatório do projecto (Breve introdução à avaliação em educação, Lisboa: GEP, Novembro de 1977, pp. 5-6) que "o problema do uso desta estratégia para a mudança educativa que foi muito discutida na Suécia é que sendo o mesmo organismo o responsável quer pela implementação quer pela avaliação, a avaliaçăo não dará uma perspectiva nova e crítica sobre o sistema educativo. Ao contrário, a avaliaçăo funciona na realidade como justificação e legitimação dos planos educativos produzidos pelo National Board of Education. Uma maneira de resolver este problema é evidentemente organizar a avaliação de modo a que ela exista económica e juridicamente independente dos organismos de planeamento. Isto significa pelo menos um tipo de independência necessária para uma avaliação em educação que possa trabalhar criticamente e como base real para decisōes políticas». Todavia, ao centrar a problemática da autonomia do campo científico da avaliação no seu formato orgânico, faz-se crer que as relaçōes de poder entre política e ciência se passam sobretudo nesta possibilidade de contaminaçăo provocada pela concentração no mesmo organismo das funçōes de planeamento e avaliaçăo. Também por este motivo, as reflexōes introduzidas pelo PAESU terão um papel importante no modelo utilizado, posteriormente, na cooptaçăo dos especialistas para diversos grupos de trabalho e para a Comissão de Reforma do Sistema Educativo. A externalidade progressiva destes, integrados que estão na vida académica, garante-lhes uma autonomia orgânica que năo corresponde, automaticamente, à possibilidade de fazer trabalho crítico sobre as decisōes políticas. Ainda assim, neste primeiro momento, é notória a diferença entre a tradição das Ciências da Educação na Suécia, que já fizera o percurso da cooptação orgânica para a discussão pública, e a tradiçăo portuguesa, ainda constrangida pela dependência hierárquica. O conflito desencadeado por um artigo publicado por Stefan Haglund no Diário de Notícias (intitulado Escola e Mudança) é a este propósito muito elucidativo. Em reacçăo a esta iniciativa do coordenador sueco do Projecto, o grupo português dirige-se ao Director do GEP, em 18 de Janeiro de 1980, nos seguintes termos: «this group 
vincular os indivíduos e os grupos a certos territórios. As relaçōes sociais que decorrem neste espaço geram novos actores sociais com poder desigualmente distribuído em função de identidades primordiais tais como a etnia, a zona de habitação ou a reputação local, dando lugar a dispositivos de poder assimétricos ou nivelados, mas, em qualquer caso, bastante diferentes das míticas comunidades educativas convivenciais e isentas de contradições.

O quadro seguinte faz uma primeira aproximação mais específica destes contextos a partir das noções de tecnologias e racionalidades da governamentalidade, tendo por referência o Projecto de Avaliaçăo do Ensino Secundário Unificado (PAESU). (ver pág. seguinte).

Numa primeira análise do quadro sobressaem os diferentes modos de reflexão e de impulso ético que subjazem ao objectivo de equalização de oportunidades educacionais para diferentes grupos sociais. De forma esquemática, podemos dizer que nestes quatro conjuntos formados por racionalidades e tecnologias, com ponto de aplicação no ESU, se encontram os impulsos essenciais que marcarão todo o período analisado. A fractura, que é simultaneamente uma articulaçăo, entre os objectivos técnicos de governo e o direito moral à auto-realização já se encontra presente nos quatro domínios que, no nosso modelo de análise, constituem as principais criaçōes do ESU, a saber:

A criaçăo de um nova matriz social que, ao integrar todos os grupos sociais na problematização das trajectórias escolares, estabelece novos critérios de desigualdade escolar através da medida, entre outras, das "taxas de desperdício» (abandono e repetição) por grupo socioeconómico.

A criação de uma nova cartografia de inserção da escola que, ao estabelecer as regiões administrativas, as zonas e os casos (estabelecimentos específicos) como o espaço de observação e avaliação do sistema educativo, desloca também o campo privilegiado de intervenção das políticas educativas.

thinks that, from a professional point of view, it was not correct to publish this article taking into account the following considerations: the author of the article is, simultaneously, co-ordinator for the swedish part of tha Project of the Evaluation of Ensino Unificado which gives him access to that data. A great part of the information referred to is based on data already analysed but not yet published. It is the opinion of this group that data not yet published should be used in individual reports or articles, only after it has been made public by the Governmental Institution where the Project is located; GEP within the Ministry of Education». Ao que Stefan Haglund responde, em carta dirigida ao eng. ${ }^{\circ}$ Mário Cordeiro, da direcçăo-geral do ensino superior, explicando, simplesmente, que «in Sweden, it is normally the case that during a research or development work, even though the work is not completed, a public discussion is held round the issue». 
A criaçăo de um novo vocabulário comum aos diferentes níveis do sistema educativo que, ao constituir homologias linguísticas, estabelece novas formas de coordenação discursivas onde as antigas formas estruturais parecem falhar.

A criação de uma nova forma de individualização do aluno por intermédio da escolarização que, ao constituir um conjunto de métodos e estratégias de auto-regulação e autonomia, inscreve novos atributos da subjectividade no corpo social.

Quadro 14 - Problematizaçōes de governo da educaçăo inscritas na avaliação do Ensino Secundário Unificado

\begin{tabular}{|c|c|c|c|}
\hline & LUGAR-COMUM & RACIONAUDADES & TECNOLOGIAS \\
\hline MATRIZ & $\begin{array}{l}\text { - Democratização } \\
\text { - Igualdade de } \\
\text { oportunidades } \\
\text { - Quantidade }\end{array}$ & - Interesse Geral & $\begin{array}{l}\text { - Indicadores estatísticos: } \\
\text { distância casa-escola, } \\
\text { tipo de transporte, modo de } \\
\text { deslocação, número de } \\
\text { pessoas em casa, número de } \\
\text { divisōes, periodicidade da } \\
\text { leitura de jornais, número de } \\
\text { livros. } \\
\text { - Escalöes socioeconómicos } \\
\text { - Classificação: mais } \\
\text { favorecido, médio superior, } \\
\text { médio inferior, menos } \\
\text { favorecido. } \\
\text { - O social: encarregados de } \\
\text { educaçăo e empresas. }\end{array}$ \\
\hline CARTOGRAFIA & - Regionalizaçăo & $\begin{array}{l}\text { - Lealdade Nacional/Local } \\
\text { - Lealdade Territorial }\end{array}$ & $\begin{array}{l}\text { - Regiōes administrativas } \\
\text { - Estudos de caso } \\
\text { - Zonas: urbana, suburbana, } \\
\text { rural } \\
\text { - Dimensăo das escolas }\end{array}$ \\
\hline 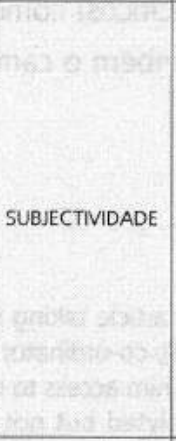 & $\begin{array}{l}\text { - Individualização } \\
\text { - Autonomia } \\
\text { - Auto-estima } \\
\text { - Motivação }\end{array}$ & - Laços Pessoais & $\begin{array}{l}\text { - Investigaçăo individual } \\
\text { - Trabalho em grupo } \\
\text { - Critérios de avaliação } \\
\text { (participaçăo, progressăo, } \\
\text { aquisiçăo, aplicação) } \\
\text { - Capacidades individuais } \\
\text { - Participação nas aulas } \\
\text { - Trabalho de casa } \\
\text { - Disciplina } \\
\text { - Pedagogia por Objectivos } \\
\text { - Expectativas quanto ao } \\
\text { prosseguimento de estudose } \\
\text { inserção profissional }\end{array}$ \\
\hline VOCABULARIO & - Unificaçăo & $\begin{array}{l}\text { - Eficácia } \\
\text { - Competência }\end{array}$ & $\begin{array}{l}\text { - Criação de novas disciplinas } \\
\text { - Ressurgimento do } \\
\text { desenvolvimento curricular } \\
\text { - Interdisciplinaridade } \\
\text { - Intradisciplinaridade }\end{array}$ \\
\hline
\end{tabular}




\section{Uma nova matriz social}

O lugar-comum utilizado na criação de uma nova matriz social é o da igualdade de oportunidades e da democratização: «a importância da educação numa sociedade tecnicamente avançada transforma a educação num instrumento para planeamento económico e cumprimento de programas políticos. É objectivo básico de uma democracia garantir a igualdade de oportunidades, numa sociedade de bemestar, através do acesso à educação. A unificação de um sistema educativo diferenciado resulta, portanto, da necessidade de garantir a todos uma base educativa a partir da qual possa ser escolhida uma educação posterior e possa ser encontrado um lugar no mercado de trabalho». ${ }^{(90)}$

Estes lugares-comuns utilizados para formar o communis principiu são lugares de quantidade: "a igualdade de oportunidades só é possível com mais alunos no ESU». Como expressamente nota Perelman (1969, 1996: 98), o lugar da quantidade fundamenta certas concepçōes de democracia devido à superioridade do que é admitido pelo maior número e do mérito atribuído às pessoas ou instituições que prestam serviços a um maior número. Porém, o lugar da quantidade é frágil e evolui facilmente para o lugar da qualidade: «esperar que a escola, por si só, compense as desigualdades sociais é, hoje, para qualquer educador ou político consciente, domínio do mito, da utopia ou da ignorância. Assim, esperar que a escola opere milagres só porque se garante, dentro dos seus muros, uma apregoada 'igualdade de oportunidades' que não está consonante com a realidade extra-escolar, deverá ser também matéria cuja năo veracidade se deve encarar (...) A análise do rendimento escolar dos alunos e a sua relação com as variáveis de caracterização socioprofissional parecem apontar neste sentido: o insucesso escolar, as repetências, os níveis mais baixos de rendimento escolar fazem parte da bagagem dos estratos socioprofissionais situados nos escalões inferiores da hierarquia social» (/dem, Ibidem, p. 515-516) .

A escola é apresentada como fazendo parte das contradições da sociedade, sendo a reforma «lenta, morosa e difícil, porque implica a interiorização desses novos objectivos; este processo de interiorização é tanto mais moroso quanto não é acompanhado por medidas e estruturas adequadas» (Idem, Ibidem, p. 516). O grande número dá assim lugar ao que é difícil, raro e distintivo. Apresentar a reforma como difícil ou rara é um meio de valorizá-la, mas a sua precaridade é um valor qualitativo

(90) In Ensino Secundário Unificado. A caminho duma Reforma do Ensino Secundário Unificado. Relatório Final. Dezembro de 1981, p. 87. 
oposto ao valor quantitativo. São as tecnologias de distinção, separação e classificação que asseguram esta passagem lógica da quantidade para a qualidade: escalōes socioeconómicos, taxas de abandono e repetição, indicadores de condições de vida, indicadores de consumo cultural demonstram as assimetrias sociais e, portanto, a (im)probabilidade de uma transiçăo simples para a igualdade de oportunidades.

No modelo de avaliação apresentado, cujo objectivo declarado é o de compatibilizar filosofia política e pragmática da avaliação, ${ }^{(91)}$ a distinção entre o estado ideal das pessoas e as pessoas em si-mesmas, medidas por indicadores estatísticos, ocupa um lugar central. É esta operação de julgamento dos indivíduos em situação que permite a passagem do princípio formal de acesso democrático à incerteza dos momentos críticos. A análise desses momentos permite-nos verificar como a incerteza de aplicação do princípio deve, simultaneamente, enfrentar as contingências da situação e justificar-se segundo princípios gerais.

A problematização cria situações de prova năo-presenciais semelhantes às situações de prova presenciais analisadas por Boltansky e Thévenot (1991). Nestas situações os actores devem pôr à prova ou fazer prova de que a sua definição de situação ou a sua proposta de acçăo é a melhor em face das propostas de outros. Nas situaçōes de problematização o registo de comunicabilidade é garantido por um enunciado aparente de todas os princípios racionais possíveis para aquela situaçăo de prova. A fim de tornar este exercício não presencial possível é suposto que a estes princípios se possam associar objectos mensuráveis com as quais as pessoas se comparem e do mesmo lance comparem a validade dos princípios. Esta situação de prova conduz as pessoas a pôr-se de acordo sobre a importância relativa dos seres e objectos envolvidos na situação, sejam eles recursos, programas, disposições regulamentares, alunos, professores, etc.. Sublinhe-se que não se trata de um acordo sobre o principio ou princípios envolvidos, por que estes podem estar sujeitos ao diferendo, mas do acordo quanto à ligação e disposição dos seres e objectos numa montagem suficientemente coerente para que a sua articulação tenha verosimilhança, para que o julgamento possa ser possível e para que os processos esperados se possam efectivar.

(91) A necessidade de fazer este balanço é constantemente repetida em passagens como a que segue: «a unificaçāo do sistema escolar é, ao mesmo tempo, base de resposta para exigências de produção e para o cumprimento de objectivos políticos fundamentais numa sociedade democrática de bem-estar. Assim, a estratégia para o desenvolvimento tem sempre que se centrar sobre como equilibrar o ensino unificado e a diferenciação dentro e através da educação» (Idem, Ibidem, p. 88). 
O período revolucionário é marcado por tendências contraditórias em outros campos onde o princípio da igualdade de oportunidades deveria aplicar-se. Não obstante a centralidade da quantidade, as problematizações técnicas começam a responder a questões que são mais abertamente discutidas no contexto político. A democratizaçăo do acesso levantara problemas urgentes no final do ensino secundário, por força do acesso maciço à Universidade. As preocupaçōes principais com o excesso de quantidade acolhiam-se então no Serviço Cívico Estudantil.(92) Como se depreende da discussão realizada no Conselho de Ministros de 21 de Outubro de 1975(93) (pp.6-8): «o Primeiro Ministro [Pinheiro de Azevedo] afirmou que estavam em discussão dois pontos de vista totalmente distintos. O primeiro defendia que o serviço cívico era no fundo uma parte da educação da juventude e que a consequência lógica seria a sua obrigatoriedade com o consequente planeamento e postos de trabalho fixos; segundo o segundo ponto de vista o serviço cívico justificar-se-ia unicamente para permitir ao aparelho de Estado a recuperação do seu atraso em matéria de construções escolares e formação de pessoal docente e neste caso deveria ser meramente facultativo". Entretanto, o Ministro da Educaçăo [Vitor Alves] clarifica a sua posição nos seguintes termos: «na prática efectivamente o serviço cívico havia funcionado como uma medida de tampão para impedir a entrada na universidade de indivíduos que esta já não comportava e que actualmente se deveriam decidir certos tipos de problemas muito concretos, nomeadamente quem superintendia no serviço cívico e se deveria ou não admitir-se os numerus clausus na universidade. Quanto à questão das construções escolares o Ministro afirmou que no seu entender o Governo se deveria concentrar no ensino de base como prioridade». Depois de uma prolongada discussão, as tentativas de consenso são abertamente contraditórias, como se infere da sintese tentada pelo primeiro-ministro e pelo relator: «o Primeiro-Ministro depois de profunda discussão do assunto tirou o consenso do Conselho de Ministros que ia no sentido da manutenção do serviço cívico sobre responsabilidade do MEIC, mantendo-se o seu carácter obrigatório e definindo-se que deveria começar o mais cedo possível (...) Foi então amplamente discutido se o serviço cívico estudantil devia ou não ter carácter obrigatório, inclinando-se o Conselho para que efectivamente ele năo tivesse características obrigatórias».

(92) O Serviço Cívico Estudantil foi criado, depois de algumas hesitaçōes iniciais, pelo decreto-lei $270 / 75$ de 22 de Maio de 1975.

(93) In Súmulas das Reuniōes do Conselho de Ministros (23 de Setembro de 1975 a Julho de 1976), Espólio Vitor Alves. 
No interior desta contradiçăo encontra-se tacitamente equacionada a resistência cada vez maior dos estudantes e das associações de pais ao serviço cívico. Os estudantes de direita opunham-se ao serviço cívico porque ele comprometia os tradicionais privilégios sociais da classe média (Mailer, 1977); as associações de pais reagem fortemente pelo mesmo motivo, opondo à primazia do critério da origem social no acesso à universidade, o princípio do mérito de cada um;(94) os estudantes de algumas organizações de esquerda criticam a contradiçăo de o princípio de ligação às classes trabalhadores ser organizado e planeado por um governo de natureza capitalista (Stoer, 1986: 190-192). Também neste caso se utilizou o formato do grupo de trabaIho especializado como forma de dissipar as contradições. A Comissão conclui, entretanto, que se devem manter os objectivos estabelecidos, actualizando-os do seguinte modo: «a) assegurar aos estudantes uma adequada integração na sociedade portuguesa e um mais amplo contacto com os seus problemas a par de uma melhor compreensão das necessidades e carências da população; b) prepará-los, assim, para intencionar o seu curso no sentido de dar resposta aos problemas vividos da comunidade nacional; c) contribuir, pelo trabalho concreto realizado para melhorar as condições de vida das populações mais necessitadas». (95) As conclusões reforçam, noutro contexto e por outra via, o mesmo tipo de problematização da relação entre escola e sociedade que se fazia no caso do ESU: «como o sistema escolar tem que responder, ao mesmo tempo, às exigências da vida activa e de um mercado de traba-

(94) Entre outras posições públicas, a interassociação de pais e encarregados de educação opõese ao serviço cívico estudantil num comunicado sobre Política educativa, datado de 5 de Setembro de 1975, nos seguintes termos: "o decreto que institue o serviço cívico como condição obrigatória para o acesso ao ensino superior, excepto para os trabalhadores estudantes, ou não tem em conta as realidades da sociedade em que vivemos ou tem objectivos que se não coadunam com os princípios propalados, de igualdade de acesso à cultura e de preferência pela competência. Basta ter em conta dois pontos: 1. A grande maioria dos pais opor-se-á ao serviço cívico, não autorizando, sobretudo as raparigas, o afastamento dos lares paternos. Certamente que raparigas de 16,17 e 18 anos, dentro da sociedade portuguesa actual, não serão logicamente, autorizadas pelos pais a seguirem em bandos de rapazes e raparigas, ao Deus dará, por esse país além (Desejar-se-á dificultar o acesso das mulheres às Faculdades?). 2. As prioridades para o acesso às Universidades em que a primeira é atribuída à origem social, por outras palavras, aos filhos dos trabalhadores (mas o que săo trabalhadores?) e apenas em quarto lugar se considera o aproveitamento escolar! (A competência é menos importante que a origem do indivíduo) s.

(95) O despacho 156/76 de 11 de Junho cria uma comissăo para «repensar globalmente a problemática do Serviço Cívico Estudantil, sua organização e funcionamento em função dos objectivos que o justificam e atendendo à experiência entretanto adquirida e às críticas que por diversas entidades e sectores de opinião Ihe têm sido formuladas». Esta comissão, presidida pelo coronel Joăo CorteReal Araújo Pereira e constituída por Duartina Barbosa da Silva, José Augusto Seabra, Adérito Sedas Nunes, António Manuel Hespanha, Maria Manuela Silva e Maria Teresa Dória Monteiro Gomes viria a apresentar o seu relatório em 20 de Julho de 1976. 
Iho diferenciado, a igualdade da educaçăo é definida no âmbito da noçăo de uma sociedade meritocrática. A igualdade da educação é, assim, vista como a garantia dada a cada indivíduo de desenvolver iguais possibilidades, aptidões e capacidades, sendo essas capacidades que darão a cada um, um lugar no mercado de trabalho». (96)

Problematizada nestes termos probabilisticos, a relação entre escola e sociedade induz a construção de duas esferas de acção: por um lado, a localização geográfica, o estatuto socioeconómico, a constituiçăo da célula familiar, a afectaçăo de recursos, a dimensão das turmas e os transportes, entre outros, săo dados de condiçăo — «OS factos», segundo os Relatórios - em relaçăo aos quais pouco se pode fazer a não ser conhecê-los; por outro lado, há os objectivos, os programas, as condições pedagógicas, as atitudes e capacidades dos alunos, dos encarregados de educação e das empresas que se inscrevem no voluntarismo político necessário à melhoria da sua situaçăo.

Estas duas esferas de acção tornam-se visíveis nas recomendações do Relatório final: «a curto prazo situam-se os problemas cuja solução pode ser imediata, porque se apresenta simples, garantida que seja a intençăo de a encontrar. Pensamos que os serviços executivos encontrarão na leitura dos diferentes relatórios publicados ao longo do Projecto, a enumeraçăo de problemas para os quais não lhes será difícil, se quiserem e puderem, encontrar remédio. Essa tarefa necessitará, porém, da tomada de consciência, por parte desses serviços, das suas próprias limitações e do seu espaço de actuaçăo. Os problemas de solução a longo prazo apresentam-se mais complexos já que têm que ver com a consciencialização dos problemas educativos como problemas fundamentalmente sociais e a que a sociedade terá que dar resposta, necessitando por isso de assumir claramente aquilo que pretende que sejam as geraçôes futuras» (p. 527).

Dentre os factores que progressivamente serão problematizados como factores de intervenção encontram-se as opiniōes das empresas e dos encarregados de educação. A incorporação do espaço doméstico e do espaço da produção no interesse geral é realizada através do questionamento e da construçăo de indicadores do nível social. O nível social é aqui representado por uma amostra de encarregados de educação e por uma amostra de empresas. No primeiro caso, os encarregados de educação são problematizados a partir de dois eixos centrais: qual o prolongamento que estão capazes de fazer no contexto doméstico das opçōes pedagógicas da escola? Quais

(96) In 17- Ensino Secundário Unificado. A caminho duma Reforma do Ensino Secundário Unificado. Relatório Final. Dezembro de 1981, p. 88. 
os handicaps socioculturais que limitam a pedagogização da família? ${ }^{(97)}$ No caso das empresas procura-se sobretudo verificar qual a adequação dos objectivos do Unificado às expectativas sociais. ${ }^{\left({ }^{98}\right)} \mathrm{Em}$ ambos, a operação de transformação destes dois contextos estruturais parcelares, limitados e particularistas em contextos de referência do social é realizada por uma operacionalização de indicadores estatísticos, os quais obtêm como única validação a necessidade de medir o grau de legitimaçăo das medidas de política educativa tomadas: "o estudo que nele se relata, procurou analisar qual o impacto e significado da Reforma nos sectores mais directamente ligados às funções de 'produção', às empresas e, simultaneamente, detectar quais as exigências e aspiraçōes manifestadas por aquelas relativamente a este sector de ensino». (99) Inverte-se assim a lógica de legitimação típica das democracias liberais: da lógica da oferta, que era a do estado-educador, transita-se, pouco a pouco, para a lógica da procura. ${ }^{(100)} O$ projecto da modernidade incluía nos seus pressupostos iniciais um potencial democrático que se alargava a domínios mais amplos que o da democracia representativa. ${ }^{(101)}$ Neste estudo, apresenta-se uma problematização precisamente a

(97) O estudo é realizado através de entrevistas a encarregados de educaçăo de alunos dos $6 .^{\circ}$, $9 .^{\circ} \mathrm{e} 10^{\circ}$ anos de escolaridade. A entrevista está dividida em quatro blocos, cada um dos quais trata as seguintes temáticas principais: a) atitude do educando face à escola: grau de interesse pela escola, grau de sucesso, quais as expectativas profissionais do filho, carências da escola; b) atitude do encarregado de educação face à escola: frequência de contactos com a escola, importância atribuída a essa relação, tipo de comunicação e de relação entre a criança e a família, atitude face aos professores; c) atitude do encarregado de educação face ao sistema de ensino e à sociedade: funções da escola, grau de conhecimento do ensino unificado, expectativas profissionais para o filho; d) caracterização escolar e profissional do entrevistado.

(98) O guião das entrevistas às empresas estende-se por um extenso leque de dezasseis temas, dos quais referimos aqui os seis temas sujeitos a uma análise no Relatório 16: 1) conhecimento e análise crítica dos objectivos do ensino unificado; 2) adequaçăo dos objectivos à expectativa social; 3) adequaçăo dos objectivos à estruturas física e pedagógica das escolas; 4) conhecimento e análise crítica das inovaçōes curriculares; 5) dificuldades na execuçăo da reforma; 6) inserçăo do ensino unificado no sistema escolar.

(99) In 16-Ensino Secundário Unificado. Relatório de avaliação: impacto social da reforma do Ensino Secundário Unificado. Entrevistas a empresas, 1979/80. Novembro de 1981, p. 14. Ver também, a propósito da justificaçāo das entrevistas a encarregados de educação, o relatório 14. Ensino Secundário Unificado. Relatório de avaliação do 9. ${ }^{\circ}$ ano de escolaridade de 1978/79. Entrevistas a Encarregados de Educação do 6., $9^{\circ}$ e $10{ }^{\circ}$ anos. Julho de 1981 , pp. 19-23.

(100) Bernard Charlot (1987) esquematiza do seguinte modo esta transição. A lógica de oferta tradicional seguia um vector com a seguinte sequência: Saberes estruturados em disciplinas/Valores culturais e sociais - Transmissăo dos saberes e inculcaçăo dos valores - Formação do indivíduo - Acesso ao emprego. A lógica subjacente à procura percorre um vector diferente com a seguinte sequência: Necessidades da produçăo - Procura de qualificações das empresas - Oferta de empregos no mercado de trabalho - Expectativas de formaçăo da família - Definiçăo de uma formação de qualidade.

(101) Ver sobre este tema e neste mesmo sentido a discussăo de Boaventura Sousa Santos no capítulo «Subjectividade, cidadania e emancipaçăo» de Pela mão de Alice, Porto: Afrontamento, 1994, pp. 203-241. 
contrario: procura-se nos contextos, entretanto despolitizados, a fonte de aceitaçăo e legitimação das políticas estatais. A teoria política liberal transformou a cidadania num espaço especializado de exercício da democracia representativa, relegando as restantes dimensões da prática social, designadamente as do espaço doméstico e da produção, para uma zona não-política. Nesta zona privada, o autoritarismo, a ausência de partilha de autoridade e mesmo o despotismo, encontram-se protegidos pelo direito de propriedade e pelo direito da família. Embora o Estado-Providência constitua a forma mais adentrada de cidadania no espaço doméstico, as suas características especificamente incipientes, no Portugal democrático, andaram a par da devoluçăo de algumas tarefas sociais para o interior das famílias. Especialmente visíveis sāo os efeitos negativos que tal devolução tem na sobrecarga de tarefas domésticas sobre as mulheres, ${ }^{(102)}$ na subsistência das desigualdades entre os géne$\operatorname{ros}^{(103)}$ e na manutençăo da especializaçăo feminina nas tarefas reprodutivas. ${ }^{(104)}$ Para que a família, enquanto tal, possa legitimamente aspirar a um escrutínio directo sobre as políticas da cidadania, deveria, simetricamente, abrir-se também à identificaçăo das suas específicas formas de poder. E o mesmo se pode dizer das relações sociais de produção que, para poderem aspirar à co-determinação nas decisões escolares deveriam sujeitar-se a um processo de politização recíproco, de participação alargada dos trabalhadores nas decisões da empresa, designadamente na componente que envolve os processos de trabalho e de produção. Como sublinha Santos (1994: 235), embora seja possível detectar na fábrica instituições isomórficas do campo político liberal, estas são muito mais despóticas. Com efeito, a representação dos trabalha-

(102) Cf. em especial a distância entre as representaçōes dos jovens portugueses casados, favoráveis à partilha das tarefas domésticas e dos cuidados com os filhos e a divisão real do trabalho doméstico que as mantém concentradas nas mulheres (cf. José Machado Pais, «Familia, sexualidade e religiāo», Análise Social, 86, 1985, pp. 362).

(103) Ver, entre outros, M. do Carmo Nunes, "A mulher: entre a familia e o trabalho», Economia e Socialismo, 63, 1984, pp. 71-76; Beatriz Ruivo, "A mulher e o poder profissional: a mulher em actividades de investigaçāo cientifica em Portugal’, Análise Social, XXII(87-89), 1986, pp. 669-680; Virgínia Ferreira, "Padrōes de segregação das mulheres no emprego», in B. Sousa Santos (org.), Portugal: um retrato singular, Porto: Afrontamento, 1993, pp. 231-257; Dina Canço e Teresa Joaquim, coord., Portugal - situação das mulheres 1994, Lisboa: Comissão para a igualdade e para os direitos das mulheres, 1994.

(104) Cf. Pedro Vasconcelos, "Conjugalidade e sexualidade», in M. Villaverde Cabral e J. Machado Pais, coord., Jovens portugueses de hoje, Lisboa: Celta, 1998, pp. 215-305: analisando um questionário aplicado a uma amostra de jovens portugueses, conclui que a maioria $(59,5 \%)$, independentemente do género, continua a considerar como traço marcante da condiçẫo feminina o primado da maternidade sobre a realização profissional. Esta mesma tendência havia sido encontrada também num estudo anterior de Ana Nunes de Almeida e Maria das Dores Guerreiro, «A Família», in Luís de França, coord., Portugal - Valores europeus, identidade cultural, Lisboa: IED, 1993, p. 212. 
dores, o direito da produção e do trabalho ou a lealdade à empresa são cada vez mais polarizadas e descaracterizadas: «no pólo benevolente, são detectáveis relações de produção relativamente horizontalizadas, com uma convivência entre capital-trabalho que mais parece organizada segundo o principio da comunidade do que segundo o princípio do mercado; são as empresas-comunidade, onde trabalha a nova aristocracia do operariado. No pólo despótico, pululam as sweat shops do fim do século e a exploração do trabalho infantil, caracterizados por relações de produção cuja violência as aproxima da pilhagem típica da acumulação primitiva; são as empresas-campos de concentração onde trabalham os hilotas do nosso tempo». No seu conjunto e tudo somado, o empobrecimento do projecto democrático nos contextos doméstico e da produção resulta num empobrecimento da participação democrática das famílias no contexto escolar e na imposição do particularismo privatista das empresas. Desde logo, porque as relaçōes entre a escola-estatal, as empresas e as famílias não se resume a um processo isomórfico único, devendo distinguir-se processos distintos de antroponomia; (105) depois, porque năo existe a família mas antes familias; (106) finalmente, porque ao investir as necessidades das empresas e das famílias do estatuto de inevitabilidade, tende a incorporá-las no discurso educativo sem qualquer possibilidade de controlo político da cidadania. É que ao serem tratadas como representação estatística das necessidades sociais tendem a deixar de ser consideradas políticas, quer dizer, sujeitas à tensão entre a lógica democrática da igualdade e a lógica liberal da liberdade.

(105) Seguimos de perto, neste particular, a designação introduzida por Daniel Bertaux em Destinos pessoais e estrutura de classe, Lisboa: Moraes, 1978. O autor, partindo da analogia entre processos económicos e processos antroponómicos reserva para estes a reproduçăo intergeracional da ordem económica, distinguindo entăo os processos de consumo, de reprodução e distribuiçăo de homens. Enquanto nos processos de consumo e distribuiçăo a empresa é a unidade institucional central, nos processos de reprodução săo a familia e o sistema educativo que assumem esse papel nuclear: «aos aparelhos de distribuição Familia e Escola, alguns acrescentam, como bons weberianos, o mercado de trabalho. No entanto, isto nada traz de novo. Ou então limitam-se a verificar que no 'mercado' os proprietários de meios de produção estão mais bem colocados do que os não proprietários, e que os titulares de diplomas estão mais bem colocados do que os não titulares: ora é evidente que năo se está a falar da mesma coisa, que nảo há 'um' mercado, mas vários (sem contar que é verdadeiramente por eufemismo que se pode falar de mercado para designar a passagem dos poderes do industrial para o filho) (...) O erro desta problemática é procurar pensar a questão da distribuição dos seres humanos independentemente daquilo que vêm a ser depois no mundo do trabalho e do capital, no mundo da economia politica. Seguimo-los crianças e estudantes de liceu, através de famílias e escolas, depois abandonamo-los à sua sorte; como se essa sorte não tivesse desde o princípio orientado toda a trajectória. Preocupamo-nos com as aspiraçōes dos jovens, sem procurar saber o que é que os aspira" (Bertaux, 1978: 49-50).

(106) Assim como não há um mercado mas vários mercados, também não existe a familia mas várias famílias. A introduçāo da variável estatuto socioprofissional nas entrevistas e questionários 


\section{Uma nova cartografia de inserção espacial da escola}

A inserção espacial da escola ou, como Popkewitz (1998) a designa, a politica espacial da pedagogia é determinada pela construção de um espaço imaginário a partir do qual o aluno é visto, problematizado e regulado. Se bem que o espaço tenha aqui uma existência denotativa ele é sobretudo conotativo; estes espaços são discursivos mais do que físicos. A nossa tese consiste no seguinte: as tecnologias de avaliação utilizadas desde o lançamento do ESU, em articulação com os novos indicadores estatísticos e os novos modos de planeamento, contribuiram decisivamente para o estabelecimento de novos espaços imaginários de governo da população escolar. Estes espaços permitiram a recomposição dos poderes de governo da escola, emergindo das novas relações os especialistas da planificação e os especialistas em ciências da educação. A expansão da investigação aplicada em educação e a utilização mais alargada de métodos empíriços facilitou a criação de um estatuto académico às ciências da educação e a sua crescente profissionalização.

Devemos então proceder a uma análise das superfícies discursivas no conjunto dos seus sistemas de inteligibilidade e de poder. Temos vindo a desenvolver a ideia de que todo o conhecimento é contextual. Torna-se necessário esclarecer agora o duplo sentido desta asserçăo: o conhecimento é contextual porque é produzido numa rede de relações marcadas por específicas formas de poder; mas é-o também por via da sua intertextualidade, dotando-o de um léxico recorrente que articula campos específicos de conhecimento aparentemente dissimelhantes. Os três quadros que a seguir apresentamos estabelecem estas relaçōes a partir das seguintes categorias organizadoras: tipo de inserção espacial; instrumentos de problematização; tipo de problematizaçăo; oposições estabelecidas; actores envolvidos e prescrições explícitas ou tácitas. Pode concluir-se desde logo que a cartografia de inserção da escola ganha uma nova complexidade.

\footnotetext{
administrados aos encarregados de educação năo ilustra o reconhecimento da assimetria da condiçăo familiar devida à classe social, mas, contrariamente, a incorporação desta variável independente na variável dependente ilustrada pelas suas atitudes. É nesta inversão que reside o principal efeito de problematizaçăo da família enquanto representaçăo do social, quando o contrário pareceria ser mais adequado. Como sublinha Bertaux (1978: 285-286) «concentrar-se na relação mãe-filho para tentar mostrar as diferenças de práticas educativas consoante os meios, sem ter passado pela estrutura de classe e pelos seus efeitos sobre as relaçōes intrafamiliares, é praticar um erro metodológico monumental. Com efeito, se há qualquer coisa de comum às diferentes classes, são precisamente certos traços da relação da mãe com os filhos».
} 
Quadro 15 - A nova cartografia espacial da escola: a Região

\begin{tabular}{|c|c|}
\hline OPOSIÇOES & $\begin{array}{l}\text { - Nordeste: baixos niveis de vida/ausência de capacidade de } \\
\text { inovaçāo/despovoamento } \\
\text { - Lisboa: assimetria entre área metropolitana (rica,congestionada, bons } \\
\text { niveis de vida) e algumas franjas (norte da cidade) (comportamento } \\
\text { médio, mau alojamento e elevado desemprego) }\end{array}$ \\
\hline INSTRUMENTOS & $\begin{array}{l}\text { - Densidade de habitantes por médico } \\
\text { - Condiçōes de habitação: alojamento, água, luz, banho e retrete } \\
\text { - Distribuição de analfabetismo } \\
\text { - Alimentaçāo }\end{array}$ \\
\hline ALVO DE ADMINISTRAÇÃO & - Populaçāo \\
\hline PROBLEMATIZAÇĀO & $\begin{array}{l}\text { - Caracterizar as áreas-problema que estabeleceram obstáculos ao } \\
\text { cumprimento dos objectivos gerais da ESU } \\
\text { - Detectar no âmbito dessas áreas, diferenças entre a Regiấo de Lisboa } \\
\text { e a Região Nordeste. }\end{array}$ \\
\hline RECOMENDACCOES & $\begin{array}{l}\text { - Possibilidade de aproveitar as opçōes para fazer uma orientação } \\
\text { vocacional } \\
\text { - Possibilidade de frequentar, sem limite, a opção que se escolheu } \\
\text { - Actividades de ligação entre escola e comunidade } \\
\text { - Maior incidência do trabalho manual }\end{array}$ \\
\hline
\end{tabular}

Quadro 16-A nova cartografia espacial da escola: a Zona

- Urbano

- Suburbano

- Rural

- Classificação SES (escalão socioeconómico-cultural): escalōes mais

INSTRUMENTOS favorecidos/escalöes menos favorecidos

- Testes padronizados de Matemática

Alvo DE ADMINISTRAÇÃo - População

\begin{tabular}{|l|l|}
\hline PROBLEMATZAÇÃO & $\begin{array}{l}\text { - Relação entre o escalão socioeconómico e cultural dos alunos e } \\
\text { rendimento escolar em Matemática } \\
\text { - Relação etre o meio e o rendimento escolar }\end{array}$ \\
\hline RECOMENDAÇOES & $\begin{array}{l}\text { - Estudar tendências de desenvolvimento curricular ao nivel } \\
\text { internacional } \\
\text { - Determinar capacidades básicas e minimas }\end{array}$ \\
\hline
\end{tabular}


Quadro 17-A nova cartografia espacial da escola: os Casos

\begin{tabular}{|c|c|}
\hline OPOSICYOES & $\begin{array}{l}\text { - Tipos de escolas: preparatórias, secundárias, liceus, escolas técnicas } \\
\text { - Dimensão das escolas: grandes/pequenas; sobrelotadas/sublotadas } \\
\text { - Envolvimento dos pais/Náo envolvimento }\end{array}$ \\
\hline INSTRUMENTOS & $\begin{array}{l}\text { - Instalaçōes, verbas, equipamento e material didáctico, apoio } \\
\text { central, transportes. } \\
\text { - Colocaçōes, estabilidade dos professores, formação de professores. } \\
\text { - Informação sobre a avaliaçăo do rendimento escolar, Interdisciplinaridade, } \\
\text { aprendizagem dos alunos, relação professor-aluno. } \\
\text { - Interesse dos pais, condiçōes em casa, relação escola-comunidade. }\end{array}$ \\
\hline $\begin{array}{c}\text { ALVO DE } \\
\text { ADMINISTRAÇĀO }\end{array}$ & - Actores especificos: Professores, Alunos, Pais, Empresas \\
\hline PROBLEMATIZAÇĀO & $\begin{array}{l}\text { - Relação entre recrutamento social e niveis de rendimento escolar dos alunos } \\
\text { - Relação entre condiçōes das instalaçóes, material e equipamento e } \\
\text { - Relaçăo entre formação de professores e cumprimento dos objectivos } \\
\text { - Relação entre modo de funcionamento da escola (existência de coordenador } \\
\text { de Unificado, reuniōes, mobilizaçāo dos professores, horários, programação) e } \\
\text { cumprimento dos objectivos }\end{array}$ \\
\hline RECOMENDACCOES & $\begin{array}{l}\text { - Melhoria das instalaçōes, do equipamento e do material didáctico } \\
\text { - Melhoria de formação de professores } \\
\text { - Aumento do apoio financeiro } \\
\text { - Melhoria da informação sobre o ESU }\end{array}$ \\
\hline
\end{tabular}

Uma primeira análise dos quadros permite-nos verificar que os níveis desagregamse em sucessivos pontos de observação, classificados segundo uma grelha com referências geográficas, económicas, sociológicas e estatísticas:

$1^{\circ}$ nível - região: constituída por divisões administrativas distritais.

$2^{\circ}$ nível - zona: constituída por três critérios: escolas rurais, suburbanas e urbanas.

$3^{\circ}$ nível - casos: constituídos por escolas preparatórias, secundárias, liceus e técnicas.

Nas duas décadas que analisamos alterou-se profundamente a localização dos problemas e patologias da escola secundária. De uma visão da escola suportada por um diagnóstico global e por uma intervenção reformadora dirigida ao organismo no seu conjunto, como era o caso da reforma Veiga Simão, passou-se à análise de aspectos particulares do sistema e à problematização de patologias particulares. A nova 
forma de ver é capacitada por instrumentos de análise intensiva como os que foram utilizados na avaliação do Ensino Secundário Unificado.(107) Apesar da ambição sistémica do projecto de avaliação este veio a centrar-se no estudo intensivo de fragmentos do sistema. Se compararmos o capítulo dos «Princípios subjacentes ao ESU» e à «Avaliação da Reforma» com as "Considerações finais» temos uma primeira aproximaçăo a esta dicotomia entre estudo extensivo versus estudos intensivos que se viria a deslocar progressivamente para esta última hipótese de trabalho.

Nos Princípios da Avaliação da Reforma anunciava-se uma intenção extensiva: «o estudo de um sistema educativo inclui a observação de diferentes níveis de análise, quer no que diz respeito a cada um deles separadamente, quer no que se refere às relaçōes entre eles. Assim, se considerarmos, por exemplo, os níveis individual, da aula, institucional e do sistema torna-se essencial verificar como cada um deles funciona e simultaneamente analisar as relaçōes de interdependência» (pp. 127-129). No entanto, as consideraçōes finais de cada relatório, ao rememorarem soluçōes concretas para problemas concretos sugerem bem o olhar fragmentado proporcionado por este estudo de avaliação.

A principal alteraçăo introduzida pelas tecnologias utilizadas no Projecto de Avaliação do Ensino Secundário Unificado é o tamanho da escala em que se propõem regular a acção social. À pequena escala característica do olhar nacional anterior, ainda visível no Ficheiro de estabelecimentos de ensino, acrescenta-se a escala média das regiões e das zonas e a grande escala dos casos. Estes novos pontos de vista têm implicações profundas no modo como os especialistas criam diferentes objectos educativos a partir dos mesmos objectos empíricos. A escala altera os critérios de pertinência, as relações entre factos, o detalhe da descrição, o peso relativo dos factos e das opiniões, a posição relativa dos comportamentos do sistema e o efeito do contexto no seu condicionamento, enfim, o que passa a ser considerado superior e inferior, aquilo de que se fala e aquilo de que não se fala.

Para Boaventura S. Santos (1988: 149-155), a ideia de diferentes escalas de 276 juridicidade tem também implicações nos padrōes de regulação e nos patamares de regulação associados com cada escala de legalidade. Embora a nossa análise se preocupe mais com as diferentes escalas de observação e de problematização dos

(107) Foram realizados dezasseis estudos utilizando diversas metodologias, dando origem a dezasseis relatórios parciais e a um relatório final. A forma como os resultados foram apresentados releva desde logo de uma visăo intensiva do estudo de avaliaçăo. Com efeito, como se reconhece em vários momentos, os estudos de caso năo teriam permitido uma completa visão de conjunto conforme se estabelecia nos objectivos iniciais. 
fenómenos educativos e menos com as escalas de juridicidade, a analogia pode tornar-se fértil. O ponto de entrada da analogia é relativamente simples: as transformações nas tecnologias de observação podem desencadear transformações da experiência educativa, das quais decorrem transformações da sua percepção enquanto fenómeno social e enquanto objecto de regulaçăo. O conhecimento não é apenas local, ele próprio nos (co)loca num espaço próprio que engendra.

Portanto, transformações nos padrões de regulação. E isto porque se estabelecem dois modos contraditórios, embora articulados nos seus efeitos, de imaginar e construir a realidade. As tecnologias de pequena escala, como vimos já em outro capítulo, estabelecem tipos gerais e abstractos, sejam eles pessoas ou objectos: tipologia dos alunos, com referência ao seu número e idade; tipologia dos professores, com referência ao seu número e estatuto; tipologia das escolas, com referência ao seu número e grau de ensino; localização e posição relativa das escolas. Esta forma de observação dos fenómenos estabelece o que podíamos designar por estática do sistema, a partir das suas posições relativas. Perde em detalhe o que ganha em rigor funcional. Fornece a posição jurídica dos sujeitos e a localização geográfica dos objectos, adequando-se a um sistema que precisa de conhecer posiçōes e de fazer distribuiçōes de pessoas e de recursos. O espaço é contado e medido para ser ocupado racionalmente segundo critérios de centro e periferia. Ao contrário, as tecnologias de grande escala tentam descrever detalhadamente os comportamentos e as atitudes, integrando-os no meio envolvente que descrevem em pormenor. Tentam estabelecer especificidades locais e têm dificuldade em generalizar para tipos abstractos. Os indicadores escolhidos para operacionalizar a observação tendem a normalizar-se, mas são plásticos na sua utilização e teoricamente ilimitados na sua extensão: os limites são de ordem metodológica e não substantiva. Esta forma de observação estabelece aquilo que podíamos chamar a dinâmica do sistema a partir dos seus movimentos. Ganha em detalhe o que perde em capacidade de prescrição funcional. Fornece os elementos de base da ocupação do espaço, adequando-se a um sistema que começa a reconhecer o nomadismo dos sujeitos e a imprevisibilidade dos seus comportamentos. $O$ espaço é analisado nos efeitos da sua ocupaçăo, definindo vários centros e várias periferias.

Quando, em 1992, estudei as culturas organizacionais de dois estabelecimentos de ensino secundário (Gomes, 1992), tive ocasião de observar que os modos de representação do macrossistema eram isomórficos com a realidade sociojurídica dominante nessas escolas, definindo muito claramente a posição relativa dos sujeitos face ao Estado e os respectivos padrōes de regulação colectivos. Podemos agora reanalisar tais padrōes de regulação locais do ponto de vista do tamanho da escala. 
Distinguiremos os seguintes padrões de regulação: quanto à gestão da escola e às suas relações com a administração e o contexto social; quanto à posição relativa de professores e alunos.

Padrões de regulação de pequena escala. A pequena escala contribui para manter o status quo de organização da escola, caracterizada pela estabilidade, permanência e controlo do trabalho da escola. Tendo por referência principal os órgãos de gestão, a pequena escala aparece associada a princípios cívicos universais representados por outras instâncias que contêm e ultrapassam os órgãos escolares. Seguindo o princípio das bonecas russas, a equivalência dos seres colectivos que vivificam a escola realiza-se na medida em que se encaixam sucessivamente em espaços maiores, também eles totais, porque representantes de uma vontade geral supra-ordenada. 0 espaço nacional cartografado pela pequena escala coloca os sujeitos no interior de um espaço cívico onde se acede a um estado de grandeza pelo sacríficio de interesses particulares e imediatos, pondo os interesses colectivos adiante dos interesses individuais. Na renúncia ao particularismo funda-se um dos principais padrões de regulação: a representação da vontade colectiva. Esse é o caminho mais curto de passagem de uma posiçāo precária porque constrangedora, para uma posiçăo segura porque protectora. ${ }^{(108)}$ Os direitos e obrigações devem ser criados a partir de um acto no qual se exprima a vontade de todos. Os representantes assim escolhidos devem ter o poder de transformar os interesses de cada um no interesse colectivo, legitimado a partir das formas legais e da eleiçăo. Porém, este suplemento de legitimidade que permite a uns poucos falar em nome do bem comum tem o contraponto no ambiente de controlo que provoca, na recusa dos interesses e objectivos particulares que reclama e na rigidez de acção que propõe.

Quanto às relações entre a escola, a administração e o contexto social, a pequena escala integra cada escola num sistema mais amplo. E ao fazê-lo reconhece que o estabelecimento educativo existe numa periferia que se relaciona com um centro re278 gulador, do qual depende para a satisfação de várias necessidades.

A concepção do professor como funcionário público é adoptada a partir das noções sociojurídicas de dar aulas e dos anos de serviço, i.e., do vínculo de trabalho que os liga ao Estado. O poder de nomeação cívica do Estado sobrepõe-se ao poder

(108) Ver, por todos, a propósito da duplicidade constrangimento/protecçăo dos sistemas burocráticos supra-ordenados, Erhard Friedberg (1993), Le Pouvoir et la Règle. Dynamiques de l'action organisée, Paris: Seuil. 
de investidura da profissão. Socialização organizacional feita de despojamento dos valores e gestos individuais na medida em que o Estado confirma o indivíduo como tendo condiçôes jurídicas e não capacidades para exercer as funções; socialização em série caracterizada pela passagem de testemunho dos mais velhos, a consequência provável é o conservadorismo e uma percepção do trabalho como constrangimento. Assim, dentro da lógica cívica o grupo de pertença saliente é o grupo disciplinar, porque é aí que são mediadas as relações entre indivíduo e estatuto reconhecido, entre particularismo e vontade geral. Trata-se de uma identidade que caracterizamos como defensiva pois exprime uma coesão pela via da coexistência implícita entre indivíduos justapostos, no quadro regulador de uma instituiçăo que ultrapassa a organizaçăo escolar - o sistema educativo. Assim, a autonomia colectiva não é sequer enunciada e a autonomia individual é valorizada apenas quando se consideram os constrangimentos da situação de trabalho.

Padrões de regulação de grande escala. A grande escala, no mapeamento de pormenor que permite, integra a escola numa comunidade imaginada. A evocação da história, da tradiçăo e da terra de origem faz parte do espírito nostálgico que elogia os valores da continuidade e da acumulaçăo de experiências colectivas. A metáfora comunitária contém uma crítica implícita a três características maiores da acção em meio escolar: a ausência de tempo e de disponibilidade para os encontros informais, a descontinuidade da acção devida à renovaçăo constante dos quadros da escola e a dificuldade em constituir uma memória perene devida à pequenez da geração mais antiga perante o crescimento explosivo dos efectivos das escolas.

Do ponto de vista orgânico os estabelecimentos escolares são representados por unidades não articuladas. Assim sendo, a escola está condenada a procurar a construção de uma unidade colectiva tanto no plano estrutural como no plano simbólico. É neste último caso que a representação em grande escala cumpre o seu papel regulador, pondo em relevo as noções de boa vontade, de afectividade, de convivialidade e de bem-estar e entre parênteses o quadro regulamentar.

O tema do espaço é recorrente quando se trata de denunciar os obstáculos à convivialidade comunitária. $\mathrm{O}$ tamanho e a fragmentaçăo espacial das escolas geram o sentimento de isolamento e de anonimato. Pela sua própria estrutura física, os estabelecimentos são representados em blocos. Os espaços assim constituídos são lugares reservados, funcionalmente especializados, colocando cada categoria de actores escolares no seu território específico. A imagem social que resulta desta apropriação diferenciada do espaço, que marca o lugar hierárquico de professores e alunos, engendra atitudes de mal-estar ou encontros artificiais. 
A grande escala, por outro lado, evidencia as obrigações de resultados que pesam sobre os estabelecimentos de ensino. A tecnologia dos casos, a desconcentração e, finalmente, a autonomia engendraram uma dupla influência quanto ao governo do estabelecimento de ensino. A mais visível é a exigência de eficácia que deve ser, tanto quanto possível, medida e controlada a partir de indicadores de resultados fiáveis. A outra consequência revela-se a partir da maior influência que o social, representado pelas categorias encarregados de educação e empresas, tem na configuração dos estabelecimentos de ensino. Por exemplo, os cursos técnico-profissionais surgem como uma exigência de as escolas responderem também ao mercado de trabalho local e às expectativas de famílias e alunos que năo pretendem prosseguir estudos prolongados.

As exigências de maior eficácia têm um impacto organizacional com a utilização de indicadores de desempenho. Algumas escolas integram na sua actividade normal alguns dos indicadores elaborados pelo GEP. Os objectos privilegiados no trabalho da gestão passam a ser as listas, os inventários, as grelhas de avaliação, os gráficos, os inquéritos. A grande escala é também o lugar dos objectos técnicos, dos métodos científicos e dos instrumentos de medida que exigem com cada vez maior frequência o contributo das tecnologias de governo da população elaboradas na regiáo continente ou no campo científico (Gomes, 2000).

A grande escala tende a regular de outro modo a distribuição de recursos. A alocação redistributiva junta-se a perspectiva de captação de recursos próprios no meio. A concepçã́o de fronteira entre a escola e o contexto sofre uma extensão evidente. $O$ meio não se limita a impôr à escola certas variáveis de composição: a estrutura social dos alunos, os recursos tradicionais. Agora, a escola deve tomar a iniciativa, desenvolver projectos, correr riscos. As relaçōes inventam-se em investimentos estratégicos que garantam o desenvolvimento. Porém, este novo modo de regulaçāo é um mundo precário, movente, sem seguranças. Sendo a escola também o resultado da opinião dos outros, e não apenas um efeito do mandato do Estado, é precisamente este carácter não essencialista e de relação que faz frágil e facilmente criticável a sua acçăo. O meio passa a ser segmentado em públicos-alvo que devem ser influenciados até obter a sua mobilização. Algumas escolas estruturam autênticos programas de relaçōes públicas que lhes permitem criar uma imagem pública. Para que as escolas possam aceder realmente ao conhecimento público devem renunciar ao segredo. Para ser conhecido e reconhecido há que aceitar revelar tudo, sem nada esconder. As regras da conivência burocrática são substituídas progressivamente pelas da informação ao meio.

A relação de compreensăo entre a imagem transmitida e o público que a confirma é regulada pelo grau de influência. $\mathrm{O}$ estado de notoriedade é o mundo onde o 
que tem valor é imediatamente conhecido e vísivel e, por isso, motivo de comparação com outras escolas. São estas comparações cruzadas que vão constituíndo uma rede de influências, amplificadora de mensagens que veiculam a informação e fazem eco das posições das escolas. Esta visăo tenta cerzir dois universos até agora separados: a pedagogia da sala de aula e a relaçăo com o meio. Mas o pedagogismo continua a manifestar o carácter limitado da sua apreensão dos fenómenos de grande escala, pelo que tem dificuldade em sobreviver como alternativa sem se socorrer do basismo comunitário. Este é acima de tudo uma forma de ver as regulações dos professores em torno da fusão expressiva, quer dizer, uma espécie de camaradagem entre iguais apoiada na comunicação em redes informais. Mas sendo esta confrontada com a necessidade de uma nova imagem da escola, o conceito de comunidade é facilmente alargado ao conjunto de actores externos até agora afastados da vida da escola. O compromisso realiza-se nessa passagem necessária entre saberes tranversais e recontextualização das práticas a partir do desvio pelo meio. Onde o compromisso tem dificuldade em manter-se é no domínio da relaçăo entre o espaço privado da sala de aula e o espaço público que produz a imagem da escola. Necessitando deste para que o alargamento das didácticas disciplinares aos saberes tranversais se possa fazer, tal deslocamento envolve perdas no etnocentrismo profissional: discutir publicamente a avaliação, partilhar poder com outros actores, concertar estratégias são excessos que năo se devem introduzir. Na expectativa do excesso actua-se por defeito: a comunidade é percebida num primeiro tempo como comunidade dos de dentro, sem partilhas de poder com os de fora.

Teremos ainda que falar das alterações nos patamares de regulação. Santos (1988: 154) designa assim a forma de cada escala de regulação definir «o que pertence à esfera do direito e o que é dela excluído». No nosso estudo, os patamares de regulação estabelecem o que está incluído na esfera de problematizações da governamentalidade e o que é dela excluído. Esta selecção procedimental segrega por si só novos conhecimentos e novos dispositivos de poder. Como se pode verificar no quadro de síntese (quadro 18) existem três dispositivos de poder: o dispositivo da relevância, o dispositivo da distinção e o dispositivo da inclusão. O dispositivo da relevância diz respeito ao grau de pormenor em que a escola é problematizada. Assim se determina o que é relevante e o que é irrelevante no diagnóstico e nas propostas de política educativa. O dispositivo da distinção diz respeito ao grau e tipo de discriminação introduzido pelos meios de diagnóstico e de avaliação. Deste modo é determinado o que sendo da mesma categoria deve ter tratamento igual e o que pertencendo a categorias diferentes deve ter tratamento distinto. O dispositivo da inclusão diz respeito ao juízo de valor que surge associado aos instrumentos de diagnóstico e de intervenção. 
Neste caso, o dispositivo constitui uma porta de vaivém entre a política e a pesquisa, entre a validade científica e a validação normativa, susceptível de distinguir o que se inclui no sistema e o que se exclui.

Se observarmos os três níveis de inserção espacial considerados na avaliação do ESU - regiăo, zona e caso - verificamos que os indicadores utilizados anunciam vários graus de institucionalização do processo educativo, que variam entre a família e a comunidade, o estabelecimento escolar e o sistema educativo formal. Para cada um destes níveis, os dispositivos de relevância/irrelevância, de igualdade/distinção e de inclusão/exclusão operam em patamares de regulação diferentes (ver quadro na pág. seguinte).

O aspecto mais saliente deste quadro diz respeito ao grau extremo de exclusividade de cada patamar de regulaçăo, isto é, a cada patamar de regulaçăo corresponde um nível de problematizaçăo. Podemos verificar também aqui como a oposiçăo clássica entre o segmentário e o centralizado tem pouca pertinência analítica. O Estado năo apenas exerce a sua acção em segmentos que ele próprio cria ou admite, como possui um segmentário próprio. Mais do que opôr o centralizado ao descentralizado, o segmentar ao total, a nossa estratégia analítica segue a pista do grau de intensidade da regulação. Distinguiremos desse modo uma regulação dura de uma regulação mole: no primeiro caso, a segmentação age a partir de um espaço homogéneo de onde retira segmentos classificados segundo as suas propriedades, a sua forma e as consequências previsíveis. O planeamento da rede escolar é um caso típico de regulação dura.

No segundo caso, a regulação mole age a partir de um território que segmenta em acto segundo as suas relações, afectos e capacidades reconheciveis. A adaptação da avaliação dos alunos é uma caso típico de regulação mole. Em síntese, podemos dizer que o Estado estabelece o relevo dos acontecimentos, a escola determina os comportamentos que inclui e a família e as comunidades distinguem as pertenças dos alunos. Em termos simbólicos, a escola parece governar-se a partir de um centro que irradia para a periferia. Nesta regulação dos três niveis de problematização podemos encontrar as premissas de todos os programas de governo da educaçăo nas duas décadas seguintes. Cada problema será tratado por programas que mobilizám conhecimentos da esfera respectiva: os estudos da administração para o sistema educativo; os estudos de psicologia, didáctica e desenvolvimento curricular para a escola; os estudos sociológicos para o contexto social, familiar e do trabalho.

No entanto, dada a heterogeneidade interna dos sistemas educativos, o centrismo simbólico do Estado assume mal o papel de centro na relação com as periferias năo-escolares da sociedade. Daí o acentrismo característico da escola portuguesa que se 
Quadro 18 - Dispositivos de regulaçăo introduzidos em cada nível de problematização

\begin{tabular}{|c|c|c|c|}
\hline \multirow{2}{*}{$\begin{array}{c}\text { NIVEL DE } \\
\text { PROBLEMATIZAÇÃO }\end{array}$} & \multicolumn{3}{|c|}{ DISPOSITIVO DE REGULAÇÃO } \\
\hline & RELEVANCIA & DISTINÇĀO & INCLUSÄO \\
\hline $\begin{array}{l}\text { FAMILIAE } \\
\text { COMUNIDADE }\end{array}$ & 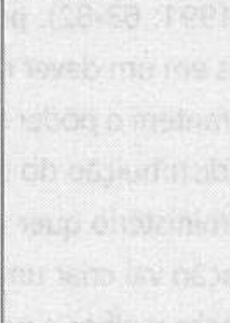 & $\begin{array}{l}\text { - Estatuto } \\
\text { socioeconómico. } \\
\text { - Expectativas quanto } \\
\text { ao prosseguimento } \\
\text { de estudos e } \\
\text { profissáo. } \\
\text { - Estrutura da célula } \\
\text { familiar. } \\
\text { - Estilo cognitivo } \\
\text { (abstracto/concreto). }\end{array}$ & \\
\hline ESCOLA & & & $\begin{array}{l}\text { - Capacidades } \\
\text { individuais } \\
\text { - Rendimento escolar } \\
\text { - Participaçăo nas aulas } \\
\text { - Trabalho do aluno } \\
\text { - Contactos com a } \\
\text { comunidade }\end{array}$ \\
\hline $\begin{array}{l}\text { SISTEMA } \\
\text { EDUCATIVO } \\
\text { (Instituiçăo) }\end{array}$ & $\begin{array}{l}\text { - Condições das } \\
\text { escolas: } \\
\text { instalações, } \\
\text { material didáctico, } \\
\text { salas de aula. } \\
\text { - Colocação de } \\
\text { professores } \\
\text { - Verbas } \\
\text { - Matemática } \\
\text { - Preparação dos } \\
\text { professores } \\
\text { - Gestão escolar }\end{array}$ & & 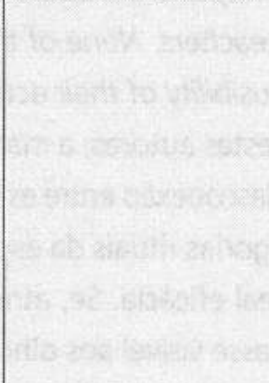 \\
\hline EMPRESA & & $\begin{array}{l}\text { - Ligaçáo à vida } \\
\text { activa } \\
\text { - Ensino abstracto e } \\
\text { teórico } \\
\text { - Qualificação dos } \\
\text { professores } \\
\text { - Via académica / via } \\
\text { profissionalizante }\end{array}$ & \\
\hline
\end{tabular}

traduz em dificuldades crescentes de diferenciação face ao exterior, conquanto os esforços continuados de fragmentar as problematizaçōes e os programas não abrandem as dificuldades de integração no interior de si mesma. Face ao exterior, a escola é facilmente contaminada, por apropriação ou incorporação, pelas problematizações e soluções encontradas por outras instituiçōes, especialmente as agências interna- 
cionais e as empresas. Trata-se, na designaação dos institucionalistas, de uma mudança por isomorfismo mimético (DiMaggio e Powell, 1991). Por seu lado, a heterogeneidade interna resultante da incorporação dos espaços familiar, comunitário, da produçăo e internacional tende a ser compensado pelo acrescento de isomorfismo coercivo e isomorfismo normativo (DiMaggio e Powell, 1991: 63-82): por exemplo, as escolas transformam o direito de participação dos pais em um dever regulamentado e regulado nas associaçōes de pais; os professores garantem o poder normativo na avaliaçāo dos alunos, na organização dos horários e na distribuição do serviço docente, protegendo-se quer do excesso de intervenção do ministério quer das influências locais.

Este défice de diferenciação e de identificaçăo vai criar uma forma muito específica de regulação que aceita a fragmentação para melhor a governar. Nos termos da nossa hipótese de trabalho, podemos interpretar a fragmentaçăo como a desconexão necessária e suficiente ao funcionamento da lógica da confiança (Meyer e Rowan, 1978, 1992: 90): «parties bring to each other the taken-for-granted, good-faith assumption that the other is, in fact, carrying out his or her defined activity. The community and the board have confidence in the superintendent, who has confidence in the teachers. None of these people can say what the other does or produces, but the plausibility of their activity requires that they have confidence in each other». No dizer destes autores, a manutenção da legitimidade das instituições escolares depende da desconexăo entre estruturas, actividades e resultados. É esta cesura que sustenta as categorias rituais da escola, por que deste modo se reduzem as incertezas quanto à sua real eficácia. Se, através da forte conexăo entre estrutura, técnica e resultados se tornasse visivel aos olhos do exterior, com frequência, que os rituais não eram eficazes, então a cadeia de confiança estaria abalada. Para outros autores, a fragmentaçăo cumpre funçōes estrategicamente deliberadas de reforço do poder central do Estado, impedindo a formação de instâncias de coordenação e controlo localizadas a nível periférico (Formosinho, 1987). Como veremos, a nossa análise, centrada que está nas racionalidades e tecnologias de problematização e não nas estruturas e regras organizacionais, permite ver melhor o fenómeno da desconexão do lado da regulaçăo. E visto deste lado, a oposição centro-periferia perde saliência em detrimento da oposição molar-molecular: à maneira de Foucault, os mecanismos miniaturizados da microfísica do poder que se exercem no detalhe e no infinitamente pequeno, compõem um diagrama final de regulação, coextensivo a todo o campo social e à multiplicidade de indivíduos a regular.

De que classificações rituais do sistema educativo falamos e onde se joga a sua regulação? No patamar da relevância jogam-se as classificações que definem uma regulação dura: determinação das credenciais, categorias e concursos de colocação 
de professores; elaboração das regras formais de classificação dos alunos por grau, nível, área ou condiçōes especiais; definição da tipologia das escolas; elaboração dos programas de estudos e dos objectivos; alocação de construções escolares, verbas e recursos escolares. Neste patamar é o isomorfismo coercivo que domina as mudanças: é o Estado que estabelece por intermédio da força, da injunção, da influência ou da persuasão o envolvimento legal, a padronização de valores e de normas e a alocação de recursos necessários à aceitabilidade da escola. É neste patamar que se dá a regulaçăo da contradiçăo entre a rigidez relativa dos direitos e a incapacidade financeira, momentânea ou persistente, de os concretizar. Em geral, a regulação desta contradição resulta numa lógica de expansão do Estado, em especial da tecno-estrutura necessária ao estabelecimento de estudos de prioridades e de planeamento de recursos. Destina-se esta tecno-estrutura à contençăo da lógica amplificadora dos direitos, segundo a qual a concessão de uns tende a criar necessidades que resultam em exigências de outros direitos. Como observa B. S. Santos (1990: 204), a crise do Estado-Providência deriva do acréscimo de legitimidade procurado pelo Estado quando concede novos direitos sociais que, progressivamente, se desvinculam da situaçăo financeira que os permitiu: «ao transformar condições económicas factualmente favoráveis em direitos, o Estado assume um compromisso de não alterar o padrão distribucional uma vez estabelecido. Qualquer deterioração deste padrão e a consequente limitação ou eliminação dos direitos sociais tendem a ser vistas como ataques injustos a uma posição social conseguida».

No patamar da diferenciação jogam-se as classificações sociais que determinam regulações de média intensidade. Mais concretamente, nas problematizaçốes da família: classificaçōes de estatuto social, cultural e económico; estrutura familiar; expectativas sociais. Nas problematizações das empresas: ligação à vida activa; fronteiras entre a via académica e a via profissionalizante; preparação dos professores; características abstractas e teóricas do ensino. Neste patamar é o isomorfismo mimético que domina as mudanças. É o esforço das famílias e dos alunos para se modelarem a um novo modo de integração social «fundado na concorrência entre agentes e grupos familiares» (Grácio, 1986: 132-138) que consolida a crença na possibilidade de ascensão social através do diploma. É a exigência das empresas no sentido de o sistema educativo se planificar em função das necessidades da «vida activa» e do «mercado de trabalho», reconhecidamente difícil ou improvável, que, ao criar uma falha permanente na escola, tem por consequência uma compensação simbólica decisiva, traduzida em maior inculcação de valores positivos perante o trabalho e a organizaçăo da produção. É este patamar de regulação que demonstra mais evidentemente que «as contradições a um dado nivel são congruências a um outro, a eclosão ou o 
agravamento das crises num dado subsistema pode ser compensada pela eliminação ou atenuação das crises noutro sistema» (Santos, 1994: 167).

No patamar da inclusão jogam-se as classificaçōes corporativas e profissionais dos professores que determinam regulações moles: avaliação do rendimento escolar; relaçăo com os alunos; técnicas pedagógicas; orientaçōes curriculares; métodos de trabalho e de estudo; forma e intensidade dos contactos com os pais. Neste patamar é o isomorfismo normativo que domina as mudanças. O esforço individual e colectivo dos professores para estabelecerem as condiçōes e os métodos do seu trabalho, bem como a base cognitiva da sua autonomia profissional é a principal fonte normativa. A adesão ao estatuto de funcionário público constitui um dos mecanismos de redução da diferenciação e de criação do mito homogeneizador da profissão e das escolas. Mas, em certas circunstâncias, a dependência em relação às regras centralizadas permite a formaçăo de um cordão protector contra toda a exigência, do ministério ou do contexto próximo, que nāo corresponda às disposiçōes normativas. A capacidade para resolver problemas e situações de trabalho contingentes constitui o mecanismo de regulação que normaliza pela diferenciação de papéis e diversificaçăo de funções. A base cognitiva da estandardização do trabalho aumenta o papel dos especialistas universitários e do associativismo profissional na invençăo de novos modelos de intervenção que se difundem com rapidez. Referimo-nos aqui ao papel da abordagem sistémica e das metodologias de investigação-acção no desenvolvimento das correntes favoráveis à inovação local e às pequenas reformas que tratámos noutro texto com maior detalhe (Gomes, 1999b).

Estes três patamares de regulaçăo demonstram em si mesmos a desconexão do campo educativo, mas estão presentes em proporções variáveis nos seus diferentes niveis. Dissemelhantes quanto à natureza e premissas, são inseparáveis e imbricados nos processos e resultados. Por isso devemos evitar quatro vieses de apreciação muito comuns quando se opõe centro e periferia, centralizaçăo e autonomia. O primeiro viés consiste no juízo de valor que associa à periferia e à regulação mole um valor positivo, como se a flexibilidade fosse em si um valor ético e não uma tecnologia de governo. O segundo consiste na confusão entre dimensões e aplicabilidade do conhecimento gerado em cada patamar, como se a regulação molecular não pudesse agir na regulação molar e esta na molecular. Em geral, o viés limita as possibilidades de regulação mole por parte do macrossistema e de regulação dura no microssistema, realidade que não tem tido validação empírica. Parece haver sempre uma relação proporcional entre as duas. O terceiro viés é do tipo psicológico e consiste em remeter a observaçăo do subjectivo e do individual para a regulação mole e a observação do real para a regulação dura, como se as estruturas representassem a realidade 
objectiva e a subjectividade representasse a inventividade e a imaginação. Nenhuma estratégia pode garantir efeitos globais se não se apoiar em relações precisas e subtis que lhe sirvam de ponto de aplicação. Entre o ponto de aplicaçăo, que năo deve confundir-se com o nível microscópico, e a estratégia de conjunto, que não deve confundir-se com o nível macroscópico, não há nem descontinuidade nem homogeneidade, mas dupla articulação. Assim, o professor não é na escola um simples representante do Estado; e este não se assemelha na sua acção educativa a uma projecção aumentada do professor. No entanto, o dispositivo profissional, naquilo que tem de insular, pormenorizado e heterodoxo, serve de suporte aos movimentos reformistas que vimos analisando; assim como o dispositivo técnico-administrativo posto em campo pelo ministério, naquilo que tem de global e isomorfo, incorpora no sistema um conjunto de indicadores e de subjectividades ainda não experimentadas. 0 que demonstra afinal que a fragmentação extrema não é incompatível com a centralização. A administração da lógica da confiança molar tem por correlato a gestão em detalhe das falhas, dos riscos e da incerteza molecular, ou, como referem Deleuze e Guattari (1980, 1997: 263), existe uma complementaridade entre a macropolítica da segurança e a micropolítica da insegurança.

A análise que se segue pretende demonstrar como as problematizações de governo da educação nos diferentes patamares de regulação podem constituir um novo vocabulário.

\section{Um novo vocabulário}

Pela primeira vez, o Projecto de avaliação do ESU, ao permitir estabelecer comparações entre a origem social, o rendimento escolar e as trajectórias escolares, transforma variáveis já utilizadas em estudos internacionais em um objecto estatístico e de governo da educaçăo em Portugal. Se bem que este estudo não tenha tido repercussões imediatas nas políticas da administração, é nele que se pode encontrar o vocabulário essencial para a compreensão do que virá a seguir. A principal característica deste vocabulário é o seu carácter binário. Como em tantas outras coisas, a administração segue o personagem mítico Janus: dotado de uma sagacidade invulgar conseguia presentificar a seus olhos passado e futuro e daí a sua representação bifronte. Utilizado em ciências sociais para caracterizar os sistemas sociais, consegue tornar igualmente operantes ideias contraditórias. Janus é a metáfora ideal para uma administração que estabelece categorizações linguísticas como tecnologia de governo da educação. 
Para obter o conjunto de dicotomias inscritas nos Relatórios de avaliaçăo procedemos a uma análise de conteúdo da totalidade das variáveis e indicadores construídos a priori para os questionários administrados a alunos, professores e Conselhos Directivos ou resultantes da análise a posteriori das entrevistas realizadas a encarregados de educação, empresas e Conselhos Directivos no quadro do PAESU. Do ponto de vista metodológico caracterizamos este procedimento como uma análise de segunda ordem de dados descritivos colhidos com outros objectivos. Este procedimento torna-se essencial quando se quer pensar as condições de formação das evidências inscritas no pensamento silencioso do sistema que, não raras vezes, se tornam evidências do próprio investigador.

O corpus ficou composto por várias centenas de variáveis e de indicadores que foram sujeitos, posteriormente, a uma sistematização segundo dois critérios: um critério que estabelece qual o actor ou actores alvo da variável ou indicador e um segundo critério que identifica quais as disciplinas científicas ou as áreas de referência que as suportam. Finalmente, seleccionámos apenas as variáveis ou indicadores que deram origem à elaboração de binários linguísticos. $\mathrm{O}$ quadro seguinte dá conta dos resultados obtidos (quadro 19).

Quanto à utilização do primeiro critério, os resultados encontrados provêm da referência directa ou indirecta aos sujeitos inquiridos: alunos, professores e encarregados de educação são os actores principais, entendidos aqui enquanto entidades abstractas. As categorias dicotómicas de que falamos dirigem-se ao aluno, ao professor e ao encarregado de educação como agregados estatísticos e não à subjectividade de um indivíduo concreto, embora o nível agregado constitua uma subjectividade monumental que contribui para o estabelecimento de subjectividades individuais com um certo grau de homogeneidade.

Quanto à utilizaçăo do segundo critério, as quatro áreas científicas referidas psicologia, sociologia, desenvolvimento curricular e pedagogia (métodos pedagógicos) - resultam menos da sua inscrição explícita nos textos analisados, que é muito rara, do que do exercício lógico extremo de integração de certos temas em disciplinas que tradicionalmente os tratam ou que os tratarão no futuro. Porém, porque este Projecto de investigação finalizada é, simultaneamente, um campo de aplicaçăo de conhecimentos disciplinares reconhecíveis e estabilizados e um campo de problematizaçōes que exige a produçăo de saberes híbridos, apenas o desenvolvimento futuro destes no campo das ciências da educaçăo lhes darăo maior visibilidade. Neste sentido, a argumentação produzida não dispensa referências ao desenvolvimento posterior de estudos nas respectivas áreas, tornando assim mais notória a lógica do esquema encontrado. 
Quadro 19 - Binários linguísticos inscritos nas entrevistas e nos questionários administrados durante a avaliaçăo do Ensino Secundário Unificado

\begin{tabular}{|c|c|c|c|}
\hline REFERENCIA & ALUNO & PROFESSOR & $\begin{array}{l}\text { ENCARREGADO } \\
\text { DE EDUCAÇÃO }\end{array}$ \\
\hline PSICOLOGIA & $\begin{array}{l}\text { - Com dificuldades } \\
\text { intelectuais/ } \\
\text { sem dificuldades } \\
\text { intelectuais } \\
\text { - Aluno normaV } \\
\text { aluno-problema } \\
\text { - Aspiraçóes altas/ } \\
\text { aspiraçőes baixas } \\
\text { - Capacidade/incapacidade } \\
\text { - Criativo/năo criativo } \\
\text { - Auto-estima/baixa-estima } \\
\text { - Auto-confiança/ } \\
\text { baixa-confiança }\end{array}$ & $\begin{array}{l}\text { - Motivado/desmotivado } \\
\text { - Boa relaçăo/má relaçăo }\end{array}$ & $\begin{array}{l}\text { - Intelectual/concreto } \\
\text { - Geral/vivenciado }\end{array}$ \\
\hline SOCIOLOGIA & $\begin{array}{l}\text { - Sucesso/insucesso } \\
\text { - Mais favorecido/ } \\
\text { menos favorecido } \\
\text { - Prática/teoria } \\
\text { - Pensamento/acção }\end{array}$ & $\begin{array}{l}\text { - Preocupado/ } \\
\text { năo preocupado }\end{array}$ & $\begin{array}{l}\text { - Participa/não participa } \\
\text { - Envolvido/ } \\
\text { não envolvido } \\
\text { - Responsabilidade/ } \\
\text { irresponsabilidade } \\
\text { - Colaborador/ } \\
\text { não colaborador }\end{array}$ \\
\hline $\begin{array}{l}\text { TECNICAS } \\
\text { PEDAGOGICAS }\end{array}$ & $\begin{array}{l}\text { - Participação/ } \\
\text { náo participação } \\
\text { - Responsabilidade/ } \\
\text { irresponsabilidade } \\
\text { - Cooperaçáo/egocentrismo } \\
\text { - Disciplinado/indisciplinado } \\
\text { - Interessado/năo interessado }\end{array}$ & $\begin{array}{l}\text { - Preparado/não preparado } \\
\text { - Com formação/ } \\
\text { sem formação }\end{array}$ & $\begin{array}{l}\text { - Comunical } \\
\text { não comunica } \\
\text { - Interesse/não interesse }\end{array}$ \\
\hline $\begin{array}{l}\text { DESENVOLVIMENTO } \\
\text { CURRICULAR }\end{array}$ & $\begin{array}{l}\text { - Aquisiçăo/não aquisição } \\
\text { - Aplicaçăo/náo aplicação } \\
\text { - Progressáo/náo progressăo } \\
\text { - Competências básicas/ } \\
\text { competências máximas }\end{array}$ & $\begin{array}{l}\text { - Formação científica/ } \\
\text { formação pedagógica } \\
\text { - Cumprimento do } \\
\text { Programa/ } \\
\text { não cumprimento } \\
\text { - Disciplinar/ } \\
\text { interdisciplinar }\end{array}$ & \\
\hline
\end{tabular}

\section{Os alunos e a ênfase na Psicologia e nas técnicas pedagógicas}

Uma das oposições mais saliente diz respeito às dificuldades intelectuais. Esta oposição não resulta de uma qualquer validação científica do pressuposto segundo o qual as capacidades intelectuais estão desigualmente distribuídas no plano biológico. A contrario, em várias ocasiōes dos Relatórios de Avaliação do Ensino Secundário Unificado se sublinha e desvaloriza tal representação de senso comum de alguns gru- 
pos sociais. É enquanto falsa representação que a opinião dos pais é introduzida no espaço técnico-moral de problematizaçăo das capacidades humanas: «a aceitação da distribuição diferenciada das capacidades por parte dos Encarregados de Educaçăo torna plausível, cientificamente, a diferenciação social, o imobilismo do tecido social e a consequente discriminação daí resultante. Para os Encarregados de educaçăo dos escalōes mais favorecidos (A e B1), a aceitação da distribuição inata das diferentes capacidades intelectuais pareceu ser axiomática, na medida em que, em função de um dado contexto socioeconómico e cultural os seus educandos na generalidade alcançam o sucesso escolar. Para os dos escalōes mais desfavorecidos (B2 e C), a aceitação da diferenciação iliba a estrutura social e institucional da Escola de qualquer responsabilidade no insucesso escolar, remetendo-a exclusivamente para o aluno. A imobilidade social e a consequente discriminação surgem como resultado não controlável de uma situação inata» (A caminho duma Reforma do Ensino Secundário Unificado. Relatório Final, p. 270).

O enunciado do problema insere-se evidentemente na crítica de algumas correntes às teorias que justificam a desigualdade de resultados como um efeito directo dos dons naturais da cada um, em especial do respectivo QI. Mas este é apenas um fragmento da crítica. A análise fica sempre a meio caminho e nunca tira consequências quanto à escola. Pelo contrário, as explicações do baixo rendimento escolar, dos abandonos e do insucesso centram-se na família e no meio social dos alunos. Trata-se do desenvolvimento de uma teoria implícita que ficou conhecida como teoria do handicap sócio-cultural. Para alguns, a origem deste senso comum estaria nos autores das teorias da reprodução. Para outros, uma sociologia por autores, desinserida da realidade social e profissional, provocaria justificaçōes fatalistas e novos bloqueios profissionais (Benavente, 1989: 95-106). Entre os autores que desenvolveram estudos sobre esta problemática, Bourdieu foi um dos mais veementes na apresentação do argumento segundo a qual a escola, por intermédio dos seus critérios de sucesso meritocráticos, num contexto de acesso formalmente igualitário, cria a aparência de uma diferenciação de resultados devida aos dons: «crer que, quando damos os mesmos meios económicos a todos aqueles que têm os 'dons' indispensáveis, estamos a dar a todos iguais oportunidades de acesso ao ensino mais elevado e à cultura superior, é ficarmos a meio caminho da análise dos obstáculos e ignorar que as aptidões medidas com o critério escolar resultam, não tanto de quaisquer 'dons' naturais (que serão sempre hipotéticos enquanto pudermos atribuir a desigualdade escolar a outras causas), mas da maior ou menor afinidade entre os hábitos culturais de uma classe, as exigências do sistema de ensino e os critérios que ai definem o sucesso» (Bourdieu e Passeron, 1964, 1981: 91). 
A extensa citação justifica-se porque ela revela que a origem das teorias do handicap sócio-cultural não se encontra tanto nos autores das ideias, quanto no conjunto de relações incorporadas em práticas discursivas, situadas, entre outras regiōes, na própria administraçăo. Para o conjunto de relatórios, a elevação das aspirações quanto ao prosseguimento de estudos e à profissão futura dos «grupos desfavorecidos» seria uma das condiçôes para o cumprimento do princípio da democratização. A elevação das aspiraçôes é, aliás, um dos resultados mais notórios da pesquisa. Contrariamente às expectativas da equipa de avaliação, todos os grupos de estatuto socioeconómico aspiram a níveis de escolaridade e de estatuto profissional superiores ao do seu grupo de origem (A caminho duma Reforma do Ensino Secundário Unificado. Relatório Final, pp. 504-509). Esta é uma fonte privilegiada da crença numa escola capaz de desenvolver as capacidades de cada um e de todos. A acumulação de resultados sobre as aspiraçôes é usada para mostrar que o anterior sistema de duas fileiras de ensino deixava de fora uma vasta reserva de talentos (Idem, Ibidem, p.376). Ao deslocar a observação das capacidades para o universo psicológico das aspiraçōes, tal problematização tornou possível que a atitude subjectiva fosse separada dos resultados escolares medidos pelos meios académicos. Esta capacidade técnica de desconectar factos e atitudes, realidades e desejos, fins ideais e resultados possiveis, mostrar-se-á crucial à demonstração, simultânea, das falhas da escola secundária e da possibilidade de construir uma escola inclusiva capaz de se relacionar com alunos possuidores de uma grande variedade de talentos.

As análises da unificação do ensino secundário enviesam com frequência as suas apreciações quando avaliam esta reforma a partir do maior ou menor grau de cumprimento de um direito universal conquistado, quando a unificação é antes de tudo um dever, uma injunção da administração destinada à produção de uma relaçăo diferente entre o Estado, as famílias e o mercado. Relação que se caracteriza por uma nova capacidade de o Estado integrar durante mais tempo grupos sociais que anteriormente se deslocavam para outros espaços estruturais e simbólicos; pela relação diferente que institui com a família, utilizando a energia dos desejos privados no espaço público, pedagógico, criado pelas associações de pais. Neste sentido, as técnicas, os dispositivos e as tácticas destinadas a captar e a tornar visíveis as desigualdades supervenientes no sistema são o meio por excelência de garantir a intervenção permanente do conhecimento burocrático da administração. A legitimaçăo realiza-se neste caso por força da capacidade de diagnosticar, problematizar e intervir continuamente nas falhas do sistema e não pela probabilidade de cumprir um certo mandato ideológico ou moral. Não foram as filosofias inclusivas que deram origem às técnicas pedagógicas inclusivas, mas, pelo contrário, as técnicas destinadas ao diagnóstico da 
parcela que havia sido segregada que revelaram os limites das medidas escolares e assim demonstraram o bem-fundado da opção pela unificação.

Todas as oposiçōes relativas aos alunos estão destinadas a um trabalho de unificaçăo. Não por acaso, o conceito reformador que estabelece a ponte entre oposições é o de unificação. Considerado um dos objectivos centrais da reforma, deve contrariar a fragmentação esperada do espaço de intervençăo das políticas educativas: «do que foi possível auscultar junto dos professores dos três anos de escolaridade que constituem o Ensino Secundário Unificado, verificou-se que a maioria estava de acordo com a adequação dos programas ao trabalho interdisciplinar. Contudo, perto de trinta por cento dos professores do $7 .^{\circ}$ ano (1976/77), para ambas as regiōes, năo concordaram com tal opinião apontando diferentes razões que contribuiram para o năo exercício de tal tarefa. Poder-se-ăo encontrar, entre outras, o desfasamento de programas e de horários, desmotivação dos professores e ainda as más condições físicas da escola» (Idem, Ibidem, pp. 436-437)

O trabalho de unificação do vocabulário é empreendido por intermédio de duas noçōes políticas tácitas: a crise e a falha. O fim do Estado Novo abalou as evidências e os fundamentos construídos durante décadas. Tais evidências tinham sido já questionadas no sistema educativo por movimentos estudantis e de professores. Mas a partir do derrube da ditadura surge a consciência pública alargada de que tudo se pode transformar em problema, que tudo pode ser negado, que tudo deve ser justificado. Os movimentos sociais manifestam que os de baixo já não querem viver como dantes, enquanto a paralisação momentânea do Estado revela que os de cima já não podem mandar como dantes. Esta crise revolucionária seria caracterizada por Boaventura S. Santos (1984) como um Estado dual, que põe lado a lado estruturas e práticas administrativas tradicionais, embora paralisadas, e movimentos instituintes que impōem por fora e por dentro do Estado novas estruturas e novas práticas. 0 diferendo toma conta da experiência educativa: divisão, conflito, separação, para alguns o caos, a crise e a anarquia. Muitos dos instrumentos tradicionais de regulação escolar são contestados. No ensino secundário são fortemente questionados os processos de avaliação tradicionais, os dispositivos de controlo administrativo das escolas, os programas das disciplinas, a ênfase no lado abstracto ou ideológico do ensino, a educação segregada e, em geral, a assimetria nas relações de poder.

A experiência de problematização dos de baixo inaugura um excesso. Não o excesso de palavras mas o excesso de acontecimentos. Ao contrário de alguns autores que encontram na tomada da palavra o sinal de que grande parte dos acontecimentos se jogou nos actos locutórios (ver Lima, 1992: 217-218), em nossa opinião o diferendo está marcado por uma exuberância da palavra que esconde o sentimento 
de dor que a não deixa pôr em frases programáticas, em novos idiomas que tornassem a imaginação de possíveis em possiveis da imaginação. Lyotard propõe a noção de diferendo para pensar esta irredutibilidade entre excesso de acontecimentos e défice de palavras: é o estado instável e o instante da linguagem onde alguma coisa que devia poder ser posta em frases não o pode ser ainda. Esse estado comporta o silêncio, que é uma frase negativa, mas faz apelo também a frases possiveis em princípio (Lyotard, 1983: 29). O motivo do diferendo reside na ausência de regras de juízo comuns, de um idioma em que a argumentação seja possível, o que obriga ao trabalho de invenção de um novo vocabulário. Porém, a falta de um horizonte comum impossibilita a simples apresentação de fundamentos outros que năo os experienciais. Os ideais, enquanto narrativas totalizantes, apenas acederiam ao universalismo por força da invocação daquilo a que Geertz (1973: 173) chamava os diagramas da realidade: factos nomeados por normas, cuja invocação automática esteriliza os factos. Ora, no período analisado, estamos em plena expansăo dos factos e na consequente crise normativa que desconecta e desarticula palavras e acontecimentos.

As problematizações de governo procuram um novo relacionamento entre as palavras e as coisas, entre significado e significante. Nalguns casos as iniciativas substituem-se às problematizações, ou aceitam-se problematizações não formalizadas para introduzir idiomas comuns. É o caso da criação das disciplinas de Educação Cívica Politécnica e de Ciências Sociais, durante a unificaçăo do ensino secundário. ${ }^{(109)}$

(109) A disciplina de Educaçăo Cívica Politécnica foi introduzida no lançamento do $7 .^{\circ}$ ano de escolaridade do Ensino Secundário Unificado e consistia numa proposta interdisciplinar. Descrevia-a assim Rui Grácio (1995: 501-502), o seu principal criador e defensor: «é um espaço, no tempo de uma manhã ou de uma tarde, especialmente propício a reforçar a função social da escola, a sua articulação aos problemas da comunidade local e regional. Representantes das instituiçōes comunitárias deverão ser chamados a cooperar com a escola no planeamento, execuçăo e acompanhamento do programa de acções, cujos objectivos gerais estão fixados pelas autoridades educativas centrais (...) Não há um programa prévio, sequer um programa mínimo nacional, definido para aquela área curricular: apenas a fixação de objectivos e, quando muito, e a título de sugestão, um rol de actividades possíveis. O que se pretende é a criação do programa anual a partir da escola/comunidade de maneira a canalizar a força de acção dos jovens para o conhecimento dos problemas dessa mesma comunidade, busca das suas soluçōes e execução de tarefas de carácter socialn. O que se apresenta nesta primeira proposta de disciplina sem programa é a possibilidade de introduzir um idioma comum a partir de conteúdos e contextos muito diversos (cf. a este propósito A. M. Bettencourt, 1979, Educaçăo Cívica Politécnica: uma inovaçăo? Raiz e Utopia (9-10), pp. 271-276, um dos poucos trabalhos descritivos e analíticos sobre a disciplina). Neste sentido, tratava-se de um espaço curricular aberto à problematizaçāo, mais tarde descrito como espaço curricular nāo disciplinar. O idioma comum consubstanciava-se nos objectivos da disciplina: consciencialização do valor da conjugaçăo de esforços e da integração do trabalho individual na produção colectiva; habituação no partilhar de tarefas e união entre o estudo intelectual e o trabalho prático. $\mathrm{O}$ que se pretende deste modo é conciliar as duas componentes - social e económica - que visavam articular alguns aspectos da aprendizagem 
É na procura de remédio para esta cesura que encontramos a matriz das tecnologias das experiências e das acçōes humanas. A nomeação, ordenação e hierarquização que a palavra pressupóe é um processo que se expande para além da esfera do Estado, alargando-o a programas de todo o género, desde o diagnóstico, ao planeamento $e$ às mundividências que lhe organizam o sentido. Em síntese, podemos dizer que as tecnologias de problematização permitem a codificação da crise. Codificação que é simultaneamente domesticação e capacidade de dominar o real, produzindo uma realidade estruturada em falha. Toda a positividade das problematizações da governamentalidade se funda numa equaçăo entre os possiveis e o existente. Em retórica política esta equação traduz-se nas fórmulas não se pode realizar tudo e ao mesmo tempo e não podemos submeter-nos ao que existe. A linguagem binária é a que melhor expressa esta tensăo que torna a falha manifesta para a poder normalizar. A capacidade de integrar o que é tipificado como disfuncional passa a fazer parte das funçōes do sistema: "com a explosāo escolar que tem a sua origem na democratização do ensino, resultante da criação do Ciclo Preparatório gratuito e obrigatório, os níveis imediatamente superiores năo conseguem dar resposta ao aumento progressivo da população escolar, facto que se vai agravando com dois factores: a criação da reforma do Ensino Unificado e o regresso da população em idade escolar das antigas colónias. E assim os factores negativos, que anteriormente constituiam disfunções do sistema, săo hoje funçōes deste, na medida em que, apesar da sua 'anormalidade' têm hoje de ser encarados como normais. Isto é, deverăo ser tomados em consideração em toda e qualquer situaçăo de Reforma do Sistema Educativo, uma vez que dificilmente podem ser anulados a curto ou a médio prazo. De forma alguma se podem atribuir à Reforma. Esta apenas contribuiu para os pôr em evidência com maior relevância» (Ensino Secundário Unificado. Relatório de avaliação do 9. ano de escolaridade de 1978/79. Inquérito a Conselhos Directivos, p. 124).

escolar no trabalho produtivo. Aprendizagem defendida, aliás, por diversos quadrantes político-ideológicos, embora cada um deles enfatizando uma das componentes da equação: a esquerda defendendo a componente social-igualitária; a direita e a esquerda social-democrata defendendo a componente económica e de formaçăo de capital humano. Em qualquer dos casos, a iniciativa política sempre se adiantou às problematizaçōes impedindo a criaçẫo imediata de uma plataforma discursiva comum. Com efeito, logo que as condiçōes políticas se alteraram, o ministro Cardia suspendeu a disciplina de Educação Cívica Politécnica com o despacho $n .^{\circ} 268 / 76$ de 26 de Agosto, pondo fim a uma experiência que, mais tarde, regressará sobre outras versões domesticadas pelas sucessivas problematizaçōes. Referimo-nos às disciplinas de Educação Cívica e de Desenvolvimento Pessoal e Social que continuam a filiar a sua separação nas duas componentes originais: uma politica, que acentua a educaçāo para a cidadania; outra sócio-moral que acentua a articulaçăo entre as tecnologias do self e o governo do social. 
Todos os estudos de avaliação sobre as desigualdades educativas que se seguirão, no quadro da administração do sistema educativo, não farão mais do que confirmar o sucesso do seu objectivo. Com efeito, as estatísticas, embora sublinhem a manutenção de desigualdades, confirmam o exercício do poder das tecnologias administrativas, capazes que são de pôr no espaço único do planeamento burocrático aquilo que corresponde à fractura mais persistente das sociedades contemporâneas: a formação de diferentes classes sociais no contexto do trabalho e da produçăo. $\mathrm{Na}$ nossa análise, o sucesso destes estudos não se mede pelo grau de cumprimento da igualdade, coisa que as estatísticas não revelam, mas antes pela capacidade que têm de reprogramar em larga escala as problematizaçōes de governo e de refazer o regime de verdade sobre o domínio educativo. Doravante, o sistema educativo português iria incorporar novas oposiçōes nas suas categorias administrativas: urbano/rural, sucesso/insucesso, pais envolvidos/pais não envolvidos, alunos favorecidos/alunos menos favorecidos, professores motivados/professores não motivados, aluno normal/aluno-problema, igualdade/diversidade, etc.. Tais oposiçōes estabelecem um regime de poder a partir do dispositivo de presença/ausência de certos atributos, sendo a ausência definida pela incapacidade momentânea de certos grupos sociais em risco ou de certos alunos com problemas se integrarem completamente no sistema ou de este os integrar. Em qualquer dos casos, a oposiçăo provém da mesma episteme que, ao estabelecer um espaço moral comum, constrói relaçōes duplas. Popkewitz (1998) utliza a noçăo doublets para designar esta construção de oposições normativas que, simultaneamente, colocam certos alunos no limbo da normalidade e procuram caminhos positivos para a sua salvação: «to save children from the conditions of their urban and rural lives, the negative, oppositional poles of 'reason' are made into principles of a 'relevant' and successful teaching» (p. 41)

O dispositivo da presença/ausência de atributos classifica o que falta a uma criança ou a um grupo de crianças socialmente tipificado. Mas, ao contrário do que um certo discurso crítico pouco avisado fez crer, não está animado por um intrínseco mandato de exclusão social. Embora os sistemas educativos incorporem dispositivos de coacção que previnem distúrbios e provocam exclusão não é desses que nos ocupamos aqui. Essas são noções negativas de poder que pretendem prevenir ou punir acçōes. Em qualquer caso, a coacçẫo é um dispositivo residual na exclusăo escolar; pelo contrário, a escola apresenta de forma tácita ou explícita um conjunto de prescriçōes que visam tornar as carências em potencialidades. É no investimento positivo e produtivo de conhecimentos que orientem as acções e reflexões sobre o ensino que podemos encontrar o principal mecanismo de inclusão/exclusão. A noção de população escolar inscrita nas técnicas estatísticas usadas nesta avaliação garante a 
normalização de cada indivíduo tendo em conta os respectivos agregados estatísticos. Do mesmo lance, tendo em consideração as características dos agregados, estabelece automaticamente o tipo de supervisão necessária a uma remediação ou ao desenvolvimento de cada indivíduo: «populational characteristics function as causal associations between a statistical grouping of people and the attributs of particular children, even though, strictly speaking, statistical predicyions no bearing (no predictive power) on individuals». (Popkewitz, 1998: 45-46)

$\mathrm{O}$ que estas estatísticas realmente pretendem medir é o intervalo entre as diferenças de estatuto socioeconómico e a utilização óptima da formaçăo social escolar, não o intervalo que separa cada grupo social de um qualquer direito absoluto ao integral desenvolvimento das capacidades de cada um. A principal conclusão da avaliação é relativamente simples. Na escola estão muitos alunos que não deviam lá estar, porque destinados a estudos que a escola ainda não proporciona, mas há também muitos que năo estando, lá deveriam estar. A pedagogia e as ciências da educaçăo săo interpeladas nestes vinte anos por esta constatação que, simultaneamente, as implica na problematização da igualdade de oportunidades no currículo e na sala de aula. As pedagogias da diversidade, do ensino individualizado e do ensino integrado não são mais do que a expressão desta dicotomia administrativa. Neste sentido, e apenas neste sentido, as estatísticas sobre as desigualdades sociais face à educaçăo são uma mera tecnologia de governo da educação com repercussões evidentes na negociaçăo entre igualdade e diversidade. Elas manifestam antes de tudo a capacidade de a administração dar nome e existência aos problemas que pretende governar e não a representação do fenómeno-em-si.

Concordamos neste ponto com a intuição de Hunter (1994: 111), segundo a qual "the yardstick for this measurement and problematisation was not the principle that 'all men are created equal'». Com efeito o que parece estar em causa é a contribuiçăo que a reserva de talentos, constituída pelos alunos de grupos sociais até entăo afastados da escola, pode dar à prosperidade económica e à harmonia social. As intençổes de governo mais eficaz da população estão presentes em todos os Relatórios, pelo que nos limitamos a respigar um dos mais significativos: «uma sociedade industrial não é um meio onde seja fácil viver. Existem várias regras e acordos que os indivíduos têm de seguir, não só como profissionais mas como cidadãos. Num país com um sistema escolar estreito onde só talvez $25 \%$ das crianças obtenha uma educação completa, existem sempre muitos indivíduos que não conseguem cumprir os seus deveres de cidadãos nem defender os seus direitos. Por outro lado, não existem suficientes profissionais especializados. Na realidade, esta situação é bastante dispendiosa para qualquer país e também um impedimento para a expansão industrial (...) No nosso país, presentemente, é provável que metade da população não 
consiga obter educação escolar suficiente a permitir-lhes ser bons cidadãos e profissionais competentes» (Ensino Secundário Unificado. A aprendizagem da Matemática em 1977/78, 7. ${ }^{\circ}$ e $8 .^{\circ}$ anos. Relatório 4, pp. 26-27).

Conceitos como escolas urbanas, suburbanas e rurais, escolas pequenas e escolas grandes, escolas de regiões desenvolvidas e escolas de regiōes problema passam a incluir no seu interior uma racionalidade de enquadramento da população que estabelece novas fronteiras, novos binários linguísticos e novas formas de intervenção. Tais atributos passam também a constituir critérios de selecçăo de objectos de pesquisa, em vez de serem eles próprios sujeitos à análise enquanto objectos de administraçăo social. Assume-se assim que tais atributos săo qualidades universais das escolas, categorias fixas de que não é possível fazer a genealogia. Deste modo se naturalizam as categorias de espacialização, julgando que estes são dados da estática da escola, a chamada estrutura. É justamente este efeito de obnubilação das categorias de administração, introduzidas como categorias neutras e objectivas, que analisámos a partir dos Relatórios de avaliação do ESU. O facto de os Relatórios terem um campo de produção ambíguo, entre o enquadramento administrativo da maioria dos seus membros e a metodologia e o discurso científico que os orienta, apenas amplia a eficácia do efeito de naturalização de tais categorias. As novas regras de classificação e de inteligibilidade produzem um continuum de valores a partir do qual se constituem novos espaços dicotómicos que incluem e excluem.

Seguimos aqui algumas das sugestōes de Thomas Popkewitz (1998: 122-123) feitas a partir da noção de scaffolding of discourses. Para este autor não são as etiquetas e as classificaçōes que estabelecem fronteiras, são antes os sistemas de inteligibilidade que estão inscritos no modo como tais palavras diferenciam, distinguem e dão significado aos novos espaços habitados por professores e alunos. Dito de outro modo, os novos espaços passam a conter num único plano conjuntos de ideias e de práticas provenientes de origens diversas, por vezes contralógicos, mas capazes de se articularem em práticas. Simplesmente dá-se um encontro de formas năo-necessário. Popkewitz (1998: 123) exemplifica esta ideia a partir da dicotomia urbano/rural: «the urbaness/ruralness of the child and teacher is a recursive system of recognition and division that 'tells' what is included and excluded, qualified and disqualified, from action and participation. That is, the different discourses in pedagogical practice 'decree' not only the limits of 'reason', but also the limits of who is included as reasonable and normals.

A categorização permite a normalizaçăo por força do controlo da própria experiência social. Mas esta normalização não deve ser confundida com as labeling theories que na sociologia da educação tentam desconstruir os imperativos categoriais presentes nas linguagens que circulam no contexto escolar. Enquanto estas teorias tentam 
relacionar o modo como as categorizaçōes estabelecem expectativas e profecias quanto à identidade dos alunos, e como estas se tendem a realizar, o nosso ponto de observação atende aos sistemas de regras e de inteligibilidade. Estes binários não são o resultado de um esquema de pensamento previamente estabelecido, mas a consequência năo esperada da correlação entre os contextos discursivo e não-discursivo das tecnologias de governo da educaçăo. Dentre o contexto discursivo do PAESU destaca-se a relaçăo estabelecida entre a demografia, a estatística, a geografia, a sociologia, a pedagogia e o currículo que permite, pela primeira vez, uma autonomização dos estudos de avaliação das reformas. No contexto não-discursivo destaca-se a relação estabelecida entre o campo administrativo e o campo científico e entre o espaço nacional e o espaço das organizaçōes internacionais.

Este trabalho político de legitimação é em primeiro lugar uma transformação das condições de existência e de funcionamento do discurso sobre a educação, não a expressão ou transposiçăo automática em novos conceitos, métodos e objectos das ciências da educação. $\mathrm{O}$ que é transformado por este trabalho săo as regras de formação do objecto e não o objecto propriamente dito: inquirição da população sujeita à reforma; registo dos antecedentes e da evolução dos seus atributos sociais e escolares; observação do socia/ num espaço objectivado pela família e pelas empresas. $\mathrm{O}$ que é transformado pela prática política não são os métodos de análise, mas o sistema da sua formação: aumento exponencial dos registos administrativos; registo de novos elementos pelos professores das escolas - constituiçăo da célula familiar, rendimento escolar anterior, interesses socioculturais, ocupaçăo dos tempos livres, situação socioeconómica, etc.; o que é transformado não são os conceitos, mas o seu sistema de formaçăo: a substituiçăo do conceito de repetência pelo de insucesso escolar, por exemplo, constitui um efeito do alargamento das fontes de informação sujeitas a análise, mais do que um trabalho conceptual originado no campo científico.

3. O aperfeiçoamento das tecnologias de governo da população escolar: as tecnologias da autonomia e a nova subjectividade para a cidadania

A forma como até aqui temos problematizado a educação escolar não pretende reconciliá-la com a estrutura económica e política da sociedade. O nosso principal interesse consiste em demonstrar como a educação funciona como uma disciplina ética, por intermédio da qual cada indivíduo da geraçăo mais nova se converte ele próprio em sujeito reflexivo de acção moral. Não se trata de fazer uma sociologia das prescriçōes morais, mas de captar as práticas de relação com o self. O que nos inte- 
ressa na construção das subjectividades são as técnicas utilizadas pelos indivíduos na sua reflexão sobre si e sobre a sua acção, como se conhecem a si próprios e se auto-examinam, enfim, como se perfilam a si mesmos como objectos de melhoria e decifração. As técnicas de si são práticas de reflexão voluntárias através das quais os alunos, mas também os professores, se procuram transformar a si próprios, fixar-se regras de conduta e modificar-se na sua singular forma de ser. Trata-se do principal dispositivo de autogoverno dos indivíduos, que se exerce continuamente sem necessidade que haja quem governe directamente a conduta de cada um. A governamentalidade é-lhe suficiente que haja quem se sinta governado e, portanto, aja como se se governasse a si próprio. O que não se coaduna com a destruiçăo das subjectividades, mas, contrariamente, exige uma particular forma na sua construção.

Foucault estudou estas tecnologias de subjectivação nos três volumes da História da Sexualidade, referindo-se a quatro dimensões das artes de viver, como eram designadas no século XVIII. Este esquema pode ser adaptado com vantagem à apreciação sumária das práticas de criação de novas subjectividades surgidas no sistema educativo português e bem representadas pela imagem do aluno autónomo, responsável, participativo e automotivado e pela figura do professor enquanto profissional reflexivo.

A primeira dimensão destas práticas consiste na especificação da parcela de si que é relevante para o julgamento ético pessoal. Qual é a matéria principal da conduta que deve ser sujeita ao julgamento ético? Naturalmente que a resposta a esta pergunta tem sofrido variações históricas importantes. $O$ escrutínio que cada um realiza em relaçăo a si próprio pode ter a sexualidade, a alimentação, as intenções ou o carácter como critérios de relevância principais. No caso em apreço, a substância ética é formada pela auto-realização do aluno. Estabelecer uma relação apropriada entre aspirações, expectativas e auto-realização de ambas parece ser a matéria por excelência das práticas éticas.

A segunda dimensão é caracterizada por aquilo a que Foucault chama o modo de submissão, isto é, os caminhos que o levam a reconhecer uma obrigação moral. Esta assumiu diferentes formas nas sociedades pré-modernas e modernas: leis divinas e códigos morais num caso e melhoria da qualidade de vida ou libertaçăo das potencialidades individuais noutro caso. De qualquer modo a equação que orienta os modos de sujeição, coloca o pensamento moderno em dualidade: de um lado, o pensamento sobre as normas sociais; do outro, pensamento sobre a autenticidade das opções individuais. A diferença fundamental entre normas sociais e opções individuais é de escala. Como sucede com a nova cartografia do sistema educativo, as normas tentam cobrir grandes territórios e populações, sem atender aos detalhes, enquanto as opções atendem à variabilidade dos pequenos territórios e à indeterminação 
da curta duração. É neste hiato que se formam novos cenários para a prática ética do aluno autónomo e motivado. Os cenários de formação do aluno autónomo tem características pastorais e destina-se à melhoria das capacidades individuais. Sem pretensão de exaustividade, distinguiremos dois cenários principais onde têm lugar tais operações: na subjectivaçăo do trabalho escolar e na terapeutizaçăo da comunicação.

A terceira dimensão diz respeito às práticas do self propriamente ditas. A ascesis define as formas de elaboraçăo do trabalho ético que cada um efectua na busca do seu eu verdadeiro. Assim, se considerarmos o exercício escolar como o espaço-tempo por excelência do trabalho de ascese escolar, verificamos que este pode ser praticado segundo regimes bastante diferentes, que podem assumir a forma de conhecimento de si, de cuidado de si ou de domínio de si. O conhecimento de si diz respeito às actividades de autoclarificação, que assentam no imperativo de reconhecimento próprio: reflexão sobre a acção e na acção, interpretação cuidadosa do significado pessoal dado aos conteúdos escolares, apreciação da evolução escolar na forma de auto-avaliação. $O$ domínio de si pode ser praticado por intermédio de um controlo regular da conduta do aluno, pelos seus próprios meios ou com a ajuda de terceiros, à qual se aplica um conjunto de operaçōes que visam um certo estado de aperfeiçoamento, de realizaçăo ou de sabedoria na utilização das tecnologias intelectuais como a escrita, a leitura, a memorização, o cálculo, a interpretação e por diante. O cuidado de si refere-se, entre outras coisas, ao que Marcel Mauss designava por técnicas do corpo e Elias $(1939,1989)$ por condutas corporais. Embora, no primeiro caso, o termo contemple, sobretudo, a clássica descrição dos usos diferenciais do corpo, enquanto instrumento técnico, em funçăo das culturas, năo prescinde também, necessariamente, dos códigos explicitos que, mais tarde, Elias descreveria com tanta mestria a partir da análise da etiqueta e dos manuais de civilidade. Em qualquer dos casos, tanto as técnicas do corpo quanto as condutas corporais dependem de um específico regime corporal baseado nas formas como os indivíduos monitorizam as funções e aç̧ões corporais. Sobre este tema são especialmente estimulantes as investigações antropológicas e históricas de P. Brown (1989) e M. Mauss (1979). Nelas se demonstra como nem todas as capacidades humanas săo sujeitas, em todas as épocas e culturas, à problematizaçăo moral introspectiva, ou, demonstrando a tese a contrario, que o alvo de tais problematizações está sujeito a mutações históricas de grande alcance. É particularmente esclarecedora a hipótese enunciada por Brown (1989: 178-186), segundo a qual o facto de o ocidente moderno ter eleito a introspecção da conduta sexual como alvo de controle dos desejos humanos e de elevação espiritual, em vez do vegetarianismo ou das dietas, se ter devido mais a 
uma contingência histórica do que a uma qualquer descoberta de uma parcela, consciente ou inconsciente, do self, que apenas por intermédio da conduta sexual moderada se revelaria. $O$ estudo detalhado que $o$ autor faz da espiritualidade do cristianismo primitivo revela que a eleiçăo da conduta sexual como objecto primeiro da vigilância moral, emerge num contexto de práticas ascéticas muito específicas - de virgindade e abstinência - que não são gerais e muito menos esgotam as diferentes tecnologias de procura da santidade. Que se trata de um particularismo histórico, que acabou por se transformar num substracto do self moderno, por força dos desenvolvimentos posteriores e especialmente dos decorrentes de Freud, é sublinhado pela comparação que Brown faz com outras práticas virtuosas como as propostas por Plotino, para quem a atracçăo corporal generalizada por carne vermelha constituía a sua principal preocupação ética.

A quarta dimensão incide no que Foucault designa por teleologia do sujeito moral. Para que uma acção seja ética ela não se resume a práticas pontuais e parcelares, integrando-se num modo de ser a que o sujeito aspira por via da acção moral. É nesta dimensão que aparece mais nitidamente a distinção entre uma história da moralidade e a análise da ascese. Enquanto a primeira estuda em que medida as acçōes de certos grupos e indivíduos estão em conformidade aos preceitos e aos códigos de conduta, a segunda preocupa-se antes do mais com aquilo que permite a cada um e a todos manter o domínio de si e das suas condutas. Não que os códigos não tenham um papel na determinaçăo do modelo de sujeito escolhido. $O$ ascetismo do homem puritano do século XVII pouco tem a ver com a ascese do homem contemporâneo, e isto por força, também, do código de moral vigente em cada período. Mas deve manter-se no método de análise a distinção entre os elementos que correspondem à regra e os elementos que correspondem ao esforço realizado para procurar, transmitir e aperfeiçoar as práticas de si que podem ou não conduzir ao estado moral socialmente pretendido. Dito de outro modo, o estado de cidadão cumpridor das leis e participativo tem no Estado e nos seus códigos o quadro de referência, mas é nas tecnologias do desenvolvimento pessoal e social, na busca incessante do seu próprio caminho e opções que se constrói a subjectividade do aluno-futuro-cidadão.

\section{Substância ética}

A determinação da substância sujeita ao julgamento ético individual do aluno sofre frequentes deslocações históricas. No período analisado deu-se uma deslocação da interdição e da vigilância sobre os comportamentos, como matéria principal da con- 
duta moral, para a regulação das expectativas, das aspirações e da auto-realização como objectos centrais de preocupaçăo ética. Dito de outra forma, passa-se de uma fase em que a conduta é sobretudo uma construção extrinsecamente pilotada pelo estrito respeito das obrigações estipuladas, para uma outra em que se procura na construção intrínseca, assente na motivação do próprio aluno, ou dos seus movimentos contraditórios, o balanço entre aspiraçōes individuais e necessidades sociais. O Perfil cultural desejável do diplomado do Ensino Secundário (1988a)(110) é a esse respeito um documento essencial de análise, desde logo porque tenta fazer uma síntese que integra as contribuiçôes das teorias da motivaçăo de McClelland (1961) com as teorias do desenvolvimento sócio-moral de Kohlberg (1987) e Kegan e as correntes pedagógicas metacognitivas de Sternberg (1985) e Presseisen (1985). Enquanto no modelo de McClelland se deriva a configuração motivacional de cada cultura nacional dos valores inculcados pelos agentes de socialização, nos estádios de desenvolvimento sócio-moral procuram-se as invariantes intra-individuais que asseguram a transiçăo entre sucessivos estados de diferenciaçăo e integraçăo que levam a criança e o jovem da dependência à autonomia. No entanto, não obstante os níveis diferentes de análise, busca-se em ambos a aprendizagem da autonomia que estaria associada a certos comportamentos económicos, designadamente o espírito empresarial na criação de mais valia. O Perfil (1988: 121) é muito explícito a esse respeito: «não poderá haver desenvolvimento económico em Portugal se não houver concomitantemente um surto de espírito empreendedor que pode ser definido pelas seguintes características: gosto de tomar riscos moderados como função das aptidões e não de sorte; energia e actividade instrumental; responsabilidade individual;

(110) Este Perfil cultural resulta de um projecto encomendado pelo Ministro da Educaçăo e Cultura, João de Deus Pinheiro, ao Centro de Estudos dos Povos e Culturas de Expressão Portuguesa da Universidade Católica Portuguesa. Uma equipa, constituída por seis personalidades, coordenada pelo eng. ${ }^{\circ}$ Roberto Carneiro, que assegurou também a ligação com outros projectos da reforma educativa, procedeu a um conjunto de reuniōes e seminários durante os anos de 1987 e 1988. Para além de Roberto Carneiro, especialista em Planeamento e Economia da Educação, integraram a equipa permanente os seguintes membros: Pedro da Cunha (Ciências da Educaçăo), que asseguraria a redacção do relatório, Guilherme de Oliveira Martins (Direito e Relaçōes Internacionais), Mário Pinto (Direito e Relaçōes Laborais), Eduardo Prado Coelho (Literatura e Análise Política) e Odete Valente (Fisica e Didáctica das Ciências). Durante os trabalhos, esta equipa convidou para o debate de certas temáticas os seguintes elementos: Victor Crespo (deputado do PSD), Bártolo Campos (deputado do PRD), António Barreto (deputado do PS), Teresa Ambrósio (IED), Luís de França (IED), Victor Barreto (vice-provedor da Casa Pia), Maria Celeste Colarinha, Miguel Novais e António Sobral Mendes (membros de conselhos directivos de escolas secundárias), Aida Pinto e Carlos Ribeiro (alunos). No decurso do trabalho foram realizados três seminários e encomendados sete estudos sobre aspectos concretos do Perfil cultural. 
vontade de conhecer os resultados das decisões; utilização do dinheiro como medida dos resultados; antecipação de possibilidades futuras; competência organizacional». A ideia de subjectividade autónoma e de cidadania activa é um complemento necessário de uma cultura empreendedora. Daí que não destoe a articulação com tecnologias de regulação que operam năo na busca do estoicismo, mas da maximização da escolha e da auto-realização: «a capacidade de agir sobre a realidade nasce da progressiva consciencialização de que o eu não está absorvido no outro, que não está dependente do mundo de tal modo que tenha de aceitar o destino com a fatalidade de quem é apenas elemento. Pode agir, modificar e criar» (Idem, Ibidem: 40). A necessidade de sucesso e o espírito empreendedor forjam o liame entre a forma como somos governados pelos outros e o modo como nos devemos governar a nós próprios. A necessidade de sucesso designa um conjunto de regras para a conduta na vida de todos os dias, com tradução pedagógica: iniciativa, ambição, calculismo e responsabilidade pessoal. $\mathrm{O}$ indivíduo autónomo e empreendedor deve, portanto, maximizar o seu próprio potencial, projectar-lhe um futuro e aspirar à sua realizaçăo. Em ordem a vir a ser o que se quer, o self do aluno deve ser capaz de se decifrar a si próprio, calcular realisticamente as suas aspiraçōes, identificar o que age sobre si e melhorar-se a si próprio. Doravante, de acordo com as novas racionalidades do liberalismo moderno, não é suposto que os futuros cidadãos necessitem de instruçōes precisas das autoridades políticas e pedagógicas sobre como regular a sua existência quotidiana. Esse passa a ser o espaço da liberdade regulada pelas escolhas de cada um, na procura da felicidade e da auto-estima.

Gradualmente, as formas de aprendizagem reflexivas e autobiográficas regressam ao contexto escolar. As práticas de metacognição passam a fazer parte das situaçōes de exercício: reconhecer a motivação para fazer uma tarefa escolar (Porque quero fazer isto?), avaliar a auto-estima no curto prazo (Quero continuar os estudos?), verificar a auto-estima no longo prazo (O que quero fazer quando for adulto?), hierarquizar as disciplinas (Quais as disciplinas de que mais/menos gosto?), compreender os estados emocionais associados à atracção/rejeição de certos conteúdos (ver e.g. Morais e Valente, 1991: 35-56). Deste modo, as pedagogias construtivistas, suportadas em noçōes da psicologia cognitivista, requerem uma participação activa do sujeito, já nắo apenas no autocontrolo dos seus comportamentos, mas, em primeiro lugar, na formaçăo do seu carácter e da sua identidade. A auto-estima e a motivação intrínseca são as instâncias psicológicas onde se localiza a substância ética, enquanto os conceitos de capacidade e de adaptabilidade são os operadores linguísticos que asseguram a justificaçăo dos modos de trabalho da pedagogia concreta ligada à vida. No nosso entender, a genealogia do sujeito automotivado e com auto-estima e a 
genealogia do sujeito capaz e adaptável são autónomas, embora, como temos argumentado, estejam intimamente relacionados. No primeiro caso, podemos filiar a nova subjectividade no tradicional veio pastoral da escola. A metacogniçăo reactiva e actualiza, na sua forma de razăo prática pedagógica(111) as antigas técnicas de reflexão espiritual da tradiçăo cristã: «the puritan, like every rational type of asceticism, tried to enable a man to mantain and act upon his constant motives, especially those which it taught him itself, against the emotions. In this formal psychological sense of the term it tried to make him into a personality» (Weber, 1930: 119). Na versão moderna, a escola e os professores são chamados a regular não tanto os hábitos e a moral dos jovens escolarizados, mas os seus sentimentos, desejos, ansiedades, vontades e emoções.

Há quem veja neste dispositivo uma homologia com o perfil desejado para os novos profissionais de um sistema de emprego imprevisivel, tanto no volume como nas formações requeridas: trabalhadores abertos à inovação, mas dedicados; criativos, mas com atitudes empenhadas; disponíveis para a formação permanente, mas ambiciosos; identificados com a empresa, mas competitivos. A questão tem sido tratada do lado da adaptação dos sistemas educativos às novas condições pós-fordistas do trabalho (Dale et alii., 1990; Shilling, 1989). Tal homologia decorre de um silogismo transitivo que, em nossa opinião, impede a análise autónoma da genealogia da auto-estima e da automotivação no contexto escolar. O objectivo desta pedagogia pastoral não é formar uma força de trabalho eficaz, dócil e adaptada aos novos regimes de

(111) A psicologia do adolescente não se apresenta nas escolas na sua formalização teórica, mas na forma de razăo prática pedagógica, isto é, em articulaçăo com outros discursos. B. Bernstein (1996) dá a este processo a designaçăo de recontextualizaçăo, querendo com isto evidenciar o efeito de regionalizaçăo do discurso de um conhecimento singular quando este entra em contacto com o campo de prática. Assim, a psicologia, enquanto conhecimento singular, auto-referenciado e com classificaçōes fortes, ao entrar em contacto com o campo de prática educativa, sofreria uma recontextualização que tornaria as classificaçōes mais fracas. Bernstein conclui que, cada vez que se dá um processo de recontextualizaçăo, se abre uma brecha para a irrupção da ideologia. Nesta versão, a ideologia introduz um efeito de distorção sistemático, facto que nos imporia a busca da origem verdadeira dos enunciados. Ora, o nosso ângulo de análise, ao seleccionar como objecto de estudo os regimes de verdade, não há-de acolher conceitos e metodologias que fixam, ou aceitam, eles próprios o jogo da verdade. Neste jogo, o investigador persegue sempre uma essência, que deriva de princípios gerais, que nāo se encontram todos eles presentes no comportamento dos individuos concretos. Preferimos por isso utilizar as noções foucauldianas de articulaçăo, deslocamento e dispositivo, já que elas nos permitem cumprir três cautelas metodológicas: a) pôr em plano de igualdade os saberes provenientes das várias regiōes discursivas, não dando qualquer primazia às regiōes continente ou insulares; $b$ ) individualizar os discursos provenientes dos campos de prática, não os remetendo ao estatuto de eterna dependência dos conhecimentos singulares; c) analisar as dependências interdiscursivas sem estabelecer hierarquias substantivas aprioristicas. 
acumulação. Incorreríamos em petição de princípio se fossemos além dos objectivos de auto-reflexăo e de autogoverno inscritos em tais tecnologias. É nelas que se exprime o actual poder pastoral numa astuciosa combinação das técnicas de individualização com procedimentos totalizantes. Nesta combinação articulam-se sobretudo o princípio do Estado e da cidadania e os processos de subjectivaçăo. 0 capitalismo tem sabido conviver com diferentes soluções e modelos de subjectividade. Max Weber, na sua obra A Ética Protestante e o Espírito do Capitalismo, demonstra a existência de afinidade electiva entre certas crenças calvinistas e a ética económica da actividade capitalista moderna, sem, contudo, concluir que existe uma relação de causalidade ou de homologia. Também na contemporaneidade se dá um encontro de formas entre o poder pastoral escolar e o novo perfil de trabalhador proposto pelos modernos meios empresariais, mas daí não podemos retirar a conclusão de que se trata de um mesmo processo. As categorias motivação e auto-estima já haviam feito a sua aparição nos relatórios do PAESU. Concluíam estes que as dificuldades de ensino encontradas no unificado estavam fortemente determinadas pelas expectativas das famílias e dos alunos, pelo grau de envolvimento dos pais e pela motivaçăo dos alunos. Contudo, estes problemas não eram resolúveis apenas por intermédio de uma maior implicação das famílias e dos alunos; havia questões de hierarquização social que limitavam o alcance de tal mobilização. Como vimos, tal conclusão năo decorre da formalização de uma teoria sociológica sobre os efeitos de reprodução social. Esta problematização resulta, antes do mais, das referências ao contexto social depositadas pela crise revolucionária nas tecnologias administrativas de governo da população. Esta memória institucional começa, entretanto, a ser confrontada com a psicologização do discurso, resultante do Perfil desejado e dos fundamentos da Reforma curricular. Estes remetem para o indivíduo a possibilidade de cada um aceder a um projecto de vida capaz de o resgatar de um destino social rigidamente determinado. Neste caso, o conceito de si passa a ser o nódulo de articulação de todos os restantes discursos: uma construção internamente regulada, que toma a forma de uma narrativa explicita de cada um sobre si, a introjecção, e o controlo simbólico de atentas terapêuticas pedagógicas. Na verdade, o processo de subjectivaçăo năo abole os códigos e as normas; a autenticidade não quer dizer falta de pudor; a atenção do espaço público da escola ao interior privado da pessoa não quer dizer exposição completa. A imagem do gabinete do analista, criam-se espaços recolhidos de atendimento dos alunos e dos pais, promovem-se encontros personalizados com os alunos, nos casos mais difíceis enviam-se os alunos para o psicólogo ou para o terapeuta.

O objectivo comum das práticas de reflexão parece poder ser caracterizado por aquilo que Foucault (1994c) designa como conversão a si. Contudo, esta conversão 
tem traços muito diferentes dos que Foucault registou nos filósofos estóicos. As sociedades actuais, profundamente escolarizadas, desenvolveram um fascínio sem precedentes pelo autoconhecimento e pela auto-realização a par da proliferação de uma nova sensibilidade terapêutica (Lipovetsky, 1989) arrimada na oferta de orientação psicológica, técnicas de comunicação e meditação e outras ginásticas da mente e do corpo. Ao consumo de consciência de si, havemos de acrescentar a reflexividade da vida social (Giddens, 1992). Hoje em dia, muitos alunos do ensino secundário e as suas famílias sabe, por exemplo, que as taxas de insucesso em certas disciplinas são elevadas e que o contingente dos que entram nos cursos mais nobres é muito inferior à procura. $\mathrm{O}$ conhecimento destes factores pode afectar as decisões individuais que, por sua vez, estão impregnadas de saber sociológico («na escola somos todos iguais mas os ricos têm mais oportunidades que os outros»). Contudo, esta reflexividade nem sempre acrescenta capacidade de domínio da situaçăo exterior aos actores. Contrariamente, intimida e inibe, frequentemente, as possibilidades de opção. Como bem argumenta Giddens (1992: 33), o maior conhecimento sobre a vida social não tem equivalente num maior controlo sobre o nosso destino: «a expansão da nossa compreensão do mundo social podia produzir um entendimento progressivamente mais esclarecedor das instituições humanas e, em consequência, aumentar o controlo 'tecnológico' sobre elas, se se desse o caso de a vida social ser inteiramente separável do conhecimento humano sobre ela, ou de poder ser continuamente infiltrado conhecimento nas razões para a acção social, produzindo, a par e passo, aumentos na 'racionalidade' do comportamento». Tal opacidade, criada pelo excesso de reflexividade, é também a consequência da atmosfera de rigidez e de imobilidade ao nível global da sociedade (Offe, 1987). A sociedade total parece imune a qualquer mudança, enquanto as reformas permanentes se deslocam para a empresa, a escola, a comunidade, a família, mas, sobretudo, para o próprio indivíduo. Num momento em que os limites de conhecimento da sociedade no seu conjunto exaure as suas capacidades de mudança, o conhecimento de cada indivíduo sobre si e as possibilidades de alteraçăo de percurso que parece assegurar, tornam-se no último reduto do desenvolvimento. Os individuos sabem as respostas para si, mas não as questões do mundo. O individualismo possessivo substitui assim a consciência social das desigualdades; o desenvolvimento psicológico reveza o crescimento económico; a consciência de si recolhe nela a consciência do mundo.

A principal característica deste deslocamento do social para o individual é o pressuposto de que é na ordem natural do desenvolvimento do jovem adolescente que se encontram as bases do que lhes deve ser ensinado. Porém, aquela já năo é aferida a uma instância ontológica última a que haveria que os devolver por intermédio da 
normalização. A natureza primeira é substituída por uma natureza segunda, que tem no conceito de estima de si, a necessidade ou o valor que o indivíduo visa na sua conduta. As ciências da educaçăo e a psicologia, na sua mais recente fase, ao debruçarem-se sobre o aluno, em vez de o produzirem como normalidade, contribuiram para o produzir positivamente, multiplicando-o no que podíamos designar como ecologia das necessidades. A auto-estima é o nó que ata a cada indivíduo o retorno da ética na escola contemporânea. O indivíduo é incitado a ser ele próprio, não nos termos da obediência a um sistema de regras, mas antes nos termos de uma autonomia privada sobre a qual a escola renuncia progressivamente a pronunciar-se. Giddens (1994: 13) descreve este regresso da ética como auto-reflexividade «na qual a pergunta 'como hei-de viver?' tem de ser respondida através de decisões diárias acerca de como comportar-se, o que vestir e o que comer - e muitas outras coisas - , bem como interpretada no desenrolar temporal da auto-identidade». É neste sentido que a ética escolar contemporânea acrescenta algo às tradicionais tecnologias pastorais: o eu transforma-se num projecto reflexivo permanente que tem lugar num contexto de escolha múltipla. Sendo esta filtrada por sistemas abstractos, em especial os que têm origem nos fluxos de informação social e psicológica sobre as opções e modos de vida, há-de articular mudança pessoal e mudança social. Como sugere Giddens (1994: 12), o eu-reflexivo substitui os ritos de passagem que marcavam os estádios da vida das sociedades antigas: «a auto-identidade forma uma trajectória através dos diferentes cenários institucionais da modernidade ao longo da durée do que costumava chmar-se o 'ciclo de vida', um termo que se aplica com mais rigor a contextos năo modernos do que aos modernos». O lugar dado ao autoconhecimento coloca a autenticidade do que se é na base da constituição do sujeito moral.

São estas bases que determinam as necessidades universais do aluno. Poderíamos neste passo discutir os fundamentos epistemológicos desta formulação, procurando assim incorporar as críticas aos modelos dos estádios, em especial aos estádios de desenvolvimento piagetianos. No entanto, a nossa problemática afasta-nos deste veio argumentativo que se propõe avaliar o valor racional e empírico das correntes psicológicas ou pedagógicas. A genealogia do conhecimento psicológico interessa-nos em virtude da descriçăo e análise das práticas que permite e não enquanto objecto teórico ou epistemológico. Ou, se captarmos esta ideia pelo seu contraponto, o objecto teórico interessa-nos na medida em que nele pudermos recolher as regras discursivas que circunscrevem um certo regime de verdade. Em bom rigor, as práticas não existem fora de um regime de racionalidade que determina o domínio de objectos sobre os quais é possível articular proposiçōes falsas e verdadeiras. Tão-pouco renuncia à codificação e prescrição de práticas. É neste segundo eixo 
que temos vindo a desenvolver a nossa análise, para agora nos determos no primeiro, isto é, nos regimes de verdade.

As teorias desenvolvimentistas de tipo piagetiano, embora confirmem a existência de uma criança universal, sujeita a típicos estádios de desenvolvimento, não se identificam com o maturacionismo. De acordo com Jean Piaget, as actividades da criança e do jovem são importantes na medida em que retroalimentem a sequência de desenvolvimento. Tal asserçăo tem duas importantes consequências na racionalidade do acto pedagógico: por um lado, responsabiliza o sujeito pelo seu próprio desenvolvimento; por outro lado, fornece uma justificação complementar para a criaçăo de situações de contexto estimulantes, em virtude do papel activo que as situaçōes de aprendizagem, criadas pelos adultos, têm no desenvolvimento. Esta última consequência será sujeita, nos anos 70 e 80, a uma expansão evidente, quando a sociologia crítica submete o modelo piagetiano à evidência empírica de uma variabilidade e indeterminação maiores do que as que o modelo dos estádios fazia crer (Perrenoud, 1977; Benavente e Correia, 1980; Bernstein, 1996). Tal variabilidade residia antes do mais nos factores de contexto social: diferenças de situação económica, diferenças de condições e modos de vida, diferenças escolarmente significativas, diferenças de formação escolar e profissional (ver esquema de Perrenoud in Cortesăo e Torres, 1990: 78). A ideia de contexto passou a estar presente em todos os discursos pedagógicos, quer para justificar diferenças e handicaps (Benavente, 1989), quer para propor estratégias igualitárias assentes em envolvimentos activos (Cortesão e Torres, 1990: 58-82).

A introdução exuberante da noção de contexto é essencial ao deslocamento do conceito piagetiano de competência para o de capacidade. A noção de capacidade vem somar-se à de competência que, por sua vez, havia substituído ou complementara a de performance dos comportamentalistas. Segundo Bernstein (1996: 72), a noção de capacidade surge em contextos «where life experience cannot be based on stable expectations of the future and one's location in it». Em tais contextos, o trabalho e a vida são sujeitos à efemeridade do curto prazo. Assim sendo, a noção de capacidade responde directamente às exigências de um mundo turbulento, indeterminado e saturado de riscos, onde não havendo respostas universais deve existir um universal: o aluno adaptável e capaz de gerir as contingências da sua acção. Este universal abstracto é o aluno com capacidade, um conjunto de destrezas gerais que subjazem às suas realizaçōes específicas. Dito de outra forma, a capacidade não descreve aquilo que o aluno faz realmente, mas estabelece normativamente uma identidade ideal, um arbitrário social, no qual este se deve rever. A validação desta identidade é realizada pela forma, pela treinabilidade, não pela substância. Aliás, a capacidade năo é 
substantiva, em virtude da infinidade sem limites da sua aplicação às contingências mais diversas da vida e do trabalho. Tal dessubstancialização da capacidade conduz inevitavelmente, segundo Bernstein (1996: 73), ao seu esvaziamento: «there seems to be an emptiness in the concept of trainability, an emptiness which makes the concept self-referential and thus excluding». A questão que, consequentemente, Bernstein enuncia é a de saber como é que os actores se reconhecem, a eles e aos outros, se a identidade produzida pela treinabilidade das capacidades é uma identidade vazia. A resposta de Bernstein é coincidente com a de muitos cientistas sociais que, como Lipovetsky (1983), (112) descrevem as sociedades actuais como sociedades narcísicas que atravessam uma era do vazio: «by the materialities of consumption, by its distributions, by its absences. Here the products of the market relay the signifiers whereby temporary stabilities, orientations, relations and evaluations are constructed 》 (Bernstein, 1996: 73). Deste modo, as tecnologias pedagógicas inscritas nos conceitos de capacidade e adaptabilidade, seriam um meio por excelência de socialização dos futuros consumidores. ${ }^{(113)}$ A formação para o mercado de trabalho seria mediada pela formação para o consumo, estratégia consonante aliás com um período de crise económica e de desemprego estrutural.

O lugar-comum que melhor representa este período é o do equilíbrio entre igualdade e diversidade. Assumindo formas variadas consoante o contexto, a familia pedagógica (Donzelot, 1979) constitui uma das instituiçōes improvisadas para renovar o contrato entre a família e a escola sob as novas condições da escola de massas unificada. Na esteira de Donzelot é preciso reconhecer nas práticas discursivas e não-

(112) A descrição deste padrăo psicológico tem a sua filiaçăo no perfil other-directed descrito inicialmente por Riesman (1952) e retomado por Cristopher Lasch (1979), embora um e outro pareçam de natureza diversa. Com efeito, o homem other-directed de Riesman está orientado para os outros, retirando das suas relaçōes as preferências e os critérios de acção. Tem por isso a tendência para se dissolver no grupo e na multidão. Pelo contrário, o argumento que tanto Lasch como Lipovetsky expandem está ancorado no reconhecimento da progressiva desvalorização paródica da sociedade $\mathrm{e}$ do sobre-investimento do Eu. Mas este novo objecto de culto não se confunde com o homem de conviç̧ões inner-directed do passado, antes se aproximando da imagem do jogador imerso num contexto de valores públicos decaídos, em que o "experimentar para ver» se dá num espaço social de indiferença pura.

(113) Não se pretende neste trabalho demonstrar tal tese, mas apenas estabelecer uma pista de trabalho que facilmente encontra pontos de apoio em outros argumentos, tais sejam: a) o reconhecimento de que o prolongamento dos estudos e a democratização do ensino cumprem uma funçăo latente de parqueamento escolar dos contingentes juvenis que, de outro modo, engrossariam as estatisticas do desemprego; b) este prolongamento do tempo escolar coincide com uma socializaçăo mais fortemente ligada a estilos de vida de consumo do que a estilos de vida centrados na ética do trabalho (Cabral e Pais, coord., 1998); c) o reconhecimento empírico de que os valores do consumo estão mais presentes nas representaçôes sociais dos jovens escolarizados do que os valores do trabalho. 
-discursivas do psy-complex as novas formas de mediação da experiência que no lugar da normalização ou da disciplina introduzem as tecnologias adaptativas. Estas técnicas abrem um estilo de regulação não coercivo que actua nos interstícios existentes entre o público e o privado, entre a escola estatal-burocrática e a família. Os interstícios são constituídos pelo desperdício institucional, a cuja gestão se dedicam as agências de aconselhamento que envolvem o sistema escolar: alunos com problemas comportamentais, crianças e jovens com dificuldades de aprendizagem, alunos com insucesso, jovens pertencentes a famílias de risco. Segundo Hunter é o psy-complex que transforma a família num anexo da escola, criando um espaço no interior ou ao longo da escola estatal em que a família se possa rever nas suas ambições. Simultaneamente, desloca os problemas do excesso de diversidade para outras instâncias. Do seguinte modo: «in targeting students with behavioural problems, for example, psychoanalytically inflected counselling institutions like the Parents School located the source of scholastic difficulties in family relationships. The child with 'learning difficulties' was thus deployed as a 'relay point' between the school and the family. And in applying adjustive therapies to these problems, such institutions made it possible for families to internalise bureaucratic norms in a non-coercive manner» (Hunter, 1994: 128) A eficácia das técnicas de reflexăo e de intervenção assim introduzidas dão também um sinal de adaptação da própria escola ao desejo de as famílias promoverem os seus membros. Adaptação que, segundo Donzelot (1979: 205-207), sofreria de um viés classista, já que é a classe média que está em melhores condiçōes para recorrer às instituiçōes especializadas em aconselhamento e orientação vocacional, aos terapeutas e à intervenção por meio das associações de pais.

\section{Os novos cenários éticos: a terapêutica}

Com efeito, a familia pedagógica não é o único mediador das novas trocas entre o estado-educador e as expectativas das familias. As práticas de si decorrem também em outros cenários éticos. A terapêutica individual e familiar assumiu nos últimos anos uma presença fulgurante, por força da intervenção pública crescente de alguns académicos ligados a tais práticas clínicas, da linguagem próxima do senso comum que utilizam e, também, devido ao registo analítico e prescritivo do seu conteúdo. Em especial, a intervenção de Daniel Sampaio, com assinalável popularidade, que a reedição consecutiva dos seus livros confirma, merece-nos neste ponto uma atenção dedicada.

Os subtítulos do capítulo «Momentos decisivos» de Inventem-se Novos Pais (1994), um dos livros de Daniel Sampaio com mais sucesso editorial, é, em si mesmo, um indicador dos momentos críticos em que devem actuar as tecnologias de si de pais e 
de filhos: acordar ou deixar dormir, faltas às aulas, refeições, discotecas e saidas à noite, férias, futebol, concertos, namoros, mentiras. Dir-se-ia que, do acordar ao exame de consciência nocturno, antes do deitar, passando pela relação amorosa e familiar, tudo é motivo para uma ascesis, para um escrutínio, para a elaboração de um trabaIho de si sobre si. As relaçōes dos adolescentes com os amantes, amigos, colegas, pais e professores são desveladas para aparecerem como elementos chave da felicidade pessoal e da eficácia social. Todo o género de patologias ou distúrbios da relação estão destinados a ser refeitos e reconstruídos de modo a obter o resultado essencial que leva o adolescente à idade adulta - a autonomia. É o próprio Daniel Sampaio (1994: 45) que o repete exaustivamente: «num recente curso para Clínicos Gerais/ Médicos de Família, perguntei o que achavam ser característico da adolescência. Muitos falaram de crise, da contestaçăo, do conflito pais/filhos, da sexualidade e de outros temas, mas quase ninguém referiu este período como uma simples etapa do desenvolvimento que leva à idade adulta e cuja questăo essencial é a da autonomia».

Porém, a independência nem sempre chega de um modo contínuo, "antes ocorre ao longo de um processo que tem avanços e recuos» (Idem, Ibidem, p. 45). Disrupções na escola, frustrações em casa, namoros mal sucedidos, pais divorciados, famílias desestruturadas, escolas desinteressantes, são momentos que podem expressar incapacidades na relação com os outros. Tais incapacidades podem ser remediadas por terapeutas que, capazes de diagnosticar patologias ou simples episódios críticos, prescrevem os modos de pais, filhos e professores se conduzirem na sua relação mútua. O quadro seguinte fornece uma síntese dos principais momentos críticos e das tecnologias de si que Ihe estão associadas. Nele se revela, antes do mais, uma linguagem diferente da intimidade: ansiedade, mal-estar, atitudes, relações, culpa, desejos, sexualidade e frustrações são termos psicológicos profusamente disseminados no interior da família, ligando a procura do seu bem-estar a uma inserção mais eficiente nos outros contextos institucionais como a escola. Esta linguagem năo nos interessa tanto por aquilo que ela significa, mas principalmente pelos efeitos que produz nos que são alvos directos ou indirectos delas: quais as dimensōes de reflexăo que induzem, que ligações com outros acontecimentos permite, quais os critérios de verdade que privilegia, quais os espaços sociais de referência que utiliza.

As principais actividades terapêuticas sugeridas săo a comunicação («a conversa»), a negociação, o autocontrolo, a autoconfissão e a narrativa. Tais actividades resultam do processo de codificação das vicissitudes do comportamento individual. Muitos dos comportamentos e condutas críticas tomam os aparelhos de regulação e administração como referência, especialmente a escola. Nikolas Rose (1996b), fazendo uma análise crítica da Psicologia no último século, considera que, historicamente, os 
Quadro 20 - Momentos críticos e Tecnologias de si

MOMENTOS CRÍTICOS

\section{TECNOLOGIAS DE SI}

ACORDAR

FALTAS AS AULAS

REFEIÇOES

DISCOTECAS E SAIDAS A NOITE

312

FERIAS
«Ninguém vai para a escola porque os pais obrigam, se isso não faz qualquer sentido no interior do filho. Então o acordar é assunto de cada um» (p.50)

Responsabilização

«a agressividade excessiva mostrada em casa pode corresponder a um periodo de intenso mal-estar que as faltas escolares objectivam. Será então possivel, a partir desse

facto concreto, estabelecer uma conversa sobre a vida do adolescente e as dificuldades do processo de desenvolvimentos (p. 52) Conversa-Comunicação

"O meu primeiro gesto terapéutico nestes casos é pedir à familia que tente jantar em conjunto (...) será então possivel que a familia pressinta, muitas vezes com a satisfação da descoberta, como é bom falar uns com os outrosn (pp. 53-54)

Conversa-Comunicação

"Quando as coisas são faladas lá em casa ná é grave uma noitada semanal, se nas outras noites é possivel estar em familia (...) Mas deixemos que cada geraçāo encontre em si própria a necessária diversão de que necessitas (p. 59)

Auto-controlo

*Dado que as férias grandes são mesmo muito grandes, talvez seja possivel, com antecedência, combinar um período em que toda a família possa estar reunida, num local ou programa que contemple os interesses e gostos de todos (...) Mas estes filhos também precisavam compreender que não podiam decidir as férias sozinhos, com esquemas que não tinham recebido a aprovação parental» (p. 61)

Negociaçăo 

contribuir decisivamente para se atingir a identidade e a autonomia que vẫo caracterizar a idade adulta, a sua perturbaçăo, quando se mantém, é fonte de inúmeros conflitos e frustraçōes, como nos dois exemplos que se seguem» (seguem-se cartas de dois rapazes que narram e reflectem sobre a sua vida sexual e amorosa) * Concordo consigo que uma dor partilhada é uma dor aliviada (...) Peço-the que pense

em si próprio, pesquise o que de vivo há em si e procure uma colher de café de amorn (p. 73)

Narrativa

MENTIRAS

$$
\begin{array}{r}
\text { «Estão acima de tudo a lutar contra a mentira onde } \\
\text { foram criados. Mas há ocasiōes, cada } \\
\text { vez mais frequentes, em que eles próprios } \\
\text { mentem, primeiro aos outros, depois a si } \\
\text { próprios (a pior das mentiras). (...) A noite, } \\
\text { na intimidade do seu quarto, o adolescente } \\
\text { procura um sentido para a vida, valores, } \\
\text { a sua identidade talvez definitivamente } \\
\text { perdida, um pouco de compreensão, mas a } \\
\text { mentira do seu dia não o deixa adormecer» (p. 80) } \\
\text { Autoconfissão }
\end{array}
$$

conhecimentos psi se alinharam com os sistemas de visibilidade institucionais por intermédio das suas normas e sistemas de julgamento: «that is to say it was the normativity of the apparatus itself - the norms and standards of the institution, their limits and thresholds of tolerance, their rules and their systems of judgement - that conferred visibility upon certain features and illuminated the topography of the domains that psychology would seek to render intelligible» (Rose, 1996b: 61). Quer isto dizer que as actividades terapêuticas propostas se enquadram no que Foucault designava pelo termo modalidades enunciativas: a comunicação, a narrativa ou a autoconfissão não habitam espaços funcionalmente homogéneos e amorfos, onde se processaria uma transacção redutível às categorias linguísticas utilizadas. Pelo contrário, estas práticas situam-se em espaços que acolhem procedimentos particulares e relações de poder específicas. Por conseguinte, as relações entre signos que a fala pressupõe são sempre montadas em outras relações que procedem à distribuiçăo do poder no seu interior, estabelecendo quem ouve e quem fala, delimitando quem julga e quem é julgado, quem avalia e quem é avaliado, quem cura e quem é curado. 
Se tomarmos como exemplo de práticas discursivas a comunicaçăo e a narrativa do encontro terapêutico, podemos avançar um pouco mais neste argumento. As narrativas săo histórias que contamos aos outros e a nós próprios. Falar sobre si, num registo de autonarrativa, é constitutivo não apenas das formas de autodomínio e de autocompreensão, como também das práticas sociais elas próprias. Embora o objecto da autonarrativa seja o indivíduo singular, seria desadequado interpretá-la como um exercício ensimesmado de si sobre si. A autonarrativa é dialógica porque compreende no seu interior a reconstrução de acontecimentos nascidos da interacção social e implica uma audiência. Deste modo, os atributos do self săo entendidos mais como o resultado de conversações e vocabulários, do que enquanto funcionamento de mecanismos mentais. Benveniste (1971) argumenta que é através da linguagem que o homem se constitui a si próprio como sujeito. Para demonstrar tal asserçăo põe especial destaque nas propriedades dos pronomes pessoais, dentre os quais o eu, como objecto de enunciação, permitiria a criação de um lugar para o aparecimento do sujeito. As formas pronominais seriam signos vazios que se enchem logo que o falante as introduz numa instância discursiva. Todavia, os processos de subjectivação não se reduzem a meras operações linguísticas ou gramaticais, integrando-se em modalidades enunciativas, quer dizer, em regimes de espaço-tempo que estabelecem quem pode falar e que relaçōes estão em jogo na tríade formada por objecto do discurso, sujeito que fala e sujeitos a que se destinam os discursos. Neste particular, o regime de narrativa proposto para a relação entre o terapeuta e a família cria uma ponte entre o mundo interno do psiquismo e o mundo externo da conduta, ou melhor, permite a inteligibilidade desta nos termos daquele com a mediação interpretativa do terapeuta. Esta relação desequilibrada fornece as formas de linguagem para conversar sobre os determinantes internos da conduta e os meios para pensar como esses determinantes podem ser organizados. O Eu resultante desta interacção é o produto de um conjunto de relações que podem ser apreendidas pela noção de texto. Ora, como recorda Shotter (1989: 136), o texto da modernidade sobre o self está marcado pelo individualismo possessivo:(114) «we talk this way

(114) Macpherson (1962) caracterizou o individualismo possessivo como uma forma de afirmação do carácter intrínseco das capacidades de cada um. Assim, a inteligência, a personalidade, o carácter, o nivel de realização e por diante, seriam dados que poderiam ser identificados e medidos independentemente das relaçôes sociais de cada um. Segundo Popkewitz (1991: 150-159), que utiliza abundantemente esta noção, sujeitando-a a uma crítica cerrada em diferentes campos, a sua principal implicaçăo pedagógica reflecte-se num mandato explícito ou implícito segundo o qual a escola serve para garantir oportunidades para todas as crianças desenvolverem as características intrínsecas que possuem, usando-as para uma melhor inserção social. 
about ourselves because we are entrapped within what can be thought of as a 'text', a culturally developed textural resource - the text of 'possessive individualism' - to which we seemingly must (morally) turn, when faced with the task of describing the nature of our experiences of our relations to each other and to ourselves». Com efeito, existe uma tecnologia do fazer falar e de falar segundo a verdade interior de cada um, que inclui sequências de perguntas, de gestos e de palavras. Falar num encontro terapêutico equivale a colocar as palavras num campo científico com as suas regras próprias, em que a voz é o meio de diagnóstico e de investigaçăo. A análise de dois dos livros mais vendidos de Daniel Sampaio permitir-nos-á decifrar algumas destas tecnologias da narrativa do self que năo se centram em aspectos parcelares do adolescente, mas, antes de tudo, na sua autonomia, isto é, nas características mais fundas e intimas de cada um. ${ }^{(115)}$

O vocabulário utilizado pelo autor apresenta duas faces: por um lado, o vocabulário proveniente da autoridade científica, justificado por algumas, poucas, referências à investigação científica; por outro lado, o vocabulário e a linguagem de senso comum, por vezes mesmo o jargão utilizado na interacçăo quotidiana pelos adolescentes, reconhecível por cada um como os termos comuns usados para descrever pessoas e situaçōes. Mais importante do que a linguagem científica utilizada nestes relatos, que é escassa e esparsa, o leitor é conduzido a uma aprendizagem da autodescrição através da identificação com os personagens reais que văo percorrendo a narrativa. É esta espécie de introjecção das interpretaçōes subtis do autor que nos interessam na análise que se segue e năo o valor científico das teses que subjazem ao conteúdo dos livros. A par desta centraçăo nas tecnologias da narrativa e da comunicação, interessa-nos também o carácter silencioso das prescrições que as acompanham. Na verdade,

(115) Os relatos das sessões de terapia familiar publicados em alguns dos livros de Daniel Sampaio constituem uma porta de acesso a estas práticas. Embora não se apresentem sob o formato de manual de instruções, ou de obras de divulgação científica, os relatos incluem grande parte das técnicas de exame e avaliaçăo do self, tais sejam o auto-exame, os modos de trazer à reflexāo os pensamentos e as condutas, o vocabulário a utilizar, o registo das dificuldades em diário. Na discussăo que se segue utilizaremos sobretudo os dois livros que mais informação contêm sobre as tecnologias do self: Vozes e ruidos. Diálogos com adolescentes. Lisboa: Caminho, 1993 e Inventem-se novos pais. Lisboa: Caminho, 1994. No primeiro livro, o autor procede a um conjunto de diálogos com adolescentes normais, a que chama «dar a voz aos adolescentes» (p. 12), seguindo-se vários capítulos sobre a adolescência patológica, em que vários membros da sua equipa ilustram situaçōes diversas «mas todas elas caracterizadas por bloqueios do processo de desenvolvimento" (pp. 11-12). No segundo livro, o autor faz alguns retratos de adolescentes que habitualmente preocupam os pais. Seguem-se vários capítulos dentre os quais destacamos as entrevistas com pais de adolescentes e o relato de algumas sessōes de terapia familiar. A eficácia epistémica destas obras não reside no aparato científico sofisticado de que se mune, mas na identificação com as personagens que procura. 
a prescrição ambiciona sempre o estatuto de invisibilidade nos livros de Daniel Sampaio. Um dos traços marcantes da sua retórica consiste na recusa determinada do conselho ou do moralismo: "quando escrevi este livro foi a pensar em todos os pais e filhos de adolescentes que ainda não desistiram de o ser. Sei bem que posso ser tomado por moralista ou conselheiro familiar. Ninguém deve dizer o que se deve passar na casa dos outros, quando muitas vezes não sabe o que fazer em casa própria. $E$ não há nada pior que um psiquiatra ou psicólogo para deixar tudo em confusăo. Por isso, leiam o livro e se não gostarem esqueçam tudo e funcionem com a vossa intuiçăo e experiência de vida» (Sampaio, 1994: 10-11). Esta oposição à prescriçăo é repetida de diferentes formas, até se tornar num discurso pedagógico destinado a transformar as relações entre pais e filhos, a partir do interior de cada um e de cada família. Não que Daniel Sampaio não prescreva, porque o faz com muita abundância, mas logo que a prescrição se faz presente, o autor procede à sua rasura. ${ }^{(116)}$ Esta conduz habitualmente à valorizaçăo do amor, da afeiçăo e da atençăo, no interior de imperativos morais tais como o dever, a obrigaçăo, a responsabilidade social, a consciência e o respeito. Tudo isto realizado numa linguagem tão próxima quanto possível da que é utilizada no comum quotidiano: «para os pais resta talvez o mais importante: estar lá para o que der e vier. Se a sexualidade na adolescência pode contribuir decisivamente para se atingir a identidade e a autonomia que văo caracterizar a idade

(116) Tomamos apenas alguns exemplos dos livros em análise. No primeiro capítulo do livro Inventem-se novos pais o autor dedica-se à descriçăo de «adolescentes que preocupam, mas que devem ser ouvidos e respeitados. Pode ser que encontrem lá alguém parecido com o vosso filhoproblema, ou nada Ihes fará sentido e ainda bem» (p. 11). Depois deste chamamento à identificaçăo com personagens-tipo, o autor conclui cada retrato com uma ou várias prescriçōes, antecedidas do verbo dever ou da expressão é preciso: «é preciso urgentemente ajudá-los a estudar menos, a 'curtir' mais a vida, a integrarem-se no grupo de jovens (...) A escola năo deve ser só um sítio onde se estuda e se tiram boas notas, deve ser basicamente um local onde se aprende a viver» (p. 21); "Custe o que custar, é preciso falar com estes jovens. Claramente dizer-lhes que näo permitiremos insultos, mas estamos dispostos a ouvir as suas dúvidas. Aos pais devemos perguntar por que se deixam bater» ( $p$. 29). No terceiro capítulo, dedicado aos momentos decisivos, sāo analisadas algumas situaçōes do quotidiano dos jovens que podem conduzir a conflitos. Depois da análise segue-se a prescriçăo, muitas vezes mitigada por expressões como é desejável ou bom seria: "há uma única maneira possível de lidar com este problema: pura e simplesmente confrontar o filho com as faltas que ele ou ela andam a dar» (p. 52); «é desejável que haja programas diferentes numa família, que às vezes os pais possam sair até casa de um familiar ou amigo, ou os filhos irem a um jantar de anos ou ficarem em casa da pessoa com quem andam» (p. 55); "năo obriguem irmãos que não se dão bem ou têm idades e, portanto, necessidades bem diferentes a andar juntos em excursões pela noite» (p. 59); «bom seria que muitos pais de adolescentes estivessem atentos aos interesses dos seus filhos pelo futebol» ( $p$. 64); "os pais não devem assim desvalorizar o namoro, chamando-lhe namorico, ou passar a vida a fazer perguntas ou a dar piadas» (p. 69). Deste conjunto de prescriçōes torna-se notório o efeito pretendido: produzir uma identificação com as situaçōes, aduzindo-lhe depois uma interpretação. 
adulta, a sua perturbação, quando se mantém, é fonte de inúmeros conflitos e frustrações» (Idem, Ibidem, p. 72); «há outras famílias bem diferentes. Onde as crianças foram educadas a não esconder dos seus pais o seu dia-a-dia, onde os adolescentes foram respeitados como pessoas» (Idem, Ibidem, p. 80). O leitor é orientado para a descoberta do que, no cenário familiar, pode manifestar tensões entre dependência e medo da independência, necessidades de intimidade, vulnerabilidade e barreiras entre gerações. O discurso terapêutico sobre as emoçōes é difundido de tal forma que seja possível a cada leitor tornar-se o autor da sua própria história. O que se transmite não vale tanto pelo conteúdo e pela norma tácita que inclui, quanto pela técnica e pela linguagem: o leitor aprende uma forma de seleccionar o que é importante, a representar medos e necessidades interiores e a geri-los por intermédio da narrativa das emoções. Depois de o fazer pode e deve esquecer os casos concretos: «se apreciarem o que escrevi, façam por esquecer na mesma, porque o que não conseguirem deitar fora será suficiente para os ajudar» (Idem, Ibidem, pp. 10-11).

Neste contexto, o dispositivo da presença-ausência prescritiva é essencial à nivelação da comunicação pedagógica e à verosimilhança das tecnologias da autonomia. A presença requer a adesăo a um exemplo prescritivo sem prescriçāo; a consequência para o leitor é a de acreditar ter poder para inventar uma maneira de viver diferente, sem o ter realmente. A ausência produz-se por intermédio de um corte entre o dizer e o fazer das narrativas exemplares utilizadas nos livros; a consequência é a possibilidade de aderir inconscientemente a formas, sem o fazer necessariamente quanto aos conteúdos. Não por acaso, o autor termina o livro Inventem-se novos pais com um manifesto de onze regras, em que a última chama ao esquecimento dos conteúdos do livro: «última regra: jamais este livro será citado ou comentado em qualquer interacção familiar. Caso algum membro da família desobedeça a este preceito, outro familiar deverá deitar para o lixo o exemplar desta obra em uso indevido. Ou seja: cada família inventará diariamente a sua maneira de viver» (p. 247). E esta é verdadeiramente a principal regra das técnicas de regulação da subjectividade sugeridas pela terapia familiar: propor a todos a construção de um projecto biográfico, a criação de um estilo de vida e a configuração da existência quotidiana nos termos de uma ética da autonomia. Porém, ao conferir também a este conceito uma conotação normativa, está de facto a colocar os leitores numa situaçăo de duplo constrangimento do tipo ordeno-te que sejas livre e autónomo.

Antes de continuar havemos de situar e discutir as repercussões da relaçăo entre conhecimento científico e conhecimento do senso comum na construção da retórica discursiva. Como vimos, a técnica de escrita e de construção dos livros de Daniel Sampaio consiste em traduzir a retórica científica em retórica de senso comum. Esta 
relação tem sido estudada a partir de diferentes pontos de vista. Interessa-nos, neste particular, a argumentação realizada no campo da Psicologia Social, por Moscovici e Hewstone (1984) e por B. Sousa Santos (1989) no campo da Sociologia. No primeiro caso, reconhece-se que o conhecimento científico está condenado a ser reciclado e apropriado sob a forma de senso comum, sofrendo nesse processo efeitos não esperados, subtracções, distorções e adições. Porém, como argumenta Santos, é preciso introduzir algumas precauçōes metodológicas nesta análise, já que a caracterizaçăo do senso comum é usualmente feita a partir da ciência e, portanto, carregada de preconceitos negativos. Daí que proponha uma caracterização alternativa do senso comum em que procura evidenciar alguns dos seus traços positivos, tais como: coincidência de causa e intenção; visão do mundo assente na acção e no princípio da criatividade e da responsabilidade individual; uso de uma linguagem retórica e metafórica; incidência na persuasão em vez do ensino; reproduçăo associada às experiências de vida de um dado grupo social. A partir desta matriz podemos verificar que a técnica de escrita de Daniel Sampaio se tenta deslocar para alguns dos parâmetros do senso comum do contexto doméstico, mas sem o ónus de se situar nesse contexto, por que continua a falar do lugar da ciência. E, ao fazê-lo, confirma a hegemonia cultural de uma comunidade socialmente reconhecida como comunidade de saber universal, seleccionando uma perspectiva de senso comum, quer dizer, a que é mais conveniente à demonstração necessária das teses científicas que săo o seu substracto. Sublinhe-se que o senso comum de que fala Santos é um estado anterior à dupla ruptura epistemológica, antes que esta o conduza ao reencontro do saber científico. E que este reencontro se faz a partir da autonomia de argumentação de cada contexto. Procedendo à tradução directa do saber científico em senso comum o autor corre o risco de, em vez de distribuir de forma mais equitativa as competências interpretativas, escamotear eventuais contradições e apoucar definições alternativas, substituindo-se à dinâmica própria do senso comum. Uma das maiores limitações deste tipo de técnica de tradução da linguagem científica em linguagem do senso comum consiste na parcialidade. Daí a tendência para o enviesamento das acçōes seleccionadas que, ao favorecer um certo tipo de acontecimentos, constitui um corpus de dados compreensivo, mas que mais não é do que o corpus da preferência do investigador. Ora, como sublinha Santos (1989: 182-183) «se o objectivo é ampliar o espaço de comunicação e distribuir mais equitativamente as competências argumentativas, os limites e as deficiências de cada um dos saberes locais superam-se, transformando esses saberes por dentro, interpenetrando-os com sentidos produzidos noutros saberes locais, desnaturalizando-os através da crítica científica. É fundamental que essa transformação ocorra no seio de cada um dos contextos estruturais - doméstico, 
da produção, da cidadania, da mundialidade — para que possa ocorrer em todos os outros contextos de interacção a cada momento feitos, desfeitos, refeitos na nossa sociedade».

Delimitada a problemática da relação entre senso comum e conhecimento científico podemos dar um passo mais na análise das tecnologias da narrativa e da comunicaçăo. Analisaremos sucessivamente o cenário da narrativa, as imagens e a linguagem criada para o seu desenvolvimento, as técnicas de diagnóstico e as interpretações produzidas. Em primeiro lugar vem o cenário em que o encontro terapêutico ou a entrevista tem lugar. Cada pessoa do grupo familiar é situada num campo democrático, aparentemente igualitário, de confissão e de julgamento simultâneo por todos: «Daniel — numa família é importante que cada um fale por si. Todos vão ter oportunidade para falar» (Sampaio, 1994: 156); "Daniel — de todos os problemas que os preocupam, vamos seleccionar um. Podem discutir os três e decidir por onde vamos começar» (Idem, Ibidem). A veracidade do espaço democrático é acentuada pelos papéis moderadores mais frequentes do terapeuta: fazer perguntas que fornecem uma orientação para a discussão; examinar as respostas e os argumentos, dando-lhes uma interpretação; chamar à participaçăo no diálogo, ou nas decisôes, quando há pontos de vista concorrentes ou elementos que participam pouco. Todavia, este é um espaço ficcional onde a democratizaçăo do espaço terapêutico se faz pela transferência do poder patriarcal para o terapeuta. Na verdade, o desnivelamento das relações no contexto doméstico e a politização do seu funcionamento, quer dizer, a democratização das suas decisões, à imagem do contexto da cidadania, nunca chega sequer a ser enunciado. Pelo contrário, são as hierarquias escolares e familiares que se recordam e reafirmam: «aos pais devemos explicar-lhes que na aula é o professor que coordena e na família săo os pais que mandam» (Idem, Ibidem, p. 29). Importaria, talvez, reconhecer ainda que, no gabinete de consulta, manda o terapeuta.

Durante a interaç̧ăo, o especialista reconduz subtilmente o sujeito, sempre que precisa, para uma relação com novas imagens mais envolventes porque mais de acordo consigo próprio, isto é, com a representaçăo que o próprio terapeuta tem das necessidades do adolescente. Numa dada sessão, quando a mãe descreve os insultos de que foi alvo por parte do filho, quando tentou entrar na casa de banho, o terapeuta pergunta ao adolescente «por que razão não fechaste a porta à chave?». A imagem da privacidade é então eleita como uma questão fundamental da autonomia adolescente, provocando uma alteração da imagem dominante no encontro terapêutico. Da má educação passa-se à privacidade: «pareceu-me que neste momento entrávamos numa questăo fundamental — a privacidade necessária à autonomia adolescente. Era como se a família não tivesse fronteiras, não estava definido o papel de cada um, 
o espaço individual era constantemente invadido por outro. Na intimidade necessária ao crescimento adolescente, a passividade do pai e a ansiedade da mãe irrompiam no vivido do Pedro. Foi possível ir mais longe e verificar que naquela casa ninguém fechava as portas, tudo aparentemente era conhecido de todos» (Idem, Ibidem, p. 160).

A persuasão é também uma tecnologia presente, através de formas muito contrastadas, que podem ir da interpretação coerciva até à sugestão ou à interrogação pura e simples. A interpretação coerciva irrompe sempre que as narrativas e as observações dos sujeitos são integradas em imagens transcendentes de normalidade, vida familiar, sexualidade e responsabilidade pessoal, tais como: "Daniel — pois, mas há famílias onde essa coisa aparentemente simples que está a dizer de estarem os quatro à mesa não acontece. As pessoas perderam um pouco o hábito de se sentarem em volta de uma mesa. Cada um come à sua hora e numa bandeja» (Idem, Ibidem, p. 111); «Daniel - eu acho que isso é muito importante porque a certa altura eles começam a vida sexual muito mais cedo do que nós começamos e isso assusta muito os pais. Alguns pais ficam muito assustados com isso, mais com as raparigas. Muitas vezes desatam a fazer muitas perguntas e eles retraem-se muito» (Idem, Ibidem, p. 89); «Daniel - é importante admitir que erram? (...) Não é muito frequente porque os pais sentem-se muito postos em causa pelos filhos em relaçăo a muita coisa e têm muita dificuldade em admitir que erram. Eu, por exemplo, acho importante que a certa altura a pessoa possa reflectir e achar que exagerou» (Idem, Ibidem, p. 99). Os comentários parecem limitar-se a descrever situações ou a parafrasear, mas, pelo contrário, constituem interpretaçōes definitivas dos relatos produzidos pelos entrevistados. Como se o terapeuta inscrevesse uma conclusão lógica e evidente naquilo que fora dito anteriormente.

Outras vezes é a técnica da interrogaçăo que persuade e conduz os fragmentos da narrativa para uma história coerente e sequencial, onde o narrador é simultaneamente actor e autor da sua própria vida: «O permanente contexto acusatório, em 320 que os pais criticavam o filho e este respondia com crescente agressividade, a não ser alterado, conduzia a uma repetição, na sessão, das disputas familiares. Lembrei-me entăo que o Pedro se interessava muito por música, fazia parte de uma banda rock e queria aprofundar os seus conhecimentos musicais. Daniel — vamos falar de outra coisa. As colegas que falam com o Pedro individualmente falaram-me do seu interesse pela música. Queres falar um pouco disso?» (Idem, Ibidem, p. 162). Noutra ocasiăo, a interrogação persuade a um olhar para dentro, para os traumas pessoais ou familiares: «Daniel - se calhar os pais têm outras coisas que os fazem menos atentos, outras preocupações, talvez mais antigas [dirigindo-se ao pai do adolescente que relata 
o episódio traumático da trágica morte do seu próprio pai na infância] O senhor quer falar um pouco sobre isso?» (Ibidem, Idem). E é este sucessivo caminhar de fora, dos comportamentos mais quotidianos, e mais próximos, para dentro, para a biografia de cada um e para a história das suas emoções, que marca o caminho da autonomia: «a única forma é ajudar estas famílias a encontrarem uma alternativa a partir de si próprias» (Idem, Ibidem, p. 174). A regra da terapia é assim confirmada, por que estabelece que os sujeitos estão destinados a deixá-la e a viver a sua vida. Contudo, as técnicas terapêuticas também têm uma regra de descontextualização que lhes permite acompanhar o sujeito em toda a sua vida. Para tanto, as técnicas de exame e avaliação do self são objecto de transmissão e educação específica.

Uma das técnicas de exame usadas consiste na elaboração de diários do tipo confessional. A família no seu conjunto, ou alguns dos seus elementos, são chamados a manter um registo quotidiano de pensamentos, das dificuldades concretas e das formas de as resolver: «ao prescrever a todos a tarefa de registarem, durante um mês, as dificuldades resultantes das novas regras estabelecidas, pretendi implicar desde o início toda a família num necessário processo de mudança» (/dem, Ibidem, p. 158). Este é o primeiro passo de uma longa aprendizagem da avaliação do self e de diagnóstico dos seus avanços e recuos, operando uma reestruturação das práticas sobre as quais a relação se apoia. Caracterizamos como confessional esta técnica porque ela está implicada na produção da verdade - a verdade de cada indivíduo e do conjunto da família. Mas, contrariamente ao regime de verdade do contexto da cidadania, baseado no poder legal, no contexto da relação terapêutica surge como dádiva, uma iniciativa do próprio, reforçada ainda pelo poder autobiográfico da escrita. Através desta, cada indivíduo pode adquirir a sua autonomia e escolher com conhecimento interior o que é bom e o que é mau para si. Ora, os autores dos registos escrevem nos seus termos uma linguagem que já está dita, que está presente e é actualizada pelas fórmulas do terapeuta. Não que esta arte da narrativa escrita dê continuidade ao tradicional projecto de interiorização das normas sociais. Inversamente ao projecto de socialização da modernidade inicial, ancorado na relação com um modelo exemplar, esta técnica pretende fazer da vida de cada um uma obra que integra certos valores e um estilo pessoal. Deste modo, os atributos pessoais adquiridos são-no por alguém que procura transformar-se a ele próprio como um exemplo para os outros. É todo um modo de se constituir como sujeito que tem em relação a si cuidados de reflexăo especiais. E esse é um trabalho que exige a subjectivação das normas sociais num projecto de total desenvolvimento pessoal. A relação com o self assim produzida dá um especial relevo à escrita porque acredita na modificação da sua maneira de ser e dos outros por esse meio. 
Daí que se assista à revalorizaçăo, entre os adolescentes, de uma escrita confessional, na forma de diário, de carta, de registo diário de dificuldades ou de diálogo cibernauta, que não condiz com a vox populi que prognostica a morte da escrita e a ascensão transbordante da oralidade nos actuais estilos de vida juvenis. $\mathrm{O}$ papel da narrativa exemplar, como modo de transformaçăo do próprio, é bem visível em formas mais complexas de registo confessional. Tomemos como exemplo os relatos de experiências de amor de dois adolescentes que o autor transcreve num dos livros (Idem, Ibidem, pp. 72-79). Um dos relatores é tratado pelo terapeuta-autor há bastante tempo. Também por isso, parece perfeitamente socializado nos métodos de auto-reflexăo e narração. Um dos aspectos mais interessantes das narrativas é a procura constante de domínio de si, especialmente dos desejos e dos prazeres. Escreve um dos adolescentes: "é também nesta altura que surgem e se desenvolvem as grandes paixões, com o rigor da juventude e com a pretensão de se julgar ter idade para se saber o que se quer. Mas seja como for, é assim que nós queremos e como é no nosso querer que está o poder, então é melhor termos muito cuidado com o que queremos» (Idem, Ibidem, p. 74). O relato inicia-se, pois, com o modelo de auto-reflexāo escolhido: porque o adolescente almeja a autonomia do seu querer deve ter uma relação agonística consigo próprio, desconfiar de si, sujeitar-se a um escrutínio rigoroso. Depois de relatar uma infância infeliz, marcada pela separação dos pais, continua o seu relato confessional no mesmo registo: «quis o destino que eu conhecesse uma bela menina que me encheu não só os olhos, mas também o coração. Quis conhecê-la bem e acabou também por possuir a minha mente. Começámos a namorar e de um momento para o outro esqueci tudo» (Idem, Ibidem, p. 76). Segue-se o relato da primeira discussão, do caos instalado na vida do adolescente, dos estudos que correm mal e da inevitável separação. A tentativa de suicídio sobrevém, embora mal sucedida e o ano escolar está perdido. Começa então o relato do renascimento, como o próprio designa o processo de moderação dos sentimentos que se segue. A esta percepção do prazer como força temível que é preciso controlar, corresponde, do outro lado, da subjectividade do jovem contendor, uma construçăo de si como adversário vigilante que procura domar as piores consequências do amor e do desejo: "os problemas estão todos na mesma. Pelo menos aqueles de que eu me queixava, mas agora o que mudou fui eu. $\mathrm{O}$ que mudou foi a minha capacidade de suportar os problemas (...) Nunca estive tão mal como agora, no entanto estão-se a criar as infra-estruturas para eu poder criar uma nova vida» (Idem, Ibidem, p. 78).

Esta narrativa situa-se num eixo de luta e resistência que se permite retirar prazer da moderação, sem renunciar ao amor. Por isso a narração termina, citando, com evidente agrado, uma das máximas utilizadas nos encontros semanais pelo terapeuta: 
"o óptimo é inimigo do bom». Mas a batalha a travar é sobretudo um processo interno, que tem lugar de si para consigo. Os sentimentos são acontecimentos que passam a ser resguardados por um dispositivo que os arruma no espaço privado. Depois da exposição pública vem o privatismo: «em relação a Ela, năo esperem que vos diga o que hoje em dia sinto, até porque se calhar ela virá a ler tudo isto" (Ibidem, Idem). Esta é uma outra forma de confirmar o princípio inscrito neste tipo de narrativas exemplares. Contrariamente ao princípios normativo do faz como eu digo ou do faz como eu fiz, apresenta-se o princípio do self autónomo: faz-te como eu me fiz. Neste final concentra-se um dos principais efeitos destas novas formas de construir a família e a adolescência. Produz-se uma alteração das tradicionais fronteiras entre o espaço público e o espaço privado, que consiste num avanço simultâneo do espaço público para o interior da família, por meio das profissões terapêuticas, e do espaço privado para o interior de cada um, por meio da ética da autonomia individual. 0 adolescente com problemas de desenvolvimento passa a constituir o ponto de ligação entre a escola, a família e os especialistas. Este avanço é, simultaneamente, um recuo porque as novas subjectividades assim constituídas parecem ser sujeitas a um processo narcísico, fazendo da realidade social coisa individual, pela necessidade de a fazer circular como comunicação, em que cada um corre o perigo de perder as suas últimas características próprias, na procura de uma identidade mítica que já não é a sua, mas aquela que a cultura dominante lhe devolve em imagem narcísica satisfeita consigo mesma. Embora a subjectividade possa aparecer como a nossa mais íntima esfera da experiência pessoal, a sua promoção como valor ético e político contemporâneo é inextricável da expansão das linguagens psi. São elas que fornecem as técnicas e as retóricas que habilitam o homem contemporâneo a pensar-se. Processo narcisista que surge mais nítido quando o referenciamos a outros contextos institucionais e a outras profissões da autonomia. Analisemos então com mais detalhe o cenário ético escolar.

\section{Modo de sujeição}

A subjectivação do trabalho escolar envolve a saturação do corpo do futuro diplomado do ensino secundário com signos contraditórios: por um lado sensaçōes, emoções, desejos e aspirações; por outro, cálculo, optimização de objectivos e racionalidade de meios. A transformação do trabalho escolar em uma matéria de realização pessoal e identidade psíquica, surge associada ao cálculo dos benefícios económicos ou de influência social futuros. A emergência de um discurso sobre o papel da «confiança nas possibilidades e capacidades próprias» no desenvolvimento 
sócio-moral tivera já, como vimos, um ponto de inserçăo importante nos relatórios de avaliaçăo do ESU, mas é no Perfil cultural desejável do diplomado do ensino secundário (1988) que atinge cumes de teorização e articulação entre diferentes saberes, com a consolidaçăo definitiva do conceito de autonomia. Enquanto nos relatórios do PAESU esta constituía uma probabilidade, no perfil desejável apresenta-se como um atributo inato. A autonomia é definida a partir de dois critérios: um critério moral, sustentado na teoria do desenvolvimento sócio-moral de R. Kegan (1982) e um critério de motivaçăo, necessidade de sucesso e espírito empreendedor ancorado nas teorias de McClelland (1961).

No primeiro caso, a autonomia é designada na negativa, por aquilo que năo deve ser: «Esta autonomia que se opõe tanto à dependência como à desconfiança de si $\mathrm{e}$ timidez» (Ibidem, p. 49). O estado de autonomia requer, portanto, competências de interacção e relacionamento social que devem ser promovidas nas práticas pedagógicas. No segundo caso, a autonomia é estabelecida positivamente e tem evidentes pressupostos e repercussões na racionalidade económica: «estar disposto para lançar as bases do seu próprio posto de trabalho se essa for a melhor via de realizar os seus valores e interesses» (Ibidem, p. 49); "planear as suas actividades a longo e médio prazo de modo a que possa estabelecer prioridade de objectivos e racionalidade de meios» (Ibidem, p. 57).

No seu conjunto, esta dupla definição de autonomia coincide com o perfil do individualismo possessivo que alguns autores anglo-saxónicos tomam como tipo-ideal das sociedades liberais de matriz protestante: uma visão ontológica dos indivíduos enquanto origem e guardiões das suas próprias capacidades. O quadro da página seguinte resume algumas das capacidades e traços inerentes ao futuro diplomado do ensino secundário, bem como as práticas pedagógicas destinadas a promovê-los.

Um rápido exame deste quadro torna evidente que os comportamentos e atitudes que a escola se propõe desenvolver mantêm uma relação funcional entre os indivíduos e a estrutura social. A participação e a educação para a cidadania sobressaem, mas a relação com a estrutura económica está também presente noutras passagens: «exigindo a sobrevivência (do país) uma resposta de desenvolvimento, de modernizaçăo e um espírito de inovação e criatividade, há que compreender que estamos num momento de viragem. Isso deve ser tido em conta ao traçarmos o perfil do jovem saído do $12 .^{\circ}$ ano da escolaridade. Jovem que não continuará a ser protegido por uma instância pública, distante e omnipresente (guarda-chuva para as incapacidades), uma vez que irá deparar com a concorrência dos compatriotas e dos outros cidadãos europeus» (Ibidem, p. 42). 


\section{Quadro 21 - Capacidades e Práticas pedagógicas do perfil desejável do diplomado do ensino secundário}

\begin{tabular}{|l|l|}
\hline \multicolumn{1}{|c|}{ CAPACIDADES } & PRÁTICAS PEDAGOGICAS \\
\hline Interesses pessoais & - Participação activa do aluno \\
Aspiraçōes & $\begin{array}{l}\text { - Liberdade para a gestão dos } \\
\text { tempos livres e tempos de estudo }\end{array}$ \\
Integridade & $\begin{array}{l}\text { Aceitaçăo da defesa dos } \\
\text { interesses académicos ou pessoais }\end{array}$ \\
Valores & $\begin{array}{l}\text { Responsabilização dos alunos } \\
\text { na elaboração das regras de conduta }\end{array}$ \\
Realizaçăo & \\
\hline
\end{tabular}

O traço comum dos discursos psicologizantes sobre as capacidades intrínsecas ao desenvolvimento individual sublinham a ideia de que a sociedade é melhorada pelo esforço de cada um dos seus membros, em ordem à melhoria das suas posições e destinos, através da participação política, do trabalho árduo e produtivo e do espírito empreendedor. Esta gramática das formas de vida autónoma é inteiramente consistente com a visão liberal democrática da sociedade e do indivíduo, segundo a qual a capacidade de adaptação e de ser um agente de mudança, num mundo em constante mutação, faz parte da própria realização individual. O aluno autónomo é, antes do mais, aquele que se sente realizado na profissão futura, suficientemente flexível para se adaptar às mudanças tecnológicas e motivado para continuar a sua formação ao longo da vida (Ibidem, p. 65).

A equação tailorista da produção de massa, assente na correspondência entre posto de trabalho e destrezas necessárias para o seu desempenho, é substituída pelas referências pós-fordistas da especializaçăo flexível, da democratização do trabalho e da previsivel nova divisão internacional do trabalho. As homologias entre os novos regimes de acumulaçăo pós-fordistas e as propostas de perfil săo evidentes e muito directas. Utilizando como referência o quadro síntese dos regimes de acumulação alternativos ao fordismo, proposto por Boyer (1992: 28), podemos ter uma primeira aproximação a tais homologias. Lado a lado apresentamos as consequências previsíveis de cada regime de acumulação nas habilitações no quadro de uma nova 
organizaçăo industrial, e os traços homólogos previstos no Perfil desejável do futuro diplomado do ensino secundário. ${ }^{36}$
Quadro 22 - Comparação das habilitaçōes previstas na nova organização do trabalho e os traços homólogos do Perfil desejável
(adaptado de Boyer, 1992)

\begin{tabular}{|c|c|c|}
\hline & $\begin{array}{c}\text { HABILITAÇOES E RECICLAGEM } \\
\text { NA ORGANIZAÇÄO } \\
\text { INDUSTRIAL. }\end{array}$ & $\begin{array}{l}\text { CARACTERISTICAS DO PERFIL } \\
\text { DO JOVEM DIPLOMADO DO } \\
\text { ENSINO SECUNDARIO }\end{array}$ \\
\hline $\begin{array}{c}\text { DEMOCRATIZAÇÃO } \\
\text { DO TRABALHO }\end{array}$ & $\begin{array}{l}\text { - Actualização das } \\
\text { habilitaçőes pode resultar } \\
\text { da motivaçăo dos } \\
\text { trabalhadores através da } \\
\text { democratizaçăo. } \\
\text { - Aprendizagem pelo próprio } \\
\text { processo de trabalho. }\end{array}$ & $\begin{array}{l}\text { - «Possui uma base sólida de cultura } \\
\text { humanística e cientifica que lhe } \\
\text { permite a escolha de uma profissáo } \\
\text { em que se sinta realizado, a } \\
\text { flexibilidade para se adaptar à } \\
\text { mudança tecnológica e a motivação } \\
\text { para continuar a sua formação ao } \\
\text { longo de toda a vida» (p. } 65 \text { ). } \\
\text { - «Desenvolvimento de um espírito } \\
\text { de criaçăo e inovaçāo nas várias } \\
\text { áreas do saber, a aquisiçăo de uma } \\
\text { grande flexibilidade e agilidade } \\
\text { mental para a mudança contínua de } \\
\text { tecnologia» (pp. } 61-62 \text { ). }\end{array}$ \\
\hline $\begin{array}{l}\text { ESPECIALIZAČÃO } \\
\text { FLEXIVEL }\end{array}$ & $\begin{array}{l}\text { - São desejáveis } \\
\text { trabalhadores } \\
\text { polivalentes. } \\
\text { - Modernização do artesão } \\
\text { proudhoniano através da } \\
\text { microelectrónica. }\end{array}$ & $\begin{array}{l}\text { - «Estar familiarizado com as } \\
\text { possibilidades da moderna } \\
\text { informática, podendo pelo menos } \\
\text { utilizar programas de } \\
\text { processamento de texto, base de } \\
\text { dados, folhas de cálculo e correio } \\
\text { electrónico» ( } p .67 \text { ). } \\
\text { - «Ter adquirido competência } \\
\text { técnica pelo menos numa área do } \\
\text { saber-fazer que lhe permite alguma } \\
\text { ocupação remunerada imediata, } \\
\text { caso o queira» (p. } 67 \text { ). }\end{array}$ \\
\hline $\begin{array}{l}\text { REGIME DE } \\
\text { CRESCIMENTO } \\
\text { INTERNACIONAL }\end{array}$ & $\begin{array}{l}\text { - Possibilidade de uma } \\
\text { nova divisāo do trabalho: } \\
\text { as indústrias de média e } \\
\text { alta tecnologia podem } \\
\text { estender-se à periferia. } \\
\text { - Nova polarização de } \\
\text { habilitaçóes. }\end{array}$ & $\begin{array}{l}\text { - «Uma estrutura de conhecimentos } \\
\text { e capacidades que o habilitem a } \\
\text { fazer face aos desafios da } \\
\text { sociedade moderna, da integraçăo } \\
\text { na CEE e do novo papel de } \\
\text { Portugal no mundo» (p. 61). }\end{array}$ \\
\hline
\end{tabular}

(117) Utilizamos propositadamente a tipologia de Boyer, por que esta problematiza modelos teóricos alternativos e não analisa realidades empíricas. O Perfil desejável constitui também um modelo de problematizaçăo, embora bastante normativo e prescritivo que, em grande medida, imagina um regime de acumulação post-fordista completamente incipiente ou inexistente em Portugal. 
O que sobressai deste quadro é a imagem do futuro produtor cindida dentro de si mesma: por um lado, os que seguirão uma formação profissional, orientada para o trabalho manual pouco qualificado; por outro lado, os que seguirão uma formação geral, longa, orientada para o trabalho mais qualificado. Tal dicotomia está, no entanto, destinada à intercomunicação e reprodução permanente por via de uma correcção das tendências que a radicalizam. No passado, a dicotomia correspondia a fileiras separadas de ensino - o liceu e a escola técnica e comercial. Agora, a decisão é remetida para as capacidades individuais, para a motivaçăo e para a realização pessoal, isto é, para o mérito de cada um. É o nível de autonomia, de auto-estima e de auto-realização que decidirá o destino de cada um. As propostas de correç̧ão de tendências negativas na sociedade portuguesa apenas confirmam a continuidade futura da dicotomia, por que esta está inscrita no mais fundo das capacidades próprias de cada um: "quanto a este aspecto convém corrigir duas tendências na sociedade portuguesa: a tendência para a especializaçăo precoce quer dos que trabalham manualmente, quer dos que prosseguem os estudos, deixando os primeiros sem capacidades de reciclagem e modernização, e deixando os segundos sem capacidade de emprego imediato ou facilidade na aplicaçăo concreta de conhecimentos abstractos adquiridos; a tendência para a especialização precoce e rígida nalgumas áreas do saber, atrofiando assim importantes dimensōes humanas» (Ibidem, p. 63).

Deste modo se confirma duplamente a dicotomia educaçăo-trabalho. Em primeiro lugar, porque a tentativa de articular no mesmo plano de estudos conhecimentos canónicos e conhecimentos práticos parte do pressuposto de que pode existir uma relação sequencial entre educação e trabalho. Tal relaçăo acredita na possibilidade de fazer corresponder estavelmente os fluxos de titulação com a oferta de empregos. Ora, se alguma coisa ficou demonstrado nos anos que o Perfil desejável analisa, foi a desconexão estrutural entre a produção de qualificações pelo sistema de educação e as qualificações requeridas pelo sistema produtivo. (Santos, 1994; Correia, 1997). Em segundo lugar, e contribuindo também para esta desconexão, a acelerada transformaçăo dos processos produtivos e de serviços faz com que a educação seja um processo tendencialmente simultâneo aos processos produtivos. Ora, a descoincidência entre os tempos da formação e os tempos da sua aplicação são cada vez maiores, por força do prolongamento da escolaridade e do efeito de parqueamento originado pelo aumento do desemprego juvenil. Daí que as propostas de reforma surgidas nos anos oitenta, não podendo descuidar a resposta à procura social de educaçăo, por evidentes motivos de legitimaçăo, e não conseguindo produzir perfis profissionais adequados, por notória improbabilidade de o sistema produtivo estabilizar as suas necessidades, optem por desvalorizar os conteúdos e sobrevalorizar 
a autonomia do aluno. Esta passa a constituir o substituto funcional de uma relação educação-trabalho desejada, mas improvável.

Porém, a autonomia, como entidade ontológica global, năo circula apenas no espaço público da escola, contendo outras esferas, públicas umas, privadas outras: relações com os pais, sexualidade, regime alimentar, estilos de vida e de apresentação, emoções, medos, relações amorosas, desejos e por diante. Constitui-se assim uma linha bissectriz entre o público, o doméstico e o privado onde é possível pôr em contacto aspiraçōes sociopolíticas tradicionais do sistema estatal de ensino com desejos e frustrações, até então do domínio privado, no processo de afirmação e realização pessoal. Nestas esferas de governo da autonomia actuam, entretanto, como vimos, outros especialistas: psiquiatras, terapeutas da família, médicos e psicólogos. No mesmo lance de dados, a autonomia do aluno garante a criação de um nódulo onde se encontram discursos até então desconectados.

O segundo elemento da homologia entre o pós-fordismo e o perfil do futuro diplomado diz respeito à simultaneidade dos operadores linguísticos utilizados num e noutro caso: flexibilidade, adaptabilidade e realização săo traços que definem as capacidades e disposições a desenvolver pela escola e que coincidem com os novos contextos de trabalho. A competência em destrezas específicas de trabalho dá lugar a uma fórmula bem mais exigente, que podemos expressar, adaptando uma outra inscrita num relatório da OIT,(118) do seguinte modo: Adapto-me + Percebo + Sou capaz + Realizo-me = Capacidade para o trabalho.

O terceiro aspecto da homologia está directamente relacionado com a lógica da autonomia. A autonomia não é uma finalidade a obter no final de um determinado percurso; também não é um instrumento destinado a garantir certos efeitos e aquisições; é uma capacidade prévia que todos têm e que pode ser potenciada por uma adequada prática pedagógica, ou retraída por uma pedagogia desadequada. Não por acaso, o perfil do aluno autónomo é desenhado a partir dos métodos, mais do que dos conteúdos; da forma mais do que da substância: «ensinar a procurar e analisar a informação deve ser a preocupação dominante de todos os professores. Tal competência é com efeito mais importante que a absorção de qualquer conhecimento que depressa pode ser desactualizado» (Ibidem, p. 69). O aluno passa a ser o conteúdoforma, coincidindo aliás com o lugar-comum pedocêntrico, segundo o qual o aluno

(118) Este relatório da OIT expressa as novas capacidades requeridas pelo trabalho do seguinte modo: I understand it + I can do it + I care about it = capacity. 
deve estar no centro dos processos de aprendizagem e da escola. É neste contexto que as noçōes e as tecnologias do Aprender a aprender e do Aprender a estudar cumprem o seu papel disciplinador (ver quadro das Tecnologias de si).

O ressurgimento da subjectividade no contexto escolar não pode ser encarado como um fenómeno separado de outros contextos, em especial dos novos contextos de trabalho, reais ou imaginários. Os novos procedimentos de uma pedagogia do concreto, centrada na resolução de problemas ou na pedagogia do projecto dá uma nítida prioridade dos procedimentos sobre os saberes. Estes são considerados na sua precaridade de saberes provisórios e efémeros. As situações de trabalho escolar propostas visam a formaçăo geral da pessoa e năo a formaçăo para um posto de trabalho: formação na tomada de decisões, formação no trabalho de equipa e na colaboraçăo, desenvolvimento das capacidades de adaptação, desenvolvimento das relaçōes humanas e de camaradagem. Deste ponto de vista, as tecnologias pedagógicas propostas apresentam uma adequação funcional bastante evidente com as novas representações de um mercado de trabalho em que os perfis profissionais estāo em constante mutação. Uma socializaçăo escolar não-profissionalizante, centrada na inovação, na ambição pessoal e numa atitude positiva perante o trabalho intenso e em equipa seria uma matriz essencial às exigências actuais dos processos produtivos (Santos, 1994: 172).

A pedagogia do concreto e a atençăo dada aos saberes envolvidos nas práticas de si e de si com os outros não são uma invenção contemporânea ou uma novidade completa. Os antigos princípios comunitários parecem presidir ao perfil proposto. Confiança, proximidade entre os seres, calor afectivo, globalidade do ser põem em primeiro plano a inserçăo futura no meio ou na comunidade. Seria no entanto inexacto ver nestas reflexōes sobre o valor da subjectividade individual apenas a manutenção de uma velha tradição pedocêntrica rousseauiana (Mónica, 1997). E, certamente, mais anacrónico seria presumir que estas problematizaçōes teriam alguma continuidade com as chamadas pedagogias não-directivas que, em Portugal, nunca tiveram mais que ténues manifestações. Como veremos, pelo contrário, é num ambiente de neodirectivismo e de racionalização do acto pedagógico, por força da presença hegemónica da Pedagogia por objectivos, que a subjectivação deve ser analisada. É certo que năo se deve desconhecer o que pode haver de continuidade e de reactivação discursiva. $\mathrm{O}$ discurso pedagógico sempre primou por esse movimento de vaivém entre fórmulas cuidadosamente mantidas e a sua reactivação, anos passados, em contexto político-institucional muito diverso e com objectivos completamente díspares. Tudo se passa como se a pedagogia tivesse escassos recursos intelectuais à sua disposiçăo, que não Ihe permitissem fazer mais do que misturar, em proporçōes diversas, discur- 
sos e instituições anteriormente formalizadas. No entanto, há muitos modos de à geração actual fazer regressar textos passados: o divulgador que cita, o historiador que interpreta e reconstrói, o crítico que desconstrói, o senso comum que se apropria e renova, os especialistas que problematizam. O que significa que o texto original nunca é reproduzido nas condições iniciais da sua produçăo. Neste caso, uma parcela do discurso rousseauiano e dos seus divulgadores funciona como um depósito de formas e conteúdos dispersos, tornando-o ambíguo pela sua simplicidade e opaco pelo excesso de visibilidade. A sua actualização é, simultaneamente, uma nova estratificação que os integra em outros conjuntos discursivos. A esta operação damos o nome de deslocamento e consiste esta em reactivar enunciados antigos, reconhecíveis pelo communis sensus do auditório electivo, em contextos institucionais contemporâneos. Neste deslocamento constituem-se novas regularidades e dispersões, isto é, novos relacionamentos de força que determinam regras singulares e, portanto, modificações no diagrama final das forças. As modificações não dependem de um novo significado que é aposto pelo presente ao significado original, verdadeiro, do enunciado. Os discursos não são meros sistemas de significados, por que fazem eles próprios parte de dispositivos técnicos e práticas que dão um lugar e um estatuto aos que o fazem, de tal modo que aquele apenas se torma inteligível em relação ao conjunto de conexões técnicas e discursivas que o compõem. Daí que o deslocamento não seja discernível por uma exegese hermenêutica que tende a conferir à origem um valor absoluto. Teremos então que captar o ponto de encontro das séries discursivas e verificar como se actualizam, se remodelam e se redistribuem.

Feito este ponto de ordem, continuemos a discussão. As diferenças sociais são remetidas à sua ínfima expressão individual, reduzidos que são os mecanismos de poder derivados da exploração a intrigantes, porque desconhecidos («por qualquer motivo»), meios de atingir "níveis saudáveis de autonomia». O redactor do Perfil desejável descreve do seguinte modo as contradiçōes básicas da sociedade: "o desenvolvimento do indivíduo projecta-se sempre na sociedade que ele forma. Em sociedades em que grande parte das pessoas atingiu níveis saudáveis de autonomia e integração, as relações humanas, legais e económicas são caracterizadas por um sentido profundo de democracia, liberdade, justiça e colaboração. Em contraposição, sociedades em que, por qualquer motivo, grande parte dos indivíduos não atingiu níveis saudáveis de autonomia, são sociedades em que tanto na vida civil como religiosa e económica, dominam as relações de dependência, exploração e opressão. Os poucos que exploram os muitos não atingiram a verdadeira autonomia, fazendo lembrar crianças que ainda julgam que o mundo anda à volta delas. Os muitos que se deixam explorar ou que se habituaram à dependência, perderam o 
estatuto de adulto, e portanto da capacidade criadora e a motivação de progredir » (Ibidem, pp. 40-41).

Neste quadro simplificado e vulgar das teorias do desenvolvimento sócio-moral a democracia, a justiça e a liberdade são concebidas de forma normativa. Os antagonismos sociais săo explicados a partir de um sujeito unitário, abstracto, que foge ao estado de autonomia. A multiplicidade de posições do sujeito é vertida num conceito racionalista de um indivíduo homogéneo, anulando assim, num lance único, a variabilidade das suas identidades e a diversidade das relações de subordinação que o podem afectar. Os sistemas educativos estatais não se limitam a formar o cidadão autónomo e responsável, entidade universal e abstracta que legitima a lealdade de cada um para com o Estado. Pelo contrário, formam subjectividades diferenciadas segundo o género, a classe e a etnia (Green, 1994): o trabalhador diligente e dócil, o profissional conhecedor e independente, o contribuinte complacente, o soldado honrado, o pai prudente e moderado, a boa mãe consciente dos deveres domésticos, o empresário racional e eficaz, o imigrante integrado e aceite. Quais os códigos de conduta e de conhecimento que sustentam estes perfis normativos? A que tipo de valorização ética estão associados? Os princípios de justiça em que se fundam são universais? Como podemos apreender esta multiplicidade de relaçōes de subordinação que podem afectar um indivíduo se os encararmos como entidades homogéneas? Contrariamente a esta sugestão, fundada nos pressupostos do liberalismo político e económico e em alguns modelos normativos de desenvolvimento sócio-moral, parece-nos decisivo sublinhar a heterogeneidade e especificidade de modelos que assistem a práticas sociais diversas e a contextos estruturais não homólogos. A unificação das práticas de subjectividade deve antes ser entendida como um esforço de certos programas políticos e científicos; não como o resultado inevitável da natureza ou da cultura humanas.

\section{Práticas de si}

As tecnologias de si são mecanismos de auto-regulação que mobilizam práticas de experimentação, compreensão e julgamento da conduta própria. Tais práticas são realizadas sob tutela de um regime de verdade, seja ele pedagógico, psicológico, terapêutico ou familiar. Em cada um destes campos, o que está em causa é a relação de reciprocidade entre o corpo de conhecimentos e de práticas e a produção mesma do self. Melhor que ninguém, Foucault analisou, no seu último período, o processo histórico do desenvolvimento heterogéneo de poderes nas sociedades modernas, para nos permitir a conclusão de que a obrigação de ser livre e autónomo se tornou na 
forma moderna de dominaçăo da subjectividade, cuja eficácia reside na desconexăo entre os poderes centrais e a regulaçăo interna das esferas institucional, doméstica e individual. Trata-se de um processo heterogéneo e não totalizante, em que as ciências humanas ocupam um lugar central, por que intervêm nos vários segmentos de subjectividade em que o indivíduo circula, reconstruindo-o depois enquanto eu autónomo. É importante reconhecer que a proposta central de Vigiar e Punir (1975), de uma subjectividade à imagem e semelhança da institucionalização das disciplinas na escola, no asilo, na prisão, nos quartéis, na família — , evoluiu para um projecto de análise do rasgão aberto entre a imposição de controlos de conduta e as formas de vida adoptadas por cada indivíduo. É precisamente neste rasgão que as técnicas e os vocabulários da pedagogia e das psicociências operam, cerzindo, a reconstrução de um sujeito unitário, como fonte primeira da inteligibilidade das suas acções.

Parece-nos profundamente desadequada a visăo de alguns cientistas sociais que vêem na expansão das terapêuticas uma simples extensão da regulação estatal sobre o conjunto social. A este propósito, os debates em torno das teorias de Foucault e Habermas sobre o poder (ver Miller, 1987; Kelly, 1994) proporcionaram momentos de aprofundamento dos argumentos, que recolocaram bem as posiçōes desenvolvidas por Foucault nos anos oitenta (Foucault, 1988), nas liçōes do Colégio de França e nas conferências americanas (Dreyfus e Rabinow, 1983; Rabinow, ed., 1984). Nestas fica claro que Foucault designa o poder como um modo de acção sobre a acção de outros, que assim estrutura o campo de possibilidades da sua acçăo. As relaçōes de poder estabelecidas atravessam o conjunto das relações sociais, na forma de jogos estratégicos entre liberdades. Criticando a ideia habermesiana de dissolução das relações de poder, por intermédio de uma utópica comunicação transparente, considera que todas as relações de comunicação, ao modificarem o campo de informaçōes entre as partes, produzem efeitos de poder. As práticas e as tecnologias de poder passam a ser o eixo principal das suas pesquisas, acrescentando as técnicas do self às técnicas de produçăo, de significação e de dominação. Nesta expansão reside o principal deslocamento da sua teorização. Com efeito, enquanto nas investigaçōes anteriores a subjectividade emergia à imagem e semelhança dos poderes individualizantes, agora a subjectividade é antes do mais autoformação e cuidado de si. Neste sentido, o significado das terapêuticas pedagógicas e psicológicas reside menos no facto de permitirem a extensão da dominação, do que na obrigação de promoverem o ser livre e autónomo.

No contexto escolar, tais práticas apresentam características gnósicas (conhecimento de si), de provação (domínio de si) e de preservação (cuidado de si). O quadro seguinte faz uma listagem inicial do conjunto de tecnologias propostas no Perfil 
desejado que será analisado e expandido à medida que formos introduzindo os saberes provenientes das regiões insulares do discurso educativo.

Quadro 23 - Tecnologias de si e Práticas pedagógicas inscritas no Perfil desejável

\begin{tabular}{|c|c|}
\hline TECNOLOGIAS DE SI & PRÁTICAS PEDAGOGICAS \\
\hline DOMINIO DESI & 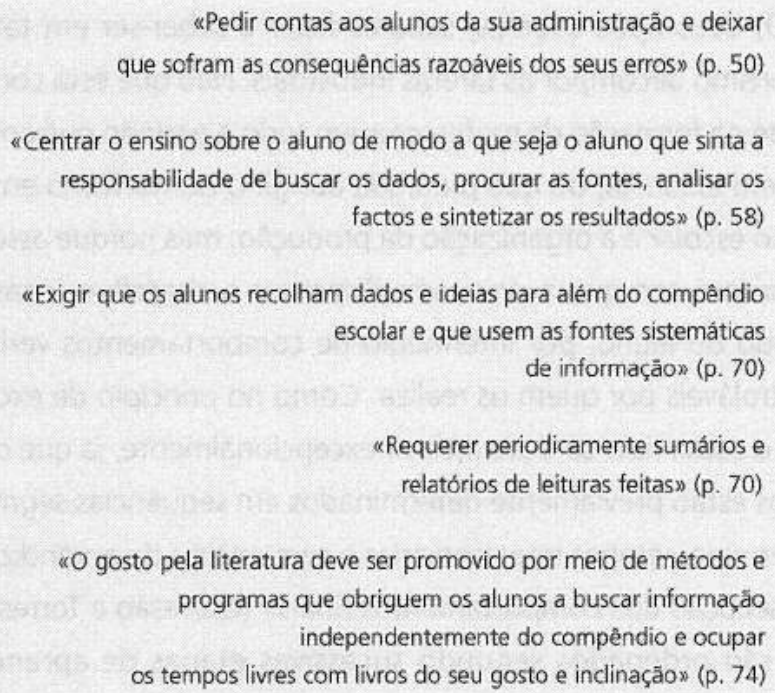 \\
\hline CONHECIMENTO DE SI & $\begin{array}{l}\text { «Exigir do aluno reflexāo frequente } \\
\text { sobre as suas estratégias de pensamento e acção de modo a corrigir } \\
\text { irracionalidades e promover eficiência» (p. 58) } \\
\text { «Premiar o mérito e estimular o sentido da auto-superação» (p. 60) } \\
\text { «Os alunos devem ter ampla oportunidade de falar em público, sendo a } \\
\text { sua actuação comentada e aperfeiçoada» (p. 74) } \\
\text { «Tempo profissional para que alguns professores (de literatura, de } \\
\text { filosofia, de religiăo) ou outros profissionais năo } \\
\text { docentes (psicólogo, conselheiro) possam dedicar-se ao atendimento dos } \\
\text { alunos, acompanhando-os individualmente na sua reflexão sobre } \\
\text { problemas mais existenciais» (p. 82) }\end{array}$ \\
\hline CUIDADO DE SI & $\begin{array}{l}\text { «Cuidar da sua saúde orientado por noçöes cientificas de higiene física e } \\
\text { mental, em áreas como as da limpeza, } \\
\text { da dieta, do exercício fisico, do descanso e do divertimento» (p. 82) } \\
\text { «Prática de programas de autocontrolo visando o domínio das variáveis } \\
\text { psicofisiológicas das reacçóes emocionais» (p. 92) }\end{array}$ \\
\hline
\end{tabular}


Comecemos por isolar os procedimentos das tecnologias de provação. A categoria domínio de si desempenha uma dupla função de permitir a progressão numa aquisiçăo e de avaliar o estado a que se chegou. Como em todo o exercício, a sequência e a progressividade são elementos essenciais, porque permitem a ordenação do tempo e a economia na sua utilizaçăo. $O$ desejo de racionalizar a actividade do aluno para a tornar mais performante é uma constante. A Pedagogia por objectivos (PPO) decompōe saberes, saberes-fazer e saber-ser em taxonomias, à maneira do tailorismo decompor as tarefas industriais. Não que esta corrente pedagógica, dominante na formação de professores em todo o período que analisamos, tenha a mesma origem tailorista, ou que pretenda atingir o isomorfismo entre a organização do trabalho escolar e a organização da produçăo; mas porque assegura o mesmo efeito do tailorismo aos que a praticam: dispensar o supérfluo, constituindo a soberania do estudo do aluno, por intermédio de comportamentos verificáveis pelo professor e controláveis por quem os realiza. Como no princípio de excepção do tailorismo, em que o supervisor só deve intervir excepcionalmente, já que os comportamentos ajustados estão previamente determinados em sequências segmentadas, também a PPO determina «etapas intermediárias e sequenciais da aprendizagem que vão permitir a consecução dos comportamentos finais» (Cortesão e Torres, 1990: 124). Os objectivos são ordenados segundo sucessivas etapas de aprendizagem, derivando daí objectivos intermediários e objectivos finais. A redacção dos objectivos a partir de verbos de acções a realizar pelo aluno denuncia a dupla observação que neles se inscreve: observação do professor, dirigida para a regulação externa, e auto-exame do aluno, dirigido para o domínio de si e dos seus comportamentos. A psicologia comportamentalista forneceu um primeiro horizonte a este olhar duplo com a introdução das taxonomias de acçōes físicas observáveis. Mas rapidamente se concluiu que estas não permitiam acesso à caixa negra, quer dizer, ao que se passa no mais intimo de cada aluno. A psicologia cognitivista e as taxonomias que delas derivam ampliam sobremaneira o horizonte de observação e de autocontrolo do aluno. Muitos críticos vêem nas teorias e nas taxonomias comportamentalistas (Birzea, 1979) o paradigma de uma psicologia da adaptaçăo social, apenas preocupada com a conduta explícita dos indivíduos, submetendo assim as experiências e motivaçōes individuais às finalidades do poder. Mas nem sempre cuidam de verificar esses mesmos efeitos nos paradigmas construtivistas. Em especial os que relevam da focalização da acção pedagógica nas qualidades psicológicas do indivíduo, tais como os estilos de aprendizagem e os níveis de auto-estima. Na verdade, as taxonomias cognitivistas tornam o interior de cada um o local por excelência para o exercício da regulação 
social, ao mesmo tempo que consolidam o tratamento dos conteúdos escolares como objectos fixos e estáveis.(119)

A utilização de critérios de êxito referenciados à performance do aluno denuncia a preocupação com a obtenção de algo que aquele ainda não possui. O conceito de défice desequilibraria assim a equação aquisição/capacidade para o lado da aquisição e, consequentemente, para o lado do transmissor. Para obviar a tais limitações, o critério cognitivista de operacionalização dos objectivos «procura trabalhar em mecanismos internos, tratam de saber o que se passa na mente da criança enquanto se processa a aprendizagem. Isto para tentar reformular, corrigir as suas estratégias de acordo com as necessidades e as características de cada aluno" (Cortesão e Torres, 1990: 120). O cognitivismo parece assim aproximar-se mais da verdade do eu que o comportamentalismo. Esta alternativa é justificada pela sua pertinência relativamente ao projecto democrático. Desembaraçar os conteúdos dos seus implícitos culturais, adaptando-os às necessidades de cada aluno, torná-los-ia acessíveis a todos. Segundo Birzea (1982), nesta derivaçáo dos objectivos estaria a possibilidade de a escola passar da igualdade de oportunidades à igualdade de resultados. A operação retira a questão da selecção escolar do universo político e moral para a colocar no plano técnico da definição de objectivos e da medida precisa, fiável e válida das aprendizagens. Uma psicologia bastante instrumentada e uma avaliação criterial estão à cabeça do projecto democrático de autonomização do sujeito que aprende. Tal projecto tem, porém, um ónus para os alunos, obrigando-os a ser autónomos: responsabiliza-os por buscar dados, procurar fontes, analisar factos e sintetizar os resultados; exigeIhes que recolham dados e ideias para além do compêndio escolar; requer-lhes sumários e relatórios periódicos; obriga-os a ocupar os tempos livres com livros do seu gosto e inclinação; obriga-os ao autocontrolo das reacções emocionais; pede-lhes contas pela sua administraçăo e pelos seus erros.

(119) Sobre este particular ver a discussão de Popkewitz (1998: 26-29) sobre a alquimia das disciplinas e dos conteúdos escolares: «the alchemy of school subjects makes possible the alchemy of the child. The treatment of school subjects as fixed and unyielding enables pedagogical discourses to focus on the processes by which children learn or fail in curriculum mastery. It is not the knowledge of the disciplines struggled over. With knowledge fixed, the soul is the site of struggle for norms of achievement, competence and salvation». Thomas Popkewitz tem sido um dos autores que no campo educativo tem tentado colocar a análise crítica das ciências da educação e das ciências cognitivas no terreno da análise dos seus efeitos de poder. A discussão realizada neste capitulo aproveita algumas das pistas apresentadas pelo autor, especialmente as que são desenvolvidas nos livros A Political Sociology of Educational Reform, New York: Teachers College Press, 1991, pp. 136-190 e em Struggling for the Soul, New York: Teachers College Press, 1998. Referimo-nos designadamente às relaçôes saber-poder inscritas nas reformas educativas e à consolidação de uma episteme escolar centrada na articulação entre conhecimento, desenvolvimento integral das capacidades individuais e progresso social. 
A avaliação e, em especial, a auto-avaliação assume um papel nuclear neste regime de autonomia. É nela que a questão da veracidade e o princípio do conhecimento de si se desdobram em práticas de auto-exame. Dentre as diversas funçōes da avaliação, săo as que dizem respeito às designadas por avaliaçāo formativa e avaliação sumativa que mais saturadas se apresentam dos factores de auto-exame. As práticas pedagógicas sugeridas dizem respeito ao aprofundamento do exame de consciência e à utilização de técnicas metacognitivas de pensar sobre o pensamento. A par das técnicas de autocontrolo, também neste caso existe uma instância que induz, incita ou impōe. Assim, "exige-se reflexão frequente sobre as estratégias de pensamento", "estimula-se o sentido de auto-superação», fornece-se feed-back público ou privado, "acompanha-se o aluno na sua reflexão sobre problemas existenciais». Em qualquer caso, os termos empregados são significativos. Propõe-se a reflexão e a superação. Neste exame, a relaçăo do sujeito consigo próprio sofre um dobramento de modo a que a descoberta do verdadeiro eu seja possível, não tanto sob a forma de uma relação de puniçăo moral, mas de apreciação de um trabalho realizado. 0 exame não incide em infracções, embora estas possam surgir em condições de erros regulamentares, mas no modo de «corrigir irracionalidades e promover eficiência». É uma exame produtivo e não coercivo; indutor e não punitivo; correctivo e não vexatório. A avaliação formativa, que pode e deve passar pela auto-avaliação, contribui na sua medida para «fornecer ao professor e aluno um feed-back respeitante ao progresso do aluno; determinar onde e porquê o aluno fracassou» (Cortesão e Torres, 1990: 103). Neste dispositivo o aluno está confrontado consigo mesmo. O eu performante está diante do eu íntimo, o eu que age está sujeito ao escrutínio do eu que reflecte durante e depois da acção. É a avaliação criterial que expressa mais subtilmente tal duplicação porque situa cada aluno relativamente a critérios de êxito pré-estabelecidos e porque compara cada sujeito consigo próprio, isto é, com a sua progressão (Idem, Ibidem, p. 87-108). A partir da rememoraçăo de um fracasso ou de um êxito, a auto-avaliaçăo e a avaliação formativa garantem o apetrechamento necessário a uma conduta mais eficaz.

A este exercício que «ajuda o aluno a compreender o que se pretende com o curso, o que fará com que ele desenvolva os seus esforços em sincronismo com o professor» (Idem, Ibidem, p. 107), junta-se o trabalho do pensamento sobre ele mesmo. Quais as estratégias de pensamento, quais os estilos cognitivos utilizados, quais os mais eficazes em cada tarefa, são questôes que procedem a uma triagem permanente das representações mentais. Mais do que saber o impacto real destas propostas, há que saber como elas contribuem para a episteme do aluno autónomo e do seu 
correlato principal — a noção de formação ideal da pessoa. Na sua versão democrática, esta consiste no completo desenvolvimento das capacidades do indivíduo e, consequentemente, no conhecimento e governo da sua própria conduta. Este ideal do desenvolvimento completo e integral da pessoa está presente em numerosas versōes, incluindo a versão crítica neomarxista que projecta tal desenvolvimento num contexto de emancipação social e, portanto, de resistência colectiva à dominação. Um dos exemplos mais difundidos, quer pela administração do sistema educativo quer por obras de divulgação pedagógica, apresenta as capacidades como uma alternativa aos dotes: "Contrastando com a ideia de utilização das escolas para fins de selecção está o conceito de que a educaçăo tem como objectivo fundamental o desenvolvimento do aluno. Nesta perspectiva a tarefa fundamental da escola é desenvolver no estudante aquelas características que o tornem capaz de viver, efectivamente, numa sociedade complexa. Na base de tudo isto está o facto de se admitir que as capacidades podem ser desenvolvidas por meios educacionais e que o máximo das potencialidades da escola deveria ser empregue no aumento de eficiência de cada indivíduo e não a predizer e seleccionar quais os mais bem dotados» (Bloom, Hastings, Madaus, 1971, in Cortesăo e Torres, 1990: 104). Para que este objectivo seja obtido supōe-se a possibilidade de harmonizar as capacidades em cada indivíduo, numa versão mais liberal, ou de harmonizar os indivíduos em sociedade, numa versão mais colectivista, sendo certo que esse será sempre o resultado de um desenvolvimento ideal da pessoa. É interessante verificar como esta concepção, ancorada na ordem natural do desenvolvimento do aluno e no exercício livre das suas faculdades, determinada que está por observações e investigaçōes sobre o seu comportamento em vários estádios de desenvolvimento, tem uma tão grande pregnância. Nesta formulação articulam-se saberes de regiōes diversas: a administração que, deste modo, propõe formas racionais e igualitárias de planeamento da educação e de formação de professores; a pedagogia, que assim recupera a racionalidade de intervenção e o mito do indivíduo, posto em causa pela crise revolucionária; a psicologia, que retoma o papel charneira na explicação dos processos de desenvolvimento, de aprendizagem e de metacogniçăo.

Para caracterizar a atitude de Aprender a pensar os autores do Perfil desejado utilizam três obras de referência (Valente et alii, 1987; Presseisen, 1985 e Sternberg, 1985). Em grande medida, a segunda característica do perfil cognitivo-moral determina a bitola da atitude: «informa-se sobre a realidade presente com espírito crítico procurando basear-se em estratégias conscientes de selecção, avaliação e integração de mensagens, de modo a evitar o excesso de informaçōes ou a compreensăo super- 
ficial» (p. 69). Tais limites coincidem com as três atitudes que Dewey (1933) considerava necessária para a reflexăo: abertura de espírito, responsabilidade e sinceridade. A abertura de espírito refere-se a uma atitude activa de procurar mais do que uma opiniăo, de recolher alternativas possíveis e de admitir o erro: "avaliar as orientações básicas dos jornais e revistas que lê e complementar naturais distorções ideológicas com fontes de orientação oposta» (Perfil desejado, p. 69). A responsabilidade exige a ponderação pessoal das consequências de certas opções. Finalmente, a sinceridade culmina o processo de aprender a pensar com os meios que fixam a metacogniçăo: conservação e arquivo sistemático de notas pessoais (p. 69), exposição pública de comportamentos adequados e desadequados (p. 58), seminários sobre técnicas de conversação (p. 70).

O conhecimento de si, que o aprender a pensar promove, está ancorado numa perspectiva optimista do homem formulada pela teoria triádica da inteligência de Sternberg (1985). Encarando o ser humano como um potencial a desenvolver em uma infinidade de situaçōes e de interacçōes, utiliza o mítico modelo triádico para sugerir a hipótese de a inteligência implicar componentes que podem concorrer ou limitar a sua expressão, designadamente as componentes de planeamento e controle, as componentes de realização e as componentes de aprendizagem. Uma das consequências desta distinção consiste numa diferente interpretação dos desempenhos inferiores de alguns alunos, quando comparado com uma norma avaliativa dada. Em vez da ausência de capacidades ou da ausência de conhecimentos, prefere-se uma visão optimista que se firma na conviç̧ão de que o aluno nem sempre é capaz de mobilizar as suas capacidades reais, quer por razōes ligadas ao seu percurso biográfico quer por não ter sido sujeito a um adequado trabalho das competências cognitivas. Como referem dois dos autores que procederam à divulgação dos trabalhos de Sternberg em Portugal «uma outra leitura possivel das dificuldades de realização pode basear-se no uso deficiente dos pré-requisitos inerentes aos processos de codificação e de registo de informação, de tratamento dessa informação e de generalização desses processos para as várias situações de aprendizagem ou de realização» (Almeida e Morais, 1989: 38). A orientação designada de aprender a aprender insere-se nesta crença na possibilidade de todos acederem ao interior do seu potencial, pondo-o em acção. Porém, este acesso tem um ónus que consiste na penetração cada vez mais frequente da escola nos factores emocionais e motivacionais do aluno. Em boa verdade, as teorizaçōes metacognitivas reconhecem todas elas que a experiência metacognitiva está profundamente ligada com a afectividade. E propõem programas destinados a controlá-la. Se tomarmos o exemplo de uma das unidades do progra- 
ma CORT, (120) relatado no número especial da Revista de Educação dedicada ao Aprender a Pensar, podemos ficar com uma ideia aproximada do procedimento: «a unidade $\checkmark$ centra-se no papel desempenhado pela informação e pelo sentimento implicado no pensar. O objectivo das lições é fazer com que os alunos tomem consciência da informação e dos sentimentos envolvidos numa situação. Uma liçăo sobre uma determinada informação ensina o estudante a usar a seguinte estratégia: o estudante escreve primeiro toda a informação existente na situação; a seguir assenta toda a que foi deixada de fora. Na lição chamada 'emoções' informa-se o estudante da função extremamente importante das emoçōes no pensar. $\mathrm{O}$ aluno também aprende que há dois géneros de emoções: emoções (como a ira, o amor ou o medo) e emoções do ego (como o orgulho, o poder e a insegurança). Ao nível da prática incluem-se situaçōes como a de um autocarro que transporta uma criança da escola para casa, tem uma avaria e faz com que ela chegue atrasada. Pergunta-se ao estudante como reagiria o pai da criança a esta situação: a) se ele estivesse contente com a filha devido às suas boas notas nos exames; b) se estivesse descontente com ela devido a ter chegado na noite anterior demasiado tarde a casa. A questão é chamar a atenção do estudante para como as emoções do pai podem afectar a maneira como este reage à situação" . Os alunos da escola contemporânea são incitados a viver de acordo com um projecto de vida que inclui a decifração e melhoria do seu universo emocional, interpretação da vida doméstica e familiar, desenvolvimento de um estilo de vida que maximize a auto-realização. Autonomia e consciência são noções sedutoras que remetem para o indivíduo a responsabilidade da sua própria aprendizagem: «se se pretende desenvolver uma aprendizagem que reforce o saber pensar é necessário que se desloque para o aluno o pólo da responsabilidade pela sua própria aprendizagem, bem como o controlo da mesma» (Valente, Salema, Morais, Cruz, 1989: 50). E esta deslocação é considerada tanto mais necessária quanto maior é a sua ligação a práticas escolares intimamente associadas a sentimentos de aversão e de hostilidade.

É o caso da planificação do estudo individual, considerado por muitos como a pedra de toque do desenvolvimento da autonomia do aluno: «é importante que os alunos reconheçam que um plano de trabalho não tem que ser — não deve ser uma forma de controlo externo restritivo da liberdade de acçăo. É importante que se reconheça que, pelo contrário, ao elaborarem eles próprios um plano de trabalho

(120) O CORT (Cognitive Research Trust) é um programa desenvolvido por Edward De Bono que é descrito a partir do livro de Paul Chance, Thinking programs in the classroom, traduzido e adaptado pelo grupo do projecto Dianóia na Revista de Educaçăo, (1)3: 77-83. 
racional e ao respeitarem-no, este esforço poderá traduzir-se numa economia de tempo e energia e numa maior autonomia no seu funcionamento escolar» (Carita et al., 1997: 54). Este exercício introspectivo, por intermédio do qual os alunos se problematizam a si próprios, está dependente de uma atenta relação pedagógica. Desde logo, porque requer a abertura da sala de aula à experiência privada do aluno, estabelecendo a intimidade necessária à expressão das suas rotinas diárias. Em seguida, porque a expressão das técnicas pessoais de estudo obriga o professor a introduzir, subtilmente, algumas normas que os alunos estejam dispostos a aceitar como sendo provenientes da sua própria deliberação: «para haver um efectivo rendimento escolar, é fundamental que o aluno interiorize a necessidade de gerir o seu tempo (...) Cada aluno terá de encontrar o seu método pessoal, aprendendo a distribuir o seu tempo de uma forma flexível e adaptada às necessidades, permitindo que se efectuem alteraçōes ou mudanças em função das tarefas que têm de ser levadas a cabo e dos trabalhos que se espera que ele realize» (Idem, Ibidem). Aprender a estudar passa a ser uma das modalidades de metacogniçăo que mais sucesso obtém. Durante a década de 90 são publicados em Portugal vários livros sobre a temática do estudo e das competências de estudo. Apoiados na reforma do sistema educativo, designadamente na arquitectura da avaliaçăo formativa, que prevê apoios suplementares, a maior parte destas obras assumem o formato normativo e prescritivo de guias ou de manuais com indicaçōes de aplicaçăo. (121) Os pressupostos das actividades sugeridas estăo ancorados nas duas dimensōes mais referidas pelos autores responsáveis pela sua introdução no campo educativo (Flavell, 1976): conhecimento dos processos e dos produtos dos processos cognitivos e regulação desses processos cognitivos. A primeira dimensão é explicitada nos seguintes termos no livro Como ensinar a estudar (Carita et al., 1997: 16): «trata-se antes de mais de aprender sobre si próprio, sobre o seu estilo pessoal de aprendizagem, sobre o seu modo de desempenhar o papel de estudante e de a partir daí crescer: Como aprendo? Como estudo? Como comunico? Como escuto? Como registo? De que ajudas necessito?». A segunda dimensão diz respeito aos dispositivos de auto-regulação dos processos

(121) Referimos a título de exemplo: Estanqueiro, A., Aprender a estudar: um guia para o sucesso na escola, Lisboa: Texto Editora, 1992. Silva, A. e Sá, I., Saber estudar e estudar para saber, Porto: Porto Editora, 1993; Carita, A., Silva, A. C., Monteiro, A. F., Diniz, T. P., Como ensinar a estudar, Lisboa: Editorial Presença, 1997. Utilizamos como fonte principal este último livro porque embora seja um dos que mais tarde foi publicado, decorre da experiência de um programa de métodos de estudo desenvolvido pelos técnicos de Serviço de Psicologia e Orientação de uma escola de $3 .^{\circ} \mathrm{Ciclo} \mathrm{e} \mathrm{ensino}$ secundário de Lisboa no período subsequente à reforma de 1989. 
cognitivos, incluindo nestes a capacidade de julgar a actividade cognitiva e as decisões tomadas para reforçar ou inflectir as estratégias cognitivas utilizadas anteriormente. São estas que fazem a ligaçăo entre o mundo interno do psiquismo e o mundo externo da conduta, ou melhor, permite a inteligibilidade desta nos termos daquele com a mediaçăo interpretativa do psicólogo ou do professor. Na verdade, a modelagem é o princípio básico: «a maior parte dos programas de intervenção baseia-se no princípio de que a melhor maneira de promover o desenvolvimento de competências metacognitivas requer a sua modelagem, discussão e prática» (/dem, Ibidem, p. 33). Neste formato da aprendizagem do estudo apresentam-se as duas principais características do moderno currículo humanista, travejado numa pedagogia da formação-da-consciência: técnicas de liberdade supervisionada e correcção por intermédio da auto-expressão. Pode dizer-se que o tema da formação-da-consciência, enquanto treino prático indispensável para que o indivíduo se constitua como sujeito moral, se concretiza numa certa forma de o próprio se problematizar. A modelagem não diz respeito a conteúdos, mas a um limiar de interrogação que conduz o trabalho ético. Esta reflexão começa a ser organizada como um corpus de práticas privadas, distintas dos tempos e dos espaços escolares, que constituíria uma espécie de caminho para o aluno estudioso e virtuoso. O capítulo "a sessăo de estudo», da obra que vimos analisando, dá-nos uma aproximação bastante impressionista às práticas de auto-exame, de auto-integração e de autocontrolo, quando regista os «passos fundamentais de uma boa sessão de estudo em casa» (Idem, Ibidem, p. 104-105). O quadro seguinte organiza os dez passos propostos segundo os niveis de problematização correspondentes. $\mathrm{O}$ que se torna saliente na lógica dos passos é a intíma relação entre o aparelho escolar e as tecnologias da autonomia propostas. A cada passo dado no sentido da autonomizaçăo corresponde um passo mais no liame do aluno com a escola e o professor. O que vem contrariar as formas habituais de algumas teorias críticas e da resistência apresentarem a relação entre poder e subjectividade. Algumas destas correntes pensam o poder nos termos do domínio e repressão da subjectividade, quando o que as tecnologias escolares contemporâneas nos mostram é a acção por intermédio da produtividade do sujeito subjectivo.

O que importa sublinhar na nossa análise é o modo como este método converte as práticas pedagógicas em técnicas de revelação e descoberta de capacidades psicológicas, distribuindo-as segundo os desvios individuais das funções psicológicas normais. Um dos exemplos mais característicos disto são as técnicas propostas para o tratamento da informação escrita. Com efeito, de acordo com os critérios de compreensão de um texto narrativo, é suposto, por exemplo, que o aluno seja capaz de analisar as imagens principais do texto e parafraseá-lo quando questionado pelo pro- 
Quadro 24 - Problematizaçōes inscritas nos métodos de estudo

NIVEL DE

COMO SE ESTUDA EM CASA?

PROBLEMATIZAÇÃO

\section{AUTOCONTROLO}

Relaçâo agonistica em

relação ao corpo, às

distracçōes e aos prazeres.

Diferimento da gratificaçāo.
«1. Reunir o material de que vai necessitar para năo ter que se

levantarx (p. 104)

«2. Procurar concentrar-se nos objectivos da sessáo de estudo, tentando afastar-se de estímulos distractivos e antecipando em pensamento os bons resultados que irá obter depois de ter estudado (p. 104)

\section{AUTO-INTEGRAÇĀO}

Ajustamento da disciplina escolar às necessidades $e$ ao nivel atingido.
«3. Preencher o seu plano geral de estudo a partir das sugestóes dadas na sessão 'Planificação do estudo', tendo em vista a(s) disciplina(s) a que se vai dedicarn ( $p .104)$

«4. Começar o seu estudo pela disciplina que no seu plano colocou em primeiro lugar, identificando dentro desta o assunto especifico a trabalhar. Procurar então construir sobre 0 assunto uma ideia geral através da leitura rápida dos apontamentos das aulas e do adequado

capitulo do manual e fazendo ligaçōes com temas anteriormente tratados. Fazer algumas perguntas a si próprio sobre as ideias básicas e sobre o que já sabe sobre o tema, poderá ajudá-lo a situar-se perante o objecto de estudo» (p. 105)

«5. Estudar no manual a matéria que o professor deu na aula, lendo agora um parágrafo de cada vez, retirando a ideia principal de cada parágrafo, sublinhando e fazendo o resumo do texton (p. 105)

«6. Fechar o livro e o caderno e tentar dizer por palavras suas o que acaba de aprender e verificar posteriormente se năo se esqueceu de nada. Escrever numa folha o que aprendeu nesta sessäo de estudo, olhando o livro e o caderno para se certificar de que o que escreveu está certo» (p. 105)

47. Realizar os trabalhos de casa, pedidos pelo professor, no âmbito dessa disciplina» (p. 105)

«8. Para completar o estudo, podem ser consultados outros livros, a enciclopédia ou até mesmo um artigo de jornal ou revista. Pode depois voltar ao manual e reconsiderar um ou outro aspecto que não tenha sido percebido. Se persistirem dúvidas, anotar numa folha e na aula perguntar ao professor» (p. 105)

\section{AUTO-EXAME}

Reconhecer em si próprio e no seu esforço se merece o descanso e o prazer. Transferência da temperança da conduta escolar para outras áreas da vida pessoal.
«10. Acabou a sessăo de estudo. Se o aluno seguiu estes passos deve sentir-se orgulhoso de si e satisfeito por se ter esforçado.

Merece ir fazer qualquer coisa de que goste muito. Também năo se deve esquecer que é importante alimentar-se bem e dormir pelo menos oito horas» (p. 105) 
fessor. Converte-se, assim, uma forma particular de compreensão do texto, nos signos comportamentais de processos cognitivos profundamente inscritos na natureza de cada criança: «parafrasear, ou seja, recontar o que leu, utilizando o aluno as suas próprias palavras, é uma forma de este saber se integrou todos os objectivos que se pretendia atingir com a leitura de um texto. Ao parafrasear, o aluno mobiliza várias competências cognitivas e metacognitivas, fundamentais ao seu processo de aprendizagem e assimilaçăo dos conteúdos programáticos» (Idem, ibidem, p. 65).

Os métodos da metacognição estabelecem o ponto onde forma e significado da educação estética, científica ou literária se podem reencontrar. Ao referenciar o significado do texto ou da escrita às práticas de auto-regulaçăo cognitiva, desloca-o da literatura propriamente dita para a substância ética de cada um. É esta sensibilidade ao interior de cada um que assim se abre ao escrutínio do outro, à sua observação e correcção. Não se podendo ter acesso aos processos mentais que o escrevente utilizou para orientar o processo de escrita, a análise de textos transforma-se num processo em que mais importante que o conteúdo específico é a tomada de consciência dos processo mentais e das estratégias operacionais do aluno: «o ensino da composiçăo deve explicitar os processos mentais (...) quando se recorre à análise de textos, o conteúdo é explorado em função das ideias em si e não em função da identificação explícita dos processos que produziram a organização global do texto (...) O ensino deve pois explicitar a organização do conteúdo do texto e identificar os recursos linguísticos que marcam este tipo de organizaçâo» (Salema, 1989: 62).

E o mesmo se passa com a lição sobre tomada de apontamentos e atitude na sala de aula (Carita et al., 1997: 93-98). Esta liçăo baseia-se no pressuposto de que a ordenaçăo e categorização das palavras durante a aula proporciona algumas regras necessárias ao conhecimento e à compreensão. Aprender a tomar apontamentos é aprender a ordem natural das coisas, embora de uma forma autónoma e individualizada. A regra está inscrita no conhecimento propriamente dito e não na forma de elaborar os apontamentos: «muitas vezes os alunos têm a ideia de que tomar apontamentos é reproduzir quase na totalidade a informaçăo ouvida, o que não thes permite a necessária compreensão activa. Por isso, o professor deverá sensibilizá-los para o facto de que os apontamentos devem, antes pelo contrário, ser tão curtos e claros quanto possivel (...) os apontamentos são um registo pessoal de cada aluno não existindo propriamente regras específicas para a sua elaboração». O processo de tomar notas é visto como a expressão individual das regras lógicas que subjazem a todo o conhecimento, incluindo neste a disciplina mental que o induz: «ficamos mais atentos e activos (...) ficamos mais concentrados (...) ajuda a memorizar (...) são uma base fundamental para o estudo em casa». 
Marcel Mauss (1979), no seu muito conhecido ensaio sobre as técnicas corporais, demonstra que grande parte dos atributos e capacidades corporais tais como os estilos de andar, as formas de dormir, as técnicas de cuidar o corpo e por diante, são adquiridas através da imitação e da inculcação, escapando assim ao controlo racional a que chamamos conhecimento de si. Năo porque isso constitua uma falha do nosso conhecimento do self; não porque apenas se possa verificar esse conhecimento por intermédio do acesso à representação inconsciente; mas porque estas técnicas dizem respeito a uma esfera da existência que năo está governada por esse específico regime de escrutínio. É a esta luz que devemos entender também as teses de Wittgenstein (1979) sobre as capacidades matemáticas. Segundo o autor, o pensamento do número seguinte numa sequência numérica não é o resultado de uma fórmula abstracta, inscrita na superfície da consciência, mas o resultado do treino numa rotina de cálculo, que não está ele próprio sujeito aos procedimentos do autoconhecimento. Nesta visão apresenta-se uma alternativa à concepçăo essencialista que alega uma capacidade genérica de autoconhecimento, capaz de se instalar em todas as esferas da existência e de as controlar. Assumir que é possível desenvolver uma tal capacidade genérica, como o fazem, de modo implícito, a metacognição e as práticas pedagógicas nela filiadas, é presumir a continuidade dos seres humanos como sujeitos históricos, essencialmente equipados com a capacidade de dar significado à experiência. Porém, o modo como os sujeitos dão um significado à experiência tem a sua própria história, não dependendo de um equipamento cognitivo pronto a desenvolver, mas, antes do mais, dos próprios dispositivos de produção de significado. Destes dispositivos destacámos as grelhas de leitura e de visualização das obras, os vocabulários destinados ao conhecimento próprio, os sistemas de narração e de julgamento da experiência que são eles próprios criadores de experiências. Porque estas tecnologias cognitivas não se apresentam num estado acabado, nem tăo pouco se articulam previamente, precisam de se sujeitar a um processo de estabilização e disseminação que lhes dê a aparência de unidade. O ponto seguinte discorre sobre os processo conceptuais e práticos em virtude dos quais o sistema educativo tem condições de obter uma subjectividade unificada.

\section{Teleologia}

A teleologia define o tipo de sujeito que cada um pretende ser por intermédio da acção moral. Quais os estilos de vida, os modelos e as finalidades que suportam os ideais sociais? Que regimes de verdade e que códigos de conhecimento lhe subjazem? Que tipo de valorizações éticas Ihe estão associados? Estas são algumas das ques- 
tões que presidem à construção da subjectividade heterogénea da modernidade tardia. A subjectividade é heterogénea num duplo sentido: é-o em função dos modelos desencadeados em diferentes práticas sociais; mas é-o também em função da circulação de cada indivíduo por contextos que se articulam com formas particulares de lidar com problemas e soluções para a conduta humana. Os tipos descritos por Rose (1996b: 27-28), embora sugestivos, são apenas ilustrativos e não esgotam a multiplicidade de práticas éticas que a fragmentação crescente da subjectividade pode conter: «the professional persona exercising a vocation with wisdom and dispassion; the manly warrior pursuing a life of honor through a calculated risking of the body; the responsible father living a life of prudence and moderation; the laborer accepting his or her lot with a docility grounded in a belief in the inviolability of authority or a reward in a life to come; the good wife fulfilling her domestic duties with quiet efficiency and self-effacement; the entrepreneurial individual striving after secular improvements in 'quality of life'; the passionate lover skilled in the arts of pleasure». A existência destes e de outros ideais-tipo da modernidade tardia confirma a imagem convencional de uma subjectividade coerente, duradoira e individualizada. Que assume forma no conceito de identidade pessoal e social das ciências sociais. Mas, simultaneamente, questiona-a, porque apresenta formas múltiplas, transitórias e sobrepostas de cada um se apresentar ao mundo, de tal sorte que o self dificilmente se mostra compreensível nos termos de um espaço fechado em cada individualidade.

É esta descoincidência entre fragmentação social do self e procura da individualidade que abre o caminho às práticas e às conceptualizações que visam a montagem do sujeito uno. À imagem do problema colocado pela estratificação orgânica do corpo que se traduziu na questão - como fazer um organismo deste corpo? - , a segmentaçăo do self traduz-se na questão: como fazer uma subjectividade no interior deste corpo? O individualismo possessivo corresponde à noção que melhor agrupa todas as teorias e práticas que visam desenvolver a subjectividade como um dado primordial. A sua pregnância epistémica é tāo extensa que lhe permite pontos de inserçăo em outras regiões do discurso. A vulgarização de algumas teorias do desenvolvimento sócio-moral, como as de Keagan (1982) e as de Kohlberg (1981, 1983, 1987), veio permitir o tratamento da autonomia como um problema técnico que resulta da aprendizagem diferencial dos sujeitos. Os modelos cognitivistas do desenvolvimento moral, bem como os modelos da clarificação de valores (Raths, Harmin e Simon, 1966), introduziram a crítica aos modelos de educaçăo centrados nas virtudes, salientando o papel central da decisão moral como contexto privilegiado do exercício da liberdade individual e da autonomia. Durante os anos 60, o psicólogo Lawrence Kohlberg desenvolve a bem conhecida teoria dos seis estádios 
de desenvolvimento cognitivo-moral, ${ }^{(122)}$ com base em estudos empíricos realizados em contextos culturais diferentes. Aprofundando a lógica dos estádios, o autor rapidamente conclui que o contexto escolar pode fomentar uma progressão mais rápida das crianças para estádios mais avançados de raciocínio moral. Acrescenta assim ao formalismo dos estádios a contingência dos contextos. $\mathrm{O}$ trabalho pedagógico sugerido inicialmente por Kohlberg reflecte a sua perspectiva cognitivista, contrária à endoutrinação. Daí que o conflito cognitivo se encontre no núcleo central da sua proposta de acção pedagógica, reflectindo a crença na hipótese de a passagem para estádios mais avançados de desenvolvimento se fazer com base na argumentação em torno de conflitos de valores e dilemas morais. O papel do professor consistiria mesmo em apresentar dilemas éticos difíceis, ou em introduzir uma perspectiva de soluçăo alternativa derivada de um juizo moral mais elevado, pondo os alunos em situação de desequilíbrio que os obrigasse a superar o nível presente de raciocínio. Seria este tipo de metodologia que impediria a endoutrinação, porque não se dirigi-

(122) Năo sendo este um livro de Psicologia, nem pretendendo discutir directamente o valor teórico e a validade empírica do modelo, não nos pareceu adequado integrá-lo no corpo do livro. Porém, a discussão do regime de verdade e da linguagem inscrita na proposta de Kholberg aconselham a apresentaçăo de uma síntese dos pressupostos e dos estádios de desenvolvimento moral numa nota prévia. É o que faremos. As principais conclusōes da pesquisa empírica de Kohlberg podem resumir-se em quatro eixos: a) o desenvolvimento cognitivo-moral processa-se por estádios, cada um dos quais reconhecivel pelo raciocínio moral usado; b) os estádios dispõem-se segundo uma hierarquia em que cada estádio superior integra os estádios inferiores; c) os estádios seguem uma sequência invariante que não admite omissōes; d) os estádios sāo universais, permanecendo válidos nos mais diversos contextos culturais. São três os níveis de desenvolvimento moral segundo Kohlberg, cada um dos quais se divide em dois estádios, o que resulta num total de seis estádios. Embora a descrição dos estádios tenha sofrido várias alteraçōes que ajudaram a clarificar o modelo e a responder a alguns dos seus críticos, a estrutura primitiva que leva a criança de um ponto de vista egocêntrico ao jovem com uma orientaçăo baseada em princípios universais mantém-se. NíVEL I - PRÉ-CONVENCIONAL. Estádio 1 - Orientaçăo baseada nas regras e nos castigos. Deferência egocêntrica para com o poder superior das autoridades, ou confusão entre a perspectiva da autoridade e a perspectiva pessoal. Năo estabelece relação entre dois pontos de vista. Estádio 2 - Orientação individualista concreta. Age em funçăo das suas próprias necessidades e ocasionalmente de outros. O bem é avaliado de acordo com o que corresponde a uma troca ou acordo igualitário. NIVEL II-CONVENCIONAL. Estádio 3 - Orientaçăo para a conformidade interpessoal, baseada na aprovação e nas expectativas dos que estăo próximos. Conformismo para com as regras e a autoridade, na base do qual se conduz o bom comportamento estereotipado. Estádio 4 - Orientação para a manutenção do sistema social e consciência moral. Imperativo de consciência que responde às obrigações estabelecidas por cada um. Cumprimento dos deveres acordados segundo o sistema de papéis e de regras de cada sistema. NIVEL III - REGIDO POR PRINCÍPIOS. Estádio 5 - Orientaçăo para o contrato social. Reconhecimento da existência de um ponto de partida fundado na obrigação perante as leis respeitantes ao bem-estar de todos e à protecçăo dos direitos de todos. Estádio 6 - Consciência dos princípios éticos universais. Quando as leis violam estes princípios age-se de acordo com os princípios universais de justiça, igualdade de direitos do homem e respeito pela dignidade dos ser humano. 
ria à transmissão específica de um contéudo de valor, mas antes de tudo ao estímulo de novas formas de pensar e de julgar. ${ }^{(123)}$

Para que uma acção moral se possa inscrever num percurso destinado ao completo desenvolvimento humano, a psicologia do desenvolvimento cognitivo-moral procedeu à separação do momento e dos dispositivos da cogniçăo moral — julgamento e raciocínio morais - do momento e dos dispositivos da acção moral. Com esta distinção obtém-se uma formulação conceptual mais adaptada aos contextos pedagógicos e ainda a possibilidade de cindir em dois a subjectividade do sujeito moral, assim tornado capaz, não apenas de agir segundo princípios de justiça, como também de julgar a sua própria acçăo.(124) É nesta articulação entre o eu que age e o eu que julga o que age que se encontra o núcleo central das tecnologias do self. $E$ isto porque se apresentam diversas combinações possiveis entre interior e exterior, entre sujeito e contexto, entre inteligência e conduta: pode dar-se o caso de o nível de juízo moral elevado de certos sujeitos não os conduzir a um comportamento moral correspondente; pode dar-se o caso de as condiçōes de funcionamento da escola não favorecerem a expressão da justiça aprendida nos dilemas apresentados; pode tam-

(123) Não obstante a insistência dos argumentos de Kohlberg contra a endoutrinaçăo, o sistema dos três niveis de desenvolvimento nāo é, evidentemente, neutro quanto aos valores. Contrariamente à perspectiva dos autores que nos anos 60 impulsionaram o movimento dito de clarificação dos valores (cf. Raths, Harmin e Simon, Values and teaching, Columbus, Ohio: Charles E. Merril, 1966), que evita colocar os alunos diante de uma hierarquia de valores, defendendo a inexistência de valores universais e, portanto, a neutralidade da escola, o programa de desenvolvimento cognitivo-moral supōe que os estádios mais elevados são melhores que os iniciais porque claramente comprometidos com o princípio da justiça. Todavia, como o movimento de um estádio inferior para um estádio superior é, segundo Kohlberg, um movimento natural, por que se orienta para a única direcçãoo em que pode ir, nunca poderia ter uma natureza doutrinária. Argumenta ainda o autor que os procedimentos sugeridos para os professores utilizarem nos debates, no confronto de opiniōes e no interrogatório socrático, evita deliberadamente a imposiçăo de valores.

(124) Kohlberg só consolidou esta distinção no seu aparato teórico a partir do momento em que se envolveu directamente nas reformas educativas, nos anos 70 e 80 . A partir da intervenção nas prisōes e em escolas especiais Kohlberg concluiu que a educaçăo moral năo se podia resumir à discussão de dilemas morais, que se ficavam quase sempre pela formulação de julgamentos e pela produçăo de raciocínios, sem qualquer repercussão nas acçōes morais e, o que era mais grave, as práticas escolares podiam mesmo contrariar os julgamentos realizados em nome da justiça. Em 1978, o autor fixa em texto a consciência que então adquire do problema: «l realize now that the psychologist's abstraction of moral cognition (judgement and reasoning) from moral action, and the abstraction of structure in moral cognition and judgment from content are necessary abstractions for certain psychological research purposes. It is not a sufficient guide to the moral educator who deals with the moral concrete in a school world in which value content as well as structure, behavior as well as reasoning, must be dealt with. In this context, the educator must be a socializer teaching value content and behavior, and not only a Socratic or Rogerian process-facilitator of developments (Kohlberg, 1978: 14). 
bém dar-se o caso de os juízos morais exibidos num certo conteúdo não serem transferíveis para um conteúdo diferente; pode, ainda, acontecer que a conduta moral exercida num dado contexto político - institucional ou organizacional — não se exerça, ou não tenha condições para se exercer, em contexto diverso. Em qualquer dos casos, é a autonomia do juízo moral dos indivíduos que é apresentada como reserva última para a resolução destas incongruências. E quanto mais incongruência existe, mais os processos psicológicos internos são eleitos para as tarefas de descontextualizaçăo, devido ao seu grau de generalidade e desterritorializaçăo. ${ }^{(125)}$ Como sublinha Campos (1989: 19): «se os comportamentos e atitudes politicos são prioritariamente atinentes à educação para a democracia, já os valores e os processos psicológicos são também relevantes para as outras vertentes da formação pessoal e social». A questão que esta tecnologia coloca é a de saber como controlar o excesso de desterritorialização, que é também um excesso de impotência social. Confirmando, talvez, a eficácia relativa desta forma de socialização para a autonomia, todos os estudos realizados na década de 80 sobre os valores dos jovens portugueses, confirmam uma maior orientação para os valores pessoais do que para os sociais. Esta conclusão conduziu mesmo o autor de um dos estudos a interrogarse sobre a relaçăo entre autonomia pessoal e autonomia cidadă, nos seguintes termos: "será que a par do que parece ser a emergência de uma elevada procura de autonomia pessoal, se regista igualmente o crescer de um sentimento de impotência, de ausência de controlo sobre os fenómenos sociais e políticos? Se assim for, compreende-se que percam saliência os valores de igualdade, solidariedade e intervenção social e que se tornem objecto de valor as estratégias individuais de resolução dos problemas vividos» (Vala, 1986: 26). (126)

(125) Utilizamos aqui a noçăo de desterritorializaçăo das subjectividades à maneira de Deleuze $\mathrm{e}$ Guattari (1980, 1997: 166): «ce qui distingue le plus essentiellement le régime signifiant et le régime subjectif, aussi bien que leurs redondances respectives, c'ést le mouvement de déterritorialisation qu'ils effectuent (...) Nous avons vu que le régime subjectif procédait tout autrement: justement parce que le signe rompt son rapport de signe, et se met à filer sur une ligne de fuite positive, il atteint à une déterritorialisation absolue, qui s'exprime dans le trou noir de la conscience et de la passion. Déterritorialisation absolue du cogito. C'est pourquoi la redondance subjectif a l'air de se greffer sur la signifiante». Neste sentido, o absoluto de consciência obtido pela subjectividade é também um absoluto da impotência social. A subjectivaçăo é essencialmente constituida por processos lineares finitos porque a consciência é o seu próprio duplo.

(126) Durante os anos 80 realizaram-se dois estudos sobre os valores da juventude portuguesa, ambos utilizando a Escala de valores de Rokeach. O primeiro foi realizado pelo Instituto de Estudos para o Desenvolvimento em 1983 e utilizou apenas os valores finais da escala e foi sujeita a duas análises. Na primeira, Jesuíno (1983) conclui que existe a predominância dos valores pessoais sobre os sociais. 
Não obstante, a corrente de pensamento do desenvolvimento cognitivo-moral viria a ter uma grande divulgaçăo no período que precedeu a chamada reforma curricular e em especial durante as discussões a propósito das disciplinas de Educação Cívica e de Desenvolvimento Pessoal e Social dos novos planos curriculares dos ensinos básico e secundário, aprovados pelo decreto-lei n. ${ }^{\circ}$ 286/89 de 29 de Agosto. Estas realizaram-se a partir de duas componentes: uma, política, centrada no conceito de educação cívica; outra, psicológica, centrada na vertente sócio-moral.(127) No primeiro caso, as referências do debate retomam, numa forma moderada pela mediação do direito, a querela entre educação confessional e educação laica, nos termos da qual «os planos curriculares dos ensinos básico e secundário integram ainda o ensino da moral e da religiăo católica, a título facultativo, no respeito dos princípios constitucionais da separação das igrejas e do Estado e da não confessionalidade do

Na segunda, Vala $(1985,1986)$, procedendo a uma maior desagragaçăo dos valores pessoais, distinguindo valores hedonistas e de desenvolvimento e valores de expressão e afirmaçăo do eu, e introduzindo os valores relacionais num nível intermédio ao nível social, que mantém, conclui existir uma hierarquia entre estes agrupamentos de valores com a seguinte ordenação: 1 . valores pessoais associados à satisfação e gratificação imediatas; 2 . valores relacionais ou afiliativos; 3 . valores pessoais de desenvolvimento e realizaçăo; 4 . valores sociais. 0 segundo estudo foi realizado no âmbito do Projecto «Portugal, Ano 2000 », conduzido pelo Serviço de Ciência da Fundaçăo Calouste Gulbenkian (Figueiredo, 1988). Abrangendo uma amostra de pais e filhos do Concelho de Matosinhos, o estudo utilizou a escala de valores finais e a escala de valores instrumentais, concluindo quanto à primeira que os jovens dão mais importância aos valores pessoais e relacionais, enquanto nos valores instrumentais privilegiam os valores de auto-realização.

(127) Ver, a propósito, os textos de dois colóquios realizados em Portugal sobre este tema. O primeiro, foi organizado pelo Instituto de Inovaçăo Educacional, entre 17 e 20 de Outubro de 1989. no âmbito do colóquio de directores de Institutos de Investigaçăo Educacional, promovido pelo Conselho de Cooperação Cultural (CDCC) do Conselho da Europa. Subordinado ao tema Socialização e Educação para os Valores Democráticos e os Direitos do Homem, viria a dar origem a um número especial da revista Inovação, 1989, contendo as comunicações apresentadas e o relatório final. O segundo colóquio decorreu em Lisboa, nos dias 7 e 8 de Novembro de 1991, por iniciativa do grupo de projecto Educação Pessoal e Social da Sociedade Portuguesa de Ciências da Educaçăo. Deste colóquio, intitulado Educação e Desenvolvimento Pessoal e Social resultou a publicação de um livro com a quase totalidade das conferências e comunicaçōes apresentadas: Júlia Formosinho et alii, Formação Pessoal e Social, Porto: SPCE, 1992. Sobre este tema ver ainda, no contexto da reforma curricular, do Conselho Nacional da Educaçăo, Pareceres e recomendaçōes, 88-89. I e II volumes, 1990, de João Fraústo et al., Proposta de reorganização dos planos curriculares dos ensino básico e secundário. Relatório preliminar (policopiado), 1987, e de Pinto Machado et al., Relatório da Comissão Executiva do Grupo Coordenador para o Estudo da Formação Pessoal e Social (policopiado), 1990. No contexto académico e de divulgação científica: Júlia Formosinho, A educação pessoal e social na LBSE e na reforma educativa. Braga: Universidade do Minho, 1988; Ramiro Marques, Educação cívica e desenvolvimento pessoal e social. Lisboa: Texto Editora, 1990; Ramiro Marques, A educação para os valores morais no ensino básico: o currículo implicito e explícito. Tese de doutoramento. Aveiro: Universidade de Aveiro, 1991. 
ensino público» (128) Sem embargo, outro será o nosso ponto de observação, se quisermos perceber de que modo o Estado se propõe refazer e redistribuir as técnicas cristãs de orientação pastoral para fins laicos e seculares (Hunter, 1996: 149). Dir-se-á que no interior deste debate um outro veio de problematizações, mais determinante, fizera o seu caminho entre o período das primeiras iniciativas de Educação Cívica, associado à criaçăo do ESU, e a publicação da LBSE. Referimo-nos à passagem de uma orientação colectiva e normativa de educação cívica dos jovens, para uma orientação individual e contingencial, logo, vinculada ao valor da responsabilidade. Atentemos ao percurso desta transiçăo. Nos primórdios da educação cívica, em tem-

(128) $\mathrm{Cf} . \mathrm{n} .^{\circ} 2$ do artigo $47 .^{\circ}$ da Lei de Bases do Sistema Educativo. Em torno deste artigo geraram-se as mais dispares interpretaçōes, debates e formulaçōes jurídicas, originando, para além de negociaçőes entre o governo, o Presidente da República [Mário Soares] e a Igreja, pareceres do Conselho Nacional de Educação, da Comissão de Reforma, da Igreja Católica e de uma Comissão [coordenada por Pinto Machado] constituída por personalidades de diferentes meios políticos e culturais. Também o Tribunal Constitucional viria a exercer o seu poder regulador através do Acórdāo n. ${ }^{\circ} 423 / 87$ de 27/10. Todo este trabalho de legitimaçăo da decisão política, realizado entre 1987 e 1991, tivera já como antecedentes um parecer da Comissāo Constitucional $\left(n .^{\circ} 17 / 82\right)$ ao decreto registado sob o n. ${ }^{\circ} 338-\mathrm{G} / 82$ do MEU, que viria a balizar toda a discussão ulterior. O que revela bem como, no cerne da discussão política, se encontra ainda a Concordata assinada entre o Estado português e a Santa Sé em 7 de Maio de 1940. Com efeito, o referido diploma visava regulamentar o artigo XXI da Concordata, confirmada pelo artigo II do Protocolo Adicional, de 15 de Fevereiro de 1975, entretanto ratificado pelo decreto n. ${ }^{\circ} 187 / 75$, de 4 de Abril. Estabelece este decreto, ao longo do seu articulado, as seguintes condiçōes, entre outras, de funcionamento da disciplina de religião e moral católicas: art. ${ }^{\circ} .^{\circ}-\mathrm{o}$ Estado garante $\mathrm{o}$ ensino das ciências humanas, morais e religiosas nas escolas; art. $^{\circ} 2 .^{\circ}-$ o Estado ministrará o ensino da religiāo e moral católicas nas escolas públicas elementares, médias e complementares, desde que não pedida isenção; art. $^{\circ} 3 .^{\circ}$ - o pedido de isenção terá de ser formulado em boletim de matrícula ou boletim de inscriçăo; art. ${ }^{\circ} 4 .^{\circ}$ - a disciplina da religião e moral católicas faz parte do curriculum escolar normal daquelas escolas; art. ${ }^{\circ} 5^{\circ}$ - à igreja católica compete a exclusiva responsabilidade pela orientaçăo doutrinária e pedagógica desse ensino, sendo a elaboração e modificaçăo dos programas da disciplina da competência do Episcopado; art. ${ }^{\circ}$ $6 .^{\circ}$ - compete ao Episcopado a aprovação dos manuais de ensino da disciplina e dos instrumentos auxiliares de trabalho. Apesar da evidente inconstitucionalidade da norma que acomete aos que nāo desejam receber o ensino da religião e moral católicas, a exigência de formularem tal pedido de isençăo, o parecer da Comissão Constitucional confirma a constitucionalidade em nome do «direito dos pais na escolha da educaçāo a ser proporcionada aos filhos menores abarcará naturalmente a área do ensino religioso". Apenas dois membros da Comissão Constitucional votariam vencidos. Hernâni de Lencastre, argumentará na declaraçăo de voto a favor da inconstitucionalidade do ensino obrigatório da religiăo e moral católicas, por que a "encarada hipótese de isençăo (artigo $3 .^{\circ}$ ) não a afasta visto que se assume como excepçăo, excepção que para se verificar terá de obedecer a um pedido e este a condiçōes de legitimidade, tempo e forma»; Armindo Ribeiro Mendes, na mesma linha de argumentaçāo, declarará que o regime proposto «é, todo ele, claramente inovatório em matéria tão delicada como a da liberdade religiosa, pretendendo o legislador governamental fazer vingar uma soluçăo que suscitara larga polémica em 1970 e acabou mesmo por ser repudiada». Cinco anos passados, o Tribunal Constitucional declararia inconstitucional norma semelhante inscrita no $\mathrm{n} .^{\circ} 1$ do art. $^{\circ} 2 .^{\circ}$ do decreto-lei n. ${ }^{\circ} 323 / 83$. 
po de democracia, a sua justificação discursiva insistia na função social e patriótica da escola. Tanto os que defendiam as disciplinas de Educação Cívica Politécnica e os programas de Introdução à Política como os que os atacavam, se reuniam afinal numa plataforma discursiva comum: a da necessária educação num projecto nacional, referenciado aos direitos e aos deveres relativamente ao Estado e aos restantes cidadãos, incorporando fortemente os futuros cidadãos na política nacional e nos projectos estatais. ${ }^{(129)}$ Mais tarde, vai transitar-se para uma perspectiva centrada na educação ética dos indivíduos, de modo a favorecer o exercício por cada um do autodomínio, disciplina, previsão e autocontrolo. Doravante, não se trata de cumprir um programa codificado de cidadania, segundo a moldura constitucional de direitos e deveres, mas de responsabilizar o indivíduo pelas consequências das suas escolhas. Contrariamente ao que foi referido por alguns autores, esta mudança não facilitou a distinção entre inculcação de valores confessionais, proposta pela igreja, e o «desenvolvimento da competência do sistema pessoal para a resolução criativa das tarefas da existência», proposta pelos autores que, no campo científico, promoveram, no suceder dos anos

(129) É certo que os discursos políticos não eram textualmente sobreponiveis, mas não teremos dúvidas em afirmar que tinham a mesma natureza, não obstante pugnarem uns pela incorporaçăo em projectos mobilizadores de defesa da revolução, de cariz mais social, e outros em projectos de dominaçâo burocrática, de cariz mais político. Exemplo tenaz do primeiro grupo foi Rui Grácio que, em artigo de 1978 (pp. 4-7), na revista O Professor (in Grácio, 1995: 371-377) ordena nas seguintes três categorias os objectivos nacionais do sistema educativo: "por um lado, a educaçăo escolar deve contribuir para o desenvolvimento da personalidade individual, potenciando as virtualidades próprias de cada um, de maneira equilibrada e harmoniosa; por outro lado, deve contribuir para o desenvolvimento e progresso da comunidade nacional, para a sua prosperidade económiva e para a sua estabilidade, ou para o seu dinamismo social, nomeadamente preparando māo-de-obra e quadros técnicos e culturais qualificados e, se possivel, motivados; finalmente, a educação escolar deve contribuir para reforçar a coesão social e um sentimento colectivo de identidade cujo produto histórico e cultural leva o nome de Nação, de Pátria». Esta coloraçăo patriótica da educaçăo cívica foi também surpreendida por Steve Stoer (1986: 195), embora partindo de diferente aparelhagem analítica. Em outro registo discursivo, Lucas Estêvăo, chefe de gabinete do ministro Sottomayor Cardia, num exercício prospectivo realizado no final do seu mandato, em Agosto de 1978, intitulado Educaçăo nos anos 80 (pp. 2-3, policopiado), sublinha a vertente de educação para a democracia constitucional, denunciando as influências sergianas: "o primeiro obstáculo a vencer é o que resulta de nem todos disporem dos instrumentos mínimos que possibilitem, na prática, o exercício do poder político que a Constituição confere a todos os portugueses. (...) A participação activa dos trabalhadores na empresa, na gestão das autarquias, nas colectividades de cultura e recreio, nos sindicatos, em suma a participaçăo política, impōe ainda, para além da formação básica, que entre os temas da acçăo educativa se incluam o cooperativismo, as regras de funcionamento da economia, a defesa do ambiente, o sindicalismo, a utilizaçăo criteriosa dos meios de comunicação social». Passado o ciclo da 'normalizaçăo', centrada em medidas políticas de sinal contrário ao ciclo revolucionário, retoma-se assim alguns dos temas da incorporação colectiva na cidadania. Em qualquer dos casos, trata-se de uma educaçăo que especifica o aluno como cidadão que deve adquirir os seus direitos civis, políticos e sociais. 
80, a problematização da transmissão neutral de valores. ${ }^{(130)} \mathrm{Em}$ boa verdade, os anos 80 foram os anos do regresso dos valores no formato de uma renovada articulação entre o juízo moral das virtudes cristãs «universalmente aceites», assentes agora no consenso da «matriz cultural portuguesa», e o encorajamento de uma ética prática da vida quotidiana. Postas as coisas de uma maneira um pouco diferente, enquanto no contexto político da cidadania e no contexto neutral dos especialistas das ciências psicológicas e pedagógicas, se fazia um percurso favorável a uma educação para os valores no âmbito do desenvolvimento cognitivo-moral de cada indivíduo; no contexto religioso, procurava-se a actualização dos valores consensualmente aceites seja na forma universal, nacional ou comunitária. Paradoxalmente, é a igreja que ocupa o espaço público, da criação de uma identidade colectiva, de um nós, enquanto o discurso político-científico se refugia no indivíduo e na sua ética individual. Produz-se assim, mesmo que temporariamente, um défice de discurso político no domínio público e um excesso de discurso moral no domínio pessoal. Com efeito, o discurso inscrito no desenvolvimento cognitivo-moral, para se resguardar da politização excessiva, recua para uma posição năo-política de cidadania, filiada numa das características da concepçăo política de justiça de Rawls. Se bem que Rawls apenas

(130) Esta formulação pertence a Bártolo Paiva Campos que num dos artigos publicados sobre a temática da Formação Pessoal e Social formula a hipótese de esta designaçấo se prestar a «acentuar duas perspectivas que, embora com zonas sobreponiveis, fazem evoluir a implementação da área em direç̧ōes completamente divergentes e a que, para simplificar, chamarei a 'educaçăo para os valores' e 'o desenvolvimento da competência do sistema pessoal para a resolução criativa das tarefas da existência'. As forças socio-politicas que impulsionam a primeira, até agora as mais fortes, focalizamse na designação e em todos os objectivos da Lei que apoiam esta interpretaçăo. As que impulsionam a segunda, até agora as mais frágeis, estão sempre a chamar a atenção para as componentes e para as dimensōes com elas relacionadas que estão aquém do processo de interiorização dos valores; sem grande eficácia até agora». (Campos, 1992: 15-16). Em boa verdade, o facto de a designaçăo Formaçăo Pessoal e Social conter perspectivas que servem de suporte a forças sociais e políticas diversas, corresponde a uma relação não necessária entre discursos heterogéneos. É o caso da relação entre o discurso social-cristão dos valores, o discurso do desenvolvimento cognitivo-moral da psicologia e o discurso cívico da tradição republicana. A totalidade que as correlaciona num determinado momento define a montagem de discursos de proveniência diversa e até contraditória, mas que se articulam para produzirem uma narrativa única representativa do todo. Como argumentamos em capítulo introdutório, se neste processo de rearticulaçăo, que decorre em tempos e espaços muito diversos, nunca se chegar a uma equivalência total, isto é, à reduçăo do campo discursivo a duas plataformas antagónicas, então é bem possivel que a hegemonia de um momento se torne na institucionalização da hegemonia e no reconhecimento, pelo campo discursivo, da existência objectiva e autónoma do objecto arbitrariamente construido. Podendo concluir-se, por conseguinte, que a hegemonia não anula os discursos que têm uma existência exterior ao campo discursivo em causa, apenas Ihe definindo uma regra comum, um regime de verdade, formas específicas de reactivar discursos anteriores, ou seja, aquilo que temos vindo a designar por episteme. 
seja referido indirectamente, ${ }^{(131)}$ dificilmente se pode fugir à influência da sua concepção política de justiça, por que segundo o enunciado da sua terceira característica, esta «não é formulada em termos de uma doutrina religiosa, filosófica ou moral geral ou abrangente, mas antes em termos de certas ideias intuitivas fundamentais latentes na cultura política pública de uma sociedade democrática». (132) Kohlberg traduz esta concepção para o contexto escolar e pedagógico nos termos da sua teoria das comunidades justas: «just community theory postulate that all older children and adolescent have two central moral concerns or passions. The first is a passion for justice whatever this stage of justice of the student. The worst thing a student can say about a teacher or a school is that is unfair. The seconde is passion for community, for a sense of membership in a group which has collective solidarity, care and loyalty. The theory does not romantically postulate that students are always or naturally wise or good. It does postulate students are usually responsive to teacher advocacy which is

(131) Com efeito, Kohlberg faz referência em alguns textos à tradição liberal e racional de Kant, Mill, Dewey e Rawls. É o caso de um artigo de 1975, publicado na revista Educational Leadership, $33, \mathrm{pp} .46-54$, no qual filia a distinçăo entre principios universais de justiça e regras na «liberal or rational tradition running from Kant through Mill and Dewey to John Rawls. Central to this tradition is the claim that an adequate morality is principled, that is, that it makes judgments in terms of universal principles applicable to all people. Principles are to be distinguished from rules. Conventional morality is grounded on rules, primarly 'thou shalt nots' such as are represented by the Ten Commandements. Rules are prescriptions of kinds of actions: principles are, rather, universal guides to making a moral decision». Para o liberalismo, o julgamento racional requer o desenvolvimento completo e equilibrado do carácter. Tenha-se em consideraçăo, por exemplo, que a teoria da justiça de Rawls pressupōe a neutralizaçăo prévia de tudo o que nas caracteristicas individuais pode enviesar o julgamento verdadeiro. $\mathrm{O}$ apelo de Rawls no sentido de cada um se imaginar fora da sua posiçăo social inicial, de modo a poder julgar equitativamente e a não tirar vantagens para si, năo é mais do que a expressăo de uma imagem idealizada de um indivíduo abstracto, capaz de exercer a perfeiçăo do seu verdadeiro julgamento moral num vácuo social.

(132) Utilizamos aqui a tradução de Rawls citada por Chantal Mouffe no seu livro $O$ regresso do politico, Lisboa: Gradiva, 1996, p. 70. A citaçăo original encontra-se no artigo "The idea of an overlapping consensus», Oxford Journal of Legal Studies, 7(1), 1987, p. 6. E fazêmo-lo porque a análise crítica da concepção năo-política de cidadania da teoria de Rawls a que a autora procede se insere no nosso próprio percurso crítico das teses de Kholberg e dos seus divulgadores em Portugal. Chantal Mouffe refere-se nos seguintes termos ao discurso moral de Rawls: «assim restam-nos as ideias intuitivas para compreendermos em que sentido uma concepção de justiça é politica. Por outro lado, como já vimos, sendo as duas ideias intuitivas fundamentais de que ele parte a de que a sociedade é um sistema equitativo de cooperação social e a de que os cidadãos são livres e iguais em virtude de possuirem duas competência morais - (1) capacidade para um sentido de justiça e (2) capacidade para uma concepçăo do bem - , estamos ainda no dominio do discurso moral e a sua concepção de cidadania dificilmente é uma concepção politica.» (Idem, ibidem). Conclui mais adiante que «pensar a politica nos termos de uma linguagem moral, como Rawls faz, leva necessariamente a negligenciar o papel desempenhado pelo conflito, o poder e o interesse» (Idem, Ibidem, p. 71). Comparem-se as duas competências morais de Rawls com as duas paixôes morais de Kohlberg, designadamente a paixão pela justiça e pelo sentido de comunidade, que analisaremos no corpo do texto. 
fair and is at a somewhat higher stage than their own, in a context of reciprocity and equality» (Kohlberg, 1987: 336-337). Desta teoria resulta uma ideia intuitiva fundamental, que estaria inscrita implicitamente na cultura pública da escola e dos professores: uma visão da escola e da sociedade como um sistema justo de cooperação entre pessoas livres e iguais. Uma das questões cruciais que está em jogo neste ponto de vista é a criação de uma identidade colectiva, de um nós. Kohlberg e os que o seguem consideram que esta não deve ser pensada na base da endoutrinação de valores substantivos, mas antes enquanto dispositivo de discussão e deliberação democráticas ou enquanto desenvolvimento dos processos psicológicos. A neutralidade da escola e dos professores quanto aos valores estaria garantida por este abandono da substância em favor do procedimento ou dos processos psicológicos internos de cada um. No primeiro caso, o estabelecimento da democracia directa ou participativa fornece a prevalência do direito sobre o bem. Porém, esta prevalência deriva da existência de uma ideia de bem comum constituída pelos princípios políticos hegemónicos. ${ }^{(133)}$ Nem Kohlberg nem os seus émulos têm dúvidas de que a ênfase nos procedimentos não anula a necessidade de excluir algumas concepções de justiça do consenso possível. Porém, uma vez que, segundo Kohlberg, o movimento para estádios mais avançados de julgamento moral é natural, quando um ponto de vista é excluído, é-o por necessidade imperativa do exercício da razão, omitindo as relaçōes de poder do processo de decisão. Dessa forma, as relações de poder tipicamente escolares são encobertas por um véu de racionalidade que desqualifica como irrazoáveis e irracionais todas as posições que se afastam da universalidade normativa, apresentando-as como o resultado de uma racionalidade puramente deliberativa. O argumento de Mouffe (1996: 72) a propósito da concepção de política de Rawls parece adequar-se perfeitamente ao funcionamento das comunidades justas de Kohlberg: «parece acreditar que as discordâncias apenas respeitam às questões religiosas e filosóficas e que, evitando essas questões controversas, é possivel alcançar

(133) Num artigo já citado, datado de 1978 (Moral Education reappraised, The Humanist, 38, p. 14), Kohlberg estabelece uma forma mais activa de obter consensos generalizados nas comunidades escolares: «I now believe that moral education can be in the form of advocacy or 'indoctrination' without violating the child's rights if there is an explicit recognition of shared rights of teachers and students and as long as teacher adocacy is democratic, or subject to the constraints of recognizing student participation in the rule-making and value-upholding process». O que Kohlberg tem em mente é a criação de condiçōes ideais de discussão racional, baseadas em normas amplamente aceites nas sociedades modernas. Diálogo racional e respeito equitativo seriam as duas normas capazes de especificar um ponto de vista a partir do qual todos os membros da escola poderiam examinar a justiça das instituiçōes e das condutas. 
um consenso quanto à formas como as instituições básicas da sociedade podem ser organizadas. Está tão confiante em que só existe uma solução para este problema e em que individuos racionais, deliberando dentro dos limites do razoável e guiados apenas pelo seu proveito racional, escolherão os seus princípios de justiça que considera que seria suficiente que um único homem calculasse o interesse próprio racional de todos».

No segundo caso, a passagem por uma hierarquia necessária de estádios do desenvolvimento cognitivo-moral fornece a prevalência dos processos psicológicos internos de cada um sobre a impessoalidade e imparcialidade dos princípios de justiça universais. É neste pressuposto que Kohlberg tenta trazer para o campo pedagógico o confronto tradicional entre moral e política, que tem motivado as reflexões de outros liberais. ${ }^{(134)}$ Nos seus termos, Kohlberg propõe que comecemos por resolver esta contradição no conflito que cada indivíduo em formaçăo encontra em si mesmo, estabelecendo depois relações entre os valores morais da comunidade e os valores de cada indivíduo. Para os que advogam a neutralização da política por intermédio das comunidades, é o seu estatuto primordial ou pré-político que lhe fornece a capacidade de obter mais facilmente a convergência relativamente aos ideais morais: «the just community approach uses appeals to justice and to solidarity to support a common morality. It appeals to justice to develop a sense of community and a sense of collective solidarity, to develop justice of community. Fairness and respect between students and between teachers and students builds a sense of community, a sense of belonging to a good or worthwhile group. A sense of solidarity and shared valuing of the group and its goals makes students feel the importance of acting fairly. If students vote for and make rules and disciplines, they feel they own the rules, they identify with them» (Kohlberg, 1987: 337). Apresentam-se assim os elementos de uma etico-política que conjectura a responsabilização de cada um para consigo próprio e para com os outros. De qualquer modo, a moral daqui resultante é descontextualizada ${ }^{(135)}$ porque a incorporação dos valores resultante é um bem pessoal e não social. Mas estes têm

(134) Ver, por todos, Thomas Nagel, Equality and Partiality, Oxford, 1991.

(135) Utilizamos aqui este conceito com o sentido que lhe é dado por Giddens, embora procedendo a uma expansão evidente da sua aplicação. Enquanto Giddens (1992: 16) se refere à descontextualizaão dos sistemas sociais como «desinserção das relaçōes sociais dos contextos locais de interacção e à sua reestruturaçăo através de extensōes indefinidas de espaço-tempo», nós referimonos à descontextualizaçăo das práticas éticas pessoais que, depois de incorporadas, se tornam transportáveis e sujeitas a actualizaçōes nos espaços-tempos indeterminados em que o indivíduo circula. 
de ser trazidos à vida em contextos de vida muito diferentes. Trata-se então de saber quais os contextos de práticas sociais que formarăo as futuras comunidades em que os alunos actualizarão este bem pessoal. A concretização desta teorizaçăo no campo de aplicaçăo pedagógica e curricular, em Portugal, fornece-nos algumas pistas importantes para responder a esta pergunta. Desde logo, a Lei de Bases do Sistema Educativo, por influência directa de alguns especialistas das ciências da educaçăo, (136) introduz no n. ${ }^{\circ} 2$ do artigo $47 .{ }^{\circ}$, os contextos em que a formação pessoal e social se situará: a educação ecológica, a educação do consumidor, a educação familiar, a educação sexual, prevenção de acidentes, a educação para a saúde e a educaçăo para a participaçăo nas instituições, serviços cívicos e outros do mesmo âmbito. Mais tarde, estes contextos serão encaminhados para diferentes desenhos curriculares: a CRSE propõe que é «necessário reservar uma hora semanal para o desenvolvimento autónomo deste domínio ou área de formaçăo» (CRSE, 1988: 100), embora entenda que deve ser tratado como um espaço curricular năo disciplinar; a igreja católica propõe que esta área seja obrigatória, disciplinar e alternativa no âmbito da educação ética; o CNE recomenda também a criação de espaços curriculares não disciplinares de fre-

(136) Bártolo Paiva Campos, deputado pelo PRD e membro da subcomissão que negociou e elaborou a redacçáo final da Lei de Bases, relata assim o modo como esta influência directa se concretizou: «esta determinação da Lei de Bases não constava de nenhum dos cinco projectos apresentados pelos partidos à Assembleia da República. Foi proposta na subcomissāo parlamentar que negociou e elaborou o articulado final e foi votada por unanimidade. Infelizmente, uma unanimidade que nåo foi precedida de discussão ampla. Como surgiu tal proposta? Num debate que o grupo parlamentar, de que fazia parte, organizou com especialistas de ciências da educação, vários presentes acentuaram a importância desta dimensăo da educaçăo escolar. Foi pedido a um deles que redigisse um pequeno texto sobre a questão e, sendo eu e um colega de bancada, respectivamente, presidente e secretário da referida subcomissão parlamentar, apresentámos ai a proposta $\left(n .^{\circ} 2\right.$ no art. $\left.^{\circ} 47 .{ }^{\circ}\right)$. O que foi aceite por todos os partidos sem a menor dificuldade» (Campos, 1992: 14). Estranhando esta unanimidade, dificil de obter em outros momentos da negociaçăo da Lei, Campos deixa a seguinte interrogaçăo: «como se explica que esta 'intrusão', imediatamente oriunda do mundo das ciências da educaçăo, tenha obtido facilmente a adesão de todas as forças politicas do parlamento?» (Idem, Ibidem). Tentando responder a tăo estranha intrusão, o autor coloca uma hipótese que, como veremos, se aproxima bastante, embora por outra via, da nossa própria interpretação: «será que a fácil adesão a esta área estará na linha do pressentimento dos legisladores de que era preciso inserir algo mais para aumentar a probabilidade da educação escolar preparar para a vida?» (Idem, p.15). Com efeito, ao contrário do que a estranheza inicial revelada pelo autor faz crer, a introduçấo de uma perspectiva fragmentada da cidadania năo encontra qualquer oposiçâo porque já se encontra suficientemente apoiada nas problematizações da modernidade tardia.

(137) Decreto-lei n. ${ }^{\circ} 286 / 89$ de 29 de Agosto. Este decreto determina também, seguindo a posiçâo da igreja católica, que em alternativa à disciplina de Desenvolvimento Pessoal e Social os alunos poderão optar pela disciplina de Educação Moral e Religiosa Católica $\left(n .^{\circ} 4\right.$ do art. $\left.^{\circ} 7 .^{\circ}\right)$, condicionando à obrigatoriedade da frequência de uma das duas disciplinas $\left(n .^{\circ} 5\right.$ do $\left.\operatorname{art}^{\circ}{ }^{\circ} . .^{\circ}\right)$, em clara violaçăo da Constituiçāo. 
quência obrigatória; finalmente, o decreto da reforma curricular ${ }^{(137)}$ decide-se por uma opção mista de natureza transdisciplinar - quando prevê que todas as componentes curriculares devem contribuir para a formação pessoal e social -, e multidisciplinar - quando determina que a área-escola deve incluir obrigatoriamente um programa de educação cívica. Nesta operacionalização da decisão, o que sobressai é a ambiçăo de tornar transversal a todo o currículo escolar as preocupaçōes de educação ética e cívica, evitando, contudo, a simples dispersão por conteúdos disciplinares vários. Mas por um motivo bem diverso das preocupaçōes de controlo do Estado-educador. Enquanto estas se debatiam com a necessidade de incorporar o futuro cidadăo num espaço único de lealdade para com o Estado, o que se prevê agora é a circulação dos indivíduos por uma miríade de espaços sujeitos a diferentes lealdades.

Talvez se perceba melhor, assim, porque razão as propostas provenientes dos especialistas da educaçăo obtiveram tanto apoio tácito. Contrariamente à estranheza inicial manifestada por um desses especialistas [Bártolo Paiva Campos], a introdução de uma perspectiva fragmentada da cidadania não encontra qualquer oposição porque já estava suficientemente estribada nas problematizações que vinham sendo feitas, quer no interior quer no exterior do sistema educativo. Estas, como vimos, permitiram que a episteme da escola ligada à vida fizesse o seu longo percurso que a levou de uma concepçăo inicial, ${ }^{(138)}$ vinculada ainda ao discurso marxista e a um ponto de vista estatista, baseado na ligação à produção e na superação da distinção entre trabalho manual e trabalho intelectual, até à fragmentaçăo da esfera pública da cidadania dos anos 80, assente na destotalização da sociedade. Esta destotalizaçăo é, antes do mais, o mapeamento da sociedade segundo um espaço năo homogéneo, cindido em diferentes domínios: do ambiente à sexualidade, da saúde à vida familiar, do consumo à prevenção do risco. Mapeamento conseguido à custa de um escrutínio público cada vez mais desagregado — nas décadas de 70/80 regista-se a proliferação de inquéritos sobre atitudes, valores e sexualidade; estudos de opinião, de produtos e de mercado; estudos dirigidos a grupos ou a públicos-alvo como os jovens, ${ }^{(139)}$ as mulheres, os pobres e as minorias étnicas —, o resultado é a produção destas comu-

(138) Referimo-nos à disciplina de Educação Cívica Politécnica do ESU.

(139) Para uma análise da naturalizaçăo da juventude a partir da chamada crise juvenil, e dos seus efeitos na construção de uma problemática jovem e de uma comunidade jovem, ver o excelente artigo de Sérgio Grácio, Crise juvenil e invenção da juventude. Notas para um programa de pesquisa. In S. R. Stoer (org.), Educaçăo, Ciência Sociais e realidade portuguesa: Uma abordagem pluridisciplinar. Porto: Afrontamento, 1991, pp. 33-57. 
nidades como realidade social empírica. Num segundo plano, cada um destes domínios passou a conter ou a assegurar institucionalmente o aumento das escolhas possiveis. $O$ consumidor tem direito a aconselhar-se sobre a relaçăo custo-qualidade, os géneros têm direito a uma opção de orientação sexual, o cliente tem direito à escolha dos serviços, o votante tem direito a ser sondado sobre a sua opinião entre eleições, o cidadão prudente tem direito a escolher entre riscos de magnitude diversa, enfim, o cidadão tem direito a pensar segundo uma microética individualista que o confina ao âmbito restrito da sua acção. Porém, como sublinha Apel (1984), raramente esta capacidade microética de pensar tem competência para pensar ou pedir responsabilidades numa escala global, isto é, a partir de uma macroética. É neste espaço social do aumento das escolhas, sem a correspondente extensão das capacidades de escolha, que se insere o projecto da disciplina de Desenvolvimento Pessoal e Social. Os especialistas tomam consciência de que existe um défice de valores e de moral porque, como sublinha Rose (1999: 190-191) «within this culture of the self, techniques of citizen formation - in schools and colleges, in the little pedagogies of confessional talk shows and soap operas - are no longer about the inculcation of externally validated morals and obligations. They address themselves to the practices, techniques and styles of self-reflection and self-management necessary for the active construction of an ethical life». É neste contexto que se desenvolve a actualização da velha ambição dos sistemas educativos resgatarem num indivíduo abstracto a plena apropriação das suas capacidades próprias.

Na nossa interpretação, a forma utilizada pela LBSE para caracterizar a área da formação pessoal e social constitui a primeira tentativa para alargar as tradicionais tecnologias de integração dos jovens nos mitos da cidadania estatal, com expressão corrente na educação cívica, aos temas da formaçăo para a construção da sociedade civil, inicialmente representados por um agregado de instituições cujos membros estão envolvidos em actividades não estatais. Daí a referência privilegiada a domínios

358 privados, corporativos e quase-públicos que vão da família (educação familiar e educação sexual) ao consumo (educação do consumidor), da preservação do ambiente à prevençăo rodoviária, da intervenção em instituiçōes públicas à intervenção no associativismo nāo-estatal. A cidadania deixa de se realizar apenas numa relação directa com o Estado ou numa única esfera pública, estendendo-se agora à produção económica e cultural, à vida familiar e privada, ao associativismo voluntário e às áreas de risco social, tais sejam as da saúde, da sexualidade, do trânsito e do ambiente. O futuro cidadão é cindido em tantos cidadãos-locais quantos os domínios da subjectividade privilegiados. Assim, o cidadão-consumidor deve tornar-se num agen- 
te activo de regulação e de estímulo da qualidade; o cidadão-produtor deve formar-se enquanto agente activo de inovação e regeneraçăo industrial; o cidadão-prudencial deve consciencializar e prevenir os riscos; o cidadão-chefe-de-familia deve preparar-se para a vida familiar; o cidadão-politico deve cumprir as suas obrigações de participação nas organizações da sociedade civil. Em sintese, a cidadania deve ser activa e individualista e não passiva e dependente.

É esta cisão do sujeito em diversas subjectividades que torna imprescindível a articulação de um espaço vertical disciplinar com um espaço transversal de natureza transdisciplinar. Tanto um como o outro devem, segundo a CRSE, procurar o enraizamento e ligação à comunidade.Trata-se de criar as condições para uma nova ficção que recrie e congregue a zona das liberdades naturais. Esta nova ficçăo é a comunidade. Em outros paises este caminho fez-se com a teorização de um terceiro espaço entre os aparelhos burocráticos dos serviços estatais e o mercado livre. O terceiro sector passou a ser apresentado pelos comunitaristas como a possibilidade de regressar a uma política baseada numa ordem moral comum. Embora as referências à comunidade tenham ressonâncias muito diferentes, as práticas que lhe correspondem vão fazendo o seu caminho unificador: trabalho social voluntário e caritativo; mediadores escolares para as minorias étnicas; redes de apoio local aos desempregados; participação dos pais na gestão escolar. A comunidade, nos seus contornos iniciais pouco definidos, não é um espaço geográfico delimitado nem tão pouco um espaço determinado por serviços ou uma certa constituição sociológica. Apresenta-se antes como um espaço de relaçōes, um campo moral que envolve as pessoas em interacções duráveis. Etzioni (1997: 127), um comunitarista liberal, define do seguinte modo este novo campo da governamentalidade: "community is defined by two characteristics: first, a web of affect-laden relationships among a group of individuals, relationships that often criss-cross and reinforce one another... and second a measure of commitement to a set of shared values, norms, and meanings, and a shared history and identity - in short, to a particular culture».

É nesta linha que a reflexão moral se desenvolve em Portugal no final dos anos 80. Tanto o ministro Roberto Carneiro como os seus dois secretários de estado da Reforma Educativa, levam a cabo uma verdadeira batalha de restauração e de regresso aos valores. Mas como fazê-lo sem encorajar uma visão moral única e assim rejeitar o pluralismo liberal? Como pode educar-se para os valores numa sociedade multicultural e multiconfessional, sem ferir os pressupostos da liberdade individual e da autonomia pessoal? A opção năo consiste em fazer um recuo a uma ordem baseada em deveres impostos, mas antes na evocação de alguns valores nucleares, suposta- 
mente partilhados pelos membros de todas as comunidades. ${ }^{(140)}$ Para o cumprimento desta tarefa, o discurso político vai procurar uma dupla aliança com a igreja e com os especialistas. Porque esta moralidade é considerada um limiar mínimo do discurso público, deixando intocadas as concepçōes controversas de felicidade em que cada um se pode empenhar, não se estranha que o campo político entregue aos especialistas, com cada vez maior frequência, a tarefa de encontrar uma justificação neutra para a neutralidade moral do Estado. Em Portugal, a introdução de uma ética-politica no sistema educativo está inextricavelmente associada aos especialistas. Contrariamente ao que tem sido dito, os especialistas têm introduzido frequentemente temas

(140) O secretário de estado da Reforma Educativa, Pedro d'Orey da Cunha, foi particularmente prolixo na divulgaçăo desta posiçăo que anuncia o regresso do raciocínio moral aplicado ao tratamento das instituiçōes politicas. Para recuperar o aspecto normativo sāo introduzidas na discussão política preocupaçōes morais sobre a autonomia, a solidariedade e a imparcialidade, numa matriz europeia comum que, sublinha-se, é a matriz católica: «se é certo que os acontecimentos de 1989/90 nos fizeram surgir uma 'Nova Europa' cheia de desafios educativos, também é certo que, numa segunda aproximaçăo, o que podemos ver sāo manifestaçōes cada vez mais surpreendentes e ricas de uma Velha Europa que desce às fontes da sua identidade e destrói os esquemas que a aprisionavam. Na origem da identidade cultural europeia, a civilizaçăo grega e a cultura cristă, encontra-se, sem dúvida, o conceito de homem como pessoa, que exige, num mesmo elo de ligaçăo lógica, a máxima autonomia para si e a máxima doaçăo ao outro; o homem como fim em si mesmo e o homem como membro da comunidade; o homem como realizando-se no seu projecto e o homem como só se salvando na doação ao outro" (In intervençăo do secretário de estado da Reforma Educativa no seminário Nova Europa e Reformas Educativas, 17 de Janeiro de 1991, documento policopiado, pp. 7-8). É neste veio de reflexão que se vão acamar os pontos de vista da igreja católica, como os que são defendidos, em proposta de 20 de Maio de 1988, enviada pelo Presidente da Comissăo Episcopal de educação cristã ao ministro da educaçăo: "1. que seja criada uma área de formaçăo pessoal e social (art. ${ }^{\circ} 47 .^{\circ}, \mathrm{n} .^{\circ} 2$ da Lei de Bases do Sistema Educativo), que garanta a formaçăo dos alunos nos valores da respectiva confissão religiosa e nos valores tradcionais da nossa cultura. 2. Que nesta área pluridisciplinar seja obrigatória a frequência de uma das seguintes disciplinas, em alternativa: Religiăo e Moral Católicas (art. ${ }^{\circ} 47 .^{\circ}$, $n .{ }^{\circ} 3$ da Lei de Bases), disciplina equivalente a outras confissōes religiosas e outras disciplinas de educaçăo ética, que veiculem os valores universalmente aceites e aqueles que constituem a matriz cultural portuguesa». Embora nunca se chegue a concretizar de que se fala quando se enfatizam os valores universais e os valores da matriz cultural portuguesa, resulta daqui a proposta de uma formaçăo pessoal e social simultaneamente avessa ao relativismo e ao endoutrinamento: "ao caírem os blocos, dois fenómenos se podem facilmente observar. Ou as pessoas se sentem tăo aliviadas das antigas opressōes que nunca mais se queiram preocupar com os valores e a sua transmissăo, e entâo se instalam num relativismo moral despido de toda a racionalidade; ou as pessoas se sentem subitamente desprotegidas e vazias, sem princípios de orientaçāo nem regras de conduta e, então, caíam numa profunda depressão, sem entusiasmo nem desejo para assumir a nova liberdade (...) Portugal passou também por um processo de crise ideológica profunda, nos princípios dos anos 70 . Só volvidos 17 anos, se conseguiu começar a reorganizar, no sistema educativo, um sistema de educaçăo para os valores, que promova uma autêntica visáo ética da realidade dos nossos alunos e uma formaçăo de carácter que possibilite a tradução do juízo ético no comportamento habitual. O desafio consiste em que o consigamos fazer, não à base da transmissão de receitas, mas à base da discussão de princípios, não à base da endoutrinação, mas do diálogo crítico, năo à base de recepçăo de ideias feitas, mas por meio de acçăo empenhada" (Pedro d'Orey da Cunha, Ibidem, pp. 6-7). 
na agenda política, embora esta colaboração poucas vezes tenha assumido um formato orgânico sistemático. Na verdade, quer a fragilidade discursiva quer a fragilidade associativa das ciências da educação não tem permitido a sua participação regular enquanto comunidade, não obstante o papel determinante desempenhado por alguns especialistas em momentos fulcrais da reforma educativa.

É a linguagem do indivíduo empreendedor, com iniciativa e eficácia própria, que vai articular dois universos aparentemente contraditórios. Como faz notar Pedro d'Orey da Cunha, depois da queda do Muro é possível também chegar a uma plataforma de estabilidade entre ciência e religião e entre orientações ideológicas até entăo irreconciliáveis: «ora, creio que temos hoje em dia na Europa a possibilidade de, embora partindo de pontos de vista opostos, chegarmos a uma plataforma de estabilidade em que os que realçavam sobretudo a autonomia, se empenham agora também na solidariedade; e os que enfatizavam a solidariedade querem recuperar, de braços abertos, a autonomia (...) Na linha da abertura à autonomia, significa em primeiro lugar um muito maior empenho na educação para essa mesma autonomia. Os métodos de aprendizagem têm de ser dirigidos ao reforço da auto-estima do aluno, à promoçăo da sua criatividade, espírito de empreendimento, de iniciativa, de eficácia própria» (Idem, Ibidem, pp. 8-9). Nas mãos dos especialistas é colocada a tarefa de reconciliar os princípios de racionalidade do liberalismo: requerendo que os indivíduos se conduzam, simultaneamente, enquanto sujeitos de liberdade e sujeitos sociais. Estes, ao tornarem visíveis domínios anteriormente discutidos no terreno da filosofia, tornam possível imaginar a regulaçăo da existência individual e colectiva através de um conhecimento que funde valores e virtudes. ${ }^{(141)}$ A auto-estima, a criatividade, o

(141) O tema das virtudes é reintroduzido no debate sobre a formação pessoal e social por intermédio das propostas de Kevin Ryan (1986). Mais uma vez, é Pedro da Cunha um dos mais constantes divulgadores das suas posiçôes, introduzindo a diferença entre desenvolvimento cognitivo e formação do carácter. Não por acaso, a experiência acumulada pela igreja católica é tomada como um exemplo a seguir nos seus métodos: «na base dos estudos modernos sobre a criança, de Piaget a Kohlberg e a J. Kegan, toma-se a sério o facto de a área mais propriamente sócio-moral ser uma questão de desenvolvimento; que esse desenvolvimento está relacionado com o desenvolvimento cognitivo, mas não necessariamente; que pode haver paragens, avanços e recuos, que se podem criar métodos, materiais e actividades que promovam, por si, esse desenvolvimento e o articulem com o desenvolvimento mais propriamente cognitivo. Até agora, apenas a moral e religiáo católica tinha experiência de um processo de desenvolvimento assim concebido e assim estruturado. Procurou-se agora que todos os alunos pudessem participar em tal experiência, embora dando à sua escolha a integração do ponto de vista propriamente religioso. $E$ assim que a nova disciplina se intitula, com propriedade, 'desenvolvimento pessoal e social': não se trata apenas de formação, trata-se de desenvolvimento, de processo, de caminho. (...) Foi mérito próprio do professor Kevin Ryan o ter 
espírito empreendedor e a auto-eficácia passam a estar associados a tecnologias de diagnóstico psicológico e a racionalidades pedagógicas que operam as conexões necessárias entre ética e política. Os alunos ligam-se a um campo social por intermédio de actos de escolha regulados e não por força do constrangimento ou da obrigaçăo. São as novas categorias psicológicas que escrutinam o self e a renovada pedagogia da autonomia que assegura a transferência dos problemas do governo do Estado para os indivíduos. Como faz notar o ministro da educação Roberto Carneiro, na abertura do seminário sobre Formaçăo Pessoal e Social organizado em Janeiro de 1991 pelo IIE:(142) «este trabalho é de grande dificuldade técnica e científica, pois năo se trata de elaborar programas em moldes tradicionais, como matérias de leccionaçăo, mas sim percursos de desenvolvimento e de integração. Tais percursos, balizados por orientações universais e comuns, devem ser delineados e desenvolvidos pelos próprios alunos, pois pretendem, essencialmente, constituir o campo em que eles, como pessoas em sociedade, se constróem no seu próprio itinerário de maturação. Trata-se de libertar e não de constranger; visa-se acolher, com naturalidade, a diferença e a escolha ao invés de impor, arrogantemente, o molde e a marca. Com justeza, encara-se esta vertente essencial da reforma educativa com critérios de exigência e de qualidade». Neste parágrafo estão condensadas as três principais formas de conexão entre os especialistas, psicólogos e educadores, e as novas formas de governo liberal: racionalidade, autonomia e um novo privatismo. Racionalidade em primeiro lugar: o exercício da dominação legítima sobre a cidadania exige uma base técnica e científica. Embora o discurso educativo deste período sublinhe sempre o primado dos referenciais axiológicos, é na ciência que se procuram os cálculos e as justificaçōes respectivas. É esta dependência do poder político face a um conhecimento verdadeiro e a técnicas eficazes que abre um vasto e prometedor território aos especialistas, quer por intermédio da intervenção individual, quer das suas organizaçōes corporativas, ou, ainda, da tecno-estrutura do próprio ministério.

Autonomia é o tema hegemónico do discurso político, ético e científico, sem distinçăo ideológica. Esquerda e direita confundem-se nos seus arroubos autonómicos.

vindo a alertar, nos Estados Unidos, para a necessidade de concretizar o desenvolvimento moral que se dá no campo cognitivo e afectivo com a formaçăo de carácter que se efectua no comportamento. O desenvolvimento pessoal e social só é completo quando se exprime em virtude, em hábito, em aç̧ōes continuadas». (In intervenção do secretário de estado da Reforma Educativa na sessăo de encerramento do seminário Formaçăo Pessoal e Social, oportunidade do momento presente, Lisboa, 23 de Janeiro de 1991, documento policopiado, pp. 7-8).

(142) Discurso do ministro da educaçăo, Roberto Carneiro, na abertura do seminário Formaçăo pessoal e social em debate, Lisboa, 22 de Janeiro de 1991, documento policopiado, p. 11. 
O homem liberal a que aspira a formação pessoal e social deve construir todos os aspectos da sua vida como o resultado de escolhas entre várias opções. Cada atributo da pessoa deve realizar-se por intermédio de decisões pessoais e é justificada nos termos das necessidades, motivações e aspiraçōes do self. As tecnologias propostas pela Psicologia ganham um peso tanto maior quanto mais evidente é o seu envolvimento no projecto de resgate da personalidade integral do indivíduo. ${ }^{(143)} \mathrm{Os}$ enunciados são conhecidos e são um lugar-comum: a tarefa da pedagogia é transformar as crianças e os jovens em cidadãos modernos e autónomos, motivados e responsáveis, capazes de resolver problemas em contextos turbulentos e incertos. Faltando modelos com respostas universais apresenta-se uma nova tecnologia de controlo social. Em vez da pilotagem directa, a acção à distância; ao contrário da imposição normativa, a determinação de resultados e de perfis a obter; em vez da definição de procedimentos estritos de trabalho, a sugestão de modos de auto-regulação; substituindo o conceito de conhecimento curricular fixo e estável, o conhecimento plural e contingente; somando-se às tradicionais competências cognitivas de saber e saber-fazer surgem as competências do saber-ser.

O local de exercício do poder desloca-se para a actividade produtiva de cada sujeito, para as suas capacidades e, em última instância, para a construção da subjectividade de cada um. Năo age tanto pela coacçăo, constrangimento ou extracçăo, mas antes pela incitação, indução e produção. Tudo se encaminha para a formação de sistemas de acção à distância cada vez mais alargados. Quando se elabora um consenso local, fora das estruturas formais de poder, em que cada um interpreta os valores de outros na sua própria linguagem, definindo assim um padrão subjectivo regulador da sua própria conduta, forma-se um sistema de acção à distância. Estes sistemas de acção constituem novas relações de poder, não percebidas enquanto tal, porque formalmente distintas e autónomas das tradicionais fontes de poder.

(143) É a Proposta Global de Reforma que mais explicitamente sintetiza a perspectiva da autonomia, vista do ponto de vista dos psicólogos e o seu empenhamento no desenvolvimento integral do self: "podemos dizer que está hoje comprovado que se pode estimular o funcionamento para níveis cada vez mais complexos da actividade psicológica, isto é: a) um pensamento mais compreensivo que entre em conta com todas as variáveis e as suas relaçōes, que coloque alternativas e antecipe consequências; b) a capacidade de perceber vários pontos de vista (de outros mais próximos e de outros mais distantes) e incorporar esses pontos de vista no diálogo e nas decisões; $c$ ) a capacidade de ter um comportamento empático integrando nas atitudes a sensibilidade a círculos cada vez mais alargados de relaçōes humanas; d) o desenvolvimento do self tanto mais identificado quanto mais integrador de possibilidades múltiplas, de perspectivas e sentimentos diferentes; e) e, finalmente, a construçăo de valores universais que orientam o pensamento e o posicionamento moral do sujeito para além das meras convençōes" (CRSE, 1988: 124). 
Finalmente, a problemática da governamentalidade liberal depende da criação de novos espaços privados, exteriores à moldura formal dos poderes públicos. Os espaços privilegiados são a família e as organizaçōes. Os objectivos estabelecidos para o ESU e para o ensino secundário no seu conjunto recuperam grande parte do discurso psicológico e pedagógico sobre a autonomia, a individualização e a auto-responsabilidade do aluno. Não se trata de uma novidade, mas de uma remanência das antigas técnicas de si. O próprio termo individualização năo surgiu evidentemente neste período e assinala mais do que uma alteração de vocabulário. $\mathrm{O}$ uso do termo foi reactivado em relação com outros fenómenos: o desenvolvimento de domínios de conhecimento diversos, que văo dos mecanismos psicológicos do eu até às variantes sociais do comportamento; a elaboração de um conjunto de regras e de normas, parte delas tradicionais, que se apoiam na escola e na família; mudanças também no modo como os alunos foram levados a conferir sentido e valor à sua conduta, aos seus deveres escolares, aos prazeres, aos sentimentos e às sensações. 


\section{CONCLUSÃO}

\section{Arqueologia}

A análise arqueológica exige que cada unidade do discurso seja entendida estritamente em função de si própria, para só depois ser articulada com outros discursos. Consequentemente, é o discurso que articula as condiçöes técnicas, económicas, sociais e políticas com a teia de práticas que servem à sua reprodução. Ao elegermos como domínio arqueológico os campos definidos pelas tecnologias e racionalidades que têm na estatística e no planeamento os seus elementos predominantes, pretendeu-se caracterizar discursivamente aquilo que numa visăo tradicional das políticas educativas é considerado como estrutura ou como dados objectivos. Nesta visão, seriam estes elementos reais e positivos da situaçăo do sistema educativo que permitiriam o exercício de intençōes, programas, estratégias e vontades. O nosso dispositivo de observação examinou a contrario: prescindindo da autonomia das formas de saber, incluindo a autonomia do saber científico, por força da sua inserção em regiões discursivas moventes, procurámos nas tecnologias positivas do poder, designadamente nas zonas de maior interface entre o discurso técnico-científico e o discurso político, a emergência de redes hibridas, envolvendo plataformas de entendimento entre diversos sujeitos e articulações não esperadas de conhecimentos de proveniência variada. O resultado deste empreendimento năo são observações de comportamentos ou de ideologias, mas a reconstrução das problematizaçōes através das quais a escola se apresentou ao mundo como podendo e devendo ser pensada. Por outras palavras, os comportamentos, os factos e as ideias contam sobretudo por aquilo que depositam no horizonte discursivo comum que resulta do seu entretecimento. É este horizonte discursivo que constitui o sistema conceptual sob os qual a escola é vista e interpretada: um conjunto de regras impostas num dado período histórico que permitem pensar e falar de qualquer coisa. 
O nosso ponto de observação e de análise incidiu nesse exercício positivo da vontade de conhecer como forma de dominar a situação e de a administração exercer o poder à distância. Esta vontade de conhecer foi interpretada não tanto nos termos do seu sucesso, mas precisamente nos termos das dificuldades específicas de a operacionalizar. Pretendemos, deste modo, caracterizar a estatística, a tecnologia do planeamento da rede escolar e a evoluçăo das formas organizacionais da administração como regiōes discursivas onde as políticas educativas foram acamadas. A questão central que assim obtém resposta é a de perceber uma parcela dos complexos mecanismos que permitem ligar os cálculos e problematizações realizadas num local, à acção noutro lugar distante. $\mathrm{O}$ único discurso sério sobre a escola passou a produzir-se numa episteme utilitarista, ou seja, numa linguagem sobre vantagens, desvantagens, relações custo-benefício e taxas de aproveitamento ou desperdício de recursos. A paisagem que propomos revela um conhecimento político muito distante do conhecimento baseado na virtude ou nas regras de justiça. $O$ que se oferece à vista é um conhecimento mundano travejado em índices, indicadores, percentagens e ratios. Apresentados em quadros de dupla entrada, gráficos, tabelas, correlações e cálculos de probabilidades tentam fornecer uma imagem real do sistema, a previsão de tendências ou a determinação de cenários prováveis. O que se nos depara é o vínculo dos departamentos da educação estatal à comunhão e à paridade de distribuição de recursos. Esta racionalidade tenta associar o baixo desenvolvimento dos recursos com a vitalidade industrial e o progresso económico nacional. Contudo, articula-se também, progressivamente, com a identificação dos interesses pessoais e com as expectativas particulares das famílias, tentando erradicar o liame entre origem social, treinabilidade e performance escolar, fazendo da escola e não da casa o espaço comum em que as capacidades podem ser identificadas, desenvolvidas e avaliadas. Neste suceder de articulações tem início uma nova estandardizaçăo: mede-se a participação educativa no contexto da sala de aula; medem-se os resultados académicos diferenciais na escola; monitorizam-se os efeitos do funcionamento escolar; registam-se as disparidades regionais dos recursos educativos nacionais.

Em qualquer dos casos podemos fazer um inventário dos efeitos da política dos grandes números a partir de quatro eixos.

O primeiro diz respeito ao papel dos instrumentos de diagnóstico na razão política, técnica e científica. Os números resultantes da sua aplicaçăo tornam possíveis e verificáveis os modos de governo modernos. O grau de exequibilidade é tanto maior quanto mais perto estiverem dos domínios em que devem operar. Se as políticas, os argumentos, as análises e as prescrições se propõem elaborar respostas, fazem-no 
em relação a um conjunto de questões. O estatuto técnico-racional da resposta está dependente da existência prévia de tais questões. Se, por exemplo, a flexibilização e a territorialização da construção escolar são apresentadas num determinado momento como as respostas para a explosão escolar, isso deve-se mais à questão da diversidade técnica do mapeamento escolar, quer dizer, à discriminação da observação do espaço escolar por regiões, zonas, casos e sítios, que passam a incluir no seu interior a observação de grupos sociais até então excluidos, do que à existência de um princípio moral de desenvolvimento integral das capacidades de todos. O novo espaço escolar assim constituído desagrega-se sucessivamente em dois tipos de problemáticas: por um lado, análise das aspirações e expectativas de pais, alunos, professores e empresas, mais tarde transformadas em estados ou funçōes psicológicas individuais, que revelam a formaçăo de expectativas elevadas na escolarizaçāo crescente; por outro lado, análise das condições de desenvolvimento social e económico local, mais tarde expressas em indicadores de empregabilidade e de probabilidade de inserção no mundo do trabalho, que tentam demonstrar o atavismo do sistema educativo face à dinâmica da inovação tecnológica. As tensōes entre democratização e modernização daqui decorrentes não são a expressão de formulações ideológicas contraditórias que, inscrevendo-se em programas sociais diferentes, desaguariam em mandatos contraditórios para o sistema educativo, mas antes a expressão decaída do novo mapa cognitivo da escola. Em bom rigor, democratização e modernização, quantidade e qualidade, não correspondem a esferas diferentes de intervenção da governamentalidade, por que se filiam no mesmo tipo de problematizaçăo. Em qualquer dos casos, a reflexividade institucional é introduzida na própria base da reprodução do sistema, na forma de exame da informação adquirida sobre essas mesmas práticas e não sobre a forma de princípios morais de justiça social. A confiança no sistema abstracto que estas problematizaçōes presentificam são, simultaneamente, uma forma de actualizar os compromissos năo-presenciais «em que se mantém a fé no funcionamento de saberes sobre os quais o indivíduo comum é largamente ignorante» (Giddens, 1992: 68).

O segundo eixo sublinha que a relação entre os grandes números e a política educativa é de reciprocidade e de mútua dependência. Na verdade, a quantificaçăo realizada pela tecno-estrutura do Estado, ou pelas suas assessorias técnicas, é politizada não porque seja manipulável, mas porque os julgamentos políticos estão presentes em toda a cadeia de processamento da informação estatística, desde a selecção do que se vai medir até à forma de apresentação e de interpretação dos resultados, passando pelos modos de recolha da informação (Alonso e Starr, 1987). 
O terceiro eixo considera que as imagens legítimas da política educativa são configuradas pela realidade social que as tecnologias quantitativas supõem revelar. $E$ isto não apenas devido ao seu valor simbólico, capaz de racionalizar e credibilizar a decisão política, mas sobretudo porque protege a estrutura de decisão formal da administração e das organizações de eventuais incertezas provenientes do exterior. Os números, bem como outros dispositivos de inscrição, tornam representável numa forma estática e domesticada os domínios que devem ser sujeitos à deliberação. Esta forma de pôr à distância, que recorta o mundo pela categoria e pelo número, característico da tecnologização moderna de toda a experiência social, estabelece uma reflexividade social capaz de confirmar a problemática de governo mesmo quando esta é contestada. Na verdade, é em nome do desenvolvimento integral das capacidades, da pertença a certos grupos sociais, de género ou de etnia, da educação responder às necessidades e capacidades ou de integrar certos grupos que o poder do Estado é injuriado ou invocado.(144) O princípio de confiança tem nos sistemas periciais uma forma simbólica de se actualizar: o governo social é um governo dos especialistas. Os dispositivos do Estado-Providência, quer nos países centrais quer nos países semiperiféricos, abrem uma variedade enorme de novos espaços à intervenção dos juízos dos especialistas tanto na área dos conhecimentos como da formação e das técnicas.

O quarto eixo retoma o veio do carácter paradoxal dos grandes números, por que embora estes sejam indispensáveis à racionalidade política, săo-no também para retirar certas áreas do escrutínio público. Os números refazem as relaçōes entre política e objectividade por força da principal regra que instauram, segundo a qual existem mecanismos técnicos para fazer julgamentos, problematizar situações, hierarquizar problemas e distribuir recursos. É a nova visibilidade criada pelos factos que torna possivel a espiral de especialização técnica e o imperativo de recorrer aos especialistas que os reunem e interpretam.

(144) Como argumenta Burchell (1991: 145) «it is in the name of our governed existence as individual living beings, in the name of our health, of the development of our capabilities, of our membership of particular communities, of our ethnicity, of our gender, of our forms of insertion into social and economic life, of our age, of our environment, of particular risks we may face and so on, that we both revile and invoke the power of the state». Na verdade, este jogo de confirmação ou contestação constitui uma forma de governamentalizaçāo do Estado, na medida em que tomaram forma a partir das imagens criadas pelas tecnologias de problematização postas em acção pelas suas diversas agências. 


\section{Genealogia}

Recapitulemos resumidamente as consequências mais importantes da genealogia da educação. Em primeiro lugar, verificámos que a educação para todos, a educação para a modernização do país ou a educação para o desenvolvimento das capacidades individuais não emergem de um mandato ideológico unitário ou de um mandato político tríplice. Dito de outro modo, não se trata tanto de uma síntese prévia sobre as finalidades da educação ou sobre os princípios morais que a devem orientar, mas antes do resultado de práticas de governo, contingenciais, postas em acção por actores policentricamente colocados que fazem das condições físicas, cognitivas e morais da população um objecto de governo. A relação entre os actores individuais e colectivos, entre o Estado e a sociedade civil, entre a administração, as escolas e as famílias, entre as assessorias técnico-científicas e os especialistas académicos é, antes do mais, uma articulação não-necessária que produz efeitos e não um acordo prévio ou uma maquinaçăo que pretende obter uma certa meta. É nesta rede de articulações e de movimentos que as novas técnicas de orientação pastoral, dirigidas ao indivíduo, se combinam com antigas formas de governo da populaçăo, resultando daí novas tecnologias de treino moral das jovens gerações. Nesta articulaçăo, o papel de alguns especialistas no interior da administração é incomparavelmente mais importante que o papel dos ministros da educação; as tecnologias e as tácticas de problematização, com origem na administração, fora dela ou em enlace com elas, frequentemente pouco visíveis, constituem mais decisivamente o discurso educativo, do que o aparato jurídico-legal. É no interior de uma nova racionalidade e com a mobilização de novas tecnologias ou a reactivação de velhas que um diferente mapa moral se constitui no sistema educativo português. Pela primeira vez, as estatísticas, o planeamento, a pedagogia, a psicologia, as famílias e os especialistas, por caminhos diferentes, com objectivos frequentemente contraditórios, constituem a episteme da escola da massas, no interior da qual o desenvolvimento educativo do conjunto da população e de cada indivíduo se tornou um objecto pensável e realizável.

Desenvolveram-se então duas espécies de problematizaçōes: as que se alojaram no espaço de representação mental, e que, pelo estudo da auto-estima, dos mecanismos de motivaçăo, dos dispositivos da metacognição, da articulação comum ao contexto escolar e ao organismo, funcionam como uma espécie de substracto ético; ai se descobria que as trajectórias escolares têm condições psicofisiológicas, que se formavam pouco a pouco no próprio corpo, que o interior era uma disposição e que esta não podia ser dissociada das particularidades do comportamento escolar do aluno. 
Em resumo, há uma natureza psicológica do conhecimento humano que determina as formas mentais. Produziram-se também as análises que, pelo estudo do diferencial entre representação e realidade - e.g.: entre expectativas e inserção realista no sistema de emprego - funcionaram como uma espécie de chamada à realidade; deste modo se mostrava que as trajectórias escolares tinham condiçôes históricas, sociais e económicas, que se formavam no interior das relações que os homens tecem entre si e que estas não eram independentes da forma particular que assumiam em cada contingência histórica. Este é o espaço da (des)ilusão e (des)alienação escolares.

O que há de particular nestas análises não é o facto de parecerem dispensar-se uma à outra, embora esse resultado pareça muitas vezes verosímil em virtude das fortes classificaçōes institucionais que separam e autonomizam o conhecimento psicológico e o conhecimento sociológico. Paradoxalmente, é a unidade e conjugaçăo destes conhecimentos que assegura a rigidez e a estabilidade de outras oposiçōes, estas bem mais decisivas, porque consensualmente aceites, em função da sua opacidade enquanto divisões: a que distingue o conhecimento do indivíduo, daquele que se considera o conhecimento do envolvimento ou da sociedade; a que distingue a ilusăo do discurso dos indivíduos sobre si e sobre a sociedade, do discurso científiço e das categorias capazes de organizar o senso comum em conhecimento verdadeiro; a que separa a verdade ontológica do objecto, da verdade da linguagem capaz de o representar; enfim, a que organiza o saber sobre o mundo em conhecimento dito objectivo, que confirma as análises positivistas, e em conhecimento dito subjectivo, que confirma as reflexōes escatológicas.

A crise de legitimidade que, sobretudo a partir da década de 80 , se vem tornando mais nítida, afinal sempre existiu, parecendo ser uma condição estrutural da educação. As noções de mudança e de inovação, profusamente introduzidas antes e depois do discurso «modernizador» dos anos 80 , dá conta dessa crise permanente. Até entăo, a crise ocultava-se sob discursos legitimadores assentes numa soma considerável de mitos sociais com forte consensualidade no imaginário social: o mito do 370 indivíduo, o mito do progresso individual e nacional, o mito do Estado enquanto garante da segurança da nação. A escola consubstancia assim os ideais do projecto moderno através de três pilares. $\mathrm{O}$ primeiro pilar é constituído pela articulação da racionalização e secularização da vida colectiva: a crença moderna no progresso linear e constante que a razão e a ciência anunciam. O segundo pilar é constituído pela crença no desenvolvimento de um sujeito autónomo e livre num espaço de cidadania público: a absorção progressiva e generalizada de toda a população no Estado tem na escola a instituiçăo integradora por excelência. $O$ terceiro pilar insere-se no rasgão introduzido nas ordens com o nivelamento dos privilégios hereditários e na 
crença na mobilidade social: a capacidade de o Estado acolher e gerir as expectativas sociais numa instituiçăo niveladora, regula e modera muito cedo as expectativas irrealistas. $\mathrm{O}$ ideal democrático da igualdade de oportunidades de acesso à escola e o consenso generalizado em uma escola única, capaz de expressar o interesse geral, são as grandes referências contemporâneas deste projecto. A escola pública do Estado Novo encarregou-se de introduzir distorçōes importantes neste projecto que apenas com a Reforma Veiga Simão e com a crise revolucionária de 74/75 começa a ter expressão mais nítida.

Contrariamente à homogeneidade e isomorfismo estatal que reverbera da sua superfície, os marcos principais que fazem da escola uma instituição à beira de uma crise de legitimidade permanente, andam a par da não-homogeneidade do espaço estrutural que a educação ocupa. A construção da Pedagogia enquanto ciência da educação, capaz de dar conta da unicidade do acto pedagógico, rapidamente se converteu em Ciências da Educação, que acentua o fracasso de tal empresa. A pluralidade e fragmentação do campo científico, na sua superfície epistemológica, tem no objecto escola, e nas múltiplas refraç̧ões a que está sujeito, a verdadeira raiz das oscilaçōes que ora o unificam ora o desestabilizam. A escola, com a sua gramática própria reconhecível, começa a perder a auto-evidência e as ciências da educação, como campo de conhecimento que ratifica o campo, conhece uma crise de identidade.

A nossa tese consiste no seguinte: as tecnologias de avaliação utilizadas desde o lançamento do ESU, em articulação com os novos indicadores estatisticos e os novos modos de planeamento, contribuíram decisivamente para o estabelecimento de novos espaços imaginários de governo da população escolar. Estes espaços permitiram a recomposição dos poderes de governo da escola, emergindo das novas relações os especialistas da planificação e os especialistas em ciências da educação. A expansão da investigação aplicada em educação e a utilização mais alargada de métodos empiricos facilitou a criação de um estatuto académico às ciências da educação e a sua crescente profissionalização. Esta é uma tese que confronta as análises estritamente epistemológicas que, ao fazerem a economia das condições sociais de inserção das ciências da educação, situam a sua emergência, em Portugal, na confluência da crescente auto-referencialidade internacional deste campo científico. Năo sendo este um eixo central do presente livro, as referências tranversais a esta temática colocam-na desde já como um dos seus prolongamentos necessários. Esclarecer qual o poder que a sociedade exerce sobre a comunidade científica e o poder que esta exerce nela foi uma das interrogações que surpreendeu o itinerário desta investigação e que, não obstante não tenha obtido uma resposta completa, nem por isso deixou de iluminar 
algumas das nossas interrogações. Sendo certo que a ciência é um dos poderes-saberes que circula na sociedade, especialmente adaptado à mediação entre a região continente dos discursos educativos e as suas regiões locais, é particularmente importante analisar as suas relaçōes com os restantes poderes, designadamente aqueles que atravessam com maior incidência o espaço-fronteira que é o da escola.

A educação escolar é heterogénea na sua constituição interna, em virtude da combinação de elementos provenientes de outros espaços discursivos com maior homogeneidade e autonomia estrutural. Dentre os espaços referidos sobressaem os da família, da produção e do Estado, sofrendo estes, por sua vez, à medida que são incorporados no contexto escolar, uma perda considerável da autonomia original das suas específicas formas de poder. Assim, as relações sociais típicas da família, assentes no casamento, no patriarcado e na discriminação afectiva, são transformadas, entre outras formas, na gestăo das emoçŏes e das expectativas escolares dos alunos, no que Donzelot (1979) designa por pedagogização das familias, ou em necessidades colectivas das familias, civicamente integradas pelo associativismo regulado pelo Estado. As relações sociais características da empresa, baseadas na exploração e no lucro, são tornadas em necessidades técnicas de modernização ou em formação diferenciada de mão-de-obra adaptada aos novos perfis de trabalho pré-definidos. As relações sociais estaduais, sustentadas pela dominaçăo legítima, são convertidas em contrato pedagógico ou em autonomia regulada por técnicas pastorais de si.

Quando se comparam as transformações operadas pelo contexto escolar em cada um destes espaços, é-se atraído pela homologia dos discursos utilizados. De facto, parece existir um murmúrio que se reproduz em duas direcções contraditórias. Como no Deus Janus, o rumor é feito a duas vozes: numa acentuam-se os traços tradicionais das formas burocráticas e tecnocráticas de regulação; na outra propõe-se o regresso à comunidade e aos princípios de informalidade e reciprocidade das relaçōes. Tal duplicidade tem sido apresentada como o resultado da desestabilização a que a escola tem sido sujeita pelo ataque cruzado da crítica pós-marxista e do neo372 liberalismo (Ball, 1990, Silva, 1995). Do lado pós-marxista e pós-estruturalista, o questionamento do sujeito autónomo, centrado e unitário no seu essencialismo, poria em causa as traves mestras da razão e do progresso. Do lado neoliberal, o questionamento do espaço público da educaçăo, deslocando-a para o domínio do consumo e da escolha das familias, ou da requisição da esfera produtiva, converteria a sociedade civil em domínio privado, situadas que estão, tanto a família como a empresa, fora do espaço político da cidadania. Com efeito, a família e a produçăo constituem dois redutos de resistência à politização e à democratização. A família resiste à politização porque subsistem fortes desigualdades sociais entre os géneros 
no seu interior e é muito discutível que o seu fim se possa consumar sem a dissolução do próprio modelo familiar. Embora a escola mantenha o compromisso de tratar cada aluno como uma singularidade, o seu interesse continuado pelas expectativas e interesses particulares das famílias não a deixa ao abrigo das suas capacidades de influência desiguais. Não por acaso, esta marca de diferenciação aparece de forma indelével nos estudos que integram o indicador classe social na caracterização das famílias. Com efeito, o estatuto socioeconómico presume a família nuclear, com a respectiva divisão de papéis sexuais e uma definição empírica do rendimento familiar a ser realizada por intermédio do rendimento do chefe de família, uma palavra inclusiva que deixa antever, no entanto, o domínio do papel masculino. Por seu lado, o espaço da produçăo resiste-Ihe porque as fontes de desigualdade nos contextos de trabalho são multidimensionais, não se limitando à relação de exploração capital-trabalho analisada pelo marxismo. As relações de poder que se misturam neste contexto envolvem, para além destas, as relações de produção e as relações na produção. No primeiro caso, estão envolvidos os processos de trabalho e de produção que têm desequilibrado de forma incontrolável, por força do determinismo tecnológico, as relações entre capacidade de acção e capacidade de previsăo. Quanto maior é o automatismo tecnológico maiores parecem ser também os riscos envolvidos para toda a humanidade, desequilíbrio este que tem nos sistemas educativos modernos um socializador comum, apostado na aceitaçăo de todo e qualquer automatismo tecnológico como um sinal de mudança e desenvolvimento inevitáveis. Esta ocultação das relações sociais de poder existentes por trás do véu de ignorância tecnológico tende a reproduzir no espaço escolar o mesmo efeito desresponsabilizador que aceita os danos possiveis em nome de uma expectativa desejável.

No caso das relaçōes na produção o que está em causa são as relações de poder entre trabalhadores, designadamente as que se repercutem em assimetrias de género e etnia. Se estas relações de poder parecem invadir o espaço da produção, a regulação do espaço escolar não se resume a um isomorfismo por intermédio das noçōes de competiçăo, meritocracia e selecção social. A ambiguidade torna-se imprescindivel à legitimaçăo das relações privilegiadas entre o espaço escolar de cidadania, baseado em direitos, e o espaço da empresa, baseado na exploração da mais-valia económica. O regresso da escola às noçōes de informalidade, trabalho de grupo e reciprocidade de relações, assentes em princípios pedagógicos comunitários, são também uma forma, nem sempre confortável, de fazer coexistir os imperativos de produtividade da indústria nacional com os imperativos de auto-realização do potencial individual de cada jovem. O mesmo é dizer que se trata de tentar compatibilizar o estatuto de futuro cidadão com o de futuro trabalhador. Nesta tentativa sempre falhada, mas sempre 
renovada, acolhe-se o direito à igualdade de ser tratado de forma desigual, quer dizer, o direito à selecçẫo social baseada no mérito e na sua medida normativa comum. A cidadania compreende, nestas condiçōes, um estatuto social determinado, para o qual os indivíduos devem ser munidos com os respectivos atributos e capacidades. Decorre daqui a dupla filiação das tecnologias escolares: por um lado, o sistema escolar continua a responsabilizar-se pelo direito absoluto à realizaçăo individual ou colectiva; por outro lado, permanece como a fonte maior de distribuição normativa da população pelo mercado de trabalho, confirmando o seu lugar na arquitectura da desigualdade legítima (Hindess, 1993). Pontos de vista aliás consistentes com o projecto de modernização liberal: parcerias sociais entre o Estado e o mercado na esfera da economia e parcerias morais entre a família e o Estado na esfera do desenvolvimento individual, ambas articuladas por uma crescente teorização do carácter comunitário das escolas. A estas se recomenda que interpretem a cidadania como actividade de coordenação, potencialmente consensual, dos impulsos provenientes das parcerias económicas e das parcerias éticas. Espera-se das escolas que tratem cada indivíduo como impulso original, espécie de direito predestinado à racionalidade e à autodeterminaçăo; sem abandonar, entretanto, a sua responsabilidade na formação directa da razão e do carácter. Do mesmo modo, as escolas hão-de reconhecer aos indivíduos os seus direitos prévios à cidadania futura; sem renunciar, todavia, à formação de alunos-empreendedores, competentes para o trabalho e para o exercício de responsabilidades vocacionais. Aberta esta primeira camada das tecnologias de governo da educaçăo, importa agora prolongar a análise ao nível propriamente curricular, no encalce das novas racionalidades que apenas se afloraram neste trabalho, designadamente as que subjazem aos novos perfis de trabalho e cidadania: espírito crítico, criatividade, disponibilidade para a inovaçăo, ambição pessoal, atitude aberta ao trabalho e equipa e à competitividade, capacidade de negociação. Este é o segundo eixo dos prolongamentos previstos neste trabalho.

\section{Legitimidade e contigência}

O governo da educação é uma actividade de problematização das dificuldades que o acontecer educativo coloca. A problematização realiza-se num duplo sentido: por um lado, detecta, nomeia, mede e rectifica as falhas e as limitações do sistema, traduzindo-as numa representação do real e, por outro lado, inscreve no governo de todos e de cada um ideais de harmonia, estabilidade e produtividade social dos cidadãos, decorrentes desse mesmo combate constante e sempre inacabado às 
dificuldades e falhas de governo. É em torno das dificuldades e das falhas que se constroem as racionalidades e tecnologias que analisámos. A noção de crise, tanto nos seus aspectos conceptuais como nas suas consequências politicas e sociais, representa a consciência máxima da impossibilidade de optar exclusivamente ou pela legitimidade ou pela resposta à contingência. No seio da noção e das práticas de crise concentra-se a experiência da cisăo entre transcendência e imanência, entre subjectivo e objectivo, entre crítica e falha, entre fundamento e estrutura. $O$ discurso político da crise tem uma aptidão notável para deslocar sentidos, dramatizar consequências, amortecer diferenças, esquecer princípios em nome das contingências ou rasurar contingências para lembrar princípios. A racionalidade política năo há-de ter, portanto, o carácter sistemático e fechado dos conhecimentos disciplinares. Contrariamente, está povoada de elementos com proveniências muito diversas. Seguindo a pista das racionalidades e dos discursos analisados nesta obra podemos identificar doutrinas filosóficas, discursos sobre a justiça, versões contraditórias da natureza social e humana, crenças sobre a eficácia das acções e justificações cognitivas que precedem ou sucedem às acções. Se procurarmos os conteúdos dificilmente encontramos regularidades que se possam sujeitar a uma classificaçăo. Mas se seguirmos a sua forma podemos discernir certas regularidades. Adaptando a classificação sugerida por Rose e Miller (1992) distinguimos três características principais das racionalidades políticas: assumem uma forma moral, articulam-se com certas formas de conhecimento e são transformadas em tecnologias intelectuais por intermédio de idiomas distinguíveis.

Comecemos pelo matiz moral, porque de matiz se trata. A justificação moral consiste em enunciar os princípios em virtude dos quais o governo da educação deve ser orientado: liberdade, justiça, equidade, responsabilidade mútua, cidadania, eficiência económica, prosperidade individual, crescimento económico e modernização são alguns dos que percorremos na nossa análise arqueológica e genealógica. Subjacente a todos eles a imagem ideal da pessoa enquanto sujeito possuído de impulso interno para o desenvolvimento, que aprende através da liberdade e que apenas procura na escola o instrumento da sua auto-realização. Porém, as metas que a governamentalidade propõe para si própria năo são justificações que existam no seu exterior, na forma de valores ou de princípios universais, cuja força e pregnância obrigariam à sua adjudicação automática ou ao seu abandono inconsequente. Dito de outro modo, não existe um mandato para a educaçăo inscrito em princípios morais universais. Estes mesmos valores apenas se tornam eticamente pertinentes quando os indivíduos são sujeitos à indução nas disciplinas de governo. É este o verdadeiro sentido da insistência de Foucault no Vigiar e Punir segundo a qual não são os princípios educacionais, 
mas as premissas da escola, que são centrais na maximizaçăo da gestão do território e das populações do Estado territorial. Ora, as premissas da escola são práticas subjacentes. No caso presente, mais não são do que a probabilidade de as tecnologias da autonomia, da auto-regulação do estudo e de conhecimento de si associarem activamente cada indivíduo à busca de uma forma de existência que garanta, simultaneamente, a realização pessoal e beneficie a família, a comunidade e o bem-comum da nação. A genealogia de Foucault permite-nos assim uma escapatória à analítica comum a liberais e às correntes críticas, de raiz marxista e neomarxista, que encontram no completo desenvolvimento pessoal do homem a finalidade última dos sistemas educativos. Em bom rigor, trata-se da recusa de uma escolaridade que lhe estivesse vinculada na essência. Desde logo porque tal mandato é ambíguo. Uma vez que o homem-escolar não se oferece ao conhecimento e aos exercícios escolares senăo na medida em que a própria escola faz da auto-realizaçăo o seu objectivo disciplinar central, poderá a sua subjectividade ser outra coisa senão o nó inextricável de uma forma sintética da pessoa (a personalidade integral) com o seu domínio formativo ideal (a experiência pessoal)? Mas então o homem-escolar, cultivado, não é ele próprio histórico? Uma vez que a personalidade cultivada depende de um conjunto limitado e definido de técnicas éticas, ${ }^{(145)}$ não são as necessidades de desenvolvimento integral que são a razão para que certas formas de conhecimento e certas técnicas se disponham nas escolas, mas, contrariamente, são o resultado de tal disposiçăo que, por seu lado, não encontra justificação senão na sua própria referencialidade e na capacidade de se articular com outros conhecimentos.

E essa é a segunda característica comum a todas as racionalidades políticas: o seu carácter epistemológico. Que neste contexto significa a capacidade de se articular com uma ou várias imagens dos objectos a governar. Como sublinha Burchell (1991), retomando P. Veyne, a racionalidade política especifica o campo sobre o qual o governo se exerce: sujeitos legais com direitos, rebanho que deve ser guiado, crianças que devem ser educadas ou tuteladas, recursos que devem ser explorados ou populações que devem ser geridas são algumas das imagens escrutinadas. Verificámos que, em grande medida, a definiçăo de uma nova matriz social de inserção da escola foi determinada pelos níveis de contingência burocrática. A contingência burocrática,

(145) Referimo-nos aqui às técnicas agrupadas nas quatro dimensões das artes de viver discutidas no capítulo V, designadamente os exercícios de domínio de si, de conhecimento de si e de cuidado de si na dimensâo ascesis; a identificaçăo das necessidades e a treinabilidade das capacidades na dimensão modo de sujeição; a auto-reflexão sobre as aprendizagens, o estudo e as aspiraçōes na dimensão da substância ética; a integraçăo de regras de conduta e a formação de disposiçōes para o trabalho em equipa e para a participação na dimensão teleologia. 
enquanto fenómeno não intencional, inesperado e indeterminado cumpriu funções compensatórias de uma descentralização ainda inexistente. Permitindo a canalização dos grupos de interesse, por intermédio de diferentes sectores da administraçăo, garantiu-se a dispersão das zonas de conflito e das contradições; promovendo a relação directa com especialistas da educação e com agências internacionais de natureza não-governamental, criou-se a possibilidade de tradução de diversos interesses numa problemática única; impulsionando a criação de novos objectos de regulação, tais como o projecto educativo ou os indicadores de desempenho, abriu-se caminho à delegação política nos objectos, quer dizer, à cristalizaçăo de conceitos instáveis em dispositivos materiais permanentes.

O aumento gradual dos mecanismos de interface entre a administraçăo e a sociedade civil, parcialmente constituída pela própria administraçăo, estabeleceu novos meios da governamentalidade. A desconcentraçăo de 1986 e o aumento dos níveis de contingência burocrática que Ihe sucedeu resultou também na reduçăo da intervenção casuística. $O$ caso, a excepção e a aberração passaram a inscrever-se no próprio sistema de planeamento, obrigando este a adoptar modelos probabilísticos de coordenação a partir dos resultados. Confirma-se assim o fenómeno da goal substitution que consiste numa variante da auto-referencialidade dos sistemas administrativos referida por Luhman (1990a): cada sector especializado do Estado tende a criar alguma autonomia por intermédio da capacidade repetitiva de substituir ou modificar os objectivos impostos pelo governo, traduzida em aumento da sua importância relativa no conjunto da administraçẵo. A elaboraçăo de programas que com cada vez mais frequência recorrem a agentes independentes da administração - psicólogos, especialistas da educação e do currículo, gestores, orientadores escolares, planeadores e trabalhadores sociais - aumenta os níveis de tradução(146) dos seus objectivos

(146) Utilizamos o conceito de tradução com o sentido que the foi dado por Callon e Latour (1981: 277-303): o movimento de deslocaçăo dos objectos sociais do seu espaço original para o espaço dos objectos científicos e destes para objectos de intervenção social não se dá por determinação ou derivação simples, mas por intermédio de operaçōes de tradução que consistem em demonstrar que o programa em causa constitui um ponto de passagem obrigatório para a obtenção dos interesses particulares de todos. Santos (1989: 166-168) discute as relaçōes privilegiadas entre a ciência e o poder do Estado a partir da noção de conversão reguladora, concluindo que as comunidades científicas podem usá-la «como forma de regular a transformação do conhecimento científico numa nova configuração do saber e, do mesmo passo, a sua própria transformação numa comunidade científica năo necessariamente menos científica, mas certamente mais comunitária». Esta seria a forma de a ciência viver a sua dependência em relaçăo às forças sociais que determinam o ritmo e o sentido do seu desenvolvimento. Se bem que reconheçamos o carácter contraditório da conversão reguladora, não nos revemos nesta passagem quase obrigatória da comunidade científica pelas alianças transitórias ou permanentes com os objectivos de governo. 
sociais em objectivos da ciência e destes em programas da administração. A nossa tese consiste em considerar que a contingência burocrática é a fractura que assegura a relaçăo cada vez mais penetrante entre o Estado e os domínios científicos que orbitam em torno do campo educativo. Desse modo, quer a paralisia generalizada do Estado, provocada pela luta de vários sectores políticos pelo seu domínio, durante a crise revolucionária, quer a fragmentação provocada pelo crescimento demográfico do sistema, mais do que desarticulação interna colocaram a administração ao abrigo dos excessos de politização. Com efeito, tanto o papel nuclear assumido pela tecno-estrutura do ministério, designadamente do GEP, como a participação vincada de alguns especialistas portugueses ligados às ciências da educação e à psicologia nos processos de assessoria técnica, e ainda a participaçăo de alguns grupos de cientistas internacionais ligados às ciências da educação, revelam a necessidade de certos sectores da administração arranjarem aliados externos para se legitimarem. Mas também revelam a procura crescente de aliados por parte dos cientistas da educação que se consideram afastados dos centros de decisão das políticas educativas.

$\mathrm{O}$ trabalho de influência sobre as esferas sociais exteriores à ciência, mas que detêm o poder sobre os recursos necessários à actividade científica, ou o poder de legitimar socialmente a importância de um determinado conhecimento, faz-se através da forte inserçăo individual de cientistas sociais nos organismos consultivos que requerem a sua participação. A par deste movimento de fora para dentro da administração, regista-se também um movimento de dentro para fora, com expressão no recrutamento que as universidades fazem junto dos especialistas da tecno-estrutura, que passam a circular numa rede alargada de produção de conhecimento em contexto de aplicação. A frágil autonomia do campo das ciências da educação, visível na débil auto-referencialidade e na deficiente auto-regulação, bem como a sua baixa intervenção pública, constituem uma das características mais marcantes da sua inserção social periférica. ${ }^{(147)}$ Tais condições dão origem a uma situaçăo de dupla regulação.

(147) Ver sobre este tema a intervençăo de António Nóvoa, no Forum de Projectos de Inovação e Investigação, Lisboa, 7 de Setembro de 1995 (documento policopiado), intitulada «O IIE e a investigação educacional». Partindo da análise dos 67 projectos apoiados pelo IIE (Instituto de Inovação Educacional) nos anos de 1989, 1991, 1993 e 1994 conclui o autor, entre outras coisas, que: a) existe a predominância de referências estrangeiras nas bibliografias de referência dos projectos de investigação, b) regista-se um peso considerável de obras de autores nacionais que năo têm como identidade académica as ciências da educação, c) os investigadores responsáveis apresentam um grau de internacionalizaçăo muito baixo. No seu conjunto, estas conclusōes apontam para uma baixa auto-referencialidade da comunidade científica das ciências da educação bem como para uma inserção periférica que configura uma forte dependência das comunidades dos países centrais. 
Por um lado, as estratégias de inserção de cientistas individuais ou de grupos de cientistas, através da participação em redes de investigação aplicada, nomeadamente de avaliação de experiências pedagógicas ou de administração escolar e de desenho ou acompanhamento de reformas, confere-lhes maior visibilidade e capacidade de intervenção; por outro lado, nas actuais condições de produção das ciências da educação, o impulso provocado por este enlace arrasta uma força política normativa que a débil comunidade científica tem dificuldade em converter em estímulo disciplinar autónomo. Mais do que a aplicação de conhecimentos produzidos em contexto disciplinar, o que aparece como dominante é o envolvimento crescente na produção de conhecimentos em redes cada vez mais complexas que envolvem a administração, a universidade e grupos de interesses variados, incluindo as externalidades económicas e organizacionais. É neste contexto social que valoriza o conhecimento aplicado que devem ser interpretadas as referências crescentes à análise sistémica e à investigaçăo-acção, já que elas participam no projecto mais global de reconstrução da representação total do sistema educativo, a partir dos niveis micro e meso e dirigem-se à mobilização dos sujeitos nos seus contextos de trabalho.

O recurso à dramatizaçăo da fragmentação e desconexão como principal problema da administação contribuiu decisivamente para a institucionalização dos dispositivos de dispersão, tais como a inclusão, a exclusão, a não-decisão e a aplicação selectiva. A procura de estratégias novas, adequadas à solução de problemas no interior da administração, passou pela construção de um discurso dicotómico - concentração/desconcentração; centro/periferia; tradição/modernização; estabilidade/ mudança; individuo/sociedade; escola/vida activa; manual/intelectual; global/local — que hegemoniza e reduz as possibilidades de solução, acentuando um ou outro lado da dicotomia, mas nunca a resolvendo. Os próprios programas tornam o real mais complexo, de tal forma que as soluções para um programa tendem a ser problemas de outro. É este estado de imperfeição da solução que faz da sua procura um processo potencialmente infinito. A nossa tese é que esta noção de crise cumpre o papel funcional de dissipar as contradiçōes situadas na dinâmica do sistema económico, por intermédio da sua relocalização num sistema mais heterogéneo e, portanto, com mais possibilidades de mobilizar diferentes actores sociais para o governo da crise. Por outro lado, ao introduzir as novas racionalidades sob o formato organizacional de projectos ou de programas, ainda que contraditórias com a vontade política do momento, o Estado previne ou domestica potenciais conflitos futuros numa estrutura excêntrica aos fluxos normativos principais da administraçăo.

Finalmente, as racionalidades políticas articulam vários idiomas numa lógica interna que está para além da mera retórica. A legitimidade constitui-se num projecto 
de resposta à emergência e à circunstância; é nele que se fazem os alinhamentos entre os objectivos individuais da cidadania e as imagens mais gerais de ordem social. A necessidade de legitimaçăo dos sistemas educativos decorre de perspectivas bastante diferentes que agora sintetizamos: a) conferindo ao princípio da razão o dever de tudo justificar em nome do bem comum; b) em obediência ao pressuposto da escola como expressão prática de uma manifestação ontológica que seria a procura da verdade ou da comunicação universal; c) em relação com o pressuposto da existência de uma faculdade primordial do homem que o destina à auto-realizaçăo e ao desenvolvimento integral.

De acordo com a primeira perspectiva é preciso encontrar critérios ou determinar funções do sistema e com bases neles julgar, inventariar, classificar, contabilizar, arquivar. Que se passe a problematizar todos os actos, ordenando-os; que se passe a justificar todas as instituiçőes, hierarquizando-as; que se passe a separar mais nitidamente as palavras e as coisas, nomeando-as; tudo isso instaura uma era de maior tecnologização da experiência escolar. Analisando o processo de autonomizaçăo da avaliação do sistema educativo, o qual consiste essencialmente na passagem de uma relativa subordinação à legitimação externa para a constituição de um campo que produz os seus próprios mecanismos de legitimação, podemos considerar diversos factores: a diversificação dos discursos sobre as reformas e o aparecimento de técnicos especialistas a elas ligados; a constituição de uma opinião pública educativa, inicialmente formada por alunos, professores, encarregados de educação e empresas susceptível de introduzir uma (des)legitimação paralela; o aparecimento de diversas instituições nacionais e internacionais que colocam a legitimaçăo das produções reformistas na sua dependência (e.g.: os Institutos Internacionais de Educação, as Faculdades de Educaçăo e de Ciências da Educação). Também neste âmbito se verificou que, no presente livro, temas houve que transbordaram do seu leito inicial sem que pudessem ser tratados de forma autónoma, designadamente os que dizem respeito à formação de um novo espaço público educativo e ao papel da inserção progressiva do sistema educativo português no espaço europeu. Constituem pois o terceiro eixo dos prolongamentos deste trabalho.

A legitimação não é um processo que se tivesse realizado num acto, mas que decorreu ao longo do período analisado. É esta associaçăo entre objectivos de governo, conhecimento científico, inserção internacional, perícia profissional e aspirações individuais que são fundamentais no processo de regulação e de legitimação da escola secundária. A regulaçăo não toma a forma de escrutínio directo do Estado sobre todos e cada um dos detalhes da vida social, institucional, organizacional e pessoal. 
Tăo-pouco age, exclusivamente, através dos mitos e dos ritos institucionais que suportam o princípio da confiança. O processo de acção à distância é menos insidioso e mais eficaz porque é capaz de mobilizar os diferentes níveis da vida social a partir dos esquemas de compreensão e de interpretação das acções. Esses esquemas são antes de tudo vocabulários específicos, mas são também formas de inserçăo e creditação dos especialistas, novas tecnologias da subjectividade, formas diferentes de as inscrever nas práticas escolares. Como confirma Nikolas Rose (1996: 73), esta acção à distância age pelo desequilíbrio gerado pela consciência da discrepância entre o que a vida é e aquilo que julgamos possível fazer dela: «such action at a distance is made possible by the dissemination of vocabularies for understanding and interpreting one's life and one's actions. Vocabularies that are authoritative because they derive from the rational discourse of science, not the arbitrary values of politics. It depends upon the accreditation of experts, who are accorded powers to prescribe ways of acting in the light of truth, not political interest. And it operates not trough coercion but through persuasion, not through the fear produced by threats but through the tensions generated in the discrepancy between how life is and how much better one thinks it could be».

Considerámos já em outro momento da nossa argumentação que tanto os processos de diagnóstico e avaliação do sistema educativo, quanto os de elaboração e operacionalização das reformas, se orientam por uma lógica legitimadora que, ao mesmo tempo que fala do lado da ciência, tem um vínculo institucional evidente ao Estado. A legitimação não se dá como efeito da aproximação da experiência à universalidade das leis da ciência, mas precisamente na medida em que a avaliação se afirma na ordem do singular, com uma relação privilegiada com o real e com o aqui e agora. É nesta ordem que o campo escolar se constitui a partir de discursos de legitimação: crítica, juízos, confronto uma vezes, partilha de opiniōes outras, propostas de explicação sempre, procedem à racionalização a posteriori das motivações e à elaboração de discursos que fazem apelo aos grandes princípios da igualdade e da equidade. $\mathrm{O}$ que se apresenta como a consciência moral do sistema não é senão o véu de universalismo moral que continua a ocultar as técnicas renovadas de dominaçăo que rumorejam no seu interior.

Como denominador comum dos processos de legitimação do sistema educativo, quer do lado da burocracia estatal quer do lado das correntes críticas, subjaz o mito humanista do desenvolvimento pleno e integral da personalidade individual. Para além das tensões filosóficas próprias desta representação da subjectividade, há ainda que ter em conta que o sujeito é o produto de instituições religiosas e morais do mundo 
ocidental, que esse é um longo processo que não se subordina inteiramente a projectos filosóficos, possuindo por isso os seus efeitos próprios. A capacidade de cada um questionar as suas condutas, habilidades e potencialidades relacionando-as com um princípio intrínseco de escrutínio e controlo ético, parece ter todas as aparências de uma real capacidade. Porém, não é nessa capacidade que se fundam as potencialidades individuais e tăo-pouco se pode considerar a matriz de todos os mundos da vida individual. A capacidade de problematizar o ser-próprio é o produto de técnicas e práticas do mesmo nível de outras técnicas corporais ou da consciência, (148) com uma inserção histórica específica. Demais, o facto de em certas condições históricas e culturais ter sido possivel proceder à problematização do self não significa que só entăo se tenha acedido à sua descoberta, mas que apenas nesse período estabilizou um certo número de técnicas, habitus e modos de vida que o tornaram na única forma possível de imaginar a nossa própria subjectividade. Daí que tenhamos procedido à genealogia das práticas que localizam os seres humanos em formaçăo em regimes do self específicos, fazendo um contraponto às análises que vêem as mudanças de subjectividade como o resultado de transformaçôes culturais e sociais mais gerais.

Tanto o novo mapa cognitivo da escola, quanto a nova subjectividade se articulam por intermédio de tecnologias com autonomia própria para formar uma representação diferente da acção escolar. Mais do que a convergência é a divergência que preside a esta articulação não-necessária. Enquanto a cartografia do sistema educativo privilegia a representação das características objectivas, gerais e mensuráveis dos processos educativos colectivos, as novas subjectividades constituem-se por uma representação subjectiva, particular e qualitativa da acção individual. O ponto de encontro dá-se quando os limites das tecnologias colectivas as empurram para um olhar metodologicamente individualista e quando os limites das tecnologias individuais as empurram inelutavelmente para um olhar mais global. A mecânica do poder que atravessa todos os dispositivos de observação e avaliação do sistema educativo e dos indivíduos năo pretende suprimir a variedade de que dá conta; apenas Ihe atribui uma realidade analítica, visível e permanente. E ao fazê-lo divulga um princípio de classificação e inteligibilidade que se dissemina no real e se incorpora nos indivíduos.

(148) Sobre este tema são especialmente esclarecedoras as investigaçōes antropológicas e históricas de P. Brown (1988) e M. Mauss (1985), amplamente discutidas no capítulo V. 


\section{Governamentalidade}

Analisar as políticas educativas por intermédio do aparato teórico e metodológico da governamentalidade nāo supōe qualquer descrição prévia das instituições, das estruturas ou dos padrões funcionais. Longe de tentar obter uma qualquer teoria geral do Estado ou do governo, os estudos realizados neste âmbito concentram-se na heterogeneidade de autoridades que participam no governo da conduta, na variedade de estratégias que constituem o diagrama de forças, nos dispositivos técnicos que tornam imanentes certos fins, nos conflitos e tensões que contêm e na forma como tais conflitos se presentificam nas acçōes actuais.

Tal aproximação às questōes do governo da conduta apenas se pode concretizar pelo estudo do seu principal meio de inteligibilidade: a linguagem e o discurso utilizados para descrever o espaço de problematizações e de acçōes. Todavia, o dispositivo analítico que utilizámos não se centrou na linguagem enquanto campo de significados, mas antes na busca das convenções partilhadas (Tully, 1995), (149) naquilo que designamos por regime de enunciaçăo. Dentre os regimes de verdade que pudemos analisar, o da formaçăo ao longo da vida é o que revela maior expansão epistémica no governo da subjectividade escolar. Nas suas formulaçōes mais iniciais o topos dominante é o da mudança: mudança individual ao longo da vida, por intermédio da formação e adaptação constantes; mudança social através da modernização que a educaçăo permanente permitiria. $\mathrm{O}$ contexto motriz da mudança é o ritmo da mudança tecnológica; a finalidade última é a transformação da subjectividade do futuro trabalhador em ordem a um ajustamento adequado aos contextos turbulentos de trabalho. $\mathrm{O}$ emprego e o desemprego passam a ser problematizados como uma questăo de competitividade das diferentes forças de trabalho. No Perfil cultural desejável o que sobressai é uma recodificação da competitividade nacional nos termos de uma competitividade psicológica, quer dizer, enquanto impulso inscrito nas aspirações, motivaçōes e expectativas pessoais dos alunos-futuros-produtores. Deste modo, cada indivíduo é solicitado como um potencial aliado do sucesso económico das empresas e da nação.

(149) Na mesma linha de Quentin Skinner $(1978,1996)$, este autor refere-se nos seguintes termos ao tipo de história critica que praticam: «consists in a survey of the language employed in order to identify the shared conventions (the distinctions, concepts, assumptions, inferences and assertability warrants that are taken for granted in the course of the debate) which render problematic and give rise to the range of solutions» (Tully, 1995: 35). 
Mais do que as velhas interdições inscritas na percepção do Estado-Leviathan, esta forma de poder exige para se disseminar uma presença constante que procede através de observaçōes persistentes; supōe a delegação nos objectos; requer discursos interescalares capazes de circular numa variedade infinita de contextos, desde os mais longínquos aos mais próximos; implica dispositivos de individualização de todas as periferias - sejam elas individuais ou organizacionais - e uma especificação nova dos indivíduos. O escolar do último quartel do século xx tornou-se num personagem com direito a uma anamnese, a um carácter, a um interior que é individual, na medida em que é medido pelas atitudes e expectativas, mas também é colectivo pela forma estatística de amostras populacionais que assume. A organização escolar da transição de século caminha para se tornar na principal alavanca da nova subjectividade, alicerçada no axioma do progresso linear. Entendido este como desenvolvimento infinito resultante do crescimento económico e do desenvolvimento tecnológico e na possibilidade do seu próprio desenvolvimento a reboque daquele. E daí a importância dos dispositivos de monitorização e de auditoria das escolas: a sua eficácia não decorre tanto das tecnologias de controlo e dominação que incorporam, mas antes das tecnologias de autonomia e responsabilização que promovem. A inculcação de uma mentalidade de cálculo é capaz de tornar as organizações em redes de cálculo duplicadas sobre si mesmas, por que são, simultaneamente, objectos de observação e participantes activos. Na verdade, o gestor escolar pode calcular o desempenho da sua escola, ao mesmo tempo que o professor tenta maximizar a sua performance nos termos das normas de desempenho em que é suposto ser avaliado e o ministério pode realizar auditorias inspectivas.

Sem dúvida que assistimos ao aumento da eficácia e a uma extensão do domínio controlado. O que produz um efeito duplo: ao poder é conferido um impulso pelo seu próprio exercício (dispositivo produtivo do poder policêntrico); aos que se querem autonomizar das formas de poder burocrático é garantida a legitimidade de vigiar o seu próprio comportamento (dispositivo de tradução do poder policêntrico). Desta forma, quanto maior é a intensidade da observação maior é o impulso que relança a curiosidade do escrutínio. Isso mesmo se observa nas formas cada vez mais frequentes de as escolas procurarem, em associação com os especialistas, exercer um poder local que interroga e traga à luz o seu verdadeiro funcionamento. A adopção de uma matriz quantitativa nesse tipo de estudos corre o risco de despojar os saberes locais de que se reclama, com as evidentes repercussōes nas relaçōes de poder que as comunidades científicas interpõem entre representação e aqueles que pretende representar (dispositivo de acção à distância). 
A mentalidade de governo não se resume ao exercício de acçōes em eśpaços naturais. Pelo contrário, o exercício do governo pressupõe um recorte da experiência em certos espaços abstractos (Lefebvre, 1974), recorte que garante a regulaçăo da integração, da distinção e da relevância $\mathrm{O}$ aspecto mais saliente desta forma de distribuir a experiência escolar pelos diferentes espaços diz respeito à variedade de espaços entretanto construídos. A nova cartografia espacial da escola assenta no lugar-comum da regionalização, captando nessa territorialização do pensamento político, discursos de origem muito diversa. Longe de homogeneizar o espaço discursivo, o que se verifica é a intersecção por outros discursos, especialmente os discursos verazes do método científico e os discursos da retórica moral, com a sua própria história e problemáticas específicas, e cuja relação com as problemáticas de governo se fazem por tradução e não por relação causal. Distinguimos nesta síntese final as três dimensões da nova cartografia espacial que garantem as condições desta articulação não-necessária: territorializaçăo do pensamento político; espacialização da observação e modelização dos espaços a governar.

A territorialização diz respeito à escala de observação dos fenómenos a governar, enquanto a modelização estabelece a forma de distribuição e de relação de conceitos, configurando assim a sua localização. Na nossa pesquisa pudemos verificar que durante o período analisado se sobrepuseram três tipos de espaços: o tradicional espaço em grelha, de pequena escala, de tipo serial, adaptado às acções repetitivas, aos produtos reproduzíveis - sejam eles recursos educativos ou programas - e ao intercâmbio de comportamentos e actividades. Privilegiando as leis da oferta e da procura do bem educativo, determina as fronteiras do que é considerado relevante no sistema. Associado às metáforas da quantidade e aos princípios de justificação cívicos, é um espaço estriado apenas sensível à estática, articulando-se com os saberes técnicos e científicos da estatística e do planeamento tradicional. A população é o terreno por excelência do exercício do governo; os inquéritos extensivos são a base de observação. O segundo espaço, de escala média, com origem na economia política, é do tipo reticular e tenta responder probabilisticamente às solicitações da procura. Mais sensível aos movimentos, encontra na cascata espacial variada - região, zona, caso, cidade, sítios - os elementos essenciais à problematização política. Associada às metáforas da qualidade, sem abandonar as da quantidade, e aos princípios de justificação comunitários, é um espaço misto sensivel aos movimentos, articulando-se com os saberes técnicos e científicos da análise sistémica e do planeamento estratégico. O nível de intervenção privilegiado é o dos actores específicos e das organizações; os estudos de caso constituem a superfície de observaçăo. O terceiro espaço, de grande 
escala, é liso e tenta responder casuisticamente às necessidades individuais. Mais sensível aos afectos, às relações e à comunicação, procura nos espaços privados da família e da vida quotidiana de cada um os elementos essenciais à acção. Privilegiando as leis da maximização das aspirações individuais, determina as fronteiras do que é incluído ou excluído no sistema. Associada à metáfora da coesão moral e aos princípios de justificação domésticos, é um espaço liso adaptado ao nomadismo dos actores, articulando-se com as tecnologias psi do conhecimento e domínio de si. O nível de intervenção privilegiado é o da relação terapêutica; o olhar clínico constitui uma pirâmide de olhares com diferentes cenários éticos que vão do gabinete do terapeuta à relaçăo individualizada professor-aluno.

A espacialização da observaçăo caracteriza o tipo de mapa cognitivo que subjaz aos dispositivos de inscriçăo. Mapas, gráficos, diagramas e quadros estabelecem marcas e objectivam a experiência efémera. Tais dispositivos são frequentemente inefáveis: nestes objectos delega-se a actualização de formas de ver que desencadeiam estruturas cognitivas, automaticamente, sem necessidade de Ihe associar uma retórica. São estas inscrições que tornam os indicadores seleccionados em formas estáveis, móveis, duráveis e comparáveis de difundir convicçōes. Sendo dispositivos intelectuais que fazem parte da reflexividade social e da reserva de conviç̧ōes năo abaladas, săo também técnicas materiais que garantem a extensăo da autoridade sobre aqueles que descrevem. Na nossa pesquisa referenciamos três filiações distintas dos mapas cognitivos utilizados: o mapa cognitivo referente, o mapa cognitivo significante e o mapa cognitivo do sentido.

O mapa cognitivo referente assenta na realidade objectiva, no conhecimento técnico-administrativo e na análise factual. Provoca separaçōes e autonomias fortes entre alta cultura e cultura de massas, entre conhecimento científico e conhecimento do senso comum, procedendo ainda à demarcação de fronteiras disciplinares dentro da racionalidade científica. A sua finalidade última é do tipo auto-referencial porque se situa na elaboração de normas, de regulamentos e de programas que padronizam o planeamento e o trabalho escolar. No limite, a realidade que projectam tem um alcance universal em virtude da previsibilidade dos processos operativos e da ignorância em que se mantém quanto à variaçăo do envolvimento. É este mapa cognitivo que faz crer num poder político assente na oposição entre Estado e vida privada, situando a construção da subjectividade neste último.

O mapa cognitivo significante está ancorado na diferenciação adaptativa, no conhecimento sistémico e nas decisões imperativas. À imagem da sociedade industrial e do mercado, as formas colectivas parecem ser bonecas russas que se encaixam umas nas outras. A sua finalidade consiste em obter certos resultados mesmo que à custa 
de caminhos muito diversos. A equifinalidade pressupõe a distribuição selectiva de recursos e a criação de pontos de partida diferentes tão-só adaptados às contingências sociais e espaciais da sua inserção. Decorrendo daqui um certo nivel de incerteza, a representação do alcance totalizante das respostas encontradas é feita em cada estabelecimento educativo. É neste mapa cognitivo que surge a organizaçăo como o nivel adequado à reconstrução da totalidade sistémica.

O mapa cognitivo do sentido baseia-se na tradição, no conhecimento ético e nas decisões intuitivas sobre o que julga ser o conhecimento. A supressão da distância provocada pela globalização e a correspondente saturação do espaço resulta numa inevitável crise da sua representação. Daí o avanço para o espaço inefável de tipo holográfico a par do recuo para o espaço próximo das identidades e lealdades reconhecíveis. A dispersão e fragmentação das condições de existência dos sujeitos torna cada vez mais difícil a sua compreensão global. A expansão da globalização teve como efeito a separação no sujeito da experiência fenomenológica e da representação do mundo, ou melhor, uma fractura entre o excesso e rapidez das experiências locais e o défice de compreensão do mundo. É neste rasgão que agem todas as hermenêuticas: exegese dos sujeitos em relação à interpretação do seu interior; exegese dos actores locais quanto à possibilidade de criarem lealdades comunitárias; exegese dos especialistas quanto às culturas e valores dos sujeitos que estudam. Em suma, sugere-se que ao conhecimento de objectos suceda a compreensão mútua entre sujeitos capazes de comunicar e de agir.

O quadro da página seguinte sintetiza os elementos essenciais da reflexividade social incluída nas problematizações de governo da escola, organizando a sua variaçăo segundo o mapa analítico dos cinco contextos simbólicos inicialmente propostos.

Demos início a este percurso com um exercício de distância e de hesitaçăo antecipada quanto ao objecto de estudo, que visava tornar incomum o que nos é tăo familiar. Pretendíamos deste modo abalar alguns dos operadores mais persistentemente arreigados na forma de representar a escola. A empresa só agora começa, mas a ideia de uma escola-sem-princípios, que se furta a todas as pretensōes taxonómicas, em busca de uma legitimação presentista, parece ter agora uma boa base de trabaIho. A demonstrar que os mundos que fogem às nossas referências habituais, quer porque fazem das lógicas que nos esforçamos por rejeitar a sua fonte de pensamento, quer porque escapam à episteme dominante, são um horizonte possível da imaginação sociológica. 
Quadro 25 - Mapa analítico das problematizaçōes de governo da escola segundo os contextos simbólicos

\begin{tabular}{|c|c|c|c|c|c|}
\hline \multirow{2}{*}{ ELEMENTOS } & \multicolumn{5}{|c|}{ CONTEXTO } \\
\hline & CIVICO & DOMÉSTICO & INDUSTRIAL & RENOME & COMUNITARIO \\
\hline ESCALA & - Pequena & - Grande & - Média & - Pequena & - Grande \\
\hline $\begin{array}{l}\text { DISPOSIIVO DE } \\
\text { REGULAÇAO }\end{array}$ & $\begin{array}{l}\text { - Relevância } \\
\text { - Inclusão }\end{array}$ & - Distinçăo & - Distinção & - Inclusão & - Distinçăo \\
\hline $\begin{array}{l}\text { RELAÇOES } \\
\text { ENTRE REGIOES }\end{array}$ & - Realismo & - Fonte de heterogeneidade & - Recurso & - Comunicação & - Hermenêutica \\
\hline AUDIENCIAS & - Universal & - Particular & - Especializada & - Opiniăo pública segmentada & - Local \\
\hline $\begin{array}{l}\text { TIPO DE } \\
\text { PROJECCAAO } \\
\text { ESPACIAL }\end{array}$ & $\begin{array}{l}\text { - Estriado } \\
\text { Grelha-Rede }\end{array}$ & - Liso & $\begin{array}{c}\text { - Reticular } \\
\text { Malha }\end{array}$ & $\begin{array}{l}\text { - Imagem } \\
\text { Emissor-receptor }\end{array}$ & $\begin{array}{l}- \text { Liso } \\
\text { Sitios }\end{array}$ \\
\hline $\begin{array}{l}\text { FORMADE } \\
\text { LEGITMAÇĀO }\end{array}$ & - Verdade dos juízos & - Bom senso & $\begin{array}{l}\text { - Sucesso } \\
\text { das acçōes }\end{array}$ & - Reconhecimento das acçôes & - Tradiçăo \\
\hline TECNOLOGIAS & $\begin{array}{l}\text { - Participação } \\
\text { - Expectativas e aspiraçōes }\end{array}$ & $\begin{array}{l}\text { - Conhecimento de si } \\
\text { - Domínio de si }\end{array}$ & $\begin{array}{l}\text { - Capacidades } \\
\text { - Treinabilidade }\end{array}$ & - Apresentaçāo ao mundo & $\begin{array}{l}\text { - Necessidades } \\
\text { - Valores }\end{array}$ \\
\hline SUBJECTIVIDADE & - Autonomia & - Amor próprio & - Capacidade & - Interesse & - Necessidade \\
\hline
\end{tabular}




\section{BIBLIOGRAFIA}

\section{Livros e Artigos citados}

ACKERMAN, Bruce (1980). Social Justice in Liberal State. New Haven.

AGUIAR, J. (1989). A política de Defesa Nacional como politica pública interdepartamental. Lisboa: INAIDN.

Almeida, Ana Nunes, Guerreiro, M. a D. (1993). A Família. In L. de França (coord.), Portugal Valores europeus, identidade cultural, Lisboa: IED, p. 212.

ALMEIDA, J. F., COSTA, A. F., MACHADO, F. L. (1994). Recomposição socioprofissional e novos protagonismos. In A. Reis (coord.), Portugal 20 Anos de Democracia. Lisboa: Círculo de Leitores, pp. 307-330.

AlmeidA, J. F., PINTO, J. M. (1986). Da teoria à investigação empírica. Problemas metodológicos gerais. In A. S. Silva e J. M. Pinto (orgs.), Metodologia das Ciências Sociais. Porto: Afrontamento, pp. 55-78.

ALMEIDA, L., MORAIS, F. (1989). Da inteligência à cogniçăo e ao desenvolvimento cognitivo. Revista de Educaçăo, 1(3), pp. 35-39.

Alonso, W., StARR, P. (eds.) (1987). The politics of numbers. New York: Russell Sage Foundation.

AltBACH, Philip (1987). The Knowledge Context: Comparative Perspectives on the Distribution of Knowledge. Albany: State University of New York Press.

ALtBACH, Philip (1994). International Knowledge Networks. In T. Husen e T. N. Postlethwaite, The International Encyclopedia of Education, $2^{\text {nd }}$ edition, vol. 5. Oxford: Pergamon-Elsevier, pp. 2993-2998.

Alves, N., CABRITO, B., CANÁRIO, R., Gomes, R. (1996). A escola e o espaço local: políticas e actores. Lisboa: IIE.

Alves PINTO, M. ${ }^{a}$ C. (1987). Disparidades regionais nos níveis de instrução dos jovens. Lisboa: GEP-CRSE.

AmARAL, Diogo F. (1986). Curso de Direito Administrativo. Vol. I. Coimbra.

AmARAL, Diogo F. (1988). Curso de Direito Administrativo. Vol. II. Lisboa (policopiado).

ANDERSON, Benedict (1983). Imagined Communities. Reflections on the Origin and Spread of Nationalism. London e New York: Verso.

ÂNGELO, Vítor (1975). O ensino discriminatório: Liceu e escola técnica - resultados de um inquérito. Análise Social, 44, pp. 576-629. 
Angulo, F. (1993). Evaluación del sistema educativo. Cuadernos de Pedagogia, 219.

ANYON, J. (1983). Intersections of gender and class: accomodation and resistance by workingclass and affluent females to contradictory sex-roles ideology. In S. Walker e L. Barton (eds.), Gender, Class and Education. London: Falmer Press.

APEL, Karl-Otto (1984). The situation of Humanity as an ethical problem. Praxis International, 4, pp. 250.

ARCHER, Margaret (1979). Social Origins of Educational Systems. London and Beverly Hills: Sage. ARCHER, Margaret (1982). Introduction: Theorizing about the expansion of Educational Systems. In M. Archer, The Sociology of educational expansion. Beverly Hills: Sage, pp. 3-64.

ARENDT, Hannah (1963). On Revolution. New York: Viking.

ARIEs, Philipe (1960, 1973). L'enfant et la vie familiale sous I'Ancien Régime. Paris Plon; ed. ut.: Paris: Éditons du Seuil.

AtLAN, H. (1972). L'organisation biologique et la théorie de l'information. Paris: Hermann.

BACHARACH, S. (1981). Organizational behaviour in schools and school districts. Praeger Pub.

BALL, S. (1990). Management as Moral Technology. In S. Ball (org.), Foucault and Education. Discipline and Knowledge. London: Routledge.

BALLION, Robert (1982). Les consommateurs d'école. Paris: Stock.

BALION, Robert (1986). Le choix du collège: le comportement éclairé des familles. Revue Française de Sociologie, pp. 712-734.

BALLION, Robert (1991). La bonne école. Paris: Hatier.

BARRETO, António (org.) (1996). A Situação Social em Portugal, 1960-1995. Lisboa: Instituto de Ciências Socias da Universidade de Lisboa.

BARROSO, João et al. (1988). Práticas de gestão dos estabelecimentos de ensino não-superior: da diversidade de iniciativas à diversidade dos contextos. Lisboa: GEP.

BARROSO, Joăo (1992). Fazer da escola um projecto. In R. Canário (org.), Inovaçăo e Projecto Educativo de escola. Lisboa: Educa, pp. 17-55.

BARROSO, Joăo (1996). O estudo da autonomia da escola: da autonomia decretada à autonomia construída. In J. Barroso (org.), O Estudo da Escola. Porto: Porto Editora, pp. 167-189.

BARTOLOVICH, C. (1996). Mapping the spaces of capital. In R. Paulston (ed.), Social cartography. Mapping ways of seeing social and educational change. New York, London: Garland Publ., pp. 375-398.

BAUMAN, Zygmunt (1987). Legislators and Interpreters: Modernity, Post-modernity and Intellectuals. Ithaca, NY: Cornell University Press.

BENAVENTE, A. (1989). Que Sociologia na formação de professores? Sociologia - Problemas e Práticas, 7, pp. 95-106.

BenAvente, A., Correia, A. P. (1980). Obstáculos ao sucesso na escola primária. Lisboa: IED.

Benavente, A., Costa, A. F., MAChado, L., Neves, M. a C. (1987). Do outro lado da escola. Lisboa: IED.

BENVENISTE, Emile (1971). Problems in general linguistics. Miami: University of Miami Press.

BERGER, P., LUCKMAN, Th. (1966). The social construction of reality. New York: Doubleday.

BERNARD, R. (1989). Research methods in cultural Anthropology. London: Sage.

BERnSTEIN, Basil (1996). Pedagogy, Symbolic control and Identity. London: Taylor \& Francis.

BERTAUX, Daniel (1978). Destinos pessoais e estrutura de classe. Lisboa: Moraes. 
Bettencourt, A. M. (1979). Educação Cívica Politécnica: uma inovação? Raiz e Utopia (9-10), pp. 271-276.

BIRZEA, C. (1979). Rendre opérationnels les objectifs pédagogiques. Paris: PUF.

BIRzEA, C. (1982). La pédagogie du succès. Paris: PUF.

BLANCHET, A. et alii (1985). L'entretien dans les sciences sociales. Paris: Dunod.

BlumenBERG, Hans (1983). The legitimacy of the Modern Age. Cambridge, Mass.: The MIT Press. Boввıо, N. (1988). O futuro da Democracia. Lisboa: Publicações Dom Quixote.

Bou, John (1987). World Polity sources of expanding state authority and organizations, 1870-

1970. In G. Thomas, J. Meyer, F. Ramirez e J. Boli, Institutional Structure. Beverly Hills: Sage, pp. 71-91.

Boul, John (1989). New Citizenship for a new society: The institutional origins of mass schooling in Sweden. New York: Doubleday.

BOLI, John, RAMIREZ, F., MEYER, J. (1985). Explaining the Origins and Expansion of Mass Education.

Comparative Education Review, 29(2), pp. 145-170.

BoltANSKY, Luc (1982). Les cadres. La formation d'un groupe social. Paris: Éditions de Minuit.

Boltansky, Luc, THÉVENOt, L. (1991). De la justification. Les économies de la grandeur. Paris:

Gallimard.

Bourdieu, Pierre (1982). Ce que parler veut dire. L'économie des échanges linguistiques. Paris: Fayard.

BOURDiEU, Pierre (1989). O Poder Simbólico. Lisboa: Difel.

BouRdieu, Pierre (1994). Raisons pratiques. Sur la théorie de l'action. Paris: Éditions du Seuil.

BOURDIEU, Pierre (1996). As regras da arte. Génese e estrutura do campo literário. Lisboa: Editorial

Presença.

Bourdieu, Pierre, PASSERON, (1964, 1981). Les Héritiers. Paris: Minuit; ed. ut.: Os herdeiros: o

ensino superior e as desigualdades sociais, in M. ${ }^{a}$ Filomena Mónica, Escola e Classes Sociais

(antologia), Lisboa: Editorial Presença/GIS, pp. 85-95.

BOWLES, S., GINTIS, H. (1976). Schooling in Capitalist America: Educational reform and the contradictions of economic life. New York: Basic Books/Harper.

Bowles, S., GINTIS, H. (1986). Democracy and Capitalism, New York: Basic Books.

BOYER, R., MISTRAL, J. (1978). Accumulation, inflation, crises. Paris: PUF.

BOYER, R. (1992). Alternativas ao Fordismo: uma análise provisória. Revista Crítica de Ciências Sociais, 35, pp. 15-51.

BRIAND, J.-P., CHAPOULIE, J.-M., PERETZ, H. (1979). Les statistiques scolaires comme représentation

et comme activité. Revue Française de Sociologie, Xx, pp. 669-702.

BROCH, M.-H. \& CROS, F. (1989). Ils ont voulu un projet d'établissement. Paris: INRP.

BRoWN, P. (1989). The Body and Society: Men, Women and sexual renunciation in Early

Christianity. London: Faber.

BURCHELL, G. (1991). Peculiar insterests: Civil society and governing 'The system of natural Liberty'.

In G. Burchell, C. Gordon e P. Miller (eds.), The Foucault Effect: Studies in Governamentality.

Chicago: The University of Chicago Press, pp. 119-150.

BURCHELL, G., Gordon, C., Miler, P. (Eds.) (1991). The Foucault Effect: Studies in Governamentality.

Chicago: The University of Chicago Press.

BURNS, I., STALKER, G. (1961). The management of innovation. London: Tavistok Publications. 
CABRAL, M. V., PAIS, J. M. (1998). Jovens portugueses de hoje. Oeiras: Celta

CAETANO, Marcello (1972). Manual de Direito Administrativo. Tomo I, 10. edição.

CAETANO, Marcello (1974). Depoimento. Rio de Janeiro: Distribuidora Record.

CALABRESE, Omar (1988). A ldade neobarroca. Lisboa: Edições 70.

CALDWELL, B. J., SPINKS, J. M. (1988). The Self-managing School. London: The Falmer Press.

CALDWELL, B. J., SPINKS, J. M. (1992). Leading the Self-managing School. London: The Falmer Press.

CALLON, Michel (1986). Éléments pour une sociologie de la traduction. La domestication des coquilles Saint-Jacques et des marins pêcheurs en baie de Saint-Brieuc. L'Année Sociologique, 36, pp. 169-208.

CALLON, Michel, LATOUR, B. (1981). Unscrewing the Big Leviathan: how actors macrostructure reality and how sociologists help them to do so. In K. Knorr-Cetina e C. Cicourel (eds.), Advances in Social Theory. London: Routledge and Kegan Paul, pp. 277-303.

CAMPOS, B. P. (1989). Desenvolvimento psicológico e formação pessoal e social na escola. Inovaçắo, número especial, pp. 13-33.

CAMPos, B. P. (1992). A formação pessoal e social na reforma educativa portuguesa. In J. Formosinho et alii, Formaçāo Pessoal e Social. Porto: Sociedade Portuguesa de Ciências da Educação, pp. 13-33.

CANÁrIO, Rui (1992). O estabelecimento de ensino no contexto local. In R. Canário (org.), Inovação e Projecto Educativo de escola. Lisboa: Educa, pp. 57-85.

CANÇO, Dina, JOAQUIM, Teresa (coord.) (1994). Portugal - situaçăo das mulheres 1994. Lisboa: Comissão para a igualdade e para os direitos das mulheres.

CANDEIAS, António (1993). Políticas Educativas Contemporâneas: Críticas e Alternativas. Inovaçăo, 6, pp. 257-286.

CARITA, Ana, SILVA, A. C., MonteIRo, A. F., DINIZ, T. P. (1997). Como ensinar a estudar. Lisboa: Editorial Presença.

CARnEIRO, Roberto (1978). O planeamento e a prospectiva da educação. Lisboa: IDL.

CARneIRO, Roberto (1980). Planification de la reforme de l' éducation. In Les Réformes de l'éducation: expériences et perspectives. Paris: UNESCO, pp. 59-70.

CARNEIRO, Roberto (1988). Portugal, os próximos 20 anos. V volume - Educação e emprego em Portugal: uma leitura de Modernização. Lisboa: Fundação Calouste Gulbenkian.

CARNEIRO, Roberto (1994). Manifesto contra o Estado hegemónico. In R. Carneiro (org.), Ensino Livre - Uma fronteira da hegemonia estatal. Porto: Asa, pp. 15-16.

CARNOY, M. (1995). The economics of education: then and now. In M. Carnoy (ed.), International Encyclopedia of Economics of Education (2 ${ }^{\text {nd }}$ ed.), Oxford: Pergamon, pp. 1-7.

CAUPERS, Joẩo (1993). A administraçăo periférica do Estado. Dissertação de doutoramento. Lisboa: Faculdade de Direito de Lisboa.

CHABвOT, Colette (1997). Defining development: the making of the International development field, 1945-1990. In J. Boli e G. Thomas (ed.), World polity formation since 1875: World culture and International non-governamental organizations. Stanford, Calif.: Stanford University Press.

CHABвOT, Colette, RAMIREZ, Francisco (em publicaçăo). Development and Education. In T. Hallinan (Ed.), Handbook of Sociology of Education. New York: Plenum.

CHARLOT, Bernard (1987). L'école en mutation. Paris: Payot. 
CHARLOT, Bernard (coord.) (1994a). L'école et le territoire: nouveaux espaces, nouveaux enjeux. Paris: Armand Colin.

CHARLOT, Bernard (1994b). La territorialisation des politiques éducatives: une politique nationale. In B. Charlot (coord.), L'école et le territoire: nouveaux espaces, nouveaux enjeux. Paris: Armand Colin, pp. 27-48.

Charpentier, Jean, Engel, C. (1992). Les regions de l'espace communautaire. Nancy: Presses Universitaires de Nancy.

CHARTIER, Roger (1990). As práticas da escrita. In P. Ariès e G. Duby (dir.), História da vida privada. 3-Do Renascimento ao século das Luzes. Porto: Afrontamento, pp. 113-161.

Cicourel, A. (1973). Cognitive Sociology. Middlesex: Penguin Education.

CLímACO, M. C. (1990). A avaliaçăo e a renovaçăo das escolas: indicadores de desempenho. Inovação, 3(4), pp. 109-116.

CLIMACO, M. C. (1991). Os indicadores de desempenho de escola na gestão e avaliação da qualidade educativa. Inovaçăo, 4(2-3), pp. 87-125.

COLEMAN, J. et alii (1966). Equality of educational opportunity. Washington, DC: Government Printing Office.

ColuINs, Randall (1971). Functional and conflict theories of educational stratification. American Sociological Review, 36(1), pp. 2-18.

Couluns, Randall (1979). The Credential Society: An Historical Sociology of Education and Stratification. New York: Academic Press.

CONNELL, R. W., ASHENDEN, D. J., KesSLER, S., DOWSSET, G. W. (1982). Making the difference: Schools, families and social division. Sydney: Allen \& Unwin.

CorrelA, J. A., Stolleroff, A., S., Stoer, S. (1993). A ideologia da modernização no sistema educativo em Portugal. Cadernos de Ciências Sociais, 12/13, pp. 25-51.

CORREIA, J. A. (1997). Formaçăo e trabalho: contributos para uma transformação dos modos de os pensar na sua articulação. In R. Canário (org.), Formação e situações de trabalho. Porto: Porto Editora, pp. 13-42.

CORTESÃo, Luísa, TORRES, M. a A. (1990). Avaliaçăo pedagógica I. Insucesso escolar (4. a ediçāo revista e melhorada). Porto: Porto Editora.

COSTA, A. F., MACHADO, F. L. (1992). Meios populares e escola primária. Pesquisa sociológica num projecto interdisciplinar de investigaçăo-acçăo. In A. J. Esteves e S. Stoer (orgs.), A Sociologia na escola - professores, educação e desenvolvimento. Porto: Afrontamento, pp. 303-329.

COSTA, F. Dores (1995). Os problemas do recrutamento militar no final do século XVIII e as questōes da construção do Estado e da Naçăo. Análise Social, xxx (130), pp. 121-155.

CralG, John E. (1981). The Expansion of Education. In David C. Berliner (Ed.), Review of Research in Education (American Educational Research Association), 9, pp. 151-213.

CREEMERS, B. P., REYNOLDS, D. (eds.) (1989). School Effectiveness and School Improvement. Lisse: Swets \& Zeitlinger.

CREEMERS, B., SCHEERENS, J. (1989). Conceptualizing school effectiveness. International Journal of Educational Research, 13(7), pp. 685-825.

Crozier, M. (1964). The bureaucratic phenomenon. Chicago: The University of Chicago Press.

CRUz, M. B. et alii (1988). A situação do professor em Portugal. Análise Social, XXIV (103-104), pp. 1187-1293. 
DALE, Roger (1989). The State and Education Policy. Milton Keines: Open University Press.

DALE, Roger (1998). Globalisation: a new world for comparative education. In J. Schriewer (Ed.), Discourse and Comparative Education. Berlin: Peter Lang.

DALE, Roger (1999). Specifying globalization effects on national policy: a focus on the mechanisms. Journal of Education Policy, 14(1), pp. 1-17.

DALE, Roger et alii. (1990). The TVEI story: policy, practice and preparation for the work force. London: Open University Press.

DeBESSE, M., MIALAREt, G. (coord.) (1978).Traité des Sciences Pédagogiques. vol. 7. Paris: PUF. Deleuze, Gilles $(1988,1998)$. Foucault $\left(2{ }^{\text {a }}\right.$ ed.). Lisboa: Vega.

Deleuze, Gilles, Guattarı, F. (1980, 1997). Mille Plateaux (2.e ed.). Paris: Les Éditions de Minuit. Demally, D. (1991). Le Collége. Crise, mythes e métiers. Lille: Presses Universitaires de Lille.

DEROUET, Jean-Louis (1988). Désaccords et arrangements dans les collèges (1981-1986). Revue Française de Pédagogie, 83, pp. 5-22.

DEROUET, Jean-Louis (1992). École et Justice. Paris: Métailié.

DEROUET, Jean-Louis (1996). O funcionamento dos estabelecimentos de ensino em França: um objecto científico em redefiniçắo. In J. Barroso (org.), O Estudo da Escola. Porto: Porto Editora, pp. 61-85.

DERRIDA, Jacques (1990). Du Droit à la philosophie. Paris: Galilée.

D'ESPINEY, Rui et alii (1988). Práticas de gestão. Ensinos preparatório e secundário. Lisboa: GEP. DesRosiéres, Alain, THÉVENOT, L. (1988). Les catégories socioprofessionelles. Paris: Éditions La Découverte.

DEWEY, J. (1933). How we think. Chicago: Henry Regnery.

DiMAGGIO, P., PowELL, W. (1991). The Iron Cage revisited: Institutional isomorphism and collective rationality in organization fields. In W. Powell e P. DiMaggio (eds.), The new institutionalism in organizational analysis. Chicago: The University of Chicago Press, pp. 63-82.

Donzelot, Jacques (1979). The Policing of Families. New York: Pantheon Books.

DreYFus, H. L., RABINOW, P. (1983). Michel Foucault. Beyond Structuralism and Hermeneutics. Chicago: University of Chicago Press.

DUNCAN, W. (1985). Engendering School Learning. Studies in Comparative and International Education. Estocolmo: Institut of International Education.

Eco, Umberto (1979). Lector in Fabula. Milano: Bompiani.

EDELMAN, Murray (1964). The Symbolic Uses of Politics. Urbana: University of Illinois Press.

EISENSTAD, Samuel (1992). A reappraisal of theories of social change and Modernization. In $\mathrm{H}$.

Haferkamp e N. Smelser (ed.), Social Change and Modernity. Berkeley: University of California Press, pp. 412-429.

EL HACHEM, T. F. (1992). A quoi sert le plan? Un regard sur le sytème éducatif. Paris: Economica. Eulas, N. $(1939,1989)$. O Processo civilizacional $\left(1 .^{\circ}\right.$ volume). Lisboa: Publicaçōes Dom Quixote.

El.strom, P. (1983). Four faces of educational organizations. Higher Education, 12, pp. $231-$ 241.

ERIKSON, F. (1986). Qualitative methods in research on teaching. In M. Wittrock (ed.), Handbook of Research on teaching ( $3^{\text {rd }}$ ed.). New York: Praeger, pp. 119.161. 
ESTANQuelRo, A. (1992). Aprender a estudar: um guia para o sucesso na escola. Lisboa: Texto Editora.

Estévāo, C. V. (1998). Políticas de Privatização e Educaçăo. Educaçăo, Sociedade \& Culturas, 9, pp. 69-94.

Etzıoni, A., Dubow, F. (Eds.) (1970). Comparative Perspectives: Theories and Methods. Boston: Little Brown.

ETzIONI, A. (1997). The New Golden Rule: Community and morality in a democratic society. London: Profile.

FÄGERLIND, I., SAHA, L. J. (1985). Education and National development: A comparative perspective. Oxford: Pergamon.

FAZENDEIRO, António (1992). Suporte metodológico dos trabalhos de carta escolar. In GEP, Carta Escolar da Regiāo Alentejo. Lisboa: ME/GEP, pp. 71-82.

FERnANDES, L. G., RodRIGUeS, E. F., RIBEIRO, J. F. (1984). Portugal: modernização da economia e especialização internacional. In APEC, Il. ${ }^{2}$ Conferência Nacional dos economistas. Lisboa: APEC.

FerreiRA, E. Sousa, RATo, Helena (orgs.) (1994). Portugal Hoje. Maia: Instituto Nacional de Administraçāo.

FerReIRA, Virgínia (1993). Padrōes de segregação das mulheres no emprego. In B. Sousa Santos (org.), Portugal: um retrato singular. Porto: Afrontamento, pp. 231-257.

FigUEIREDO, Eurico (1988). Portugal, os próximos 20 anos. II volume - conflito de gerações, conflito de valores. Lisboa: Fundação Calouste Gulbenkian.

FLAVELL, (1976). Metacognitive aspects of problem-solving. In L. B. Resnik (eds.), The nature of intelligence. Hillsdale, NJ: Erlbaum.

Formosinho, Joăo (1980). As bases do poder do professor. Revista Portuguesa de Pedagogia, ano XIV, pp. 301-328.

FORMOSINHO, Joăo (1987). Educating for passivity - A study of portuguese education (19261968). Ph. D. Thesis. University of London (policopiado).

FormosinHo, Joăo (1991). Concepçōes de escola na Reforma Educativa. In Ciências da Educação em Portugal: situação actual e perspectivas. Porto: SPCE, pp. 31-51.

FORMOSINHO, João (1992). Da crise da educação escolar à diversificação da função docente. Reflexões sobre a formação de professores. CEFOPE (documento policopiado).

FORMOSINHO, Joăo (1998). A administração das escolas: entre a evoluçăo e a continuidade. Rumos, 22, p. 30 .

FormosinHo, Júlia (1988). A educaçăo pessoal e social na LBSE e na reforma educativa. Braga: Universidade do Minho.

FormosinHo, Júlia et alii (1992). Formação Pessoal e Social. Porto: Sociedade Portuguesa de Ciências da Educaçăo.

FouCAult, Michel (1969). L'Archéologie du Savoir. Paris: Gallimard.

FouCAULT, Michel (1972). The Discourse on Language. Appendix to The Archaelogy of Foucault, Michel (1975). Surveiller et Punir. Paris: Gallimard.

FouCault, Michel (1981). Omnes et Singulatim: Towards a Criticism of 'Political Reason'. In S. McMurrin (ed.), The Tanner Lectures on Human Values, vol. II. Salt Lake City: University of Utah Press, pp. 225-254. 
FOUCAULT, M. (1988). The political technology of individuals. In L. Martin, H. Gutman \& P. Huttan (Eds.), Technologies of the self: A seminar with Michel Foucault. Amherst: University of Massachusetts Press, pp. 145-162.

Foucault, Michel (1991a). Politics and the Study of Discourse. In G. Burchell, C. Gordon \& P. Miller (Eds.), The Foucault Effect: Studies in Governmentality. Chicago: University of Chicago Press, pp. 53-72.

FouCAult, Michel (1991b). Governmentality. In G. Burchell, C. Gordon \& P. Miller (Eds.), The Foucault Effect: Studies in Governmentality. Chicago: University of Chicago Press, pp. $87-$ 104.

FouCAult, Michel (1994a). História da sexualidade - I. A vontade de saber. Lisboa: Relógio D'Água.

FouCAULt, Michel (1994b). História da sexualidade - II. O uso dos prazeres. Lisboa: Relógio D'Água.

FouCAult, Michel (1994c). História da sexualidade - III. O cuidado de si. Lisboa: Relógio D'Água. FRAústo, J. et al. (1987). Proposta de reorganizaçăo dos planos curriculares dos ensino básico e secundário. Relatório preliminar (policopiado).

FreIdSON, E. (1988). Professional Powers: A Study of the Institutionalization of Formal Knowledge. Chicago: University of Chicago Press.

FREYSSINET, J. (1991). Les modes d'insertion professionelle des jeunes: trajectoires nationales face à la crise. Problèmes Economiques, 2221, pp. 1-8.

FriedberG, Erhard (1993). Le Pouvoir et la Règle. Paris: Seuil.

FULlER, Bruce (1991). Growing-Up Modern. New York: Routledge.

FULLER, B., GARNIER, M., HAGE, J. (1990). State action and labor structure change in Mexico. Social Forces, 68, pp. 1165-1189.

FULLER, Bruce, RUBINSON, R. (Eds.) (1992). The Political Construction of Education: The State, School Expansion, and Economic Change. New York: Praeger.

FURET, F. (1981). Interpreting the French Revolution. Cambridge: Cambridge University Press.

FURET, F., Ozouf, J. (1976). Literacy and Industrialization: The Case of the Département du Nord in France. Journal of European Economic History, 5, pp. 5-44.

GARNIER, M., HAGE, J., Fuller, B. (1989). The strong state, social class, and controlled school expansion in France, 1881-1975. American Journal of Sociology, 95, pp. 279-306.

GEERTZ, C. (1973). The interpretation of cultures. New York: Basic Books.

Gellner, E. (1983). Nations and Nationalism. Ithaca: Cornell University Press.

GerRIG, R. J., HeAly, A. F. (1983). Dual processes in metaphor understanding. Comprehension and appreciation. Journal of Experimental Psychology: Learning. Memory, and Cognition, 4, pp. 667-675.

Ghiglone, R., Beauvois, J.-L., Chabrol, C., Trognon, A. (1980). Manuel d'analyse de contenu. Paris: Armand Colin.

GIDDENS, Anthony (1979). Central problems in social theory: Action, Structure, and contradiction in social analysis. Berkeley: University of California Press.

GIDDENS, Anthony (1984). The constitution of society: An outline of the theory of structuration. Cambridge: Polity. 
GIDDENS, Anthony (1992). As consequências da modernidade. Oeiras: Celta.

GIDDENS , Anthony (1994). Modernidade e identidade pessoal. Oeiras: Celta.

GIL, Fernando (1984). Mimésis e Negação. Lisboa: Imprensa Nacional - Casa da Moeda.

GIL, José (1996). Salazar: a retórica da invisibilidade. Lisboa: Relógio d'Agua.

GIMPL, M. L., DAKIN, S. R. (1984). Management and Magic. California Management Review, Fall, pp. 125-136.

Giroux, H. (1989). Schooling as a Form of Cultural Politics: Toward a Pedagogy of and for

Difference. In H. Giroux e P. McLaren (eds.), Critical Pedagogy, the State, and Cultural Struggle. New York: State University of New York Press.

GoffMAN, E. (1959). The Presentation of Self in Everiday Life. Anchor Book.

GOLDTHORPE, J. H. (1984). The end of convergence: Corporatist and dualist tendencies in Modern Western societies. In J. H. Goldthorpe (ed.), Order and Conflict in Contemporary Capitalism. Oxford: Clarendon, pp. 315-343.

Gomes, Rui (1992). Culturas Organizacionais de escola e Identidades profissionais dos professores. Tese de Mestrado. Cruz-Quebrada: UTL-FMH.

Gomes, Rui (1993). Culturas de escola e identidades dos professores. Lisboa: Educa.

GoMES, Rui (1996a). Teses para uma agenda de estudo da escola. In J. Barroso (org.), O Estudo da Escola. Porto: Porto Editora, pp. 87-107.

GOMES, Rui (1996b). The Reform of Mass Schooling in Portugal (1974-1991). Mediterranean Journal of Educational Studies, 1(1), pp. 29-42.

Gomes, Rui (1997). A Análise do Discurso: As Políticas Educativas como Texto. In A. Estrela e J. Ferreira (org.), Métodos e Técnicas de Investigaçăo Científica em Educaçăo. Lisboa: Aipelf/Afirse Portugaise e Faculdade de Psicologia e de Ciências da Educação, pp. 409427.

GOMES, Rui (1998). Racionalidades e Tecnologias de Governo da Educaçăo: as Estatísticas e o Planeamento das Políticas Educativas em Portugal (1974-1991). In A. Estrela e J. Ferreira (org.), A Decisão em Educação, Lisboa: Aipelf/Afirse Portugaise e Faculdade de Psicologia e de Ciências da Educação, pp. 180-200.

GomES, Rui (1999). 25 Anos depois: Expansão e crise da escola de massas em Portugal. Educação, Sociedade \& Culturas, 11, pp. 133-164.

GoMEs, Rui (1999b). A Genealogia do governo da educaçăo: a autonomia, os indicadores de desempenho e os modelos sistémicos. Revista Portuguesa de Pedagogia, ano 33, n. ${ }^{\circ} 3, \mathrm{pp}$. 5-47.

Gomes, Rui (2000). Legitimaçăo e Contingência na Escola Secundária Portuguesa. Arqueologia,

Genealogia e Simbólica da Escola. Dissertaçăo de Doutoramento. Lisboa: Universidade Técnica de Lisboa.

GOMES, Rui (2002). A crise de legitimidade da organizaçăo escolar. Os dispositivos de legalizaçăo e a actualizaçăo dos mitos institucionais. Organizações e Trabalho, 28, pp. 49-68.

GoodLAD, J. I. (1975). The dynamics of educational change. New York: McGraw-Hill.

GORDON, Colin (1991). Governmental Rationality: An introduction. In G. Burchell, C. Gordon e P. Miller (eds.), The Foucault effect: Studies in governmentality. Chicago: Chicago University Press, pp. 1-52.

GrÁcio, Rui (1981). Educação e Processo Democrático em Portugal. Lisboa: Livros Horizonte. 
GrÁCıO, Rui (1985). Evolução Política e Sistema de Ensino em Portugal: dos anos 60 aos anos 80. In J. E. Loureiro (coord.), O futuro da educação nas novas condições sociais, económicas e tecnológicas. Aveiro: Universidade de Aveiro, pp. 53-154.

GrÁCIO, Rui (1995a). Obra Completa. I - Da educação. Lisboa: Fundaçăo Calouste Gulbenkian.

GrÁC1O, Rui (1995b). Obra Completa. II - Do Ensino. Lisboa: Fundação Calouste Gulbenkian. GrÁcio, Sérgio (1986). Politica Educativa como Tecnologia Social. Lisboa: Livros Horizonte.

GrACIO, Sérgio (1991). Crise juvenil e invenção da juventude. Notas para um programa de pesquisa. In S. R. Stoer (org.), Educação, Ciência Sociais e realidade portuguesa: Uma abordagem pluridisciplinar. Porto: Afrontamento, pp. 33-57.

GREEN, Andy (1990). Education and State Formation: The Rise of Education Systems in England, France, and the USA. New York: St. Martin's Press.

GREEN, Andy (1994). Education and State Formation Revisited. Historical Studies in Education, 6(3) \& History of Education Review, 23 (3), pp. 1-17.

HABERMAS, J. (1975). Legitimation crisis. Boston: Beacon.

Habermas, J. (1973, 1978). Raison et légitimité. Paris: Payot.

HABERMAS, J. (1979). Communication and the Evolution of society. Boston: Beacon.

HABERMAS, J. (1987, 1990). O discurso filosófico da modernidade. Lisboa: Dom Quixote.

HACKING, lan (1981). How should you do the history of statistics? In G. Burchell, C. Gordon e P. Miller (Eds.), The Foucault Effect: Studies in Governmentality. Chicago: The University of Chicago Press, pp. 181-196.

HACKING, Ian (1986). Making up people. In T. C. Heller, M. Sosna e D. E. Wellberg (eds.), Reconstructing Individualism. Stanford: Stanford University Press, pp. 222-236.

HACKING, lan (1990). The taming of chance. Cambridge: Cambridge University Press.

HALLAK, J. (1976). La mise en place de politiques éducatives: rôle et méthodologie de la carte scolaire. Bruxelles/Paris: Fernand Nathan/Les Presses de I'Unesco.

HALLAK, J. (1977). La carte scolaire: tendances recentes et perspectives. International Review of Education, XXIII (1), pp. 47-58.

HALlaK, J. (1978). El mapa escolar: un instrumento de la politica de educación. Paris: UNEsCO/ IIPE.

HALLAK, J. (1980, 1991). Education for all: high expectations or falses hopes. UNESCO: Institute for International Educational Planning.

Hannan, M., Freeman, J. (1981). Obstacles to comparative studies. In P. S. Goodman e J. Pennings (e ass.), New perspectives on organizational effectiveness. San Francisco: Jossey-Bass Pub., pp 106-131.

HANSON, M. (1985). Educational administration and organizational behavior (2 ${ }^{\text {nd }}$ ed.). Boston: Allyn and Bacon.

HARGREAVES, Andy (1989). Curriculum and assessment reform. Milton Keynes: Open University Press.

HAVELoK, R. (1970). Guide to innovation in education. Michigan: University of Michigan.

HeRPIN, N. (1982). A sociologia americana. Escolas, problemáticas e práticas. Porto: Edições Afrontamento. 
HINDESS, B. (1993). Liberalism, socialism and democracy: variations on a governmental theme. Economy and Society, 22(3), pp. 300-313.

HOFSTEDE, G. (1986). Culture's consequences: international differences in work-related values ( $2^{\text {nd }}$ ed.). London: Sage.

HoSkIN, Keith (1979). The examination, disciplinary power and Rational Schooling. History of Education, 7, pp. 135-146.

HOSKIN, K., MACVE, R. (1994). Writing, examining, disciplining: the genesis of accounting's modern power. In A. G. Hopwood e P. Miller (Eds.), Accounting as social and institutional practice. Cambridge: Cambridge University Press, pp. 67-97.

HüFner, K., MEYer, J., NAumann, J. (1987). Comparative Education Policy Research: A World Society Perspective. In M. Dierkes, H. Weiler \& A. B. Antal (eds.), Comparative Policy Research. Learning from Experience. Aldershot: Gower, pp. 188-243.

HUNTER, Ian (1988). Culture and Government. The emergence of Literary Education. London: Macmillan Press.

HUNTER, Ian (1990). Personality as a vocation: the political rationality of the humanities. Economy and Society, 19(4), pp. 391-430.

HUNTER, Ian (1994). Rethinking the School: Subjectivity, Bureaucracy, Criticism. New York: St. Martin's Press.

HUNTER, Ian (1996). Assembling the school. In A. Barry, T. Osborne e N. Rose (eds.), Foucault and political reason. London: UCL Press, pp. 143-166.

Huntington, S., Watanuky, J., Crozier, M. (1975). The crisis of Democracy. Report on the governability of democracies to the Trilateral Commission. New York: New York University Press.

HusÉN, Torsten (1960). Loss of talent in selective school systems. Comparative Education Review, $48(2)$, pp. $70-4$.

HusÉN, Torsten (1972). Social background and educational career. Paris: OCDE.

HusÉN, Torsten (1975). Social influences on educational attainement. Paris: OCDE.

HUYSSEN, Andreas (1986). After the great divide. Bloomington e Indianapolis: Indiana University Press.

IED (1981). Politica Educacional num Contexto de Crise e Transformação Social. Lisboa: Moraes Editores/Instituto de Estudos para o Desenvolvimento.

ILICH, Ivan (1973). Deschooling Society. Harmondsworth: Penguin.

INHOFF, A., DUFFY, P., CARROLL, P. (1984). Contextual effects on metaphor comprehension in reading. Memory \& Cognition, 12 , pp. 558-567.

IRIBARNE, P. (1989). La logique de l'honneur: gestion des enterprises et traditions nationales. Paris: Seuil.

JAMESON, (1984, 1991). Postmodernism or the Cultural Logic of Late Capitalism. Durham, Nc: Duke University Press.

Jesuíno, Jorge C. (1983). Valores finais da juventude portuguesa em 1983. In Situação, Problemas e Perspectivas da Juventude em Portugal. Vol. VIII. Lisboa: IED, pp. 121-139.

Jodelet, D. (1984). Représentation sociale: phénomènes, concept et théorie. In S. Moscovici (org.), Psychologie Sociale. Paris: PUF. 
JOSEPH, I. (1982). L'analyse de situation dans le courant interaccioniste. Ethnologie Française, XII, 2.

KAESTLE, C. F., VINOVSKIS, M. A. (1980). Education and Social Change in Nineteenth-Century Massachusettes. Cambridge, Eng.: Cambridge University Press.

KEATES, J. S. (1982). Understanding Maps. London: Longman.

KEGAN, R. (1982). The evolving self. Cambridge, Ma: Harvard University Press.

Kelly, M. (ed.) (1994). Critique and Power. Recasting the Foucault/Habermas debate. Cambridge, MA: The Mit Press.

KLUCHNIKOV, (1980). Reflexiones sobre la teoria y la práctica de la planificatión de la educación. Perspectivas, X (1), pp. 29-43.

KoCKA, J. (1981). Class Formation, Interest Articulation and Public Policy: The Origins of the German White-Collar Class in Late Nineteenth and Early Twentieth Centuries. In S. Berger (ed.), Organizing Interests in Western Europe. Cambridge: Cambridge University Press.

KOHLBERG, L. (1975). Moral education for a society in moral transition. Educational Leadership, 33, pp. 46-54.

KOHLBERG, L. (1978). Moral Education Reappraised. The Humanist, 38, p. 14.

KoHLBERG, L. (ed.) (1981). The Philosophy of moral development. San Francisco: Harper \& Row.

KOHLBERG, L. (ed.) (1983). The Psychology of moral development. San Francisco: Harper \& Row.

KOHLBERG, (1987). Child psychology and childood education: a cognitive-developmental view. London: Longman.

KOHN, R. C. (1994). La notion de réseau. In B. Charlot (coord.), L'école et le territoire: nouveuax espaces, nouveuax enjeux. Paris: Armand Colin, pp. 107-118.

KOSELLECK, Reinhardt (1959, 1979). Le règne de la critique. Paris: Minuit.

KOSELLECK, Reinhardt (1988). Critique and Crisis: Enlightenment and the Pathogenesis of Modern Society. Oxford: Berg.

KRISTEVA, Julia (1970). Une poétique ruinée. In M. Bakhtin, La poétique de Dostoievski. Paris: Seuil.

KUHN, Thomas (1983). La structure des révolutions scientifiques. Paris: Flammarion.

KUMON, S., Rosovskr, H. (eds.) (1992). The political economy of Japan. Vol. 3: Cultural and social dynamics. Stanford University Press.

LACLAU, Ernesto, MOUFFE, Chantal (1985). Hegemony and Socialist Strategy: towards a radical democratic. London: Verso.

LASCH, C. (1979). The culture of narcisism. American Life in an Age of diminishing expectations. New York: Norton \& Co.

LATOUR, B. (1984). Les microbes. Guerre et paix. Paris: A. M. Métailié.

LATour, B. (1989, 1995). La science en action. Paris: Éditons La Découverte (1989), Éditions Gallimard (1995).

LAWRENCE, P., LORSCH, J. (1967). Organization and environment. Boston: Harvard University Press. LeFEBVRE, Henri (1974). La production de l'espace. Paris: Anthropos.

LestHAeGHe, R. J. (1977). The Decline of Belgian Fertility, 1800-1970. Princeton: Princeton University Press. 
LIMA, Licínio (1992). A escola como organização e a participação na organização escolar. Braga: Instituto de Educação.

LıMA, Licínio (1992a). Organizações educativas e administração educacional. Relatório de disciplina. Braga: Universidade do Minho - Instituto de Educaçăo.

LIMA, Licínio (1995). Reformar a administraçăo escolar: a recentralização por controlo remoto e a autonomia como delegaçăo política. Revista Portuguesa de Educação, 8 (1), pp. 57-71.

LIMA, Licínio (1996). Construindo um objecto: para uma análise crítica da investigação portuguesa sobre a escola. In J. Barroso (org.), O estudo da escola. Porto: Porto Editora, pp. 15-39.

LIMA, Licínio (1998). A evolução do sistema educativo e o Prodep. Administração do sistema educativo e das escolas. Lisboa: ME/Departamento de Avaliação e Prospectiva.

LIPOVETSKY, G. (1989). A Era do vazio. Ensaio sobre o individualismo contemporâneo. Lisboa: Relógio D’Água.

LUHMAN, N. (1976). A general theory of organized social sistems. In G. Hofstede e M. S. Kassen (eds.), European contributions to organization theory. Assen: Van Gormm, pp. 97-113.

LUHMAN, N. (1982). The differentiation of society. New York: Columbia University Press.

LUHMAN, N. (1990). The cognitive program of constructivism and a reality that remains unknown.

In W. Krohn et al. (eds.), Selforganisation: Portrait of a scientific revolution. Dordrecht: Kluwer.

LUHMAN, N. (1990a). Essays on Self-Reference. New York: Columbia University Press.

LUHMAN, N., SCHORR, K.-E. (1979), Reflexionsprobleme im Erziehungsystem. Stuttgart: Klett-Cotta.

LYNCH, Kevin (1960). The image of the city. Cambridge, Ma: Mr Press.

LYOTARD, Jean-François (1983). Le différend. Paris: Minuit.

MACHADO, Pinto et al. (1990). Relatório da Comissão Executiva do Grupo Coordenador para o Estudo da Formação Pessoal e Social (policopiado).

MACPHERSON, C. (1962). The political theory of possessive individualism: Hobbes to Locke. New York: Oxford Press.

MAGos, Maria Júlia Tomás (1985). Recomendaçōes sobre construçăo escolar no âmbito do ensino preparatório e secundário unificado. Lisboa: DGEE (trabalho apresentado para concurso interno).

MAlLER, Phil (1977). Portugal, the impossible Revolution. London: Solidarity.

MARCH, J. (1981). Footnotes to organizational change. Administrative Science Quarterly, 26, pp. 563-577.

MARQUes, M. ${ }^{a}$ M. Leitẫo (1996). Administração consultiva em Portugal. Lisboa: Conselho Económico e Social.

MARQUES, Ramiro (1990). Educaçẫo Civica e desenvolvimento pessoal e social: objectivos, conteúdos e métodos. Lisboa: Texto Editora.

MARQUES, Ramiro (1991). A educação para os valores morais no ensino básico: o currículo implicito e explicito. Tese de doutoramento. Aveiro: Universidade de Aveiro.

MARTINS, G. Câncio (1981). Centralizaçăo e descentralização. In M. Silva e M. Isabel Tamen (coord.), Sistema de ensino em Portugal. Lisboa: FCG, pp. 95-116.

MARTINS, Hermínio (1996). Hegel, Texas e outros ensaios de Teoria Social. Lisboa: Século XXI.

MATEUS, A. (1983). Política económica e transformação planeada do sistema produtivo nacional. In Evolução recente e perspectivas de transformação da economia portuguesa, vol. I. Lisboa: CISEP - ISE, pp. 394-416. 
MAuss, M. (1979). Body techniques. In Psychology and Sociology: Essays. London: Routledge \& Kegan Paul, pp. 95-123.

MCCARTHY, C. (1988). Rethinking liberal and radical perspectives on racial inequality in schooling: Making the case for nonsynchrony. Harvard Educational Review, 58(3), pp. 265279.

MCCARTHY, C. (1990). Race and Curriculum - Social inequality and the theories and politics of difference in contemporary research on schooling. London: Falmer Press.

MCCLelLand, (1961). The achieving society. Princeton, NY: Van Nostrand.

MCNEELY, Connie (1995). Constructing the Nation-State: International Organization and Prescritive action. Westport, Conn.: Greenwood.

MERRIAM, S. (1988). Case study research in education. A qualitative approach. San Francisco: Jossey-Bass Pub.

MERTON, Robert (1968). Social theory and social structure. New York: Harper and Row.

MEYER, John (1977). The Effects of Education as Institution. American Journal of Sociology, 83, pp. 55-77.

MEYER, John, BOL, J., THOMAS, G. M. (1987). Ontology and rationalization in the Western cultural account. In G. Thomas, J. Meyer, F. Ramirez e J. Boli (eds.), Institutional structure: constituting State, society, and the individual. Newbury Park; Ca: Sage.

MeYer, John, Bolı, J., ThOMAS, G. M., RAmirez, F. O. (1997). World Society and the Nation-State. American Journal of Sociology, 103(1), pp. 104-181.

MeYer, John, HANnAN, M. T. (eds.) (1979). National development and the World System: Educational, economic, and political change, 1950-1970. Chicago: University of Chicago.

MEYER, John, KAMENS, D., BENAVOT, A. (1992). School Knowledge for the masses: World models and national primary curricular categories in the Twentieth Century. London: Falmer Press.

MEYER, John, RAMIREZ, F. (1998). The globalization of education. Stanford (policopiado).

MeYer, John, RAMiREZ, F., RUBinSON, R., Boli-BEnNet, J. (1979). The World Educational Revolution, 1950-1970. In J. W. Meyer \& T. Hannan (Eds.), National Development and the World System: Educational, Economic, and Political Change, 1950-1970. Chicago: University of Chicago Press, pp. 37-55.

MEYER, John, RAMIREZ, F., SOYSAL, Y. (1992). World Expansion of Mass Education, 1870-1980. Sociology of Education, 65, pp. 128-149.

MEYER, John, ROWAN, B. (1977). Institutionalized Organizations: Formal Structure as Myth and Ceremony. American Journal of Sociology, 83, pp. 340-363.

MEYER, John, RowAN, B. (1978, 1992). The Structure of Educational Organizations. In M. Meyer et al. (ed.), Environments and Organizations. San-Francisco: Jossey-Bass, pp. 78-109; ref. ut.: J. Meyer e R. Scott (1992). Organizational Environments. Ritual and Rationality, Newbury Park: Sage, pp. 71-97.

MeYer, John, TYACK, D., NAGel, J., GORDON, A. (1979). Public Education as Nation-Building in America: Enrollments and Bureaucratization in the American States. American Journal of Sociology, 85 (3), pp. 591-613.

MILLER, P. (1987). Domination and Power. London: Routledge and Kegan Paul.

MintzBerG, H. (1982). Structure et dynamique des organisations. Paris: Hommes et Téchniques. MintzBerg, H. (1994). The Rise and Fall of Strategic Planning. New York: Prentice Hall. 
Miranda, José A. B. (1997). Política e Modernidade. Linguagem e violência na cultura contemporânea. Lisboa: Edições Colibri.

MiTCH, D. (1978). Alternative Approaches to the Spread of Literacy. Paper presented to the Economic History Workshop, October. University of Chicago.

MÓNICA, M. ${ }^{a}$ F. (1997). Os filhos de Rousseau. Lisboa: Relógio D'Água.

MORAIS, Margarida, VALENTE, Odete (1991). Pensar sobre o pensar: ensino de estratégias metacognitivas para recuperaçăo de alunos com dificuldades na compreensão da leitura na disciplina de Língua Portuguesa. Revista de Educaçắo, II (1), pp. 35-56.

MORGAN, William, ARMER, M. (1992). Western versus Islamic Schooling: Conflict and Accomodation in Nigeria. In B. Fuller e R. Rubinson (Eds.), The Political Construction of Education: The State, School Expansion, and Economic Change. New York: Praeger, pp. 75-88.

Morrow, Raymond, TORRES, C. (1995). Social Theory and Education: A critique of theories of social and cultural reproduction. Albany: State University of New York Press.

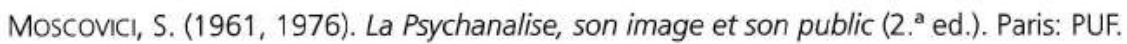

Moscovici, S., Hewstone, M. (1984). De la science au sens commun. In S. Moscovici (ed.), Psychologie Sociale. Paris: PuF, pp. 539-566.

Mouffe, Chantal (1996). O Regresso do Politico. Lisboa: Gradiva.

NAGEL, Thomas (1991). Equality and Partiality. Oxford: Oxford University Press.

NóvoA, António (1991). As Ciências da Educação e os processos de mudança. In A. Nóvoa et al., Ciências da Educação e Mudança, Lisboa: Sociedade Portuguesa de Ciências da Educaçã̃o, pp.17-67.

NóvoA, António (1994). A Educação Portuguesa 1945-1992. In C. Lozano (coord.), Educacion Ibero Americana: 500 años. México: Garcia Valadés Editores.

NóvoA, A., CAmpos, B., PONTE, J. P., SANTos, M. B. (1991). Ciências da Educação e Mudança. Lisboa: Sociedade Portuguesa de Ciências da Educaçăo.

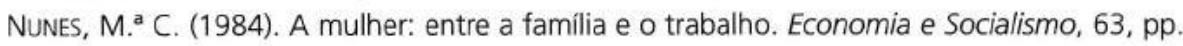
71-76.

OAKES, J. (1989). What educational indicators? The case for assessing the school context. Educational Evaluation and Policy Analysis, 11(2).

OBIN, J.-P. (1993). La crise de l'organisation scolaire: de la centralisation bureaucratique au pilotage par objectifs et projets. Paris: Hachette Livre.

OfFE, Claus (1975). The Theory of the Capitalist State and the Problem of Policy Formation. In L. Lindberg et al. (orgs.), Stress and Contradiction in Modern Capitalism. Lexington: Lexington Books, pp. 125.

Offe, Claus (1984a). Problemas estruturais do Estado capitalista. Rio de Janeiro: Tempo Brasileiro.

OfFE, Claus, Keane, John (1984b). Contradictions of the Welfare State. London: Hutchinson.

OfFE, Claus (1987). The utopia of the Zero-Option: Modernity and modernization as normative political criteria. Praxis International, 7: 1.

Offe, Claus (1996). Modernity and the State. East, West. Cambridge: Polity Press. 
ORIVEL, F. (1995). Planification et coûts: la construction des politiques d'éducation et de formation. In B. Charlot e J. Beillerot (dir.), La construction des politiques d'éducation et de formation. Paris: PUF, pp. 69-78.

OSBORNE, D., GAEBLER, T. (1992). Reinventing Government: How the entrepreneurial spirit is transforming the public sector.

PACI, M. (1982). A educação e o mercado de trabalho. In S. Grácio et alli (orgs.), Sociologia da Educação - I. Lisboa: Livros Horizonte, pp. 193-217.

PAIS, J. M. (1985). Família, sexualidade e religião. Análise Social, 86, pp. 362.

PAIS, J. M. (1998). Grupos juvenis e modelos de comportamento em relação à escola e ao trabalho: resultados de análises factoriais. In M. V. Cabral, J. M. Pais (coord.), Jovens portugueses de hoje. Oeiras: Celta, pp. 135-188.

PAPADOPOULOS, George Papadopoulos (1994). L' OCDE face à l'Éducation, 1960-1990. Paris: OCDE. PARKINSON, C N. (1986). Parkinson's Law or the pursuit of progress. London: Penguin Books. PARSONS, Talcott (1971). The System of Modern Societies. Englewood Cliffs, NJ: Prentice Hall. PASQUINO, Pasquale (1978). Theatrum politicum: police and the state of prosperity. Ideology and Consciousness, 4, pp. 41-53.

PAULSTON, Rolland (ed.) (1996). Social cartography. Mapping ways of seeing social and educational change. New York, London: Garland Publishing.

PEIRCE, Ch. S. (1958). Selected Writings. New York.

PERELMAN, Chaïm, OlBRECHTS-TYTECA, L. $(1969,1996)$. Tratado da argumentação. A nova retórica. Săo Paulo: Martins Fontes.

PERELMAN, Chaïm (1993). O império retórico. Porto: Edições Asa.

PerRenoud, P. (1977). L'inegalité sociale devant l'évaluation des compétences. Genève: Service de la Recherche Sociologique.

PINTO, J. Madureira (1991). Considerações sobre a produçẫo social da identidade. Revista Crítica de Ciências Sociais, 32, pp. 217-231.

PINTO, J. Madureira (1994). Propostas para o ensino das Ciências Sociais. Porto: Afrontamento. PoCoK, J. G. A. (1985). Virtue, Commerce, and History. Cambridge: Cambridge University Press.

POPKEWITZ, Thomas (1984). Paradigma e ideologia en investigatión educativa. Madrid: Mondadori.

POPKEWITZ, Thomas (1991). A Political Sociology of Educational Reform: Power/Knowledge in teaching, teacher education, and research. New York e London: Teachers College Press.

POPKEWITZ, Thomas (1996a). Constructing the new democratic citizen. Pedagogical discourses in the reconstituting of the participatory subject. Comunicação na Conferência «Democracy, Citizenship and Education», University of Turku, Finland, May 24-25.

POPKEWITZ, Thomas (1996b). Rethinking decentralization and state/civil society distinctions: the state as a problematic of governing. Journal of Education Policy, 11(1), pp. 27-51.

POPKEWIT, Thomas (1998). Struggling for the Soul. The politics of Schooling and the Construction of the Teacher. New York e London: Teachers College Press.

POPKEWIZ, Thomas, BRENNAN, M. (1998). Foucault's challenge. Discourse, Knowledge, and power in Education. New York, London: Teachers College, Columbia University. 
POPPER, K. R. (1988). O Universo aberto - Pós-escrito à lógica da descoberta científica. Vol. II. Lisboa: Dom Quixote.

POWELL, W., DIMAGGIO, P. (eds.) (1991). The new institutionalism in organizational analysis. Chicago: The University of Chicago Press.

PRESSEISEN, B. Z. (1985). Thinking skills: Meanings and models. In A. L. Costa (ed.), Developing minds: A resource book. Alexandria, VA: ASCD.

PRIGOGINE, llya, Stengers, I. (1986). A nova aliança. Lisboa: Gradiva.

Propositions pour l'enseignement de l'avenir (1985), élaborées à la demande de M. Le président de la République par les professeurs du Collège de France. Paris: Collège de France.

PSACHAROPOULOS, G. (1973). Returns to education: an international comparison. London: Elsevier Scientific Publ.

PSACHAROPOULOS, G. (1981a). Returns to education: an updated international comparison. Comparative Education, 17(3), pp. 321-341.

PSACHAROPOULOS, G. (1981b). Education and the structure of earnings in Portugal. The Economist, 129(4), pp. 532-545.

PSACHAROPOULOS, G. (1983). An analysis of the determinants of the demand for upper secondary education in Portugal. Economics of Education Review, 2(3), pp. 233-251.

PSACHAROPOULOS, G. (1989). Time trends of the returns to education: Cross-National evidence. Economics of Education Review, 8, pp. 225-231.

RabinOW, P. (ed.) (1984). The Foucault Reader. Harmondsworth: Penguin.

RAMIREZ, F. O., BOLI, J. (1987). The Political Construction of Mass Schooling: European Origins and Worlwide Institutionalization. Sociology of Education, 60(2), pp. 2-18.

RAMIREZ, F. O., RUBInSON, R. (1979). Creating Members: The Political Incorporation and Expansion of Public Education. In J. W. Meyer \& T. Hannan (Eds.), National Development and the World System: Educational, Economic, and Political Change, 1950-1970. Chicago: University of Chicago Press, pp. 72-82.

RathS, L., HARMIN, M., SIMON, S. (1966). Values and teaching. Columbus, Ohio: Charles E. Merril. RAWLS, John (1971). A Theory of Justice. Oxford: Oxford University Press.

RAWLS, John (1987). The idea of an overlapping consensus. Oxford Journal of Legal Studies, $7(1)$, p. 6.

REESE, William (1986). Power and the promise of school reform: Grassroots movements during the Progressive Era. Boston: Routledge \& Kegan Paul.

Ricoeur, P. (1975). La métaphore vive. Paris: Éditions du Seuil.

RICHARDS, I. A. (1936). The Philosophy of Rethoric. Oxford: University Press.

RIESMAN, D. (1952). The Lonely Crowd. New Haven: Yale University Press.

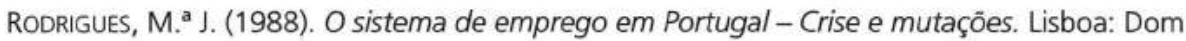
Quixote.

RODRIGUES, M. a J. (1991). Competitividade e recursos humanos. Lisboa: Publicaçōes Dom Quixote. RORTY, R. (1984, 1990). Science et solidarité: La verité sans le pouvoir. Cahors: L'Éclat.

RoSE, Nikolas (1990). Governing the Soul: The Shaping of the Private Self. London: Routledge. RoSE, Nikolas (1994). Expertise and the Government of Conduct. Studies in Law, Politics and Society, 14, pp. 359-397. 
ROSE, Nikolas (1996a). The death of the social? Re-figuring the territory of government. Economy and Society, 25, pp. 327-356.

Rose, Nikolas (1996b). Inventing our selves. Psychology, power, and personhood. Cambridge: Cambridge University Press.

ROSE, Nikolas (1999). Powers of Freedom. Reframing political thought. Cambridge: University Press.

ROSE, Nikolas, Miller, Peter (1992). Political power beyond the State: problematics of government. British Journal of Sociology, 43, pp. 173-205.

Rose, R., Peters, G. (1978). Can government go bankrupt? New York: Basic Books.

Rowunson, William (1974), German Education in a European Context. In T. G. Cook, The History of Education in Europe. London: Methuen.

RUBINSON, Richard (1986). Class Formation, Politics, and Institutions: Schooling in the USA. American Journal of Sociology, 92, pp. 519-548.

RUBINSON, Richard, RALPH, J. (1984). Technical change and the expansion of schooling in the United States. Sociology of Education, 57, pp. 134-152.

RUIvo, Beatriz (1986). A mulher e o poder profissional: a mulher em actividades de investigação científica em Portugal. Análise Social, XXII (87-89), pp. 669-680.

RYAN, K. (1986). The new moral education. Phi Delta Kappan, 68, pp. 228-233.

SABEL, C. F. et al. (1987). Regional prosperities compared: Massachusetts and BadenWürttemberg in the 1980's. Berlin: Wissenschaftszentrum Berlin für Sozialforschung.

SACK, R. (1981). Una tipologia de las reformas de la educación. Perspectivas, XI (1), pp. 45-60.

SALEMA, M. H. (1989). Aprender a pensar: a composiçăo escrita. Revista de Educaçăo, 1(3), pp. 59-63.

SAMPAIO, Daniel (1993). Vozes e ruídos - Diálogos com adolescentes. Lisboa: Caminho.

SAMPAIO, Daniel (1994). Inventem-se novos pais. Lisboa: Caminho.

SANCHES, Maria F. (1987). Reformar o contexto da gestão das escolas secundárias: a voz dos Conselhos Directivos. Revista de Educação, 2, pp. 27-39.

SANTOS, B. Sousa (1974). Law Against Law: Legal Reasoning in Pasargada Law. Cuernavaca: CIDOC.

SAntos, B. Sousa (1980). O discurso e o poder: ensaio sobre a Sociologia da retórica jurídica. Boletim da Faculdade de Direito, número especial.

SANTOS, B. Sousa (1982). O Direito e a comunidade: as transformaçōes recentes da natureza do poder do Estado nos países capitalistas avançados. Revista Crítica de Ciências Sociais, 10, pp. 9- 40.

SANTOS, B. Sousa (1985). On Modes of Production of Law and Social Power. International Journal of Sociology of Law, 13, pp. 299.

SANTOS, B. Sousa (1988). Uma cartografia simbólica das representações sociais: prolegómanos a uma concepção pós-moderna do Direito. Revista Crítica de Ciências Sociais, 24, pp. 139172.

SANTOS, B. Sousa (1989). Introduçăo a uma ciência Pós-Moderna. Porto: Ediçōes Afrontamento.

SAntos, B. Sousa (1990). O Estado e a Sociedade em Portugal (1974-1988). Porto: Afrontamento. 
SANTOS, B. Sousa (1991). Subjectividade, Cidadania e Emancipaçăo. Revista Critica de Ciências Sociais, 32, pp. 135-191.

SANTOS, B. Sousa (org.) (1993). Portugal: um retrato singular. Porto: Afrontamento.

SANTOS, B. Sousa (1994). Pela mão de Alice. O social e o político na Pós-Modernidade. Porto: Edições Afrontamento.

SAntos, B. Sousa (1996). A Queda do Angelus Novus. Revista Crítica de Ciências Sociais, 45, pp. 5-34.

SAUSSURE, Ferdinand de (1916, 1983). Course in General Linguistics. London: Duckworth.

SCARDIGLI, V. (ed.) (1993). L'Europe de la diversité: La dynamique des identités regionales. Paris: Éditions du CNRS.

SCHEERENS, Jaap (1992). Effective Schooling. Research, Theory and Practice. London e New York: Cassell.

SCHMITTER, P. C. (1986). Democratic Theory and neo-corporatist practice. Selected Working papers of the European University Institute. Firenze: Badia Fiesolana.

SCHMUCK, R. (1980). The school organization. In J. H. McMillan (ed.), The social psychology of school learning. Academic Press.

SCHRIWER, Jurgen (1998). World-System and Interrelationship Networks. The Internationalization of Education and the Role of Comparative Inquiry. In T. Popkewitz (ed.), Educational Knowledge: Changing Relationships between the State, Civil Society, and the Educational Community. Buffalo: Sate University of New York Press.

SCHultz, Th. (1961). Investment in Human Capital. American Economic Review, 51, pp. 109117.

SCHULTZ, Th. (1971). Investment in Human Capital. The role of education and research. New York.

SCHULTZ, T. P. (1993). Returns to women's education. In Women's education in developing countries. Washington, DC: The World Bank, pp. 5-93.

SERIEYEX, H. (1989). Le projet d'entreprise, mode d'emploi. Futuribles, 137, pp. 63-78.

SHILING, C. (1989). Schooling for work in capitalist britain. London: The Falmer Press.

SHOTTER, J. (1989). Social accountability and self specification. In K. J. Gergen e K. E. Davies (eds.), The Social construction of the person. New York: Springer Verlag, pp. 168-190.

SIIVA, A., SA, I. (1993). Saber estudar e estudar para saber. Porto: Porto Editora.

SILVA, Manuela, TAMEN, M. Isabel (coord.) (1981). Sistema de Ensino em Portugal. Lisboa: Fundaçăo Calouste Gulbenkian.

SILvA, Pedro (1999). Escola-Família: o 25 de Abril e os paradoxos de uma relaçăo. Educação, Sociedade \& Culturas, 11, pp. 83-108.

SILVA, Tomaz Tadeu (1995). O projeto educacional moderno: identidade terminal? In A. J. da Veiga-Neto (org.), Crítica pós-estruturalista e educaçāo. Porto Alegre: Sulina, pp. 1-17.

SKINNER, Quentin $(1978,1996)$. As fundaçōes do pensamento político moderno. São Paulo: Companhia das Letras.

SKocPol, Theda, EVAns, P., RUESCHEMEYER, D. (1985). Bringing the State Back In. New York: Cambridge University Press.

SKOCPOL, Theda, SOMERS, M. (1980). The Uses of Comparative History in Macrosocial Inquiry. Comparative Studies in Society and History, 22(2), pp. 174-197. 
SMYTH, J. (1991). International perspectives on teacher collegiality: a labour process discussion based on the concept of teacher's work. British Journal of Sociology of Education, 12(3), pp. 323-346.

SMYTH, J. (ed.) (1993). A Socially Critical View of the Self-managing School. London: The Falmer Press.

Soares, M. C., Säo Pedro, M. E., M. E., Magalhães, M. M. (1981). Análise custo-benefício do sistema educativo português. Lisboa: GEP/ME.

SOMERVILLE, John (1982). The Rise and Fall of Childhood. Beverly Hills: Sage.

SORGE, A., WARNER, M. (1987). Comparative factory organization - An Anglo-German comparison of management and manpower in manufacturing. Aldershot: Gower.

SOYSAL, Y. N., STRANG, D. (1989). Construction of the First Mass Education Systems in NineteenthCentury Europe. Sociology of Education, 62, pp. 277-288.

SternBerg, R. J. (1985). Beyond I. Q.: A Triarchie theory of human intelligence. Cambridge: University Press.

StOER, Stephen (1980). A Democracia e o Socialismo na Educação em Portugal. Análise Psicológica, 2(1), pp. 243-257.

StOER, Stephen (1982). Educação, Estado e Desenvolvimento em Portugal. Lisboa: Livros Horizonte.

StOER, Stephen (1985). A Revoluçăo de Abril e o Sindicalismo dos Professores em Portugal. Cadernos de Ciências Sociais, 3, pp. 61-83.

STOER, Stephen (1986). Educaçăo e Mudança Social em Portugal. Porto: Afrontamento.

StOER, Stephen (1993). Construindo a escola democrática através do "campo da recontextualizaçăo pedagógica». Educaçăo, Sociedade \& Culturas, 1, pp. 7-27.

STOER, Stephen (1994). O Estado e as políticas educativas: uma proposta de mandato renovado para a escola democrática. Revista Crítica de Ciências Sociais, 41, pp. 3-33.

STOER, S., ARAújo, H. C. (1992). Escola e aprendizagem para o trabalho num país da (semi)periferia europeia. Lisboa: Escher.

StOER, S., DALE, R. (1987). Education, State, and Society in Portugal, 1926-1981. Comparative Education Review, 31(3), pp. 400-418.

StOer, S., Stoleroff, A. D., CorrelA, J. A. (1990). Um novo vocacionalismo na política educativa em Portugal e a reconstrução da lógica da acumulaçăo. Revista Crítica de Ciências Sociais, 29, pp. 11-53.

Strauss, G. (1978). Negotiations. San-Francisco: Jossey-Bass.

STROMQUIST, N. (1989). Determinants of educational participation and achievement of women in the Third World: A review of the evidence and a theoretical critique. Review of Educational Research, 59(2), pp. 143-183.

TAYLOR-GOOBY, P. (1983). Legitimation deficit, public opinion and the Welfare State. Sociology, 17(2), pp.

TODD, Emmanuel (1990). L'invention de l'Europe. Paris: Edtions du Seuil.

TORRES, Carlos (1996). State and Education Revisited: Why Educational Researchers should think politically about education. In M. Apple (Ed.), Review of Research in Education, 21. Washington, DC: American Educational Research Association, pp. 255-331. 
TORRES, Carlos, PANnU, R., BACCHUS, M. K. (1993). Capital Accumulation, Political Legitimation and Educational Expansion. In J. Dronkers, International Perspectives on Education and Society. Greenwich, Conn.: JAl Press, pp. 3-32.

TRIST, E. L., BAMFORTH, K. (1951). Some social and psychological consequences of the longwall method of coal-getting. Human Relations, 4(1), pp. 3-38.

TRIST, E. L. et al. (1963). Organizational choice. London: Tavistock.

Tulıy, J. (1995). Strange multiplicity: Constitutionalism in an age of diversity. Cambridge: Cambridge University Press.

TURNER, L., AUER, P. (1992). The Political economy of new work organization. Different road, different outcomes. Berlin: Wissenschaftszentrum Berlin für Sozialforschung.

TYACK, David (1966). Forming the National Character: Paradox in the Thought of the Revolutionary Generation. Harvard Education Review, 36(1).

TYACK, David, TOBIN, W. (1994). The 'Grammar' of schooling: Why has it been so hard to change? American Educational Research Journal, 31(3), pp. 453-479.

VALA, Jorge (1985). Representaçōes sociais dos jovens: valores, identidade e imagens da sociedade portuguesa. Lisboa: IED.

VALA, Jorge (1986). Identidade e valores da juventude portuguesa - uma abordagem exploratória. Desenvolvimento, n. ${ }^{\circ}$ especial, pp. 17-28.

VALENTE, O. et alii (1987). Aprender a pensar. Lisboa: Departamento de Educaçăo da FCL.

Valente, O., Salema, M. H., Morais, M. M., Cruz, M. N. (1989). A metacognição. Revista de Educação, 1(3), pp. 47-51.

VASConcelos, P. (1998). Conjugalidade e sexualidade. In M. Villaverde Cabral e J. Machado Pais (coord.), Jovens portugueses de hoje. Lisboa: Celta, pp. 215-305.

VATtIMO, Gianni, RovatI, P. (org.) (1983). Il pensiero debole. Milano: Feltrinelli.

VERDERY, K. (1983). Transylvanian Villagers. Berkeley: University of California Press.

Wallerstein, I. (1982). Crisis as Transition. In S. Amin et al., Dynamics of Global Crisis. New York: Monthly Review Press.

WALleRSTEIN, I. (1984). The politics of World-Economy. Cambridge: Cambridge University Press. WALlERSTEIN, I. (1991). Geopolitics and Geoculture: Essays on the Changing World-system. Cambridge: Cambridge University Press.

WEBER, E. (1976). Peasants into Frenchemen. Stanford: Stanford University Press.

WEBER, Max (1930). The Protestant Ethic and the spirit of capitalism. Allen \& Unwin.

WEBER, Max (1947). The theory of social and economic organization. Glencoe: Free Press.

WEBER, Max (1956, 1971). Economie et société. Paris: Plon.

WEICK, K. (1979). The Social Psychology of organizing (2 ${ }^{\text {nd }}$ ed). Reading, Ma: Addison-Wesley.

WEILER, H. N. (1983). Legalization, expertise and participation: Strategies of compensatory legitimation in educational policy. Comparative Education Review, 27(2), pp. 259-277.

WEILER, H. N. (1990). Comparative perspectives on educational decentralization: an exercise in contradiction. Educational Evaluation and Policy Analysis, 12, pp. 433-488.

WitTGENSTEIN, L. (1979). Wittgenstein's Lectures, Cambridge, 1932-1935. Oxford: Blackwell. 
WittGenstein, L. (1958, 1987). Tratado Lógico-Filosófico. Investigaçōes Filosóficas. Lisboa: Fundaçăo Calouste Gulbenkian.

WolfE, A. (1977). The limits of Legitimacy: Political contradictions of contemporary capitalism. New York: Free Press.

Woods, P. (1986, 1989). La escuela por dentro. La etnografia en la investigation educativa (2 ed.). Barcelona: Ed. Paidós.

Young, Robert (1997). Torn halves. Political conflict in literary and cultural theory. Manchester e New York: Manchester University Press.

\section{Fontes}

ACTAS DA COMISSÃO DE REDE ESCOLAR, 1975-1982.

AsSembleia dA RePública (1990). Seminário sobre a Reforma do sistema educativo. Lisboa: Comissão de Juventude da Assembleia da República.

Comissão de Reforma do Sistema EduCATIVo (1988a). Planeamento educativo. Lisboa: Me/Gep.

Comissão de ReForma do Sistema Educativo (1988b). Proposta Global de reforma. Lisboa: ME/ GEP.

COMISSÃo dE REFORMA do SistemA EducATIVo (1988c). A gestão do sistema escolar. Lisboa: ME/ GEP.

CoMISSÃo de REFORMA do SISTEMA EduCATIVo (1988d). Medidas que promovam o sucesso educativo. Lisboa: ME/GEP.

COMISSÃo dE REFORMA do SISTEMA EdUCATIVO (1988e). Um sistema estatístico no sector educativo. Lisboa: GEP/ME.

Comissão de Reforma do Sistema Educativo. Gabinete de Estudos e Planeamento (1987). Disparidades Regionais dos Niveis de Instrução dos Jovens. Lisboa: GEP /ME.

CONSELHO NACIONAL DE EDUCAÇĀO (1990). Pareceres e recomendações, 88-89. I e ll volume. Lisboa: ME.

CONSELHO NACIONAL DE EDUCAÇÃo (1991).

DiRECÇĀo GeRAL dAS CONSTRUÇōes EsColaRes (1985). Recintos escolares. Critérios para designaçăo urbanistica, Lisboa: DGCE.

410 Gabinete de Estudos e Planeamento (1976). Lançamento do ano Lectivo de 1976/77 (ensinos básico e secundário). Participação dos estabelecimentos de ensino (documento policopiado).

GABINETE DE ESTUDOS E PLANEAMENTO (1977). Breve introdução à avaliação em educação. Lisboa: GEP /ME.

Gabinete de Estudos e Planeamento (1978a). Ensino Secundário Unificado. Avaliação da aprendizagem da Matemática, $7 .^{\circ}$ e $8 .^{\circ}$ anos. I. Testagem. Maio de 1978. Lisboa: Gep/ME.

Gabinete de Estudos e Pleneamento (1978b). Ensino Secundário Unificado. Frequência do 7. ${ }^{\circ}$ ano de escolaridade 75/76. Breve análise estatística retrospectiva. Lisboa: GEP/ME.

GABINETE DE Estudos E PLANEAmEnto (1979). Rede dos cursos complementares em função da situaçāo sócio-económica e do inventário de carências em instalaçōes escolares. Lisboa: GEP. 
Gabinete de Estudos e Planeamento (1979a). Inventário de Carências em instalações aos níveis dos Ensinos preparatório e secundário. Fichas preparatórias. Lisboa: GEP/DGEE.

GABINETE DE ESTUdOS E PLANEAMENTO (1979b). Inventário de Carências em instalaçōes nos Ensinos preparatório e secundário. Processo de diálogo com as autarquias envolvidas (1978-1979). Lisboa: GEP.

GABINETE DE Estudos E PLANEAMENTO (1979c). Ensino Secundário Unificado. Relatório de Avaliação do 7. ${ }^{\circ}$ ano de escolaridade, 1975/1976. Junho de 1979. Lisboa: GeP/ME.

GABINETE DE Estudos E PLANEAMENTo (1979d). Inventário de Carências em instalaçōes aos níveis dos Ensinos preparatório e secundário. Análise da evoluçăo do sistema de cobertura escolar do ensino preparatório. Lisboa: GEP/DGEE.

GABINETE dE Estudos E PLANEAMENTo (1980a). Ensino Secundário Unificado. Avaliaçăo do $8 .^{\circ}$ ano de escolaridade, 1977/78. Estudos de caso. Abril de 1980. Lisboa: GEP /ME.

GABINETE de Estudos e PLANEAmento (1980b). Ensino Secundário Unificado. A aprendizagem da Matemática em 1977/78, $7 .^{\circ}$ e $8 .^{\circ}$ anos. Novembro de 1980. Lisboa: Gep/ME.

GABINETE de Estudos e PLANEAMENTo (1980C). Ensino Secundário Unificado. Relatório de Avaliação do $7 .^{\circ}$ ano de escolaridade, 1976/77. Fevereiro de 1980. Lisboa: GEP /ME.

GABINETE DE ESTUdOS E PLANEAMENTO (1980d). Ensino Secundário Unificado. Inquérito a professores do 9. ${ }^{\circ}$ ano de escolaridade, (1978/79). Fevereiro de 1980. Lisboa: GEP/ME.

GABINETE DE EsTUdOS E PLANEAMENTO (1980e). Ensino Secundário Unificado. Relatório de avaliaçāo do $7 .^{\circ} .8^{\circ}$ e $9 .^{\circ}$ ano de escolaridade de 1977/78. Julho de 1980. Lisboa: GEP /ME.

Gabinete de Estudos e PlANEAMENTo (1980f). Ensino Secundário Unificado. A aprendizagem da Matemática em perspectiva: o 9. ano de $1978 / 79$ e sua relaçáo com os $7 .^{\circ}$ e $8 .^{\circ}$ anos de 1977/78. Julho de 1980. Lisboa: GEP/ME.

Gabinete de Estudos e PlaneAmento (1981a). Ensino Secundário Unificado. A aprendizagem da Matemática: influência da escola e da familia - 7. ${ }^{\circ}, 8^{\circ} \mathrm{e} 9 .^{\circ}$ anos de escolaridade de 1977 a 1979. Maio de 1981. Lisboa: GEP/ME.

GABINETE DE Estudos e PLANEAMENTo (1981b). Ensino Secundário Unificado. Relatório de avaliação do 9. ${ }^{\circ}$ ano de escolaridade de 1978/79. Inquérito a Conselhos Directivos. Maio de 1981. Lisboa: GEP /ME.

Gabinete de Estudos e Planeamento (1981c). Ensino Secundário Unificado. Relatório de avaliação do 9. ${ }^{\circ}$ ano de escolaridade de 1978/79. Os alunos. Maio de 1981. Lisboa: Gep /ME.

GABINETE DE Estudos e PLANEAMENTo (1981d). Ensino Secundário Unificado. Relatório de avaliação do 9. ${ }^{\circ}$ ano de escolaridade de 1978/79. Entrevistas a Encarregados de Educação do 6. ${ }^{\circ}$ 9. ${ }^{\circ}$ e $10{ }^{\circ}$ anos. Julho de 1981. Lisboa: GEP /ME.

Gabinete de Estudos e Planeamento (1981e). Ensino Secundário Unificado. A aprendizagem da Matemática: a capacidade em cálculo básico matemático. Setembro de 1981. Lisboa: GeP ME.

Gabinete de Estudos e Planeamento (1981f). Ensino Secundário Unificado. Relatório de avaliação: impacto social da reforma do Ensino Secundário Unificado. Entrevistas a empresas, 1979/ 80. Novembro de 1981. Lisboa: GEP /ME.

Gabinete de Estudos e Planeamento (1981g). Ensino Secundário Unificado. A caminho duma Reforma do Ensino Secundário Unificado. Relatório Final. Dezembro de 1981. Lisboa: GEP/ ME. 
GABINETE DE ESTUdOS E PLANEAMENTO (1982a). O desenvo/vimento da escolarização a nivel Regional: o caso da escolaridade obrigatória.. Lisboa: GEP.

Gabinete de Estudos e PlaneAmento (1982b). Classificaçăo dos Distritos do Continente em Matéria de Condições de Desenvolvimento da Escolarização. Lisboa: GEP.

GABINETE DE Estudos E PLANEAMENTo (1982c). Inventário de Carências em instalaçōes aos níveis dos Ensinos preparatório e secundário: localização, priorização e dimensionamento dos tipos de intervenção previstos entre 1979 e 1984. Lisboa: GEP.

GABINETE DE Estudos E PLANEAMENTo (1982d). Inventário de Carências em instalaçōes aos niveis dos Ensinos preparatório e secundário: Dossier de estudos de caso de alternativas propostas. Lisboa: GeP.

Gabinete dE Estudos e PLANEAmento (1983). Inventário de Carências em instalações aos niveis dos Ensinos preparatório e secundário: Relatório do estado do processo. Lisboa: GEP.

GABINETE DE ESTUDOS E PLANEAMENTO (1984). Inventário de Carências em instalaçōes para os Ensinos preparatório e secundário referido ao período 1985/90. Lisboa: GEP.

GABINETE DE EsTUdOS E PLANEAMENTo (1986). Regionalização do ensino (alguns estudos realizados). Lisboa: GEP.

GABINETE DE Estudos E PLANEAMENTo (1987). A escola e o desenvolvimento dos alunos. Lisboa: ME/GEP.

Gabinete de Estudos e Planeamento (1988a). A escola serve para educar? Relatório final do projecto 'A função educativa da escola e o desenvolvimento da criança e do adolescente'. Lisboa: ME/GEP.

GABINETE de Estudos e PlANEAMENTo (1988b). Medidas que possibilitem o efectivo cumprimento da escolaridade obrigatória. Lisboa: ME/GEP.

Gabinete de Estudos e Planeamento (1989-90). Prática pedagógica. Análise da situação (2 volumes). Lisboa: ME/GEP.

Gabinete de Estudos e PlaneAmento (1989a). Primeira contribuiçăo para a Carta escolar. Lisboa: GEP.

GABINETE de Estudos e PLANEAMENTo (1989b). Segunda contribuiçăo para a Carta escolar. Lisboa: GEP.

Gabinete de Estudos e Planeamento (1990). Critérios de planeamento da rede escolar. Lisboa: GEP.

Gabinete de Estudos e Planeamento (1991a). Monitorizaçăo das escolas. Indicadores de desempenho. Lisboa:GEP.

Gabinete de Estudos e Planeamento (1991b). Roteiro de informaçăo de escola. Indicadores de desempenho. Lisboa: GEP.

Gabinete de Estudos e Planeamento (1992a). Carta escolar da Região Centro. Lisboa: Gep.

Gabinete de Estudos e Planeamento (1992b). Carta escolar da Região Alentejo. Lisboa: Gep.

Gabinete de Estudos e Planeamento (1992c). Análise custo-benefício do sistema educativo português. Lisboa: GEP.

Ministério da AdMinistração Interna. Comissóes de Planeamento Regional (1978). Criação de um Ficheiro de estabelecimentos de ensino. Lisboa: MAI.

MINISTÉRIO DA EDUCAÇÃo (1988). Relatório de Avaliação do programa especial de execução de escolas preparatórias e secundárias. Lisboa: ME. 
MINISTÉRIO DA EDUCAÇÃo (1988a). Perfil cultural desejável do diplomado do Ensino Secundário. Lisboa: GEP /ME.

Ministério da EducaÇĀo. DiRecÇÃo Geral dos Ensino BAsico e SECundário (1992). Práticas de autonomia. Lisboa: ME/DGEBS.

Ministério dA EdUCAÇÃo. Gabinete de Estudos e PLANEAmento (1982). Relatório da Comissão de Rede Escolar, 1981/82. Tomo I. Lisboa: GEP.

Ministério dA EDUCAÇĀo. GABINETE de Estudos e PLANEAMENTo (1983a). Relatório da Comissão de Rede Escolar. Movimento de rede escolar 1982/83. Regulação do processo interactivo. Tomo I. Lisboa: GEP.

Ministério da EducaÇĀo. Gabinete de Estudos e Planeamento (1983b). Relatório da Comissão de Rede Escolar. Movimento de rede escolar 1983/84. Regulação do processo interactivo. Tomo I. Lisboa: GEP.

MinISTERIO dA EdUCAÇĀo. SECRETARIA dE Estado dA Reforma EdUCATIVA (1989). As linhas mestras da Reforma Educativa. Conferência do secretário de estado em 27/11/89. Lisboa: SERE (documento policopiado).

MINISTERIO DA EDUCAÇÃo E CULTURA (1978). Projecto de Decreto-Lei do novo sistema de formação de professores. Julho.

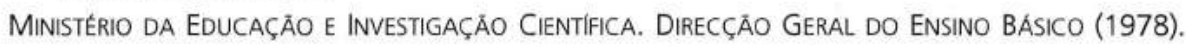
Memorial. Problemas de âmbito geral. Fevereiro (dactilografado).

Ministério dA EduCAÇÃo E InVESTIGAÇĀo CIENTIFICA. GABINETE do Ministro (1977). Realizaçōes levadas a efeito pelo MEIC desde a tomada de posse do Governo Constitucional. (dactilografado).

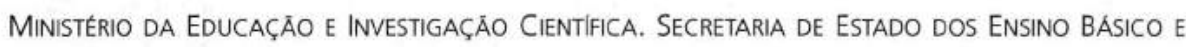
SECUNDÁRIo (1978). Memorial. Ensino Secundário Complementar. 17 de Agosto [Aldónio Gomes] (dactilografado).

Ministério da habitaçāo, Obras Públicas e transportes. Direç̧ão Geral das Construçóes EsCOLARES (1979). Explosão escolar e carências de instalaçōes. Lisboa Ministério da Habitação,Obras Públicas e transportes.

Direcção Geral das Construçóes Escolares (1982). Políticas de instalações escolares. Contribuiçōes para o problema da racionalizaçăo. Documento para discussão por John Mayfield. Tradução de documento da OCDE /PEB. Lisboa: CDI.

Ministério da habitação, Obras Públicas e transportes. DirecÇÃo Geral das Construçoes Escolares (1985). Políticas para instalaçōes escolares flexíveis. [John Mayfield]. Tradução de documento da OCDE /PEB. Lisboa: CDI.

OCDE (1966). La modernisation de l'enseignement: la réforme des programmes et le développement de l'education. Paris: OCDE.

OCDE (1975). L'école et la construction industrialisée. Paris: OCDE.

OCDE $(1975,1980)$. L'école et la collectivité, vol I e vol. II. Paris: OCDE /CERI.

OCDE (1976). Pourvoir aux changements futurs. Adaptabilité et flexibilité dans la construction scolaire. Paris: OCDE.

OCDE (1978-80). Collectivité, équipement, école, vol. I-V. Paris: OCDE /PEB.

OCDE (1979). L'enseignement et le développement régional. Paris: OCDE. 
OCDE /PEB (1981). Activité 3: Preoccupations particulieres aux Pays dont le systeme educatif est en developpement (Note du Secrétariat). Peb (81)3.Paris, 8 octobre 1981 (documento policopiado de difusão restrita).

OCDE (1983). Activité 3: Preoccupations particulieres aux Pays dont le systeme educatif est en developpement. Evolution du role des autorites centrales, regionales et locales dans le domaine de la construction scolaire. Principales conclusions du séminaire de Madrid tenu du 19 au 22 avril, 1982 (par Jean Ader). Paris, septembre 1983 (documento policopiado de difusăo restrita).

OCDE (1984). La qualité de L'enseignement. Paris: OCDE (Comité Directeur, documento policopiado).

OCDE (1985, 1989). O ensino na sociedade moderna. Porto: Ediçōes ASA.

OCDE (1995). Les processus de décision dans 14 systèmes éducatifs de l'OCDE. Paris: OCDE/ CERI.

UNESCO (1983). La gestion de l'éducation au niveau local. Paris: UNESCO.

UNESCO (1988). As funções da administração da educaçăo. Lisboa: UNEsco /GEP.

\section{Outras Fontes impressas}

Boletim do Gabinete de Estudos e Planeamento (policopiado), n. ${ }^{\circ}$ (Abril de 1975) ao n. 19 (Out-Nov-Dez 1978).

Breve Relatório do Encontro Internacional de funcionários com alta responsabilidade administrativa no domínio da educação sobre 'Comunidade escolar e problemas práticos de planificação regional', de Maria de Fátima Lencastre Ascenso, sem data [entrada no gabinete do ministro a 5/3/79 com a menção «tomei conhecimento do relatório e documentação, que considero do maior interesse»].

Pareceres da Comissão Constitucional (1977-1982, 21 volumes). Lisboa: Imprensa Nacional Casa da Moeda:

Parecer n. ${ }^{\circ} 17 / 82\left(19 .^{\circ}\right.$ vol., pp. 253-279): năo confessionalidade do ensino. Separaçăo entre as Igrejas e o Estado. Liberdade religiosa.

Parecer da comissão para a elaboraçăo dos programas do $8 .^{\circ}$ ano de escolaridade [Espólio Vitor Alves].

Parecer da comissão encarregada de repensar a problemática do Serviço Cívico Estudantil [Espólio Vítor Alves].

Pareceres das comissōes encarregadas da análise dos programas de História, Ciências Sociais, Vida Politica, Introdução à Politica e Filosofia do ensino secundário [Espólio Vítor Alves].

Processos da direcção-geral dos ensinos básico e secundário.

Programa de Actividades do Ministério da Educaçăo no âmbito do Programa do V Governo Constitucional, Lisboa: Ministério da Educação, 1979.

Relatórios das actividades da Comissão consultiva de estatística do Ministério da Educaçăo (19741980).

Relatórios do Provedor de Justiça, 4 volumes (1976, 1977, 1978, 1979). Lisboa: Secretaria de Estado da Comunicaçăo Social/Direcçăo-Geral da Divulgação. 
Relatórios do Provedor de Justiça, 12 volumes (1980, 1981, 1982, 1983, 1984, 1985, 1986, 1987, 1988, 1989, 1990, 1991). Lisboa: Serviço do Provedor de Justiça.

Resoluções do Conselho da Revolução entre 1975 e 1982 [Espólio Vitor Alves].

Resumo de reuniōes das Interassociaçōes de Pais e Encarregados de Educação e MEIC e MEIC e interassociaçōes, entre 26 de Junho de 1974 e Junho de 1976) [Espólio Vítor Alves].

Série de despachos do gabinete do ministro (1974-1988).

Série dos despachos do ministério da educaçăo, Setembro de 1975 a Julho de 1976 [Espólio

Vitor Alves].

Série de despachos da inspecçăo geral do ensino (1982-1986).

Série de despachos da secretaria de estado da administração escolar (1974-1983; 1985-1987).

Série de despachos da secretaria de estado da educaçăo (1980-1981).

Série de despachos da secretaria de estado da educação e juventude (1981-1982).

Série de despachos da secretaria de estado da reforma educativa (1987-1989).

Série de despachos da secretaria de estado dos ensinos básico e secundário (1977-1980; 1983 1987).

Série de despachos da secretaria de estado de orientação pedagógica (1974-1978; 1982-1983)

Série de despachos do secretário de estado adjunto do ministro (1983-1985; 1988-1989)

Súmulas das reuniōes de Conselho de Ministros entre Dezembro de 1974 e Julho de 1976 [Espólio Vítor Alves].

\section{Legislação consultada}

Decreto-Lei 491/69, de 24 de Julho: Lei Orgânica da Direcçăo-Geral das Construçōes Escolares. Decreto-Lei 408/71 de 27 de Setembro: Direcçăo-Geral da Administração Escolar.

Decreto-Lei 46/73: Lei Orgånica da Direcção-Geral da Administraçăo Escolar.

Decreto-Lei n. ${ }^{\circ}$ 735-A/74, de 21 de Dezembro: Gestão democrática dos estabelecimentos de ensino preparatório e secundário.

Despacho do Secretário de Estado da Orientaçăo Pedagógica de 15/5/75: Secretariado da Reestruturaçăo do Ensino Secundário.

Decreto-lei n. ${ }^{\circ}$ 270/75 de 22/5: Serviço Cívico Estudantil.

Circular n. ${ }^{\circ} 3 / 75$ do MEC de 27/6/75: objectivos do $7 .^{\circ}$ ano de escolaridade.

Despacho ministerial $\mathrm{s} / \mathrm{n} .^{\circ}$ de $1 / 8 / 75$ : criaçăo do Ensino Secundário Unificado.

Despacho 523/75 de 22/12: lançamento do $8 .^{\circ}$ ano de escolaridade.

Despacho n. ${ }^{\circ} 10 / 76$ de 23/1: relaçōes internacionais.

Despacho n. ${ }^{\circ}$ 31/76 de 9/2: grupo de trabalho para a organização dos serviços regionais do MEIC.

Despacho n. ${ }^{\circ} 32 / 76$ de 9/2: grupo de trabalho para a gestão financeira.

Despacho n. ${ }^{\circ} 156 / 76$ de 11/6: comissão para repensar globalmente a problemática do Serviço Cívico Estudantil.

Despacho n. ${ }^{\circ}$ 243/76 de 4/8: substituição das Ciências Sociais pela História no $7 .^{\circ}$ ano de escolaridade.

Despacho n. ${ }^{\circ}$ 247/76 de 9/8: extinção do Secretariado da Reestruturaçăo do Ensino Secundário. 
Despacho n. ${ }^{\circ}$ 268/76 de 26/8: suspensão da disciplina de Educação Cívica Politécnica.

Despacho conjunto n. ${ }^{\circ} 113 / 77$ de 28/4: define as habilitações próprias para a docência no ensino preparatório e secundário.

Resoluçăo do conselho de ministros n. ${ }^{\circ} 341 / 79$ de 31/10: cria o Gabinete para a desconcentração dos serviços do ministério da educação.

Decreto-lei n. ${ }^{\circ} 76 / 80$ de 15/4: programa especial de execuçăo de escolas preparatórias e secundárias.

Decreto-lei n. ${ }^{\circ} 46 / 86$ de 14/10: Lei de Bases do Sistema Educativo.

Despacho 53/ME/87: comissăo de avaliaçăo do programa especial de execução de escolas preparatórias e secundárias.

Decreto-lei n. ${ }^{\circ}$ 43/89: autonomia ds escolas.

Decreto-lei n. ${ }^{\circ}$ 286/89 de 29/8: novos planos curriculares dos ensinos básico e secundário.

\section{Discursos, Intervenções, Declarações e Entrevistas}

\section{Sottomayor Cardia}

Declarações: "Manifestaçăo não é de professores mas de adversários do Governo», A Luta, n. ${ }^{\circ}$ 341,12 de Outubro de 1976, p. 1.

Entrevista: «Política responsável para o ensino». Tempo, 14 de Outubro de 1976.

Entrevista: "Tornar o MEIC um serviço do Estado e não o feudo de um Partido». Jornal de Notícias, n. ${ }^{\circ} 133,16$ de Outubro de 1976, p. 2.

Entrevista: "Cardia define orientaçăo do MEIC». Jovem Socialista, $n .{ }^{\circ} 28,16$ de Outubro de 1976, p. 1.

Declaraçōes: «O PC está desesperado comigo porque me vê destruir o império que tinha no sector da educaçăo». Jornal Novo, n. ${ }^{\circ} 446,19$ de Outubro de 1976, p. 20.

Declaraçōes: "Cardia defende-se e contra-ataca quanto à política do seu Ministério». Diário Popular, n. ${ }^{\circ} 12064,19$ de Outubro de 1976, p. 28.

Entrevista: «Estou em plena fidelidade de consciência e acçăo em relaçăo aos objectivos por que sempre lutei». A Luta, n. ${ }^{\circ} 351,22$ de Outubro de 1976, p. 3.

Entrevista: "Somos contra os Carneiros Pachecos da educação». A Luta, n. ${ }^{\circ} 352,23$ de Outubro de 1976, p. 2.

Entrevista: «A maioria dos estudantes está comigo». Jornal Novo, 26 de Outubro de 1976, p. 8. Discurso proferido pelo ministro da educação e investigação científica do I Governo Constitucional, Mário de Sottomayor Cardia, em 28 de Outubro de 1976, na RTP. [editado pela Secretaria de Estado da comunicação social, com o tíulo Educação e Democracia, 1977] Entrevista: «É preciso não ter medo de decidir». Vida Mundial, n. ${ }^{\circ} 1911,28$ de Outubro de 1976, p. 15.

Entrevista: «Abra-se o debate nacional para ajudar o Governo nas suas decisões». Nova Terra, n. ${ }^{\circ} 80,24$ a 30 de Novembro de 1976.

Intervençăo na sessão de 26 de Novembro da Assembleia da República. Diário da Assembleia da República, n. ${ }^{\circ}$ 46, 27 de Novembro de 1976, p. 1469. 
Intervenção na sessã̃o de 30 de Novembro da Assembleia da República. Diário da Assembleia da República, n. ${ }^{\circ}$ 48, 2 de Dezembro de 1976, p. 1519.

Entrevista: "Nenhumas das actuais estruturas são ideais no Ministério da Educação». Diário de Notícias-Funchal, n. ${ }^{\circ} 33342,5$ de Dezembro de 1976, p. 3.

Comunicaçăo na RTP a propósito do encerramento da Universidade de Coimbra, 1977.

Artigo: «Bases gerais do sistema educativo». Diário de Notícias, 28 e 29 de Agosto de 1978.

Mesa-redonda de responsáveis da educaçăo [A. Brotas, A. Hespanha, J. H. Saraiva, J. Veiga Simão, M. S. Cardia, R. Fernandes] organizada pela revista, in «Educar em Portugal», Raiz e Utopia, 9-10, Primavera-Verão de 1979, pp. 55-133.

Intervenção do ex-ministro da educação Sottomayor Cardia na mesa-redonda organizada pelo O Jornal de Educaçăo [com a participação de Fraústo da Silva e de António Teodoro], in "1974-84: como é a educaçăo dez anos depois do 25 de Abril?», O Jornal de Educação, 76,1984, p. 22.

\section{Vitor Crespo}

Discurso na tomada de posse dos directores gerais do Ministério da Educação e Ciência, sem data (documento policopiado).

Discurso de abertura ao XXV Congresso do Instituto Internacional de Sociologia, Lisboa, 10/4/ 80 (documento policopiado).

Discurso na Assembleia da República durante a discussão do orçamento de estado de 1980 , 29/4/80 (documento policopiado).

Discurso na tomada de posse do presidente do LNICT e do director-geral do ensino secundário, 26/8/80 (documento policopiado).

Discurso na tomada de posse do presidente do GEP, 20/11/80 (documento policopiado).

Discurso na tomada de posse do director-geral do ensino superior, 12/3/81 (documento policopiado).

Discurso na tomada de posse de dirigentes do ministério da educaçăo (director-geral e subdirector geral do ensino secundário e sub-director geral do Equipamento Escolar), 27/10/ 81 (documento policopiado).

Discurso no encontro nacional das Associaçōes de Pais (SNAP), 27/2/82 (documento policopiado).

Discurso na tomada de posse do secretário-geral do ministério da educação, 30/4/82 (documento policopiado).

Discurso no Instituto de Defesa Nacional, 15/5/81 (documento policopiado).

Discurso na $38^{\mathrm{a}}$ sessão da Conferência Internacional da Educação, Genebra, Setembro de 1981 (documento policopiado).

Discurso na tomada de posse dos directores escolares, 15/12/81 (documento policopiado).

Discurso nas cerimónias do aniversário do IST, 3/5/82 (documento policopiado).

Roberto Carneiro

Discurso do ministro da educaçăo intitulado A Reforma educativa e a gestăo escolar, na Conferência Internacional «Reforma de todos e para todos», Lisboa, 29 de Novembro de 1989 (documento policopiado). 
Discurso do ministro da educação na abertura do seminário Formaçăo pessoal e social em debate, Lisboa, 22 de Janeiro de 1991 (documento policopiado).

Palavras do ministro da educaçăo no seminário A Educaçăo e a Cultura: imperativos da Europa no mercado interno, Évora, 1 de fevereiro de 1991 (documento policopiado).

\section{Pedro d’Orey da Cunha}

Discurso do secretário de estado da Reforma Educativa no Congresso Nacional da Qualidade das indústrias de serviços e dos serviços das indústrias, sessăo de encerramento, 12 de Maio de 1989 (documento policopiado).

Conferência do secretário de estado da Reforma Educativa, intitulada As linhas mestras da Reforma Educativa, 27 de Novembro de 1989 (documento policopiado).

Palestra proferida num encontro do Movimento da Escola Católica, intitulada Para uma deontologia da Carreira Docente, Leiria, 17 de Fevereiro de 1990 (documento policopiado).

Intervenção do secretário de estado da Reforma Educativa na Conferência organizada pelo Movimento dos educadores católicos, intitulada $O$ perfil do professor de acordo com a Reforma Educativa, Centro Paulo VI, Fátima, 5 de Maio de 1990 (documento policopiado).

Comunicação do secretário de estado à reunião do Comité da Educação a nível ministerial da OCDE, realizada em 13 de Novembro de 1990, intitulada Educaçăo para a busca do sentido e a educaçăo para os valores, factores essenciais da qualidade do ensino (documento policopiado).

Intervenção do secretário de estado da Reforma Educativa no seminário Nova Europa e Reformas Educativas, 17 de Janeiro de 1991 (documento policopiado).

Intervençăo do secretário de estado da Reforma Educativa na sessão de encerramento do seminário Formação Pessoal e Social, oportunidade do momento presente, Lisboa, 23 de Janeiro de 1991 (documento policopiado).

\section{Fontes do NEO (Núcleo de Escolas do Oeste)}

Acções de formação pontuais e organizaçăo das jornadas pedagógicas da região oeste. Acta de constituição do NEO (Dezembro de 1987).

Actas de reuniões com o GEP.

Análise de legislação.

Análise do Projecto de organizaçăo e administração das escolas do ensino básico e secundário. Balanços dos processos de matrícula.

Correspondência com a administração central e regional sobre matrículas e zonas pedagógicas. Diagnóstico de ocupaçăo, carência de instalaçōes e determinação de zonas de influência pedagógica.

Documentos de caracterização das escolas.

Documentos preparatórios de várias reuniões de coordenaçăo do NEO.

Documentos de trabalho. 
Documento-sintese das conclusōes apresentadas pelos grupos docentes no debate acerca da reorganização dos planos curriculares dos ensinos básico e secundário e organização e administração das escolas do ensino básico e secundário, Escola secundária de Madeira Torres, 26 de Fevereiro de 1988 (documento dactilografado).

Exposiçōes ao ministro da educação.

Intervençōes do NEO em encontros sobre inovaçōes pedagógicas.

Levantamentos da rede escolar.

Mapas de fuga à escolaridade.

Organizaçăo da jornada de convívio entre os professores da região Oeste (Farra Profoeste).

Planos de actividades das escolas.

Previsão de frequências.

Projectos de colaboraçăo entre várias escolas e entre estas e a Câmara Municipal de Torres Vedras.

Projecto educativo da Escola Secundária Madeira Torres.

Projecto educativo da Escola Secundária Henriques Nogueira.

Reflexōes sobre política educativa (gestăo, planos curriculares, autonomia, relaçōes escola-meio e estatuto da carreira docente). 
Série

Ensino

Coimbra

Imprensa da Universidade

2005 